\title{
RUSSIAN STUDIES ON
}

Age-Associated

Physiology,

Biochemistry, and

Morphology

A Translation from the Russian

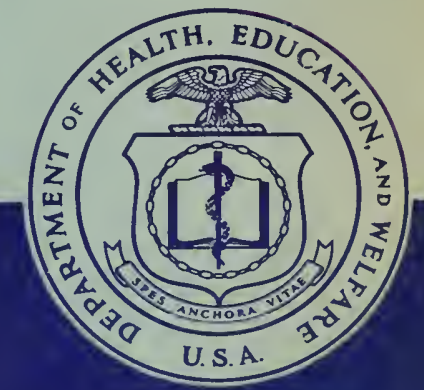

U.S. DEPARTMENT OF

HEALTH, EDUCATION, AND WELFARE

Public Health Service

QP

86

N 58 



\section{RUSSIAN STUDIES ON}

\section{Age-Associated \\ Physiology, Biochemistry, \\ and Morphology}

Historic Description With Extensive Bibliograpby

by Prof. V. N. Nikitin, Corresponding Member of the Academy of Sciences U.S.S.R. Original title: Otechestvennye Raboty po Vozrastnoi Fiziologii, Biokbimii i Morfologii — istoricheskii ocherk i bibliografia State Publ. House of Khar'kov Labor Order of the Red Cross, A. M. Gorki State University, Khar'kov, $1958 ; 201 \mathrm{pp}$.

slation sponsored and distributed by

er for Aging Research, Division of General Medical Sciences IONal Institutes of Health • Bethesda 14, Md. • 1961 
Public Health Service Publication No. 857

For sale by the Superintendent of Documents, U.S. Government Printing Office, Washington 25, D.C.-Price 60 cents 


\section{Foreword}

PROFESSOR V. N. NIKITIN, USSR, has provided a comprehensive review of Russian studies and theories of age-associated physiology, biochemistry, and morphology spanning the years 1761 to 1958. With its almost 3,000 references it is a document of significant historical interest. For this reason it is being made available to all those engaged in aging research in this country.

Except for a few minor editorial changes and deletions, this monograph is a faithful translation from the Russian original, for which we are indebted to the staff of the Library of the National Institutes of Health.

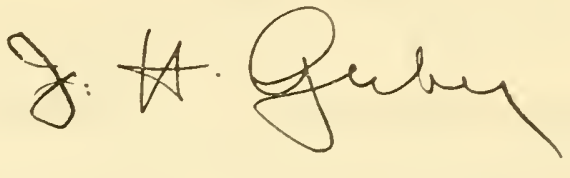

Joseph H. Gerber, M.D., Director

Center for Aging Research

Division of General Medical Sciences

National Institutes of Health 


\section{Contents}

FOREWORD ...................... III

TEXT:

I. First Steps in the Physiology of Aging in Russia . . . . . . . 1

II. Physiology of Aging before the October Revolution . . . . . 5

III. The Post-Revolutionary Period of Development of Sovict AgeAssociated Physiology . . . . . . . . . . . 15

IV. Bibliographic Sources . . . . . . . . . . . . 39

RUSSIAN ALPHABET WITH TRANSLITERATION . . . . . 42

BIBLIOGRAPHY $\ldots \ldots \ldots \ldots \ldots \ldots \ldots \ldots \ldots$ 


\section{FIRST STEPS IN THE PHYSIOLOGY OF AGING IN RUSSIA}

\section{(The period of accumulation of individual facts and initial generalizations)}

The U.S.S.R. is the motherland of the physiology, biochemistry, and morphology of aging. The works of such cminent scientists as I. I. Mechnikov, M. S. Mil'man, I. P. Pavlov, A. A. Bogomolets, A. V. Palladin, N. P. Krenke, A. V. Nagorniy, and others have substantially enriched the contemporary knowledge of aging in the higher organisms. Through the work of A. V. Nagorniy and his pupils, the problem of aging and the fight for longevity led to the development of a new branch of biology (physiology), namely, age-associated physiology and biochemistry. At its distant basc stands the giant figurc of the founder of Russian science, M. V. Lomonosov. In his lecture "On the multiplication and preservation of the Russian people" (I761), he traced a remarkably clear picture of premature death from overexhaustion, undernourishment, epidemics, and the lack of adequate medical care among a large part of the working population of Russia in the days of serfdom.

Lomonosov angrily wrote: "All the cities must have an adequate number of doctors, medical practitioners (tr.: i.e., without foreign training), and drug stores that can supply medicines, even if only those that are fitting for our climate. All of these are not available even in one hundredth part of what is needed, and even the Russian Army is very inadequately supplied with physicians, so that the physicians do not even have time to bandage the wounded, much less examine each patient, question him in detail, give mcdicines, and comfort the suffering. Because of this lack of foresight, many dic who could have lived."

Somewhat later, Professor S. G. Zybelin, of the Moscow University, published his "Remarks on the proper carc of infants" (1775). Onc of the aspects of this problem of proper care that he discussed was that of striving to assure the sound biological development, health, and longevity of the population of our Motherland under the social-economic conditions of that period. Five years later, he again appeared in print with his "Remarks on how to prevent the cause of the not unimportant slow multiplication of the population." Finally, in 1797 , Zybelin again returned to the problem of assuring an increase in the population and its longcvity in his address "On medical means of promoting an increasc in the populousness of the community." 
In 1812, I. P. Kamenskiy, Profcssor of Anatomy, Physiology, and Forensic Mcdicine at the Kazan University, lectured on "The physical rearing of children and its influence on their mental and moral state" and was subsequently cxiled as a frce-thinker. In this lecturc, he discusscd the physical rcaring of children as the science of "prescrving thcir good health and eliminating whatever influcnces may have a harmful effect upon it." He subsequently considered the effccts of temperature, food, drink, movement, "mcntal excrcisc," and emotions on the child, and on the basis of this developed the doctrine of hygiene and medical care of children.

Kamenskiy ascribcs an cxtremcly grcat importance to emotions, both pleasant (prolonging life) and unpleasant (shortening it), in the proper upbringing of children and longevity. Pleasant passions (joy, hope, love, competition) give rise to "unpleasant stimulation of the nervous, vascular, and muscular systems; good composition and volume of blood; a favorable physiology and good spirits. Unpleasant passions act in the opposite way." Among the unpleasant passions Kamenskiy lists fear, grief, anger, hatred, envy, and jcalousy.

There is an evident similarity between the views of I. P. Kamenskiy and those of A. N. Radishchev on the rearing of children.

L. O. Vanotti, Professor of Anatomy and Physiology at Kharkov University, lectured in 1818 on the significance of public health in human longevity. The lecture was entitled "The probable curability of almost all diseases." In it, he points out that "a long and healthy life is, beyond a doubt, the most neccssary and dcsired of the gifts for which we pray to our most gracious Providence. But there are so few who are granted this highest boon, as we learn from our everyday experience of the usual mortality rate among human beings." Vanotti advanced a view that anticipated by a half century a similar statement advanced by I. I. Mechnikov: "Life is always too short to attain the goals set for it by nature; it is interrupted violently by illnesses.... Extreme old age is very often nothing other than a prolonged and incurable disease."

In his lecture, Vanotti stresscd the qualitative peculiarities of the organism at various stages of its chronological development: "There are changes not only in the organism's external appearance but also in its entire internal structure, even in its very essence, with the continuous formation of new organs of strength and action in it, which progressively develop and again disappear, so that at different periods of life it presents an entirely different appearance to the supcrficial observer."

In particular, Vanotti stressed the possibility of artificial strengthening of the regeneration phenomena in the organism, and hence of a complete restoration of health after any illness. He further emphasized the fact that "all discases are curable, and only the physician's lack of knowledge of the cause is at fault if patients die."

In 1833, there was issued from the press a largc book by Parfeniy Yengalychev entitlcd "Prolongation of human lifc. Means of attaining a healthy and happy advanccd old age, of protecting the health by suitable measures, and of making use of the medicaments that are to be found almost 
everywherc before our eyes according to the indications of the diseases involvcd, as compiled from the best Russian and foreign writcrs." Yengalychev stressed in particular the nccd for making use of the "therapeutic strength of naturc," prcventing discase by gencrally observing the corrcctly formulated dietctic rules, treating diseases carly and rationally if they do dcvelop, and toughening the organism by means of systematic physical exercisc and cxposure to fresh air, strict observance of the rules of personal hygiene, and avoidance of alcoholic beverages. It is interesting that Yengalychev regarded walking to the bathhouse as an important means of preserving the health and vital tone of the organism.

In 1839, I. O. Kalenichenko lectured at Kharkov University on "Influence of the ages of human life on mental and moral powers." He was an eminent zoologist and physiologist who taught a course on human physiology at the Medical School.

In this lecturc, we find the very interesting statement that "life and death exist in us at every moment; we live, and yet continually die; we die, and yet continually revive."

Kalenichenko emphasized with great force the uninterrupted changes that go on during the chronological development of all living matter: "'The immeasurable expanse of vitality discovered in innumerable forms of organic nature is born, matures, and fades away with the well-known manifestations of normal mutability, demarcated into more or less distinct periods. All the members of the formative area of nature, from the smallest blade of grass to the human organism, are necessarily subject to change in all the processes of their vital activity ..."

Russian pediatrics began to develop at an carly period. Its founder was Prof. S. F. Khotovitskiy (1796-1885), of the St. Petersburg Medical-Surgical Academy. In his "Pediatrics," published in 1847, he presented a number of ideas that have been extremely important for the development of the physiology of aging. Of particular value are his statements as to the specificity (qualitative characteristics) of the human organism at various stages of ontogenesis:

"... The considerable duration of childhood is associated with the gradual development of the child organism and the approximation of the child to the adult organism, and this evidently cannot be accomplished without qualitative and quantitative changes in its structure and functions. And for this reason the child organism, in a healthy or ailing state, is startling, at first glance, in its very considerable difference from the adult organism, which does not manifest itself only in the smaller size of the organs nor only in the lesser strength of the functions characteristic of the human organism but also in the specific character of the composition of the organs and the direction of their action, healthy or ailing ..."

The studies by S. F. Khotovitskiy constitute the initial stage of the development of the physiology of aging during this period, which amounted, in essence, to a more or less random collection of individual pieces of information on hygiene, gerontology (the study of old age), and thanatology (the study of death), and of somewhat more detailed knowledge about the normal state and 
pathology of childhood and of the clever generalizations and statements that were made on the problems of macrobiotics, which were, however, based on cxtremcly little scientific material. It was I. I. Mechnikov (1873-1916) who brought the problem of the control of premature aging and of promoting a long, happy, and fruitful life to its present scientific heights. 


\section{PHYSIOLOGY OF AGING BEFORE THE OCTOBER REVOLUTION [tr.: 1917]}

\section{(Establishment of the first scientific schools and theories in ontophysiology)}

A rcmarkable Russian biologist, the author (with A. O. Kovalevskiy) of evolutionary embryology and the founder of the theory of phagocytosis, I. I. Mechnikov investigated the problem of longevity for more than 40 years and established a valuable theory of aging. He published 39 experimental studies and monographs in this area, among them such fundamental and now classic works as "Studies of the nature of man" (1903-1904), "Studies of optimism" (1907), "Prolongation of life" (1912), "Forty years of searching for a rational Weltanschauung" (1913), and others.

Mechnikov expressed the remarkable thought that "human life fails halfway along its course, and our old age is a disease, which must be treated, like any other." This idea is basic to many of his investigations, which were the first to introduce the concepts of pathological and physiological aging into science. He sought to give man an opportunity to achieve a normal physiological old age, without senility or deep degradation of physical and intellectual powers. He conjectured that attainment of extreme old agc would eliminate that disharmony of the nature of man which he so clearly depicted in the following words: "Our strong desire to live finds itself contradicted by the weakness of old age and the briefness of life. This is the greatest disharmony of human nature." When the organism is "used up," man accepts death as happily and peacefully as he always accepts rest and sleep after a fruitful and productive day of work. It must be noted, however, that this last vision expresscd by Mechnikov is not fully justified. Even very old people do not lose their instinct to live.

In his theory of aging and death, Mechnikov combined the concept of an intoxication of the organism that continued to increasc with age (attributable, to a certain extent, to a decay of the intestinal microflora) with the idea of the non-uniform sensitivity of diffcrent tissues to this intoxication. The "noble" (most valuablc and dclicatc, tissues, especially the parcnchyma of the brain and heart, kidneys and liver, are very susceptible to poisons; connective tissuc, on the other hand, retains its full valuc and ability to multiply to advance old age. Hence the "struggle," in the aging organism, between the tissues, the growth of the connective tissue and its supplantation of the "noble" tissues, which is accompanied by a consumption of the dying cells of the nerve, muscle, and glandular tissues by macrophages that are activated during old age. 
"I have formulated my view in the following manner: in senile atrophy, we always encountcr one and the same picture, namely, an atrophy of the noble and specific elements of the tissues and thcir replacement by hypertrophied connective tissue. The nerve cells in the brain, i.e., those that serve for the highest forms of activity - mental and sensory functions and the guiding of movements, etc.- disappear and yield their place to lower elements known as neuroglia, a kind of connective tissue of the nerve centers. In the liver, connective tissue supplants the hepatic cells that play an important part in the feeding of the organism. This same tissue also invades the kidneys; it constricts the canals that are necessary to rid us of a multiplicity of harmful substances. In the ovaries and testes, the specific elements that serve for the multiplication of the species are similarly supplanted and replaced by cells of the granular layer from the connective-tissue series.

"In other words, old age is characterized by a struggle between the noble elements of the organism and the simple primary ones, a struggle that terminates in favor of the latter. Their victory is reflected in a weakening of mental powers, nutritional disturbances, impaired metabolism, and so forth.

"When I speak of a 'struggle,' I am not using a metaphor. We are concerned here with a veritable battle in the very depths of our bodies."

Mechnikov ascribed considerable importance in aging to the destruction of the brain cells by macrophages: "... in senile degeneration, an espccially important role is played by the atrophy of the nerve cells with the aid of the macrophages."

In the fight against premature aging, Mechnikov recommends orthobiosis, i.e., the doctrine of the healthy and hard-working life without excesses. Also an important factor in the fight against premature aging, according to him, is the suppression of putrefactive processes in the large intestine by the use of lacticacid bacteria (he recommended kefir, kumys, and acidophillin): "In order to render old age actually physiological, it is necessary to counteract the discomforts resulting from the development of the large intestine." ". . . thus, it is entirely clear that for the purpose of shortening these slow poisonings, which weaken the resistancc of our noble elements and strengthen the phagocytes, we should introduce kefir, and even better, sour milk, into our dietary regimen."

Mechnikov believed that a third way to fight for a longer life was to suppress the macrophages by increasing the amounts of specific antimacrophagic immune serum. Mechnikov did not succeed in working out this control method successfully.

Mechnikov's ideas formed the basis for the investigations of a number of his pupils and successors. These ideas found a certain echo and furthcr development in each of the great investigators in the field of longevity.

The works of I. I. Mechnikov laid the basis for the contemporary Soviet science of aging and death, and contributed to the fight for longevity. From that time on, research in this field was widespread in Russia. The first formation of almost all branches of the physiology, biochemistry, and morphology dates back to the 80 's and 90 's of the last century. 
The comparative statistical approach to the problems of aging and the human life span first appeared in the Russian literature on ontophysiology in a study by K. A. Andreyev (1871): "On mortality tables." He set the task of "finding a correlation between the mortality rate and the various factors that influence it; in other words, of finding an analytic formula in which the mortality rate would be expressed as a function of all the factors that influence it." It is interesting that the critical age for males, i.e., the age that he regarded as most dangerous to males (the greatest percentage of deaths), was given by him as between 40 and 45 years.

Thirty-two years after this study, the prominent physical chemist P. D. Khrushchev (1903) studied in detail, by the statistical method, the causes of death at each age and the problem of the natural duration of human life.

He showed that the mortality curve was very high for early infancy, dropped by 14 years, gradually rose to the age of 71.5 years, then sank [tr.: sic], soon meeting the abscissa at 106 years. Here we find support for Mechnikov's view that ordinary old age is pathological old age and that the great majority of deaths are premature. Having established the five critical periods in human life, Khrushchev came to the conclusion that there are no "sharply detached and entirely independent ages. Life proceeds smoothly and continuously from the beginning to the end; strictly speaking, there are no individual ages but rather five special groups of causes and conditions that create life and lead to death; the majority of them act over periods of many years, others for almost the entire lifetime, but they predominate during certain years of existence, when it is especially convenient to recognize, study, and investigate them."

During the 80's and 90's of the last century, the investigations of the distinguished Russian zoologists N. A. Kholodkovskiy (1882) and V. M. Shimkevich (1893) and the eminent physiologist I. R. Tarkhanov (1891) were directed to development of theories of aging. Kholodkovskiy was particularly interested in the problem of the existence of natural death among protozoans and the genesis of death in higher animals. Shimkevich regarded aging as the result of a peculiar degeneration of the tissue cells, due to an imperfect process of karyokinesis: "It seems to me that it is in this imperfection of the process of division" (the fact that it is not possible to divide the biophores in a strictly equal manner between the daughter cells, V. N.) "that we should seek the cause of aging of organisms and degeneration of cells ... If Nature could develop a cell with an ideally exact structure and with mathematically accurate division, it would create immortality."

Tarkhanov formulated the concept of death as the exhaustion of a hypothetical substance present in limited amounts in the fertilized ovum. This substance, bound to the nucleus, is parceled out, in the course of metazoan multiplication and differentiation, into "so many trillions and quadrillions of particles that, as a result of their endless division in the course of cell multiplication, they must attain such minimal magnitudes that they are no longer able to exert any creative force, and then they cannot overcome the damage incurred during life... The cause of natural death is not the wear and tear on the cells themselves but rather the progressive reduction of the ability of the cells 
to create and multiply, attributable to the progressive depletion of the nucleusforming substance... The number of generations of cells that can develop in the course of a whole lifetime from the fertilized egg, thanks to its original store of creative energy, also determines longevity and hence the maximum length of life that can be attained by various organisms . . The quantity of this creative energy seems to be standardized for cach species ..." This theory, as formulated in several variations by Butschli (1882) and J. Locb (1903, 1908), cannot be subjected to critical evaluation within the scope of this review. This has been done in an excellent fashion in a monograph by A. V. Nagorniy (1940). The basic objection to the theory is the fact that after millions of years of existence of life, this hypothetical sulsstance would long since have been used up (in the rery first generations of living matter).

During the 80 's of the last century, some excellent studies appeared, written by I. M. Sechenov, on the physiology of the central nervous system. Some of them contain very extensive discussions of problems relating to the origin of the higher forms of behavior in the early ontogenesis of man. In his work entitled "For whom and how should psychology be developed?" (1873), Sechenov gives the classic definition of the tasks of materialistic psychology:

"(1) Psychology should study the history of the genesis of the individual elements of the picture. ${ }^{1}$

"(2) It should study the method by which the individual elements are joined into a continuous whole.

"(3) Finally, it should study those springs [tr.: 'triggering mechanisms'?] that detcrmine each new development of psychic activity after an interval."

In other words, if we translate these expressions into scientific language:

(1) Psychology must study the history of development of feelings, concepts, thoughts, sensations, and so forth.

(2) It must then study the combinations of all these species and genera of mental activities with one another...

(3) Finally, it must study the reproduction of mental activity. ${ }^{2}$

"On the basis of all its content, scientific psychology cannot be anything other than a series of studies on the origin of mental activities." ${ }^{3}$

In "Elements of thought" (1878), Sechenov indicated, one after another, the stages of the ontogenetic formation of higher nervous activity (behavior) in the child. He asserted that "in the mental life of man, only early infancy presents cases of the actual genesis of thought of ideational states from psychological products of a lower form, which do not have the character of thought. It is only here that observation reveals the existence of a period in which man docs not think, and after this the ability to think gradually makes its appearance." 4

I. M. Sechenov was the first to work on the ontogenetic physiology of higher nervous activity.

${ }^{1}$ Higher nervous activity, V. N.

${ }^{2}$ I. M. Sechenov: Collected works. 152, p. 208.

3 Ibid., p. 209.

4 Ibid., p. 272. 
In 1884-1897, the remarkablc Russian physiologist V. M. Bechterev published his studies of the charactcristics of the age-associated morphology and physiology of the central ncrvous system. Hc was particularly interested in the very earliest stages of ontogenesis.

During the same period, A. N. Alelekov (1892) investigated senile changes in the functions of the nervous system. In his dissertation, he included a very detailed review of the literature (starting with 1537), but unfortunately without consideration of the contemporary need for providing bibliographic material.

This group of studies is evidence of the appearancc of a new and important orientation of research, along the lines of the physiology of aging of the nervous system, which found its culminating expression in the works of I. P. Pavlov's school.

To this same period belong the classic studies of I. P. Pavlov (1895-96), who studied the causes of death of dogs that had been subjected to bilateral vagotomy. Pavlov succeeded in showing that vagotomized dogs were still capable of living. These were Pavlov's first papers on the significance of the nervous system as regards the ability of higher animals to survive. The flowering of the work of Pavlov and his pupils on senile changes in the nervous system (and also on the ontogenetic development of the cerebral cortex) came in later years.

An important place in scientific investigations must be given to the Russian teacher, anatomist, and physician P. F. Lesgaft, who concerned himself with the problems of the morphology, morphophysiology, and ontogenesis of aging in human higher nervous activity. He bascd his remarkable system of physical education, as well as his system of general education of the child, on his deep knowledge of his functional anatomy and psychology.

Lesgaft gives the following excellent formulation (1884) of the tasks and methods of family education (and education in general): "The whole secret of family education consists in giving the child an opportunity to develop himself, to do everything himself; the adults must not fuss with him and should not do anything for his personal comfort and pleasure but should always, from the first day of his life, treat the child as a human being, with full recognition of his personality and of the fact that this personality must remain inviolate."

The problems of education, conceived of so deeply and humanely, require a broad knowledge of the successive phases of the ontogenetic development of the child's structure and function and of the changes in the level of his mental activities. In his "Fundamentals of Theoretical Anatomy" (1905), Lesgaft gave a good deal of space to an investigation and evaluation of the morphology of aging in the child and adult. He made a particularly thorough study of the age-associated development of cardiovascular and muscle systems of man. In "Family Education of Man and its Significance" (1884-1910), Lesgaft made a deep and original analysis of the progressive development of higher nervous activity and analyzers in the child, especially in very young infants.

According to Lesgaft, "we find that according to the gradual and successive course of development of mental abilities in the normal child, his development can be broken down into the following periods. 
(1) A chaotic period, characteristic of the newborn infant.

(2) A reflex-experimental period, usually extending to the appearance of spcech, or approximately to the beginning of the sccond year after the child's birth.

(3) An imitativc-practical period, up to school agc.

(4) An imitativc-ideational period, the school period up to the age of 20 years.

(5) A critical-creative period, essentially that of mature adults, with some subdivisions."

This attempt to subdivide the periods of development of the human psyche had an undoubtedly progressive significancc for that time.

Lesgaft gives a remarkable characterization of the early stages of development of the child's scnsory organs and psyche (up to the age of 2 ycars):

"In the newborn infant, the higher senses are still not well enough dcveloped for us to detect any activity associated with them; through their instrumentality, only some reflex factors receive a signal. The child gradually begins to perceive tactile and muscle sensations, taste, odor, and visual and auditory sensations. But thcse sensations are not yet differentiated consciously so long as the interaction of the sensations that excite the various sensory organs has not determined their conditionality. It is only then that ideas are formed from sensations. In addition to this, the child begins to distinguish the pleasant from the unpleasant: he is a smiler. This occurs before the end of the third or at the beginning of the fourth month. The infant goes from a lying to a sitting position at the beginning of the second half of the first year; he begins to crawl and look at everything that surrounds him: he is an observer. During the ninth or tenth month, the infant begins to stand on his feet; he utters some articulated sounds and grasps everything: he is a grasper. During the first half of the second year, the infant moves easily and continues to accelerate his movements: he is a runner, and in the second half of the same year he easily utters articulated sounds and masters more and more words: he is a babbler and imitates everything. It is also at this time that he begins to form his habits. Toward the end of the second year or at the beginning of the third, he isolates himself, by making a comparison, from the surrounding environment and speaks of himself in the first person as I."

At the beginning of the 90's, the studies of I. V. Troitskiy (1890-1912) and especially those of N. P. Gundobin (1891-1912) raised the development of Russian pediatrics to new heights.

Troitskiy proceeded from a recognition of the singularity of the infant organism and of its qualitative difference from the adult organism: "The infant is not a minaturc edition of the adult" (A. Jacoby). He emphasized the fact that "the anatomic-physiological modifications that regularly occur in the course of growth, the sensitivity of the child organism in general and of its individual organs in particular, very different in the various periods, with respect to harmful factors, the ability to counteract these, weak at the start but gradually increasing with age: all of this, taken as a whole, gives the pathology of childhood its independent character" (I. V. Troitskiy, 1907). 
Troitskiy made valuable studies of the digestion and metabolism of small children. His fundamental work is "The Study of Childhood Diseases" (1907).

One of I. V. Troitskiy's pupils, P. P. Eminet (1907-1911), made a thorough study of age-associated changes of the sphygmogram in children (from 1 to 15 years of age) and the properties of the blood platelets in the growth period of the organism and showed the marked toxicity of dyspeptic feces of year-old children.

The work of N. P. Gundobin (1891-1912) was very important in Russian pediatrics. During the seven years that he was director of the Children's Academy Clinic, Gundobin established a major scientific trend in the study of the anatomic-physiological characteristics of childhood and the peculiarities of children's diseases. He and his pupils established more than 100 papers on ageassociated physiology and anatomy and on pediatrics. Gundobin generalized the results of these investigations in his excellent monograph entitled "Characteristics of Childhood. Basic Facts for the Study of Children's Diseases" (1906). Gundobin's monograph was reprinted several times in Russia and translated into foreign languages (the first German edition appeared in 1912).

Gundobin provided a firm basis for his initial view as to the qualitative singularity of the child organism: "In view of his anatomical, physiological, and chemical characteristics, the infant differs sharply from the adult human being and merits special study."

Gundobin also wrote the excellent pediatrics textbook entitled "Upbringing and Treatment of the Child up to the Age of Seven Years," which was published three times: in 1907, 1909, and 1913.

Gundobin's experimental work was directed to the study of the characteristics of the digestion, the morphology and pathology of the blood, and higher nervous activity in the child. Finally, he also wrote "General and Patricular Therapy of Children's Diseases" (published in 1896, 1900, and 1907).

A further development of Russian pediatric thought appeared in the form of a two-volume monograph by N. V. Vyazemskiy entitled "Changes in the Organism during the Period of Formation" (1901), in which the author gave the results of the scientific investigations of that period in the fields of the anatomy, physiology, psychology, and pathology of the child, adolescent, and young adult (up to the age of 20 years). This book contains a detailed list of the Russian and foreign literature in this field and also presents the extensive material of Vyazemskiy's own observations, which are of considerable scientific significance.

During the 80's and 90's of the past century, the investigations of A. Ya. Danilevskiy (1881-1891) provided the first contributions to Russian age-linked biochemistry.

Danilevskiy, who may be regarded as the founder of Russian biochemistry in general, laid considerable stress, in his splendid works, on the study of proteins as the basis of the vital process. It was his opinion that "protein is the basic material for life on earth. There is no vital process in our organs in which a protein compound does not take an active part in one way or another. Proteir is the instrument and carrier of our joys, sorrows, and thoughts. It also makes 
our movements possiblc." This formulation is very close to the remarkablc conccpt expressed by F. Engels, who described the lifc proccss as a mcans of existcnce of protein substanccs: "Life is a method of existence of protein substances, and this method of cxistencc consists cssentially in a continuous rencwal of the constituent chemical parts of thesc substances' ${ }^{5}$

Danilcvskiy confronted biochemistry with the task of studying the phyloand ontogenetic evolution of protcins and other substanccs of the protoplasm: "Beyond a cloubt, knowledge of the coursc and laws of the chemical evolution or organs, tissues, and the organism as a wholc represcnts one of the most important links in our understanding of life on earth" (a statement of his pupil N. F. Baymakov, 1904).

Danilevskiy suggested (1886) that synthetic (plastic) processes are accomplished in the organism with the aid of special plastic enzymes. Effective functioning of thesc cnzymcs requires the action of the so-called stimulin (a specific stimulator). In ontogenesis, there is a continucd cxpenditure of the supply of stimulin, which is laid down in the embryo and there bound to protein substanccs. When the protoplasm is in an active state, stimulin is dissociated from its combination with proteins and acts on the plastic cnzymes, giving risc to a heightened rate of synthesis (neoformation) of proteins. Even in youth, the stimulin supply is sharply decreased, and this causes a decrease in the growth rate. With old age, the organism retains only insignificant traces of stimulin, which leads to a catastrophic lowering of the neoformation of the proteins of the protoplasm.

In essence, therefore, Danilevskiy's theory of the biochemical basis of aging is close to I. R. Tarkhanov's concept of the depletion of a hypothetical vital substance in ontogenesis and has the same fundamental defect: an acknowledgement of the formation of the vital substance in phylogenesis and a nonrecognition of this process in ontogenesis. Unlike Tarkhanov, Danilevskiy suggested that stimulin can be regenerated in youth, although not in its totality.

Danilcvskiy (1891) was the first to establish qualitative and quantitativc differcnces in protein composition bctween young and adult animals (puppics and adult dogs).

In 1886, S. D. Kostyurin (a pupil of V. V. Pashutin) studied changes in the macro- and microstructure of the human brain with aging, and in 1890 he investigated the effects of Brown-Sequard cxtract from the seminal glands of the scnile organism (the first steps in age-associated endocrinology).

During the period from 1900 to 1917 (up to the Great October Socialist Revolution), there was further development of Russian age-linked physiology, biochemistry, and morphology. A number of ncw major trends and schools arosc during this period, and somc of thesc rcached their flowcring after the Revolution.

The investigations of M. S. Mil'man (1900-1940) the eminent Russian histologist and one of the leading Russian ontophysiologists, began in 1900 . In the years before the Revolution, he worked principally on the charactcris-

BF. Engels: Anti-Duhring, 1948, p. 77. 
tics of the agc-linked changes in the nerve cells, especially the storage of "senilc pigment" in them and the degradation of the nucleoli. Mil'man made a thorough investigation of the dynamics of the change in the weights of organs in the course of ontogenesis and found that "thc organs that grow for the longest time are the lungs, heart, and arteries, the organs that supply the organism with food and also with one of the most important substances, namely, oxygen. These are followed immcdiately by the intestines, so that we find the same thing in the complex organism as in the simple one: the feeding surface of the body increases for the longest time, since in man and animals this is not the skin but the vessels and intestines."

It was during this same pcriod that Mil'man formulated the first statements of his theory of aging as a process of starvation (oxygen, food) of the central parts of the cells and of the organs at a distance from the periphery. Growth, increasing the dimensions of the individual cells and worsening the conditions under which oxygen and nutrients are furnished to them and to cntire organs, givcs rise to a lowering of vital activity, atrophy, and destruction (death). This draft of Mil'man's theory, later worked out in detail, was first publishcd in 1901 (Das Wachstum und das Alters).

A number of studies in the field of the theory of aging and death were published in 1900-1907 by the prominent zoologist and zootechnologist N. M. Kulagin.

Starting in 1912, such eminent Russian scientists as A. A. Bogomolets (1912-1946), S. I. Metal'nikov (1912-1937), M. S. Maslov (1913-1947), P. Yu. Shmidt (1915-1924) G. N. Speranskiy (1914-1948), and A. V. Palladin (starting in 1916) began almost simultaneously their investigations of physiological aging.

The flowing of the scientific creativity of almost all these scientists falls in to the post-Revolutionary period; for this reason, their fundamental studies will be reported later. S. I. Metal'nikov formulated his theory of aging somewhat earlier (1912-1917).

Onc of the eminent zoologists who did a grcat deal of work on the physiology of the digestion of infusoria, S. I. Mctal'nikov (1912-1937), developed in a particularly thorough fashion his view of the heterochronicity of aging of different tissues and organs. He was one of the founders of the theory of aging as the result of differentiation and specialization of the protoplasm and lowering of the vitality of the cell under the conditions to be found in higher organisms. "Progressing in one direction, the cell must necessarily regress in other directions." "... And the higher and stronger this organization as a wholc, the more solid and integral this ncw individuality of a higher order, the greater will be the enslavement of the individual elements that cnter into it (cclls, V. N.). Thus, the cvolution of the entire organic world progresses in two differcnt, and as it were, opposite directions. At the same time that the complex multiccllular organism gradually perfects itself and progresses on the principle of division of labor and specialization of the individual elements, i.e., cells, its components regress in many respects." (S. I. Metal'nikov, 1917). Thus, "a multicellular differentiated organization already carries within itself the embryo of future 
disharmonies ... which will strive to restore the disturbed harmonies ... Once this harmony is disturbed anywhere, even if only very slightly, the activity of the whole is disturbed and the entire system begins to be destroyed."

Extreme differentiation, connected with a loss of the cells' ability to divide and of the protoplasm's to be restored, is considered by S. I. Metal'nikov as also explaining the loss of the ability to regenerate among higher animals. This loss leads to death: "If man possessed the same ability to regenerate his amputated extremities or his head that we find in many worms and insects, if he could restore his damaged intestine as do holothurians, then, of course, neither death nor old age would be terrible to him" (1917).

S. I. Metal'nikov also wrote such fundamental works as "The Problem of Immortality in Contemporary Biology" and "La Lutte contre la Mort" (1937). 


\title{
III. THE POST-REVOLUTIONARY PERIOD OF DEVELOPMENT OF SOVIET AGE-ASSOCIATED PHYSIOLOGY
}

\author{
(Its formation as a science and the establishment of the more \\ prominent scientific schools)
}

The greatest development of the research of Russian scientists in the fields of age-associated physiology, biochemistry, and morphology has been achieved since the Great October Socialist Revolution. During this period, the struggle for a long and happy human life, with retention of the ability to work, became the task of the State and assumed importance for the entire people. The structure of the socialist society creates the social prerequisites for success in this struggle: a radical improvement in the life and environment of the workers, a maximum concern for their work and rest, a great expansion of medical services, State care for the aged, care for mothers and children, construction of a network of sanatoria and rest houses, large-scale development of physical culture and sports, etc.

Soviet science, which was provided with extremely favorable conditions for its growth, found itself confronted with one of the most pressing of problems: the development of the necessary prerequisites for longevity. This has been described in an excellent fashion in the classic work on Soviet ontophysiology written by A. V. Nagorniy (1940): "And now, when the last shadows of the social conditions that shortened life are fading into the past, when the earth is ceasing to be 'a world of groans and tears,' Soviet science is confronted with the great task of overcoming those biological disharmonies that interfere with longevity and that, long before death, condemn man to senile weakness and senile degradation."

In the development of Soviet ontophysiology, there has been an organic fusion of both those trends and schools that had arisen before the October Revolution and the new scientific schools and trends. Out of the uncoordinated individual investigations and efforts of the narrow scientific communities of post-Revolutionary ontophysiology, there developed a powerful, rapidly growing outgrowth of the science with many large schools and trends.

A remarkable contribution to the problems of age-linked physiology was made by I. P. Pavlov (1908-1936) and many of his pupils. The creation of an integral science of higher nervous activity inevitably necessitated an expansion of research on the phylogeny and ontogeny of conditioned bonds in the animal 
world. From this there arose two extremcly fruitful trends in the Pavlovian studics: on the comparative and on the agc-associated physiology of temporary bonds.

I. P. Pavlov later madc a spccial point of dirccting the research of a number of his pupils to the problems of the agc-linked physiology of the central nervous system. These investigations were carricd out along two lines:

(a) a study of the genesis and carly forms of conditioned-rcflex activity;

(b) a study of the characteristics of higher nervous activity in old age.

The first line was represented by the works of many investigators of the Pavlovian school. The cmbryogencsis and carly postembryogenesis of reflex activity wcrc first studicd and are still bcing investigatcd by A. A. Volokhov (1938-1951) and his coworkers (G. A. Obraztsova, Yc. P. Stakalich), I. A. Arshavskiy (1936-1956) and his coworkers (E. I. Arshavskaya, V. D. Rozanova, S. I. Yenikcyeva), and others.

According to A. A. Volokhov, "the study of the characteristics of nervous activity in the embryonic and early postnatal periods make it possible for us to understand the coursc of its historical genesis and from this to clarify those complex phenomena of nerve functions that take place in the highly dcvcloped adult organism" (p. 267, 1953). The gencral picture of the early ontogenesis of brain activity is characterized by A. A. Volokhov in the following words: "On the basis of the studies that have bcen made, we can come to the conclusion that the development of reflex activity in ontogenesis is an extremely complex matter. Arising during the early stages of ontogencsis in the form of individual local rcflexes, this activity quickly becomes more complicated and transforms itself into generalized forms of reflex reactions. Later on, we observe the conversion of the generalized reactions into specialized reflex acts, which progressively rcach that degree of maturity which is characteristic of the adult animal." (See collection: "Tcachings of I. P. Pavlov in Theoretical and Practical Medicine," Moscow, Medgiz, p. 287, 1953).

I. A. Arshavskiy's studies later developed into a very interesting trend in ontophysiology, revealing the mechanisms of the age-associated formation of the fundamental nerve processes (according to the orientation of the school of N. Ye. Vvedenskiy and A. A. Ukhtomskiy) and of the regions of the visceral nervous system. Arshavskiy and his pupils are to be credited with more than 150 experimental studies, which made a substantial contribution to the development of Soviet age-associated physiology and in particular to that of the ontophysiology of the nervous system.

The first investigations of the Pavlovian school on the early ontogcnesis of higher nervous activity in man were the studics of N. I. Krasnogorskiy on the characteristics of the formation of conditioned reflexes in children (1907-1908). I. P. Pavlov strongly approved of them: "Your experiments arc very in teresting. It is natural that after analyzing conditioned reflexcs in animals we should wish to make an attempt to comparc our findings with the phcnomena of our internal world. Then these experiments must be reproduced on human beings, and first of all on children. And when a similarity has been established accurately and scientifically, it is then time to compare the phenomena of the 
intcrnal and cxtcrnal worlds. Thus, your experiments secm to me to be both nccessary and important." (Complcte Collectcd Works, vol. 1, p. 396, 1940).

In reality, the investigations of I. S. Tsitovich (1911), who experimented on newborn puppies and shower that natural conditioned reflcxes appcar as a result (derivative) of the cxperiences of life, belong to the very earliest investigations of Pavlovian physiology on the ontogencsis of higher ncrvous activity.

Higher nervous activity of children was studicd in detail by N. I. Krasnogorskiy (1907-1954), A. G. Ivanov-Smolenskiy (1929-1956), N. M. Shchelovanov (1925-1930), N. I. Kasatkin (1935-1955), and other investigators.

A number of Pavlov's pupils investigated the formation of conditionedreflex activity in the early ontogcnesis of animals. The studies wcrc pcrformed on puppies (F. P. Mayorov, 1929-1933), calvcs (F. S. Pavlov, 1938, guinea pigs (K. L. Golubeva, 1939-1949), and young birds (L. S. Gorsheleva, 1936).

All the investigators showed that in early ontogenesis the conditionedreflex activity gradually assumes the full value and high functional formation and vigor characteristic of the adult individuals of the species, with a definite sequence for the exciting and inhibiting processes. In very young animals, conditioned reflexes are formed more slowly and inhibition develops more slowly than in the adults. The inhibitory functions of the cortex generally lag somewhat behind the excitation in development. The concentration of the nerve processes is also still very weak at the beginning of ontogenesis, and there is, to the contrary, a predominance of irradiation. Formation of differentiation in very young animals gives rise to subsequent inhibition and sleep, whereas differentiation in older animals is accompanied by positive induction, as a result of the concentration processes that have been formed.

The great importance of the work of I. P. Pavlov's school on the early development of higher nervous activity in animals, and particularly in man, was also emphasized by N. I. Krasnogorskiy: "Thus, strictly physiological study of cerebral activity in children has become a new and very important subject for pediatric studies. This has enriched pediatrics with knowledge of the work of the higher areas of the brain in children during various age periods and has provided a substantial basis for the further study and physiological understanding of the most complex brain processes." (Papers on the Study of the Higher Nervous Activity of Man and Animals, vol. 1, p. 311, 1954.)

In the years that followed, I. P. Pavlov gave a great deal of attention to the study of the characteristics of higher nervous activity in late ontogenesis. As early as 1912, A. V. Tonkikh carried on investigations along these lines on conditioned reflexes in old dogs. It was already clear at that time that new conditioned reflexes are formed toward the end of life with very great difficulty and are characterized by their extremely temporary character and lability. Further work along these lines was done by L. A. Andreyev (1924), D. A. Biryukov (1929), M. Ya. Mikhel'son (1934), N. A. Podkopayev (1938), D. I. Soloveychik (1932-1938), A. I. Pavlov (1938), G. V. Fol'bort and A. V. Semernina (1940), N. K. Zol'nikova (1940), M. K. Petrova (1938-1953), M. A. Usiyevich (1938-1953), and others. 
The problems of the age-linked and comparative physiology of the ccntral nervous systcm werc of great intcrest to such prominent representatives of Pavlovian physiology as L. A. Orbcli (1933-1955) and K. M. Bykov (19461949),

I. P. Pavlov, on the basis of the "mcan" rcsults of many investigations notcd a "natural declinc of the stimulation process" in old agc. The inhibition process suffers to an cven grcatcr cxtent: "With aging, there is first a wcakening of the inhibition process, and then the mobility of the ncrve process suffers, with an increase in inertia." He formulated his vicws as to senile changes in higher nervous activity in more detail, in the following manner: "... On the basis of all the material at our disposal, we can say that the inhibition process is the first to succumb to old age, and after this, it would appcar that the mobility of the nervous processes is affected. This is evident from the fact that a large percentage of our aging dogs ccascd to tolerate the previous more complex conditioned-reflex system. The responses become chaotic, the effects fluctuate in an entirely irregular fashion, and good results can be obtained only by simplifying the scheme. I think that this can very legitimatcly bc ascribed to the fact that mobility decreases with the years. If we have a distinct effect in a large system, this means that one stimulus does not interfere with another and docs not sprcad its effect to the next nerve process. When a nerve process is delayed, however, the remaining traces of each stimulus become prolonged and influence the succeeding ones, i.e., we have a chaotic state and confusion." (Pavlovian Environments, vol. 2, pp. 121-122, Izd-vo AN SSSR, M.-L., 1949).

In addition to this, I. P. Pavlov's pupils established cases of exceptionally long maintenance of full higher ncrvous activity (as, for example, in thc case of the dog Postrel in Fedorov's experiments.)

In her extensive experiments on the nervous systems of dogs aging under various conditions of functional stress, $\mathrm{M}$. K. Petrova established the very great significance of the preservation of the nervous system in longevity. As a result of this, Pctrova is inclined to regard a progressive weakening of the nervous system as the principal cause of the age-associated changes in the organism: "... In our dogs, we were able to observe both normal physiological and pathological old age. Our experimental findings indicate that the major and leading role in the process of aging of the organism is played by the central nervous system, and particularly by the cerebral cortex and the other systems associated with it." (On the Role of the Functionally Weakened Cerebral Cortex in the Genesis of Various Pathological Processes in the Organism, Medgiz, L., p. 70, 1946).

Having indicated that there can be no doubt of the great significance of the nervous system for the organism as a whole and for its agc-linked changes in particular, A. V. Nagorniy (1954) suggests that it may indecd be a major factor in longevity. "It can be shown that of all the systems of the intact organism (in the absence, of course, of pathological manifestations), the most stablc, the most plastic, the most intensely functioning and longcst-lived is the system of the cerebral hemispheres" (p. 26). 
Comparative and age-associated biochemistry and physiology, particularly the age-associated changes in the gradient of intestinal automatism, the physiology of the skeletal musculature, the trophic influence of the nervous system, and a number of problems of embryo-chemistry have been studied (and are still being studied) by Kh. S. Koshtoyants (1931-1954) and his coworkers (R. L. Mitropolitanskaya, A. M. Ryabinovskaya, G. A. Buznikov, V. A. Muzikantov, and others). In this connection, they have paid particular attention to the comparative physiology and biochemistry of amphibians, fish, and some invertebrates (Bombyx mori).

M. S. Mil'man's investigations (1900-1940) were of special interest in the field of Russian age-linked physiology. On the basis of a large group of anatomical and histological findings, Mil'man advanced his theory of aging as being the result of atrophy from starvation (food, oxygen, and neurotic). According to Mil'man, starvation of cells (and especially of their central nuclei) is the result of their growth. In the cell, "the position of the peripheral particles [tr.: molecules?] is more favorable: they can receive more substances for assimilation than can the central ones. The result of this is an unequal growth of the external and internal parts.... The protoplasm is more favorably situated with respect to the surface, i.e., to the source of food, than is the nucleus, and for this reason the latter, in the course of growth, reveals signs of starvation and atrophy earlier than does the protoplasm."

The growth of cells brings with it, according to Mil'man, a whole series of "bioreductive processes": (a) changes in their size and shape; (b) changes in structure and chemical composition; (c) displacement of the protoplasm by metaplasmatic formations; (d) death of the cells.

"Consequently, the growth of the cells gives rise not only mechanically to arrest and regression of growth but also chemically: nutritional deficiences and autointoxication, accumulating, bring about the death of the cells of the organism ... The organ cannot atrophy if it is fed properly" (M. S. Mil'man).

In the multicellular organism, the conditions of tissue nutrition are still worse, and especially those of its centrally situated cell groups: "With an increase in the number of cells, the vessels are unable to reach every cell, for the simple reason that they can grow only in two spatial directions, whereas the mass of the cell grows in three directions."

Hence Mil'man regards as bioreductive phenomena the differentiation of nuclei in cells, cell division, tissue differentiation, and the growth of extracellular masses and connective tissue, and it is to these that he ascribes the age-linked arrest of the organism's growth and its subsequent death. "... Aging begins very early, even with the first cell division, with the first manifestation of life. The concept of life also includes that of aging ... In its first multiplication, the cell creates an obstacle to its nutrition. With each division, these obstacles increase. Growth depends on nutrition, and continuously digs its own grave."

"The severe worsening of the nervous system's nutrition with increasing age leads to its premature atrophy, and this brings with it the early death of the entire organism as a result of impaired nutrition of the tissues." Although the first cause of starvation of the cells is to be found in the conditions of its growth, 
and the ehanges in the nervous system are actually the consequences of ehanges in the cells of the organism, we find that in old age the role of the nervous system becomes the major one, and atrophy from aging is of neurotrophic origin" (M. S. Mil'man). [Tr.: This quotation has an end but no beginning.]

The significance of Mil'man's work is to be found above all in the accumulation of a great deal of anatomical-histological material on the processes of senile atrophy and dystrophy. His theory of aging, although characterized by its consistency, is constructed in an extrcmely one-sided manner and does not cover the real wealth of the relationships betwcen growth, nutrition, and tissue differentiation in the organism. We ean seareely regard the dimensions of the cells as the factor that limits their nutrition; as a compensation, the protoplasm becomes more penetrable. It is entircly impossible to explain cell and tissue differentiation by nutritional defieiency. The fact that the tissues of higher animals are supplied by the circulatory system with capillaries docs not impair but rather improves considerably the supply of oxygen and nutrients to their tissues, and this is indicated by the higher energy metabolism levels of mammals and birds as compared with the lower vertebrates, although their body masses fluctuate within narrow limits. Senile changes in the microstructure of nerve tissue are not greater but even smaller than those of many other tissues.

In view of all of this, we cannot express our agreement with the one-sided theory of the aging of organisms advaneed by M. S. Mil'man, although we do commend his extensive research activities. Grasping only the one aspect of growth to which his simplified concept applied, Mil'man saw the growth and development of organisms only as regressive (bioreductive) processes. The phenomena of biological progress do not fit into Mil'man's concept at all.

During the Twenties, in addition to the echoes of A. Steinach's and S. Voronoff's hormonal theories of aging (1920 and 1921, respeetively) that spread into the Russian literature, there appeared some new vicws as to the causes of aging in higher organisms. An unusual variation of the theory of the lack of vitality of the somatic cells (in contra-distinction to the full vitality and potential immortality of the germ cells) was developed by V. Krasheninnikov (1924). He believed that the somatic cells receive an insufficient supply of certain substances that are important for their vital activity at the very time of their formation.

"The somatic cell at its very birth from the germ cell already differs sharply in its morphological structure from the germinal clements. The characteristics of the internal nature of the somatic cell determine its future fate and its specific dependence on the organism as a whole, as well as its limited existence.

"We suggest that the somatic cells, at their very birth from the germ cells, receive a definite and limited store of vital cnergy corresponding approximately to the time needed for the growth of the sexual elements" (V. Yc. Krasheninnikov, 1924). In addition to this, for their entire life they systematically supply the germ cells with special substanecs that are of great genetic importance. All of this leads, at the end of ontogenesis, to a sharp decrease in the biological potential of the somatic eclls and to their death. 
Thus, Krasheninnikov assigns to the somatie cells the role of "suppliers" of the sexual elements, so that those that arc still capable of growth during the first period of life ean still not only supply' valuable substances to the gcrm cells but also rapidly synthesize its own protoplasm. During the second period of ontogenesis, there is an ever-increasing progrcssivc attrition of the somatic cells.

The groundlessness of such a division of the cells of thc body into immortal germ elements and mortal somatic cells scarccly necds to be demonstrated. According to A. V. Nagorniy, "we need only point out that if this were actually so, castrated animals would have to be immortal, whereas the facts indicate that, on the contrary, the aging and death of the soma is sometimes even accelerated aftcr castration" (1940).

A number of studies were published by B. M. Zavadovskiy (1922-1936) and M. M. Zavadovskiy (1924-1941) from the viewpoint of a special modification of the hormonal theory of aging. M. M. Zavadovskiy regards the agelinked development of organisms as a process of prolonged morphogenesis, determined at each age by the substantial shifts in the composition and amounts of the hormones that are produced. "Despite the view, widespread among physicians and physiologists, that treats aging as a disease, and in recent times, particularly in connection with Steinach's work, as a disturbance of the 'normal' relationships in the incretory system of glands, I regard aging as a natural and inevitable finale of form development...

"The onset of old age must be eharacterized as a natural change in the activity of the incretory glands, comparable to that whieh, as we know, takes place when adoleseenee sets in during youth, when the activity of the thymus is exhausted and the gonads begin to funetion" (M. M. Zavadovskiy, 1924).

"... As a biologist, I could characterize our approaeh to the problem of aging as a morphogenetic one. It regards the phenomena of aging as the result of the normal, regular, inevitable eourse of development of the organism, the direction of which is determined by the incretory glands" (1924).

The concept of the hormonal dependence of aging was later defended by N. A. Shereshevksiy (1936-1940) and S. S. Khzlatov (1940). Shereshevskiy here regarded aging as being largely a manifestation of insufficiency of the thyroid gland.

That an important role is played by the age-linked ehanges in the glands of internal secretion in the processes of development and aging of the organism ean scarcely be denied. In ontogenesis, there are substantial ehanges in the system of the endoerine glands; the susceptibility of the tissues to hormones also changes.

In addition to this, this eoncept elearly underestimates the role of the nervous system in the ontogenesis of higher organisms. The most important objection to the hormonal theories of aging is the absenee in them of any answer to a major question: Why do the glands of internal seeretion themselves age (or, in general, change with age)? It is evident that it is in the age-linked changes in all tissues of the organism, including those of the glands of internal secretion, that the deep-seated general eauses are to be found. These factors are not touehed upon by the hormonal theories of aging. 
A. A. Bogdanov (1927) attempted to develop a theory of aging based on the fact that the differentiation of the organism has a negative side, leading to a contradiction in its systems. "The strength of the organism lies in the exact coordination of its parts, in the strict correspondence of the individual mutually connccted functions. This correspondence is maintained during the continuing growth of the tectological differenccs, but not to an unlimitcd degree: a moment comes when it can no longer be maintained completely and begins to regress. Parts of the whole become... so different that thcy diverge both as regards the very tempo of life and as regards the strength of their relative resistance to the environment. And this inevitably leads to a disorganization, whether slower or faster, that is determined by the sum of the conditions."

Bogdanov dcrived this theory of the "deterioration" of the organism with aging from the idealistic principles, developed by him, of so-called tectology (a variety of empiriomonism). In it there is no scientific basis for what he postulated as an abstract contradiction between the development of the parts and units of the integral animal organism. Of somewhat greater interest are his attempts to prolong life by systematic blood transfusions. The interpretation of the blood-transfusion problem from a broader viewpoint as a means of heightening tissue tone was successfully dcvcloped by A. A. Bogomolet's school (the appearance of the so-called "colloidoclasia") and is still being studied today. The explanation of the tonicizing ("rejuvenating") action of transfused blood is given by Bogdanov in a very peculiar manner:

"To change the blood means to change the internal environment of the organism, the basic conditions of the vital activity of its cells ...", for "foreign blood presents different relationships, different deficiencies and surpluses; it may even contain elements that are entirely absent from the blood in question. To the extent that the lack of coincidence of the deficiencies and excesses when the bloods are mixed must necessarily equalize them to a certain degree, to the extent that the vital environment becomes more harmonious, to the extent that new elements are introduced, it becomes enriched. Consequently, we find that when the choice is successful, this process is favorable to the life of cells and tissues. It may lead to an improvement of their functions, and this then in its turn has a favorable effect upon the blood, which receives material from them, as well as on its composition and properties, and even on the velocity and regularity of its circulation, and this indicates a further improvement of the internal environment."

According to Bogdanov, the transfusion of blood in higher animals is somewhat suggestive of conjugation in protozoa. Both the one and the other leads to a heightening of the biological potential of organisms. Despite his primitive notion of the character of the biological action of blood transfusion, the efforts for expansion of blood transfusion programs in the USSR and Bogdanov's establishment of a blood transfusion institute in Moscow (1926) have doubtless been of great importance for medicine and biology.

A Bogdanov died while performing one of his blood-transfusion experiments on himself. 
A considerably more valuable concept of the nature of the tonicizing action of blood transfusion was given by A. A. Bogomolets (1932). He advanced the extremely interesting theory of colloidoclasia, which appeared to be the basis for the concept of the "rejuvenating" action of blood transfusion. Specifically, the introduction into the recipient organism of several proteins from the donor's blood that differ in their physical-chemical (electrocolloidal) properties gives rise to peculiar "electro-colloidal storms" (colloidoclastic shock). In this condition, there is a precipitation and automatic elimination of proteins from the protoplasm, chiefly of the older ones with lowered colloidal stability, and it, having been freed from them, is rejuvenated somewhat.

"We have already spoken of the fact that aging of the protoplasm of cells occurs as a result of a 'maturation' of the cellular colloids and micelloids and the conversion of these into precipitates and flocculates, forming biologically inert inclusions and depressing the vital activity of the cells. The majority of these flocculates are already incapable of redispersion. They have not yet, however, reached (and can never reach) those degrees of coagulation that are necessary for them to be destroyed by the intracellular enzymes. It would appear that we have here an analogy with the processes of digestion of food: the colloids and micelloids of milk undergo digestion by the digestive enzymes only after they have been coagulated. Blood transfusion provides us with a means of freeing the cell, by means of colloidoclasia, from the products of the aging of the protoplasm with which it is littered." (A. A. Bogomolets, 1940).

Over a period of many years (1912-1946), Bogomolets worked on the problems of age-associated physiology and founded in this area (aside from his other scientific services) a very prominent scientific school. Regardless of the extent to which some of his theoretical views may or may not be regarded as wellsubstantiated, he did have a notable role in the development of Russian physiology and pathophysiology of aging and the search for means of prolonging life. Bogomolets did a very great deal for the organizational unification and strengthening of all the principal laboratories that were working on behalf of human longevity in the USSR.

The starting point for the theory of aging advanced by Bogomolets is to be found in his idea of the extremely great significance of the connective tissue system in the organism. This system represents a special "root" of the organism, determining the extent to which the other tissues are supplied with oxygen, nutrient substances, and hormones and their excretion of carbon dioxide and other waste products. The connective tissue is an intermediary between the blood and all other tissues. Its aging begins earlier than that of other tissues and is of very great significance as regards the general aging of the organism.

"My viewpoint on the significance of the activity of the physiological system of the connective tissue for the longevity of the organism is exactly opposite to that of Mechnikov. It is my opinion that the aging of the organism begins precisely with the connective tissue. The organism is as old as its connective tissue. By no means is the connective tissue merely the elastic skeleton of the organism. I believe that the connective tissue with its diverse cellular elements is the physiological system of the organism that performs the extremely impor- 
tant trophic functions, that it constitutcs, in its way, thc root of the organism, since it is through it and with its activc participation that the substances neccssary for their vital activity rcach the parcnchymal cells from the blood. The type of the connective tissuc detcrmines, to a considerable cxtent, the constitution of the organism. As carly as 1924, I designated four basic types of constitution, as detcrmincd by the character of the connective tissuc: pasty, fibrotic, lymphomatous, and asthenic." (A. A. Bogomolcts, 1940).

The changes in the connective tissue with aging (likc those in the other tissucs of the organism) arc based, according to Bogomolets, on the biological hystercsis of its colloids: ". . . The hysteresis of the connective tissuc, the aging of its colloids, their thickening and condensation, their loss of water (senile desiccation of colloids), the lowcring of their capillary activity, the qualitative and quantitative changes in the electrical charges of the cellular (perhaps also cxtraccllular, V. N.) micelles of the connective tissue: all of these factors affect in a very substantial fashion the general state of the organism, the nutrition of its tissues, and its overall physiological activity" (1940).

According to Bogomolets, there is an ever increasing accumulation of aging, partially coagulatcd, colloidal (largely protein) particles [tr.: molecules?] in the tissues of the organism. They are unable, however, to undergo autolytic removal (autodigestion), sincc the degree of change in the aging protein particles, thcir denaturation, is still insufficient for them to become accessible to autolytic enzymes. The colloidoclastic "electrical storm" comes to the aid of the autolytic enzymes; by this means, the aged protein particles are denatured to a sufficient degree to enable them readily to fall prey to the autolytic enzymes. "It would appear that, under the influence of colloidoclasia, coagulation of the least stable 'senescent' micelles takes place and is followed by their enzymatic splitting, with the formation of autocatalysts, substances of the type of Carrel's proteases, which manifest a stimulating action on the vital activity of the cell" (A. A. Bogomolets, 1940).

Starting with the hypothesis that the tempo of aging of the connective tissue outstrips considerably that of the corresponding processes in other tissues, Bogomolets suggested that stimulating doses of the so-called antireticular cytotoxic serum (ACS) be used. The latter is obtained in response to the injection, into a donor animal, of serum from three varieties of "physiologically activc conncctive tissue": bone marrow, spleen, and liver. Bogomolets developed a method for determining the titer of this serum and began to use it as a means of stimulating ("rejuvenating") the corresponding types of connectivc tissue in the aging organism.

Bogomolets compared the two means of "rejuvenation" (blood transfusion and administration of ACS) in the essence of their effects on tissues. In both cases, electrical storms in the protoplasm play a part, ridding the protoplasm of its aged and inert clements. Only in the second case is the action localized selectively in the connective tissue.

Bogomolets asserted that "study of the stimulating effect of our antireticular cytotoxic serum has confirmed the varicd and important significance of the physiological system of the connective tissuc. Stimulation of its functions in- 
creases the level of immune substances in the blood, increases the resistance of the organism to infection, ... and heightens the organism's resistance to cancer by promoting the absorption of fairly large neoplastic metastases and restoring the cancerolytic properties of the serum in cancer paticnts ..." (1940).

Unfortunately, use of ACS as a means of heightening the potential of the organism in old age and prolonging life has not yet given highly encouraging results.

In addition to stimulation of the connective tissue, Bogomolets also sought to discover immunobiological ways of reactivating other tissucs: "It may be that it will also be possible to carry out Mechnikov's idea, to the effect that it will some day be possible, by the use of specific cytotoxins, to activate the functions of the parenchymal cells and thereby to combat their premature attrition" (1940).

Two of Bogomolets's pupils (N. B. Medvedeva and N. D. Yudina) reported the stimulating ("rejuvenating") action of hemolytic serum on the proteins and cellular composition of the blood.

Of particular interest are the extensive biochemical, physiological, and clinical studies of very aged persons that were conducted by some of Bogomolets' pupils (I. V. Bazilevich, I. M. Turovets, and L. I. Pravlina, B. V. Krayukhin and N. M. Shcherbakov, R. B. Gragerova, and others (1939-1940)). On the basis of these observations, Bogomolets advanced the notion of the harmonic depression of functions in persons of very advanced old age, in contradistinction to the disharmonic processes of pathological old age.

Substantial contributions to the development of the physiology of aging were made by the investigations of some of Bogomolets' pupils: R. Ye. Kavetskiy (1939-1947), N. N. Sirotinin (1934-1951), N. B. Medvedeva (1937-1950), and others.

In Bogomolets' theory of aging, we cannot fail to note a one-sided emphasis on the exceptionally important role of the connective tissue ("the root of life") in the processes of the age-linked development of the organism and especially in the processes of its aging. We can scarcely agree with this exaggeration of the significance of the connective tissue. In Bogomolets' statements, this is connected with an understatement of the importance of the age-linked changes in other tissues, especially the nerves, and in the system of the glands of internal secretion. I. I. Mechnikov's original concept of the sprcading of a number of forms of connective tissue in old age cannot be regarded as disproved.

And aside from this, the totality of the studies by Bogomolets, the extremely important factual data obtained by him and by his pupils, the various features of his teachings on colloidoclasia and the harmonic depression of functions in the very aged, his efforts to unite the uncoordinated scientific forces around the struggle for longevity: all of this has found its lasting place in the basic foundations of Russian age-associated physiology.

A large series of studies by I. I. Shmal'gauzen (1926-1938) have been devoted to the problems of growth mechanisms. On the basis of a very large number of experimental findings, he proposed his widely used growth formula and introduced into scientific practice the concept of the growth constant $\left(k=\mathrm{C}_{\mathrm{v}} \mathrm{t}\right)$. 
He showed that in higher animals the decrcase in the rate of growth is inversely proportional to the time that has elapsed since the beginning of development. According to Shmal'gauzen, the reduction of the ratc of growth is the principal detcrminant of the onset of the processes of attrition of tissues and the death of the organism.

Shmal'gauzen distinguishes four factors that determine the growth of organisms: a) the growth (increase in the mass) of the cells; b) the growth of undifferentiated tissues as a result of the multiplication of cells; c) the growth of differentiated cells of tissues; d) the increase in the apoplasm (metaplasm) [tr.: deutoplasm?]

$\mathrm{He}$ assigns a leading part in the cessation of growth and in the weakening of the autoregeneration of the protoplasm to a decrease in the mass of the undifferentiated cells in the organism. Differentiation of the cells leads to a cessation of their growth, which is as exponential in the early period of embryogenesis as it is in some bacterial cultures. In embryos "in the period of intense growth, the phenomena of differentiation are in the background, while during the period of intense differentiation growth is inhibited" (I. I. Shmal'gauzen, 1936).

In the multicellular organism, the age-associated lowering of the growth rate is determined largely by the dccrease in the mass of the undifferentiated tissue elements. Undifferentiated cells continue to grow as rapidly (with the same growth constant) as in early ontogenesis. Hence, "the relative mass of indifferent cells with exponential growth decreases in inverse proportion to its age. We have here, to be sure, the entire substance of our growth law, which could be designated, with equal success, as the law of gradual differentiation of the organism" (I. I. Shmal'gauzen, 1936).

On the basis of this concept of the mechanisms of growth and its relationship to differentiation, Shmal'gauzen developed his theory of aging. One of the fundamentals of this theory is a recognition of the fact that aging and death are regarded as the result of the increasing differentiation of the tissues (cells).

In addition to this, and contrary to the view of M. S. Mil'man, Shmal'gauzen must be aware that specialization of cells not only increases their functional capabilities but also increases their life span (vital stability) substantially, as well as the integral system of the organism. "Specialization of the somatic cells of higher animals is connected with a more nearly perfect accomplishment of certain fixed functions, and in the exact coordination of the activity of the individual cells and various organs of a complex organism it assures the best conditions for their existence and we should not be surprised, therefore, that this specialization leads to a considerablc incrcase in the life span of the individual cells. In higher animals, this life span of the more specialized and therefore unchanging cells (such as those of the nervous system, for example) is determined by the life of the whole individual i.e., it is measured in years, decades, and even centuries. The stability of the somatic cells has been increased considerably as a result of their specialization, and the most stable of these are always the most specialized nerve and muscle cells" (I. I. Shmal'gauzen, 1926). 
Strictly speaking, what is it that limits the vital activity of the individual, already specialized, cells of the highly organized organism? To this qucstion, Shmal'gauzen givcs the following answer: "Wc believc the cause of death to be...the limitation of growth. The genesis of death is connected with the progrcssive development of a stable highcr individuality of limited dimcnsions and strictly determinate shapc with a fully harmonious rclationship of the parts. In all complex animals, thcre is some internal apparatus that establishes the limits of growth and is passed on to the next generation, just like the other signs of organization. This apparatus, at the same time, also limits life to certain norms, since a limitation of growth is a limitation of the assimilative activities, without which it is not possible to have a complete restoration of functional damage. We designate incomplete restoration as attrition" (I. I. Shmal'gauzen, 1926).

The nature of this internal apparatus is not sufficiently clear. In this connection, Shmal'gauzen writes as follows: "This internal apparatus may be intracellular - as, for example, in the form of a well known supply of enzymes, which are used up in the course of successive divisions, and may be extracellular in the form of the specific hormones that inhibit the cell division that leads to an increase in the dimensions of the body in animals with limited growth" (1938).

Shmal'gauzen did a great deal for the study of the characteristics of growth of bacterial cultures and higher organisms and rightly stressed the significance of the increasing differentiation of the cells in the lowering of the tempo of growth and multiplication of the cells. He also stressed (together with G. S. Maynot) (1926) the significance of differentiation in the process of lowering the autoregeneration of protoplasm during the first periods of ontogenesis.

There are, however, some very substantial shortcomings in the concept of aging developed by I. I. Shmal'gauzen. First of all, we cannot agree with the statement that the growth rate of indifferent cells remains uniform during the entire course of ontogenesis. Moreover, the very existence of indifferent cells that are qualitatively identical at all ages is doubtful.

Furthcrmore, Shmal'gauzen's idea of "internal factors" that determine the duration of the life of the specialized cells is at least insufficient. In the first place, as has already been shown earlier (in our examination of I. R. Tarkhanov's theory), any theories that involve an expenditure of vital forces, enzymes, vital substances, and so forth, that are initially stored in them are clearly unsound. In the second place, although we cannot deny the very considerable significance of the age-linked changes in hormonal influences in the organisms of higher animals, the processes of aging ripen in all tissues without exception, i.e., also in the tissues of the glands of internal secretion, and for this reason the causes of aging cannot be sought only in a change in the formation of one or another hormone or even all the hormones as a group.

The prominent Russian physicist P. P. Lazarev (1928-1938) made a very original contribution to the development of the science of aging. Specifically, he studied the rate of the age-associated decline of the sensitivity of a number of analyzers (of sensory organs). In particular, he studied the mechanisms of the weakening of optic sensitivity with old age. Having established the rate at 
which this sensitivity drops in elderly persons from 60 to 80 years of age, Lazarev extrapolated this eurve further and found that it drops to zero (to the level of the axis of abseissae) for an age of 120-150 years. In other words, the sensitivity of the nervous system disappears eompletely at this extreme agc.

This gave further physiological evidence that the normal duration of liuman life should exeed a hundred years.

After N. P. Gundobin, the problems of the physiology and pathology of childhood were further investigated by M. S. Maslov (1913-1947).

A number of studies on the charaeteristies of mctabolism in early childhood were made by N. F. Tolkachevskaya (1947-1955) and her co-workers.

In addition to age-associated physiology, there has been an cver broadening investigation of agc-associatcd biochcmistry, beginning with A. Ya. Danilcvskiy. The need of such investigations was formulated in a program paper by $\mathrm{V}$. S. Gulevich entitled "Signifieance and course of development of eomparative biological chemistry of animals" (1933). In it, Gulevieh speaks, first of all, of the timeliness of the establishment of this new branch of seience: "It would appear somewhat strange to speak of the significance of a non-existent scienee, but the time has now come when comparative biological chemistry must enter the fraternity of the other disciplines and when we must eonsider, along general lines, what must be the content of this inchoate seience and its significance, as well as the lines along which it should develop."

Gulevich asserted that the comparative-evolutionary approach should be the guiding orientation of eomparative bioehemistry: "Biochemical studies of man inust not be isolated from the eorresponding studies of other elasses of animals: in the study of his chemistry, man must not be separated from the rest of the tremendous and varied animal world. Just as eomparative anatomy reveals an uninterrupted evolutionary ehain from the simplest animals to man, so in biologieal chemistry it will be necessary to undertake a systematic study of the ehemical staties and chemical dynamies of animal organisms on all zoological levels and to bind the study of man to eomparative biological chemistry."

This was written long before the comparative bioehemieal studies by $\mathrm{E}$. Baldwin (1938) and Florken (1941).

V. S. Gulevich indieated that phylogeny is organically eonneeted with ontogeny. In the region of age-associated biochemistry, he pointed out a series of courses for investigation: embryoehcmistry, the ehemical study of ontological development as the accelerated and shortened course of phylogenctie development, and the biochemistry of the ehild organism.

An extremcly valuable contribution to the development of age-associated biochemistry was made by A. V. Palladin (starting in 1916) and his pupils. As early as the publieation of his early monograph ealled "Study of the formation and isolation of creatine in animals" (1916), he reported a series of investigations connected with the age-associated characteristics of the organism. Later on, Palladin made a detailed study of the eharacteristics of creatine metabolism in children (1926-29) and then studied, in a number of papers, the changes in the creatine content at various ages and during the period of embryogenesis in a number of laboratory animals (1936-1938). In his subse- 
quent works, Palladin madc a detailed study of agc-associated changes in a number of biochemical indices in mammalian tissues and at the same time conducted his investigations on a broad planc of comparative biochemistry.

Specifically, Palladin developed the biochemistry of the age-associated development of organisms and also concerned himsclf with the problems of the general theory of aging (1923).

Palladin has been studying very diligently the age-associated changes in the enzymatic properties of tissues and organs and the small details of the intermediate metabolisn of proteins and carbohydrates. In recent years, the central orientation of Palladin's research has been the comparative biochemical study of the protein and nucleotide metabolism of the central nervous system. Particular attention has been paid to the age-linked biochemistry of the brain (and especially its embryochemistry). In Palladin's school of functional biochcmistry of the brain, ontobiochemical investigations occupy an important place.

Among A. V. Palladin's pupils, who have done a great deal for the development of age-associated biochemistry, we must mention D. L. Ferdman, A. M. Utevskiy, L. I. Palladina, Ye. S. Savron', L. Ye. Rozenfeld', and many others.

The biochemistry and metabolic characteristics of childhood have been studied and are still being studied by O. P. Molchanova (1935-1948) and N. P. Tolkachevskaya (1939-1954). The latter, together with her co-workers, has made a particularly detailed investigation of gas exchange and protein and carbohydrate metabolism in young children.

Extensive investigations in the area of pediatrics, and particularly in the physiology of childhood, have been conducted in the laboratories of G. $N$. Speranskiy (1914-1945) and A. F. Tur (1927-1947). The work of V. G. Shtefko and his pupils (1924-1946) was devoted to the morphophysiology of early ontogenesis.

A great deal of work was done in the field of biochemistry of phylogenesis and ontogenesis of plants by A. B. Blagoveshehenskiy (1935). He believed that a tendency to cyclization, i.e., replacement of organic compounds with an open carbohydrate [tr.: sic] ring by compounds with a closed ring, is one of the basic mechanisms of both the phylogenesis and ontogenesis of plants. In this way, he formulated in a changed form the view of $\mathrm{A}$. Pictet that in ontogenesis there is a gradual rcplacement of the more reactive and higher energy aliphatic compounds by less reactive and lower energy cyclic compounds. The ageassociated cyclization of substances is one of the manifestations of an increase in entropic processes during the period of old age.

It must be noted that the theory of eyclization (as it was developed by $\mathrm{A}$. Pictet) cannot be regarded as acceptable. A strong criticism of this theory was advanced by A. V. Nagorniy (1940): "Inasmuch as cyclic compounds contain less free encrgy than acyclic ones, the transformation of the latter into the former in closed systems is a natural spontaneous process. Since the living organism is an open systcm, subject to the unceasing processes of matter and energy metabolism, it is entirely clear that the processes of cyclization cannot be primary but are only a reflection of certain characteristics of the metabolism and subordinate to them. 
"It is evident, therefore, that substances that exhibit the phenomena of cyclization and hysteresis in the living organism can do so only under conditions of total or partial preliminary loss of the ability to be metabolized.

"Thus, the theory of cyclization, which ignores metabolism, that fundamental quality of life, is entirely unacceptable from the methodologic viewpoint, as are in general all theories that attempt to understand individual evolution and its mechanisms from the viewpoint of the law of entropy" (A. V. Nagorniy, 1940).

The valuable experimental material obtained by A. V. Balgoveshenskiy retains its significance for the age-associated and evolutionary biochemistry of plants. Its interpretation must bear in mind the fact that the increase in cyclic compounds in the ontogenesis of plants is the result and not the cause of agelinked changes in metabolism. In addition to this, even in plants the relationships are far from being as simple as the cyclization theory would make them. As far as the animal organism is concerned, we find that the changes in the composition of the protoplasm that are actually observed are extremely complex and do not fit into the simplified schema of cyclization.

The problem of the age-associated development of plants was studied by N. P. Krenke (1933-1939) and his pupils (1933-1950). He advanced his theory of "cyclic aging and rejuvenescence" of plant organisms. In his fundamental monograph, which appeared posthumously (in 1940), he formulated the basic elements of his theory in the following manner:

"1. The individual inevitably grows old and dies.

"2. Aging, i.e., changes in the age-associated condition, does not usually agree with the calendar age of the individual.

"3. Aging, and hence the duration of life, are dependent on evolutionary factors but are greatly affected by the external conditions of development.

"4. All phenomena in the organism are connected to some extent with its age-associated state.

"5. Aging proceeds without interruption but not uniformly both for the individual as a whole in its various age-associated and phasic states and for the individual parts and signs of the individual.

" 6 . In the process of total individual aging, there is inevitably an uneven cyclic rejuvenscence in the neoformation of the living elements of the individual. But the absolute degree of this rejuvenescence progressively drops, i.e., aging is reflected in a progressive decrease of rejuvenescence.

"7. Rejuvenescence is the neoformation and development of young structures and substances and also the retardation of the aging of existing elements, but not a restoration of the past.

"8. The development of the organism is a struggle and unity of opposing processes in it: aging and rejuvenation.

"9. The age-associated condition of the parts of the individual is determined by the inherent and general age-associated state. The specific ageassociated condition is the result of the processes that have gone on from the time of formation of the part in question, but these processes depend on the 
general age-associated state of the individual as a whole up to the timc of the formation of the part in question.

"10. The mechanism and intensity of the aging process differ in resting and in dividing cells."

Krenke was of the opinion that the slowest aging of all is exhibited by resting meristematic cells, which retain their capacity for energetic division. Among such tissue elements are the points of growth of sleeping and adventive [tr.: ?] buds and the growth points of germinating seeds. The aging process proceeds at the highest rate in "stormy" cell divisions.

"11. The age-associated variability has its regular morphologicphysiologic and biochemical expression, being characterized by curves with ascending and descending branches or with evident derivatives of thesc curves, i.e., on the ascending and descending branches, the development of aging is expressedin general-in an opposite way."

Krenke made a sharp distinction between two concepts of age: inherent and general age and maturity. "The inherent age of a part of a plant is that time that has elapsed from the moment of its formation to the time under consideration, whereas the general age of this same part is determined by its inherent age and the age of the individual as a whole to the time of formation of the element in question.

"The term maturity is used to designate the actual vital capacity of the individual and its parts at the time under consideration, which is not usually fully correlated with their calendar age." He supports this position by the following example:

"As a rule, with the same inherent maturity, those simple organs or parts of them that possess a greater general maturity will be older. For example, month-old leaves of young tea or mulberry plants will be definitely younger than month-old leaves, developing under the same conditions, of old individuals of the same races of plants."

Krenke's theory has had a certain importance in selection (especially of perennial plants), in the multiplication of plants (especially vegetative), in plant surgery and phytopathology. It has doubtless enriched contemporary ideas about the very concept of age and the character of age-associated changes in plant organisms, i.e., in objects in relation to which these concepts are especially complex and least investigated. A plant is a much less "compact" and indivisible biological system than an animal. In the plant world, we find most strongly represented a "dismemberment" and a considerable independence of the parts of the organism. In addition to this, we find in plants the greatest contrasts in the duration of life: from several minutes or hours in primitive microscopic plants to several thousand years among the Macrozamia, in Wellingtonia, the yew, the oak, the baobab, the Lebanese cedar, the Australian eucalyptus, and the Mexican cypress.

The ontogenesis of plants is highly dependent on their passing through various states (the "staged" character of their development is very pronounced), and this also complicates the establishment of a unitary theory of their ageassociated development. 
It is natural that we will still need a prolonged development of plant physiology before we ean establish the fundamental premises of a fully valid theory of the ontogenesis of the plant organism. Krenke's theory represents the first steps in this extremely important area. Some of his propositions are very questionable or obseure. Thus, it is diffieult to agree with his reduetion of the development of the organism to a struggle between aging and rejuvenescenee, and henee with his reduetion of the eonecpt of vital eapaeity to the eoneept of maturity. The development of the organism proceeds in time and gives rise to extensive age-associated ehanges, but this development is certainly immeasurably rieher in its differentiation, adaptation, and change in its interaetions with external conditions than the inherent agc-associated changes. Hence the vital potential of the organism also is not the consequence of its age alone, although it is indeed dependent on it to a considerable degree. Also questionable is his statement that the meehanism of aging differs in the resting and in the dividing eell. The tempos of aging may actually be different in them, but we eannot agree with the view that rapidly dividing tissue ages most rapidly of all. Thus, the vigorously dividing eells of the malpighian layer of the cutaneous epidermis, the intestinal epithelium, and the hemoeytoblasts of the bone marrow in the higher vertebrates retain their viability to the greatest extent. The rate of division of cells is by no means always proportional to the rapidity of their differentiation.

In any ease, N. P. Krenke's theory must be reeognized as a scrious attempt to develop a general theory of ontogenesis with respeet to the peculiar conditions in the plant organism.

Proeeeding from her ideas about the hemato-encephalie and histo-hematic barriers, L. S. Shtern (1935-1940) stressed the great importance of the ageassociated consolidation of the colloids of these barriers and the resultant lowering of their permeability with the onset of old age. Both in the studies by her school and in a number of other investigations we find some eviclence in support of such a reduetion of permeability. Thus far, it is diffieult for us to asecrtain the actual significanee of these still relatively unstudied changes in the total complex picture of aging of the organism as a whole.

O. B. Lepeshinskava (1935-1953) regards aging as the consequence of the age-associated condensation of the colloids of the ecll membranes. Ageassoeiated eondensation of the "superficial cortex" of the cytoplasm may be regarded as having been established in a number of eases. In addition to this, we must bear in mind the fact that the uninterrupted flow of the metabolism "sweeps away," after a few days or even hours, the molccules and their colloidal aggregates and does not give time for the appearance of hysteresis of the colloids (and espeeially of the proteins) in a pure form in the living protoplasm. Hence the condensation of the protoplasmic colloids is a eonsequenee of the qualitative changes in protein metabolism with age.

A number of studies by V. A. Negovskiy and his pupils (1939-1954) have not dealt with the struggle against premature aging but rather with premature human death, oecuring at a time when it is still possible for man, by making 
use of his vital rescrves, to save himself from death. This oricntation is of considerable importance in the development of Russian thanatology and in gencral mcdical practicc.

In 1945, a monograph appcared by Z. G. Frenkcl' entitled 'Prolongation of lifc and activc old agc." On the basis of a large amount of statistical material, this monograph sheds light on the problcms of the social-economic prerequisites of longevity and of the prescrvation of good spirits and hcalth even in extremc old age. Frenkel's charactcrizes thc oricntation of his investigations in the following fashion:

"Whercas other studies of old age and longevity usually take up and investigate from the biological vicwpoint the naturc and coursc of the aging processes in the organism, their plysiology and pathology, I have sct mysclf the task, in this book, of considering and clarifying the significance of the problem of old age in the total complex of the social-demographic problems that arise and develop in the course of the socialist reconstruction of socicty. My task is that of showing the social-economic and social-structual limits of the problem of the control of aging and of the mean life span. Achievement of this task is largcly connected with an analysis and evaluation of statistical-demographic materials."

The creation of a new branch of physiological-biochemical science, namely, that of agc-associated physiology and biochemistry, is inscparably linked with the scientific work of A. V. Nagorniy (1923-1953). In his investigations, he sct himself the task of clevating the study of the problems of aging and longevity to the levcl of the establishment of a new branch of biological scicnce, namely, ontophysiology, covering the mechanisms of the entire vital cycle of development of the whole animal organism, from its conception to its death.

Nagorniy's first theoretical study appeared as early as 1923: "Life, Old Age, and Death," and in 1934 he began his extensive experimental investigations, together with his pupils (I. N. Bulankin, V. N. Nikitin, A. A. Rubanovskiy, I. D. Shumenko, V. I. Makhin'ko, O. P. Silin, R. I. Golubistkaya, Ye. V. Parina, M. P. Kuznetsova, Ye. A. Sazonova, and others), for the purpose of making a systematic study of age-associated changes in higher animals. At thc same timc, many ideas were accumulated for the establishment of a future theory of ontogenesis.

Procecding from the dialectic-materialistic rcpresentation of life as a continuous process beginning with the fertilization of thc ovum and terminating with aging and death, Nagorniy formulated the subject and final objectives of age-associated physiology:

"Age-associated physiology is that science which studies the functional evolution of the individual vital process from its bcginning and up to its natural end and has as its final task the discovery of the objective mechanisms that are fundamental to the individual life cycle" (1936). General and comparative physiology is organically linked to age-associated physiology, the initial principle of which is exprcssed in the following words of F. Engels: "A plant, an animal, evcry cell at cvery instant of its life is identical with itsclf and yct differs from itsclf as a result of its assimilation and cxcretion of substances, as a result of the 
respiration, formation, and dying off of cells as a result of the continuing process of circulation, in a word, as a result of the sum of the continuous molecular changes that constitute life and whose total results appear before our eyes in the form of the vital phases: embryonic life, youth, sexual maturity, the process of multiplication, old age, and death."'6

Regarding the organism as an integral system in which chemical, physicalchemical, functional, and structural characteristics and properties are mutually dependent on one another and indissolubly bound, forming a closed unity of chemistry, structure, and function, Nagorniy believed that the cstablishment of a complete theory of individual evolution is possible only on the basis of a deteiled study of all these forms of appearance of vital activity in their age-associated evolution.

Nagorniy's ideas have confronted and are confronting age-associated physiology, biochemistry, and morphology with such major tasks as the following:

(a) the creation of a total picture of the age-associated changes in the biochemistry, structure, and functions of the animal organism that will cover fully and consecutively all the stages of its ontogenesis;

(b) the establishment of the major factors in the ontogenetic changes of the organism that determine the shifts in the stages of age-associated development from the stage of progressive growth to the stage of deep regression;

(c) on the basis of this, the discovery of ways to affect the ontogenesis of the animal organism and thereby effect a change in its nature in the direction of an increase in the duration of life and preservation of the vitality of the organism during the period of late ontogenesis;

(d) the creation of a valid and effective theory of the age-associated development of organisms, which will be of decisive importance in the search for ways of influencing the nature of organisms.

Nagorniy's laboratory performed some very important work on the ageassociated changes in structure, the colloidal state, biochemistry, and physiological processes in higher animals. Particularly full studies were made of the biochemical features of the ontogenetic changes in the protein composition of protoplasm, linkages of proteins with nucleic acids and lipids, changes in the ratios of the fractions of nucleic acids (RNA and DNA), qualitative and quantitative changes in the nucleic acids (the ratios of pentoses and phosphorus in them), changes in the so-called structural proteins, the amino acid composition of proteins and of their various fractions, the colloidal-chemical stability and electrical charge of the protoplasmic proteins, and the enzymatic "spectra" of protoplasm.

A thorough study was made of the ontogenetic changes (in tissucs and organs) of water, mineral substances, lipids, phosphatides and sterols, reserve alkalinity and $\mathrm{pH}$, active acidity and buffer propertics of the tissues, their reduction and oxidation potentials, electroconductivity, the energy of activation of enzymes and of the protein substrate, and many other matters.

- F. Engels: Dialectic of Nature, Gospolitizdat, 1948, pp. 170-171. 
Among the physiological indices of age-associated changes in tissues and organs, they investigated the changes in the total levels of the oxidative processes, tissue respiration, the activity of the individual enzymatic links in the oxidationreduction process, glycolysis, the characteristics of energy, protein, carbohydrate, and mineral metabolism, the composition and properties of the urine, and so forth. A thorough investigation was made of the ontogenetic changes in the functional capacities of the entire organism and of its individual tissues and organs, the synthetic abilities of the organism, especially in connection with the synthesis of proteins, formation of ATP, and oxidative phosphorylation, synthesis of urea in the liver, protective syntheses, stimulation of tissue respiration in the whole organism by various factors, the ontogenesis of the reactivity of the organism to the introduction of a variety of hormones and the influence of loss (removal) of a number of glands of internal secretion on its metabolism at various ages, and many other matters. Studies were made of age-associated changes in biochemistry and functions of denervated organs, which provided a good deal of data for judging the ontogenetic evolution of the relations between the nervous system and the peripheral organs.

Nagorniy and his pupils also conducted extensive histochemical and micro-anatomical investigations, which provided a considerable amount of material for age-associated histophysiology.

All these investigations laid a broad experimental basis for recognition of the major features of the age-associated changes in the animal organism as a whole.

The following very important conclusions can be drawn from these studies.

1. The ontogenetic development of the organism from its beginning in the form of the fertilized ovum to its death does not by any means represent a fatal path of uninterrupted degradation of the colloidal state, biochemistry, physiological functions, and macro- and microstructures. The first early stages of ontogenesis are connected with an increase in many potentialities and in the activity of the protoplasm. Even in later ontogenesis, there are some high potentialities of vital activity, often found in a latent form.

2. The aging processes in the organism appear chiefly in the form of disturbances of synthesis, the assimilatory phase, which indicates the major significance of the changes in this phase ("synthetic, reactive nodes" of the protoplasm) in the processes of ontogenesis. Along with this, aging is accompanied by substantial changes in the processes of dissimilation and an impairment of the reciprocal "fit" of the processes of synthesis and breakdown.

3. The functional and biochemical evolution of organisms does not proceed uniformly in the various organs and tissues, also not uniformly with respect to the unity of the assimilatory and dissimilatory phases of the life process. With increasing age, there is an increase in the disharmony of the adjusted unity of the total animal organism.

4. With increasing age, the processes of synthesis become all the more "expensive" as regards energy. An increasingly small part of the organism's energy metabolism is used for the synthesis and resynthesis of the substances of the protoplasm. 
5. The aging processes are connected with a "falling off" of the utilization of the energy of oxidational processes for the synthesis of macrocrgic systcms of tissues, and the very consumption of the energy of the macrocrgs "falls off" with the processes of synthesis. As a result, therc is a progressive decline of the synthetic potentialities of the organism with increasing age.

6. With increasing age, there is an increasing disharmony in the neurohormonal regulation of the vital processes and in the coordination and reciprocal "fit", dependent on this regulation, of the processes of the animal organism as a whole. There is a decline of the vitality of the neurohormonal regulation and a decrease of the ability of the tissues to respond to this action.

7. In ontogenesis, thcre is a progressive suppression of the capacity for restoration of the composition of the protoplasm of the organism to its full valuc, a decrease in autoregencration of the protoplasm complex, which leads to irrcversible changes in the composition of the entire organism and of its individual tissues and organs.

This last concept is based on the following extremely important statement by F. Engels: "Life is a method of existence of protein substances, and this method of existence consists essentially in a continuous renewal of the constituent chemical parts of these substances . . ."7

This autoregeneration of proteins (protoplasm) develops with age, and this development is not a simple restoration of that composition of the protoplasm which is characteristic of the preceding stage of ontogenesis. In addition, the agc-associated development at the carliest stages is characterized by a capacity for autorcgeneration such that the total biochenical and functional potential does not drop but, on the contrary, incrcases. Thus, in his work entitled "Characteristics of the individual evolution of the animal organism" (1947), Nagorniy wrote as follows: "The amount of cnergy evolved by a unit of live weight after fertilization of the ovum first incrcases, then reaches a certain maximum at an age that is fixed and characteristic for the species in question, and thereafter decreases during the entire rest of the animal's life. This pattern is characteristic not only of the whole organism but also of its parts taken individually: of its organs and tissues, and consequently, of living matter itself."

Some very intcresting idcas are cxpresscd by Nagorniy as to the significance of the progressive structuration of protoplasmic formations at the beginning of ontogencsis. He starts with the notion that structural and functional specialization of protoplasm, arising in the differcntiation of cclls and tissues, initially plays the rolc of heightening the vital potential. It increascs the heterogenicity of the protoplasm, creates new colloidal surfaces, and intensifies the disequilibrium of the living matter as a whole.

"The resting ovum," writes Nagorniy, "exhibits an insignificant metabolism, and also, at the same time, apparently, an insignificant differentiation. The development of the ovum is also characterized by a heightened metabolism and an increased differentiation. This differentiation is multiple and varied;

${ }^{7}$ F. Engels: Anti-Duhring, Gospolitizdat, 1948, pp. 77-78. 
thanks to it, the organism in its various parts rcveals pliysical, physical-clicmical, and chemical hetcrogencity, and also, consequently, a capacity for work and mctabolism. It is entirely clcar that prolonged prescrvation of these heterogeneitics, esscntial for the rcalization of the vital proccss, rcquircs a certain spatial localization and fixation of the hetcrogencous parts, or in other words, morphological differentiation."

Nagorniy assigned a major role in the functional and structural spccialization of the protoplasm to the metaplasm. In the later stagcs of ontogcnesis, the activating role of the specialized formations and especially of the mctaplasma is reduced and then is climinated entirely, and phenomena of degradation make their appearance in the metaplasm. The tissues, overloaded by the metaplasm, lose their activating role, weaken, and grow old. Especially pronounced in this connection is their loss of their capacity for self-renewal.

Further investigations by pupils of A. V. Nagorniy showed (I. N. Bulankin, 1954; V. N. Nikitin, 1954) that differentiation leads to nucleoprotein depletion of the protoplasm and subsequent qualitative degradation of these nucleoproteins. Specifically, this can be one of the decisive conditions of the age-associated lowering of the synthesizing potentialities of the tissues.

Thus, Nagorniy removed aging from among the basic properties of life, from the contradictions inherent in the unity of life: ". . . because of causes that are to be found in the very essence of life, individual evolution, beginning with a marked predominance of the ascending processes, terminates with the victory of the descending processes. The contradiction that is the cause of the vital process is found, ultimately, to be also the cause of the negation of this life, the cause of the limitation of individual cxistcnce" (1940).

During the last years of his scientific creativity, Nagorniy advanced the concept of the nervous system as a factor that promotes longevity. He suggested that "the functions of the human cortex under certain conditions may be preserved without any apprcciable weakening for an extremely long time, and in any case longer than the fully efficient activity of the other systems of the organism" (1954). He bascd this vicw on the remarkable statement by I. P. Pavlov:

". . O Our nervous system is self-regulatory to the highest degree, and it is itself capable of self-improvement. One of the most important and strongest and most regular impressions that we obtain from studying higher nervous activity by our method is that of the extreme plasticity of this activity and of its trcmendous capabilities: nothing remains fixed, and everything can be achieved or changed for the better, provided that suitablc conditions exist.", 8

Developing this idea and applying it to the conditions of ontogenesis, Nagorniy writes as follows:

"No other part of the organism posscsses these propertics, this capacit! for almost unlimited alteration. It may be said that all systcms of the organism have 'lagged behind' the cortex of the cerebral hemispheres in their plasticity, and as a result of this it is completely conceivable that there are situations in

${ }^{8}$ I. P. Pavlov: Poln. sobr. trudov. vol. III, 1st ed., 1949, p. 454. 
which the cortcx is not in a position to ovcrcomc the 'inertia' both of the other parts of the central nervous system subordinatc to it and of the peripheral systems. It is casy to understand that as a rcsult of this conflict, the prescrvation of the harmonicity of the wholc becomcs impracticablc. This brings with it the hetcrochronicity of age-associated cvolution in the various parts of the organism, and, as a finale, the picture of a vigorous mind in a helpless body, with the terminal victory of the latter ovcr the formcr" (1954).

Nagorniy's ideas about the motive factors of ontogenesis represcnt the first draft of a major thcory, the development of which, as he himself understood, rcquired a grcat amount of subsequent work on the part of many research groups. It is natural that some elements of Nagorniy's teachings will be subjected to revision and amplification in this later work. Some weak aspects of Nagorniy's conccpts are to be found in a certain overrating of the significance of the role of metaplasia as the underlying factor of age-associated changes in organisms and a certain one-sided evaluation of the significance of thermodynamic mechanisms in the development of the vital processes in ontogenesis. Aside from this, however, contemporary ontophysiology knows how much it owes to Nagorniy for his great contribution to the creation of this rapidly developing branch of biological science.

The future valid and complete theory of ontogenesis will doubtless take into consideration all the great advances that have been made in the field of age-associated physiology by many of its investigators. In the great outflow of creative thought, in the rapid replacement of the sometimes very contradictory and one-sided concepts of the age-associated development of the organism, it has gradually become possible to select and critically evaluate many important concepts and to enlarge them substantially. The individual elements of a fullvalued theory of ontogenesis will doubtless contain the thoughts and discoveries of I. I. Mechnikov, M. S. Mil'man, A. A. Bogomolets, I. P. Pavlov, A. V. Palladin, N. P. Krenke, A. V. Nagorniy, and a whole pleiad of eminent Russian biologists and physicians.

In the present brief review of the history of Russian age-associated physiology, an effort has been made to present concisely the course of development of this outgrowth of science. This review has shown how much has already been accomplished in the creation of a fully satisfactory theory of ontogenesis and what have been the premises for the establishment of this Russian science. And it has also been made clear that much still remains to be done before we can accomplish the noble tasks of the remarkable science of thc causes of the age-associated development of organisms and of ways of promoting longevity. 


\section{BIBLIOGRAPHIC SOURCES}

At present, the problems of age-associated physiology, biochemistry, and morphology are being studied on a very large scale. We need only mention the fact that the bibliographic list published in the Journal of Gerontology (USA) last year contained 13,000 source references. In many coun tries, special journals are published that are devoted to the problems of aging, longevity, and ontophysiology (understood as the total study of the age-associated development of organisms). Among these, we should mention such journals as the following (the data in parentheses include the country and city where the journal is published and the year its publication started):

(a) Journal of Gerontology (USA, St. Louis, 1946)

(b) Geriatrics (USA, Minneapolis, 1946)

(c) Journal of American Geriatrics (USA, Baltimore, 1953)

(d) Bulletin of the Institute of Gerontology (USA, Iowa, 1954)

(e) Zeitschrift fur Alterforschung (GDR, Dresden, 1938)

(e) Longevita (Italy, Milan, 1952)

(f) Revista di Gerontologia e Geriatria (Italy, Rome, 1956)

(g) Acta Gerontologica (Italy, Milan, 1951)

(h) Giornale di Gerontologia (Italy, Florence, 1953)

(i) Revue Francais de Gerintologie (France, Paris, 1956)

There has been a widespread establishment of a variety of special societies and the convocation of annual international conferences and meetings on problems of age-associated physiology.

Unfortunately, bibliographic reviews of Russian ontophysiology and biochemistry are very rare and by no means reflect, to a sufficient extent, the great contributions of Russian scientists in this new and important branch of science. The review of work in this field written by A. V. Nagorniy (1938) is a very valuable one, but naturally it does not include the more recent studies. In 1951, there appeared a review of the literature entitled "Russian literature on age-associated changes in the metabolism and reactivity of the organism," by O. S. Shur'yan, I. V. Piskarskaya, and T. N. Stolyarova, in the proceedings of a conference at the Academy of Sciences, UkrSSR, devoted to these problems. Although this review covers only a part of the problems of age-associated physiology and pathology and even in these areas includes only some of the related material, it is of some scientific interest.

The present bibliography of Russian studies on ontophysiology is an attempt to fill the existing gap to some extent. Naturally, it has its flaws and has by no means succeeded in including all the older and newer studies. The author 
would be very grateful for any advice as to the possibility of completing the list, filling its gaps, and correcting its inaccuracies. The list is given in alphabetic order. 'This has its drawbacks (c.g., as compared with a subject breakdown of the material), but also its advantages. The most important of its advantages is the fact that an alphabetic list provides an opportunity to collect in one place all the works of each of the investigators who have worked in the field of ontophysiology: In addition, this order facilitates greatly the finding of individual studies.

In pre-Revolutionary Russia, studies on age-associated physiology, biochemistry, and morphology appeared periodically in individual journals. Some of these journals are still being published. Up to 1917, periodical collections devoted to ontophysiological problems were extremely rare.

After October [tr.: i.c., the 1917 Revolution], there was a considerable increase in the number of studies on age-associated physiology. They are published in many journals, and many of these first appeared during this period. Scientific conferences on these problems are organized regularly, and the results reported therein appear in periodic collections and special publications. A series of outstanding monographs are being published on the problems of aging, promotion of longevity, age-associated physiology, biochemistry and morphology, and pediatrics.

The following list gives the names and years of publication of a number of the basic scientific journals that have published comprehensive bibliographies on these problems.

Vrach, St. P., 1880-1901

Prakticheskaya meditsina, St. P., 1885-1917; L., 1923-1928

Arkhiv biologicheskikh nauk, St. P., L., 1892-1917, from 1922

Russkiy vrach, St. P., P., 1902-1913

Populyarniy literaturno-meditsinkiy zhurnal d-ra Oksa, St. P., 1906-1916

Gigiyena i sanitariya, St. P., 1910-1913; M., 1933; 1936-1940; from 1943

Pediatriya, M., 1911-1914; 1924-1930, from 1937 and currently. It has been combined with a number of closely related journals:

(a) Zhurnal po izucheniyu rannego detskogo vozrasta, 1922-1931

(b) Okhrana zdorov'ya detey i podrostkov, 1931-1932

(c) Zhurnal po rannemu detskomu vozrastu, 1932-1933

Russkiy arkhiv anatomii, gistologii i embriologii, M.-L., 1916; 1924-1930

Profilakticheskaya meditsina, Kharkov, 1922-1937

Zhurnal teoreticheskoy i prakticheskoy meditsina, Baku, 1924-1930

Ukrainski medichni visti, Kiev, 1925-1931

Ukrainskiy medichniy arkhiv, Kharkov, 1927-1932

Ukrainskiy biokhimichniy zhurnal, Kiev, from 1928

Voprosy pediatrii i okhrana materinstva i detskva, L., from 1929

Vrachebnaya praktika, M., 1929-1930

Arkhiv anatomii, gistologii i embriologii, M.-L., from 1931

Medichniy zhurnal AN USSR, Kiev, from 1931

Voprosy pitaniya, Moscow, 1932-1941; 1948-1951; collections, since 1952 
Uspekhi sovremennoy biologii, M., from 1932

Fiziologicheskoy zluurnal SSSR im. I. M. Sechenova, L., from 1932

Doklady AN. SSSR, Novaya seriya, M., from 1934

Akusherstvo i ginekologiya, M.-L., from 1936 and up to the present

Biokhimiya, M.-L., from 1936

Byulleten' eksperimentalnoy biologii i meditsiny, M., Medgiz from 1936

Tsentral'niy referativniy meditsinskiy zhurnal, M., 1936-1938; from 1929, broken down into series

Pediatriya, akusherstvo, i ginekologiya, Kiev, from 1939

Profilaktichna meditsina, Kiev, from 1930

Zhurnal obshchey biologii, M., from 1940

Zhurnal vysshey nervinoy deyatelnosti im. I. P. Pavlova, M.-L., from 1951

The number of Russian monographs and collections devoted to ontophysiological problems is so great that there is no possibility of reporting even the more important of them in the present paper. The best of them are the books by I. I. Mechnikov: "Studies of the Nature of Man" (1904) and "Studies of the Organism" (1907), and by A. V. Nagorniy "Problem of aging and longevity" (1940).

June 7, 1960. Paul DePorte, Translator.

Translated at the

National Institutes of Health, Bethesda, Md. 
RUSSIAN ALPHABET WITH TRANSLITERATION* (Same used for the Ukrainian)

$\begin{array}{lll}A & \mathrm{a} & \mathrm{L} \\ \mathrm{B} & \sigma & \mathrm{b} \\ \mathrm{B} & \mathrm{B} & \mathrm{J} \\ \Gamma & \Gamma & \mathrm{g} \\ \text { I } & \text { I } & \mathrm{d} \\ \mathrm{E} & \mathrm{e} & \mathrm{e} \\ \mathrm{K} & \mathrm{J} & \mathrm{zh} \\ 3 & 3 & \mathrm{z} \\ \mathrm{H} & \mathrm{I} & \mathrm{I} \\ \mathrm{K} & \mathrm{K} & \mathrm{k} \\ \mathrm{I} & \mathrm{I} & \mathrm{I} \\ \mathrm{M} & \mathrm{M} & \mathrm{m} \\ \mathrm{H} & \mathrm{H} & \mathrm{n} \\ \mathrm{O} & 0 & 0 \\ \Pi & \mathrm{I} & \mathrm{p}\end{array}$

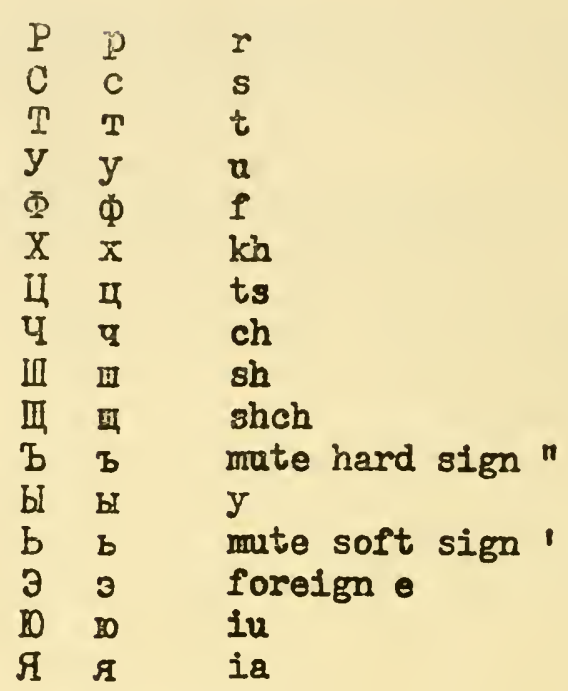

* Applicable to bibliographical references from 287-on. 


\section{Bibliography}

[Items are alphabetized by their transliteration from the Russian-See page 42]

A

1. Abashidze, V. S. "Ontogenesis of the Cerebrospinal Neural Plexuses in Man." Trudy Instituta Eksperimental'noy Morfologii A. N. Gruzinskoy SSR, 4: 215-241, 1953.

2. Abbakumova-Zepalova, O. N. "AgeAssociated Variations in the Content of Cholesterol and Lipoidal Phosphorus in the Skeletal Muscles of the White Rat." Byull. Eksperimental'noy Biologii $i$ Meditsiny, XXVI (1): 53-55, 1948.

3. Abel'man, M. A. "Contemporary Theory on the Role of Mineral Salts in the Physiology and Pathology of Breast-fed Infants." Pediatriya, (1): 137, 1911.

4. Abel'man, M. L. "The Problem of Infection in the Fetus and in the Newborn Infant." Pediatriya, VIII (1): 37-50, 1924.

5. Abramson, F. L. "Data on the Problem of Age-Associated Characteristics in the Ennervation of the Lungs." Izvestiya Akademii Pedagogicheskihk Nauk RSFSR, 60 131-142, 1954.

6. Abros'kin, V. V. “Ontogenetic Development in Vertebrates of Adipose Inclusions in Cartilage Cells and Its Physiological Relation to Growth." Trudy Voronezskogo Instituta, 42, (1): 56-58, 1955.

7. Abutalybov, M. G., and Geibov, Z. G. "The Aging and Development of Plants Under Various Feeding Regimens of Nitrogen and Phosphorus." $D A \mathcal{N}$ (Reports of the Academy of Sciences) Azerbadzhan SSR, 2 (3), 1946.

8. Avazbakieva, M. F. "Restoration of Cardiac Activity and Respiration After the Setting-in of Clinical Death in Young Dogs." Izvestiya Akademii Nauk Kazakhskoy SSR, No. 45, Seriya Fiziologicheskaya, v. 1. Collection of papers on age-associated and comparative physiology. Alma-Ata, 1948, p. 63.
9. Avakyan, A. A. "Some Problems of Individual Development in Plants." Agrobiologiya, (2): 10-21, 1948.

10. Avizonis. "Age-Associated Changes in the Eyes." Russkiy Oftal'mologicheskiy Zhurnal, XI (5): 635-645, 1930.

11. Avrekh, V. V., and Geronimus, Ye. S. "Serological Analysis of Ontogenisis in the Bee." Byull. Eksperimental'noy Biolobii i Meditsiny, IV (6): 505-507, 1937.

12. Avsarkisyan, S. O. "Age-Associated Changes in the Activity of the Physiological System of Connective Tissue as Revealed by Intradermal Trypan Blue Tests." Pediatriya, (6), 1949.

13. Ageychenko, F. Ye. "Age-Associated Changes in the Epiphysis." Sbornik Anatomofisiologicheskie Osobennosti Detskogo Vozrasta, Biomedgiz, Moscow-Leningrad, 1935, pp. 229-266.

14. - "Age-Associated Characteristics in the Structure of the White Matter in the Brain". Arkhiv Patologii, (5): 45-52, 1947.

15. Ado, A. A. "Certain Age-Associated Characteristics in the Reactivity of Tissues." Tezisy Konferentsii po Vozrastnym Izmeneniyam Obmena Veshchesto $i$ Reaktivnosti Organizma (Theses Presented at the Conference on AgeAssociated Changes in the Metabolism and Reactivity of the Organism), Kiev, 1949.

16. ㄴ. "Certain Age-Associated Characteristics in the Allergic Reactivity of the Organism." Trudy Konferentsii Povozrastnym Izmenemiyam Obmena Veshchesto $i$ Reaktionosti Organizme (Transactions of the Conference on Age-Associated Changes in the Metabolism and Reactivity of the Organism), $\mathrm{Kiev}$, 1951.

17. Akopyan, K. A. "Age-Associated Variability of the Blood Complex in Cattle. Doklady VASKhHIL (Reports of the All- 
Union Lenin Academy of Agricultural Sciences), (5-6): 1939.

18. Akuun, A. A. "The Anatomy of Renal Nerves in Hogs." Uch. zap. Vile-Bskogo Veterinarnogo Instituta (Scientific Annotations of the Vitcbsk Vetcrinary Institute), (12): 1949-155, 1953.

19. - "The Blood Supply of the Spinal Cord and of the Ccrebrospinal Ganglia in Dogs-X-ray Studies." Uch. znp. Vitebskogo Veterinarnogo Instituta (Scientific Annotations of the Vitebsk Veterinary Institute), (12): 141-148, 1953.

20. Alad'ina, A. N., and Surikov, M. P. "The Effect of Glutathione on Oxygen "vakat" and Upon the Oxidation Factor in the Urine of Aged Rats." Byull. Eksperimental'noy Biologii $i$ Meditsiny, 38 (1): 37-39, 1954.

21. Aleksandrov, G. N. "Age-Associated Characteristics of the Blood Supply of the Lower Jaw." Trudy Uzbekskogo Gos. Instituta, II, 83-89, 1935.

22. Aleksandrov, S. N. "The Age-Associated Rate of Dissemination of Musculary Lesions in Frogs." DAN SSSR (Reports of the Academy of Scicnces USSR), 63 (4): 459-462, 1948.

23. Aleksandrova, K. P. "Opsonin Index in Children of Tender Age." Voprosy Pediatrii i Okhrany Materinstva i Detstva (Problems of Pediatrics and the Care of Mother and Child), I2 (9): 417-423, 1940.

24. Aleksanyan, A. M. "Ccrtain Methods of Studying the Evolution of a Function Ontogenctically." Fiziologicheskiy Zhurnal SSSR, 34 (1): 27-32, 1948.

25. Alekseev, A. M. "The Effect of the Water Regimen on the Age-Associated Variability of Wheat Leaves." Trudy Kazanskogo S.-Kh. Instituta im. Gor'kogo, (1): 20-39, 1947.

26. Alekseeva, G. I. "The Effect of Temperature and Humidity on the Growth and Development of Young Hogs." Trudy XVI Plenuma Veterinarnoy Sektsii VASHIhNII ('Transactions of the 16th Plenary Session of the Veterinary Section of the All-Union Lenin Academy of Agricultural Sciences), 21-22 Feb. 1940.

27. —- "The Effect of Relative Air Humidity on the Nitrogen Metabolism and the Blood Complex of Piglcts. Sbornik po zootekhnikei parazitologii. Institut botaniki $i$ zoologii, $i z d-v o A \mathcal{N} U z S S R$ (published by the Academy of Sciences Uzbek SSR), Tashkent, 34-51, 1948.

28. Alemseeva, L. V. "Changes in the Composition of the Red Blood Cells and Body Weight in Femalc Monkeys in Relation to Sexual Cycles. Byull. Experimental'noy Biologii i Meditsiny, (1): 54-58, 1954.

29. Alekseeva, T. T. "Pharmocological Characteristics of the Neuromuscular Synapse in Ontogcnesis." Byull. Eksperimental'noy Biologii $i$ Meditsiny, 16 (6): 42-45, 1943.

30. Alemseenko, N. Yu., Samsonova, V. G., Alekseev, N. A., Martycheva, L. D. "Certain Characteristics of the Interaction of the first and second signal systems in analysing of optical and auditory stimuli in grownup humans." Eighth All-Union Conference of Physiologists, Biochemists, and Pharmacologists. Tesisy Dokladov, Isdatel'stvo ANSSSR (Theses of Reports, Published by the Academy of Sciences USSR), Moscow, 21, 1955.

31. Alelekov, A. N. "Old Age-a Clinical Study in the Area of the Nervous System and Psychoplyysiology." Thesis No. 64 of a series of theses defended at the VoennoMeditsinskaya Akademiya (Military Medical Academy) in 1891-1892. SPb (St. Petersburg), 1812.

32. Aliev, B. A. "Erythrocyte Index in Sheep in Relation to Sex, Age, and Reproduction." ANSSR (Academy of Sciences USSR), VIII (3): 1947.

33. Alpatov, V. V., and Pearl, R. "Experimental Studies on the Duration of Life." XII. Americ. Natur., 63: 37, 1929; 64: 37, 1930.

34. Alpatov, V. V. "Population Density as an Ecological Factor." Uspekhi Sovremennoy Biologii, III, (2): 229, 1934

35. - "Environment and the Growth of Animals." Sbornik Rost Zhivolnykh (Collection of Papers on the Growth of Animals), edited by S. Ya. Kaplanskiy and others. Biomedgiz, Biomedgiz, Moscow-Leningrad, 326-366, 1935.

36. Aluker, R. A. "Age-Associated Characteristics in the Elimination of Sulfur in 
Infants During 'Their First Year of Lifc." I-ya Sessiva Moskovshogo Obshchestva Fiziologov, Biokhimikov, Farmakologov First Session of the Moscow Society of Physiologists, Biochemists, and Pharmscologists - - a collection of reports cdited by docent M. V. Kirzon, Prof. M. P. Nikolaev, and others, Moscow-Leningrad, Medgiz, 9-1 1, 1941.

37. "Sulfur in the Urine of Infants During Their First Year of Life." Voprosy Meditsinshoy Khimii, 6: 62-69, 1953. 38. Al'banskaya, T. I. "The Cytology of

Lesions of the Mouth Mucosa in Children.' Stomatologiva, (3): 21-25, 1949.

39. Al'tgauzen, N. F. "A Study of the Effect of Anesthetics in Labor on the Newborn Infants." Akusherstvo i Ginekologiya, (4): $71-74,1937$.

40. - "The Newborn Infant and His Ailments." Textbook on the ills of early childhood, edited by G. N. Speranskiy, Biomedgiz, Moscow-Leningrad, ch, 5, 94-115, 1938.

41. Al'kilovskiy, M. YE. "Manifestations of Aging in the Lumbosacral Section of the Spine." (X-ray and Anatomical Study) Vestnik Rentgenologii $i$ Radiologii, 18 (2): 113$124,1937$.

42. Amirov, KH. N. "Morphology of the Pclvic Section of the Sympathetic Nervous System in Children." Trudy Kazanskogo Meditsinshogo Instituta, No. 1, collection of papers by the Chair of Human Anatomy, 109-132, 1948.

43. Andreev, K. A. "Mortality Statistics -A Theoretical Study on the Laws Governing Mortality and the Compilation of Mortality Tables for Russia." Tipografiya Moscouskogo Universiteta (Moscow University Press), Moscow, 1871.

44. Andreev, L. A. "Data Pertaining to the Study of Age-Associated Functional Alterations in the Central Nervous System." Trudy Fiziologicheskikh Laboratoriy Akad. I. P. Pavlova, v. 1, No. 1, 1924; 2nd edition, published by the Academy of Medical Sciences USSR, Mfoscow, 74-82, 1953.

45. Andreev, L. G., Avdusina, YE. I. "The Karyotype (chromosomal constitution) of the Soma in a Full-grown Man." Report $\mathrm{V}$-On the Karyology of Certain Precanroids of the Skin. Byull. Eksperimental'noy Biologii i Meditsiny, LX (6): 386-388, 1940.
46. Andreev, S. V. "Phylo- and Ontogenetic Laws in the Restoration of the Heartbeat in Human Cadavers." Arkhiv Patologii, VIII (5-6): 37, 1946.

47. Andres, A. G. "The Shifting of the Isoelectric Point in Erythrocytes in Relation to Age." Zhurnal Eksperimental'noy Biologii Meditsiny, VI (17): 285, 1927.

48. Anisimova, V. V., and others. "The Effect of a Testoligature by the Mikhaylovskiy Method Upon the Higher Nervous Activity of an Old Dog." Klinicheskaya Meditsina, XIV (4): 528-530, 1936.

49. Anichkov, N. N. "Pathologic Anatomy and Pathogenesis of Atherosclerosis by the Data from International Autopsy Materials." Arkhiv Biologicheskikh Nauk, 3g (1): 51-86, 1935.

50. - "Current Status of the Problem of the Etiology and Pathogenesis of Sclerosis." Klinicheskaya Meditsina, XV (3): 347-355, 1937.

51. "Alterations in the Arteries in Advanced Old Age and in Atherosclerosis." Trudy Voenno-Meditsinskoy Akademii Krasnoy Armii im. S. M. Kirova, XXXIII, Leningrad, 5-19, 1941.

52. Anorova, N. S. "Characteristics in the Development of the Chick Embryo in Relation to the Age of the Parents." DAN SSSR (Reports of the Academy of Sciences USSR), XCI (4): 981-983, 1953.

53. - "The Effect of Parental Age on the Post-embryonic Development and Viability of the Offspring in Birds." $D A \mathcal{N}$ SSSR (Reports of the Academy of Sciences USSR), 100 (2): 369-372, 1955.

54. Anokнin, P. K. "Systemogenesis as the Prevailing Pattern of the Evolutionary Process." Byull. Eksperimental'noy Biologii $i$ Meditsiny, 26 (8): 81-89, 1949.

55. - "The Physiological Gradient, Reflex, and Functional System as Factors in the Embryonic Development of Unconditioned Reactions." Zhurnal Obshchey Bio$\log \ddot{i i},(5)$ : 361-385, 1949.

56. Antonov, A. N. "Variations in the Weight of Newborn Infants During the First Days of Life in Relation to Their Milk Intake." Referativny Zhurnal po Izucheniyu Rannego Detskogo'Vozrasta, 1 (5-6):_115-116,\$1923. 
57. "Erythroblastoses in Newborn Infants." Voprosy Pediatrii $i$ Okhrany Materinstva $i$ Detsiva, XII (4): 127-150, 1940.

58. - "Intra-uterine Respiratory Movements of the Fetus." Voprosy Pediatrii i Okhrany Materinstva i Detstva, XIII (2): 119-124, 1941.

59. "The Newborn During the Leningrad Siege (1942) - the Effect of Starvation in Pregnancy on the Newborn Infant." Voprosy Pediatrii $i$ Okhrany Materinstva i Detstva, XV (2): 26-39, 1947.

60. Antoshinina, Ye. D. "Ontogenetic Development of Thermal Control. Communication 1. Development of Temperature Control in Rats Bred Under Normal Conditions." Fiziological Journal of the USSR, 26, (1): 3-15, 1939.

61. "Ontogenetic Developinent of Thermal Control. Communication II. Development of Thermal Control in Rats Bred Under Conditions of High and Low Temperature." Fiziologicheskiy Zhurnal SSSR, 26 (1): 16-29, 1939.

62. - "Ontogenetic Development of Thermal Control. Communication 3. Age-Associated Characceristics of the Reaction of Rats to Heat Injection." Fiziologicheskiy Zhurnal SSSR, 30 (2): 160-168, 1941.

63. Anucrin, A. A. "Internal Patterns of the Process of Growth." Byull. Eksperimental'noy Biologii $i$ Meditsiny, II (1): 32-34, 1936.

64. Araratyan, A. G. "Assimilation as Ontogenesis of Living Matter." Izvestiya $A \mathcal{N}$ (Academy of Sciences) Armyanskoy SSR, Biological and Agricultural Sciences, 8 (10): 87-96, 1955.

65. Argutinsky, P. "Ueber eine regelmassige Gliederung in der gramen Substanz des Ruckenmarks bein Neugeborenen und Ueber die Mittelzellen." Arch. Mikrosk. Anat. Bd. 48, S. 496-522, 1896.

66. ARINkIN, M. I. "Clinical Manifestations of the Diseases of the Blood and of the Homopoietic Organs." Prakticheskaya Meditzina (Practical Medicine), 33-34, 1928.

67. Arist, I. D. "The Vaginal Cycle in Senile Women as a Biological Test of the Functional Activity of the Estrogenic Hormone." Akushersivo $i$ Ginekologiya, 2: 7-9, 1948.
68. ARKIN, YE. A. "Characteristics of School Age." Osobennosti Shkol'nogo Vozrasta, Moscow, 1947.

69. ARKuSsKIY, YU. I. "Rentgenokymographic Study of Blood Circulation and Respiratory Organs in the Newborn. Communication I." Voprosy Pediatrii i Okhranymaterinstva i Detstva, 15 (5): 57-58, 1947.

70. - "Orthodiagraphic Study of the Heart and the Aorta in Children in Conjunction with Somatometry." Vestnik Rentgenologii $i$ Radiologii, 3 (2): 143-152, 1947.

71. Aroni, M. "The Erythrocyte Precipitation Reaction in Children." Vrachebnoe Deto, (6): $423,1927$.

72. Arsen'yev, A. F., Solum, A. S. "Hypovitaminosis $\mathrm{B}_{2}$ in Chicks." Fiziologicheskiy Zhurnal SSSR, XVIII (2): 318-328, 1935.

73. ARsen'yev, A. F. and Khlibnikov, N. I. "The Effect of Autoclave Hydrolysates on the Growth of Chicks." Problemy Endokrinologii, II (1): 49-58, 1937.

74. Artemov, N. M. "Studies in the Hormonal Function Development at Various Stages of Ontogenesis. Communication I. Content of Adrenalin-like Substances in the Chromaffin Organs of Cow Embryos." Byull. Moskovskogo ob-va Ispytateley Prirody, Biological Division, 46 (6): 323-329, 1937.

75. - and VAledinskaya, L. $\mathrm{K}$. "Study of the Development of the Hormonal Function at the Early Stages of Ontogenesis. Communication II. Thyroid Hormone and Iodine Content in the Thyroid Gland of Cow Embryos." Byull. Moskouskogo ob-va Ispytateley Prirody, Biological Division, 47 (2): 188-193, 1938.

76. Artem'yev, I. N. 'Age-Associated Sexual and Occupational Shifts in Blood Pressure." Gigiyena Truda, (5), 1928.

77. Arutyunova, A. YA. "Age-Associated Variations in the Number of Nerve Cells and Glia(neuroglia) in Man." Azerbayanskiy Meditsinskiy Zhurnal, (1): 150-155, 1938.

78. ARUTYUNYaN, S. I. "Innervation of the Heart in Fetuses and in Newborn(extracardial part)." Diss. Leningradskiy Pediatricheskiy Institut, Leningrad, 1946.

79. Arkiangel'skaya, M. F. "Carotid Sinus Reflex to Respiration in Ontogenesis." 
Byull. Eksperimental'noy Biologii i Meditsiny, XI (5): 439-441, 1941.

80. - "Carotid Sinus Reflex to Respiration in "Young Dogs." Izvestiya $A \mathcal{N}$ (Academy of Sciences) Kazakhskoy SSR, 45, Physiological Series, (1): 50-52, 1948.

81. Arkhangel'skaya, N. A. “Metabolism Control in a Premature Infant after Food Intake." Fiziologicheskiy Zhurnal SSSR, XL (4): 431-440, 1954.

82. ARKhangel'SkiY, I. I. "Sensitivity of Young Pigs to Scarlatina Toxin." Zhurnal Mikrobiologii, Epidemiologii, $i$ Immunobiologii, (11-12): 98-101, 1939.

83. Arkhangel'skiy, M. I. "Determining the Zones of Comfort for the Newborn." Sovetskoye Zdravookhranenie Turkmenii, (1), 1940.

84. Arshavskaya, E. I., and Yenikeeva, S. I. "The Mechanics in the Formation of Edema of the Lungs in Relation to Various Age Periods." Byull. Eksperimental'noy Biologii i Meditsiny, XVI (4-5): 27-28, 1943.

85. Arshavskaya, E. I. "Cardiovascular and Respiratory Reflexes During Various Stages of Ontogenesis in Response to Stimulation of Various Afferent Nerves." Brull. Eksperimental'noy Biologii $i$ Meditsiny, XVI (6): $39-42,1943$.

86. - "The Mechanics of the Formation of Traumatic Shock in Tender Age." Byull. Eksperimental'noy Biologii $i$ Meditsiny, XVIII (3): $41-43,1944$.

87. "Analysing the Mechanics of Histamine Intoxication during Various Age Periods. Communication I. Resistance of Dogs to Histamine in Relation to Age." Farmakologiya i Toksikologiya, VIII (3): 5-10, 1945.

88. _- "Restoration of the Loven Reflex in Ontogenesis." Byrll. Eksperimental'noy Biologii $i$ Meditsiny, XXII (3): 66-69, 1946.

89. - "Cardiovascular and Respiratory Reflexes in Response to Stimulation of Afferent Nerves of Various Receptor Areas in Ontogenesis." Fiziologicheskiy Zhurnal SSSR, XXXII (2): 229-236, 1946.

90. - "Respiratory and Cardiovascular Reflexes in Response to Stimulation of the Mucosa of the Trachea and Bronchial Tubes in Relation to Age." Fiziologicheskiy Zhurnal SSSR, 32(3): 377-384, 1946.

91. "The Mechanics of Vasodilatation in Response to Various Defensive Reactions(motor and inflammation)in Ontogenesis." VII Vsesoyuzny S"yezd Fiziologov, Biokhimkkov, Farmakologov, Moscow, Medgiz, 516-518, 1947.

92. - "The Mechanics of Age-Associated Stability to the Effect of Histamine." Fiziologicheskiy Zhurnal SSSR, 34(4): 495-504, 1948.

93. - "Characteristics of the AgeAssociated Vasomotor Component of the Inflammation Reaction." Byull. Eksperimental'noy Biologii $i$ Meditsiny, 25(6): 414-417, 1948. Abstracts of Papers by the Academy of Medical Sciences USSR, No. 5, Clinical Sciences, Moscow, 1948.

94. - "The Loven Reflex in Ontogenesis." Fiziologicheskiy Zhurnal SSSR, 34(2): 277-284, 1948.

95. —_. "Age-Associated Characteristics of Histamine Intoxication." Fiziologicheskiy Zhurnal SSSR, 34(4): 495-504, 1948.

96. - "Reactivity and its Characteristics in Ontogenesis." Tezisy Konferentsii po Vosrasinym Izmeneniyam Obmena Veshchestv $i$ Reaktivnosti Organizma (Theses of Conference on Age-Associated Variations in Metabolism and Reactivity), Kiev, 1949.

97. —A "Age-Associated Formation of Experimental Shock in Response to Nociceptive Stimuli. Communication 2." Fiziologicheskiy Zhurnal SSSR, 36(13): 333, 1950.

98. —. "Characteristics of Vasomotor Effects of Sympathetic Innervation at Various Stages of Ontogenesis." Byull. Eksperimental'noy Biologii i Meditsiny, 29(2): 120-122, 1950.

99. - "Reactivity and its Characteristics in Ontogenesis." Transactions of the conference on age-associated variations in metabolism and reactivity. Izdatel'stvo $A \mathcal{N} Y \mathrm{kr} S S R$ (Published by the Academy of Sciences Ukr SSR), Kiev, 173, 1951.

100. "The Formation of AgeAssociated Anaphylactic Shock in Dogs." Fiziologicheskiy Zhurnal SSSR, 38(6): 708-714, 1952. 
101.

"Age-Associated Pliysiological Mechanics in the Course of Fraumatic Shock, Anaphylactic Shock, and Shock Rcsulting from Loss of Blood." Problemy Reaktiznosti Shoka (1'roblems in Shock Reactivity) Trudy I V'sesoyuznoy Konferentsii Patofiziologov, Kazan, 31 Jan-4 Feb 1950, Moscow, Medbiz, 216,1952 .

102. "Hyperergia in Ontogenesis." Brull. Ehsperimental'noy Biologii i Meditsiny, (1): 49, 1953 .

103. "Age-Associated Neuroreflex Mechanisms in Animals and Humans." Trudy I Nauchnoy Konferentsii po Vozrastnoy . Korfologii $i$ Fiziologii (Transactions of the First Conference on Age-Associated Morphology and Physiology). Published by the Academy of Pedagogical Sciences RSFSR, Mloscow, 132-138, 1954.

104. "The Age-Associated Growth and Transformation of Neural Regulation in the Activity of the Vascular System." Materialy II Konferentsii po Voprosam Vosrastnoy Morfologii $i$ Fiziologii. Published by the Academy of Pedagogical Sciences RSFSR, Moscow, 11, 1955.

105. and Arshanskig, I. A. "AgeAssociated Formation of Experimental Shock in Response to Nociceptive Stimulation." Referay Nauchmo-issled. Rabot, AMNSSSR (Abstracts of Research Papers, Academy of Medical Sciences USSR), No. 5, Clinical Sciences, Moscow, 43-44, 1948.

106. Arshavskaya, E. I. and Arshavskiy, I. A. "Age-Associated Formation of Experimental Shock in Response to Nociceptive Stimulation. Communication I. Fiziologicheskiy Zhurnal, 35(6): 699-708, 1949.

107. Arshavskaya, E. I. and Sokolova, N. F. "Characteristics of the Inflammation Reaction and the Natural (physiological) Immunity during the Embryonic Period in Mammalia." Tezisy Dokladov na Soveshchanii Embriologov v Leningrade, Leningrad, published by Leningrad State University, 164, 1955.

108. Arshavskiy, I. A. "Neural Regulation of Cardiovascular Activity in Ontogenesis." Biomedgiz (State Publishing House for Biomedical Sciences) Moscow-Leningrad, $75,1936$.

109. "Regulation and Physiological Characteristics of the Variational Func- tional State of thc Pancreas in Ontogenesis". Arkiv Biologicheshikh Jauk, 51(1-2): 125, 1937.

110. - "Regulation and Physiological Characteristics of the Variational Functional State of thc 1 leart, Glands, and Skelctal Muscles in Ontogenesis." Sbornik Dokladov VI Vsesoyuznogo s"yezda Farmakologov, Biokhimikov, i Farmakologov, * published by the Organizational Committee of the Conference, Tbilisi, 379, 1937.

111. - "Agc-Associated Physiology." Report of the Research Activities of the VIEM (All-Union Institute of Experinental Medicinc) for 1933-1937, Moscow, 311, 1938.

112. and Rozanova, V. D. "Part Played by the Sympathetic Innervation in the Physiological Changes in Skeletal Muscles Ontogenetically." Byull. of Eksperimental'noy Biologii i Meditsiny, 5(2): 136-138, 1938.

113. Arshavskiy, I. A. and Malkiman, I. V. "Variation in the Chromxia of the 'n. cruralis' in Relation to Stimulation of the Sympathetic Innervation at Various Stages of Ontogenesis." Byull. Eksperimental'noy Biologii $i$ Meditsiny,

5(2): 142-144, 1938

114. Arshavskiy, I. A. "Parameter of Lability in Evolutionary Physiology." Fiziologicheskiy Zhurnal SSSR, 25(3): 199-207, 1938.

115. - and Kryuchikova, A. P. "Physiological Characteristic and Regulation Mechanism of the Salivary Glands in Ontogenesis." Fiziologicheskiy Zhurnal SSSR, 25(3): 208-217, 1938

116. ArshavskiY, I. A. "Control Mechanism for the Activity of Salivary Glands in Grown Animals." Collection by the AllUnion Institute of Experimental Medicine. $\kappa$ Mekhanizman Regulyatsii Devatel'nosti Pishchevaritel'nyu Zhelez (On the Control Mechanisms in the Activity of Peptic Glands), Biomedgiz, Moscow-Leningrad, 127, 1939.

117. and Rozanova, V. D. "The Refractory Phase of Skeletal Muscles in Ontogenesis. Communication 1." Fiziologicheskiy Zhurnal SSSR 26(6): 629-639, 1939.

*sic (should be: "Farmakologov, Biokhimikov, i Fiziologov") 
118. Arsilavskiy, I. A. "The Secretin Mcchanism for the Regulation of the Pancreas in Ontogcnesis." Fiziologicheskiv Žhurnal SSSR, 27(5): 540-551, 1939.

119. "Decerebration Rigidity in Kittens in Ontogenesis." Fiziologicheskiv Zhurnal SSSR, 28(5): 475-488, 1940.

120. - "Physiological Basis of Means Used to Prevent Asphyxia in Newborn Infants." Akusherstvo i Ginekologiya, (4): 11, 1940.

121. "Lipase in Mother's Milk and its Significance in Evaluating the Bottle Formula for Infants." Sovetskaya Pediatriya, (4): 11, 1940.

122. "The Sequence in the Formation of the Vasomotor and AdaptationalTrophic Effect of the Sympathetic Innervation on the Salivary Gland in Ontogenesis." Fiziologicheskiy Zhurnal SSSR, 29(1-2): 33-37, 1940.

123. "Neural Regulation of Respiratory Activity in Ontogenesis. Communication 3. The Evolution of the Initial Extrauterine Respiration Mechanism." Fiziologicheskiy Zhurnal SSSR, 29(5): 417-423, 1940.

124. ㄴ. "Neural Regulation of Respiratory Activity in Ontogenesis. Communication 4. The Evolution of the Respiratory Center in Ontogenesis." Fiziologicheskiy Zhurnal SSSR, 20(6): 517-525, 1940.

125. - and Yenikeeva, S. I. "Chromaxia and the Rhythm of the Heart in Ontogenesis." Arkhiv Biologicheskikh Nauk, 57(2-3): 47-54, 1940.

126. Arshavskiy, I. A. and Rozanova, V. D. "Chromaxia and the Rhythm of the Jellyfish Piloma Pulmo in Ontogenesis." Byull. Eksperimental'noy Biologii i Meditsiny, 9(6): 412-415, 1940.

127. Arshavskiy, I. A. "Analysing the Effect of Vagus Inhibition on the Heart Activity." Byull. Eksperimental'noy Biologii $i$ Meditsiny, 12(3-4): 169, 1941.

128. and Morachevskaya, YE. V. "Physiological Variations in the Gastrointestinal Tract as a Result of Dysentery Intoxication at Various Stages of Ontogenesis." Arkhiv Biologicheskikh Nauk, 61(2): 18$25,1941$.
129. ArsilavskiY, I. A. "The Fvolution of the Vasomotor Cinter in Ontogenesis." Fiziologicheshiy zhurnal SSSR, 30(1): 65-71, 1941.

130. "Physiological Characteristic and Regulation Mechanisms of the Cardiovascular System in Ontogenesis." Trudy Voenno-Meditsinskoy Akademii Krasnoy Armii im. S. M. Kirova, 33, Leningrad, 1941.

131. and Oganisyan, A. A. "Pfluger's Law on the Stimulation of a Nerve Tract by an Electric Current in Relation to its Polarity in Ontogenesis." Byull. Eksperimental'noy Biologii i . Keditsiny, 13(3-4): $70,1942$.

132. Arshavskiy, I. A. and OzeretskovSKAYA, N. YE. "The Evolution of Initial Intrauterine Respiration." Byull. Eksperimental'noy Biologii $i$ Nieditsiny, 15(4-5): 42 , 1943.

133. Arshavskiy, I. A. "Oxygen Therapy for Infants of Tender Age (oxygen tent)." Pediatriya, (2): 47, 1943.

134. - "Physiological Basis for the Sanitation-and Hygiene Standards to be Established for Children's Collective Gas Shelters." Pediatriya, (4): 9, 1943.

135. - Krasnovskaya, L. A., MaYAtnikova, V. A. "The Progress of Hypoxemia and the Adaptation Mechanism in Children of Tender Age." Pediatriya, (5): $7,1943$.

136. Arshavskiy, I. A., Krasnovskaya, L. A., Mayatnikova, V. A. "The Sensitivity of Children of Tender Age to Oxygen Deficiency." Byull. Eksperimental'noy Biologii i Meditsiny, 15(6): 40, 1943.

137. Arshavskiy, I. A. and Rozanova, V. D. "Physiological Basis for the Possibility of Individual Protection of Sucklings in an Unventilated Hermetically-sealed Gasproof Envelopes." Byull. Eksperimental'noy Biologii i Meditsiny, 16(6): 36, 1943.

138. Arshavskiy, I. A. and MorachevsKAYA, YE. V. "Age-Associated Physiological Mechanism of Anatomical Alterations in the Gastrointestinal Tract as a Result of Dysentery Intoxication." Dizenteriya $i$ Detey Grudnogo i Rannego Vozrasta (Dysentery in Sucklings and Infants of Tender Age). Central Scientific-Research Institute of Pediatrics under the Commissariat of Health RSFSR, Moscow, 191-200, 1944. 
139. Arsilavskiy, I. A. "Age-Associated Experimental Physiology, its Assignments and Channels of Development in the USSR." Pediatriya, (1): 18, 1944.

140. "The Appearance of Secondary Asphyxia in Premature Infants during the Act of Feeding." Pediatriya, (6): 33, 1945.

141. "Age-Associated Mechanism of Adaptive Reactions to Anoxemia." American Review of Soviet Medicine, Aug. 1954, New York, 1945.

142. - . "Physiological Bases for the Protection of Children Against Chemicalwarfare Attack." Monografiya NKZ SSSR (Monograph of the Peoples Commissariat of Health, USSR), Medgiz, Moscow-Sverdlovsk, 1945.

143. Morchevskaya, Ye. V., and Shtamler, S. M. "Lysozyme in the Saliva -in Ontogenesis." Byull. Eksperimental'noy Biologii i Meditsiny, 21(4): 69, 1946.

144. Arshavskiy, I. A. "The Physiological Significance of Intrauterine Respiratory Movements." Byull. Eksperimental'noy Biologii i Meditsiny, 22(1): 34-37, 1946.

145. "The Physiological Significance and the Regulation Mechanism of Intrauterine Respiratory Movements." Fiziologicheskiy Zhurnal SSSR, 32(4): 495-503, 1946.

146. - "Basic Indications and Methods of Combatting Asphyxia in Newborn Infants." Fel'dsher i Akusherka, (12): 42, 1946.

147. … "Physiological Mechanisms of Age-Associated Reactivity." Novosti Meditsiny, No. 6. Voprosy Pediatrii, Moscow, Academy of Medical Sciences USSR, 4-6, 1947.

148. - and others. "The Appearance of Primary and Secondary Atelectasis of the Lungs in Newborn Infants." Novosti Meditsiny, No. 6. Voprosy Pediatrii, Academy of Medical Sciences USSR, 15-17, 1947.

149. Arshavskiy, I. A. "The Mechanics of the Shift to Extrauterine Respiration." Byull. Eksperimental'noy Biologii i Meditsiny, 24(4): 296-298, 1947.

150. - "Physiological Understanding and an Analysis of Factors Involved in the Evolution of Form at the Early Stages of Ontogenesis in the Light of the Vvedenskiy-Ukhtomskiy Theory." Vesinik Leningradskogo Instituta, (12): 47-61, 1947.

151. "The Principle of So-called Double Antagonistic Innervation and Regulation of Activity of Various Systems of Organs (specifically, the heart) in the Light of Ontogenetic Data." VII Vsesoyuzuy S'yezd Físiologov, Moscow, Medgiz, 1947, 285-288.

152. - Yenikeeva, S. I., Ingberman, YE. M. "The Effect of Blindness during the First Days of Life on the Ontcg natic Transformation of Skeletal Muscles in Rabbits and Dogs." Byull. Eksperimental'noy Biologii i Meditsiny, 25(5): 321-323, 1948.

153. Arshavskiy, I. A. "The Significance of Muscular Activity during the Prenatal Period as a Determining Factor in the BloodCirculation Rate of the Fetus." Brull. Eksperimental'noy Biologii i Meditsiny, 26(3): $175-177,1948$.

154. "The Onset of Primary and Secondary Asphyxias in Newborn Infants." Trudy Plenuma Soveta Lechebnoy Profilakticheskoy Pomoshchi Detyam, Moscow, 1948, 9699.

155. - "The Mechanics of Shift of Respiratory Movements from Intra- to Extra-Uterine." Fiziologicheskiy Zhurnal SSSR, 34(1): 61-70, 1948.

156. - - KRYUChkova, A. P., and Oganisyan. "Certain Vestibular Reactions in Ontogenesis." Byull. Eksperimental'noy Biologii i Meditsiny, 26(6): 417-419, 1948.

157. Arshavskiy, I. A. and Soboleva, V. D. "An Attempt at the Physiological Analysis of Whooping Cough and Characteristics of its Progress in Children of Various Age Groups." Collection on Koklyush (Whooping Cough), Academy of Medical Sciences USSR, 1948, 16-45.

158. Arshavskiy, I. A. "Problems of AgeAssociated Physiology at the Seventh AllUnion Conference of Physiologists, Biochemists, and Pharmacologists." Pediatriya, (1): 5-13, 1948.

159. —Physiological Mechanisms in Ontogenetic Transformation of Functions (example: shift in the type of functioning of the respiratory system)." Zhurnal Obshchey Biologii, 9(1): 31-45, 1948. 
160. "Physiological Characteristics and Regulation of the Respiratory System of Suckling Infants under Normal Conditions and under Certain Forms of Pathology." Trudy VI Vsesoyuznogo S"yesda Detskikh Vrachey, Moscow, Medgiz, 1948, p. 418.

161. "The Biogenetic Law in the Light of Ontogenetic Data." Zoologicheskiy Zhurnal, 27(2): 115, 1949.

162. - RYSKINA, YE. B., and Sokolova, K. F. "Characteristics of Natural Immunity in Mothers of Newborn Infants Stricken with Sepsis." Pediatriya, (6): 3-7, 1949.

163. Arshavskiy, I. A. "The Mechanics of Narcosis in the Light of the Theory Introduced by the Vvedenskiy-Ukhtomskiy School and Physiological Data Studied Ontogenetically." Farmakologiya $i$ Toksikologiya, (4): 19-23, 1949.

164 "Underlying Principles and the Mechanics of Transformation of Physiological Poisonings in Ontogenesis." Tezisy Konferentsii po Vozrastnym Izmeneniyam Obmena Veshchestv: Reaktivnosti Organizma (Theses of Conference on Age-Associated Variations in Metabolism and Reactivity of the Organism), Kiev, 1949. Same publication by the Academy of Sciences, UkrSSR, 1951.

165. - "Underlying Principles of the So-called Double Antagonistic Innervation and Regulation of Activity of Various Systems of Organs (specifically the heart) in the Light of Ontogenetic Data." Vsesoyuzny S"yezd Fiziologov, Biokhimikov, Farmakologov, VII, 1947, p. 285. Problemy Sovetskiy Fiziologii, Biokhimii, $i$ Farmakologii, v. 1, published by the Academy of Sciences USSR, Moscow, 1949 , p. 410 .

166. - "The Theory of Parabiosis by N. Ye. Vvedenskiy in the Light of the Physiology of Nerve Centers in Ontogenesis." Collected Doklady na Konferentsii Poszyashchennoy Pamyati N.Ye. Vvedenskogo (Reports to the Conference on the Memory of Vvedenskiy), Publ. by the Academy of Sciences USSR, 1949, p. 117.

167. - and Sokolova, K. F. "Phagoeytic Activity of Leucocytes in Ontogenesis." Byull. Eksperimental'noy Biologii $i$ Meditsiny, 27(3): 215-217, 1949.

168. Arshavskiy, I. A. and Moldanskaya, YE. A. "Features of the Inflammation Re- action and the Degree of Stabiligy to Subcutaneous Introduction of Turpentine at Various Stages of Postnatal Ontogenesis." Byull. Eksperimental'noy Biologii i Meditsiny, 27(4): 284-286, 1949.

169. Arshavskiy, I. A. and Sokolova, K. F. "The Complementary Strength of Blood Serum in Ontogenesis." Byull. Eksperimental'noy Biologii i Meditsiny, 28(5/11): 380, 1949.

170. Arshavskiy, I. A. and Rozanova, V.D. "The Role of the Innervation Mechanisms in Bringing about the Reaction on the Part of the Intestine in Dysentery Intoxication during Some Definite Age Periods." Byull. Eksperimental'noy Biologii i Meditsiny, 28(12/6): 422, 1949.

171. Arshavsk1Y, I. A. "Dominance as the Mechanism of Completeness in Reflex Motor Reactions at Various Stages of Ontogenesis." Vestnik Leningradskogo Instituta, (9): 62, 1950.

172. - Paper on N. Ye. Vvedenskiy, Medgiz, 1950, pp. 110-111.

173. - Gol'dfel'd, Khanova, T. M. "Prothrombin Content in the Blood and Characteristics of Blood Coagulation of Rabbits in Ontogenesis." Byull. Eksperimental'noy Biologii i Meditsiny, 29(4): 317, 1950.

174. Arshavskiy, I. A. "The A. D. Speranskiy Theory on the Role of Neuro-receptors in Pathology in the Light of Physiological Data in Ontogenesis." Sovremennye Voprosy Patologii $i$ Meditsiny, a collection of papers on the occasion of the 60th birthday of academician A. D. Speranskiy, published by the Academy of Medical Sciences USSR, Moscow, 1950, p. 128.

175. - "Physiological Mechanisms of Immunity and Inflammation Reactions during the Intrauterine and Puerperium Periods." Akusherstvoi Ginekologiya, (5): 32, 1950.

176. ERdman, G. M. "The Itch Reflex in Ontogenesis." Byull Eksperimen tal'noy Biologii $i$ Meditsiny, 30, 4(10): 236, 1950

177. Arshavskiy, I. A., Arshavskaya, E. I., Yenikeeva, Oganisyan, Rozanova. "Mechanisms of Implementation and the Physiological Significance of Skeleto-Muscular Motor Reactions in Mammalia during the Prenatal Period." Fiziologicheskiy Zhurnal USSR, 37, issue 2, (8): 125, 1951. 
178. Arsuavskil, I. A. and Galeeva, L. S. "The Effect of Small Doses of Strychninc in the Diet of Pregnant Femalc Rabbits upon the Growth and Devclopment of their Fetuses." Byull. Eksperimental'noy Biologii $i$ Meditsiny, 31, issue 2, (2): 102, 1951.

179. Arsuavskiy, I. A. "Certain Charactcristics in the Physiology of the Intrauterine and Puerperium Periods as Related to the Problem of 1 Icalth Protection in Early Childhood." Voprosy Pedialrii i Okhrany Materinstia i Detstza, 19(4): 1, 1951.

180. and Bulonova, YE. I. "Generalized Motor Reactions (stirring) of thc Human Fetus in Relation to the Food Intake by the Mother." Byull. Eksperimental'noy Biologii i Medilsiny, 32, issue 2, (8): 125, 1951 .

181. Arshavskiy, I. A. and Kushinarev, V. M. "Accomodation of the Neuromuscular Apparatus in Rats at Various Stages of Ontogenesis." Collection of papers on Voprosy Eksperimental'noy Biologii $i$ Meditsiny, v. 1, Moscow, published by the Academy of Medical Sciences USSR, 1951, p. 48.

182. Arshavsk1Y, I. A. "Principles and Mechanics Involved in the Transformation of Physiological Functions in Ontogenesis." Trudy Konferentsii po Vozrastnym Izmeneniyam Obmena Veshchesto Ireaktivnosti Organizma (Transactions of Confcrence on Age-Associated Variations in Metabolism and Reactivity), published by the Academy of Sciences UkrSSR, Kiev, 1951, p. 158.

183. -The Lability in Relation to the Mechanism of Transformation in Neuromuscular Activity in Ontogenesis-as Presented by N.Ye. Vvedenskiy." Uspekhi Souremennoy Biologii, 32 1(4): 18-43, 1951.

184. - - Al'tgauzen, N. F., and BeneDıкт, A. A. "Physiological Mechanism of the Effectiveness of Oxyen Therapy in the So-called Secondary Asphyxias in the Newborn." Pediatriya, (2): 26, 1952.

185. Arsuavskiy, I. A., Bulanova, Ye. I., and Tuger, I. M. "Respiratory Movements of the IJuman Fctus and Their Significance in the Normal Intrautcrine Developmcnt." Byull. Eksperimental'noy Biologii i Medilsiny, $33(3): 13,1952$.

186. Arshavskiy, I. A. "The Significance of the N.Yc. Vvedenskiy Thcory in the Development of Evolutionary and Age-Associatcd Physiology." Fiziologicheskiy Zhurnal SSSR, (2): 160-170, 1952.
187. "Physiological Basis for the

Immediated Nursing of Infants Following Birth (to forcstall the so-called physiologic loss of weight)." Voprosy Pediatrii, Okhrany Materinstva i Detstva, 20(5): 45, 1952.

188. "Agc-Associated Interrelations in the Activity of the Respiratory and Cardiovascular Systems. Neural Regulation of Circulation and Respiration." Trudy Oo' yedinennoy Sessii Meditobiologicheskikh Nauk i Oidela Flinicheskoy Meditsiny AMN SSSR S Uchastiern Ryzanskogo Medilsinskogo Instituta im. Pavlova ('Transactions of the United Session of the I Departments of Medicobiological Sciences and Clinical Medicine of the Academy of Medical Sciences USSR with the Participation of the Ryazan Medical Institute im. Pavlov), 1952, p. 62.

189. - - "Fundamcntals of Oxygen Therapy in Early Agc." Collected papers on Kislorodnaya Terapiya, published by the Acadcmy of Scienccs Ukr.SSR, 1952, p. 184.

190. "Specificity as Related to the Analysis of the Mechanics of Transformation of Functions in the Ontogenetic Process." Uspethi Sovremennoy Biologii, 34, 3(6): 384$407,1952$.

191. "Age-Associated Physiological Mechanisms of Reactivity. Problems of Shock Reactivity." Trudy I Vsesoyuznoy Konferentsii Patofiziologov, Kazan 31 Jan.-4 Feb. 1950, Medgiz, Moscow, 1952, p. 216.

192. "Age-Associatcd Physiological Basis of Hygiene in Conncction with Ontogcnetic Stagcs." Collectcd papcrs Trudy Pervoy. Vauchnoy Kionferentsii po Vozrastnoy Morfologii i Fiziologii (Transactions of First Scientific Conference on Age-Associated Morphology and Physiology), published by the Academy of Pedagogical Sciences RSFSR, Moscow, 1954, pp. 86-95.

193. Arshavskiy, I. A., Arshavskaya, E. I. and Patusunskaya, R. A. "Age-Associated Significance of the Nervous System in Physiological Reactivity Mechanisms (as exemplificd by the experimental dysentery and staphyllococeus). The Problem of Reactivity in Pathology." Ciollectcd on the occasion of the $65 \mathrm{th}$ birthday of A. D. Speranskiy, Medgiz, Moscow, 1954, p. 100.

194. Arswavsk1Y, I. A. "The Significance of the N. Ye. Vvedenskiy Theory in Resolving the Problem of Spceificity in Connection with Stages of Ontogenesis." Uch. Zap. 
LGU (Academic Records of the Leningrad State University), (176): 68-85, 1954.

195. "Characteristic Curve of the Extrauterine Variations in the Weight of Newborn Rabbits and Dogs." Byull. Eksperimental'noy Biologii $i$ Meditsiny, 38(8): 63$65,1954$.

196. "Community of Principles Underlying the Periodic Activity of the Alimentary and Respiratory Centers in Ontogenesis." Uch. Zap. LGU (Academic Recors of the Leningrad State University), No. 164, Biological Series, issue 32, 1954, p. 126.

197. "Dominate State in Pregnancy and the Problem of Physiological Completeness of Ontogenesis." Eighth AllUnion Conference of Physiologists, Biocliemists and Pharmacologists. Tezisy Dokladov, published by the Academy of Sciences USSR, Moscow, 1955, p. 43.

198. -The Basis of the Concept "development function" during the Intrauterine Period in Mammalia and Humans as Related to the Problem of Prevention of Physiological Immaturity." Tezisy Dokladov na Soveshchanii Embriologov v Leningrade, published by the Leningrad State University, Leningrad, 1955, p. 176.

199. - "The Development Function in the Ontogenetic Process and the Basis for the Prevention of Physiological Immaturity." Materialy Vtoroy Nauchnoy Konferentsii po Voprosam Vozrastnoy Morfologii $i$ Fiziologii (Data on the Second Scientific Conference on Age-Associated Morphology and Physiology), published by the Academy of Pedagogical Sciences RSFSR, Moscow, 1955, p. 9.

200. "The Dominant State in Pregnancy and the Problem of Physiologically Complete Ontogenesis." Academic Records of the Kharkov State University. Trudy Nauch.-issled. Instituta Biologii $i$ Biologicheskogo $f$-ta, 24: 161-182, 1956.

201. Asmolova, Ye. N. "Age-Associated Variations in the Nitrous Fractions and Water in the Muscles of Rabbits. Communication 1. Water, Residual Nitrogen, and Preformed Aminonitrogen." Byull. Eksperimental'noy Biologii i Meditsiny, 1(2): 118119, 1936.

202. -Age-Associated Variations in the Nitrous Fractions and Water in Rabbit Muscles. Communication 2. Total Nitro- gen and Aminonitrogen in Hydrolysate of Rabbit's Muscles." Byull. Eksperimental'noy Biologii $i$ Meditsiny, 1(2): 120-121, 1936.

203. Asratyan, E. "Age-Associated Physiology of the Cerebellum." Fiziologicheskiy Zhurnal SSSR, 19: 438, 1935.

204. Afonskiy, S. I. "Biochemical Variations in the Organism of Growing Animals." Uch. Zap. Kazanskogo Gos. Zoovetinstituta (Academic Records of the Kazan State Zooveterinary Institute), 51(1): 1939.

B

205. Babadzhanyan, M. G. "The Role of Industrial Training in the Development of Regulatory Processes in the Central Nervous System of Teen-Agers." Collected paper's Trudy 1-oi Nauchnoy Konferentsii po Vozrastnoy Morfologii $i$ Fiziologii (Transactions of the first scientific conference on age-associated morphology and physiology) published by the Academy of Pedagogical Sciences RSFSR, Moscow, 1954, pp. 205-209.

206. BABAK, O. M. "Comparative Evaluation of the Cytoarchitectonics and the Myeloarchitectonics of the Precentral Area of the Cortex Ccrebri in Children 4, 11 and 13 Years of Age." Izvestiya Akademii Pedagogicheskikh Nauk RSFSR, (60): 3-12, 1954.

207. —- "Age-Associated Development of the Muscles of the Wrist in Man." Collected papers Trudy 1-oi Nauchnoy Konferentsii po Vozrastnoy Morfologii $i$ Fiziologii (Transactions of the first scientific conference on age-associated morphology and physiology) published by the Academy of Pedagogical Sciences RSFSR, Moscow, 1954, pp. 162-169.

208. Baвich, Z. YE. "Carbon Anhydrase in the Blood of Children of Tender Age and the Effect of Blood Transfusion on the Activity of Same." Byulleten' Eksperimental'noy Biologii i Meditsiny, (11): 377-380, 1948.

209. Badyuk, Ye. Ye. "The Blood Picture in Premature Newborn." Trudy Akademii Meditsinskikh Nauk SSSR, 29: 19-25, 1953.

210. Babikova, N. I. "The Microflora in the Pharnyx of the Newborn." In book Voprosy Akusherstva $i$ Pediatrii (Problems of obstetrics and pediatrics) published in Sverdlovsk, 1956, pp. 133-138. 
211. Bazanova, N. U. "The Effect of Sinuso-Carotid Reflexes on the Blood Pressure and Respiration in Calves." Izvestiya Akademii Nauk Kazakhskoy SSR, No. 45, Physiological Series and in Pervyi Sbornik Rabol po Vozrostnoy i Sraunitel'noy Fiziologii (First collection on agc-associated and comparative physiology), Alma-Ata, 1948, p. 73.

212. - "Agc-Associated Variations in Respiration Types and Rhythms and Its Neural Control in Camels." Izvestiya Akademii Nauk Kazakhskoy SSR, No. 45, Physiologcal Series, Collection of papers on ageassociated and comparative physiology, Alma-Ata, 1948, pp. 81-85.

213. — , Stepankina, M. K., LutFullina, M. S., Fomina, N. W., KrasilevsKAYA, L. M., KozhebeKov, Z. K., and Gorokhova, L. V. "Certain Characteristics of Digestion in Agricultural Animals in Relation to the Aspects of Species, Breed, and Age." Sed'moi Vsesoyuzny S'yezd Fiziologov, Biokhimikov i Farmakologov (Seventh AllUnion Conference of physiologists, biochemists and pharmacologists). Theses published by the Academy of Sciences USSR, 1955, p. 51 .

214. Bazilevich, I. V. "Problems of Aging. Communication 1. On the Oldsters of Abkhasia." Medichniy Zhurnal AN URSR (Medical Journal of the Academy of Sciences Ukr SSR), 8(1): 7, 1938.

215. - "Problems of Aging. Communication 2. Clinical Observations on Oldsters in Abkhasia." Medichniy Zhurnal $A \mathcal{N}$ URSR (Medical Journal of the Academy of Sciences Ukr SSR), 8(1): 19, 1938.

216. - and Turovets', I. M. "Problems of Aging. Communication 3. Hemodynamics of Extremely Old People." Medichniy Zhurnal AN URSR (Medical Journal of the Academy of Sciences, Ukr. SSR), 8(1): 69, 1938.

217. Bazilevich, I. V. "Syndrome of Normal Old Age." Sbornik Starost' (Old Age), Kiev, published by Academy of Sciences, Ukr SSR. Trudy Konferenlsii po Probleme Geneza Starosti $i$ Profilaktiki Prezhdevremennogo Stareniya Organizma (Transactions of conference on the genesis of aging and prevention of premature aging), 1940, pp. 255-307.

218. Baymakov, N. F. "Organized Proteins, Iron, and Phosphorus in the Muscles During Various Stages of Tender Age in
Children and Calves." Materialy $k$ Biologii Myshts-Diss., SPb. (Data on the biology of muscle), St. Petersburg, 1904.

219. Bakit'ко, M. F. "The Peripheral Nervous System in Children." Diss. SPb. (Disscrtation St. Petersburg), 1902.

220. Balakirev, P. "Die spezifische Wärme des Zentralnervensystem der Tiere und des Menschen." Biochem. Zeilsch., 216, 312 (1929).

221. Balunova, A. A. "Characteristics of Arterial Blood Pressure in Mature and Premature Newborn Infants." Trudy l-oi Nauchnoy Konferentsii po Vozrastnoy Morfologii $i$ Fiziologii (Transactions of the first scientific conference on age-associated morphology and physiology) published by the Academy of Pedagogical Sciences RSFSR, Moscow, 1954, pp. 103-111.

222. Barabin, V. V., and Solov'euva, L. "Variation in the Intensity of Respiration at Various Stages of Life in Bursariatruneatella." Uch. Zap. Leningradskogo Gos. Pedagogicheskogo In-ta im. Gertsena (Academic records of the Leningrad State Pedagogical Institute im. Gertsin), 70: 49-66, 1948.

223. BAR1, A. S. "Excitability of the Cerebral Cortex in Newborn Animals." Diss., SPb. (Dissertation, St. Petersburg), 1898.

224. Barsuk, V., Verzhbinskaya, N., Kreps, Ye., Mikhel'son, N., and Strel'Tsov, V. "The Effect of Stimulation of the Sympathetic Innervation on the Chemical Composition and Physio-Chemical Properties of a Skeletal Muscle." Fiziologicheskiy Zhurnal SSSR, 17(3): 474-486, 1934.

225. Barysheva, L. M. "Certain Characteristies in the Development and Growth of Higher Nervous Activity in the Ontogenesis of Lower Apes." Zhurnal Vysshey Nervnoy Deyalel'nosti, 3(2): 267-278, 1953.

226. BatenKov, Ye. L., and others. "Interrelationship Between the Chlorides of the Mother, the Blood of the Placenta and of the Newborn." Voprosy Fiziologii $i$ Palologii Rannego Detskogo Vozrasta (Problems of the Physiology and Pathology of the Tender Age) Zapiski In-la Okhrany Materinstva i Mladenchestva (Annotations of the Institute of Maternity and Child Welfare), Smolensk, 1935, pp. 69-75. 
227. Bauer, E. S., and Granovskaya, A. M. "Relation of Experimental 'individual immortality' to Age." Biologicheskiy Zhurnal (Biological Journal), 3(4): 609-618, 1934.

228. Bakhurskaya, M. "The Development of Sensory Organs in the Infant." Okhrana Materinstva $i$ Mladenchestva (Welfare of mother and baby), (9): 24, 1927.

229. Bayandina, S. A. "Certain Indicators of Immunity in Septic Infections of the Newborn During the First Months of Life." Trudy VI Vsesoyuznogo S"yezda Detskikh Vrachey (Transactions of the Sixth All-Union Conference of Pediatricians), Medgiz, Moscow, 1948, pp. 192-196.

230. Bayadurov, B. I., and Trofimova, O. Kн. "The Effect of Excision of Receptors (Analysors) on the Organism of Growing Animals." Trudy Tomskogo Meditsinskogo Instituta (Transactions of the Tomsk Medical Institute), Tomsk, 10: 25-47, 1938.

231. Bayadurov, B. I. and Sirotkina, O. A. "The Effect of Excision of Receptors on the Organism of Growing Animals. The Effect of Excision of the Visual, Olfactory, and Auditory Receptors, Separately and in Combination, on Growth, Gas Metabolism, and Diurnal Motility in Chicks." Collected Papers of the Chair of Normal Physiology, Gosudarstvennyi Meditsinskii Institut (State Medical Institute), Tomsk, 6: 7-21, 1948.

232. Bayadurov, B. I. "The Trophic Function of the Brain." Medgiz, Moscow, 1949.

233. Bezvershenko, A. P. "The Healing of Wounds in Rabbits During the Embryonic Period. Medichniy Zhurnal AN URSR (Medical Journal of the Academy of Sciences Ukr SSR), 6(4): 1097-1105, 1936.

234. Belenko, L. I. "Certain Age-Associated Variations in the Innervation of the Large Arteries in Man." Problema Mezhneyronnykh $i$ Neyrotkannykh Otnosheniy (Problem of internuncial and neurohistological relations), Academy of Sciences Ukr SSR, Kiev, 1953, pp. 76-87.

235. Belikov, P. S. "Age-Associated Variations in the Accumulation of Rubber in the Russian Dandelion." Trudy In-ta Fiziologii Rasteniy im. Timiryazeva (Transactions of the Timiryazev Institute of Plant Physiology), v. 6, No. 2, published by the Academy of Sciences USSR, 1949, pp. 63-69.
236. Belkin, O. I. "Wound Hormones, Their Formation and Significance in Regeneration." Uspekhi Souremennoy Biologii, 24, l(4): 61-88, 1947.

237. Belova, T. I., and Kexcheev, K. Ki1. "Age-Associated Variations in the Sensitivity of Proprioreception. Fiziologicheskiy Zhurnal SSSR, 21(1): 14-17, 1936.

238. Belozerskiy, A. N. "Composition of Protoplasm in the Cells of Spirillum Volutans in Relation to the Age of the Culture." Mikrobiologiya, 10(2): 185-199, 1941.

239. Belousov, V. A. "The Effect of Organs of Internal Secretion on the Development of Children. Vestnik Endokrinologii, 3(4): 283-290, 1932.

240. - and Gir'man, M. A. "Nitrogen Retention in Various Animal and Vegetable Protein Ratio Diets in School Children." Problemy Kharchivanniya (Problems of Nutrition), 6: 54, 1934.

24.1. Belousov, V. A. "Optimum Protein Quantities in the Diet of School Children. Communication 1. Protein Retention from Various Dosages of Primarily Vegetable Protein." Voprosy Pitaniya, 4(4): 76-85, 1935.

242. - and Gil'man, M. A. "Optimum Protein Quantities in the Diet of School Children. Communication 3. Protein Retention from Various Ratios of Animal and Vegetable Proteins in the Diet of Healthy School Children." Voprosy Pitaniya, 5(3): 69-72, 1936.

243. Belousov, M. A. "The Chemical Activity of Sugar Beets As Related to Age and Nutritional Level." Tezisy Dokladov Soveshchaniya po Fiziologii Rasteniy 28 Tanvarya-3 Fevralya 1940 (Abstracts of reports at a conference on the physiology of plants 28 Jan.3 Feb. 1940), published by the Academy of Sciences USSR, 1940.

244. Belousov, N. F. "Old Age and Death." Izd-vo Put Prosveshcheniya (Road to Enlightenment), Khar'kov, 1923.

245. Belyayev, Ye. L. "Differentiation of the Ganglia in the Human Vagina and Uterus During the Postnatal Development." Diss. Irkutsk (Dissertation Irkutsk), 1939, p. 87.

246. Belyakov, S. A. "Patho-Anatomical Alterations in the Central Nervous System in 
Senilc Inbecility." Diss., SPb, 1887 (Dissertation, St. Pctersburg, 1887).

247. BeL'skaya, T. N. "Methods for the Study of Agc-Associated Morphological Variations in Plants." Izd-vo $A \mathcal{N}$ SSSR, 1949 (Publishcd by the Academy of Sciences USSR, 1949).

248. Benfesvkaya, O. V. "Ontogenetic Evolution of Thermorcgulation in Children." Voprosy Pediatrii, 16(4): 5-18, communication 1, 1948; 16(5): 41-45, communication 2 , 1948; 17(3): 44-49, communication 3, 1949; 19(1): 54-58, communication 4, 1951; 21(6): 13-18, communication 5, 1953.

249. - "Ontogenetic Evolution of Thermoregulation in Children. Communication 3. Thermoregulation in Fully-Matured Newborn." Voprosy Pediatrii $i$ Okhrany Materinstva i Detstva, 17(3): 44-49, 1949.

250. Beremzhanova, I. A. "Age-Associated Variability of the Vagus Reflexes in Relation to Lymph Circulation." Izvestiya $A \mathcal{N}$ (Academy of Sciences) Kazakh SSR, Ser. Meditsinskii $i$ Fiziologii (Medical and Physiological Series), (4): 139-143, 1944.

251. "Ontogenetic Regulation of the Lymph Circulation." VIII Vsesoyuzny Syezd Fiziologov, Biokhimikov i Farmakologov (Eighth All-Union Coference of physiolo-v gists, biochemists and pharmacologists). Abstracts of Reports published by the Academy of Sciences USSR, Moscow, 1955, p. 69.

252. Berenshteyn, F. YA., and Penionzhkevici, E. Z. "On the Active Reaction of the Content of thc Chicken and Duck Eggs During Incubation." Fiziologicheskiy Zhurnal SSSR, 18: 655, 1935.

253. Beritov, I., Tsereteli, M., and Aкhмeteli, M. "Study of the Individual Behavior of a Dog. Communication 3 . On the Adaptations of Young Puppies to Changes in the Usual Enironment." Fiziologicheskiy Zhurnal SSSR, 17(3): 455-463, 1934.

254. Beritov, I., Beburishvili, N. and TSEReteli, M. "Studying Individual Behavior in a Dog. Communication 4. Training a Puppy to Relax Its Anus." Fiziologicheskiy Zhurnal SSSR, 17(4): 688-697, 1934.

255. Beritov, I. and Tsereteli, M. "Studying Inclividual Bchavior in a bog. Communication 5. On the Stability and
Activity of Individual Bchavior." Fiziologicheskiy Zhurnal SSSR, 17(4): 698-706, 1934.

256. Bi:RKovicil, YF. M., and SPIRINA, V. P. "Gas Metabolism in the Newborn." Byulleten' Eksperimental'noy Biolngii i Meditsiny, 26(3): 184-187, 1948.

257. Berlyand, A. S. "The Vegctative Nervous System and K/Ca Metabolism." Terapevticheskiy Arkhiv, 7(2): 208, 1929.

258. Berman, V. M. "The Problem of AgcAssociated Immunity (Expcrimcntal Data)." Sbornik Trudov Tubileynoy Sessii Leningradskogo Gos. I'ediatricheskogo Meditsinskogo Instituta (Collected Papers from the Anniversary Session of the Leningrad State Pediatric Medical Institute), Leningrad, 1947, pp. 41-68.

259. - "The Immuno-Reactivity of a Growing Organism." Pediatriya, 1947, No. 5, pp. 26-37. Trudy VI Vsesoyuznogo S'vezda Detskikh Vrachey (Transactions of the Sixth All-Union Confercnce of Pediatricians), Moscow, Medgiz, 1948, pp. 260-271.

260. Berman, E. I. "Aspects of Water and Chloride Metabolism in Relation to Separate Ingredicnts in the Food Intake During the Nursing Period." Trudy Instituta Okhrany Materinsiva i Mladenchestva, Zapadny Obl. Nauch. Institut (Transactions of the Institute of Maternal and Child Welfare, Western State Scientific Institute), Smolensk, 1935.

261. Berman, Z. I. "Frequency of Mutation at Various Stages of Spermatogenesis in Drosophila Melanogaster." Byulleten' Eksperimental'noy Biologii i Meditsiny, 2(1): 18-20, 1936.

262. Berulava, S. I. "Results of a Study of Tropical Diseases in Very Old People of Abkhazia." Collected papers on Starost' (Old Age). Trudy Konferentsii 17-19 Dekabrya $1938 \mathrm{~g}$. AN USSR (Transactions of Conference 17-19 December 1938 of the Academy of Sciences Ukr SSR), Kiev, 1940, pp. 341-343.

263. Besser-Ballod. "Mortality Rates, Age-Group Composition, and Life Expectancy of the Orthodox-Faith Population of Both Sexes in Russia for the Period 18511890." Zap. AN, VIII Ser. Istoriko-Filologicheskogo Otdeleniya, SPb (Records of the Academy of Sciences, Serics 8 of the Division of History and l'hilology, St. Petcrsburg), 1897, p. 124. 
264. Bessonov, D. K. "Susceptibility of Lambs and Piglets to Bruccllosis Infection." Collection on Brutsellez Sel'skokhozvaystvennykh Zhivotnykh (Brucellosis in Agricultural Animals), Raboty XII Plenuma Veterinarnoy Sektsii VASKhNIL 1-6 Dekabrya 1938 g. (Transactions of the 12th Plcnary Session of the Veterinary Section of the All-Union Lenin Academy of Agricultural Scicnces, 1-6 December 1938), Sel'khozgiz, Moscow, 1940.

265. Bets, E. F. "Age-Associated Variations in the Bactericidal Characteristics of Blood." Problemy Endokrinologii, (3-4): 32$37,1938$.

266. Bekhterev, V. M. "Structure of the Lower Vertebrae as Based on the History of Their Evolution." Vrach, 5(5): 855-856, 1884.

267. "On the Excitability of the Motor Centers of Cerebral Cortex in Newborn Puppies." Vrach, 6(34): 7: 1886.

268. - "Studying the Excitability of Individual Nerve Tracts in the Spinal Cord of Newborn Animals." Vrach, 7(22): 1887.

269. "On the Excitability of Various Parts of the Brain in Newborn Animals." Vrach, 10(15): 353-356, 1889.

270. "Uber die Erregbarkeit verschiedener Hirnbezirke bei neugeborenen Thieren." Neurol. Centralbl., (18): 1889.

271. "Phenomena Observed on the Destruction of Various Parts of the Nervous System in Newborn Animals, and the Dcvelopment of Their Brain Function." Meditsinskoye Obozrenie (Medical Review), (4): 392.

272. - "On the Excitability of the Cerebral Cortex in Ncwborn Animals." Obozrenie Psikhiatrii, Nevralgii, i Eksperimental' noy Psikhologii (Review of Psychiatry, Neurology, and Experimcntal Psychology), (7), 1897.

273. and Sielovanov, N. "The Basis of Genetic Refexology." Collection on Novaye v Refleksologii i Fiziologii Nervoy Sistemy (New Developments in the Reflexology and Physiology of the Nervous System), v. 1 and 2, Medgiz, Moscow, 1925.

274. Birger, Ye. S. "Vitamin C Requirements in Children of Tender Agc." Pediatriya, (10), 1940.
275. - "The Effect of Vitamin B on the Intcrmediate Protein Metabolism in Children of Tender Age in Connection with the Pathogenesis of Hypotrophy." Referaly Nauch.-Issled. Rabot (Research Abstracts), Academy of Medical Sciences USSR, Clinical Sciences, Moscow, 1948, pp. 33-34.

276. BiRIKH, V. K., and BIRIKH, I. K. "Age-Associated Variations in the Blood Enzymes of Hogs." Trudy Molotouskogo Gos. Sel'skokhozyaystvennogo Instituta (Transactions of the Molotov State Agricultural Institute), 12: 197-201, 1948.

277. Biryukov, D. M., and Ukolov, M. "Age-Associated Characteristics of the Unconditioned Salivary Reflexes in Dogs." Russkiy Fiziologicheskiy Zhurnal, 12(2): 119126, 1929.

278. Biryukova, A. A. "The Effect of Static Efforts on the Arterial Blood Pressure in Girls 8-14 Years Old." Izvestiya Akademii Pedagogicheskikh Nauk RSFSR, 60: 241-252, 1954.

279. Biryukova, R. N. "Longer Life and Morbidity." Avtore Diss, na Soiskanie Urenoy Slepeni Kand. Med. Nauk (Author's Summary of a Thesis for the Degree of Candidate in Medical Sciences), 1952, p. 14.

280. Bitnyt-Shlyaknto, F. A. "FlatFootedness in Men of Middle Age." Ortopediya $i$ Travmalologiya, 5(3): 21-28, 1931.

281. BlagoveshchenskiY, A. V. "The Problem of Orientation in the Evolutionary Process." Byulleten' Sredne-Aziatskogo Un-tela (Bulletin of the Central-Asiatic University), (10), 1925.

282. BlagoveshchenskiY, A. V. "Biochemical Bases in the Evolution of Organisms." SORENA, 1935, p. 10.

283. - "Biochemical Basis of the Process of Evolution in Plants." Published by $A \mathcal{N}$ SSSR (Academy of Sciences USSR), Moscow-Leningrad, 1950, p. 139.

284. … and Kampova, R. "Biochemical Indications of Precocious Maturation." $D A \mathcal{N}$ SSSR (Reports of the Academy of Sciences USSR), 95: 309-312, 1954.

285. Blinov, V. A. "The Initial Formation and Rates of Differentiation of Cartilage in Various Organs of Bird Embryos." Byulleten' Eksperimental'noy Biologii i Meditsiny, 3(4): 419-421, 1937. 
286. Bloku, L. S. "Age-Associated Characteristics of Negative Induction in the Ccrebral Cortex of Infants." Collcction on Opyt Sistematicheskogo Eksperimental'nogo Issledovaniya Ontogeneticheshogo Razvitiya Korkovoy Dinamiki Cheloveka (Experimental Research in the Cortical Dynamics of Humans), published by the All-Union Institute of Expcrimental Medicine, Moscow, 5: 139-153, 1940.

287. Bцокн, L. S. "Age Traits of Differentiating Inhibition." Sb.: Opyt sistematicheskogo eksperimental'nogo issledovaniia ontogeneticheskogo razvitiia korkovoi dinamiki cheloveka. Izd-vo VIEM, M. (Collection: Study of Systematic Experimental Investigation of the Ontogenetic Development of Human Cortical Dynamics. State Publ. House of the All-Union Institute of Experimental Mcdicine, Moscow), 5: 177-188, 1940.

288. BLudorov, A. S. "Characteristics of Heat Regulation in Children of an Early Age" (Osobennosti teploreguliatsii u detei rannego vozrasta. Medgiz, M.), State Publ. House of Medical Lit., Moscow, 1954, p. 77.

289. Blium, E. A., IARmoshkevich, A. I., and IAKovchuк, A. I. "Proteolytic Enzymes of Human Embryo at Early Stages of Development." Biull. eksperimental'noi biologii $i$ meditsiny (Bulletin of Experimental Biology and Medicine), 1(2): 112-113, 1936.

290. Bliumenau. "The Adrenal Glands of Children" (O nadpochechnykh zhelezakh $u$ detei. Diss.), a dissertation, 1900.

291. Bobrov, N. N. and Brener, E. D. "Hemoglobin Variations in Juveniles in Connection with Sex, Age, Constitution, and Other Factors." Klinicheskaia meditsina (Clinical Medicine), 6(21): 1399-1407, 1928.

292. Bobrovs'KA, G. D. "Problem of the Clinic and Pathohistology of the Gliomas of Old Age" (Ukr.: Do pitannia pro kliniku $i$ patogistologiiu gliom starechogo viku). Medichnii zhurnal AN URSR (Medical Journal of the Acadcmy of Sciences of the UkrSSR), 10(4): 1225-1232, 1940.

293. Bobyleva, Z. I. "Problem of Age Changes in the Morphological Composition of the Blood of Horned Cattle." Trudy Stavropol'skogo s. $-k h$. in-ta (Transactions of the Stavropol' Agricultural Institute), 5: 00, 1950.

294. Bogachenko, L. S. "Data of the First Scientific Conference on Problems of
Age Morphology and Physiology" (Materialy pervoi nauchnoi konferentsii po voprosam vozrastnoi morfologii $i$ fiziologii. Izd. Akademii pedagogicheskikh nauk RSFSR, M.). Publication of the Acad. of Pedagogical Sciences of the Russian Soviet Federative Socialist Republic, Moscow, 1952.

295. "Study of Work on Prolonging Sleep of Children in Conditions of the Pediatric Clinic." Zhurnal vysshei nervnoi deiatel'nosti (Journal of Higher Nervous Activity), 2(2): 205-218, 1952.

296. - "Study of Work on Use of Sleep Therapy in a Pediatric Clinic for Rheumatism." Ibid., 3(4): 536-561, 1953.

297. - "Effect of a Different Sleep Cycle on the Higher Ncrvous Activity and Vegetative Reactivity of Pupils 7-8 Years Old." Izvestiia Akademii pedagogicheskikh nauk RSFSR, M. (Bulletin of the Acad. of Pedagogical Sciences of the RSFSR, Moscow), (47): 181-206, 1953.

298. - and FADEEVA, V. K. "Typological Characteristics of Higher Nervous Activity According to Data of Experimental Studies of the Contact Function and Interaction of First and Second Signal Systems in Children." Zhurnal vysshei nervnoi deiatel'nosti (see above), 3(5): 704-716, 1953.

299. Bogdanov, A. A. "Struggle for Viability" (Bor'ba za zhiznesposobnost'. Medgiz, M.), State Publ. House of Med. Lit., Moscow, 1927.

300. Bogdanov-Berezovskil. "Function of the Hearing System in Old Age" (Funktsii slukhovogo apparata $v$ starosti. Diss. SPb), a dissertation, St. Petersburg, 1897.

301. Bogdanovich, R. I. "Carbohydrate Exchange in Those of Extreme Old Age" (Ukr.: Pro vuglevodnii obmin $u$ dovgolitnikt. starikiv). Medichnii zhurnal AN URSR (Medical J. of the Academy of Sciences UkrSSR), 10(4): 1283-1291, 1940.

302. Bogomolets, A. A. "Internal Causes of Death." Izvestiia Nikolaevskogo universiteta (Bulletin of Nicholai Univ.), 3(1): 20-33, 1912.

303. "Methodological Value of Cytotoxins as Specific Stimulants." Meditsinskii biologicheskii zhurnal (Biological Journal of Medicine), (3): 35-40, 1926.

304. - "The Enigma of Death" (Zagadka smerti. M., Narkomzdrav), Pcople's 
Commissariat of Public Health, Moscow, 1927.

305. —_. Preface in S. A. Voronov's book "Conquest of Life" (Predislovie. V knige Voronov S. A. Zavoevanie zhizni. M., Medgiz), Moscow, State Publ. House of Med. Lit., 1928, pp. 3-6.

306. - "Role of the Connective Tissue Physiological System in Phenomena of Immunity and Neoplasia." Terapeuticheskii arkhiv (Archives of Therapeutics), 7(1): 108, 1929.

307. - "Problem of Regulating Functions of the Organism." Klinicheskaia meditsina (Clinical medicine), 10(19-22): 853-858, 1932.

308. Bogomolets', O. O. (Ukr. for same name). "Specific Cytotoxic Stimulation and Blockade of Cellular Functions" (Ukr.: Spetsifichna tsitotoksichna stimuliatsiia $i$ blokada klitinnikh funktsii). Sbirnik, prisviachenii tridtsiatip'iatilitn'omu iuvileiu naukovoi, pedagogichnoi $i$ gromads'koi diial'nosti akademika Mikoli Dmitrovicha Strazhesko, Kiiv, AN USSR (Collection Dedicated to the 35th Jubilee Year of the Scientific, Pedagogical, and Public Activity of the Acad. of Nikolai Dmitrovich Strazhesko, Kiev, Academy of Sciences UkrSSR), 1935, pp. 445-456.

309. Bogomolets, A. A. "Colloidoclastic Shock at Blood Transfusion." Khirurgiia (Surgery), (3): 3-19, 1937.

310. - "The Fight to Prolong Life." Gigiena $i$ zdorov'e (Hygiene and Health), (20): 3-4, 1938.

311. Bogomolets', O. O. "The Task of Experimental Medicine to Combat Premature Aging of the Organism" (Ukr.: Zavdannia eksperimental' noi meditsini $v$ borot'bi $z$ peredchasnim starinniam organizmu). Medichnii zhurnal AN URSR (Medical J. of the Academy of Sciences UkrSSR), 8(4): 993-998, 1938.

312. Bogomolets, A. A. "The Tasks of Experimental Medicine to Combat Premature Aging of the Organism." Sb.: Starost'. Trudy konferentsii 17-19 dekabria $1938 \mathrm{~g}$., Kiev, AN USSR (Collection: Old Age. Transactions of the Dec. 17-19, 1938 Conference, Kiev, Academy of Sciences UkrSSR), 1940, pp. 7-13; Vrachebnoe delo (Medical Affairs), (11-12): 809-814, 1938.
313. "Prolongation of Life" (Prodlenie zhizni. Kiev, AN USSR), Kiev, Academy of Scienccs UkrSSR, 1938.

314. Bogomolets', O. O. "Prolongation of Life" (Ukr.: Prodovzhennia zhittia. Kiiv, AN URSR), Kiev, Academy of Scienccs UkrSSR, 1938.

315. Bogomolets, A. A. "Mechanism of the Stimulating Effect of Blood Transfusion. Souremennye problemy gematologii $i$ perelivaniia krovi, M.-L., gos. izd. biologicheskoi $i$ meditsinskoi lit-ry (Current Problems of Hematology and Blood Transfusion, Moscow-Leningrad, State Publ. House of Biological and Med. Lit.), 16: 3-22, 1938.

316. - "Cytotoxic Stimulation of Functions of the Physiological System of Connective Tissue. Report V." Sovetskaia meditsina (Soviet medicine), (14-15): 8-13, 1938.

317. Bogomolets', O. O. "Cytotoxic Stimulation of Functions of the Physiological System of Connective Tissue" (Ukr: Pro tsitotoksichnu stimuliatsiiu funktsii fiziologichnoi sistemi spoluchnoi tkanini). Medichnii zhurnal, $A N$ URSR (Medical J. of the Academy of Sciences UkrSSR), 8(2): 301-309, 310-318, 1938. The same in French.

318. Bogomolets, A. A. "The Tasks of Experimental Medicine to Combat Premature Aging of the Organism." Starost'. Trudy konferentsii po probleme geneza starosti $i$ profilaktiki prezhdeuremennogo stareniia organizma. Kiev, AN USSR (Old Age. Transactions of the Conference on the Problem of the Genesis of Old Age and of the Prophylaxis of Premature Aging of the Organism. Kiev, Academy of Sciences UkrSSR), 1939, pp. 7-12.

319. Bogomolets', O. O. "Stimulating Effect of Antireticular Cytotoxic Serum on the Physiological System of the Connective Tissue" (Ukr.: Pro stimuliuiuchu diiu antiretikuliarnoi tsitotoksichnoi sirovatki na fiziologichnu sistemu spoluchnoi tkanini). Medichnii zhurnal $A \mathcal{N}$ URSR (Medical J. of the Academy of Sciences UkrSSR), 9(3): 789-799, 1939.

320. Bogomolets, A. A. "Prolongation of Life" (Prodlenie zhizni. Kiev, AN USSR), Kiev, Academy of Sciences UkrSSR, 1939, p. 126.

321. - "Introductory Speech at Conference on Problem of Genesis of Old Age and of Prophylaxis of Premature Aging of the Organism." Starost'. Trudy konferentsii 
po probleme geneza starosli $i$ profilaktiki prezhdevremennogo stareniia organizma. Kïev, AN USSR (sec above), 1939, pp. 5-6.

322. Ibidem, 1939, p. 492.

323. "Introductory Speech at Conference on Problem of Genesis of Old Age and Prophylaxis of Premature Aging of the Organism." Ibiden, 1940, pp. 5-6.

324. Bogomolets", O. O. "For" A Long Life" (Ukr.: Za dovge zhittia). Shliakh do $z$ dorov'ia (The High Road to Health), (10): 18-19 and $(11-12): 6-8,1940$.

325. Bogomolets, A. A. "For a Long Life." Oktiabr' (October), 9: 148-155, 1940.

326. - "Prolongation of Life" (Prodlenin zhizni. Kiev, AN USSR), Kiev, Academy of Sciences UkrSSR, 1940, p. I44.

327. Bogomolets', O. O. "Prolongation of Life" (Ukr.: Prodovzhennia zhittia. Kiiv, vid-tvo AN URSR), Kiev, Publ. of the Academy of Sciences UkrSSR, 1940, p. 120. Sb.: Bor'ba za dolgoletie cheloreka, Stalingrad (Collection: Struggle for Longevity of (Ian), Stalingrad, 1946.

328. Bogomolets, A. A. "A Textbook on Pathological Physiology" (Rukovodstzo po patologicheskoi fiziologii pod red. A. A. Bogomol'tsa, Kiev, AN USSR), edited by A. A. Bogomolets. Kiev, Academy of Sciences UkrSSR, 1 (part 1): 890, 1940.

329. "The Problem of Longevity" -Lecture Read in the Lecture Hall of the Moscow City Committee, All-Union Communist Party (Bolsheviks) Jan. 31, 1941. Propagandist (Propagandist), (3): 17-24, 1941.

330. - "Antireticular Cytotoxic Serum (ACS)." Nauka $i$ zhizn (Science and Life), (4-5): 4-9, 1944.

331. Bogomolets', O. O. "The Next Task of Scientific Medicine" (Ukr.: Naiblizhchi zavdannia naukovoi meditsini). Medichnii zhurnal AN URSR (Medical J. of the Academy of Sciences UkrSSR), 13: 5-9, 1944.

332. Bogomolets, A. A. "Antirectcular Cytotoxic Serum (ACS) as a Method of Specific Stimulation of the Protecting, Nourishing, and Plastic Functions of the Connective Tissue Physiological System." Lechebnoe deistvie antiretikuliarnoi tsitotoksicheskoi cyzorotki. Trudy sozeshchaniia Uchenogo medilsinskogo soveta Narkomzdrava RSFSR $18-20$ oktiabria
19.4 g. $v$ Moskve, M., Medgiz (Medicinal Action of Antircticular Cytotoxic Serum. Transactions of the Mecting of the Scientitic Medical Council of the P'eople's Health Commissariat, Russian Soviet Federative Socialist Republic, Oct. 18-20, 1944 in Moscow. State Publ. House of Med. Lit., Moscow, 1946, pp. 5-14.

333. - " "Importance of Reactivity of the Organism in Problens of Corrective Therapy". Sozetskaia meditsina (Soviet Medicine), (1-2): 4-9, 1946; Vestnik Akademii meditsinskith nauk SSSR (Journal of the Academy of Medical Sciences USSR), (1): 29, 1946; and Trudy vtoroi sessii Akademii meditsinskikh nauk SSSR (Transactions of the Second Session of the Academy of Medical Sciences USSR), Moscow, 1947, pp. 12-22.

334. Bogomolets', A. A. (sic-should be Ukr.: O. O.) "Contribution Regarding Age on the Birthday of I. I. Mechnikov" (Ukr.: Do slorichchia $z$ dnia narodzhennia I. I. Mechnihova). Aledichnii zhurnal AN URSR (Medical Journal of the Academy of Sciences, Ukrainian Soviet Socialist Republic), 16: 50-52, 1947.

335. Bogomolov, N. A. "Gas Exchange, Respiration, and Circulation in Calves of the Tagil'sk Breed in Ontogenesis and in Development of Digestive Processes." Fiziologicheskii zhurnal SSSR (Physiological Journal of the USSR), 38(1): 82-90, 1952.

336. Bogorad, S. "The Nursing Infant in Current Pediatrics." Pediatriia (Pediatrics), 4: $401,1914$.

337. Bogoslovskaia, G. IA., BogoslovksaiaStrashnikova, S. G., and Derzhavina, V. N. "The Problem of Erythrocyte Resistance in Children at an Early Age." Zhurnal po izucheniiu rannego detskogo vozrasta (Journal for Study of Early Childhood), $9(6)$ : 383-387, 1929.

338. Bokser, O. IA. "'Test Study of Higher Nervous Activity in Juvenile Chorea Before and After Sleep Therapy." Zhurnal vysshei nervnoi deiatel'nosti (Journal of Higher Nervous Activity), 3(4): 592-604, 1953.

339. Bolkhovitina, T. M. "Conditioned Respiratory Reflexes of Children." Trudy Voronezhskogo meditsinskogo in-ta (Transactions of the Voronezh Medical Institute), 14: 119$123,1948$.

340. Bondarenko, G. A. "Folliculin Action on Hematopoietic Function of Suckling 
Pigs." Problemy zhivotnovodstva (Problems of Animal Husbandry), (6): 103, 1935.

341. Borisovskir, B. "Problem of Immunity to Scarlet Fever in Early Infancy." Vestnik souremennoi meditsiny (Journal of Contemporary Medicine), (18): 955-956, 1929.

342. BORISHPOL'SKII, E. S. "Anatomical and Physiological Characteristics of the Nervous System in Children." Vrachebnaia gazeta (Medical Journal), (22): 2633-2637 and (23): 2716-2720, 1929.

343. Borovsrn, M. L. "Postembryonic Development of Human Cerebellar Cortex." Biull. VIEM (Bulletin of the All-Union Institute of Experimental Medicine), (3): 14, 1935.

344. ㄴ. "Embryonic and Postembryonic Development of the Anterior Central Convolution of the Cortex in Man and Postembryonic Development of the Motor Zone of the Cerebral Cortex in Dog. Report 1. Cytological Investigation of the Ontogenetic Development of the Anterior Central Convolution of the Cortex in Man." Arkhiv biologicheskikh nauk (Archives of Biological Sciences), 43(1): 23-40, 1936.

345. - "Embryonic and Postembryonic Development of the Anterior Central Convolution of the Cortex in Man and Postembryonic Development of the Motor Zone of the Cerebral Cortex in Dog. Report 2. "Embryonic and Postembryonic Development of the Anterior Central Convolution of the Cortex in Man and Postembryonic Development of the Motor Zone of the Cerebral Cortex in Cat." Ibidem, 44(3): 31-49, 1936.

346. "Embryonic and Postembryonic Development of the Anterior Central Convolution of the Cortex in Man and Postembryonic Development of the Motor Zone of the Cerebral Cortex in Dog. Report 3. Cyto-Architectonic Investigations of Postembryonic Development of the Anterior Central Convolution of the Cortex in Man." Ibidem, 47(1): 5-27, 1937.

347. - "Embryonic and Postembryonic Development of the Anterior Central Convolution of the Cortex in Man and Postembryonic Development of the Motor Zone of the Cerebral Cortex in Dog. Report 4. Cytological and Cyto-Architectonic Investigations of the Postembryonic Development of the Motor Lobe of the Cerebral Cortex in Cat." Ibidem, 47(2): 115-130, 1937.
348. Borodina, R. Sir, "Functional Deviations and Variants of Development of the Cardiovascular System." Fiziologicheskie osobennosti, klinika zabolevanii $i$ gigiena truda rabochikh podrostkov (Physiological Characteristics, Clinical Aspects of the Diseases, and Occupational Hygiene of Working Adolescents), Moscow, 1952, pp. 25-42.

349. Borsuk, V. N. "Ascorbic Acid in the Ontogenesis of Birds." Doklady Akademii nauk SSSR. Novaia seriia (Reports of the USSR Academy of Sciences. New series), 64(3): 421-423, 1949.

350. Borsuk, R. A., Manuilov, N. A., and Potemkina, D. A. "Relationship of Morphological and Physiological Changes in Development." Soveshchanie embriologov $v$ Leningrade, $1955 \mathrm{~g}$. Tezisy dokladov (Conference of Embryologists at Leningrad, 1955. Theses of Reports.), Leningrad, 1955, pp. 182183.

351. BortKevich, V. I. "Mortality and Longevity of the Populace of European Russia." Zapiski Akademii nauk (Records of the Academy of Sciences), 69(8) and 66(3), St. Petersburg, 1891.

352. Borts, I. L. "Calcium, Phosphorus, and Nitrogen Exchange in Suckling Pigs." Vestnik zhivotnovodstva (Journal of Animal Husbandry), (5): 98-112, 1948.

353. BoGhkarev, P. V. "The Study of Old Age." Vrachebnoe delo (Medical Affairs), (14-15): 761, 1924.

354. - Old Age and Internal Secretion." Vestnik endokrinologii (J. of Endocrinology), (1-3): 207-215, 1926.

355. Brailovskir, S. A., and Genkin, A. M. "Glycogen, Sugar, and Lactic Acid in the Blood of Children. I and III." Sovetskaia pediatriia (Soviet Pediatrics), (11): 3-77, 1936; (7): 8-13, 1937.

356. Brandt, A. "Life and Death" (Zhizn' $i$ smert'). Khar'kov, 1886.

357. Braunshtein, A. E. "Biochemistry of Amino Acid Exchange" (Biokhimiia aminokislotnogo obmena. Izd. AMN SSSR, M.), published by the Academy of Medical Sciences USSR, Moscow, 1949.

358. Breitburg, A. M., and Liberman, A. B. "Neurohumoral Regulation of the Metabolic Processes. Report VI. Effect of Diets with Limited and Increased Carbohy- 
drate Content on Free and Combined Hepatic Glycogen Equilibrium." Voprosy pitaniza (Problcms in Nutrition), 9(5): 23-30, 1940.

359. Broide. "Myofibrosis cordis" (Myofibrosis cordis. Diss.), a disscrtation. Iur'ev, 1901.

360. Bronovitskaia, Z. G. "Certain Age Changes of Tissue Protein." Pratsi nauk.doslid. zoobiologichnogo in-tu, Kharkiv, vid-tvo Kharkivs'kogo derzh. un-tetu (Transactions of the Scientific Research Institute of Zoobiology, Khar'kov State University), (1011): $33-46,1941$.

361. Bronshtein, A. I., and Petrova, E. P. "Investigation of the Sound Analyzer of the Newborn and of Infant Nurslings." Zhurnal vysshei nervnoi deiatel'nosti ( $\mathrm{J}$. of Higher Nervous Activity), 11(3): 333-343, 1952.

362. - "New Data on the State of the Sound Analyzer of the Newborn and of Infant Nurslings. Report on the Conference of the Leningrad Association of Pcdiatricians." Materialy l-i nauchnoi konferentsii po voprosam vozrastnoi morfologii $i$ fiziologii. Tezisy. Izd-vo Akademii pedagogicheskikh nauk RSFSR, M. (Materials on the First Scientific Conference on Problems of Age Morphology and Physiology. Theses. Publishing House of the Academy of Pedagogical Sciences. Russian Soviet Federative Socialist Republic, Moscow), 1952, pp. 17-18.

363. "New Data on the State of the Sound Analyzer of the Newborn and of Infant Nurslings." Trudy pervoi nauchnoi konferentsii po vozrastnoi morfologii $i$ fiziologii, izd-vo Akademii pedagogicheskikh nauk RSFSR, M. ('Transactions-ibidem), 1954, pp. 63-72.

364. Bronshtein, I. G. "Physical and Mental Development of Premature and Underweight Children Raised in the Family." Sovetskaia pediatriia (Soviet Pediatrics), (12): 73-77, 1934.

365. Brusianin, N. "The Nucleins of Certain Nutricnts" (O nukleinakh nekotrykh pilatel'nykh veshchestv. Iz gigienicheskoi laboratorii prof. A. P. Dobroslavina, Diss. na stepen' doktora meditsiny, SPb), Dissertation for a doctorate degree in medicine, from the Hygiene Laboratory of Prof. A. P. Dobroslavina, St. Petersburg, 1889, p. 29.
366. Budanova, A. M. "Arginine Content in Brain Proteins of Vertebrates." Biulleten' eksperimental'noi biologii $i$ meditsiny (Bulletin of Expcrimental Biology and Medicine), 1: 14, 1936.

367. Budrevich, P. M. "Oxygen and Carbon Dioxide in the Blood of Normal Nursing Children." Pedialriia, akusherstvo i ginekologiia (Pediatrics, Obstetrics and Gynecology), (4-5): 3-7, 1939.

368. Bulankin, I. M. "Age Changes in the Protein Fractions of Blood Serum Proteins of Rats." (Ukr.: Zmini v bilkovikh fraktsïakh sirovatki krovi bilikh shchuriv z vikom.) Pratsi zoobiologichnogo in-ty Kharkivs'kogo derzhavnogo un-tetu, Kharkiv. Derzhmedvidav (Transactions of the Institute of Zoobiology, Khar'kov State University. State Publishing House of Medical Literature, Khar'kov), 2: 53-57, 1934.

369. - and Tverdun, O. G\& "Changes in Rate of Jellification of Gelatin of Diverse Age Depending on the Concentration and Frequency of 'Excitation' of the Gelatin Jellies" (Ukr.: Zmini shridkosti dragliuzannia zhelatini riznogo viku zalezhno vid kontseniratsii $i$ chastoti "podraznennia" zhelatinovikh dragliv). Pratsi nauk. -doslid. zoobiologichnogo in-tu Kharkivs'kogo derzh. un-tetu, K harkiv, Derzhmedvidav (Transactions of the Scientific Research Institute of Zoobiology, Khar'kov State University, State Publishing House of Medical Literature, Khar'kov), 3: 170-183, 1936.

370. Bulankin, I. N. (same as the Ukr. I. M.), and Tverdun, O. G. "Changes in Rate of Jellification of Gelatin of Diverse Age Depending on the Concentration and Frequency of Melting." Kolloidnyi zhurnal Voronezhskii in-t kolloidnoi khimii (The Colloid Journal of the Voronezh Institute of Colloid Chemistry), 2(7): 533-538, 1936.

371. Bulankin, I. M. "The Aging of Organisms and the Problem of the Aging of Colloids" (Ukr.: Starinnia organizmiv i problema starinnia kolloidiv). Uchenii zapiski. Kharkivs'kogo derzh. un-letu. Kharkiv, vidtvo Kharkivs'kogo derzh. un-tetu (Annals of Khar'kov State University, State Publishing House of Khar'kov University, Khar'kov), 5: 19-38, 1936.

372. Bulankin, I. N. (Ukr.: I. M.). "Change of Viscosity and Surface Tension in the Aging of Gelatin." Kolloidnyi zhurnal (Colloid Journal), 3(8): 69l-802, 1937. 
373. Bulankin, I. M. "Changes of Viscosity and Surface Tension Depending on Concentration and Temperature at the Aging of Gelatin" (Ukr.: Zmini v'iazkosti $i$ poverkhnevogo natiagu zalezhno vid kontsentratsii $i$ temperaturi pri starinni zhelatini). Pratsi zoobiologichnogo in-tu Kharkivs'kogo derzh. un-tetu. Kharkiv, Derzhmedvidav (Transactions of the Institute of Zoobiology of the Khar'kov State University. State Publishing House of Medical Literature, Khar'kov), 5: 22-38, 1938.

374.

"Specific Rotation of Gelatin in Connection with Nutrition in Regard to Aging of Gelatin Sols and Gels" (Ukr.: Pro pitome obertannia zhelatini v zv'iazku z pitanniam pro starinnia zhelatinovikh zoliv $i$ dragliv.). Ibidem, 5: 39-58, 1938.

375. Bulankin, I. N., and Kaplan, V. A. Age Physicochemical Changes of Collagen Derivatives of the Skin." Ibidem, (7): 235-254, 1938.

376. Bulankin, I. N. "Character of Colloidal Ion Changes at Aging of Sols and Gels." (Likewise in Ukrainian). Kolloidnyi zhurnal. Voronezhskoe izd-vo in-ta kolloidnoi khimii (Colloid Journal. Publ. of the Voronezh Institute of Colloid Chemistry), 4(9-10): 657-670, 1938.

377. ——. "Data on Aging of Biocolloids (Aging Mechanisms of Gelatin Sols and Gels)" (Materialy o starenii biokolloidor (zakonomernosti stareniia zolei $i$ studnei zhelatiny)). Dissertation for a doctorate degree in biological sciences, Khar'kov State University, Publ., Khar'kov, 1939.

378. - ZEL'TSER, S. I., and SlabospitsK11, D. G. "Age and the Various Kinds of Phosphorus in the Animal Organism." Pratsi nauk. -doslid. zoobiologichnogo in-tu Kharkivs'kogo derzh. un-tetu. Kharkiv, vid-tvo Kharkivs'kogo derzh. un-tetu (Transactions of the Sci-Research Institute of Zoobiology of Khar'kov State University. Publishing House of Khar'kov State University), (1011): 17-22, 1941 .

379. and Bliumina, M. A. "Age Changes of Tissue Proteins." Ibidem, (1011): 47-58, 1941 .

380. and Kaplan, V. A. "Age Physicochemical Changes of Collagen Dcrivatives of the Skin." Kolloidnyi zhurnal (Colloid Journal), 7(2): 117-128, 1941.

381. - and Bliumina, M. A. "Age Changes of Tissue Proteins and Proteinases in the Animal Organism." Wehenye zapisk Khar'kouskogo gos. un-teta. Khar'kov, izd-vc Khar'kovskogo gos. un-teta (Annals of the Khar'kov State University. State Publishing House of Khar'kov University Khar'kov.), 25: 61-74, 1947.

382. - and Nagornyi, A. V. "Some Mechanisms of Age Changes of a Dissimilator Phase of Metabolism." VII Vsesoiuznyi s'ezd fiziologov, biokhimikov, farmakologov. Dohlady. M. Medgiz (Seventh All-Union Congress of Physiologists, Biochemists, and Pharmacologists. Reports. Moscow, State Publishing House of Medical Literature), 1947, pp. 647-651.

383. Bulankin, I. N. "Specific Rotation of Gelatin in Connection with the Aging of Gelatin Sols and Gels." Kolloidnyi zhurnal Voronezhskii in-t kolloidnoi knimii (Colloid Journal. Voronezh Institute of Colloid Chemistry), 3(7): 677-687, 1947.

384. - - Parina, E. V., and Sergienko, E. F. "Effect of Nutrition on Equilibrium of Protein Fractions in Organs of Animals of Varied Age." Trudy konferentsii po vozrastnym izmeneniiam obmena veshchestv $i$ reaktionosti organizma, 1949. Kiev, AN USSR, in-t klinicheskoi fiziologii im. akad. A. A. Bogomol'tsa (Transactions of the Conference on Age Changes of the Metabolism and Reactivity of the Organism, 1949. Kiev, Academy of Sciences of the Ukrainian Soviet Socialist Republic, A. A. Bogomolets Institute of Clinical Physiology), 1951, pp. 27-35.

385. Bulankin, I. N. "Outline of Development of Biological Chemistry at the A. M. Gor'kii Khar'kov State University and at the Medical Institute." Uchenye zapiski. Khar'kovskogo gos. un-teta, Khar'kov. Izd-vo Khar'kovskogo gos. un-teta (Annals. Khar'kov State University. Khar'kov State Univ. Publishing House, Khar'kov), 53: 41-80, 1954.

386. - Lantodub, I. Iu., Novikova, N. M., Papakina, I. K., and Frenkel', L. A. "Age Changes of the Liponucleoproteid Complex in Liver and Brain Tissues." Ibidenı, 53: 87-98, 1954.

387. Bulankin, I. N. and Parina, E. V. "Age Changes of Oxidizing Phosphorylation." Ibidem, 53: 136-141, 1954.

388. Bulankin, I. N., Novikova, N. M., and Parina, E. V. "Chemical Nature of So-Called Structural Proteins." Uchenye zapiski. (Annals), 53; Trudy nauch.-issled. in-ta 
biologii (Transactions of the Scientific Research Institute of Biology), 21: 73-80, 1954.

389. Bulankin, I. N., Nikitin, V. N., Parina, E. V., Golubitskaia, R. I., NoviKova, N. M., and SilıN, O. P. "Age Changes of Certain Biochemical Indices Connected with the Process of Protein Synthesis." VIII Vsesoiuznyi s'ezd fiziologiv, biokhimikov, farmakologiv. Tezisy dokladov, $A \mathcal{N}$ SSSR, M. (Eighth All-Union Congress of Physiologists, Biochemists, and Pharmacologists. Theses of Reports. Academy of Sciences USSR, Moscow), 1955, pp. 90-91.

390. Bulankin, I. N., Parina, E. V., Kurilenko, R. P., Mitropanova, V. M., Zisser, R. L., and Sharkevich, I. N. "Age Changes of Metabolism in Conditions of Stimulated Synthesis." Uchenye zapiski. Khar'kovskogo gos. un-teta (Annals. Khar'kov State Univ.), 68. Trudy nauch.- issled. in-ta biologii $i$ biologicheskogo $f$-ta (Transactions of the Scientific Research Institute of Biology and of Biological Pharmacotherapy), 24: 5-20, 1956.

391. Bulankin, I. N. and Parina, E. V. "Qualitative Changes of Liver Ribonucleic Acid of Different Age Animals. (Ratio Between Phosphorus and Pentose)." Uchenye zapiski. Khar'korskogo gos. un-teta (Annals. Khar'kov State Univ.), 68. Trudy nauch.issled. in-ta biologii $i$ biologicheskogo f-ta (Transactions of the Scientific Research Institute of Biology and of Biological Pharmacotherapy), 24: 35-42, 1956.

392. Bulanova, O. N. "Organic Acids of Blood in Process of Dying from Blood Loss with Subsequent Restoration of Body Life Processes." Biokhimiia (Biochemistry), 19(5): 590-598, 1954.

393. Bulanov, N. V. "Problem of Changes of Elastic Fibers of the Lungs in Senility." ( $K$ voprosu ob izmeneniiakh elasticheskikh volokon legkikh v starcheskom vozraste). Dissertation, St. Petersburg, 1897.

394. Bunak, V. V. "Importance of Mechanical Factor for Differentiation of Structure in Postnatal Ontogenesis." Trudy V $V$ sesoiuznogo s'ezda anatomov, gistologiv $i$ embriologov (Transactions of the Fifth All-Union Congress of Anatomists, Histologists, and Embryologists), Leningrad, 1951, pp. 120124.

395. Bunge, G. "Wachstumsgeschwindigkeit und Lebensdauer der Säugetiere" (Ger. for: Growth Rate and Longevity of Mam- mals). Pfügers Archio ges. Physiologie (PЯüger's Archives of General Physiology of Man and Animals), 95: 606-608, 1903.

396. Buniakovskir, V. IA. "Study of Mortality Laws in Russia." (Opyt o zakonakh smertnosti v Rossii), St. Petersburg, 1874.

397. Burdak, V. D. "Age Changes in Mucosa of the Gastrointestinal Tract of Cephalata (Mugil species). ( $O$ vozrastnykh izmeneiiakh slizistoi zheludochno-kishechnogo trakta kefalii (Mugil sp. sp.)). Doklady Akademii nauk SSSR (Reports of the Academy of Sciences USSR), 104(2): 313-314, 1955.

398. Busygin, A. T. "Age Changes in Length and Breadth of the Lower Jaw of Man." Stomalologiia (Stomatology), (3): 45-46, 1955.

399. Buknsittab, I. "Material Contributions to the Problem of the Weight, Metabolism, and Specific Gravity (Proportion) of the Brain in Subjects of Both Sexes and of Varied Age; also Dimensions of Skull and Outer Surface of the Lobes of the Brain (Anthropometric researches of Prof. P. F. Lesgaft's department)" (Materialy $k$ voprosu o vese, ob'eme $i$ udel'nom vese golounogo mozga $u$ sub'ektov oboego pola $i$ raznogo vozrasta; takzhe razmerakh cherepa $i$ naruzhnoi poverkhnosti dolei mozga (Antropometricheskie issledovaniia iz kabineta prof. P. F Lesgafta) Diss. na stepen' doktora meditsiny, $S P b)$. Dissertation for doctor of medicine degree, St. Petersburg, 1884, p. 54.

400. Byкоv, K. M. "Functional Connection of Cerebral Cortex with the Internal Organs." Fiziologicheskii zhurnal SSSR (Physiological Journal of the USSR), 16(1): 93$110,1933$.

401. - "Cortical Regulation of Activity of Internal Organs in the Light of the Time Category." Trudy iubileinoi sessii Leningradskogo gos. un-teta (Transactions of the Jubilee Session of Leningrad State University), 1946, pp. 37-5l.

402. - "Cerebral Cortex and Internal Organs" (Kora golounogo mozga $i$ vnutrennie organy. 2 izd. Medgiz, M.-L.), 2d edition State Publishing House of Medical Literature, Moscow-Leningrad, 1947.

403. - "Experiment of Studying Regulation of Physiological Functions." (Opyt izucheniia reguliatsii fiziologicheskikh funktsii. Izd-vo AN SSSR, M.-L.), Publishing House of the Academy of Sciences USSR, Moscow-Leningrad, 1949. 
404. Byкov, N. M. "Nervous Apparatus of Aortal Reflexogenic Zone in the Fetuses and Newborn of Man." Author's own abstract of his dissertation for candidate of medical sciences, Lesgaft Institute of Physical Culture, Leningrad. (Nervnyi apparat aortal'noi refieksogennoi zony u plodov $i$ u novorozhdennogo cheloveka. Avtoreferat diss. kand. med. nauk, in-t fizkul'tury im. Lesgafta, L.), 1953.

405. Byreev, P. A. "Blood Protein Picture in the Newborn." Trudy Saratovskogo gos. med. in-ta, Saratov (Transactions of the Saratov State Medical Institute, Saratov), 3(1-2): 230-235, 1940.

406. Bystroletova, G. N. "Formation in Newborn Children of a Conditioned Reflex for Time in Connection with the Daily Rhythm of Feeding." Zhurnal vysshei nervnoi deiatel'nosti (Journal of Higher Nervous Activity), 4(5): 602-609, 1954.

407. Bychkov, S. M., and ZBARski, I. B. "Changes in Content of Certain Products of Carbohydrate and Protein Metabolism at Various Stages of Development of the Worker Bee." Biull. eksperimental'noi biologii $i$ meditsiny (Bulletin of Experimental Biology and Medicine), 3(1): 16-18, 1937.

408. Bialik, L. M. "Characteristics of the ESR (Erythrocyte Sedimentation Rate) in Children During the Neonatal Period (Contribution to the Problem of the Effect of Anesthetization of Parturients on the Newborn)." Voprosy pediatrii $i$ okhrany materinstva $i$ detstva (Problems of Pediatrics and Maternal and Child Welfare), 12(9): 402-409, 1940.

\section{V}

409. V. G. (sic-initials only) "Life and Death." Mir bozhii (God's World), 1898.

410. VADENIUK, A. "Problem of the Effect of Medicaments on the Intrauterine Fetus (Effect of Quinine on the Fetus)" ( $K$ voprosu - vliianii medikamentov na vnutrimatochnyi plod (Vliianie khinina na plod) Diss. na stepen' doktora meditsiny). Dissertation for degree of doctor of medicine, St. Petersburg, 1883, p. 72 .

411. Vadova, A. V. "Character of Catalyis of Embryonic Tissue of Rabbits in Developmental Process of the Embryo." Biull. eksperimental'noi biologii $i$ meditsiny (Bulletin of Experimental Biology and Medicine), 8(1): 84-86, 1939.
412. VAlL', V. S. "Age Traits of Permeability of Mucosa of Gastrointestinal Tract." Voprosy pediatrii i okhrany materinstva i detstva (Problems of Pediatrics and Maternal and Child Welfare), 15(3): 11-18, 1947.

413. - "S. F. Khotovitskii (17961885), First Russian Pediatrician" ( $S . F$. Khotovitskii (1796-1885)-pervyi russkii pediatr. Medgiz, L.). State Publishing House of Medical Literature, Leningrad, 1949.

414. VAIL', I. S. "Study of Osmotic Stability of Erythrocytes in Children During Infectious Diseases." Pediatriia (Pediatrics), 9(2-3), 1929.

415. Vall', S. S. "Cerebral Tissue Changes of the Newborn Related to Birth Trauma." Tsentral'nyi institut akusherstva $i$ ginekologii. Tezisy dokladov iubileinoi nauchnoi sessii, $L$. (Central Institute of Obstetrics and Gynecology. Theses of Papers of the Jubilee Scientific Session), Leningrad, 1947, pp. 3536.

416. VainshteiN, B. I. "Roentgenokymographic Observations on the Effect of Physical Stress in the Environment of Operators and Juveniles in Industrial Training" (Rentgenokimograficheskie nabliudeniia nad vozdeistviem fizicheskoi nagruzki na srede rabochikh $i$ podrostkov FZO (Fabrichno-Zavodskoi Obuchenie). Diss., L.). Dissertation, Leningrad, 1949.

417. VAKSLE1GER, G. A. "Reaction of General Inertia in Dogs in the Ontogenesis." VII Vsesoiuznyi s'ezd fiziologov, biokhimikov, farmakologiv, M., Medgiz (Seventh All-Union Congress of Physiologists, Biochemists, and Pharmacologists), State Publishing House of Medical Literature, Moscow, 1947, pp. 121122.

418. Vakulenko, 1. L., and Pavlova, A. I. "Problem of Erythrocyte Stability in Blood of the Newborn." Sibirskii arkhiv teoreticheskoi $i$ klinicheskoi meditsiny (Siberian Archives of Theoretical and Clinical Medicine), 2(3-5): 236-244, 1927.

419. Valentinovich, A. A. "Reactivity Changes of the Child's Organism in Certain Pathological Processes. Report II. Reactivity of the Mesenchyma In Hepatitis, Nephritis, and Rheumatism." Voprosy pediatrii $i$ okhrany materinstva $i$ detstva (Problems of Pediatrics and Maternal and Child Welfare), 17(1): 35, 1949.

420. Val'dman, V. A. "Blood Vessel Tonus and Peripheral Circulation" (Tonus 
sosudov i perifericheskoi krovoobrashchenie. L.), Leningrad, 1928.

421. "Old Age and Work Capacity." Klinicheskaia meditsina (Clinical medicine), 12(10): 1409, 1934.

422. VAL'KeR, F. I. “Topographical-Anatomical Characteristics of Child Growth and Their Importance to the Clinic." Trudy Leningradskogo gos. pediatricheskogo med. in-la, L. (Transactions of the Leningrad State Medical Institute of Pediatrics), Leningrad, 1940 pp. 76-83.

423. "Postnatal Development of Organs in Man." (Razvitie organov u chcloveka posle rozhdeniia. Medgiz, M.). State Publishing House of Medical Literature, Moscow, 1951, p. 115.

424. " "Study of Postnatal Development of Organs in Man." Arkhiv anatomii, gistologii $i$ embriologii (Archives of Anatomy, Histology, and Embryology), (1): 43-47, 1952.

425. - "Study Methods of Growth Variability, Topography, Form, and Structure of Organs in the Human Body." Plenum pravleniia Vsesoiuznogo nauchnogo obshchestva analomov, gistologov $i$ embriologov. Tezisy dokladov. Ministerstvoz dravookhraneniia SSSR, L. (Plenum of the Directorate of the All-Union Scientific Society of Anatomists, Histologists, and Embryologists. Theses Papers. Ministry of Health SSSR, Leningrad), 1953, pp. 6-7.

426. - "Study Methods of Growth Variability, Topography, Form, and Structure of Organs in the Human Body." Souremennie metody $i$ tekhnika morfologicheskikh issledovanii. Medgiz, L. (Current Methods and Technique of Morphological Studies. State Publishing House of Medical Literature, Leningrad), 1955, pp. 252-256.

427. - "Postnatal Development of Cardiovascular System in Man" Sbornik: Trudy pervoi nauchnoi konferentsii po vozrallnoi morfologii $i$ fiziologii, izd-vo Akademii pedagogicheskikh nauk RSFSR, M. (Collection: Transactions of the first scientific conference on age morphology and physiology. Publ. of the Academy of Pedagogical Sciences RSFSR, Moscow), 1954, pp. 139-146.

428. VAL'TER, E. M. "Blood of Premature Children." Zhurnal po izucheniiu rannego detskogo vozrasta (Journal for Study of Early Childhood), 5(3): 167-173, 1927.
429. - and Fabrikant, G. I. "Active Acidity of Stomach Content in Nursing Children." Ibidem, 9(5): 279-288, 1929.

430. Vanno 1, I. O. "Probable Curability of Almost All Diseases" ( $O$ zervialnoi izilechimosti pochti 'sekh toleznei. Aktouaia rech'. Khar'kov). Assembly speech. Khar'kov, December 3'), 1818.

431. Varsilavskil, A. G. "Growth Development of Absorptive functions of the Reticulo-Endothelial Syste...." Peviztriis (Pediatıics), 4(7-8): 3-1'), 1938.

432. Vasilenko, V. KH., and Maizlish, R. I. "Variations of Prolan Elimination in Connection with Age." Sbornik: "Starost'." Trudy konferentsii $17-19$ dehabria $1938 \mathrm{~g} . \mathrm{AN}$ USSR (Collection: "Old Age." Transactions of the Conference, December 17-19. 1938, of the Academy of Sciences, UkrSSR). Kiev, 1940, pp. 117-128.

433. Vasil'ev, G. A. 'Nerve-Humoral Regulation of the Behavior of Fledglings." Sed'moe soveshchanie po problemam vysshei nervnoi deiatel'nosti, posviashchennoe pamiati akad. I. P. Pavlova (Seventh Conference on Problems of Higher Nervous Activity Dedicated to the Memory of Academician I. P. Pavlov).

434. -Dynamics of Behavioral Development of Fledgling Rooks." Ob'edinennaia sessia, posviashchennaia 10-letiiu so dnia smerti 1. P. Pavlova, M., AMN SSSR (Joint Session Devoted to the Tenth Year from the Day of I. P. Pavlov's Death), Academy of Medical Sciences, USSR, Moscow, 1948, pp. 179-181.

435. VAsil'ev, IU. A., and Voltkevici, A. A. "Development and Behavior of Thyroidectomized Fledgling Rooks." Doklady Akademii nauk SSSR (Reports of the Academy of Sciences USSR), 22(6): 00, 1939.

436. Vasil'ev, G. A., and Voitkevich, A. A. "Development and Behavior of Thyroidectomized Birds of Various Ages in the Fledgling Group." Tezisy $V$ soveshchaniia po fiziologicheskim problemam AN SSSR (Theses of the Fifth Conference on Physiological Problems, Academy of Sciences, USSR), 14, 1939.

437. Vasil'Eva, O. A. "Nucleic Acid Change in the Course of Fertilization of the Pea." Doklady Akademii nauk SSSR (see above), 95(1): 163-166, 1954.

438. Vasilevskir, N. P. "Individual Rating of the Physical Development of Children 
with Calculation of Standard Deviations of Basic Indices According to Years." Pediatriia (Pediatrics), (9): 107-112, 1940.

439. Vasnetsov, V. V. "Study of Comparative Analysis of Linear Growth of the Carp Family." Zoologicheskii zhurnal (Zoological journal), 13(3): 540-583, 1934.

440. "Divergence and Adaption in Ontogenesis." Ibid., 25(3): 185-200, 1946.

441. - "Stages of Development of the System of Organs of Nutrition in Bream, Roach, and Carp." Sbornik: Morfologicheskie osobennosti, opredeliaiushchie pitanie leshcha, vobly i sazana na vsekh stadiiakh raztiviia, izd-vo AN SSSR, M.-L. (Collection: Morphological Features that Determine the Feeding of Bream, Roach, and Carp in All Stages of Development). Publ. of the Academy of Sciences USSR, Moscow-Leningrad, 1948, p. 233.

442. - "Stages of Development of Bony Fishes." Sbornik: Ocherki po obshchim voprosam ikhtiologii, izd-vo AN SSSR, M.-L. (Collection: Synopses of General Problems of Ichthyology), Publ. of Academy of Sciences USSR, Moscow-Leningrad, 1953, pp. 207217.

443. - "Patterns of Fish Growth." Ibidem, 1955, pp. 218-226. Vasiutina, A., and Farfel', V. S. "Physiological Characteristics of the Running Children 8-9 Years of Age." Izvestiia Akademii pedagogicheskikh nauk RSFSR (Bull. of Acad. of Pedagogical Sciences. Russ. Sov. Fed. Sôc. Republic), (60): 229-240, 1954.

444. Vegel'man, Ch. A., and Polezhaeva, L. V. "Biochemical Changes in Tooth Enamel Associated with Age." Sovetskaia stomatologiia (Soviet Stomatology), (1): 39$47,1935$.

445. Vedrashko, V. F., Ozeretskovskaia, N. E., and Podrabinik, G. M. "Problem of Vitamin C Requirement in the Child Organism. Pediatriia (Pediatrics), (3): 45-46, 1946.

446. Vedrasiiko, V. F., Milovidova, M. K., and Ozeretskovskaia, N. E. "Interdependency of Vitamin B Content in the Diet and Its Elimination from the Organism in Preschool-Age Children." Fiziologicheskii zhurnal SSSR (Physiological Journal of the USSR), 34(2): 293-296, 1948.

447. Vedrashko, V. F. "Feeding Regimen of Health Preschool Age Children and the
Physiological Basis for it." Voprosy pitaniia (Problems in Nutrition), (3): 19-25, 1954.

448. Veinger, R. A. "Cutaneo-Galvanic Reflex in the Newborn and in Children of an Early Age at Applications of Algesic, Visual, and Aural Stimuli." Biull. eksperimental'noi biologii $i$ meditsiny (Bulletin of Experimental Biology and Medicine), 24(8): - 1947.

449. - "Emergence of the CutaneoGalvanic Reflex at Application of Visual and Aural Stimuli to Children in Postnatal Ontogenesis." Fiziologicheskii zhurnal SSSR (Physiological Journal of the USSR), 36(6): 653, 1950.

450. Veis, R. A., and Titaev, A. A. "Penetrability of the Heart of Mammals and the Age-Associated Characteristics of It." Biull. eksperimental'noi biologii $i$ meditsiny (see above), 2(2): 158-159, 1936.

451 Veitsman, V. "Observations on Regeneration of Bombina (Batrachian) Larve in the First Period of Development." Biulleten' eksperimental'noi biologii $i$ meditsiny (see above), 2(3): 221-222, 1936.

452. Versler, G. I. "Method of Collecting Urine of Infants." Pediatriia (Pediatrics), (2): 117-120, 1938.

453. VerbitskiI, M. K. "Biological Characteristics of the Long Able-Bodied." Starost' $i$ trudosposobnost' Sbornik rabot NIVTE, L. (Old Age and Capacity for Work. Collection of works of the Sci. Inst. of Med.Labor Consultation, Leningrad), 1936, pp. 159-174.

454. VereiskiI, V. N. "Replacing the Crystalline Lens of Adult Tailless Amphibia with Larval Skin." Doklady Akademii nauk SSSR (Reports of the Academy of Sciences USSR), 99(4): 649-652, 1954.

455. Verzhbinskaia, N. A. "Brain Cytochrome System in Phylogenesis of Vertebrates." Fiziologicheskii zhurnal (Physiological Journal), 39(1): 17-26, 1953.

456. Vermel', V. M. "Size, Multiplication, and Growth of Cells." Sbornik: Rost zhivotnykh, pod red. S. Ia. Kaplanskogo $i d r$., Biomedgiz, M.-L. (Collection: Animal Growth, edited by S. Ia. Kaplanskii, director. State Publishing House of Biomedical Literature, Moscow-Leningrad), 1935, pp. 107-163.

457. Vermel', S. B. "Renal Infarcts in the Newborn." Russkii arkhiv patologii, klini- 
cheskoi meditsiny $i$ bakteriologii (Russian Archives of Pathology, Clinical Mcdicine, and Bactcriology), 5: 596-612, 1898.

458. Verkilutina, A. I., and Efimov, V. V. "Electrical Excitability of the Eye and Its Agc, Seasonal, and Diurnal Changes." Biulleten' eksperimental'noi biologii $i$ meditsiny (Bulletin of Experimental Biology and Medicine), 23(1): 37-39, 1947.

459. Verkhutina, A. I. "Electrical Excitability of the Eye and Its Alterations from Age, Timc of Day, and Ccrtain Other Factors." Sbornik: Problerna fiziologicheskoi optiki, izd-vo AN SSSR, M.-L. (Collection: Problem of Physiological Optics. Publ. of Academy of Scicnces USSR, Moscow-Leningrad), 1948, pp. 352-358.

460. VesELk1N, N. V. "Effect of Oxygen Deficiency on the Growth and Development of Chick Embryos." Arkhiv biologicheskilhk nauk (Archivcs of Biological Scienccs), 22(4): 213, 1917.

461. ViziR, P. S. "Ontogenesis in Bacteria" (Ukr.: Pro ontogenez u bakterii). Visnik $A \mathcal{N}$ URSR (Journal of the Academy of Sciences, UkrSSR), (8): 42-50, 1954.

462. Viller, G. E. "Nitrogen Exchange of the Central Nervous System in Ontogenesis." Trudy Kuibysheoskogo gos. med. in-la (Transactions of the Kuibyshev State Medical Institute), 1: 110-118, 1948.

463. ViNBERG, G. G. "Metabolic Rate and Life Cycle of Drosophila. III. Respiratory Rate, Dimensions, and Life Cycle of Drosophila simulans." Arkhiv biologicheskikh nauk (Archives of Biological Sciences), 38(3): 657664, 1935.

464. - "Optimum Temperature for Development." Uspekhi souremennoi biologii (Advances in Contemporary Biology), 5(3): $560,1936$.

465. - and Khartova, L. E. "Metabolic Rate in Carp Fry." Doklady Akademii nauk SSSR (Proceedings of the Academy of Sciences USSR), 89(6): 1119-1122, 1953.

466. Vinitskovskaia, S., Klupt, M., and Tolkacievskaia, N. "Method of Differentiated Collection of Feces and Urine of Infants." Sovetskaia pediatriia (Soviet Pediatrics), 1(2): 92-94, 1934.

467. Vinogradov, S. I. "Problem of Dynamics of Number of Thrombocytes in
Peripheral Blood of the Newborn." Trudy Saratorskingo gos. med. in-la, 2(2-3): 1939.

468. V1NS1TOK, V. "Dependency of Weight and Growth of the Newborn on the Mother's Age and Sequence of Births." Materialy po statistike Petrograda (Petrograd Statistical Iata), 1921.

469. VIRENiUs, A. S. "Proportion of $\mathrm{CO}_{2}$ in Air of Classrooms and Sleeping Quarters of Certain Educational Institutions." (Otnoshenie uglekisloty $v$ vozdykhe klassov $i$ spalen nekotorykh uchebnykh zavedenii. Diss. na siepen' doktora meditsiny, $S P b$ ). Dissertation for degree of doctor of medicine, St. Petersburg, 1884 , p. 57.

470. VITK1ND, IU. E. "Topographical-Anatomical Characteristics of the Liver and Its Vascular System in Children." Sbornik: Anatomiia, fiziologiia $i$ patologiia pecheni detei. Trudy kaf. f-ta pediatrii pod red. Zasluzh. deiat. nauki prof. M. S. Maslova, L. (Collection: Anatomy, Physiology and Pathology of the Liver of Children. Transactions of the Chair of the Pharmacotherapy of Pediatrics. Edited by honorary active worker in sciences, Prof. M. S. Maslova, Leningrad), 1940, pp. $5-42$.

471. VitT, V. O. "Importance of Age to Animal Breeding in the Light of Michurin Biology." Sbornik: Nauchnaia konferentsiia po voprosam znacheniia vozrasta pri razvedenii sel'skokhoziaistvennykh zhivotnykh. Timiriazevskaia s.-kh. akademiia, M. (Collection: Scientific Conference on Problems of Importance of Age in Breeding of Farm Animals. Timiriazev Agricultural Academy, Moscow), 1953.

472. "Some Problems of AgeAssociated Physiology in Horse Breeding." Ibid., 1953, pp. 66-84.

473. Vishnevetskaia, L. O. "Problem of Age-Associated Development of the Blood Vessels." Sbornik: Anatomo-fiziologicheskie osobrnnosti detshogo vozrasta. Biomedgiz, M.-L. (Collection: Anatomical-Physiological Characteristics of Childhood. State Publishing House of Biomedical Literature, MoscowLeningrad), 1935, pp. 175-195.

474 "Effect of Reactivity Alteration on Character of Disease of the Lungs in Toxic Diphtheria." Pediatriia (Pediatrics), (5): 75-78, 1947.

475. - "Age - Associated Reactivity During Infections." (Vozrasinaia reaktivnost" 
pri infektsiiakh. Sverdlovsk, gos. med. in-ta). Sverdlovsk State Medical Institute, 1947, p. 255.

476. Visinevski, Iu. B. "Change of Bromine Content in Blood of Children Suffering from Rheumatism in Connection with Impairment of Their Higher Nervous Activity." Zhurnal vysshei nervnoi deiatel'nosti (Journal of Higher Nervous Activity), 5(2): 211-218, 1955.

477. "Bromine Accumulation in Blood of Children and Subsequent Removal of It Depending on Different Doses of Sodium Bromide." Fiziologicheskii zhurnal SSSR (Physiological Journal of the USSR), 41: 525-531, 1955.

478. Vladmirov, G. E. "Beitrage zur Embryochemie und Embryophysiologie" (Ger. for: Contributions to the Chemistry and Physiology of the Fetus). Biochemische Zeitschrift (Berlin), 177: ——, 1926.

479. - "Effect of Certain Factors on the Glycemia of Chick Embryos." Arkhiv biologicheskikh nauk (Archives of Biological Sciences), 31(6): 528-539, 1931.

480. - "The Gas-Electrolyte Equilibrium in Blood of Chick Embryo." Fiziologicheskii zhurnal SSSR (Physiological Journal USSR), 29(3): 215-219, 1940.

481. Vladynin, A. L. "Iso-Agglutination in the Newborn (Preliminary Report)."' Zhurnal po izucheniiu rannego detskogo vozrasta (Journal for Study of Early Childhood), 5 (2): 93-99, 1927.

482. Vlasova, V. M. "Some Functional Properties of the Cerebral Cortex of Dogs in Ontogenesis" (O nekotorykh funktsional'nykh osobennostiakh kory golounogo mozga u sobak v ontogeneze. Avtoref. kand. diss.) Author's own abstract of his dissertation for the candidate degree. Kishinev, 1955.

483. Voblir, V. "Natural Movement of People in Capitalistic Countries in a Period of General Crisis of Capitalism." (Ukr.: Natural'nii rykh liudnosti v kapitalistichnikh krainakh o period zagal'noi krizi kapitalizmu). Profilakticheskaia meditsina (Preventive medicine), (3): 23, 1934.

484. Voblikova, T. V. "Rate of Photosynthesis and Respiration of a Leaf Depending on the Age Factor." Doklady Akademii nauk SSSR (Reports of the Academy of Sciences USSR), 33(1): — , 1941.
485. Vogralik, G. "Gastric Digestion in Children of Nursing Age." (Zheludochnoe pishchevarenie u detei grudnogo vozrasta. Izd-vo Prakticheskaia meditsina). Practical Medicine Publishing House, Leningrad, 1925. "Age-Associated Biochemistry of Children and Juvcniles." Sbornik 1, Inst. okhrany zdorov'ia detei $i$ podrostkov, L. (Collection I, Institute for Health Protection of Children and Juveniles, Leningrad), 1935.

486. Voinar, A. O., VAsil'ev, L. L., and Chizhevskil, A. L. "Aging and Rejuvenation of the Organism in the Light of Electrochemistry". Problemy ionifikatsii, izd-vo Kommuna, Voronezh (Problems of Ionification. Commune Publishing Ilouse, Voronezh, RSFSR), 3: 381, 1934.

487. Vornar, A. O. "Data on the Problem of Age Changes of Brain Colloids." Trudy in-ta im. Bekhtereva po izucheniiu mozga. II. Fiziko-khimicheskie osnovy nervnoi deiatel'nosti, Biomedgiz (Transactions of the Bekhterev Institute for Study of the Brain. II. Physicochemical Bases of Nervous Activity. Publishing House of Biomedical Literature), 1935, p. 98.

488. "Data on the Problem of Age Changes in Tissue Colloids." (Materialy $k$ voprosu $v$ vozrastnykh izmeneniiakh kolloidov tkanei. Diss. Stalino, Donetskii med. in-t), Dissertation, Donets Medical Institute, Stalino, 1935 , p. 148.

489. Voitkevich, A. A. "Some Rules of Development of the Thyroid Apparatus in Higher Vertebrates." Trudy in-ta eksperimental'noi morfologii, izd-vo AN SSSR, M.-L. (Transactions of Experimental Morphology, published by the Academy of Sciences USSR, Moscow-Leningrad), 3: 169, 1935.

490. - "Investigating the Role of the Hypophysis in Processes of Growth or Differentiation." Biull. eksperimental'noi biologii $i$ meditsiny (Bulletin of Experimental Biology and Medicine), 6(1): 86-89, 1938.

491. - "Biological Activity of 'Thyroid Glands of Pigeons Thyroidectomized at Different Ages." Fiziologicheskii zhurnal SSSR, (see below) 27(1): 101-107, 1939.

492. - and Rubina, S. "Biological Activity of Thyroid Gland of Man at Varied Age." Biull. eksperimental'noi biologii $i$ meditsiny (see above), 23(3): 212, 1947.

493. Voltkevich, A. A. "Species and Age Distinctions in the Reaction of the Principal 
Endocrine Organs to Thiouracil." Fiziologicheskii zhurnal (Physiological Journal), 33(6): 791-803, 1947.

494. and Samoilova, K. "Alteration of the Thyrotropic Activity of the Human Hypophysis in the Ontogenesis." Biull. eksperimental'noi biologii $i$ meditsiny (Bulletin of Experimental Biology and Medicine). 26(1): 59, 1948.

495. Voitkevich, A. A., and Naumenko, E. V. "Qualitative Changes of a Gonadotrophic Basis of the Human Hypophysis in the Ontogenesis." Doklady Akademii nauk SSSR (Reports of the Acad. of Sciences USSR), 93(6): 1139-1141, 1953.

496. Voltkevich, A. A. "Alteration of the Hormonal Activity of the Anterior Lobe of the Hypophysis of Man in the Ontogenesis." Izvestiia $A \mathcal{N}$ Kazakhskoi SSR, ser. fiziologii $i$ meditsiny (Bulletin of the Kazakh Academy of Sciences. Series of Physiology and Medicine), 136(4): 112-119, 1954.

497. - "Dynamics of the Hormonal Activity of the Hypophysis in the Ontogenesis of Man." VIII Vsesoiuznyis'ezd fiziologov, biokhimikov, farmakologov. Tezisy dokladov, izd-vo AN SSSR, M. (Eighth All-Union Congress of Physiologists, Biochemists, and Pharmacologists. Theses Papers, published by the Academy of Sciences USSR, Moscow), 1955, p. 137.

498. Vok pianskaia, M. I. "Colloidochemical Properties of Blood Serum of the Intr?Uterine Fetus." Akusherstvo i ginekologiia (Obstetrics and Gynecology), (9): 1018$1013,1936$.

499. Volkov, K. G. "Atherosclerosis of the Coronary Arteries of the Human Heart." Arkhiv biologicheskikh nauk (Archives of Biological Sciences), 29(1): 93, 1929.

500. - "Experimental Atherosclerosis of the Coronary Arteries of Rabbit Heart." Ibid., 30(一): 269, 1930.

501. "Atherosclerosis of the Cerebral Arteries." Ibidem, 33(3-4): 581-600, 1933.

502. Volkova, V. D. "Certain Characteristics of the Development of Conditioned Reflexes to Speech Stimuli in Children." Iiziologicheskii zhurnal SSSR (Physiological Journal of the USSR), 39(5): 540-548, 1953.

503. Volovik, A. B. "Effect of Nutrition on the Activity of the Higher Centers of the
Central Nervous System in Children." Moskovskii meditsinskii zhurnal (Moscow Medical Journal), (4): 5; 1930.

504. "Study of the Dynamics of the Complex Activity of the Cerebral Hemispheres in Choldren." Russkii fiziologicheskii zhurnal SSSR (Russian Physiological Journal of the USSR), 14(2-3); 235-241, 1931.

505. "Characteristics of the $\mathrm{Pa}$ thology of Leningrad Children in 19411942." Voprosy palologii delstva, L., Medgiz (Problems of the Pathology of Childhood, Leningrad, State Publishing House of Medical Literature), 1944, pp. 75-80.

506. "Observations on the Details of the Course of Rheumatism in Children in the Postwar Years." Voprosy pediatrii $i$ okhrany materinstva $i$ detstua (Problems of Pediatrics and Protection of Motherhood and Infancy), 17(4): 32-36, 1949.

507. "Heart Diseases in Children" (Bolezni serdisa u detei, L.), Leningrad, 1952.

508. Volodarskil, N. I. "Dynamics of Growth of Stalk in Length as an Age-Associated Sign in Tobacco." Doklady Akademii nauk SSSR, novaia ser. (Reports of the Academy of Sciences USSR, new series), 59( $\left.{ }^{\circ}\right)$ : 355-358, 1948.

509. "Theory of Stage-Associated Development and Growth Potential of Plants." Uspekhi souremennoi biologii (Advances in Contemporary Biology), 37(3): 341-357, 1954.

510. Volodina, Z. S. "Problem of AgeAssociated Changes of Subcutaneous Areolar Connective Tissue of Man." Doklady Akademii nauk SSSR (Reports of the Academy of of the Academy of Sciences USSR), 99(6): 1099-1101, 1954.

511. Volokrov, A. A. "Development of Reflex Activity in Mammals in the Ontogenesis." Doklady na nauchnom soveshchanii in-ta evoliutsionnoi fiziologii $i$ patologii vysshei nervnoi deialel'nosti im. I. P. Paulova (Reports on the scientific conference of the I. P. Pavlov Institute of Evolutional Physiology and Pathology of Higher Nervous Activity), 1938.

512. - "Changes of Cutaneous Sensitivity in Animals in Ontogenesis. Report I. Study of Chronaxy of Receptor Systems in Postnatal Period." Fiziologicheskii zhurnal SSSR (see below), 30(2): 147-159, 1941. 
513. and Stakalich, E. P. "Data on the Reflex Activity of Animals in the Period of Embryonic Development." Fiziologicheskii zhurnal SSSR (Physiological Journal of the USSR), 32(1): 90-119, 1946.

514. Voloknov, A. A. "Analysis of Certain Forms of Reflex Activity in the Embryogenesis." Ibid., 33(3): 361-372, 1947.

515. "Emergence and Development of Various Forms of Reflex Activity in the Ontogenesis." VII Vsesoiuznyi s'ezd fiziologov, biokhimikov, farmakologov, M., Medgiz (Seventh All Union Congress of Physiologists, Biochemists, and Pharmacologists, Moscow, State Publishing House of Medical Literature), 1947, pp. 126-128.

516. —. "Problems of Age-Associated Immunology." Sbornik: Trudov kafedry mikrobiologii Leningradskogo gos. pediatricheskogo in-ta, pod. red. prof. V. M. Bermana, L. (Collection: Transactions of the Chair of Microbiology of the Leningrad State Institute of Pediatrics. Prof. V. M. Berman, editor, Leningrad), 1947, p. 349.

517. and Obraztsova, G. A. "Effect of a Reduced, Partial Oxygen Pressure on Activity of the Nervous System in the Ontogenesis. Report I. Stages of Functional Disorders of the Nervous System in Hypoxia." Fiziologicheskii zhurnal SSSR (Physiological Journal of the USSR), 36(3): 294-303, 1950.

518. - "Effect of a Reduced, Partial Oxygen Pressure on the Activity of the Nervous System in the Ontogenesis. Report II. Disturbance of Locomotor Function in Hypoxia." Ibidem, 36(4): 450-456, 1950.

519. - "Effect of Shutting Off the Visual System in Early Ontogenesis on the Subsequent Development of the Reflex Activity." Ibidem, 37(4): 453-460, 1951.

520. Voloknov, A. A. "The Ontogenetic Mechanisms of Nervous Activity in the Light of Evolutionary Teaching" (Zakonomernosti ontogeneza nervnoi deiatel'nosti v svete evoliutsionnogo ucheniia), Academy of Sciences USSR, Moscow-Leningrad, 1951.

521. - "Mechanisms of Development of Nervous Activity in the Ontogenesis." Sbornik: Uchenie M. P. Pavlova v teoreticheskoi i prakticheskoi meditsine. Medgiz, M. (Collection: M. (sic) P. Pavlov's Instruction in Theoretical and Practical Medicine. State Publishing House of Medical Literature, Moscow), 1953, pp. 262-288.
522. - "Comparative Study of Higher Nervous Activity of Animals in the Ontogenesis." Trudy pervoi nauchnoi konferentsii po vozrastnoi morfologii $i$ fiziologii, izd-vo Akademii pedagogicheskikh nauk RSFSR, M. (Transactions of the First Scientific Conference on Age-Associated Morphology and Physiology. Published by the Academy of Pedagogical Sciences RSFSR, Moscow, 1954, pp. 35-43.

523. and Davydova, N. N. "Development of the Bio-Electrical Activity of the Cerebral Hemispheres in Rabbit in the Ontogenesis." Ibidem, 1954, pp. 49-56.

524. Volokhov, A. A., Nikitina, G. M., Panchenkova, E. F., Polikanina, R. I., and Probatova, L. E. "Interrelationship in the Development of Conditioned and Unconditioned Reflexes in the Ontogenesis." VIII Vsesoiuznyi s'ezd fiziologov, biokhimikov, farmakologov. Tezisy dokladov, izd-vo AN SSSR, M. (Eighth All-Union Congress of Physiologists, Biochemists, and Pharmacologists. Theses papers. Publ. of the Academy of Sciences, USSR, Moscow), 1955, p. 141.

525. VoloKhov, S. A. "Concentration of Glutathione in Different Species of Rabbits at Birth." Uspekhi zootekhnicheskikh nauk (Advances in Zootechnical Sciences), 1(2): $265,1935$.

526. Volpianskaia, M. I. "Colloidochemical Properties of Blood Serum of the Intrauterine Fetus." Akusherstvo $i$ ginekologia (Obstetrics and Gynecology), (9): 10181023, 1936.

527. VoL'Fson, L. B. "Development of Innervation of the Upper Extremity. Development of the Humeral Plexus in Man." Trudy Minskogo med. in-ta (Transactions of the Minsk Medical Institute), 10(1): 99-107, 1940.

528. Vorobiov, A. M., and Kuz'menko, S. T. "Secretory and Evacuatory Work of the Stomach in Pups at Different Methods of Feeding" (Ukr.: Sekretorna i evakuatorna robota shlunku $v$ shcheniat pri riznikh sponsobakh goduvannia). Eksperimental'na meditsina (Experimental Medicine), (12): 73, 1935.

529. Vorobiov, A. M. and Epshtein, L. G. "Age-Associated Properties of Gastric Secretion" (Ukr.: Vikovi osoblivosti shlunkovoi sekretsii). Ibidem, (8): 48-56, 1936.

530. Vurobiov, A. M., and Kronzon, B. S. "Age-Associated Properties of the Evacuator 
Activity of the Stomach in Dogrs" (Ukr.: V'ikovi osoblivosti evakuatonoi diiul'nosti shlunku $v$ sobak). Ibidem, (3): 29-34, 1937.

531. Vorob'ev, A. M. (Russ. for the name abovc) "Agc-Associated Characteristics of Dischargc of Bile into the Intestines." Biulleten' eksperimentalnoi biologii $i$ meditsiny (Bulletin of Experimental Biology and Medicine), 8(3-4): 239-241, 1939.

532. Voronenkov, V. S. "Change of Calcium and Phosphorus Content in Fetuses and in Uterus of Rabbits" (Izmenenie soderzhaniia kal'tsiia i fosfora v plodakh i matke krol'chikh. Avtoref. kand. diss. na stepen' kand. s. kh. nauk, Kazanskii gos. veterinarnyi in-t, Kazan'). Author's own abstract of dissertation for degree of candidate of agricultural sciences, Kazan's State Veterinary Institute, Kazan', 1953.

533. Voronin, L. G. "Problem of the Development of Unconditioned and Conditioned Rcflexes in Macaca rhesus Newborn." Fiziologicheskii zhurnal SSSR (Physiological Journal, USSR), 34(3): 333-338, 1948.

534. VORONOV, D. L. "Reactivity of Human Skin at Mechanical Stimulation. I. Reactivity in Age-Associated Profile." $\mathrm{Ma}$ terialy kliniki po vozrastnoi patofiziologii, pod red. I. P. Razenkova i I. G. Gel'mana. VIEM, M. (Clinical Data on Age-Associated Pathophysiology. I. P. Razenkov and I. G. Gel'man, editors. All-Union Institute of Experimental Medicine, Moscow), 1937, pp. 255-264.

535. - "Problem of Primary and Secondary Allergy (Tests for Sensitivity to Light). Ibidem, 1937, pp. 264-270.

536. Voronov, S. "Prolongation of Life" (O prodlenii zhizni). V. N. Nikitin's authorized translation, published by Sabashnikov, Moscow, 1923.

537. "Transplantation of Male Gonads" (Peresadka semennykh zhelez) V. N. Nikitin's translation from the French, published by Sabashnikov, Moscow, 1923.

538. —. "Rejuvenation by Transplantation of Sex Glands" (Omolozhenie peresadkoi polorykh zhelez). E. K. Piett's authorized translation from the French, published by Practical Medicine (Prakticheskaia meditsina), Leningrad, 1924.

539. - "Transplantation of Gonads" (Peresadka polovykh zhelez). Translation.
Prof. A. A. Krontovskii, editor. l'ublished by Scicntific Thought (Nauchnaia mysl'), Khar'kov, 1924.

540. - "Old Agc and Rcjuvenation" (Starost' i omolazhivanie), Moscow, 1927.

541. 1 "Struggle for Youth" (Bor'ba za molodost'), Moscow, 1928.

542. - "Conquest of Life" (Zavoevanie zhizni, Medgiz, M.). Publishing House of Medical Literature, Moscow, 1928.

543. - "Prolongation of Life" ( $O$ prodlenii zhizni). Publishing House of Medical Literaturc, Moscow, 1929.

544. Vorontsov, V. P. "Aging and Prolongation of Life." Sbornik: Materialov po san. prosveshcheniiu, Barnaul (Collection: Data on Sanitation Instruction. Barnaul (Altai Krai, RSFSR), 1950, pp. 87-100.

545. Vorontsova, M. A., and Liozner, L. D. "Change of Rate of Metamorphosis of Host Under the Effect of a Transplant of a Different Age. Report I." Biull. eksperimental'noi biologii $i$ meditsiny (Bulletin of Experimental Biology and Medicine), 5(5-6): 439-442, 1938.

546. Vorontsova, M. A., and Liozner, D. D. (sic). "Change of Rate of Metamorphosis of Host Under the Effect of a Transplant of a Different Age. Report II." Ibidem, 7(2-3): 235-238, 1939.

547. Voskresenskaia, A. K. "Evolution of Functional Properties of Nerve-Muscle Systems of Insects in the Ontogenesis." VII Vsesoiuznyi s'ezd fiziologov, biokhimikor, farmakologov. Doklady, Medgiz, M. (Seventh All-Union Congress of Physiologists, Biochemists, and Pharmacologists. Reports. State Publishing House of Medical Literature, Moscow), 1947, p. 40.

548. Voskresenskil, B. V., and Nikolaeva, O. I. "Experiment of Immunizing and Revaccinating Monkeys with Tetanus Anatoxin in Conditions of Several Years' Observation." Arkhiv biologicheskikh nauk, (Archives of Biological Sciences), 49(2): 86-103, 1938.

549. VuL, I. M. "Age Changes in the Chronaxy of the Child." Trudy in-ta im. V. I. Bekhtereva po izucheniiu mozga. II. Fizikokhimicheskie osnovy nervnoi deiatel'nosti, Biomedgiz, L. (Transactions of the V. I. Bekhterev Institute for Brain Study. II. 
Physico-Chemical Bases of Nervous Activity. State Publishing House of Biomedical Literature, Leningrad, 1935, p. 182.

550. - "Functional Characteristics of the Nerve-Muscle System in the Ontogenesis. Report I. Investigation on Rats." Fiziologicheskii zhurnal SSSR (Physiological Journal of the USSR), 22(1): 35-44, 1937; Biull. eksperimental'noi biologii $i$ meditsiny (Bulletin of Experimental Biology and Medicine), 3(3): 326-328, 1937.

551. - "Functional Characteristics of the Nerve-Muscle System in the Ontogenesis. Report II. Investigations on Rabbits." Fiziologicheskii zhurnal SSSR (see above), 22(2): 166-177, 1937.

552. - "Functional Characteristics of the Nerve-Muscle System in the Ontogenesis of Man." Neuropatologiia i psikhiatriia (Neuropathology and psychiatry), 6(11): 51, 1937.

553. - "Genesis of Nervous Activity." Biull. eksperimental'noi biologii $i$ meditsiny (see above), 10(4): 302-304, 1940.

554. - "The Active Function of the Cerebral Cortex in the Ontogenesis." Sbornik nauchnykh rabot Krasnoiarskogo gos. med. in-ta (Symposium of scientific works of the Krasnoiarsk State Medical Institute), Krasnoiarsk, 1946, pp. 133-141.

555. —— and Plotnıkova, O. V. "Electric Excitability of the Cerebral Cortex in the Ontogenesis." Ibidem, 1946, pp. 142-150.

556. VuL, I. M. "Regular Patterns of Individual Development of Nervous Activity." VII Vsesoiuznyi s'ezd fiziologov, biokhimikov, farmakologov. Medgiz, M. (Seventh AllUnion Congress of Physiologists, Biochemists, and Pharmacologists. State Publishing House of Medical Literature. Moscow), 1947, pp. 133-136.

557. - - Vlasova, V. N., and Nika, G. A. "Formation of Function of Certain Analyzers in Early Ontogenesis." VII Vsesoiuznyi s'ezd fiziologiv, biokhimikov, farmakologov. Tezisy dokladov, izd-vo AN SSSR, M. (Ibid., Theses papers published by the Academy of Sciences USSR, Moscow), 1955, p. 152.

558. Vul'fson, P. L., and Severin, S. E. "Nitrogen Extractives of Muscle Tissue in the Process of Ontogenesis" (Ukr.: Azotistye ekstraktivnye veshchestva myshechnoi tkani o prot- sess ontogeneza) Ukrains'kii biokhimichnii zhurnal (Ukrainian Biochemical Journal), 27(3): 295-310, 1955.

559. VuL'FSON, P. L. “Carbohydrate-Phosphorus and Oxidizing Exchange of Skeletal Muscles in the Process of Ontogenesis." Biokhimiia (Biochemistry), 20(2): 179-187, 1955.

560. Vygodskaia, I. G. "Immunobiological Reactivity of the Organism of Premature Children in Certain Diseases of the Neonatal Period." Voprosy pediatrii i okhrany materinstva $i$ detstva (Problems of Pediatrics and Maternal and Child Welfare), 17(4): 13-16, 1949.

561. VYDRO, I. D.-M. "Age-Associated Traits of Catabolism in Children (Vozrastnye osobennosti energeticheskogo obmena $u$ detei. Avtoref. kand. diss. Akademiia pedagogicheskikh nauk RSFSR, nauch.-issled. in-t fizicheskogo vospitaniia $i$ shkol'noi gigieny, M.) Author's own abstract of his candidate's dissertation of the Academy of Pedagogical Sciences RSFSR, Scientific Research Institute of Physical Training and School Hygiene, Moscow, 1953.

562. - (same author?). "Estimate of Length of Human Life in Particular." Drug zdraviia. Narodnovrachebnaia gazeta (Friend of Health. National Medical Gazette), (27): 209-211, 1840.

563. Viazemskir, N. V. "Changes of the Organism During the Period of Development (Ages Ten to Twenty)" (Izmeneniia organizma $\checkmark$ periode formirovaniia. (Vozrasty ot 10-20 $(e t))$, St. Petersburg, vs. 1 and 2, 1901.

\section{G}

564. Gavashell, O. A. "Macrostructure of the Corpus dentatum in the Cerebellum of Man in the Age-Associated Aspect"' (Makrostruktura zubchatogo iadra mozzhechka cheloveka $v$ vozrastnom aspekte. Avtoref. diss. kand. med. nauk. M.). Author's own abstract of his dissertation for the degree of candidate of medical sciences, Moscow, 1953, p. 12.

565. Gavrilov, K. P. "Developmental Characteristics of Children in the Neonatal Period" (Osobennosti razvitiia detei perioda novorozhdennosti), State Publishing House of Medical Literature, Moscow, 1951.

566. Gaeviskaia, M. S. "Content of Glycogen and of Carbohydrates Capable of Fermentation in Cerebral Cortex at the Dying 
and Restoration of Life Functions of the Organism." Zhurnal vysshei nervnoi deiatel'nosti (Journal of Higher Nervous Activity), 3(4): 617-625, 1953.

567. GAKKEL', L. B. 'Experiment of Comparative Study of Disturbances of Higher Nervous Activity in Paticnts with Oligophrenia and Senile Dementia." Ibid., 3(1): 92-98, 1953.

568. - and ZininA, N. V. "Changes of Higher Nervous Activity in People Over Sixty Years Old." Fiziologicheskii zhurnal SSSR (Physiological Journal of the USSR), 39(5): 533-539, 1953.

569. Galvialo, M. IA., and Goriukhina, T. A. "Fermentative Systems of Developing Chick Embryo." Ibidem, 22(2): 215223, 1937.

570. Galevskil, A. IA. "Vestibular Nystagmus in the Newborn." Zhurnal ushnykh, nosouykh i gorlowykh boleznei (Journal of Ear, Nose, and Throat Diseases), 6: 623, 1926.

571. Galeeva-ZaK, L. S. "Effect of Prenatal Starvation on Growth and Development of the Fetus." Referaty nauch.-issled. rabot Akademii meditsinskikh nauk SSSR, klinicheskie nauki, M. (Reports of the ScientificInvestigatory Work of the Academy of Medical Sciences USSR, Clinical Sciences, Moscow), (5): 47, 1948.

572. Galeeva, L. S. "Effect of Starvation in Different Periods of Pregnancy on Growth and Development of Rabbit Fetuses." Fiziologicheskii zhurnal SSSR (see above), 36(6): 734, 1950.

573. "Effect of Experimental Anemic Anoxia in Various Periods of Pregnancy of Rabbits on Growth and Development of Fetuses." Biull. eksperimental'noi biologii $i$ meditsiny (Bulletin of Experimental Biology and Medicine), (11): 324, 1950.

574. "Effect of Chloral Hydrate Narcotization During Pregnancy of Rabbits on Growth and Development of Fetuses." Ibid., (3): 168, 1951.

575. "Changes of Resistance to Complete Starvation of Dogs on Various Stages of Intra-Uterine Development." $F_{i-}$ ziologicheskii zhurnal SSSR (see above), 38(1): 67-74, 1952.

576. — and Shiminke, T. A. "Evaluation of Motor Function of Newborn Chil- dren." Voprosy ahusherstva $i$ pediatrii (Problems of Obstetrics and Pediatrics), Smolensk Book Publishers, 1956, pp. 241-244.

577. Galitskaia, N. A. "Effect of Shutting Off Different Components" of Innervation of a Skelctal Muscle on Its? Functional Properties." Fiziologicheskii zhurnal SSSR (see above), 39(6): 710-718, 1953.

578. ent Portions of "Effect of Removing Differ-. tional Properties of Skeletal Muscle and Development of Muscular Atrophies." Trudy in-ta fiziologii im. I. P. Pavlova, izd-vo AN SSSR, M. (Transactions of the I. P Pavlov Institute of Physiology, published by the Acad. of Sciences USSR, Moscow), 3: 516-530, 1954.

579. - "Effect of Tenotomy and Denervation on Functional Properties of Striated Muscles." Ibidem, 3: 531-543, 1954.

580. Gal'perin, L. I., and Turetskil, M. IA. "Forms and Principles of Psychoneurological Help in Early Childhood." Sbornik Tsentral'nogo nauch.-issled. in-ta okhrany materinstva $i$ mladenchestva, posviashchennyi 35-letiiu nauchnoi deiatel'nosti $G$. N. Speranskogo, Medgiz, M. (Collection of the Central Scientific Research Institute of Maternal and Child Welfare, Dedicated to the 35th Year of G. N. Speranskii's Scientific Activity. State Publ. House of Med. Lit., Moscow), 1934, pp. 215227.

581. GaL'PERINA, E. I. "Morphological and Biochemical Characteristics of the Blood in Elderly People." Materialy kliniki po vozrastnoi patofiziologii pod red. I. P. Razenkova i. I. G. Gel'mana. VIEM, M. (Clinical Data on Age-Associated Pathophysiology. I. P. Razenkov and I. G. Gel'man, editors. All-Union Institute of Experimental Medicine, Moscow), 1937, pp. 171-176.

582. Galias, D. A. "Industrial Evaluation of the Work of Elderly People." Starost" $i$ trudosposobnost' Sbornik rabot NIVTE, L. Old Age and Work Capacity Collection of Works of the "NIVTE" (see above), Leningrad), 1936, pp. 76-98.

583. Gamaleia, N. F. "Pathological and Physiological Old Age." Novyi mir (New World), (12): 218-234, 1951.

584. Gambarian, L. S. "Conditioned Motor Reflexes in Pups After Removal of Posterior Portions of the Spinal Cord Column to 
the Extent of Several Segments (Tail Clipping)." Doklady akademii nauk SSSR (Reports of the Academy of Sciences USSR), 105(5): 1125-1128, 1955.

585. Gamburg, A. M. "Iso-Agglutination in the Newborn." Trudy 3-go Povolzhskogo nauchnogo s'ezd vrachei. Astrakhan' (Transactions of the Third Povolzh'e Scientific Congress of Physicians. Astrakhan), 1931, p. 301; Sudebnaia ekspertiza (Legal Examination), (1): 12-21, 1934.

586. Ganiusinina, E. Kr. "Problem of the Effect of Small Doses of Serum on the Organism." Ostrye infektsionnye bolezni detskogo vozrasta (Acute Infectious Diseases of Childhood), State Publishing House of Biomedical Literature, Moscow-Leningrad, 1943, pp. 107-118.

587. Ganiushina, S. M. "Gas Exchange, Respiration, and Blood Circulation in Calves of the Tagil Breed in the Ontogenesis and in the Postnatal Period." 1-ia Ural'skaia konferentsiia fiziologov, biokhimikov $i$ farmakologov 5-8 iiunia, 1956, g. Tezisy dokladov, Sverdlovsk (First Ural Conference of Physiologists, Biochemists, and Pharmacologists, June 5-8, 1956. Theses papers, Sverdlovsk), 1956, p. 11.

588. Garbovitskil, E. B. "Advances in Soviet Age and Evolutional Pharmacology." Farmakologiia $i$ toksikologiia (Pharmacology and Toxicology), (6): 53-57, 1949.

589. Garmashev, V. P. "Bone Marrow Change With Age" (Izmenenie kostnogo mozga s vozrastom), St. Petersburg, 1902.

590. Grat'e, E. E. (sic) The Pancreas of Fetuses and the Newborn of Man (Podzheludochnaia zheleza plodov i novorozhdennogo cheloveka. Diss. SPb.), a dissertation. St. Petersburg, 1900.

591. Gart'E, E. E. (sic). "The Inhibitive Apparatus of the Heart in Newborn Pups." Obozrenie psikhiatrii, nevrologii i eksperimental'noi psikhologii (Review of Psychiatry, Neurology, and Experimental Psychology), 1903.

592. Gauze, G. F. "Healing of Wounds and Age--A Book Report by Count du Nouy in 'Biological Time', London, 1936." Uspekhi souremennoi biologii (Advances in Contemporary Biology), 8(1): 139-141, 1938.

593. Gatsaniuk, M. D. "Biochemistry of Group III Sulfhydryls. Many Quantitative Changes of Glutathione During Growth of Whitc Rats." (Ukr.: Do bikhimii sul'figidril'nikh grup. III. Pro deiaki zmini kil'kosti gliutationu pidchas rostu bilikh shzhuriv.) Medichnii zhurnal VUAN (Medical Journal of the "VUAN"), 5(2): 273, 1935.

594. - "Biochemistry of Group IV Sulfhydryls. Quantitative Change of Glutathione During Growth of White Mice." (Ukr.: Do biokhimii sul'fgidril'nikh grup. IV. Pro zmini kil'kosti gliutationu pidchas rostu bilikh mishei). Ibid., 5(3): 501, 1935.

595. "Change of Lipocyte Coefficient from Age." Medichnii zhurnal $A \mathcal{N}$ URSR (Medical Journal of the Academy of Sciences of the UkrSSR), 9(2): 343-360, 1939.

596. - "Effect of Antireticular Cytotoxic Serum on Amount of Cholesterol, Fatty Acids, and Water in Organs of Adult and Old Rabbits" (Ukr.: Vpliv antiretikuliarnoi tsitotoksichnoi sirovatki na kil'kist' kholesterinu, zhirnikh kislot $i$ vodi $v$ organakh doroslikh $i$ starikh krolikiv). Ibidm, 10(4): 1069-1088, 1940.

597. —. "Changes of Lipocyte Coefficient from Age." Sborni, Starost'. Trudy konferentsii 17-19 dekabria $1938 \mathrm{~g}$., Kiev, $A \mathcal{N}$ USSR ("Old Age" Collection. Transactions of the Conference Dec. 17-19, 1938, Kiev, Academy of Sciences UkrSSR), 1940, pp. 221-233.

598. GE, O. L. "Problem of the PhysicoChemical State of the Serum in Connection with Age and Immunization." Zhurnal eksperimental'noi biologii $i$ meditsiny (Journal of Experimental Biology and Medicine), (29): 33-39, 1939.

599. Geiman, E. IA. "Preformed Ammonia and the $\mathrm{N}-\mathrm{NH}_{2}$ /total $\mathrm{N}$ Ratio in Brain, Heart, Lungs, Muscles, Liver, and Kidneys of Rabbit in the Embryonic and Early Postnatal Period." Fiziologicheskii zhurnal SSSR (Physiological Journal of the USSR), 28(6): 665-673, 1940.

600. - "Changes in Total Nitrogen and of Preformed Ammonia in Organs of Rabbit During Ontogenesis and Pregnancy.' Ibid., 28(6): 674-678, 1940.

601. Gein, K. "Problem of the PhysicoChemical Properties of Urine in the Newborn" ( $K$ voprosu of fiziko-khimicheskikh svoistvakh mochi novorozhdennykh. Diss. SPb). A dissertation. St. Petersburg, p. 1904.

602. Gekrer. "Activity of the Stomach in Gastro-Intestinal Disorders of Children" 
(O deialel'nosti zheludka pri zheludochnokishechnykh rasstroistvakh $u$ detei). A dissertation. St. Petcrsburg, 1094 (sic).

603. Gel'man, I. G. "Age and Pathology." Vestnik souremennoi meditsiny (Journal of Contemporary Medicine), (8): 494-498, 1927.

604. - "Combatting Old Agc." Izvestiia, 1935.

605. - "Age Problems." Ibid., May 12, 1935.

606. - and Braun, S. "Evolutional Characteristics of the Cardiovascular System. Report IV. Effect of Certain Vasodilators (Amyl Nitrite and Histamine) on the Main Functions of the Heart of Children, Juveniles, Adults, and Elderly People." Arkhiv biologicheskikh nauk (Archives of Biological Sciences), 44(3): 87-102, 1936.

607. Mar. 28, 1936.

608. - and Braun, S. B. "FunctionalEvolutional Characteristics of the Cardiovascular System of Man. I. Electrocardiographic Characteristics of the Senile Heart and That of the Child." Materialy kliniki po vozrastnoi patofiziologii pod red. I. P. Razenkova i I. G. Gel'mana. VIEM, M. (Data of the Clinic on Age-Associated Pathophysiology. I. P. Razenkov and I. G. Gel'man, editors. All-Union Institute of Experimental Medicine, Moscow), 1937, pp. 43-61.

609. "Problem of Age-Associated Changes in Functional Excitability of the Heart in Respect to Certain Vegetative (Involuntary) Stimuli." Ibid., 1937, pp. 61-70.

610. Gel'man, I. G., and Puzik, V. I. III. Pathological and Electrocardiographic Characteristics of the Heart in Advanced Old Age." Ibid., 1937, pp. 70-81.

611. Gel'fand, A. M. "Clinico-Physiological Characteristics of the Cardiovascular System in Juveniles and Young Adults." Tezisy dokladov nauchnoi sessii po voprosam kliniki, fiziologii $i$ professional'nogo truda podrostkovogo vozrasta. M. (Theses papers of the Scicntific Session on Problems of the Clinic, Physiology, and Professiona. Work of the Juvenilc. Moscow), 1935, pp. 3-4.

612. - "Principles of Evaluating Functional State of Cardiovascular System in Juveniles and Young Adults." Diagnostika funktsional'ny'kh otklonenii $v$ podrostkovom $i$ iunosheskom vozraste. (Diagnosis of Functional Deviations in Juveniles and Young Adults), Moscow, 1941, pp. 19-32.

613. "Cardiovascular System in Juvcnile and Young Adult" (Serdechno-sosudistaia sistema $v$ podrostkovom $i$ iunosheskom vozraste. Diss. M.) A Disscrtation, Moscow, 1944.

614. Genkin, A. M. "Blood Glycogen in Physiological and Pathological Conditions of Children." (Glikogen krovi pri fiziologicheskikh $i$ patologicheskikh sostoianiiakh $u$ detei. Izd. in-ta okhrany materinstva i mladenchestva Sverdlovskogo oblzdravotdela, L. (Published by the Institute of Maternal and Child Welfare of the Sverdlovsk Oblast Division of Health, Leningrad), 1939, p. 51.

615. "Glycogen Content in Whole Blood, Regular Elements, and Plasma of Children and Adults." Biull. eksperimental' noibiologii $i$ meditsiny (Bulletin of Experimental Biology and Medicine), 7(2-3): 213-215, 1939.

616. "Dynamics of Blood Glycogen in Children With Croupous Pneumonia." Ibid., 7(2-3): 216-218, 1939.

617. "State of Glycogen in the Liver." Biokhimiia (Biochemistry), 18(1): 7-11, 1953.

618. "Formation in vitro of Complex Compounds Between Liver Glycogens and Globulins." Ibid., 19(3): 280-288, 1954.

619. Geptner, F. K. "Chemical Composition of Bile in Children" (Khimicheskii sostav zhelchi $u$ detei. Diss. $S P b$.). A dissertation. St. Petersburg, 1900.

620. Gerke, P. IA. "Development of Innervation of the Lungs of Man." Sbornik rabot sektora morfologii instituta eksperimental'noi fiziologii NKZ BSSR (Collection of Works of the Department of Morphology, Institute of Experimental Physiology, the People's Commissariat of Agriculture, BelorusskaiaSSR, 1939, pp. 37-48.

621. - "Development of Ganglia in Vagus Nerves of Man." Ibid., 1939, pp. 61-76.

622. German, K. I. "External Retardation in Aging." Arkhiv biologicheskikh nauk (Archives of Biological Sciences), 7(3): 54, 1937. 
623. "Delay Arrest in Aging." Sbornik: Opyt sistematicheskogo eksperimental'nogo issledovania ontogeneticheskogo razvitiia korkovoi dinamiki cheloveka, izd-vo VIEM, M. (Collection: Systematic Experimental Investigatory Test of Ontogenetic Development of Human Cortical Dynamics. All-Union Institute of Experimental Medicine, publ., Moscow), 5: 239-248, 1940.

624. Geronimus, E. S., and Avrekh, V. V. "Serological Analysis of Ontogenesis in Grasshopper and Oak Silkworm." Biull. eksperimental'noi biologii $i$ meditsiny (Bulletin of Experimental Biology and Medicine), 9(5): 336-338, 1940.

625. Gershenzon, A. O. "Problem of Effect of Certain Factors on the Weight of the Newborn." Sbornik: Voprosy sotsial'noi gigieny, fiziologii $i$ patologii detskogo vozrasta, pod red. Al'tgauzena-Balandera, izd. Gos. med. in-ta, M. (Collection: Problems of Social Hygiene, Physiology, and Pathology of Childhood. A'lthauzen - Balander, editor. State Medical Institute, Publ., Moscow), 1929, pp. 85-95.

626. Gershenovich, Z., and Slonits'ka, G. "Physicochemical Characteristics of the Blood of Parturient and Fetus. Report 1. Buffer Capacity of Blood of Parturient and Fetus. (Ukr.: Fiziko-khimichna kharakteristika krooi rodilli i plodu. Povidomlennia 1. Buferna emkist' krovi rodilli $i$ plodu.) Pratsi Kiivs'kogo med. in-tu, Kiiv (Reports of the Kiev Medical Institute, Kiev), 4: 138-139, 1936.

627. Gize, E. A. "White Matter Components of Human Spinal Cord According to Method of Development (from the Anatomical-Physiological Laboratory in V. M. Bekhterev's Clinic of Mental and Nervous Diseases)" ( $O$ sostavnykh chastiakh belogo veshchestva spinnogo mozga cheloveka po metodu razvitiia (Iz Anatomo-fiziologicheskoi laboratorii pri klinike dushevnykh $i$ nervnykh boleznei prof. V. M. Bekhtereva)), a dissertation for the doctor of medicine degree. St. Petersburg, 1898, p. 259.

628. Gilenson, A. E., and Volnar, $\Lambda$. O. "Variability of Protein Content of Human Blood Serum Depending on Time of Year, Age, and Sex." Trudy Stalinskogo gos. med. in-ta, Stalino (Transactions of the Stalino State Medical Institute, Stalino), 8: 72-78, 1948.

629. GiLinskı1, E. IA. "Brain Blood Supply of Human Embryo." Sbornik: Voprosy fiziologii $i$ morfologii tsentral'noi nervnoi sistemy, izd.
Akademii meditsinskikh nauk SSSR, M. (Collection: Problems of Physiology and Morphology of the Central Nervous System. Published by the Academy of Medical Sciences USSR, Moscow), 1953, pp. 240269.

630. Gilula, I. O. "Problem of Work Capacity of the Old." Sbornik: Starost'. Trudy konferentsii 17-19 dekabria $1938 \mathrm{~g}$., Kiev, AN USSR (Collection: Old Age. Transactions of the Conference Dec. 17-19, 1938, Kiev. Academy of Sciences UkrSSR), 1940, pp. 383-387.

631. Giliarovskit, V. A., and Zinov'ev, P. M. "Case of Presenile Disease with Catatonic Phenomena (and Anatomic Investigation)." Sovremennaia psikhiatriia (Contemporary Psychiatry), (1): 1-14, 1913.

632. Giliarovskil, V. A. "Role of Architectonic Changes in the Genesis of Psychic Disturbances of the Later Years." Obozrenie psikhiatrii, nevrologii $i$ refleksologii (Review of Psychiatry, Neurology, and Reflexology), 1926.

633. Gimmreikh, F. I. "Total and Residual Nitrogen in Children." Zhurnal po izucheniiu rannego detskogo vozrasta (Journal for Study of Early Childhood), 3(3): 226-231, 1925.

634. Gindes, E. IA., and Beloglazov, G. I. "Problem of Studying Intradermal Reaction Provoked by the Autolysate of Dysentery Bacilli During Bacillary Dysentery of Early Childhood." Zhurnal mikrobiologii, epidemiologii $i$ immunobiologii (Journal of Microbiology, Epidemiology, and Immunobiology), 2l(3;9): 90-95, 1938.

635. Gindes, E. IA. "Clinic of Hypo- and Avitaminosis B in Children of Early Age." Pediatriia (Pediatrics), (5): 47-51, 1943.

636. Ginetsinskil, A. G. "Oxygen Transfer in the Embryonic Period." Uspekhi sovremennoi biologii (Advances in Contemporary Biology), 5(6): - 1936.

637. - "Physiology of the Embryo." Uspekhi biologicheskikh nauk v SSSR za 25 let, M.L., AN SSSR ('Twenty-Five Years' Advances in the Biological Sciences of the USSR), Academy of Sciences USSR, Moscow-Leningrad, 1945.

638. - "Kidney Functions in the Early Postnatal Period." Uspekhi souremennoi biologii (Advances in Contemporary Biology), 33(2): 233-258, 1952. 
639. "New Data on Regulating Kidney Activity." VIII Vsesoiuznyi s'ezd fiziologov, biokhimikov, farmakologov. Tezisy dokladov, izd-vo AN SSSR, M. (Eighth AllUnion Congress of Physiologists, Biochemists, and Pharmacologists. Theses Papers, published by the Academy of Sciences, USSR, Moscow), 1955, p. 170.

640. Glezina, O. M. "Age-Associated Changes of the Redox Potential in Muscles of Birds"' (Ukr.: Vikovi zmini oksidatsïnovidnounogo potentsialu muskuliv ptakhiv). Biokhimichnii zhurnal (Biochemical Journal), 12(2): 293-309, 1938.

\section{Golov, A. I. "Unemployed Oppor-} tunities in the Area of Rejuvenation and 'Therapy" (Neispol'zovannye vozmozhnosti $v$ oblasti omolozheniia $i$ lecheniia). Sverdlovsk, 1935, p. 48.

642. Golovin, E. "Problem of Development of the Ganglionic System in Vertebrates." VIII s'ezd russkikh estestvoispytateler $i$ vrachei (Eighth Congress of Russian Naturalists and Physicians), section 6, St. Petersburg, 1889, p. 21.

643. Golovina, L. L. " "Experience of 'Testing the Analytical-Synthetic Activity of the Cerebral Cortex in Respect to Age" (Opyt issledovaniia analitiko-sinteticheskoi deiatel'nosti kory bol'shikh polusharii $v$ vozrastnom aspekte. Avtoref. diss. kand. biol. nauk Moskovskogo gorodskogo pedagogicheskogo in-ta M.). Author's own abstract of his dissertation for the degree of candidate of biological sciences, Moscow State Pedagogical Institute, Moscow), 1953.

644. Goloshahekina, M. A. "Work Opportunities for Highly Qualified Aged Workers." Starost' i trudosposobnost' Sbornik rabot NIVTE, L. (Old Age and Work Capacity. Collection of Works of the "NIVTE", Leningrad), 1936, pp. 67-75.

645. Golub, D. M. "Development of the Adrenals and Their Innervation in Man and Certain Animals" (Razvitie nadpochechnykh zhelez $i$ ikh innervatsiia $u$ cheloveka $i$ nekotorykh zhivotnykh), published by the Academy of Sciences, BelorusskaiaSSR, Minsk, 1936.

646. "Structural Change of Prostate Gland at Cutting Its Secretory Nerves in Young and Adult Animals." Biull. eksperimenta noi biologii $i$ meditsiny (Bulletin of Experimental Biology and Medicine), 5(4): 372-375, 1938.
647. "Development of Innervation of the Pancreas." Sbornik rabot sektora morfologii in-ta eksperimental'noi fiziologii $N K Z$ BSSR (Collection of Works of the Department of Morphology, Institute of Experimental Physiology, the People's Commissariat of Agriculture, BelorusskaiaSSR, 1939, pp. 3-16.

648. "Age Characteristics of Innervation of the Prostate Gland." Ibidem, Minsk, 1939, pp. 27-36.

649.

creatic Parapenent of the Pantem Its Nervous System in Man." Sbornik rabot $k X V$-letiiu Belorusskogo med. in-ta, Minsk (Collection of Works for the 15th Anniversary of the Belorussian Medical Institute, Minsk), 1939, pp. 307-331.

650. "Development of Innervation of the Pancreas in Man. Part I. Development of Ganglia of the Pancreas." Trudy Belorusskogo med. in-ta, Minsk (Transactions of the Medical Institute, Minsk), 10 (Part 1): 3-16, 1940.

651. Golub, F. M. "Effect of Age Factor on 'Time of Development of Experimental Trophic Ulcers in Rabbits." Biulleten' eks, perimental'noi biologii $i$ meditsiny (see above)5(3): 306-308, 1938.

652. Golubev, A. "Data on Anatomy, Physiology, and History of Development of Capillaries" (Materialy dlia anatomii, fiziologi, $i$ istorii razvitiia volosnykh sosudob. $\mathrm{SPb}$ Diss.), a dissertation, St. Petersburg, 1868.

653. Golubeva, E. L. "Conditioned Reflexes of Newborn Guinea Pig." Arkhiv biologicheskikh nauk (Archives of Biological Sciences), 4(1): 132-142, 1939.

654. "Development of Systemic Reactions in Guinea Pig Embryos." Ref. nauch.-issled. rabot AMN SSSR, mediko-biol. nauki (Reviews of the Scientific Research Work of the Academy of Medical Sciences USSR, Medico-Biological Sciences), 7: —, 1949.

655. Golubitskaia, Z. M., and Nikitina, M. D. "Blood Carbonic Anhydrase as Reactivity Index of the Organism in Dystrophic States of Children of Early Age." Voprosy pediatrii i okhrany materinstva $i$ detstva (Problems of Pediatrics and Maternal and Child Welfare), 16(2): 29-32, 1948.

656. Golubits'Ka, R. I. “Age Changes of Protein Deposit in Organs of White Rats" 
(Ukr.: Vikovi zmini bilkovogo skladu v organakh bilikh shchuriv). Uch. zap. Kharkiv'skogo derzh. un-tetu, Kharkiv (Annals. Khar'kov State University, Khar'kov), vs. 6-7, 1936, pp. 217-222.

657. "Age Changes of Protein Picture in Rabbit Blood Serum" (Ukr.: Vikovi zmini bilkovogo dzerkala v krov'ianii sirovattsi krolikiv). Experimental'na meditsina, Kiiv, Derzhmedvidav (Experimental medicine. State Publishing House of Medical Literature, Kiev), (7): 71-78, 1937.

658. Golubitska1A, R. I. (Russian for Golubits'ka, R. I.). "Protein Composition of Organs and Age." Trudy nauch.-issled. zoologobiologicheskogo in-ta Khar'kouskogo gos. un-teta (Transactions of the Scientific Research Zoological-Biological Institute, Khar-' kov State University), 5: 81-101, 1938.

659. Golubits'Ka, R. I. "Changes in the Protein Supply of an Animal During the Course of Its Life." (Ukr.: Zmini bilkovoi masi tvarini protiagom ii zhittia) Uch. zap. Kharkivs'kogo derzh. un-tetu, Kharkiv (Annals. Khar'kov State University, Khar'kov), (12): 197-210, 1938.

660. - "Anaphylactic Shock Reaction in Animals of Varied Age and IntraUterine Sensitization" (Ukr.: Reaktsiia anafilaktichnogo shoku v tvarin riznogo viku i vnutrshn'outrobna sensibilizatsiia). Eksperimental'na meditsina, Kiiv, Derzhmedvidav (Experimental Medicine, State Publishing House of Medical Literature, Kiev), (3): 6-11, 1939.

661. "Change of Blood Protein Store and Its Stability in Growing Organisms" (Ukr.: Zmina bilkovogo skladu krovi ta iogo stiikist' u rostuchikh organizmiv). Ibid., (4): 20-23, 1939.

662. - "Age Changes in Nitrogen Composition of the Skin of White Rats" (Ukr.: Vikovi zmini azotistogo shladu shkiri v bilikh shchuriv). Ibid., (2): 34-38, 1940.

663. GolubitskaiA, R. I. "Sodium and Calcium Content in the Urine of White Rats of Various Age." Uch. zap. Khar'kovskogo gos. un-teta (Annals. Khar'kov State University), v. 25; Trudy In-ta biologii, Khar'kov (Transactions. Institute of Biology, Khar'kov), 12: 177-180, 1947.

664. Golubits'Ka, R. I. “Age Changes in Caloricity of the Animal Body" (Ukr.: Vikovi zmini kalorïnosti tila tvarin). Ukrains'kii biokhimichnii zhurnal, AN URSR, Kiiv
(Ukrainian Biochemical Journal, Academy of Sciences, UkrSSR, Kiev), 22(3): 344-348, 1950.

665. Gol'dberG, D. I. Basophilic Substances of the Erythrocytes (Bazofilnaia substantsiia eritrotsitov), published by the Tomsk Medical Institute, Tomsk, 1948.

666. Gol'dberg, I. S., and Deriugina, E. V. "Age Characteristics of the Vascular and Sudoriparous Reactions of the Skin." Material 2-i nauchnoi konferentsii po voprosam vozrastnoi morfologii fiziologii. Tezisy, izd-vo Akademii pedagogicheskikh nauk RSFSR, M. (Data of the Second Scientific Conference on Problems of Age-Associated Morphology and Physiology. Theses published by the Academy of Pedagogical Sciences of the Russian Soviet Federative Socialist Republic, Moscow), 1955, pp. 46-48.

667. Gol'dberG, L. L. “Blood Picture in Newborn Children in Their First Days of Life and Relation to Crises of the Newborn." Zhurnal po rannemu detskomu vozrastu (Journal on Early Age of the Child), 13(6): 381-389, 1933.

668. and Shishliannikova, M. A. "Blood Picture of the Newborn as Reactivity Index of the Mesenchyma in a Given Age Period." Retikuloendotelinal'naia sistema, krovetvorenie $i$ pigmentnyi obmen, Biomedgiz, M. (Reticulo-Endothelial System, Hematopoiesis, and Pigment Metabolism. State Publishing House of Biomedical Literature, Moscow), 1935, pp. 90-99.

669. Gol'dberg, L. L. “Age Characteristics of the Organism's Reactivity." Sovetskaia pediatriia (Soviet Pediatrics), 3(6): 3-8, 1936.

670. Gol'dberg, R. V. “Characteristics of the Physical Development of Child Hypotrophics One to Three Years of Age." Referaty nauch.-issled. rabot Akademii meditsinskikh nauk SSSR, klinicheskie nauki, M. (Reviews of the Scientific Research Work of the Academy of Medical Sciences USSR, Clinical Sciences, Moscow), (5): 55-57, 1948.

671. Gol'denberg, N. E., and Ostroumova, V. A. "Kinetics of Precipitation of Serum Colloids by Electrolytes in Different Age Groups." Fiziologicheskii zhurnal SSSR, 21: 263-270, 1936.

672. Gol'denberg, E. E., and Loginov, A. V. "Kinetics of Precipitation of Serum 
Colloids by Electrolytes in Different Age Groups. Report II. Dependency Between Serum Colloid Concentrations and Their Coagulations." Ibid., 22(2): 204-214, 1937.

673. Gol'DenBerg, E. E. 'Data on the Chcmistry of Age-Associatcd Evolution of the Brain." Trudy sessii in-ta mozga, Institut mozga, L. (Transactions of a Session of the Brain Institute, the Brain Institute, Leningrad), 1939, pp. 57-62.

674. - and Kondrasinna, M. P. "Proteolysis Rates in Serum at Different Stages of the Evolution of Aging." Biull. eksperimental'noi biologii $i$ meditsiny (see above), 9(4): 226-228, 1940.

675. Gol'din, L. S. 'Data on the Enibryonic and Postembryonic Development of the Cerebral Cortex of Man (Problem of Unity of Form and Function)." Sbornik: Ontogene $z$ mozga, L. (Collection: Ontogenesis of the Brain, Leningrad), 1949, pp. 24-51.

676. Gol'dman, L. N. “Electrocardiogram Changes in the Aged." Referaty nauch.-issled. rabot otdeleniia klinicheskoi meditsiny. Akademii meditsinskikh nauk SSSR za 1946 g., M. (Reviews of the Work in Scientific Research of the Department of Clinical Medicine. Academy of Medical Sciences USSR, 1946, Moscow), 2: 26-28, 1947.

677. Gol'DFEL'D, A. IA., and KRIUCHKov, A. "Effect of Exposure to an Incandescent Lamp, a Mercury Quartz Lamp, and the Sun on Basal Metabolism in Children. Report I." Sovetskaia pediatriia (Soviet Pediatrics), 3(6): 11, 1936.

678. Gol'DFEL'D, A. IA. "Reactivity of a Child's Organism in the Normal, in Certain Pathological States, and at Treatment with Ultraviolet Rays." Trudy nauchnoi sessii, posviashchennoi 25-letiiu gosudarstvennogo instituta fizioterapii. Institut fizioterapii, $M$. (Transactions of the Scientific Session Dedicated to the 25th Anniversary of the State Institute of Physiotherapy. Institute of Physiotherapy, Moscow), (Part 2): 285-297, 1948.

679. Gol'dshtein, B., and Gintsburg, M. V. "Proteinases (Cathepsin) in Tissues of a Child's Organism in Dysentery and Toxic Dispersions" (Ukr.: Proteinazi (katepsin) $u$ tkaninakh ditiachogo organizmu pri dizenterii ta toksichnii dispersii). Ukrains'kii biokhimichnii zhurnal (Ukrainian biochemical journal), 7(3-4): 147, 1935.
680. Gol'dsintein, B., and Miz'gram, E. Iu. "Proteinases (Cathepsin) in Tissues of Embryo and Mother" (Ukr.: Proteinazi (katepsin) $v$ tkaninakh embriona i materi). Ibid., 8(1): 139-168, 1935.

681. Gol'dshtein, B., and Gintsburg, M. "Proteinases (Cathepsin) in Tissues of Chick Embryo. Report I." (Ukr.: Proteinazi (katepsin) u thaninakh kuriachogo embriona. Providomlennia 1.), Ibid., 9(3): 593-602, 1936. Sbornik, posviashchennyi 30-letiiu nauchnoi deiatel'nosti akad. A.V. Palladina (Symposium dedicated to the thirty years of Academician A. V. Palladin's scientific activity), 1936, p. 64 .

682. Gol'dshtein, B., and Mil'gram, E. Iv. "Tissue Proteinases (Cathepsin) in the Organs of Animals in Different Periods of Phylogenetic Development" (Ukr.: Proteinazi tkanii (katepsin) v organakh tvarin, iaki stoiat' na riznikh stupeniakh filogenetichnogo rozvithu). Ukrains'kii biokhimichnii zhurnal (Ukr. Biochem. J.), 12(1): 105, 1939.

683. Gorbacheva, A. P., and Maslieva, O. I. "Mechanisms of Nitrogen (Protein) Exchange of Chick Embryo at Different Stages of Development." Doklady VASKHNIL (Reports of the All-Union Scientific Research Institute of the Electrification and Mechanization of Agriculture), 7: 41-47, 1951.

684. Gorbatsevich, E. "Effect of Different Color Rays on Development and Growth of Mammals" ( $O$ vliianii razlichnykh tsvetnykh luchei na razvitie i rost mlekopitaiushchikh. Diss. $\mathrm{SPb}$. A dissertation. St. Petersburg, 1883.

685. Gorbunova, G. A. "Age-Associated Changes of the $\mathrm{O} / \mathrm{N}$ Oxidizing Coefficient of Different Animals" (Ukr.: Vozrastnye izmeneniza okislitel'nogo koeffitsienta $O / \mathcal{N} u$ razlichnykh zhivolnykh). Pratsi naukdoslid. zoobiologichnogo in-tu Kharkivs'kogo derzh. un-tetu, Kharkiv (Works of the Scientific Research Zoobiological Institute, Khar'kov State Univ., Khar'kov), (10-11): 123-138, 1941.

686. Gorbunova, G. P. "Carbonic Anhydrase in the Ontogenesis of Man." Trudy fiziologicheskogo in-tuta im. I. P. Pavlova. Izd-vo $A \mathcal{N}$ SSSR, M.-L. ('Transactions of the I. P. Pavlov Physiological Institute, published by the Acad. of Sciences USSR, MoscowLeningrad), 1945, pp. 89-96.

687. Gordeeva, A. F. "One of the Forms of Ontogenesis of the Cell." DAN SSSR (Rcports of the Academy of Sciences USSR), 86(4): 1033-1035, 1952. 
688. Gordin, V. B. "Age Characteristics of the Histological Structure of the pars tuberalis of the Hypophysis." Trud MIinskogo gos. med. in-ta (Scientific Treatise of the Minsk State Medical Institute), 10 (Part II): 85-95, 1941.

689. Gorinevsku, V. V. "Child Sport and the Social-Biological Characteristics of the Preadolescent and Adolescent Child." Detskii sport, M. (Child Sport, Moscow), 1935, pp. 9-20.

690. Gornitskaia, E. A., and Umanskir, S. I. "Characteristics of Electrocardiograms of Children." Iubileinyi sbornik rabot, posviashchennyi 50-letiiu Institula usovershenstvovaniia vrachei, bibliografiia, M.-L. (Jubilee Collection of Works Dedicated to the 50th Anniversary of the Institute for Training Physicians. Bibliography. Moscow-Leningrad), 1935, pp. 133-148.

691. Gornitskaia, E. A. "Problem of Change of Reactivity of the Organism With Faulty Nutrition." Trudy VI Vsesoiuznogo s'ezd detskikh vrachei. Medgiz, M. (Transactions of the Sixth All-Union Congress of Pediatricians. State Publishing House of Medical Literature, Moscow), 1948, p. 434.

692. Gorodinskaia, R. S. "Age-Associated Characteristics of the Cyto-Architectonics of the Vagus Nerve." Trudy Khabarouskogo med. in-ta sbornik XII (Transactions of the Khabarovsk Medical Institute. Collection XII), 1952, pp. 30-39.

693. Gorodioskala, G. IA., and Drobova, G. V. "Chemical Topography of the Brain. Report IV. Nitrogen and Phosphorus of the Cerebral Cortex of Human Embryos." Fiziologicheskii zhurnal SSR (Physiological Journal of the USSR), 18(3): 449-457, 1935.

694. Gorosheleva, L. S. "ComparativePhysiological Characteristics of the Higher Nervous Activity of Birds in Connection with the Effect of Age." Arkhiv biologicheskikh nauk (Archives of Biological Sciences), 42(1-2): 117-140, 1936.

695. Gorshkova, L. S., German, O. L., and Koshchenets, I. IA. "Problem of Protein Norms for Food of Children 2-3 Years of Age." Voprosy pitaniia (Problems in Nutrition), 5(5): 17-24, 1936.

696. Gragerova, R. B. "Problems of Old Age. Report V. Morphology of the Blood of the Aged in the Abkhazian Autonomous
Socialist Sovict Republic." (Ukr.: Do problemi starosti. Povidomlennia V. Morfologiia krovi starikiv Abkhazii). Medichnii zhurnal A.V URSR (Medical Journal of the Academy of Sciences UkrSSR), 8(1): 87, 1938.

697. - "Immunobiological Properties in Advanced Age." Sbornik Starost'. Trudy konferentsii 17-19 dekabria 1938, AN USSR, Kiev (Old Age Symposium. Transactions of the Conference December 17-19, 1938, Academy of Sciences UkrSSR, Kiev), 1940, pp. 317-320.

698. Grebenshchikov, V. I. "Mortality Table for Russian Physicians, 1890-1896." Vestnik obshchestvennoi gigieny, SPb (Journal of Public Hygiene, St. Petersburg), 6: -, 1898.

699. Grebinskil, S. O. "Fundamental Mechanisms of Individual Growth of Plants" (Osnounye zakonomernosti individual'nogo razvitiia rastenii, izd-vo Khar'kovskogo gos. un-teta, Khar'kov), Khar'kov State University Publishing House, Khar'kov, 1953, p. 224.

700. Gremiatskir, M. A. "What is Rejuvenation?" (Chto takoe omolozhenie. M.-L.). Moscow-Leningrad, 1925.

701. Grzhibovskir. "Problem of the Intake Capacity of the Stomach in Early Infancy" ( $K$ voprosu o vsasyvatel'noi sposobnosti zheludka v rannem grudnom vozraste. Diss.). A disserta. tion, 1902.

702. - "Intake Capacity of the Stomach and Rectum in Early Infancy" (O osasyvatel'noi sposobnosti zheludka i priamoi kishki v rannem grudnom vozraste. Petersburg). St. Petersburg, 1902, p. 83.

703. Grigorova, O. P. "Average Norms for Percentage of Blood Hemoglobin Content in Children of School and Preschool Age." Russkaia klinika, M. (Russian Clinic, Moscow), 5(26): 800-811, 1926.

704. - "Problem of the Morphogenesis of Capillaries." Sbornik Osnovy vozrasinoi morfologii, Institut OSDiP, Medgiz, M. (Collection: Fundamentals of Age Morphology, Institute of Div. for Health Care of Children and Adolescents. State Publishing House of Med. Lit., Moscow), 1933.

705. - "Age-Associated Development of the Hematopoietic Organs in Children." Sbornik Anatomo-fiziologicheskie osobennosti detskogo vozrasta. Biomedgiz, M.-L. (Collection: Anatomical-Physiological Char- 
acteristics of Childhood. State Publ. Housc of Biomedical Lit., Moscow-Leningrad), 1935, pp. $36-64$.

706. "Agc-Associatcd Charactcristics of I Icmatopoiesis in Children." Ibidcm, V. G. Shtcfko, cditor, 1935, pp. 65-145.

707. and Ololinskaia, IU. G. "Monocytic Reaction as Indcx of Functional State of Active Mesenchyma in the Neonatal Period." Trudy In-ta akusherstva i ginekoloyii. Akademiia meditsinskikh nauk SSSR, M. (Transactions of the Institute of Obstetrics and Gynccology, Academy of Medical Sciences USSR, Moscow), 1: 147-156, 1948.

708. Grigorova, O. P. "Age-Associated Development of the Kidneys." "Trudy pervoi nauchnoi konferentsii po vozrastnoi morfologii $i$ fiziologii, izd-vo Akademii pedagogicheskikh nauk RSFSR, M. (Transactions of the First Scientific Conference on Age-Associated Morphology and Physiology. Published by the Academy of Pedagogical Sciences RSFSR, Moscow), 1954, pp. 169187.

709. Grigorovich, P. A. "Dependency of Weight, Size, and Space of Place for the Child and the Weight of the Newborn." Ginekologiia $i$ akusherstvo (Gynecology and Obstetrics), (4): 504-513, 1929.

710. Grigor'ev, Z. E. "Occupational Changes of Elderly People." Starost' $i$ trudosposobnost'. Sbornik rabot NIVTE, L. (Old Age and Work Capacity. Collection of the Works of the "NIVTE", Leningrad), 1936, pp. 7-32.

711. "Preservation of Psychomotor Functions in Elderly Invalid Workers." Ibidem, 1936, pp. 147-153.

712. Grinberg, M. M., and ZaglukhinSKA1A, L. N. "Problem of Norms and Organization of Nutrition in Institutions for Children and Adolescents." Voprosy pitaniia (Problems in Nutrition), 1(3): 7, 1932.

713. Grineva, K. A. "Psychophysiological Charactcristics of Elderly Workers." Starost' i trudosposobnost', Sbornik rabot NIVTE, L. (Old Age and Work Capacity, Collection of Works of the "NIVTE" (see 911, below) Leningrad), 1936, pp. 99-105.

714. Gromova, E. N. "Age-Associated Changes in the Amount of Nucleic Acids in Bursaria truncalella." Uch. zap. Leningradskogo pedagogicheskogo in-ta im. Gertsena (Annals of the Leningrad Gertsen Pedagogical Institutc), 70: 67, 1948.

715. Grosman, D. A. "Clinico-Physiological Characteristics of Adolescence." Soveshchanie po voprosam funktsional'nogo razvitiia sostoianiia zdorov'ia $i$ organizatsiia meditsinskogo obsluzhivaniia rabochikh podrostkov. Tezisy dokladov, M. (Confercncc on Problems of Functional Progress in Statc of Hcalth and Organization of Medical Examination for Working Adolescents. Theses Papcrs, Moscow, 1950, pp. 8-9.

716. Grubina, A. Iu., and Kaplunova, D. E. "Clinico-Roentgenological Properties of the Heart in Youngsters and Adolescents." Tezisy dokladov nauchnoi sessii po voprosam kliniki, fiziologii $i$ professional'nogo truda podrostkovogo vozrasta. Institut gigieny truda $i$ professional'nykh zabolevanii. Izd-vo Akademii meditsinskikh nauk SSSR, M. (Theses papers of the Scientific Session on Problems of the Clinic, Physiology and Occupational Work of Adolescence. Institute of Industrial Hygiene and Occupational Diseases. Publishing House of the Academy of Medical Sciences USSR, Moscow), 7-7 (sic), 1935.

717. Grubina, A. Iu., and Kaplanskala, R. S. "Problems of the Syndrome of Cardiovascular Orthostatism." Tezisy dokladov nauchnoi sessii po voprosam kliniki, fiziologii $i$ professional'nogo truda podrostkovogo vozrasta. M. (Theses Papers of the Scientific Session on Problems of the Clinic, Physiology, and Occupational Work of Adolescence. Moscow), 1935, pp. 9-9 (sic).

718. Grubina, A. Iu., and Kaplunova, D. E. "Clinoco-Roentgenological Properties of the Heart in Youth." Materialy kliniki po vozrastnoi patofiziologii pod red. I. P. Razenkova i I. G. Gel'man, VIEM, M. (Data of the Clinic on Age-Associated Pathophysiology, I. P. Razenkov and I. G. Gel'man, editors. All Union Institute of Experimental Medicine, Moscow), 1937, pp. 81-92.

719. Griaznova, E. I., and Melent'eva, E. P. "Experiment of Determining Indices of Blood Enzymes in Children. Report IV. Relation of the Catalase Index to the Amount of Hemoglobin and Erythrocytes in the Blood of Children." Zhurnal po izucheniiu rannego detskogo vozrasta (Journal for Study of Early Childhood), 4(6): 461-463, 1926.

720. Guz, A. L. "Role of Vegetative System in the Physiology and Pathology of Childhood." Pedialriia (Pediatrics), 14: 353, 1930. 
721. Gulevich, V. A. "Outline of Development of Biological Chemistry for the Last 30 Years." Uspekhi souremennoi biologii (Advances in Contemporary Biology), 3(3-4): 173-187, 1924.

722. Gulevich, V. S. "Importance and Direction of Development of Comparative Biological Chemistry of Animals." Arkhiv biologicheskikh nauk (Archives of Biological Sciences), 33(3-4): 299-306, 1933.

723. Gunar, I. I., and Krastina, E. E. "The Physiology and Biochemistry of the Stage Development of Spring Wheat." $D A \mathcal{N}$ SSSR (Reports of the Academy of Sciences USSR), 86(1): 185-188, 1952.

724. Gundobin, N. P. "Intestinal Structure in Children." (Stroenie kishechnika u detei. Doktorskaia diss., M.). Dissertation for a doctor's degree, Moscow, 1891.

725. - "Morphology and Pathology of Blood in Children" ( $O$ morfologii i patologii krovi $u$ detei), St. Petersburg, 1892; Trudy ob-va detskikh vrachei, $S P b$ (Transactions of the Association of Pediatricians, St. Petersburg), 1892.

726. - "Mental Life of the Child." Fel'dsher (The Doctor's Assistant), (20): -; 1894.

727. Children's Cutting Teeth." Meditsina (Medicine), (14-17): -, 1894.

728. - "Overall and Partial Therapy for Childhood Diseases" (Obshchaia $i$ chastnaia terapiia boleznei detskogo vozrasta), St. Petersburg, lst edition 1896, 2d edition 1900, 3d edition 1907.

729. "Efficacy of Tannalbin for Intestinal Disorders of Children." Vrach (The Physician), 18(14): 一, 1897.

730. - "Child Temperament and Character." Fel'dsher (The Doctor's Assistant), 7(9): 10, 1897.

731. - "The Oblast (Division of a Republic) and Problems of Pediatrics" (Oblast' i zadachi pediatrii). St. Petersburg, 1898.

732. - "General Characteristics of C'hildhood" (Obshchaia kharacteristika detskogo vozrasta). St. Petersburg, 1898.

733. —. "Project of Establishing a Child Hygiene Exhibit." From Depart- ment IV of the Russian Association for National Hcalth Care. Ezhenedel'nik prakticheskoi meditsiny (Practical Medicine Wcekly), (25): - 1901.

734. "Treatment of Anemia in Children." Prakticheskii vrach (The Mcdical Practitioner), (2): —, 1902.

735. - "School Hygiene. Lccture III, delivered in January 1902 in the Hall of the St. Petersburg Assembly for Teachers in Schools for Beginners" (Shkol'naia gigiena. 3 lektsii, prochitannye v ianvare $1902 \mathrm{~g} . v$ zale Peterburgskoi gorodskoi dumy dlia prepodavatelei nachal'nykh uchilishch). St. Petersburg, 1902.

736. - "Stillborn Children." Vrachebnaia gazeta (Medical journal), $(1,2,3)$ : $-, 1903$.

737. - "Current Position on the Social Diseases of Children. Report at the Ninth Pirogovsk Congress, Division of Child Diseases." Russkii vrach (The Russian Physician), (6): - 1904; Vrachebnaia gazeta (Medical Journal), (42): 52, 1904.

738. - "Certain Features in the Anatomy and Pathology wi Lymph Glands." Trudy ob-va detskikh vrachei v SPb za 1904-1905 gg. (Transactions of the Association for Pediatricians at St. Petersburg for 19041905), 11-20: -, 1904-1905.

739. —. "Anatomical - Physiological Characteristics of Childhood" (Anatomofiziologicheski osobennosti detskogo vnzrasta). St. Petersburg, 1906.

740. —. "Child Mortality in Russia and Measures for Combatting It" (Detskaia smertnost' v Rossii $i$ mery bor'by s nei). St. Petersburg, 1906.

741. "Characteristics of Childhood." Prakticheskii wrach (The Medical Practitioner), (24): - , 1905; otdel'noe izdanie, SPb (reprint, St. Petersburg), 1906.

742. "Characteristics of Childhood. Basic Facts for the Study of Diseases of Childhood." Prakticheskaia meditsina, SPb (Practical Medicine, St. Petersburg), 1906.

743. - "Training and Treatment of the Child up to Seven Years of Age." (Vospitanie $i$ lechenie rebenka do 7-letnego vozrasta). 1st edition, St. Petersburg, 1907; 2d edition, 1909; 3d edition, Moscow, 1913.

744. - "Contemporary Problems of School Hygiene." Populiarnyi literaturno- 
meditsinskii zhurnal d-ra Oksa (Dr. Oks's Popular Literary-Medical Journal), Jan. 1907.

745. - "Die Besondersheiten des Kindesalters" (Characteristics of Childhood). Berlin, 1912.

746. Gupalo, P. I. "Soaking of Lcaves in Connection with Dynamics of the Ontogenetic Development of Plants." DAN SSSR (Reports of the Academy of Sciences USSR), 67(2): 389-392, 1949.

747. "Ways for Further Development of the Theory of the Ontogenesis of Plants (Discussion). Problem of N. P. Krenk's Theory of the Age Cycle." Uspekhi sovremennoi biologii (Advances in Contemporary Biology), 38(1;4): 111-121, 1954.

748. -Use and Development of N. P. Krenk's Scientific Legacy." Selektsiia $i$ semenovodstvo (Selection and Seed Growing), (9): 76, 1952.

749. Gurevich-Lazovskaia, A. S. "Experiments of Differential Reaction of Neurons in Postembryonal Period." Biull. eksperimental'noi biologii $i$ meditsiny (Bulletin of Experimental Biology and Medicine), 5: $41-42,1938$.

750. Gurevich, D. I. "Tyrosine and Tryptophan in Muscle Proteins of White Leghorn Chickens in Relation to Age and Sex." Fiziologicheskii zhurnal SSSR (Physiological Journal of the USSR), 27(5): 615-617, 1939.

751. Gurevic11, M. O. "Outer Form of Nerve Elements of the Cerebellar Cortex in Young Mammals." Report given at the Association of Neuropathologists and Psychiatrists, Moscow University, Sept. 26, 1903 meeting. Obozrenie psikhiatrii, nevrologii $i$ eksperimental'noi psikhologii (The Psychiatry, Neurology, and Experimental Psychology Review), (1): 68, 1904.

752. Gurevicii, F. D. "Features of Sound Phases (According to Korotkov's Auscultatory Method) in Functional Testing of the Cardiovascular System in Children and Adolescents." Vrachebnoe delo (Medical Affairs), (23-24): 1042-1046, 1932.

753. Gursku, A. V. "Growth and Longevity of Areca (Palm g.) of Different Heights. (Rost $i$ dolgovechnost' archi na raznykh vysolakh). Soobshchenie Tadzhikskogo filiala AN SSSR, izd-vo TFAN SSSR (A report of the Tadzhik Affiliate of the Academy of Sciences USSR, the State Publishing House of the Tadzhik Affiliatc of the Academy of Sciences USSR), (16): 24-26, 1949.

754. Gur'ev, N. N. “Problein of a Protein Standard in Food for the Aged and the Nitrogen Metabolism in Them." Vrach (Physician), 13(24): 597-600, 1892.

755. Guseva, T. F. "Age-Associated Characteristics of Accommodation of the Neuromuscular System of Man" (Vozrastnye osobennosti akkomodatsii nervnomyshechnoi sistemy cheloveka. Abtoref. diss. kand. biol. nauk. Leningradskii gos. pedagogicheskii in-t, L.) Author's own abstract of the dissertation for the degree of candidate of biological sciences. Leningrad State Pedagogical Institute, Leningrad, 1954.

756. Gusel'Nikov, V. I. “Certain Features of the Conditioned Reflex Activity of Fish." Fiziologicheskii zhurnal SSSR (Physiological Journal, USSR), 38(5): 612-618, 1952.

757. GutNer, I. I. "Age-Associated Changes in the Nerve Elements of Intervertebral Ganglia. Preliminary Report." Biull. VIEM (Bulletin of the All-Union Institute of Experimental Medicine), (8): 23-27, 1935.

758. - "Age-Associated Changes in Nerve Elements of the Spinal Ganglia." Sbornik trudov Voenno-med. akademii RKKA im. S. M. Kirova, posviashchennykh 40-letnei deiatel'nosti $V . \mathcal{N}$. Tonkova (Symposium of transactions of the S. M. Kirov Military Medicine Academy of the Workers' and Peasants' Red Army, dedicated to the 40th anniversary of the activity of $\mathrm{V}$. N. Tonkov), 1937, pp. 358-382.

759. - "Age-Associated Changes of Schwann's Cell Inclusions." Nevropatologiia $i$ psikhiatriia (Neuropathology and Psychiatry), 2(10): 102-106, 1938.

760. - "Ontogenesis and Structure of the Posterior Central Area and Granular Retrosplenial Area of the Cerebral Cortex of Man and of Certain Animals" (Ontogenez $i$ struktura zadnei tsentral'noi oblasti $i$ zernistogo retrosplenial'nogo polia kory bol'shikh polusharii mozga u cheloveka i nekotorykh zhivotnykh. Diss.). A dissertation, 1944.

761. "Problem of the Ontogenesis and Structure of the Cerebral Cortex. Report II. Postembryonic Ontogenesis of the Cortex in (Guinea) Pig, Rabbit, Mouse, and Cat" ( $K$ voprosu ob ontogeneze $i$ strukture kory bol'shikh polusharii mozga. Soobshchenie 2. 
Postembrional'nyi ontogenez kory u svinki, krolika, myshi $i$ koshki.) Biull. eksperimental'noi biologii $i$ meditsiny (Bulletin of Experimental Biology and Medicine), 21(3): 52-54, 1946.

762. "Changes in Purkinje's Cells of the Cerebellar Cortex in the Elderly Person." Arkhiv patologii (Archives of Pithology), (6): 58-63, 1949 (7 refs).

763. G. D. "AgeAssociated Changes of Specific Fuchsinophilic Granularity of Nerve Cells of the Human Brain." DAN SSSR (Reports of the Academy of Sciences USSR), 35(1): 195-198, 1952.

764. Gutner, I. I., and Fainberg, V. B. "Evolution of the Structure of the Vitelline Sac of 3-10 Week Human Embryos." $D A \mathcal{N}$ SSSR (Reports of the Academy of Sciences USSR), 97(4): 745-748, 1954.

\section{D}

765. Davydov, G. L. "Degree of Acidity of Vaginal Secretion of the Newborn and Method of Determination." Vrachebnoi delo (Medical Affairs), (23-24): 1681-1685, 1930.

766. Davydov, E. P. "Clinical Importance of the Erythrocyte Sedimentation Rate of Nursing Children." Zhurnal po izucheniiu rannego detskogo vozrasta (Journal for Study of Early Childhood), 7(1): —, 1927.

767. Davydov, M. S. "Materials to Study Development of the Peripheral-Nervous System and the Pacini's, Herbst's, and Grandry's Corpuscles" (Materialy $k$ izucheniiu razvitiia perifericheskoi nervnoi sistemy, telets Pachini, Gerbsta i Grandri. Diss. M.). A dissertation, Moscow, 1903.

768. Davydova, S. M., and Konikova, A. S. "Intensity of Formation of Proteins of Different Organs of Rats Depending on Age." DAN SSSR (Reports of the Academy of Sciences USSR), 73(2): 349-360, 1950.

769. Daineko, L. N. "Does the Anterior Lobe of the Hypophysis of Mammal Embryos Participate in the Development of Their Genitalia?" Biull. eksperimental'noi biologii $i$ meditsiny (Bulletin of Experimental Biology and Medicine), 2(6): 455-457, 1936.

770. - Internal Secretion in the Course of Intrauterine Life (Anterior Lobe of the Hypophysis, Sex Glands, and Thyroid Gland)" (Vnutrenniaia sekretsiia v techenie vnutri- utrobnoi zhizni (peredniaia dolia gipofiza, polovye zhelezy $i$ shchitovidnaia zheleza). $\Lambda$ dissertation, "VIZh" (All-Union Institute of Animal Husbandry?), Moscow, 1937.

771. "Hormonal Activity of the Thyroid Gland in the Embryos of Farm Animals." Biull. eksperimental'noi biologii $i$ meditsiny (see above), 6(1): 98-99, 1938.

772 "Gonadotrophic Activity of the Anterior Lobe of the Hypophysis of Bovine Embryos." Ibidem, 7(6): 544-547, 1939.

773. -Dynamics of Growth of the Gonadotrophic Activity of the Anterior Lobe of the Hypophysis of Pig Embryo." Ibid., 8(3-4): 285-288, 1939.

(774. Gonadotrophic Activity of the Anterior Lobe of the Hypophysis of Sheep Embryos." Ibid., 10(3): 142-144, 1940.

775. Danilevskil, A. IA. "Myosin, seine Darstellung, Eigenschaften, Umwandlung in Santonin und Rückbildung aus demselben." Myosin, Its Preparation and Properties, Conversion into Santonin, and Reconversion to Itself). Zeitschrift für physiologische Chemie, 5: - 1881 .

776. - " "Outline of the Organoplastic Forces of the Organism" (Ocherk organoplasticheskikh sil organizma), Khar'kov, 1886.

777. - "Relationship of Anatomical and Chemical Differentiation of the Main Protein Substances of Muscle Tissue to Characteristics of Its Activity. Fiziologicheskii sbornik, Khar'kov (Physiological Collection, Khar'kov), 1: 一, 1888.

778. — and Selikovskil, A. "Content of Myosin and Myostroma in Muscles Dependent on Rest, Activity, and Other Conditions." Fiziologicheskii sbornik (Physiological Collection), 1: - 1888.

779. Danilevskil, A. IA. "Food and Character" (Pishcha $i$ kharakter). Khar'kov, 1891.

780. Danilevskil, V. IA. "Effect of Lecithin on Growth and Reproduction of Animals and Plants." Vestnik meditsiny (Journal of Medicine), $(1,14,15):-, 1896$.

781. -Preliminary Note on Therapeutic Use of Lecithin." Vrach (The Physician), 20(17): 481 and (20): -, 1899.

782. Danilov, M. D. "Change of Weight and Moisture Content of the Coniferous 
Ncedle of Ordinary Pine (Pinus silvestris) in Conncction with Its Age and the Age of the Tree." DAN SSSR (Reports of the Academy of Scicnces USSR), 59(8): 1487, 1948.

783. "Changc of Weight and Moisture Content of the Coniferous Needle of Ordinary Fir and Siberian Silver Fir in Connection with Its Age and the Age of the Tree." Ibid., (61): 375-378, 1948.

784. "Transpiration in Winter of Year-Old Shoots of Philodendron amurense Rupr. Trees of Various Age." Priroda (Nature), (5): $44-45,1948$.

785. Danilova, A. K., and Postnikova, A. N. "Gas Exchange in Ducks One to 180 Days Old." Trudy Moskouskogo zootekhnicheskogo in-ta (Transactions of the Moscow Zootechnical Institute), 3: 一, 1936.

786. Daniel'son, A. K. "Characteristics of Secondary Regeneration of Peripheral Cutting of Nerves in Different Age Periods of the Rabbit." Sbornik: Voprosy eksperimental'noi biologii $i$ meditsiny, izd-vo Akademii meditsinskikh nauk SSSR, M. (Collection: Problems of Experimental Biology and Medicine. State Publishing House of the Academy of Medical Sciences USSR, Moscow), 1951, p. 38.

787. - "Characteristics of the Development of Experimental Trophic Ulcers of Rabbits in Various Age Periods. Report I. Development of Experimental Trophic Ulcers in Adult Rabbits." Ibid., (2): 33, 1952.

788. - "Characteristics of Development of Experimental Trophic Ulcers in Rabbits in Different Age Periods. Report II. Development of Experimental Trophic Ulcers in Rabbits of Different Age." Ibid., (2): 37, 1952.

789. Dashevskaia, B. M. "Problem of Tuberculosis of the Throat in Old Age." Zhurnal ushnykh, nosovykh $i$ gorlovykh boleznei (Journal of Diseases of the Ear, Nose, and Throat), 10(6): 735-738, 1934.

790. Dasnevskaia, L. A. "Morphological Picture of the Heart of the Newborn in X-ray." Voprosy pediatrii i okhrany materinstva $i$ detsiva (Problems of pediatrics and Maternal and Child Welfare), I2(2): 43-47, 1944.

791. Dasirkovskaia, V. S. "The First Conditioned Reactions in Newborn Children Normally, and in Certain Pathological
States." Zhurnal vysshei nervnoi deialel'nosti (Journal of Higher Nervous Activity), 3(2): 247-258, 1953.

792. Dvoriankin, F. A. "In Defense of the Michurin 'Theory of Ontogenesis." Uspekhi souremennoi biologii (Advances in Contemporary Biology), 39(1): 1 I1-122, 1955.

793. Degio, K. "Scnile Atrophy of the Heart." Russkii arkhiv klinicheskoi meditsiny, patologii $i$ bakteriologii (Podvysotskogo), SPb Russian Archives of Clinical Medicine, Pathology, and Bacteriology (under Imperial pernit), St. Petersburg), 14: 591-604, 1902.

794. Degtiar', E. N. 'Certain Unconditioned Reactions of the Child in the First Months of Life." Trudy in-la fiziologii im. I. P. Pavlova, izd-vo AN SSSR, M.-L. (Transactions of the I. P. Pavlov Institute of Physiology, State Publ. House of the Acad. of Sciences USSR, Moscow-Leningrad), 1: $-, 1952$.

795. Deich, V. M. "Problem of the Interrelations of Protein and Carbohydrate Ingredients of Food and Their Effect on the Physiological Balance of the Young Child." Voprosy pediatrii $i$ okhrany materinstva $i$ detstva (see above), I0(3): I47-151, 1938.

796. Demant, B. "Uber den Glycogen gehalt der Leben (sic; should be Leber) neugeborener Hunde ( $\mathrm{Iz}$ laboratorii prof. Anrepa, Khar'kov)" (On the Glycogen Content of the Life (sic; should be Liver) of Newborn Dog. From the Laboratory of Prof. Anrep, Khar'kov), Hoppe-Selyer's Zeitschrift für physiolog. Chemie, 2(3): 142-144, 1887.

797. Dement'Ev. "Liver Functions in the Newborn" ( $O$ funktsiiakh pecheni $u$ novorozhdennogo). Doklad Pirogovskogo c'ezda (Report of the Pirogovsk Congress), 1904.

798. Demidovich. "Problem of the Effect of Age and Sex Life on the Rate of Absorption" ( $K$ voprosu o vliiania vozrasta $i$ polovoi zhizni na skorost' vsasyvaniia. Diss. SPb). A dissertation, St. Petersburg, 1896.

799. Demirghoglian, G. G., and Mirzoian, V. S. "Problem of the Development of the Electric Reaction of the Retina in Ontogenesis." DAN SSSR (Reports of the Academy of Sciences USSR), 90(3): 371-374, 1953.

800. Demianovikil, S. IA., and Doman, N. G. "Change of Chemical Composition 
of Mulberry Tree Leaves Dependent on Degree of Their Maturity." Biokhimiia (Biochemistry), 9(6): 360-364, 1944.

801. Dem'ianovskaia, N. S., and BeloZERSKIl, A. N. "Desoxyribonucleic Acid of Actinomyces globisporus streptomycini Kras in the Process of Its Development." Ibid., 19(6): 688-692, 1954.

802. Denisova, M. P., and Figurin, P. L. "Experimental Study of the Reflexes of the Newborn Child." Sbornik: Novoe v refleksologii i fiziologii nervnoi sistemy, Gosizdat (Collection: That Which is New in Study of the Reflexes and Physiology of the Newborn Child. State Publishing House), 1: 一, 1925.

803. Denisova, M. P., and Figurin, N. L. "Some Results in the Study of Reflexes in Child Behavior from Birth to the Age of One." Psikhonevrologicheskie nauki v SSSR, $M .-L$. (Psychoneurological Sciences in the USSR, Moscow-Leningrad), 1: —, 1930.

804. - "Early Conditioned Reflexes in Nursing Children." Sovetskaia pediatriia (Soviet pediatrics), 2(6): 96, 1935.

805. Denisova, M. P., Panteleeva, O. G., and Figurin, N. L. "A Contribution of Certain Data to the Problem of the Galvanic Excitability of Nerves of Children." Ibid., 2(7): 23, 1935.

806. Deparma, N. K. "A Method for Determining the Age of Moles." Biulleten' Moskovskogo ob-va ispytatelei prirody, otd. biologii (Moscow Society of Naturalists. Division of Biology), (6): 11-25, 1954.

807. Derviz, G., Bondarin, V., Sologub, I., and Golubeva, M. "Biochemical Indices of Early Maturation in Animals." Problemy zhivotnovodstva (Problems of Animal Husbandry), (1): 108-109, 1936.

808. Derviz, G. V. "Conference on the Problem of the Processes of Development of OId Age and Prophylaxis for Premature Aging of the Organism." Sovetskaia meditsina (Soviet Medicine), (5): 43, 1939.

809 "Biochemical Changes in the Organism and in Its Metabolism at Time of Aging." Sbornik: Starost'. Trudy konferentsii 17-19 dekabria $1938 \mathrm{~g}$., Kiev, AN USSR (Collection: Old Age. Transactions of the Dec. 17-19, 1938 Conference, Acad. of Sciences UkrSSR, Kiev), 1940, pp. 213-219.
810. Dergachev, I. S. "Reactivity of 'T". sue Mesenchyma During Influenzal Infection in Children at an Early Age." Retikuloendotelial'naia sistema, krovetvorenie i pigmentnyi obmen, Biomedgiz, M. (Reticulo-Endothelial System, Hematopoiesis, and Pigment Exchange. State Publishing House of Biomedical Literature, Moscow), 1935, pp. 5-24.

811. Dereviagin, P. D. "Effect of Total Action of Ultrashort Radio Waves on Growth and Weight of Young Dogs." Arkhiv patologicheskoi anatomii i patologicheskoi fiziologii (Archives of Pathological Anatomy and Pathological Physiology), 2(2): 93, 1936.

812. Derechinskaia, Sh. L., VoskresenSKaIA, G. S., and Ermakova, E. IA. "Age Characteristics of the Course of Serum Disease and Its Prophylaxis." Pediatriia (Pediatrics), (5): 3-9, 1948.

813. Derchinskit, G. D. "Reactions of the Intrauterine Fetus to Mother's Loss of Blood and Blood Transfusion." Tezisy dokladov nauch. konferentsii. Institut akusherstva $i$ ginekologii, L. (Theses papers of the Scientific Conference, Institute of Obstetrics and Gynecology, Leningrad), 1949, pp. 50-51.

814. Detinova, T. S. "Age-Associated Changes in the Ovaries of Hippobosca capensis (sic.; should be canensis) Olf., the Winged Tick Flies of Dogs." DAN SSSR (Reports of the Academy of Sciences USSR), 103: 937-940, 1955.

815. Dzhandieri, I., Semenskaia, E., Dzhandieri, M., Berulava-Devdoriani, O., Dzhorbenadze, V., and Gochitashvili, K. "Problem of the Selection of Farm Animals for the Purpose of Increasing Their Productivity and the Organization of Herds." Trudy Tsentral'noi zootekhnicheskoi stantsii NKZema Gruzii (Transactions of the Central Zootechnical Station of the People's Commissariat of Agriculture of Georgia), (1): - 1932.

816. Dzhanumov, T. S. "Dependency Between the Histostructure of a Tumor and the Age of Its Bearer." Arkhiv patologicheskoi anatomii $i$ patologicheskoi fiziologii (see above), 3(3): 131, 1937.

817. Dzgoeva, T. O. "Effect of Thyroxin on Gas Exchange in White Rats of Varied Age" (Ukr.: Vpliv tiroksinu na gazoobmin u bilikh shchuriv riznogo viku). Medichnii zhurnal, AN URSR (Medical Journal, Academy of Sciences UkrSSR), 23(2): 21-26, 1953. 
818. Dzenit, L. P. "Electrical Plicnomena in the Cerebral Cortex." Uspekhi souremennoi biologii (Advances in Contemporary Biology), 4(6): 540-542, 1935.

819. DzerzinNSK11, VI "Development of Adrenals, Their Histogenesis, Ontogenesis, and Phylogcnesis" (Razvitie nadpochechnykh zhelez, ith gistogenez, onlogenez $i$ fllogenez. Diss. na stepen' doktora meditsiny, M.). A dissertation for the degree of doctor of medicine, Moscow, 1910, p. 277.

820. Dzugaeva, S. B. "Conductor Paths of the Brain in the Aging Aspect." Vsesoiuznoe soveshchanie po neiromorfologii. Tezisy dokladov, medikobiologicheskii otdel Akademii medilsinskikh nauk SSSR, In-t fiziologii im. I. P. Pavlova AN SSSR, Vsesoiuznoe ob-vo anatomov, gistologov $i$ embriologov, L. (All-Union Conference on Neuromorphology. Theses $\mathrm{Pa}$ pers, Medico-Biological Division of the Academy of Medical Sciences USSR, the I. P. Pavlov Institute of Physiology, Academy of Sciences USSR, All-Union Association of Anatomists, Histologists, and Embryologists, Leningrad), 1952, pp. 9-12.

821. "Regional Bundle of the Human Cerebrum in the Age Aspect." Voprosy morfologii (Problems of Morphology), 2: 56-61, 1953.

822. - "Age-Associated Anatomy of the External Capsule of the Human Cerebrum." Ibid., 2: 62-66, 1953.

823. Dziubanov, V. M. "Investigation of the Chief Mechanisms of Growth and Development of the Young of "Symmentalized" (sic; ?sympathectomized) Cattle in the Postembryonic Period." Doklady nauch. konferentsii, posviashchennoi 20-letneum iubileiu Ukrainskogo nauch.-issled. in-ta zhivolnovodstva, Khar'kov (Reports of the Scientific Conference Dedicated to the 20th Year Jubilee of the Ukrainian Scientific Research Institute of Animal Husbandry, Khar'kov), 1950.

824. Dibobes, I. S., and Kvater, E. I. "Problem of the Calcium Content in the Blood in Different Periods of Pregnancy, as Well as in Septic Postnatal Diseases." Moskouskii meditsinskii zhurnal (Moscow Medical Journal), (3): 41-47, 1927.

825. Dik, A. "Data for Study of the Growth, Weight, Chest Measure, and Vital Capacity of the Lungs of Children and Adolescents, Based on Observations Made in St. Petersburg" (Materialy $k$ issledovanïu rosta, vesa, okruzhnosti grudi $i$ zhiznennoi emkosti legkikh detskogo i iunosheskogo vozrastov, osnovannye na nabliudeniiakh, sdelannykh o S.-Peterburge. Diss. na stepen' doktora meditsiny. SPb.). Dissertation for the degree of doctor of medicine, St. Petersburg, 1883, p. 168.

826. Dinaburg, A. D. "Changes of Subcortical Ganglia in the Aged (Macro- and Microglia in the Corpus striatum)." Sbornik: Starost' (Trudy konferentsii 17-19 dekabria 1938 g.), $A \mathcal{N}$ USSR, Kieo (Collection: Old Age. Transactions of the Conference December 17-19, 1938, Academy of Sciences, UkrSSR, Kiev), 1940, pp. 405-410.

827. Dinaburg, G. D., and 'Trusilins'Ka, M. M. "Changes in the Nervous System in Typhus abdominalis of Children" (Ukr.: Zmini nervovoi sistemi pri cherevnomu lifi $u$ ditei). Pediatriia, akusherstvo i ginekologiia (Pediatrics, Obstetrics, and Gynecology), (2): 8-12, 1947.

828. Dionesov, S. M. "Effect of Removal of the Salivary Glands on Sugar Content in the Blood of Dogs." Fiziologicheskii zhurnal SSSR (Physiological Journal of the USSR), 38(3): 326-331, 1952.

829. Ditrikh, M. K., and Golovacheva, R. A. "Problem of Enzyme Indices of the Blood and Their Fluctuations in Healthy and Sick Children." Meditsinskii zhurnal (Medical Journal), 1(8-9): -, 1921.

830. Dmitrenko, E. V. "Problem of the Antibiotic Properties of the Amniotic and Allantoic Fluids of Chick Embryo." Biull. eksperimental'noi biologii $i$ meditsiny (Bulletin of Experimental Biology and Medicine), 38(1f) $59-61,1954$.

831. Dimitriev, V. D. "Features of Compensation of Motor Functions in the Ontogenesis." Fiziologicheskii zhurnal SSSR (Physiological Journal of the USSR), 40(5): 582$588,1954$.

832. Dmitrieva, E. V. "The Thymus and Vitality. Report I. Weight of the Thymus in Chick Embryos." Biull. eksperimental'noi biologii $i$ meditsiny (see above), 8(1): 38-39, 1939.

833. Dmtrevskala, E. N. "Limiting Truncus sympathicus in Newborn Boys." Nauch. Izvestiia Kazakhskogo meditsinskogo Instituta, (Sci. Report of the Kazakh Med. Institute) 1950, pp. 10-16.

834a. DMitrievskil, I. "Life and Death" (Zhizn'i smert'), 10: -, 1916. 
834b. Dobatovkin, P. A. "Problem of the Chemical Composition of Subcutaneous Fat in Infants" ( $K$ voprosu o khimicheskom sostave podkozhnogo zhira $u$ detei grudnogo vozrasta, $\mathrm{SPb})$, St. Petersburg, 1900.

835. Dobrovol'skiI, N. V. "Artery Changes in Children According to Age" (Ob izmeneniiakh arterii $u$ detei po vozrastam. Diss., SPb.). Dissertation, St. Petersburg, 1902.

836. Dobrovol'skir, N. D. "Data for Study of Old Age" (Materialy $k$ izucheniiu starosti. Diss., SPb.), a dissertation, St. Petersburg, 1902.

837. Doвrokhotova, A. I. "Course of Acute Infectious Diseases Dependent Upon Age." Pedia!riia (Pediatrics), (5): , 1947; Trudy VI Vsesoiuznogo s'ezda detskikh vrachei. Medgiz, M. (Transactions of the Sixth All-Union Congress of Pediatricians. State Publishing House of Medical Literature. Moscow), 1948, p. 253.

838. Dobrunov, L. G. "Certain Positions of the Theory of the Age Cycle." Uspekhi souremennoi biologii (Advances in Contemporary Biology), 32(1): 101-112, 1951 (6 ref3.).

839. Dobrunov, L. I. "Comments on the Theory of the Cyclic Aging and Rejuvenation of Plants in the Ontogenesis (Age-Cycle Theory)." Vestnik AN Kazakhskoi SSSR (Journal of the Academy of Sciences of the Kazakh SSSR), 8(77): —, 1951.

840. Dobrynina, V. "Problem of AgeAssociated Changes of the Amino-Acid Composition of the Brain Proteins of Man. Fiziclogicheskii zhurnal SSSR (Physiological Journal of the USSR), 29(3): 225-230, 1940.

841. Dovgialo, N. D. "Shmal'gauzen's (Schmalhausen's) Law of Growth and Application to Man." Trudy i materialy Donetskogo med. in-ta (Transactions and Data of the Donets Medical Institute), (1): 11, 1936.

842 . "Growth of the Human Skull." Arkhiv anatomii, gistologii $i$ embriologii (Archives of Anatomy, Histology, and Embryology), 17: 30-71, 1937.

843. Dogel', A. S. "Old Age and Death. II." (Starost' $i$ smert'. II.) T Tentral'noi kooperativnoe izd-vo "Mysl", (The Central Cooperative Publishing House "Thought"), 1922.

844. Dogel', I. M. "Comparative Anatomy, Physiology, and Pharmacology of the
Heart" (Sravnitel'naia anatomiia, fiziologiia, farmakologiia serdtsa). Kazan', 1895.

845. Domanov, I. I. Embryonic Histogenesis and Age-Associated Changes of the Anterior Lobe of the Hypophysis of Sheep." Trudy Chkalovskogo s.-kh. in-ta im. A. A. Andreeva (Transactions of the Chkalovsk A. A. Andreev Agricultural Institute), 4(1): 300, 1951.

846. DonduA, A. K. "Phagocytosis and Inflammation at Different Stages of Development of the Chick Embryo" (Fagotsitoz $i$ vospalenie na raznykh stadiiakh razvitiia kurinogo embriona. Avtoref. diss. kand. biol. nauk, LGU, Leningrad), author's own abstract of his dissertation for the degree of candidate of biological sciences, Leningrad State Univ., Leningrad, 1954.

847. Dormidontov, A. A. "Throat and Upper Respiratory Reactions in Young Rabbits to Intravenous Injection of a Colloidal Dye." Pediatriia (Pediatrics), 6(1): 99-103, 1939.

848. Dorodnitsyna, A., and Rozhanskir, N. "Effect of Age on Nutritive Value of Proteins." Voprosy pitannia (Problems in Nutrition), (5): 64, 1937.

849. Dorfman, V. A. "The $\mathrm{pH}$ and the Anaerobic Redox Potential in the Early Morphogenesis of Amphibia." Biull. eksperimental'noi biologii $i$ meditsiny (Bulletin of Experimental Biology and Medicine), 6(4): $416-420,1938$.

850. Dragomirov, N. I. "Basic Marks of Age Changes in the Behavior of Sturgeon Larvae." DAN SSSR (Reports of the Academy of Sciences USSR), 93(4): 725-728, 1953.

851. - "Early Stage of Larval Development of (Shovel-Nosed Fish) Lopatonos' (Pseudoscaphirhynchus).'

852. Driagin, P. A. "Age Structure of the Fish Population." Zoologicheskii zhurnal (Zoological Journal), 32(1): 88-92, 1953.

853. Dubrovitskala, N. I., and Bel'skala, T. N. "Cyclic Aging and Rejuvenation of Plants." Nauka i zhizn' (Science and Life), (5):,- 1946.

854. - "The Problem of the Age Factor." Vestnik AN SSSR (Journal) of the Academy of Sciences USSR), (6): -, 1947. 
855. "Effect of Age Condition of Leaves on the Regenerative Capacity." $D A N$ SSSR (Reports of the Academy of Sciences USSR), 66(5): 961-964, 1949.

856. and KRENKE, A. N. " Criticism of the Age-Cycle Theory." Uspekhi souremennoi biologii (Advances in Contemporary Biology), 36: 64-78, 1953 (28 refs.).

857. Dudin, V. A. "Digestivc Enzymes in the Stomach of Fetuses and Premature Children" ( $O$ pishchevaritel'nykh fermentakh $v$ zheludke plodov $i$ nedonoshennykh delei. Diss.), a dissertation, 1904.

858. D'iacuenko, E. I. "Changes in Bone Growth of Rabbit Fetuses Under Effect of Complete Starvation of Their Mother" ( $\mathrm{Ob}$ izmeneniakh $v$ roste kostei utrobnykh plodov krolikov pod iliianiem polnogo golodaniia ikh malerei, Diss., SPb), a dissertation, St. Petersburg, 1897.

859. D'iacinov, A. N. "Mortality Tables of the Population of the Arkhangelsk District (and the city of Arkhangelsk), 19261927" (Tablitsy smertnosti naseleniia Arkhangel'skoi gubernii ( $i$ gor. Arkhangel'ska), 19261927 gg.), 1927.

860. Diadiusha, G. F., and Turkevich. N. M. "Tumor Inoculation in Conjunction with Age and State of the Physiological System of the Connective Tissue" (Ukr.: Pereshchepliuvanist' pukhlin $v$ zv'iazku $z$ vikom $i$ stanom fiziologichnoi sistemi spoluchnoi tkanini). Medichnii zhurnal AN URSR (Medical Journal of the Academy of Sciences UkrSSR), 20(4): 38-47, 1950.

\section{E}

861. Evtushenko, G. A. "Features of the Ontogenesis of the Tobacco Plant. Growth and Development of Plant Dependent on Length of Day and Other Factors. (Theses of doctorate dissertation)." Izv. Kirgizskogo filiala AN SSSR (Bulletin of the Kirgiz Affiliate of the Academy of Sciences USSR), (6): 167-173, 1947.

862. Egorov, O. "Data on the Propagation and Growth of the Siberian Mountain Goat." Biull. Moskovskogo ob-va ispylatelei prirody, ser. biol. (Bulletin of the Moscow Association of Naturalists, Biological Series), 58(3): 3-13, 1953.

863. Engalychev, P. "Prolongation of Human Life. The Means to Attain Health,
Happiness, and Long Lifc, to Protect Hea "th and to Treat Diseases with Proper Measures and with Indication Made up of the Best from Foreign and Domestic Writers of Principles and Medicines Found Almost Everywhcre Before Our Eyes" (O prodolzhenii chelovecheskoi zhizni. Sredsiva dostigat' zdorovoi, veseloi i glubokoi starosti, predokhraniat' zdorov'e nadlezhashchimi sredstuami $i$ pol'zovat' bolezni, pokazaniem prichin $i$ lekarstv pochti vsiudu pered glazami nashimi nakhodiashchimisia, sostavlennoi iz luchshikh olechestvennykh $i$ inostrannykh pisatelei. M., universitetskaia tipografiia). University Printing Office, Moscow, 1833.

864. ENIKeEva, S. I. "Mcchanism of the Adrenalin Decrease of Cardiac Rhythm in the Early Stages of the Postembryonic Period." Arkhiv biologicheskikh nauk (Archives of Biological Sciences), 46(2): 102-109, 1937.

865. - "Sympathetic Innervation of the Heart in the Ontogenesis." Fiziologicheskii zhurnal SSSR (Physiological Journal of the USSR), 25(1-2): 102-112, 1938.

866. -. "Chronaxy of the Pecten Obturator of Ponticus in the Ontogenesis." Biull. eksperimental'noi biologii $i$ meditsiny (Bulletin of Experimental Biology and Medicine), 9(6): 416-418, 1940.

867. - "Lability of the Heart (Extent of Mastering the Rhythm) in the Ontogenesis." Fiziologicheskii zhurnal SSSR (Physiological Journal of the USSR), 30(3): 331338,1941 .

868. "Role of the Innervation Mechanisms in Change of Cardiac Lability in Different Stages of the Ontogenesis." Ibid., (3): 339-345, 1941.

869. - "Conditions of the Formation of Emphysema in Very Young Kittens at Diphosgene Intoxication." Farmakologiia $i$ toksikologiia (Pharmacology and Toxicology), (6): 54, 1943.

870. - "Adrenalin Shock and the Mechanism of Adrenalin Bradycardia at an Early Age." Ibid., 8(3): 11, 1944.

871. "Characteristics and Mechanisms of the Course of Yperite Intoxication at an Early Age. Biull. eksperimental'noi biologii $i$ meditsiny (see above), 17(3): 52-55, 1944.

872. - "Reciprocal Innervation of Antagonist Muscles in the Ontogenesis." Ibid., 17(6): 33, 1944. 
873.

"Resistance of the Heart in Different Age Periods." Tezisy dokladov 3-i sessii Instituta pediatrii Akademii meditsinskikh nauk SSSR (Theses of Reports of the Third Session of the Institute of Pediatrics, Academy of Medical Sciences USSR), Moscow, 1946, pp. 10-11; Tezisy dokladov 4-i nauch. konferentsii, posviashchennoi 25-letiiu deiatel'nosti Instituta pediatrii AMN SSSR (Theses of Reports of the Fourth Scientific Conference Dedicated to the 25th Anniversary of the Activity of the Institute of Pediatrics, Acad. of Med. Sciences USSR), Moscow, 1947, pp. 31-32.

874. "Resistance of Isolated Heart of Dog to Chloral Hydrate in Different Age Periods." Referaty nauch. issled. rabot Akademii meditsinskikh nauk SSSR, klinicheskie nauki ( $\mathrm{Re}-$ views of the Scientific Research Work of the Academy of Medical Sciences USSR, Clinical Sciences, Moscow), (5): 38-39, 1948.

875.

"Resistance of Isolated Heart to the Effect of Chloral Hydrate in Different Age Periods." Biull. eksperimental'noi biologii $i$ meditsiny (see above), 27(6): 439-441, 1949.

876. - "Respiratory Arrhythmia as Index of Emergence of Vagus Regulation of Rhythmic Activity of the Heart in Children." Ibid., (4): 239, 1951.

877. - and Organisian, A. A. "Mechanism of Change of Cardiac Rhythm of Rats in the Ontogenesis." Sbornik: Voprosy eksperimental'noi biologii $i$ meditsiny, izd-vo Akademii meditsinskikh nauk SSSR, M. (Collection: Problems of Experimental Biology and Medicine. Publishing House of the Acad. of Med. Sciences USSR, Moscow), 1951, p. 68 .

878. Enikeeva, S. I. "Cardiac Resistance in Different Age Periods." Trudy konferentsii po vozrastnym izmeneniiam obmena veshchestv $i$ reaktivnosti organizma. Izd-vo AN USSR, Kiev (Transactions of the Conference on Age-Associated Changes of Metabolism and Reactivity of the Organism. State Publishing House of the Academy of Sciences UkrSSR, Kiev), 1951, p. 191.

879.

"Characteristics of Degree of Toxicity of the Dysentery Toxin and of the Resistance to It of Isolated Rabbit Heart in Different Age Periods." Arkhiv patologii (Archives of Pathology), (6): 22, 1951.

880. "Characteristics of the Degree of Toxicity of the Staphylococcus Toxin and Resistance to It of Isolated Heart in
Different Age Periods." Sbornik Instituta obshchei $i$ eksperimental'noi patologii AMN SSSR pod. red. Lebedinskoi, Trudy Akademii mediisinskikh nauk SSSR (Collections of the Institute of General and Experimental Pathology of the Academy of Medical Sciences USSR. Lebedinskii, editor. Transactions of the Academy of Medical Scicnces USSR, Moscow), 19: 176, 1952.

881. - "Functional Resistance of Isolated Heart in Different Age Periods." Fiziologicheskii zhurnal SSSR (Physiological J of the USSR), 39(3): $346-351,1953$.

882. - "Characteristics of Nerve Regulation of Cardiac Activity in Animals and in Man in Different Age Periods." Sbornik: Trudy pervoi nauchnoi konferentsii po vozrastnoi morfologii $i$ fiziologii. Izd-vo Akademii pedagogicheskikh nauk RSFSR, M. (Collection: Transactions of the First Scientific Conference on Age-Associated Morphology and Physiology. Publishing House of the Acad. of Pedagogical Sciences, RSFSR, Moscow), 1954, pp. 95-102.

883. - and Shtamler, S. M. "Features of Nerve Regulation of the Rhythm of Heart Contractions in Rabbits at Different Stages of the Ontogenesis." Biull. eksperimental'noi biologii $i$ meditsiny (Bulletin of Experimental Biology and Medicine), 38(7): 10-13, 1954.

884. - and Rozanova, V. D. "Physiological Mechanisms of Reactivity at Action of Tetanus Toxin in Different Age Periods. Problem of Reactivity in Pathology." Sbornik 65-letiia so dnia rozhdeniia $A, D$. Speranskogo. Medgiz, M. (Symposium Dedicated to the 65th Birthday of A. D. Speranskii. State Publishing House of Medical Literature, Moscow), 1954, p. 84.

885. ENIKeEva, S. I. "Respiratory Arrhythmia and Alteration of the Deflections of the Electrocardiogram as Indices of Emergence of Vagus Regulation of Cardiac Activity in the Ontogenesis." Fiziologicheskii zhurnal SSSR (Physiological J. of the USSR), 51(2): 227-232, 1955.

886. - "Stabilization and Reorganization of Vagus Regulation of Cardiac Activity in Connection with Change of Respiration in Different Age Periods." Materialy vtoroi nauch. konferentsii po voprosam vozrastnoi morfologii $i$ fiziologii, izd. Akademii pedagogicheskikh nauk RSFSR, M. (Data of the Second Scientific Conference on Problems of Age-Associated Morphology and Physiology. 
Publishing House of the $\Lambda$ cad. of Pcdagogical Scicnces, RSFSR, Moscow), 1955, p. 57.

887. Epel'baum, S. E., Kilaikina, B. I., and SKVIRSK'KA, E. B. 'Effect of Age on Phosphate Compounds of the Brain" (Ukr.: Vpliv viku na fosfatni spoluki mozku). Sbornik posviashchennyi 30-letiiu nauchnoi deiatel'nosti akad. A. V. Palladina (Symposium Dedicated to the 30th Anniversary of the Scicntific Activity of Academician, A. V. Palladin), 1936, p. 184; Biull. eksperimental'noi biologii i meditsiny (Bulletin of Experimental Biology and Medicinc), 3(5): 548-550, 1937.

888. —-. "Phosphorus Compounds of the Brain at Different Stages of the Embryonic and Postembryonic Development." (Ukr.: Fosforni spoluki mozku na rizniky stadiiakh embrional'nogo $i$ postembrional'nog rozvitku). Tretii Ukrains'kii z'fiziologiv, biokhimikov i farmakologiv, Dnipropetrovs'k (Third Ukrainian Congress of Plysiologists, Biochemists, and Pharmacologists. Dnepropetrovsk), 1939, pp. 29-30.

889. ERgaev, M. "Physicochemical and Morphological Properties of the Blood of Colts." Svoetskaia veterinariia (Soviet Veterinary Science), (6): —, 1940.

890. Eremin, G. P., and Kasperskaia, Z. A. "Effect of Varied Amount of Protein in the Food on Activity of Bone Phosphatose in Growing Animals." Biokhimiia (Biochemistry), 15(2): 128-133, 1950.

891. Ermakov, M. V. "On the Basis of the Historic Paths of Embryology, the Present Stand of Physiology and Pathology Regarding Development of Hen's Egg" (Suchasnii stan fiziologii $i$ patologii rozvitku kuriachogo iaitsia na osnove istorichnikh shliakhiv embriologii). Medichnii zhurnal, VUAN (Medical Journal, All-Ukrainian Acad. of Sciences), 4(2): 1934.

892. - "Tasks and Principles of Evolutional Physiology" (Ukr.: Pro zavdannia $i$ printsipi evoliutsiinoi fiziologii). Trudy konferentsii po medichnii biologii, Kiiv (Transactions of the Conference on Medical Biology. Kiev), 1937.

893. Ershov, S. I. . "Concepts and Symptoms of the Climacteric." Problemy endokrinologii (Problems of Endocrinology), (4): 337-350, 1936.

894. Esaian, G. S. "Effect of Plant Age on Chlorophyll Content in Green Leaves of Tomato." DAN Armianskoi SSR (Reports of the Acadcmy of Sciences, Armenian SSR), lo(3): $\quad, 1949$.

895. - "Age of Tomato Plants and Vitality of Their Cuttings." Izvestiia $A \mathcal{N}$ Armianskoi SSR, biol. $i$ s-kh. nauki (Bullctin of Biological and Agricultural Scicnces, Acad. of Scienccs Armenian SSR), 1l(1): 37-43, 1949.

896. - "Effect of Young Wilding on Biologically Old Graft." Izvestiia $A \mathcal{N} A r$ mianskoi SSR (Bulletin of Academy of Sciences, Armenian SSR), 11(2): —, 1949.

897. "Aging of Tomato Plants During Vegetative Propagation." Zhurnal obshchei biologii (Journal of General Biology), 11(4): 274-291, 1950 (11 refs.).

898. Efimov, V. V. "Age-Associated Physiology. Vol. I. Physiology of the Organs and Systcms" (Vozrastnaia fiziologiia, t. I, Fiziologiia organov i sistem. Izd-vo Akademii pedagogicheskikh nauk RSFSR, M.-L.). State Publishing House of the Academy of Pedagogical Sciences RSFSR, MoscowLeningrad, 1948, p. 247.

899. Efimov, M. I. "Mechanism of Effect of the Central Nervous System on the Mesenchyma Surrounding It at Establishment of the Axial Skeleton in the Ontogenesis of the Axolotl." DAN SSSR (Reports of the Academy of Sciences USSR), 82(5): 818-820, 1952.

900. Efimova, S. A. "Certain Factors That Determine the Adaptation and Activity of the Ovary at Homplasty in Rats." Ibid., 84(2): 385-388, 1952.

\section{$\mathrm{ZH}$}

901. Zhdanov, V. N. "The Formation of Lobular Division of the Lungs in the Ontogenesis of Mammals and Man in the Light of Historical Development." Ibid., 86(5): 1061-1064, 1952.

902. Zhiv, B. V. "Problem of Chromatin of the Soma of the Adult Human Report IV. Chromatin of Lutein Cells of the Ovary." Biull. eksperimental'noi biologii $i$ meditsiny (Bulletin of Experimental Biology and Medicine), 9(6): 383-385, 1940.

903. Zніркікі, Z. A. "Change of Productivity and Breeding Properties of a Bird in Connection with Its Age." Sbornik: Nauchnaia konferentsiia po voprosam znacheniia vozrasta 
pri razuedenii sel'skokhoziaistvennykh zhivotnykh, M., izd-vo Timiriazevskoi s.-kh. akademii (Collection: Scientific Conference on Problems of Importance of Age in the Breeding of Agricultural Animals. Publishing House of the Timiriazevsk Agricultural Academy, Moscow), 1953, pp. 124-130.

904. Zhizhina, A. F. "Age-Associated Characteristics of the Formation of Conditioned Reactions to Complex Visual Stimuli." Sbornik: Opyt sistematicheshogo eksperimental'nogo issledovaniia ontogeneticheskogo razvitiia korkovoi dinamiki cheloveka. Izd-vo VIEM, M. (Collection: Study of a Systematic Experimental Investigation of the Ontogenetic Development of the Cortical Dynamics of Man. State Publishing House of the All-Union Institute of Experimental Medicine, Moscow), 5: 78-88, 1940.

905. Zhila, E. S. "Data on the Comparative Physiology of Heat Regulation. Heat Regulation in Newborn Animals (Rodents, Carnivores, and Primates)." Fiziologicheskii zhurnal SSSR (Physiological J. of the USSR), (4): 335-342, 1940.

906. Zhitkov, B. M. "Age Variability." Biull. Moskovskogo o-va ispytatelei prirody (Bulletin of the Moscow Association of Naturalists), 46(4): $204-212,1937$.

907. Zhuk, N. M. "Morphology of Extramural Ganglia of the Vegetative Nervous System in Practically Healthy People." Arkhiv patologicheskoi anatomii $i$ patologicheskoi fiziologii (Archives of Pathological Anatomy and Pathological Physiology), 3(1): 58, 1937.

908. Zhukova, G. P. "Problem of the Development of the Cortical End of the Motor Analysor." Arkhiv anatomii, gistologii $i \mathrm{em}$ briologii (Archives of Anatomy, Histology and Embryology), 30(1): 32-38, 1953.

909. Zhukova, T. P. "Alteration of the Cerebral Hemispheres' Filling with Blood in the Postnatal Period of Development." Biull. eksperimental'noi biologii $i$ meditsiny (Bulletin of Experimental Biology and Medicine), 40(6): 11-13, 1955.

910. "Alteration of the Cerebral Hemispheres' Filling with Blood in Different Age Animals During Asphyxia." Ibid., 40(12): 27-31, 1955.

911. Zhuchenko, V. I., and Rendel', N. A. "X-Ray Pictures of Organs of Respiration and Circulation in Old Age." Starost' i trudosposobnost'. Sbornik rabot, Institut vrachebno-trudovoi ekspertizy (NIVTE), L., bibl. (Old Age and Work Capacity. Collection of works of the Institute of Medical-Labor Consultation. "NIVTE" (?Sci. Inst. of Med.- Labor Consultation) Leningrad, bibl., 1936, pp. 261-267.

\section{\%}

912. Zavadovskil, B. M. "Problem of Old Age and Rejuvenation (Steinach and Others)" (Problema starosti $i$ omolozheniia ( $O$ Shteinakhe $i d r$.). Izd-vo Doma pechati, M.). The House of Printing, Moscow, 1922.

913. " "Problem of Old Age and Rejuvenation in the Light of Instruction on Internal Secretion" (Problema starosti $i$ omolozheniia $v$ svete uchenïa o vnutrennei sekretsii. Izd-vo "Krasnaia Nov" ", M.). "Red Virgin Soil"' State Publishing House, Moscow, 1923.

914. "The Achievements of Zootechnical Physiology in the USSR." Problemy zhivotnovodstva (Problems of Animal Husbandry), (1): -, 1934.

915. - "Basic Results and the Tasks of Zootechnical Physiology Next in Line in the USSR." Problemy zootekhnicheskoi i eksperimental'noi endokrinologii (Problems of Zootechnical and Experimental Endocrinology), 2: - 1935.

916. - and Nesmeianova-ZavadovSKAIA, E. G. "The After-Effect of Major Doses of the Blood Serum of Mare Colts on the Sexual System of Chicks." Biull. eksperimental'noi biologii $i$ meditsiny (Bulletin of Experimental Biology and Medicine), 2(6): 419-420, 1938.

917.

"Effect of Androsterone and Testosterone on Growth of Combs in Young Cockerels." Ibid., 3(1): 29-30, 1937.

918. Zavadovski1, M. M. "Is Control of Old Age Possible?" (Vozmozhna li bor'ba so starosti'iu). Gosizdat, M.). State Publishing House, Moscow, 1937.

919. "Dynamics of Development of the Organism" (Dinamika razvitiia organizma, M. Gosizdat). State Publishing House, Moscow, 1931.

920. - "Inconsistent Interaction Between Organs in the Body of a Developing Animal" (Protivorechivoe vzaimodeistvie mezhdu organami $v$ tele razvivaiushchegosia zhivotnogo. Izd-vo MGU, M.) Publishing House of Moscow State University, Moscow, 1941. 
921. "Hormones as Mediators of Morphogenesis." Doklady VII Vsesoiuznogo s'ezda fiziologov, biolihimikov, farmakologov, Medgiz, M. (Reports of the Scventh AllUnion Congress of P'hysiologists, Biochemists, Pharmacologists. Statc Publishing I Iouse of Medical Litcrature, Moscow), 1947, p. 586.

922. Zavarzin, A. A. "Evolutional Dynamics of Tissues." Arkhiv. biologicheskikh nauk, ser. A (Archives of Biological Sciences. Series A), 36(1): 3-64, 1934.

923. - - "Age-Associated Changes of Tissues of the Inner Medium." Ocherk evoliulsionnoi gistologii krovi $i$ soedinitel'noi thani. Izbr. trudy, izd-vo AN SSSR, M.-L. (Outline of Evolutional Histology of Blood and Connective Tissue. Selected works published by Academy of Sciences USSR, Moscow-Leningrad), 4: 562-598, 1953.

924. Zav'IaLov, V. V. "Death and Immortality." Priroda (Nature), (1): columns 5160, 1914.

925. Zazybin, N. I. Embryogenesis of the Peripheral Nervous System (Embriogenez perifericheskoi nerunoi sistemy. Obl. izd-vo Ivanovo). Regional Publishing House, Ivanovo, 1936; Trudy I gistologicheskoi konferentsii, Biomedgiz, M.-L. (Transactions of the First Histological Conference. State Publishing House of Biomedical Literature, Moscow-Leningrad), 1935, pp. 266-268.

926. Zartsevskil, I. G. "An Advanced Experiment in Chick Breeding on Collective Poultry Farms of the Stavropol'sk Territory." Ptilsevodstvo (Poultry Farming), (3): 1951.

927. ZAK, L. S. "Effect of Prenatal Starvation on Growth and Development of the Fetus." Referaty nauch.-issled. rabot Akademii meditsinskikh nauk SSSR, klinicheskie nauki (Reviews of the Scientific Research Works of the Academy of Medical Sciences USSR, Clinical Sciences), (5): 627, 1948.

928. Zaks, M. G., and Likhnitskaia, I. I. "Oxygen Therapy for Hemolyzed Blood of Human Fetus." Biull. eksperimental'noi biologii $i$ meditsiny (Bulletin of Experimental Biology and Medicine), 5(4): 320-324, 1938.

929. - "Changes of the Dissociation Curve of Oxyhemoglobin of Human Fetus in the Embryogenesis." Ibid., 5(j-6): 521$524,1938$.
930. Zaks, M. "Role of Thyroid Gland in the Embryogencsis of Vertcbrates." Doklady VII Vsesoiuznogo s'ezda fiziologov, biokimikov, farmakologov, Medgiz, M. (Reports of the Seventh All-Union Congress of Physiologists, Biochemists, and Pharmacologists, State Publishing House of Medical Litcrature, Moscow), 1947, p. 590.

931. Zaks, M. G., and Zamkova, M. A "Role of the Thyroid in the Embryogenesis of Vertebrates." Fiziologicheskii zhurnal SSSR (Physiological J. of the USSR), 33(4): 449$462,1947$.

932. - "Effect of Thiourea on Gas Metabolism of Salmon and Sturgeon Larvae." DAN SSSR (Reports of the Acad. of Sciences USSR), 84(5): 1101-1103, 1952.

933. Zarits'KII, L. A. "Data on Question of Age-Associated Changes of Organs of the Pharyngeal Ring" (Ukr.: Materiali z pitannia pro vikovi zmini organiv glotkovogo kil'tsia). Medichnii zhurnal, AN URSR (see 696 above), 4(2): 309-325, 1934.

934. - "Problem of Age-Associated Changes of Mucous Glands and Cavernous Tissue of the Mucosa of the Respiratory Area of the Nose." Zhurnal ushnykh, nosovykh $i$ gorlovykh boleznei (Journal of Ear, Nose, and Throat Diseases), 15: 580, 1937.

935. Zakharov, E. I. "Problcm of Changes of the Lymph Glands in Old Age." ( $K$ voprosu ob izmeneniiakh limfaticheskikh zhelez $v$ starcheskom vozraste. Diss. $\mathrm{SPb}) . \quad \Lambda$ dissertation, St. Petersburg, 1891.

936. Zakharova, A. V. "Age Changes of Amino Acid Content in White Mice." Biull. eksperimental'noi biologii i meditsiny (Bulletin of Experimental Biology and Medicinc), 17(1-2): 53-57, 1944.

937. Zakharova, Z. M. "Catalase Content in Blood of Pregnant Women, of the Newborn, and When Gynecological Diseases are Present." Akusherslvo i ginekologiia (Obstetrics and Gynecology), 7(5): 611-625, 1928.

938. ZaKhidov, Kн. Z. "Age Characteristics in Structure of the Superior Cervical Ganglion of Man." Trudy kafedry normal'noi anatomii Tashkentskogo med. in-ta (Transactions of the Chair of Normal Anatomy, Tashkent Medical Institute), 1953, pp. 1618.

939. Zbarovskil, I. B. "Amino-Acid Composition of Organ Proteins in the Human 
Embryo." Sbornik: Voprosy meditsinskoi khimii, izd-vo Akademii meditsinskikh nauk SSSR, M. (Collection: Problems of Medical Chemistry. Publishing House of the Acad. of Medical Sciences USSR, Moscow), 1949, pp. 197-202.

940. Zviagintseva, S. G. "Burn Reaction as a Method for Determining the Reactivity of the Child." Trudy nauchnoi sessii, posviashchennoi 25-letiiu Gos. in-ta fizioterapii, $M$. (Transactions of the Scientific Session Devoted to the 25th Anniversary of the State Institute of Physiotherapy, Moscow), (2): 305-308, 1948. Zdorov'e i zdravookhranenie trudiashchikhsia SSSR (Health and Public Health Care of USSR Workers), Moscow, 1937.

941. Zeitlenok, N. A., and Korshunova, S. S. "Isolation of Influenza Virus from Patients by Direct Innoculation of Mice and Chick Embryos." Arkhiv biologicheskikh nauk (see 922 above), 59(1-2): 38-43, 1940.

942. Zelenskir, A. F. "Problem of Functional Characteristics of the Cardiovascular System in the Newborn." Akusherstoo i ginekologiia, (Obstetrics and Gynecology), (5): 30-35, 1946.

943. - "Data on the State of Circulation in Newborn Children." Trudy IV Vsesoiuznogo s'ezda detskikh vrachei, $M$. (Transactions of the Fourth All-Union Congrcss of Pediatricians, Moscow), 1947, pp. $423-428$.

944. - "Functional Characteristics of the Cardiovascular System in Evaluation of the General Development of Newborn Children." Pediatriia (Pediatrics), (6): 1319, 1951.

945. ZeLinskir, K. "A Century of People." Novyi mir (New World), (5): -, 1931.

946. Zemtsov, O., and Terekhova, A. "Influenza-Antigen Differentiation of People in the Process of the Ontogenesis." Biull. krovianykh grupp Mikrobiologicheskogo in-ta NKP (Bulletin of Blood Groups of the Microbiological Institute, Antiaircraft Artillery Fire-Direction Center), 3(2): 130-145, 1929.

947. Zimogliad, N. A. "Erythropoiesis in Some Animals in Connection with Age." Sbornik trudov Khar'kovskogo veterinarnogo in-ta (Collection of works of the Khar'kov Institutc of Veterinary Medicine), (21): - 1951.

948. Zinger, M. A. "Clinical Impressions of Use of Hypophysis Preparations in Bring- ing Up Premature Children." Voprosy pediatrii $i$ okhrany materinstva $i$ detstra (Problems of Pediatrics and Matcrnal and Child Welfare), 8(2): 90-93, 1936.

949. Zinov'eva, E. G. "Data on the Reserve Alkalinity and Calcium in Experimental Atherosclerosis." Biologicheskii zhurnal (Biological J.), 4: 531, 1935.

950. - "Age Changes in Ccrtain Constants of Rabbits' Blood." Trudy In-ta tsitologii, gistologii $i$ embriologii, izd. AN SSSR, M.-L. (Transactions of the Institute of Cytology, Histology, and Embryology. Published by the Academy of Sciences USSR, Moscow-Leningrad), 1941, p. 49.

951. Zolotarev, S. I. "Ways of Biological Regeneration of the Female Organism." Sbornik trudov po izucheniiu gistolizatov, Kazan' (Collection of Works on the Study of Histolysates, Kazan'), (2): 3-15, 1932.

952. Zol'nikova, N. K. "Change of Dynamics in Processes of Depletion and Restoration in Old Animals." Sbnrnik: Starost', Trudy konferentsii 17-19 dekabria 1938 g., AN USSR, Kiev (Collection: Old Age. Transactions of the Dec. 17-19, 1938 Conference, Acad. of Scicnces UkrSSR, Kiev), 1940, pp. 239-245.

953. Zorina, A. A. "Cytology of Anterior Lobe of Hypophysis in Man at Different Stages of the Embryonic Development." Trudy Izhevskogo med. In-ta (Transactions of the Izhevsk Medical Institute), 6: 119; 1948.

954. Zorkin, F. P. "Blood Change in Horned Cattle Dependent on Age." Laboratornaia praktika (Laboratory Practice), (6-7): -, 1933.

955. Zotov, A. "Determining the Hydrochloric Acid in Stomach of Very Young Infants by Winter's Method"' (Opredelenie solianoi kisloty po sposobu Vintera $v$ zheludke grudnykh detei rannego vozrasta). St. Petersburg, 1893, p. 31 .

956. Zubenko, P. M., and Plakhotishina, E. T. "Activity of Enzymes in Denervated Muscles Stimulated by Electric Current" (Ukr.: Aktivnist' fermentiv $v$ denervovanikh muskuliv, stimul'ovanikh elektrichnim strumom), Ukrains"kii biokhimichnii zhurnal (Ukrainian Biochemical J.), 22(4): 384-392, 1950.

957. Zubenko, P. M., Reva, A. D., and Plakhotishina, N. T. "Activity of Adenosine Triphosphatase and Amylase in Dener- 
vated Muscles." Biohhimiia (Biochemistry), 15(1): 79-85, 1950.

958. Zubenko, P. M. "Biochemistry of Denervated Muscles." Sbornik: Voprosy biokhimii myshts, izd-ro AN USSR, Kî̀u (Problems of Musele Biochemistry, published by the Acad. of Seiences, UkrSSR, Kiev), 1954, pp. 149-167.

959. Zuвkov, A. A. "Theory of the Ontogcnesis of the Rcflex Tract." Sbornik rabot po fiziologii I Moskouskogo meditsinskogo institutn. M. (Symposium of Works on Physiology of the First Moscow Medical Institute, Moscow), 1939, pp. 25-37.

960. Zybelin, S. G. "A Word About Proper Training from Babyhood" (Slovo o pravil'nom vospitanii s mladenchestva. Rech' $\mathrm{v}$ Moskovskom un-tete), a speech at Moseow University, 1775.

961. - "A Word About a Method on How to Prevent the Circumstance, an Important One, of the Slow Population Increase" (Slovo o sposobe, kak predupredit' mozhno nemalovazhnuiu, mezhdu prochim, medlennogo umnozheniia naroda prichinu. Rech' v Moskovskom un-tete), a speech at Moscow University, 1780 .

962. - "Medical Assistance that Serves to Increase the Number of Members in a Society" ( $O$ vrachebrykh posobiiakh, sluzhashchikh $k$ prirashcheniiu mnogoliudstva $v$ obshchestve. Rech'v Moskovskom un-tete), a speech at Moseow Universityf 1797.

963. ZYBinA, E. V. "Cytological Investigation of the Process of Fertilization in the Early Stages of the Development of Rabbit Ovum." DAN SSSR (Reports of the Acad. of Sciences USSR), 88(5): 917-919, 1953.

964. Zykova, Z. I. "Age Dynamies of the Simple and Elective Generalization of Conditioned Reaction to Complex Visual Stimuli." Sbornik: Opyt sistematicheskogo eskperimental'nogo issledovaniin ontogeneticheskogo razvitiia korkovoi dinamiki cheloveka, VIEM, $M$. (Collection: Study of a Systematic Experimental Investigation of the Ontogenetic Development of Human Cortical Dynamics, All-Union Institute of Experimental Medicine, Moscow), 5: 62-77,1940.

\section{I}

965. Ivanov, A. A. "Ocular Refraction of Children in the First Months of Life" (Refraktsiia glaz detei v pervye mesiatsy zhizni. $\mathrm{SPb}$ ). St. Petersburg;,1898.
966. Ivanov, G. G. "Age Changes in Capacity for Restoration of Brain and Other Tissues of the Animal Organism." Biull. eksperimental'noi biologii $i$ meditsiny (Bulletin of Experimental Biology and Mcdicine), 7(2-3): 224-226, 1939.

967. Ivanov, S. L. "Evolution of Matter in the Plant World" (Evoliutsiia veshchestva v rastitel'nom mire. Izdanic AN SSSR, M.-L.), a publication of the Acad. of Sciences USSR, Moseow-Leningrad), 1932.

968. Ivanova, O. A. "Magnitude of Erythrocytes in Horned Cattle." Biologicheskii zhurnal (Biological J.), 2: 387, 1933.

969. Ivanova, T. N. "Age Changes in Amount of Nucleic Acids in Skeletal and Heart Muscles of Rabbit." Uch. zap. Leningradskogo gos. un-teta (Annals of the Leningrad State University), (164): 351$361,1954$.

970. Ivanov-Smolenski1, A. G. "Mechanisms of Making Conditioned Connections in the Cerebral Cortex of the Child." Pediatrii (Pediatries), 13: 233, 1929.

971. "Main Problems of the Pathophysiology of the Higher Nervous Activity of Man" (Osnounye problemy patofiziologii vysshei nervnoi deiatel'nosti cheloveka. Medgiz, M.-L). State Publishing House of Med. Lit., Moscow-Leningrad, 1933 and 1949.

972. —. "Experimental Investigation of the Higher Nervous Activity of the Child." Fiziologicheskii zhurnal SSSR (Physiological J. of the USSR), 19(1): 133-141, 1935.

973. - "A Specific Kind of Disinhibition in the Cerebrum." Ibid., 24(1-2): 162-170, 1938.

974. - "Certain Premises to Experimental Investigation of the Ontogenesis of the Cortical Dynamics of Man." Opyt sistematicheskogo eksperimental'nogo issledovaniia ontogeneticheskogo razvitiia korkovoi dinamiki cheloveka, sb., Medgiz, M. (Collection: Study of a Systematic Experimental Investigation of the Ontogenetic Development of the Cortical Dynamics of Man. State Publ. I Iouse of Med. Lit., Moseow), 5: 5-14, 1940.

975. —. "Study of a Systematic Experimental Investigation of the Ontogenesis of the Cortical Dynamics of Man." Sbornik: Opyt sistematicheskingo eksperimental'nogo issledovaniia ontogeneticheshogo razvitiia horkovoi dinamiki cheloveka. Izd-vo VIEM, M. (Collee- 
tion: Study of a Systematic Experimental Investigation of the Ontogenetic Development of the Cortical Dynamics of Man. Publishing House of the All-Union Institute of Experimental Medicine, Moscow), 5: 268277, 1940.

976. "Study of the Joint Work of the First and Second Signal Systems in the Cerebral Cortex." Trudy Vsesoiuznogo o-va fiziologov, biokhimikov $i$ farmakologov, $A \mathcal{N}$ SSSR, M.-L. (Transactions of the All-Union Assoc. of Physiologists, Biochemists, and Pharmacologists, Academy of Sciences USSR, Moscow-Leningrad), (1): 7-18, 1952.

977. - ' 'Outlines of the Pathophysiology of the Higher Nervous Activity" (Ocherki patofiziologii vysshei nervnoi deiatel'nosti. Medgiz, M.), 1952.

978. IvenskalA, E. A., and Grigor'Eva, K. E. "Cholesterol Content in Newborn and Nursing Children." Zhurnal po izucheniiu rannego detskogo vozrasta (Journal for Study of Early Childhood", 11(4): 201-207, 1931.

979. IverskaiA, E. A., Kravets, E. M., and PETROV, S. "State of Hemato-Encephalitic Barrier in Premature Children." Sbornik trudov, posviashchennykh iubilieu G. Speranskogo, izd-vo AN SSSR, M.-L. (Collection of the Works Devoted to the G. Speranskii Jubilee. State Publ. House of the Acad. of Sciences USSR, Moscow-Leningrad), 1934.

980. Ignatov, I. K. "Feeding of Children of All Ages" (Pitanie detei vsekh vozrastov. Tipografiia "Poligrafkniga", M.-L.). The Polygraph Book Printing House, MoscowLeningrad, 1930.

981. Ignatov, S. I., and Khaskina-MundeR, G. N. "Chlorine and Phosphorus in the Stomach Content of Children." Biull. eksperimental'noi biologii $i$ meditsiny (see above), 2(3): 244-245, 1936.

982. IGNAT'EVA, Z. P. 'Development and Differentiation of Embryonic Parathyroid Glands of Mammals.'" DAN SSSR (Reports of the Academy of Sciences USSR), 61(1): $123,1948$.

983. - "Supplementary Innervation as a Factor Contributing to Restoration of Damaged Muscle in Mammals." D.AN SSSR (Reports of the Academy of Sciences USSR), 100(4): 817-820, 155 (sic; should be 1955?).
984. IERUSAlimksil, N. D. "Problem of the Ontogenesis of Bacteria and WVays to Solve it." Trudy In-ta mikrobiologii $A \mathcal{N}$ SSSR, M.-L. (Transactions of the Institute of Microbiology of the $\Lambda$ cad. of Sciences USSR, Moscow-Leningrad), (1): 5-43, 1951.

985. Izmailova, I. V. "Arteries of the Cerebral Dura Mater of Man." Arkhiv anatomii, gistologii $i$ embriologii (Archives of Anatomy, Histology, and Embryology), 30(3): 41-47, 1953

986. IL'1N, V. P. "Physical Culture Rest of Middle and Old Age" (Fizkul'turnyi otdykh srednego i pozhilogo vozrasta, M.-L.), MoscowLeningrad, 1936.

987. IL'1N, M. D. “Organized Proteins of Muscle Fiber (Myosin and Myostromin) and Their Genetic Relationship" (Organizovannye belki myshechnogo volokna (miozin $i$ miostromin) $i$ ikh geneticheskoe otnoshenie. Diss., SPb), a dissertation. St. Petersburg, 1900.

988. IL'in, N. A. "Problem of Man's Longevity." Moskouskii propagandist (Moscow Propagandist), (11): 44, 1950.

989. "Soviet Science and the Problem of Longevity." 'Molodoi bol'shevik (Young Bolshevik), (7): 60, 1950.

990. Il'iushina, A. I., and Kholopov, V. N. "Evacuator Function of the Stomach in the Newborn in the First Days of Life. Annotation." Pediatriia (Pediatrics), (6): 1959.

991. "Instruction on Inoculating the Newborn Against Tuberculosis by the Calmette Method." Voprosy materinstva i mladenchestva (Problems of Motherhood and Infancy), (3): 55-58, 1937.

992. Iniushkin, N. V. "Data on the Problem of Aging." Kazanskii meditsinskii zhurnal (Kazan Medical J.), (2): 169-176, 1935.

993. IoninA, A. V. "Method of Functional Investigation of Cardiovascular System of Juveniles." Problemy vrachebnogo kontrolia. M. (Problems of Medical Control. Moscow), 1939, pp. 156-164.

994. Iofe, N. S. "Raising Chicks on Collective Poultry Farms in the Summer-Fall Period." Ptitsevodstvo (Poultry Farming), (7): 一, 1951.

995. IpPoLitov. "Effect of Internal Use of Cod Liver Oil on Nitrogen Exchange in 
Children" ( $O$ vliianii vnutrennego upotrebleniia treskovogo zhira na azotistyi obmen u detei. Petcrburg), St. Petersburg, 1889, p. 53.

996. Irzilanskaia, K. N., and Fel'berbaum, R. A. "Somc Data on the ConditionedReflex Activity of Prcmature Children." Fiziologicheskii zhurnal SSSR (Physiological J. of the USSR), 10(6): 668-672, 1954.

997. Israel'iAn, L. “Physiological (Age) Dates of Childhood" (Fiziologicheskie daty detskogo vozrasta. Gruzmedgiz, Tbilisi). Georgian State Publishing House of Medical Litcrature, Tbilisi, 1940, p. 90.

998. Itina, N. A. "Properties of Muscles of Different Organs in the Ontogenesis of Vertebrates." VIII Vsesoiuznyi s'ezd fiziologov, biokimikov, farmakologov. Tezisy dokladov, izd-vo AN SSSR, $M$. (The Eighth AllUnion Congrcss of Physiologists, Biochemists, and Pharmacologists. Thescs of Papers. Publishing House of the Acad. of Sciences USSR, Moscow), 1955, p. 265.

\section{K}

999. KABAK, IA. M., and LiAPIN, N. I. "Quantitative Study of the Thyrotropic Effect of Extracts of the Anterior Lobe of the Hypophysis on Chicks." Biull. eksperimental'noi biologii $i$ meditsiny (Bulletin of Experimental Biology and Medicine), 5(4): 338$342,1933$.

1000. Kabanov, A. N. "Importance of Chronaximeiric Researches to Study of the Nervous Systcm of the Student." Izvestiia Akademii pedagogicheskikh nauk, RSFSR, M. (Bulletin of the Academy of Pedagogical Sciences of the Russian Soviet Federative Socialist Republic, Moscow), (4): 122-128, 1953.

1001. and SHrokova, E. A. "Problem of the Formation of Positive and Ncgative Conditioned Connections in Children 7-8 Years of Agc." Ibidem, (60): 171$192,1954$.

1002. "Formation of Positive and Negative Conditioned Connections on Different Visual Stimuli of Children Age 7-8." Trudy pervoi nauchnoi konferentsii po vozrastnoi morfologii $i$ fiziologii, izd-vo Akademii pedagogicheskikh nauk RSFSR, M. (Tranasctions of the First Scientific Conference on AgeAssociatcd Morphology and Physiology. Publishing House of the Academy of Pedagogical Scicnccs, RSFSR, Moscow), 1954, pp. 4-9.
1003. Kabanov, A. N "Fatigability of Students in the Light of Age-Associated Charactcristics of the Functioning of the Ncrvous System." Ibid., 1954, pp. 197205.

1004. Kavets'Kn, R. E. "The Old Age Problem in the Stalin Pcriod" (Ukr.: Problema starosti v Stalins'ku epokhu). Visti AN URSR (Journal of the Acadcmy of Sciences, UkrSSR), 8: 60-67, 1939.

1005. - "Attempt at Restoration of Functions of the Physiological System of Connectivc Tissue in the Aged Organism" (Ukr.: Sproba vidnorlennia funktsii fiziologichnoi sistemi spoluchnoi tkanini starogo organizmu). Medichnii zhurnal AN URSR (Medical J. of the Academy of Sciences UkrSSR), 9(3): 739744, 1939.

1006. Kavetskil. "Old Age and Cancer." Sbornik: Starost'. Trudy konferentsii 17-19 dekabria $1938 \mathrm{~g}$., izd-vo AN USSR, Kiev (Collection: Old Age. Transactions of the Dec. 17-19, 1938 Conference. State Publishing House of the Acad. of Sciences, UkrSSR, Kiev), 1940, pp. 191-197.

1007. Kavetsk11, R. "On the Road to Longevity" ( $N a$ shliaku do dovgolittia. Lek. tsiia, Kiiv), a lecture, Kiev, 1947, p. 36.

1008. Kaganovskaia, S. N., and Kan, I. L. "Age Changes in the Respiratory Exchange of the Peripheral Nerve of Rat." Biokhimiia (Biochemistry), 2(2): 494, 1937.

1009. KAD'1AN, A. A. "Population of the St. Petersburg City Poorhouses" (Naselenie S.-Peterburgskikh gorodskikh bogadelen. $\mathrm{SPb}$ ), St. Petersburg, 1890; v.7. Charcot's Complete Works Devoted to Old Age (VII tom. Euvres (sic; should be Oeuvres) completes de charcot posviashchen bolezniam starosti. Paris), Paris, 1890.

1010. Kazakova, E. M. "Biochemical and Morphological Indices of Blood of Calves Raised in Unheated Stalls." Sovetskaia zootekhniia (Soviet Zootechnics), (10): . 1952.

1011. "Problem of the Morphological and Biochemical Composition of Blood of Calves Raised in Unheated Lodgings." Fiziologicheskii zhurnal SSSR (Physiological J. of the USSR), 41: 410-417, 1955.

1012. Kazakova, L. P. "Effect of Ultraviolet Irradiation on Blood Serum Proteins 
of Different Age Peoplc." Sbornik nauchnykh trudov Meditsinskogo in-ta za gody Velikoi Otechestvennoi voiny (Krymskii med. in-t), Simferopol' (Collection of Scientific Works of the Medical Institute for the Years of World War II (Crimean Medical Institute), Simferopol'), 11: 122-125, 1945.

1013. Kazanli. "Problem of the Joint Changes of Old Age." ( $K$ voprosu o starcheskikh izmeneniiakh sustarov. $\mathrm{SPb}$ ), St. Petersburg, 1889.

1014. Kazantseva, M. N., Volkova, L. O., and Pletneva, I. A. "Dynamics of Prothrombin in Blood of the Newborn at Early Start of Feeding." Akusherstvo i ginekologiia (Obstetrics and Gynecology), (5): 34-37, 1946.

1015. Kazarian, V. O. "Reproductive Development and Aging of Annual Plants." $D A \mathcal{N}$ Armianskoi SSR (Reports of the Academy of Sciences, Armenian SSR), 7(3): 1947.

1016. -Dynamics of the Transfer of Plastic Substances from Leaves to Axillar Shoots in Different Phases of the Ontogenetic Development of Perilla." DAN Armianski SSR (Reports of the Armenian SSR), 9(5): 219-223, 1948.

1017. "The Stage Factor of Development and Aging of Annual Plants" (Stadiinost' razvitiia $i$ stareniia odnoletnykh rastenii. Izd-vo AN Armianskoi SSR, Erevan). Publishing House of the Academy of Sciences Armenian SSR, Erevan, 1952, p. 348.

1018. Kaz'IAN. 'Population of the St. Petersburg City Almshouses. Data on Study of Old Age Produced Under the Guidance of S. P. Botkin in 1890" (Naselenie SanktPeterburgskikh gorodskikh bogadelen. Materialy po izucheniiu starosti, proizvedennye pod rukovodstvom S. P. Botkina v 1890 godu. Diss.), a dissertation, 1890.

1019. Kakushikina, E. A., and Arkhipova, A. D. "Content of Acetylcholine-Like Substances in the Central Nervous System in the Ontogenesis." Biull. eksperimental'noi biologii $i$ meditsiny (Bulletin of Experimental Biology and Medicine), 10(6): 460-462, 1940.

1020. - "Change in Activity of Cholinesterase in the Ontogenesis." Ibid., 11(6): 533-535, 1941.

1021. "Aging of the Organism and Chemical Factors of Nervous Excitation."
DAN SSSR, novaia ser. (Reports of the Academy of Sciences USSR, new serics), 53(5): 479-481, 1946.

1022. KaKusirina, E. A. "Development of Nervous Activity and Chemical Factors of Nervous Excitation in Chick Embryos." Biull. eksperimental'noi biologii $i$ meditsiny (Bull. of Exper. Biology and Med.), 22: 21, 1946.

1023 "Development of Nervous Activity and Chemical Factors of Nervous Excitation in Cats." Ibid., 22: 65: 1946.

1024. Kalabukiov, N. I. "Life Span and Food Requirement for Bees in Their Varied Density." Trudy po dinamike razvitiia, tipografiia "Poligrafkniga," M. (Works on the Dynamics of Development, Polygraph Book Printing House, Moscow), 1935, p. 397.

1025. — and Rodronov, V. "Blood Changes in Animals According to Age. (Data on the Biology of Aging). Blood Changes in Rodents and Birds in the Period of Growth." Uch. zap. MGU (Annals of Moscow State University), (4): 22-36, 1935.

1026. Kalabukhnov, N. I., and Epshtein, A. S. "Blood Changes of Animals According to Age. (Data on the Biology of Aging)." Trudy eksperimental'noi laboratorii $i$ kurortno-sanatornogo Lechsanupra Kremlia, Biomedgiz, M.-L. (Transactions of the Experimental Laboratory and Health Resort of the Kremlin Health Therapy Administration. Publishing House of Biomedical Literature, Moscow-Leningrad), 1936, pp. 29-64.

1027. Kalashnikova, A. P. "Effect of Yolk Sac of Chick on Growth and Development of Chick in Postembryonal Period." Biull. eksperimental'noi biologii $i$ meditsiny (Bulletin of Experimental Biology and Medicine), 38(5): 69-75, 1954.

1028. Kalenichenko, I. O. "Effect of Ages of Human Life on Mental and Moral Capacities" (O vilianii vozrastov chelovecheskoi zhizni na umstvennye $i$ nravstuennye sposobnosti. Aktovaia rech'v Khar'kovskom un-tete (30 avgusta 1839 g.), Khar'kov). Public Hall Speech at Khar'kov University Aug. 30, 1839. Khar'kov.

1029. Kalinina, E. I. "Synapses of Spinal Cord of Rabbit Embryos in Period of Development of Motor Reflex Reaction." $D A \mathcal{N}$ SSSR (Reports of the Academy of Sciences USSR), 100(5): 1029-1031, 1954. 
1030. Kallinikova, M. ì. "Blood Magnesium in Child Psychoneurotics." Russhii fiziologicheskii zhurnal (Russian Physiological J.), 13(4-5): 602-605, 1930.

1031. "Blood Potassium and Calcium in Child Psychoneurotics." Ibid., 13(4-5): $606,1930$.

1032. Minker-Bogdanova, E. T., Obraztsov, G. D., and Povorinskaia, S. A. "Nitrogen Exchange in Children 7-8 Years Old in Connection with Nutrition." Vozrastnaia biokhimiia detei $i$ podrostkov. Sb. 1, Institut OZDiP, L. (Collection I. AgeAssociated Biochemistry of Children and Adolescents. Institute of the Div. of Health Care of Children and Adolescents, Leningrad), 1935, pp. 27-45.

1033. - - LiPMan, R. G., MinkeRBogdanova, E. T., Obraztsov, G. D., Petrun'kina, A. Mi, and Povorinskaia, S. A. "Problen of Forms of Urine Nitrogen Removal in Children 7-8 Years Old." Ibid., 114-128, 1935.

1034. - Minker-Bogdanova, E. T., Obraztsvo, G. D., and Povorinskaia, S. A. "Standards of Blood Chemical Affinity in Children and Juveniles 8-16 Years of Age." Ibid., 1935, pp. 147-165.

1035. KAL'FA, S. IU. "Study of Dermographism in Children by Dermographist Kuznetsov." Sovetskaia pedialriia (Soviet Pediatrics), (7): 91-97, 1935.

1036. Kamenetskala, R. A. "Reaction of the Organism to Vaccine Introduction in Early and Preschool Age." Trudy Instituta tuberkuleza Akademii medusinskikh nauk SSSR (Transactions of the Tuberculosis Institute of the Academy of Medical Sciences USSR), 4: $60-65,1948$.

1037. Kamenskaia, N. L. "Morphology of the Endothelium of the Aorta of Children." $D A \mathcal{N}$ SSSR (Reports of the Academy of Sciences USSR), 93(3): 535-538, 1953. Referativnyi zhurnal Biologii (Abstract J. of Biology), (3): abstract 6808, 1955.

1038. KaMenskil, 1. P. "Brief Outline of Observations and Experiments on Milk Damage and Use of Cereal and Meat Food for Children." (Kratkoe nachertanie nabliudenii $i$ opytov o vrednosti molochnoi $i$ o pol'ze khlebnoi $i$ miasnoi pishchi dlia detei. SPb), St. Petersburg, 1805.

1039. "The Physical Training of Children and Its Effect on Their Mental and
Moral State" (O fizicheskom vospitanii detei io vliianii ego na umstuennoe i nruvstiennoe sostoianie ikh. Aklovaia rech'. Khar'kov), 'Mublic Mall Address, Khar'kov, 1812.

1040. Kaminskaia, V. T. "The Morphology of Nerve Receptors of Vessels of the Umbilical Cord and of the Skin of the Umbilical Ring." Biull. eksperimental'noi biologii $i$ meditsiny (sec above), (7): 73-77, 1954.

1041. Kaminskaia-Pavlova, Z. A. "Senility Changes of Posterior Pigmentary Layer of the Iris." Arkhiv oftal'mologii (Archives of Ophthalmology), 3(3): 476-487, 1927.

1042. Kaminskil, L. S. "Mortality and Familial Status of the Population." Gigiena i epidemiologiia (Hygiene and Epidemiology), (8-9): 39-44, 1931.

1043. Kaminskin, S. L. "Functional Mobility of the Cortical Processes in the Phylogenesis." Problemy sovetshoi fiziologii, biokhimii, farmakologii, MI. (Problems of Soviet Physiology, Biochemistry, and Pharmacology, Moscow), 1949, pp. 177-180.

1044. Kan, I. L., and Lavrova, N. P. "Problem of the Respiratory Metabolism of Larvae and Pupae of the Worker Bee." Biull. eksperimental'noi biologii $i$ meditsiny (see above), 1(1): 53-54, 1936.

1045. KanaEv, 1. I. "Problem of Old Age." Priroda (Nature), (2): 69-70, 1946.

1046. - "Study of the Nerve Processes in the Motor Reactions of the Hands of Children." Fiziologicheskii zhurnal SSSR (Physiological J. of USSR), 40(1): 9-17, 1954.

1047. Kanarevskaia, A. A. "The Nerve Factor and Anaphylaxis of the Newborn." Biull. eksperimental'noi biologii $i$ meditsiny (see above), 22(8): 23-25, 1946.

1048. Kanasienok, P. S. "Content of Phosphorus Compounds in Gastrocnemius Muscles of Rabbit at Combined Traumas of the Nervous System." Biull. eksperimental'noi biologii $i$ medilsiny (see above), 37(4): 40-42, 1954.

1049. KANkRov, A. L. "Intracapsular Extracts of Senile Cataracts." Trudy Uzbekskogo gos. un-teta (Transactions of the Uzbek State University), 2: 3-14, 1935.

1050. Kaplan, IA. D., and Shliafirner, N. M. "Glutathione Content in Blood and 
Organs of Animals (Rabbits in the Period of Growth). Sovetskaia pediatriia (Soviet Pediatrics), (5): 23-29, 1936.

1051. Kaplanskil, S. IA. "Changes in the Chemical Composition of the Organism in the Process of Growth." Sbornik: Rost zhivotnykh, pod red. S. Ia. Kaplanskogo $i d r$., Biomedgiz, M.-L. (Collection: Growth of Animals, edited by S. Ia. Kaplanskii and others. State Publishing House of Biomedical Literature, Moscow-Leningrad), 1935, pp. 281-325.

1052. Kaplun, E. G. "Problem of Functional Characteristics of the Nervous System of Boys of Junior School Age." Izvestiia Akademii pedagogicheskikh nauk RSFSR, M. (Bulletin of the Academy of Pedagogical Sciences, RSFSR, Moscow), (47): 120-123, 1953.

1053. Kapustina, E. V. "Development of the Pia Mater Venous System in the First Two Weeks of Extra-Uterine Life." Voprosy morfologii, sb. 2, izd-vo Akademii meditsinskikh nauk SSR, M. (Problems of Morphology. Collection published by the Acad. of Medical Sciences USSR, Moscow), 2: 227236, 1953.

1054. Kapusto, M. L., and Shelagurova, A. A. "Standard Specific Allergy in Experiment Conditions and in Scarlatinal Diseases." Zhurnal mikrobiologii, epidemiologii $i$ immunobiologii (J. of Microbiology, Epidemiology, and Immunobiology), 22(1): 61-67, 1939.

1055. Karasev, P. A. "Biochemical Blood Indices of Healthy Horses of Various Ages." Trudy Alma-Atinskogo veterinarno-zoologicheskogo in-ta (Transactions of the Alma-Ata Veterinary-Zoological Institute), 5: 170-200, 1948 (78 refs.).

1056. KARASIK, V. M. "The Resistance of White Mice to Anoxia of Toxic Origin in Various Periods of Growth (in Experiments of V. S. Vail')." Biull. eksperimental'noi biologii $i$ meditsiny (see above), 10(3): 206$208,1940$.

1057. - "Problems of Age Pharmacology." Sbornik trudot (Leningradskii gos. pediatrichesh $z i$ med. in-l), L. (Collection of Works. Leningrad State Institute of Pediatric Medicine, Leningrad), 1947, pp. 166173 (173 refs.).

1058. "Pharmacological Analysis of Rigor Mortis in Various Stages of the
Ontogenesis." 4-ia godichnaia nauchnaia sessiia Leningradskogo gosudarstvennogo pediatricheskogo meditsinskogo instituta. Tezisy dokladov, L. (Fourth Annual Session of the Leningrad State Institute of Pediatric Medicine. Theses of Reports. Leningrad), 1953, pp. 33-34.

1059. Karev, V. A. "The Anaphylaxis Reaction from Desensitization as a Method for Detecting Age Characteristics of Animal Tissues. Preliminary Report. Biull. eksperimental'noi biologii i meditsiny (see above), (8): 56-60, 1954.

1060. Karelina, V. I. "Data on Age Characteristics of the Cells." DAN SSSR (Reports of the Academy of Sciences USSR), 61(2): 407-410, 1948.

1061. - "Age Changes in Protozoa." Ibid., 61(3): 589-591, 1948.

1062. - "Behavior of Paramecium caudatum to Poisons in the Various Stages of Its Ontogeny." Ibid., novaia ser. (new series), 61(1): 165-168, 1948.

1063. Karlova, A. N., and Khalezova, E. I. "Carbonic Anhydrase in Children of All Ages. Annotation." Pediatriia (Pediatrics), (1): 69, 1949 .

1064. Karnitskil, A. S. "Blood of Healthy Children" (O krovi zdorovykh detei. Diss.), a dissertation, 1901.

1065. - "Uber das Blut gesunder Kinder" (Blood of Healthy Children). Archiv f. Kinderheilk., 36: 42, 1903.

1066. - "Physiological-Chemical Observations on Blood of the Fetus at Moment of Birth." Izvestiia Voenno-meditsinskoi akademii (Bulletin of Academy of Military Medicine), 7(1,2,3): -, 1903.

1067. "Maturation of Blood of Growing Children." Zhurnal teoreticheskoi i prakticheskoi meditsiny ( $\mathrm{J}$. of Theoretical and Practical Medicine), (5-6): 589-616, 1927.

1068. - "Child Development and Age Characteristics of It" (Razvitie rebenka i osobennosti ego vozrastov. Ch. 1, Baku), Baku, Part 1, 1927.

1069. Kartasievski, E. A., and Veselkin, N. V. "Glycogen Distribution in Tissues of Chick Embryo in Early Stages of Development." Russkii vrach (Russian Doctor), 13: 201-238, 1914. 
1070. KarcinKinn, S. I. "Age Indications and Counterindications to Sending Patients to the Kislovodsk Health Resort for Treatment." Trudy Voenno-meditsinskoi akademii $R K K A, \mathrm{~L}$. (Transactions of the Academy of Military Medicine of the Workers' and Peasants' Red Army, Leningrad), 4: 199-210, 1935.

1071. Kariagina, M. K. "Comparative Biochemical Characteristics of Brain Proteins." Biull. eksperimental'noi biologii $i$ meditsiny (see above), 1: 116, 1936.

1072. KaSatK1N, N. I. "Development of Auditory and Visual Conditioned Reflexes and Their Differentiation in Infants." Sovetskiaia pediatriia. Biull. VIEM (Soviet Pediatrics. Bulletin of the All-Union Institute of Experimental Medicine), (3-4): 54$64,1936$.

1073. "Investigation of Receptor Functions of Infants by the Conditioned Reflex Method. Novosti meditsiny (Medical News), v. 6, Voprosy pediatrii. M., Akademiia meditsinskikh nauk SSSR. Problems of Pediatrics. Moscow., Academy of Medical Sciences USSR), 1947, pp. 19-20.

1074. - " "Early Conditioned Reflexes in the Ontogenesis of Man" (Rannie uslornye refleksy $v$ ontogeneze cheloveka. M., Adademiia meditsinskikh nauk SSSR). Moscow, Acad. of Medical Sciences USSR, 1948, p. 192.

1075. "Chronaxy of Cutaneous Receptor of Infants and Electro-Cutaneous Conditioned Reflexes." Referaty nauch.-issled. rabot Akademii meditsinskikh nauk SSSR, klinicheskie nauki, M. (Abstracts of the Scientific Research Works of the Academy of Medical Sciences USSR, Clinical Medicine, Moscow), (5): 48, 1948.

1076. "Outline of Development of Higher Nervous Activity in Child of Early Age" (Ocherk razvitiia vysshei nervnoi deiatel'nosti u rebenka rannego vozrasta. Medgiz, M.), State Publishing House of Medical Lit., Moscow), 1951.

1077. "The Early Conditioned Reflexes of a Child." Sbornik: 50 let ucheniia akademika I. P. Pavlova ob uslovnykh refleksakh, izd-vo AN SSSR, M.-L. (Collection: The Fifty Years of Instruction of Academician I. P. Pavlov on Conditioned Reflexes, published by the Acad. of Sciences USSR, Moscow-Leningrad), 1952, pp. 209-218.

1078. - "Early Conditioned Reflexes of the Child." Zhurnal vysshei nervnoi deiatel'nosti (J. of Higher Nervous Activity), 2(4): 572-581, 1952.

1079. "The Conditioned Reflexes and Chronaxies of the Skin of Children." Fiziologicheskii zhurnal SSSR (Physiological J. of the USSR), 38(4): 434-443, 1952.

1080. - Mirzoiants, N. S., and Khoknitava, A. P. "Rough Conditioned Reflexes in Children the First Year of Life." Zhurnal vysshei nervnoi deiatel'nosti (Journal of Iigher Nervous Activity), 3(2): 192-202, 1953.

1081. Kasatkin, N. I. "Functional Characteristics of the Sound Analysor of the Child." VIII Vsesoiuznyi s'ezd fiziologov, biohhimikov, farmakologov. Tezisy dokladov, izd-vo AN SSSR, M. (Eighth All-Union Congress of Physiologists, Biochemists, and Pharmacologists. Theses of Papers. Published by the Acad. of Sciences USSR, Moscow), 1955, p. 285 .

1082. Kas'1ANENKo, V. G. "Analysis of the Synthesis of Certain Intra-Articular Correlations, for Example the Joints of Artiodactyla Extremities." DAN SSSR (Reports of the Acad. of Sciences USSR), 32(5): 821$824,1952$.

1083. Kats, P. G. "Characteristics of Absorptive Capacity of Reticulo-Endothelial System of Animals in Various Age Periods" (Osobennosti poglotitel'noi sposobnosti retikuloendotelial'noi sistemy $u$ zhivotnykh $v$ razlichnykh vozrastnykh periodakh., L.). Leningrad, 1941.

1084. - "Age-Associated Reactivity of the Reticulo-Endothelial System and Its Importance to the Clinic." Voprosy pediatrii $v$ dni blokady Leningrada. Sb. 2, L., Pediatricheskii med. in-t (Problems of Pediatrics in the Days of the Leningrad Blockage. Leningrad, Institute of Pediatric Medicine), 2: 267-286, 1946.

1085. Kashinenko, N. F. "Death and Longevity from the Biological Point of View" (Smert' $i$ dolgoletie s biologicheskoi tochki zreniia. Izd-vo "Nauka" M.), published by "Science", Moscow, 1915.

1086. KeVork'IAN, A. A. "Problem of the Neurological Characteristics of Senility." Materialy kliniki po vozrastnoi patofiziologii pod red. I. P. Razenkova i I. G. Gel'mana. VIEM, M. (Data of the Clinic on Age Pathophysiology, edited by I. P. Razenkov and I. G. Gel'man. All-Union Institute of Experimental Medicine, Moscow), 1937, pp. 179186. 
1087.

"Certain Anatomical-Physiological Characteristics of the Nervous System in the Juvenile-Adolescent Age." Fiziologicheskie osobennosti, klinika zabolevanii $i$ gigiena truda rabochikh podrostkov, $M$. (Physiological Characteristics, Clinic of Diseases and Occupational Hygiene of Juvenilc Workers. Moscow), 1952, pp. 19-21.

1088. KeDrovsk11, B. V. "Propcrties of the Colloid Composition of Young Cells." Uspekhi souremennoi biologii (Advances in Contemporary Biology), 12(3): 468-487, 1940.

1089 "Nucleic Acids of Cell Protoplasm. Their Importance to Growth and Development and Their Role in the Healing of Wounds." Ibid., 15(3): 295-309, 1942.

1090. Keller, B. A. "Regular Changes in Individual Development of Plants Under Effect of Conditions of the Medium." Referaty rabot uchrezhdenii otdeleniia biologicheskikh nauk AN SSSR za 1944 g., izd-vo AN SSSR (Abstracts of Works of the Institutes of the Department of Biological Sciences, Academy of Sciences USSR, for 1944, published by the Acad. of Sciences USSR), 1945.

1091. Kershtens, I. "Admonitions and Precepts for Those Living in Rural Areas Who Serve to Increase the Number of Human Malcontents in Russia" (Nastavleniza $i$ pravila vrachebnye dlia derevenskikh zhilelei, sluzhashchie $k$ umnozheniiu nedovol'nogo chisla liudei v Rossii. Rech'v Moskovskom un-tete, M.). Speech at Moscow University, Moscow, 1769.

1092. KizeL', A. A. "Role of Plastin of Myxomycetes and Its Albuminoid Character." Zhurnal eksperimental'noi biologii $i$ meditsiny (J. of Experimental Biology and Medicine), 5(15): 279, 1927.

1093. —_. "Mitogenetic Irradiation of the Blood in Various Age Periods." Materialy kliniki po vozrastnoi patofiziologii, pod red. I. P. Razenkova i I. G. Gel'man. VIEM, M. (Data of the Clinic on Age Pathophysiology, edited by I. P. Razenkov and I. G. Gel'man. All-Union Inst. of Exper. Med., Moscow), 1937, pp. 117-133.

1094. Kizel' A. R. "Changes of AminoAcid Composition of Watermelon Leaves." Uch. zap. MGU (Annals of Moscow State Univ.), 4: 194, 1935.

1095. - "Specificity and Variability of Protein Construction in the Organism."
Uspekhi souremennoi biologii (Advances in Contemporary Biology), 8(2): 151, 1938.

1096. "Chemistry of Protoplasm" (Khimiza protoplazmy. Izd-vo AN SSSR). State Publishing Housc of the Acad. of Sciences USSR, 1940.

1097. Kikavskil, L. D. "A Zootechnical and Biological Analysis of Agc and Seasonal Changes in the Productivity of Hens." Trudy nauch. -issled. in-ta ptitsevodstva (Transactions of the Scientific Research Institute of Poultry Breeding), 22: —, 1952.

1098. Kissleva, Z. N. "Effect of Asphyxia on the Brain of Embryos, the Newborn, and Adults." Referaty nauch.-issled. rabot Akademii meditsinskikh nauk SSSR, klinicheskie nauki, $M$. (Abstracts of the Scientific Research Works of the Academy of Medical Sciences USSR, Clinical Sciences, Moscow), (5): 36-38, 1948.

1099. - "Study of the Remote Rcsults of Asphyxia. Report I. Features of Behavior and Reactions of the Central Nervous System of Animals That Have Undergone Asphyxia in the Embryonic Period." Biull. eksperimental'noi biologii $i$ meditsiny (Bulletin of Experimental Biology and Medicine), 40(12): 32-34, 1955.

1100. Kisin, S. V., and Lifshits, I. G. "Problem of the Erythrocyte Precipitation Reaction in Mother and Newborn." Ginekologiia $i$ akusherstio (Gynecology and Obstetrics), (5-6): 717-723, 1929.

1101. Kislitsyna, G. S., and Kurenov, I. I. "Age Dynamics of Blood Circulation in Dogs." DAN SSSR, Novaia ser. (Reports of the Academy of Sciences USSR, New Series), 62(4): 569-572, 1948.

1102. Kitaigorodskaia, O., and Badanov, V. "Observations on Erythrocyte Precipitation Reactions (E.S.R.) in Human Infants." Zhurnal po izucheniiu rannego detskogo vozrasta (J. for Study of Early Childhood), 4(4): 297-304, 1926.

1103. Kitaigorodskaia, O. D. "The Pancreas in the Human Infant" (Podzheludochnaia zheleza u grudnogo rebenka. Predislovie prof. G. N. Speranskogo, Gosmedizdat, M.-L.), Preface by Prof. G. N. Speranskii. State Publishing House of Medical Lit., MoscowLeningrad, 1931.

1104. - "Dynamics of Secretory Function of the Stomach in Children." 
Sbornik pod red. I. R. Razenkova: $\hat{\kappa}$ mekhanizmu reguliatsii deiatel'nosti pishchevaritel'njkh zhelez, VIE.M, M. (Symposium edited by I. R. Razenkov: Mcchanism of Regulatory Activity of the Digestive Glands. All-Union Institute of Experimental Medicine, Moscow), 1937, p. 193.

\section{5.}

"Dynamics of Function of the Stomach in Childhood. Report 2. Secretion of Chlorine." Novye dannye $k$ mekhanizmu reguliatsii deiatel'nosti pishchevaritel'nykh zhelez. M.-I. (New Data on the Mechanism of Regulatory Activity of the Digestive Glands. Moscow-Leningrad), 1939, pp. 177-193.

1106. KlaAs, IU. A. "Excitability of the Nerve-Muscle System in the Process of Development (Ontogenesis)." Tezisy dokladov 1 soveshchaniia biogruppy AN SSSR po fiziologicheskim problemam (Theses of Papers of the Meeting of the Bio-Group of the Academy of Sciences USSR on Physiological Problems), 53, 1937.

1107. Kladienko, D. P. "Age Changes in Water, Fat, and Protein Content in Tissues of Fish (Leuciscus idus)" (Ukr.: Vikovi zmini kil'kosti vodi, zhiru $i$ bilka $v$ tkaninakh rib (Leuciscus idus)). Medichnii zhurnal (Medical J.), 9(4): 1411-1426, 1939.

1108. Klebanova, E. A., and Leibson, A. G. "Development of Motor Function of Cerebral Cortex. Electrical Excitability of Motor Zone of Newborn Pups and Kittens." Fiziologicheskii zhurnal SSSR (Physiological J. of the USSR), 25(4): $418-425,1938$.

1109. Klebanova, E. A. "Age Changes in Oxygen Requirement of Liver Tissue" Ibid., 25(4): 426-429, 1938.

1110. Klebanova, E., and Kaveshnikova, A. "Age Change in Vascularization of the Kidney." Arkhiv anatomii, gistologii $i$ embriologii, ser. $A, k n .4$ (Archives of Anatomy, Histology, and Embryology, series A. book 4) 24(2): 209-224, 1940.

1111. Klebanova, E. A. "Changes in Bone System in Growing Animals Under Effect of Physical Stress." Sbornik: Trudy pervoi nauchnoi konferentsii po vozrastnoi morfologii $i$ fiziologii. Izd-vo Akademii pedagogich. nauk RSFSR, M. (Collection: Transactions of the First Scientific Conference on Age Morphology and Physiology. Publishing House of the Acad. of Pedagogical Sciences, RSFSER, Moscow), 1954, pp. 185-190.
1112. Kilvanskaia-Krol', E. S. “Diagnosis of Acute Infectious llepatitis in Childrcn." Sovetskaia meditsina (Sovict Mcdicine), (10-11): 4-5, 1945.

1113. "Age-Associated Reactivity in the Physiology and Pathology of Early Childhood." Ibidem, (10): 17-19, 1946.

1114. Klimenko, I. V. "Old-Age Mortality in the Population of St. Petersburg" (Smertnost' naseleniia starcheskogo vozrasta v Peterburge. Doktorskaia diss., SPb), a doctoratc dissertation. St. Petersburg, 1906.

1115. Klimova, M. S., Bereznitskala, S. A., Aizikovich, R. S., and Andrushaliuk, A. A. "Effect of Routine and Nutrition on State of Higher Nervous Activity of Children of Crib Age." Zhurnal vysshei nervnoi deiatel'nosti (J. of Higher Nervous Activity), 5(2): 219-226, 1955.

1116. Klioner, I. L. "Senile Changes in the Bone-Cartilage System of the Joints." $D A \mathcal{N}$ SSSR (Reports of the Acad. of Sciences, USSR), 24(1): 804-806, 1939.

1117. KLosovskil, B. N., and Turetskil, M. IA. "Development of Vascular Plexi in Brain of Man." Trudy Tsentral'nogo gos. nauchn. in-ta $O M \mathcal{N} N K Z, S b .1$ trudov, posviashchennykh 35-letiiu nauchnoi deiatel'-nosti $G . \mathcal{N}$. Speranskogo, M. L. (Transactions of the Central State Scientific Institute of Maternal and Child Welfare, the People's Commissariat of Agriculture. Collection of Works Dedicated to the 35th Anniversary of the Scientific Activity of G. N. Speranskii, Moscow-Leningrad), 1: 13-32, 1934.

1118. Klosovskir, B. N. and Kasatkin, I. N. "Development of Vestibular Nystagmus in Man and Animals." Arkhiv biologicheskikh nauk (see 922, above), 38(3): 711$718,1935$.

1119. KLosovskir, B. N. "Basic Data on Brain Dcvelopment of the Child" (Osnovnye dannye o razvitii mozga rebenka. Pod red. N. M. Shchelkanova, Medgiz, M.). N. M. Shchelkanov, editor, State Publ. House of Med. Lit., Moscow, 1949.

1120. - and Kosmarskaia, E. N. "Behavior of Animals After Complete Exclusion of Visual, Auditory, Olfactory, and Vestibular Receptors at an Early Age." Biull. eksperimental'noi biologii i meditsiny (Bulletin of Experimental Biol. and Med.), 40(9): 3-5, 1955. 
1121. Klusuina, T. I. "Evacuator Function of the Stomach of White Rats in the Age Profile." Ibid., (2): 112-114, 1948.

1122. "Effect of Certain Stimuli on the Evacuator Function of the GastroIntestinal Tract in Different Agc Groups of White Rats in X-ray Picture." Ibid., (8): 119-124, 1949.

1123. Kliachina, K. N. "Alkaline Phosphatase Blood Content Normal to Children." Voprosy pitaniia (Problems in Nutrition), (6): 36, 1954.

1124. Kobakova, E. M. "Changc of Motor Function of Intestines in the Ontogenesis." Referaty nauch.-issled. rabol Akademii meditsinskikh nauk SSSR, mediko-biologicheskie nauki (Abstracts of the Scientific-Research Work of the Acad. of Medical Sciences USSR, Medico-Biological Sciences), 1947, p. 118 .

1125. - "Effect of Electric Stimulation of the Cerebellum on the Motor Function of the Small Intestine in the Ontogenesis." Fiziologicheskii zhurnal (Physiological J.) 38(1): 53-59, 1952.

1126. Kobiashvili, N. N. "Problem of Normal Blood Picture of the Young (Calves)." Sbornik trudov Gos. zootechnicheskogo veterinarnogo in-ta (Collection of the Transactions of the State Zootechnical Veterinary Institute), (1): 201-207, 1939.

1127. Kovalenko, Z. P. "Capillaries and Capillary Circulation in the Skin of Healthy Children at an Early Age" (Kapilliary $i$ kapilliarnoe krovoobrashchienie v kozhe u zdorovykh detei rannego vozrasta. Diss., a dissertation. Omsk, 1945.

1128. Koval'kova, Z. P. "Posture of Children of School Age and Its Correction with Therapeutic Physical Culture at Deviation." Pediatriia (Pediatrics), (5): 25-31, 1953.

1129. Koval'skil. "The Liver of Children" (O pecheni $u$ detei. Diss.), a dissertation, 1900.

1130. Koval'skir, V. V. "Seasonal Variability of the Tissue Composition of Vertebrates" (Ukr.: Sezonna minlivist' skladu tkanin khrebetnikh). Biokhimichnii zhurnal (Biochemical J.), 12(2): 337-368, 1938.

1131. Koveshnikova, A. K. "Age-Associated Morphology of the Human Cerebellum." Izvestiia Akademii pedagogicheskikh nauk RSFSR (Bulletin of the Academy of Pedagogical Sciences, RSFSR), (35): 159$168,1951$.

1132. Kovsinarova, T. V. "The Experiment of Altering thc Simplest Stereotype of Conditioned Connections in Children of Various Age Groups." Sbornik: Opyt sistematicheskogo eksperimental'nogo issledovaniia ontogeneticheskogo razviliia korkovoi dinamiki cheloveka, izd-vo VIEM, M. (Collection: Experiment of Systematic Experimental Investigation of the Ontogenetic Development of the Cortical Dynamics of Man. Statc Publishing House of the All-Union Institute of Experimental Medicine, Moscow), 5: 249-260, 1940.

1133. Kogan, A. V., and Ivannikova, T. V. "Visual Conditioned Reflexes in Cats with the Occipital Lobes of the Cerebrum Elongated at an Early Age." Biull. eksperital'noi biologii $i$ medilsiny (Bulletin of Experimental Biology and Medicine), 40(3): 6-9, 1955.

1134. Kogan, A. D. "Age Characteristics of Thresholds of Speech Comprehension in Children." Trudy nauch.-issled. in-ta ukha, gorla $i$ nosa, izd-vo Ministerstva zdravookhraneniia RSFSR, sb. 6 (Transactions of the Scientific Research Ear, Nose, and Throat Institute. Publishing House of the Ministry of Health, RSFSR). 6: 237-250, 1955.

1135. Kozhanchikov, I. V. "Role of Energy Processes in Development in the Winter of the Chrysalis of Cutworm Moth (Agrotis segetum Schiff.) and of the Mill Pyralid Moth (Ephestia kühniella Zell.)." $D A \mathcal{N}$ SSSR (Reports of the Academy of Sciences, USSR), 2(9): 595-599, 1934.

1136. "The Hygroregulator Reaction of Agrotis and Ephestia Chrysalids as a Reaction to Environmental Humidity." Ibid., 3(7): 548-551, 1934.

1137. - "Role of Anaerobic Processes in the Larval Diapause of Certain Representatives of the Pyralidae." Ibid., 2(3-4): 322-327, 1935.

1138. - "Role and Physiological State of the Organism of Insects in Connection with the Effect of Ecological Factors." Zoologicheskii zhurnal (Zoological J.), 16(1): 88-106, 1937.

1139. - "Importance of the Age (Seasonal) Changes of Oak Leaves in the Nutrition and Growth of the Oak Silkworm" 
(Znachenie vozrastnykh (sezonnykh) izmenenii list'ev duba v pitanii i roste dubor'ogo shelkopriada. Vsesoiuznaia akademiia s.-kh. nauk im. Lenina), All-Union Lenin Academy of Agrieultural Sciences, 11: 31-36, 1948 (Translator's notc: Referenee seems incomplete).

1140. KozıN, N. I. "lixperiment of Devcloping a Conditioned Reflex to Change of Blood Pressure in Children." Arkhiv biologicheskikh nauk (Archives of Biological Sciences), 39(2): 469-476, 1935.

1141. "Age-Associated Characteristics of the Automatization of a Motor Conditioned Reaction." Sbornik: Opyt sistematicheskogo eksperimental'nogo issledovaniia ontogeneticheshogo razuitiia korkovoi dinamiki cheloveka, izd-vo VIEM, M. (Collection: Study of the Systematic Experimental Investigation of the Ontogenetic Development of the Cortical Dynamics of Man. Publ. House of the All-Union Inst. of Experimental Medicine, Moscow), 5: 47-61, 1940.

1142. "Cortical Analysis of Kinesthetic Stimu!i for Various Age Phases." Ib:d., 5: 225-238, 1940.

1143. Kozyrev, G. S. "Age Characteristics of the Position of the Center of Gravity of Man." Uch. zap. Khar'kovskogo gos. un-teta, Khar'kov (Annals of the Khar'kov State University, Khar'kov), 25: 257-274, 1947.

1144. Kolen, A. A. "Deposition of Lipids in the Eye in Connection with Age and with Lipid Deposits in Other Organs." Arkhiv oftal'mologii (Archives of Ophthalmology), 3(4): 608-629, 1927.

1145. - and Men'sirikov. F. K. "Two Cases of Senile (Lipid) Arcus corneae with Certain Features of Pathogenesis." Sbornik, posviashchennyi 25-letiiu nauchnoi deialel'nosti prof. $\mathcal{N}$. N. Anichkova, M.-L., VIEM (Collection Dedicated to the 25th Anniversary of the Scientific Activity of Prof. N. N. Anichkin, All-Union Inst. of Exper. Med., Moscow-Leningrad), 1935, pp. 121-127.

1146. Kolesnikov, M. S. "Development of the Typological Properties of Higher Nervous Aetivity in the Ontogenesis." Trudy Instituta fiziologii im. I. P. Pavlova, izd-vo AN SSSR, M.-L (Transactions of the I. P. Pavlov Institute of Physiology, published by the Acad. of Sciences, USSR, MoscowLeningrad), 2: 173-181, 1953.

1147. Kolomiets", E. F. "Cyano-Resistant Respiration Changes in Brain and Kidneys with Age" (Ukr.: Vikovi zmini tsianrezistentnogo dikhannia mozku ta nirok). Pratsi nauk.doslid. zoobiologichnogo in-tu Kharkivs'kogo derzh. un-telu, Kharkiv (Work of the Seientific Research Zoobiological Institute of the Khar'kov State University, Khar'kov), (1011): 161-166, 1941 .

1148. Kolomets, E. F. "Effect of Certain Amino Acids on Respiration of Tissues of Various Age." Uch. zap. Khar'kozskogo gos. un-teta, Khar'kov (Annals of the Khar'kov State University, Khar'kov), 25: 185-190, 1947.

1149. Kolonil, V. P., and Sharapova, A. N. "Age Analysis of Differences Generic and Between Species by Hematological Indices in Farm Poultry." Uch. zap. Kishinevskogo gos. un-teto (Annals of Kishinevskii State University), l(1): 128-175, 1949.

1150. Kolosova, S. I. "Age-Associated Morphology of the Nervous System of the Digestive Tract of Man." Sbornik 2: Voprosy morfologii. Akademiia meditsinskikh nauk SSSR, M. (Problems of Morphology. Academy of Medical Sciences USSR, Moseow), 2: 153-166, 1953; Referativnyi zhurnal. Biologïa (Abstract Jcurnal. Biology), (7): abstract $12825,1954$.

115I. Kolpakcil, I. M. "Relative Destructibility of Tissue and Non-Tissue Protein Forms in the Animal Organism and the Nature of Protein Deposit." Fiziologicheskii sbornik (Physiological Collection), v. I, 1888.

1152. Kolpakov, E. V., and Ozadovskaia, N. S. "Effect of Hypoxia on the Reproductive System of Young and Old Rats." Kislorodnaia terapiia i kislorodnaia nedostalochnost'. Kiev, AN USSR (Oxygen Therapy and Oxygen Deficiency. Aeademy of Sciences USSR, Kiev), 1952, pp. 102-109.

1153. Kolpikov, N. V., and VAsIL'EVA, M. V. "Complement of the Fetus." Trudy Krymskogo gos. med. in-la., Simferopol", Krymgiz ASSR (Transactions of the Crimean State Medical Institute, Simferopol'. Crimean State Publishing House, Autonomous SSR), 6: 3-9, 1941 .

I 154. Kolpikov, N. V. "Phagocytic Properties of Fetal Leukocytes.” Ibid., 8: 76-80, 1941 .

1155. and Vasil'eva, M. V. "Resistance of Fetal Erythrocytes." Ibid., 8: 8I-86, 1941. 
1156. KolPikov, N. V. "Thermal Reaction of Inoculatcd Fetus and of the Newborn Organism."' Ibid., 8: 87-95, 1941.

1157. —Data for Study of Infection in the Fetus. Disscrtation I, 1943." Sbornik nauchnykh trudov med. in-ta (Krymskii med. in-t) za gody Velikoi Otechestvennoi voiny. Krymgiz ASSR, Simferopol' (Collection of Scientific Works of the Medical Institute (Crimean Medical Institute) for the years of World War II. State Publ. House of Crimean Autonomous SSR, Simferopol'), 11: 9-36, 1945.

1158. - (Ukr. for same name). "Immunobiological Traits of the Fetus and the Newborn Organism" (Ukr.: Imunobiologichni osoblivosti ploda $i$ novorozhdenogo organizmu). Medichnii zhurnal AN URSR (Medical J. of the Academy of Sciences UkrSSR), 16: 208-212, 1947.

1159. - "Immunobiological Traits of the Fetus and the Newborn Organism." Trudy Krymskogo med. in-ta im. Stalina. Krymgiz ASSR, Simferopol' (Transactions of the Crimean Stalin Medical Institute. State Publ. House of Crimean Autonomous SSR, Simferopol'), 12: 91-97, 1948.

1160. Kol'tsova, M. M. "Emergence and Development of the Second Signal System in the Child." Trudy fiziologicheskogo in-ta iml I. P. Pavlova, AN SSSR, L. (Transactions of the I. P. Pavlov Physiological Institute. Acad. of Sciences USSR, Leningrad), 4: 49, 1949.

1161. -Development of Inner Inhibition of the Child." Fiziologicheskii zhurnal SSSR, (see 1163), 38(1): 27-32, 1952.

1162. - "Conditioned Reflexes in Proportions to Stimuli in Children at an Early Age." Trudy Instituta fiziologii im. I. P. Paulova, izd-vo AN SSSR, M.-L. (Transactions of the I. P. Pavlov Institute of Physiology. State Publ. House of the Acad. of Sciences USSR, Moscow-Leningrad), 1: $-, 1952$.

1163. - "Role of the Process of Inhibition in Development of Sensory Speech of the Child." Fiziologicheskii zhurnal SSSR (Physiological J. of the USSR), 41 (4): 470$476,1955$.

1164. Komarova, T. F., and Troshikin, V. A. "Some Data on the Inheritance and Variability of Typological Properties of the Nervous System in the Ontogenesis." Trudy
Instituta Fiziologii im. I. P. Pavlova, izd-vo AN SSSR, M.-L. (Transactions of the I. P. Pavlov Institute of Physiology. State Publ. House of the Acad. of Sciences, USSR, Moscow-Leningrad), 2: 228-251, 1953.

1165. Kometiani, P. A., Kokoginashivil, V. I., and Dolidze, SH. V. "Radioactive Indicator Method of Studying Exchange of Egg Yolk Phosphorus Compounds in the Process of Fetal Development." Biokhimiia (Biochemistry), 20(1): 100-105, 1955.

1166. Komisarenko, V. P. "Effect of Thymolysate on Growth of Pups" (Ukr.: Pro upliv timolizatu na rist shcheniat). Experimental'na meditsina (Experimental medicine), (6): 3540, 1937.

1167. Kompaneets, S. M. "Senile Changes in Hearing." Sbornik: Starost' (Trudy konferentsii 17-19 dekabria $1938 \mathrm{~g}$.) izd-vo AN USSR, Kiev (Collection: Old Age. Transactions of the Dec. 17-19, 1938 Conference, published by the Acad. of Sciences UkrSSR, Kiev), 1940, pp. 347-350.

1168. Konarev, V. G. "Age Changes in Plant Cells and the Iso-Electric Point of Protoplasm." DAN SSSR, novaia ser. (Reports of the Acad. of Sciences USSR, New Series), 59(4): 773-776, 1948.

1169. - "Age of Plant Cells and Behavior of Cellular Membranes to Acid and Base Dyes." Ibid., 59(5): 983-986, 1948.

1170. "Nucleic Acids and the Morphogenetic Processes in Higher Plants" (Nukleinovye kisloty $i$ formoobrazovatel'nye protsessy u vysshikh rastenii. Avtoref. diss. na soiskanie uchenoi stepeni doktora biologicheskikh nauk, M.), author's own abstract of his dissertation for the degree of doctor of biological sciences, Moscow, 1954.

1171. Kondrat'Ev, A. P. “Development of the Diploic Veins of the Cranial Vault Bone in Man After Birth." Trudy pervoi nauchnoi konferentsii po vozrastnoi morfologii $i$ fiziologii, izd-vo Akademii pedagogicheskikh nauk RSFSR, M. (Transactions of the First Scientific Conference on Age-Associated Morphology and Physiology. Publishing House of the Academy of Pedagogical Sciences RSFSR, Moscow), 1954, pp. 179-182.

1172. Konoval'chik, N. I. "Problem of the Constitution of Elderly People." Staros" $i$ trudosposobnost'. Sb. rabot NIVTU (Old Age and Work Capacity. Collection of Works of the "NIVTU" (sic; see item $2: 1$ above)), 1936, pp. 175-186. 
1173. Konchalovskil, M. P. "Problem of Premature Old Age." Vrachebnoe delo (Medical Affairs), (5): 415-420, 1935.

1174. Korziluev, P. A., Nikol'skaia, I. S., and RadzinskaiA, L. I. "The Relation Betwecn Blood and Skeletal Characteristics in the Ontogenesis of Farm Animals." VIII V'sesoiuznyi s'ezd fiziologov, biokhimikov, farmakologov. Tezisy dokladov, izd-vo AN SSSR (Eighth All-Union Congress of Physiologists, Biochemists, and Pharmacologists. Thescs of Reports Published by the Academy of Sciences USSR), 1955, p. 324.

1175. KorneEv, A. S. "Oxidation Coefficient of Rabbit Urine in Connection with Age." Trudy Krymskogo gos. med. in-la. Krymgiz, ASSR (Transactions of the Crimean State Medical Institutc. State Publishing House of Crimean Autonomous SSR), 1938, pp. 42-44.

1176. - "Oxidation Coefficient of Urine of Man in Connection with Age." Ibid., Simferopol', 1940, pp. 3-9.

1177. Korneev, G. IA. "Data for Study of Complex Stimuli in Children." Zhurnal vysshei nervnoi deiatel'nosti (Journal of Higher Nervous Activity), 5(2): 205-210, 1955.

1178. Kornienko, V. M. "Polarographic Study of Proteins." Uch. zap. KhGU (Annals. Khar'kov State Univ.), v. 68; Trudy nauch. issled. in-ta biologii $i$ biologicheskogo $f$-ta (Transactions of the Scientific Research Institute of Biology and Biological Pharmacotherapy), 24: 267-274, 1956.

1179. Korovaev, E. N. "Role of the Vegetative-Endocrine System in the Physiology and Pathology of Childhood." Kazanskii meditsinskii zhurnal, izd-vo Med. o-va Tatarii (Kazan Medical J., published by the Tatar Medical Society)....

1180. Korovina, V. M. "Change in the Embryo's Susceptibility to External Stimuli." Trudy nauchnoi sessii Voenno-morskoi meditsinskoi Akademii. Doklady i referaty, L. (Transactions of the Scientific Session of the MilitaryMaritime Mcdical Academy. Reports and abstracts, Leningrad), 1947, pp. 187-188.

1181. Koropov, V. M. "Reactivity of the Growing Organism." Veterinariia (Veterinary Science), (12): 10-15, 1954.

1182. Korotkin, I. I., and Kryshova, N. A. "Changes of Motor Chronaxy in the Sleep Process of Infants." Fiziologicheskii zhurnal SSSR (Physiological J. of the USSR), 29(3): 127-134, 1940.

1183. Korotkova, T. M. "External Inhibition of Conditioncd Reflexes in Children." Trudy laboratornoi fiziologii vysshei nervnoi deialel'-nosti rebenka pri pedagogicheskom institute im. Gertsena. Sb. I (Transactions of the Laboratory of Physiology of Higher Nervous Activity of the Child in the Gcrtsen Pedagogical Institutc. 1: —, 1930.

1184. Kossiura-Shain, M. B. "Properties of Gastric Secretion in Children of Older Age." Novosti meditsiny (Medical News), v. 6; Voprosy pediatrii, M., Akademiia meditsinskikh nauk SSSR (Problems of pediatrics, Moscow, Acad. of Med. Sciences USSR), 1947, pp. 26-27.

1185. Kostromov, I. A. "Destruction of the Venous Valves with Age." Sovetskaia meditsina (Soviet Medicine), (9): 28-29, 1948.

1186. Kostriukova, K. Iu., and GuretSKaIA, F. S. "Some Observations on the 'Theory of the Cyclic Structure and Rejuvenation of Plants'." N. P. Krenke. Selektsiia $i$ semenovodstvo (Selection and Seed Growing), (8): 76-78, 1952 (46 refs.).

1187. Kostiurin, S. D. "Change of Cerebral Cortex in Old Age." Vrach (The Physician), 7(2): 33-34, 1886.

1188. "Die senilen Veränderungen der Grosshirnrinde" (Senile Changes in the Cerebral Cortex). Medicinische Jahrbücher der Gesellschaft der Aerzte zu Wien (Medical Yearbook of the Vienna Association of Physicians), 1886; Vrach (The Physician), 7(2): 33-34, 1886.

1189. "Problem of the Effect of Subcutaneous Injection of Brown-Sequard Extract on Middle-Aged Persons and the Senile and on the Course of Diseases of the Central Nervous System." Vrach (The Physician), 11(5): 105-106 and (10): 233-235, 1890.

1190. Kosiakov, K. S. "Age Changes in Chemical Composition of Human Hair." Uch. zap. Moskouskogo gos. un-tela, v. 34, Antropologiia (Annals of Moscow State University. Anthropology), 34: 189-192, 1940.

1191. Kosiakov, P. N., and Tribulev, G. P. "M- and N-Antigens (sic) of Man in the Process of Embryogenesis." Zhurnal mikrobiologii, epidemiologii $i$ immunobiologii (Journal of Microbiology, Epidemiology, and Immunobiology), (9-10): 128-132, 1939. 
1192. Kosiakova, A. V., and Panferov, IU. K. "Character of Sugar Curves in Children During Croupous Pneumonia." Arkhiv biologicheskikh nauk (Archives of Biological Sciences), 39(3): 807-816, 1935.

1193. Kotıkov, Iu. A. "Mineral Composition of Children's Blood in Certain Diseases." Trudy VIEM M. (Transactions of the AllUnion Institute of Experimental Medicine, Moscow), 1: 135, 1933.

1194.

"Morphological Picture of the Intravital Punctures of the Hematopoietic Organs in Children." Voprosy pediatrii $i$ okhrany materinstva $i$ detstia (Problems of Pediatrics and Maternal and Child Welfare), 7(2): 94-203, 1935.

1195. " "Morphological Properties of the Erythrocytes of the Fetus." Voprosy pediatrii $v$ dni blokady Leningrada, sb. 2, Pediatricheskii meditsinskii institut, L. (Problems of Pediatrics in the Days of the Leningrad Blockade, Medical Institute of Pediatrics, Leningrad), 2: 57-63, 1946.

1196. - "Fetal Hematopoiesis." Voprosy pediatrii $i$ okhrany materinstva $i$ detstza (see above), 14(3): 11-17, 1946.

1197. - "Characteristics of Fetal Hematopoiesis." Sovetskii vrach (Soviet Physician), 5: 22-25, 1947.

1198. Kotllarevskil, L. I. "Age Characteristics of Forming a Simple Motor Conditioned Reaction in Children." Sbornik: Opyt sistematicheskogo eksperimental'nogo issledovaniia ontogeneticheskogo razvitiia korkovoi dinamiki cheloveka, izd-vo VIEM, M. (Collection: Study of Systematic Experimental Investigation of Ontogenetic Development of Cortical Dynamics in Man. State Publishing House of the All-Union Institute of Experimental Medicine, Moscow), 5: 197-208, 1940.

1199. Kocharovskir, L. L. "Urine of the Newborn and Its Toxicity" (Mocha novorozhdennykh $i$ ee iadovitost'. Diss. SPb), a dissertation. St. Petersburg, 1899.

1200. Kochergin.4, V. S. "Problem of the Development of Interaction of the Signal Systems in Healthy Children 3-8 Years of Age." Zhurnal vysshei nervnoi deiatel'nosti (J. of Higher Nervous Activity), 5(3): 363$369,1955$.

1201. Koshtolants, Kн. S. "Beitrag zur Physiologie des Embryos (Embryosekretin)" (Contribution to Knowledge of the Physiol- ogy of Embryos (Embryo Secretin)). Pfluger's Archiv für die gesamte Physiologie des Menschen und der Tiere (Berlin), 227: 359, 1931.

1202. -Physiology and Theory of Development." Pod znamenem marksizma (sic; Under the Name of Marxism), (5-6): 54-88, 1932.

1203. "Problem of the Study of a Reciprocal Bond of Physiological Phenomena (Correlations)." Priroda (Nature), (2): 4652,1934 .

1204. "Certain Ways to Solve Problems of the History of Development of Functions." Sbornik rabot laboratorii sravnitel'noi fiziologii zhivotnykh Biologicheskogo instituta im. K. A. Timiriazeva, M. (Collection of Works of the Laboratory of the Comparative Physiology of Animals, the K. A. Timiriazev Biological Institute, Moscow), 1934.

1205. - "Problem of the Evolution of Protein Exchange." Problema belka, Medgiz, M.-L. (The Protein Problem. State Publ. House of Med. Lit., Moscow-Leningrad), 1934, pp. 174-178.

1206. "Comparative Physiology, Its Problems and Methods." Sorena (sic), 8: $5,1934$.

1207. - , Muzykantov, V. A., and Mitropolitanskaia, R. L. "Physiological Characteristics of the Smooth Musculature of Intestines of Amphibia in Different Periods of the Individual Development." Fiziologicheskii zhurnal SSSR (Physiological J. of the USSR), 17(3): 527, 1934.

1208. Koshtolants, KH. S. "Functional and Morphological Gradient." Uspekhi sovremennoi biologii (Advances in Contemporary Biology), 3(6): 651, 1934.

1209. - "Anaerobiosis and Aerobiosis." Ibid., 4(6): 469-487, 1935.

1210. - and Mitropolit anskaia, R. L. "Data for Physiology of Animals in the Ontogenesis. Report III. Evolution of a Gradient of Automation of the Intestines in the Postembryonic Development of Mammals." Fiziologicheskii zhurnal SSSR (Physiological J. of the USSR), 19(3): 682-687, 1935.

1211. Koshtoiants, Kн. S., and RiabinovSKAIA, A. M. "Data on the Physiology of Skeletal Muscle of Mammals in Different Stages of Individual Development." Biologicheskii zhurnal (Biological J.), 4: 237, 1935. 
1212. "Beitrag zur Physiologie des skeketsmuskels der Säugetier auf verschiedenen Stadien ihren individuellen Entwicklung" (Contribution to the Physiology of the Skeletal Muscle of Mammals in Different Stages of Individual Dcvelopment). Pfügers Arch.; 235: 416, 1935.

\section{Kosmtolants, KH. S. "Certain} Chemical Changes in the Ontogenesis of Animals." Priroda (Nature), (2): 27-30, 1935.

1214. "Problems of Comparative and Embryonic Physiology at the 15th International Congress of Physiology." Uspekhi souremennoi biologii (Advances in Contein porary Biology), 5: 160, 1936.

1215. - "The Relationship of Vegetative Functions and of Animal Organs in the Light of Their Evolution" ( $O$ sootnoshenii funktsii vegetativnykh $i$ animal'nykh organov $v$ svete ikh evoliutsii. Izd-vo AN SSSR, M.-L.). State Publishing House of the Acad. of Sciences USSR, Moscow-Leningrad, 1937.

1216. - "Evolutionary Physiology in the USSR." Fiziologicheskii zhurnal SSSR (Physiological J. of the USSR), 23(4-5); 523-536, 1937.

1217. "Trophic Effect of the Nervous System in the Ontogenesis of Animals." Ibid., 24(1-2): 221-227, 1938.

1218. , Muzykantov, V. A., and Mitropolitanskaia, R. L. "Data on Comparative Physiology of the Smooth Musculature of Intestines of Amphibians in Different Periods of Individual Development." Ibid. 25(4): 528-534, 1938.

1219. Koshtolants, Krl. S., and MitroPOLITANSKAIA, R. L. "Data on the Physiology of Animals in the Ontogenesis. Report I. Automation of the Intestines of the Human Fetus." Ibid., 25(6): 1309-1313, 1938.

1220. Koshtolants, $\mathrm{K}_{\mathrm{H}}$. S. "The Bases of Comparative Physiology" (Osnovy sravnitel'noi fiziologii, ch. 1, izd-vo AN SSSR, M.-L.), Part 1. State Publishing House of the Acad. of Sciences USSR, Moscow-Leningrad. 1940.

1221. "Outlines of the History of Physiology in Russia, 1946, I. P. Pavlov on Comparative Physiology. From a Lecture Rcport of Nov. 16, 1920 in the PhysicoMathematical Division of the Acad. of
Sciences USSR," Arkhiv AN SSSR (Archives of the Acad. of Sciences USSR), 1(2;25): - 1940.

1222. - "Protcins, Metabolism, and Nerve Regulation" (Belkovye veshchestva, obmen veshchestv $i$ neronaia reguliatsiia. Izd-vo AN SSSR, M.) State Publishing House of the Acad. of Scicnces USSR, Moscow, 1951.

1223. - and Buznikov, G. A. "The Activity and Probable Functional Importance of the Enzyme Hyaluronidase in Different Stages of the Ontogenesis of Fish." $D A \mathcal{N}$ SSSR (Reports of the Acad. of Sciences USSR), 93(5): 937-940, 1943.

1224. Koshtoiants, Ki1. S., Bizov, A. I., and Mitropolitanskaia, R. L. "Oscillographic Investigation of the Central Nervous System of the Mulberry Silkworm in Diffcrent Stages of Development." Zoologicheskii zhurnal SSSR (Zoological J. of the USSR), 33(4): 807-814, 1954.

1225. KRavets, Z. M. "Fluctuations of Nitrogen Components in Urine of Children in Early Childhood." Zhurnal po izucheniiu rannego detskogo vozrasta (Journal for Study of Early Childhood), 10(2): 101, 1930.

1226. KRavitskaia, P. S. "Mechanical Stimulus of the Stomach in the Light of the Ontogenesis." Fiziologicheskii zhurnal SSSR (Physiological J. of the USSR), 30(6): 675$680,1941$.

1227. "Effect of Pilocarpine and Atropine on the Evacuator Function of the Stomach in the Light of the Ontogenesis." Farmakologiia $i$ toksikologiia (Pharmacology and Toxicology), (5): 20, 1944.

1228. — and LANDA, A. N. "The Roentgenological Method of Studying the Motor Function of the Stomach at Different Ages." Ibid., (5): 27, 1944.

1229. Kravitskaia, P. S. "Dependency of Evacuator Function of the Stomach on the Tonus of It in the Light of the Ontogenesis." Sbornik nauchnykh trudov Krymskogo med. in-ta, izd-vo "Krasnyi Krym" (Collection of Works of the Crimean Med. Institute. "The "Red Crimea" Publishing House), 11: 87, 1945.

1230. "Effect of Stimulation of the Vagus Nerve on Motor Function of the Stomach in the Light of Ontogenesis." Ibid., 11: 94-100, 1945.

1231. - and Kriucinova, A. P. "Periodic Activity of the Stomach Aside from 
Digestion (Periodic Hunger) in Different Age Periods." Referaty nauch.-issled. rabot Akademii meditsinskikh nauk SSSR, klinicheskie nauki (Abstracts of the Sci.-Res. Works of the Acad. of Med. Sciences USSR, Clinical Sciences), (5): 45-47, 1948.

1232. Kravitskaia, P. S. "Physiological Mechanisms of the Periodic Activity of the Alimentary Center in the Period of Brcast Feeding." Fiziologicheskii zhurnal SSSR (Physiological Journal of the USSR), 37(1): 47-51, 1951.

1233. - and Kriucirkova, A. P. "Periodic Activity of the Stomach Aside from Digestion (Periodic Hunger) in Different Age Periods." Ibid., 37(3): 329-335, 1951.

1234. Kravchinskil, B. D. "Effect of Physical Exercises and the Work Day of the Student on the Alkaline Reserve of the Blood." Russkii fiziologicheskii zhurnal SSSR (Russian Physiological J. of the USSR), 11(1-2): 415-432, 1928.

1235. - "Evolution of Kidney Function in the Ontogenesis." VII Vsesoiuznyi s'ezd fiziologov, biokhimikov, farmakologov. Doklady, Medgiz, M. (Seventh All-Union Congress of Physiologists, Biochemists, and Pharmacologists. Reports. State Publ. House of Med. Lit., Moscow), 1947, p. 645.

1236. Krasnovskaia, L. A. "Mechanism of the Cardiovascular and Respiratory Systems at Hypoxemia in Different Stages of the Ontogenesis. Report 1. (Mature Dogs and the First Group of Up to 16-18 Days)." Arkhiv biologicheskikh nauk (Archives of Biological Sciences), 64(3; 12): 46-53, 1941.

1237. - "Mechanism of Changes of the Cardiovascular and Respiratory Systems in Hypoxia in Different Stages of the Ontogenesis (From 16-18 Days Up to 1.5-2 Months)." Biull. eksperimental'noi biologii $i$ meditsiny (Bulletin of Experimental Biology and Medicine), 16(1-2; 7-8): 16, 1943.

1238. KRASNOGORSKIl, N. I. "Development of the Science on Physiological Activity of the Brain in Children" (Razvitie ucheniia o fiziologicheskoi deiatel'nosti mozga u detei. Izd. Instituta okhrany zdorov'ia detei i podrostkov, L.), Publishing House of the Institute for the Welfare of Healthy Children and Juveniles, Leningrad, 1939.

1239. - "Effect of Certain Endocrinological Factors on the Physiological
Activity of the Cerebrum in Children." VII Vsesoiuznyi s'ezd fiziologov, biokhimikov, farmakologov. Doklady, Medgiz, M. (Seventh All-Union Congress of Physiologists, Biochemists, and Pharmacologists. Reports. State Publ. House of Med. Lit., Moscow), 1947, p. 172; Problemy sovetskoi fiziologii, biokhimii, farmakologii, M. (Problems of Sovict Physiology, Biochemistry, and Pharmacology, Moscow), 1: 204-205, 1949.

1240. - "Experiment of Formation of Synthetic Conditioned Reflexes in Children of Early Age." Russkii vrach (The Russian Physician), (36): 1245, 1907.

1241. - "The Conditioned Reflexes of Children." Ibid., (28-29): —, 1908.

1242. -Basic Mechanisms of the Cerebral Cortex in Children." Jahrbuch. $f$. Kinderheilkunde, 78: 4, 1913.

1243. - "Effect of Certain Endocrine Factors on the Physiological Activity of the Brain in Children." VII Vsesoiuznyi s'ezd fiziologov, biokhimikov, farmakologov. Doklady, Medgiz, M. (Seventh All-Union Congress of Physiologists, Biochemists, and Pharmacologists. Reports. State Publ. House of Med. Lit., Moscow), 1947, p. 172.

1244. —_. "Certain Age Characteristics of the Physiological Activity of the Cerebral Cortex in Children." Ob'edinennaia sessiia, posviashchennaia 10-letiiu so dnia smerti I. P. Pavlova, izd-vo Akademii meditsinskikh nauk SSSR, M. (Joint Session Dedicated to the 10th Anniversary from the Day of I. P. Pavlov's Death), 1948, pp. 141149.

1245. - "Infrared Radiation of the Body of Children During Hypnotic (Divided) States of the Cerebral Cortex." Zhurnal vysshei nervnoi deiatel'nosti ( $\mathrm{J}$. of Higher Nervous Activity), 1(3): 376-382, 1951.

1246. "Phase Changes in Activity of the Cerebrum of Children." Ibid., 1(1): 36-46, 1951.

1247. - "Typical Characteristics of Higher Nervous Activity in Children." Ibid., 3(2): 169-183, 1953.

1248. "Method of Investigation of Conditioned Reflexes in Children." Trudy po izucheniiu vysshei nervnoi deiatel'nosti cheloveka $i$ zhivolnykh. M., Medgiz (Transactions for Study of Higher Nervous Activity of Man and Animals. Moscow, State Publ. House of Med. Lit.), 1954, pp. 227-246. 
1249. - - "Nutritive Analy'sor and $\mathrm{Ap}$ petite Disturbances (Anorexia) in Children." Doklad v Biologicheskom o-ve v Leningrade 30 Maia $1930 \mathrm{~g}$. Trudy po izucheniiu vysshei nerinoi deiatel'nosti cheloveka i zhivolnykh. M., Medgiz (Report presented to the Biological Society in Leningrad May 30, 1930), ibid., 1954, pp. 275-283.

1250. "Functional Disorders of Higher Nervous Activity in Children." Ibid., 1954, pp. 284-294.

1251. "Physiological Activity of the Cerebrum in Children as a New Subject for Pcdiatric Investigation." Ibid., 1954, pp. 291-311.

1252. "Certain Basic Patterns in the Work of the Cerebrum in Children." Ibid., 1954, pp. 311-322.

1253. "A Physiological Point of View in Problems of the Psychology and and Psychopathology of Childhood." Ibid., 1954, pp. 322-333.

1254. - "Conditioned Reflexes of the Heart in Children." Ibid., 1954, pp. 333338.

1255. - "The Pathophysiology of Higher Nervous Activity in Children." Ibid., 1954, pp. 338-353.

1256. - "Sleep Disturbances and Treatment of Them in Children." Ibid., 1954, pp. 354-361.

1257. - "Treatment of Nocturnal Enuresis of Children." Ibid., 1954, 361365.

1258. - "Conditioned and Unconditioned Reflexes in Children in Certain Infectious Diseases." Ibid., 1954, pp. 371378.

1259. - "Effect of Certain Hygienic Factors on Higher Nervous Activity of the Child." Ibid., 1952, pp. 378-384.

1260. - "Effect of Certain Pharmacological Substances on the Unconditioned and Conditioned Reflexes of Children." Ibid., 1954, pp. 384-393.

1261. - "Conditioned Reflexes in the Child Clinic." Trudy po izucheniiu vysshei nervnoi deiatel'nosti. M. Medgiz (Transactions on Study of Higher Nervous Activity. Moscow, State Publ. House of Med. Lit.), 1954, pp. 400-406.
1262. - "Physiology of the Acquisition of Child Spcech. Report 11." Trudy po izucheniiu vysshei nervnoi deiatel'nosti chelovek a $i$ zhivolnykh. M., Medgiz (Transactions on Study of Higher Nervous Activity of Man and Animals. Moscow, State Publ. House of Med. Lit.), 1: 471-482, 1954.

1263. KRASNOPOL'SKala, N. M. “Morphology of the "Thyroid Gland of Fetuscs and the Newborn in Tashkent." Biull. Uzbekshogo in-la eksperimental'noi meditsiny (Bulletin of the Uzbek Institute of Experimental Medicinc), (11): 13-36, 1939.

1264. Kratinova, E. R., and Ushakova, A. S. "Effect of Urine of Pregnant Animals on Development of the Growing Organism." Fiziologicheskii zhurnal SSSR (Physiological J. of the USSR), 22(5): 698-703, 1937.

1265. Kratinova, E. R., and Bosis, R. B. "Age Changes of Ascorbic Acid Content in Organs of White Rats and Guinea Pigs." Biull. eksperimental'noi biologii $i$ meditsiny (Bulletin of Experimental Biology and Medicine), 7(1): 101-104, 1939.

1266. Kratinova, E. R., and Butom, M. L. "Age Changes of Ascorbic Acid in Animal Tissues During Disturbance of Aerobic Respiration" (Ukr.: Vikovi zmini askorbinovoi kisloti $v$ tvarinnikh tkaninakh pri porushenni kisnevogo dikhannia). Eksperimental'na meditsina (Experimental Medicine), (3): 58-64, 1940.

1267. Kratinova, E. R. "Oxidation of Ascorbic Acid and Reduction of Dehydrazo Ascorbic Acid by Tissues of Different Age Animals." Ukrainskii biokhimicheskii zhurnal, Kiev (Ukrainian Biochemical J., Kiev), 21(1): 74-84, 1949.

1268. Krasieninnikov, V. "Biological Bases of Old Age, Its Mechanisms, and Rejuvenation in Connection with Knowledge of Internal Secretion" (Biologicheskie osnovy slarosti, ee mekhanizmy $i$ omolozhenie sviazi s ucheniem o vnutrennei sekretsii, M., Medgiz), Moscow, State Publ. House of Med. Lit., 1924.

1269. Kraiukhin, B. V., and Shcherbakov, N. M. "Motor Chronaxy in Elderly Persons of Advanced Years in Abkhazia." Sbornik: Starost' (Trudy konferentsii 17-19 dekabria $1938 \mathrm{~g}$. ), Kiev, AN USSR (Collection: Old Age. Transactions of the Dec. 17-19, 1938 Conferencc, Kiev. Acad. of Sciences UkrSSR), 1940, pp. 309-315. 
1270. KraiukinN, B. V., and Silcherbakov, M. M. (Ukr. initials for name above) "Motor Chronaxy in Old Persons of Advanced Years in Abkhazia" (Ukr.: Rukhova khronaksiia $u$ dovgolitnikh starikov Abkhazii). Medichnii zhurnal AN USSR (Medical J. of the Acad. of Sciences UkrSSR), 9(1): 117-128, 1939, and 10(2): 529-534, 1940.

1271. "Motor Chronaxy in Old Persons in Generalized Arteriosclerosis" (Rukhova khronaksïa u starikiv pri generalizovanomu arterioskerozi). Ibid., 12: 255-264, 1944.

1272. Kraiukhin, B. V., and Silcherbakov, N. M. "Motor Chronaxy in Elderly Persons of Advanced Years." Fiziologicheskii zhurnal SSSR (Physiological J. of the USSR), (4): 397-399, 1949 (bibliog. refs. on p. 399).

1273. Krenke, N. P. "Somatic Indices and Factors of Morphogeny." Sbornik: Fenogeneticheskaia izmenchivost', izd. Biologicheskogo in-ta im. K. A. Timiriazeva (Collection: Phenogenetic Variability, published by the K. A. Timiriazev Biological Institute), 1: $11-415,1933-1935$.

1274. - "Theory of Cyclic Aging and Rejuvenation of Plants" (Teoriia tsiklicheskogo stareniia $i$ omolozhenie rastenii. M., Sel'khozgiz), Moscow. State Publ. House of Farm Lit., 1940.

1275. "Basic Positions of the Theory of the Cyclic Aging and Rejuvenation of Plants in the Ontogenesis" (Theory of Age Cyclic Periodicity). Sbornik rabot po fiziologii rastenii pamiati $K$. A. Timiriazeva, izd-vo AN SSSR, M.-L. (Collection of Works on Plant Physiology Commemorative of K. A. Timiriazev. State Publ. House of the Acad. of Sciences USSR, Moscow-Leningrad), 1941.

1276. Krenke, A. N., and Dubrovitskala, N. I. "Character of the Enzyme Catalase and Its Activity Depending on the Age Structure of Tobacco Leaves." DAN SSSR (Proceedings of the Acad. of Sciences USSR), 66(4): 729-732, 1949.

1277. KRENke, N. P. "Data on the Theory of Cyclic Aging and Rejuvenation in the Ontogenesis." Regeneratsiia rastenii, $A, \mathcal{N}$ SSSR, $M$. (Regeneration of Plants. Acad. of Sciences, USSR, Moscow), 1950, pp. 428576.

1278. KREPS, E. M. "Carbonic Anhydrase in the Phylogenesis and Ontogenesis."
Trudy iubileinoi nauchnoi sessii Jeningradskogo gos. un-teta, sektsiia biologicheskikh nauk, L. (Transactions of the Jubilee Scientific Session of Leningrad State University, Biological Sciences Section, Leningrad), 1946 , pp. $161-170$.

1279. - "Carbonic Anhydrase of Nerve Tissue in Animal Ontogenesis." VII Vsesoiuznyi s'ezd fiziologov, biokhimikov i farmakologov. M. Medgiz (Seventh AllUnion Congress of Physiologists, Biochemists, and Pharmacologists. Moscow, Medgiz), 1947 , p. 565.

1280. - Pigareva, Z. D., Chetver1kov, D. A., and Pomazanskaia, L. F. "Biochemical Evolution of the Brain in Ontogenesis and Nervous Activity." Zhurnal vysshei nervnoi deiatel'nosti (Journal of Higher Nervous Activity), 2(1): 45-55, 1952.

1281. Krestovnikov, A. N. Fiziologiia sporta (The Physiology of Sport), MoscowLeningrad, 1939.

1282. VASIL'EVA, V. V., Koriakina, A. F., et al. "The Physical Development and Condition of the Cardiovascular System of Juveniles in the Palace of the Pioneers Sport School for Children, Leningrad." Teoriia i praktika fizicheskoi kul'tury (Theory and Practice of Physical Culture), (3): 22$33,1945$.

1283. Kretovich, V. L., Bundel', A. A., and Drozdova, T. V. "Sulfhydryl Compounds and Ascorbic Acid in Germinating and Maturing Seed." Biokhimiia (Biochemistry), 13(4): 332-336, 1948.

1284. Krivobok, Iu. V., Gordienko, G. L., and Kramarenko, A. S. "Age-Associated Changes at Different Type of Rearing (Different Type of Feeding) of Isoelectric Point of Tissue Protoplasm of Rabbits in a Number of Generations." Itogovaia studencheskaia nauchnaia konferentsiia KhGU. Tezisy dokladov KhGU. (All-Student Scientific Conference of the Khar'kov State University. Theses of Papers of the Khar'kov State University), 1952, pp. 189-192.

1285. KrIMER, G. I. "Instinctive Movements of the Newborn." Saratovskii vestnik zdravookhraneniia (Saratov J. of Public Health Care), 7(6-7): 42-47, 1926.

1286. Krinitsin, D. IA. "Regulation of the Continuous Secretion of the Parotid Gland and of the Abomasum in Calves." VII Vsesoiuznyi s'ezd fiziologov, biokhimikov, farma- 
ogov. Dohlady, M., Medgiz (Seventh - l-Union Congress of Plyysiologists, Bio' emists, and Pharmacologists. Reports, - oscow, State P'ublishing Housc of Mcrl. - t. ), 1947, p. 375 .

1287. Krinskain, V. I. "Thyroid Gland in the Newborn." Sovetskaia klinika (The Soviet Clinic), 17: 96-98, 354-356, 1932.

1288. Kricunska1A, E. B. "Phagocytic ACtivity of the Endothelium of Certain Organs of Chick Embryo at Differcnt Stages of Development." Biull. eksperimental'noi biologii $i$ meditsiny (Bulletin of Expcrimental Biology and Medicine), 40(8): 57-59, 1955.

1289. Krutova, T. A. "Effect of Periodic Refrigeration on Dimensions of Chick Embryo Cells." DAN SSSR (Reports of the Acad. of Sciences USSR), 98(2): 313-315, 1954.

1290. KryLov, L. N. "Presence of Neurosecretory Cells in the Hypophysial Area." Sbornik: Voprosy fiziologii i morfologii tsentral'noi nervnoi sistemy. Izd. Akademii meditsinskikh nauk SSSR, M. (Collection: Problems of Physiology and Morphology of the Central Nervous System. State Publishing House of the Acad. of Med. Sciences USSR, Moscow) 1953, pp. 226-229.

1291. Krylov, O. A. "Change of Bromine Content in Blood of Pups in the Ontogenesis." Zhurnal yysshei nervnoi deiatel'nosti (J. of I Iigher Nervous Activity), 5(2): 255-261, 1955.

1292. KrynskaiA, I. L. "Determination of the Activity of the Carbonic Anhydrase of the Blood in Rheumatic Diseases of Childhood." Nauchnaia sessiia ( $A \mathcal{N}$ Estonskoi SSR), Tartu (Scientific Session of the Acad. of Sciences of the Esthonian SSR, Tartu), 1949, pp. 122-129.

1293. Krivchikova, A. P. "Nervous Regulation of the Activity of the Respiratory System in Ontogenesis. Report I." Fiziologicheskii zhurnal SSSR (Physiological J. of the USSR ), 24(3): 523-531, 1938.

1294. - "Nervous Regulation of the Activity of the Respiratory System in the Ontogenesis. Report II. Respiratory Reflexes from the Vagus in the Ontogenesis." Ibid., 24(4): 761-769, 1938.

1295. "Mechanism of the Arising of Irreversible Fibrillation of the Heart in the Ontogenesis." Ibid., 26(2-3): 253-263, 1939.
1296. "Ptyalin in Saliva of Dog as Index of Functional State of the Salivary Glands in the Ontogencsis." Ibid., 27(3): 366-371, 1939.

1297. "Amylasc and Lipase as Indices of the Changing Functional State of the Pancreas in the Ontogencsis." Ibid., 27(4): 437-445, 1939.

1298. - "Role of the Sympathetic Nervous System in Regulation of the Functional State of the Glands in the Ontogenesis." Ibid., 29 (1-2): 7, 1940.

1299. - and Rozanova, V. D. "Age Characteristics of Reaction of the Respiratory System Toward Resistance of a Gas Mask." Biull. eksperimental'noi biologii i meditsiny (Bulletin of Experimental Biology and Medicine), 18(1-2): 1-2, 1944.

1300. KriughKova, A. P. "Mechanism of the Arising of Muscle Tone in the First Extra-Uterine Respirations." Ibid., 22(2): 18-21, 1946.

1301. "Mechanisms of the Arising and Physiological Importance of Various Forms and the Characteristics of Muscular Activity in Different Age Periods." VII Vsesoiuznyi s'ezd fiziologiv, biokhimikov i farmakolog. M., Medgiz (Seventh All-Union Congress of Physiologists, Biochemists, and Pharmacologists. Moscow, State Publishing House of Med. Lit.), 1947, pp. 61-64.

1302. - "Characteristics of Afferent Regulation of Activity of the System of the Organs of Respiration in Newborn Animals. Biull. eksperimental'noi biologii $i$ meditsiny (Bulletin of Experimental Biology and Med.), 24(4): 292-295, 1947.

1303. - "The First Respiratory Movements of the Newborn Organism and Their Connection with the Arising of Muscle Tone." Novosti meditsiny (Medical News), v. 6, Voprosy pediatrii, M., Akademiia meditsinskikh nauk SSSR (Problems of Pediatrics, Moscow. Acad. of Mcd. Scicnces, USSR), 1947, pp. 12-13.

1304. "Analysis of the Mechanisms that Determine the High Susceptibility of Newborn Animals to Overload of the Vagus Nerves in the Neck." Referaty nauch.-issled. rabot Akademii meditsinskikh nauk SSSR, klinicheskie nauki, M. (Abstracts of the Sci.-Res. Works of the Acad. of Med. Sciences USSR, Clinical Sciences, Mloscow), (5): 44-45, 1948. 
1305. and Ostrovskala, I. M. "Experiment of Studying the Typological Characteristics of Children in the First Year of Life." Trudy pervoi nauchnoi konferentsï po vozrasinoi morfologii i fiziologii, izd-vo Akademii pedagogicheskikh nauk RSFSR, M. (Transactions of the First Scientific Conference on Age-Associated Morphology and Physiology. Publishing House of the Acad. of Pedagogical Sciences RSFSR, Moscow), 1954, pp. 29-36.

1306. Kriuchrova, A. P. "Second Scientific Conference on Problems of Age-Associated Morphology and Physiology." Zhvrnal oysshei neronoi deiatel'nosti (J. of Higher Nervous Activity), 5(1): 137-143, 1955.

1307. KRIAZHEV, V. IA. Investigations of the Higher Nervous Activity of Children of School Age by a Method of Speech and Motor Conditioned Reflexes." Trudy pervoi nauchnoi konferentsii po vozrastnoi morfologii $i$ fiziologii, izd-vo Akademii pedagogicheskikh nauk RSFSR, M. (Transactions of the First Scientific Conference on Age-Associated Morphology and Physiology. State Publishing House of the Acad. of Pedagogical Sciences RSFSR, Moscow), 1954, pp. 10-20;.

1308. Kube, N. V. "Deposit of Lipids in Walls of the Aorta in Nursing Children." Arkhiv biologicheskikh nauk (Archives of Biological Sciences), 26: 163, 1926.

1309. Kudriavtsev, A. A., and KudriasHov, M. V. "Alteration of the PhysicoChemical and Morphological Properties of Blood in Sheep in Connection with Age." Trudy VIEV, M.-L. (Transactions of the "VIEV" (?All-Union Inst. of Exptl. Vet. Med.) Moscow-Leningrad), 10: 55-69, 1935.

1310. "Change of Physico-Chemical and Morphological Properties of Blood in Calves in Connection with Age." Ibid., 14: 28-39, 1937.

1311. Kudriavtsev, A. A. "Comparative Data on Gas and Energy Exchange in Growing Animals and Man" (Sravnitel'nye dannye po gazovomu $i$ energeticheskomu obmenu u rastushchikh zhivotnykh $i$ cheloveka. Diss. M., (rukopic'), a dissertation, Moscow (manuscript), 1939.

1312. Kudriavtsev, K. A. "Dependency of Length of Side Shoots of the Ordinary Pine (Pinus siliestris L.) on Its Own Capacity for Growth." DAN SSSR, novaia ser. (Reports of the Acad. of Sciences USSR, new series), 67(5): 925-927, 1949.
1313. Kudriasilov, B. A. "Toxic Effect of High-Molecular Ketones on Growing Rat Embryos." Biull. eksperimental'noi biologii $i$ meditsiny (Bulletin of Experimental Biology and Medicine), 6(2): 147-149, 1933.

1314. "Importance of Vitamins in the Process of the Individual Development of the Organism." Uspekhi sovremennoi biologii (Advances in Contemporary Biology), 25(3): $391-400,1948$

1315. Kudriashov, M. B. "Blood Alteration in Young Pigs in Connection with Age." Irudy Vsesoiuznogo in-ta eksperimental'noi veterinarii (Transactions of the AllUnion Institute of Experimental Veterinary Medicine), 15: -, 1940.

1316. Kuznetsov, A. M. "Work Efficiency of Elderly People in Industry." Starost" i trudosposobnost'. Sb. rabot VIVTE, L. (Old Age and Work Capacity, Collection of the Works of the "NIVTE" (see item 911 above) Leningrad), 1936, pp. 53-66.

1317. Kuznetsov, G. S. "Some Age Characteristics of the Hoof Articulation of Horse in X-ray Picture." Sb. rabot Leningradskogo veterinarnogo in-ta, Sel'khozgiz, L. (Collection of Works of the Leningrad Institute of Veterinary Medicine. The Farm Publishing House, Leningrad), (15): 196-199, 1955.

1318. Kuznetsov, N. N., and Khvatov, B. P. "Microscopic Structure and Age Changes of Kidney Capsule in Man." Urologiia (Urology), 15(4): 17-22, 1939.

1319. Kuznets', M. "The Problem of Changes in the Senile Skin" (Ukr.: po pitannia pro zmini $v$ starechii shkiri). Ukrains'kii medichnii arkhiv (Archives of Ukrainian Medicine), 8(1-2): 91, 1932.

1320. Kuznets, M. M. "Changes in the Senile Skin." Sb.: Starost' Trudy konferentsii 17-19 dekabria 1938 g., Kiev, AN SSSR (Collection: Old Age. Transactions of the Dec. 17-19, 1938 Conference. Kiev, Academy of Sciences USSR), 1940, pp. 117-150.

1321. Kuznetsova, M. P. "Aging of Gelatin in Presence of Many Electrolytes" (Ukr.: Starinnia zhelatini v prisutnosti deiakikh elektrolitiv). Pratsi zoobiologichnogo in-tu Kharkivs'kogo derzh. un-tetu, Kharkiv, Derzhmedvidav (Works of the Zoobiological Institute of the Khar'kov State Univ., Khar'kov. State Publishing House of Med. Lit. ), 2: 107-116, 1934.

1322. Kuz'min, A. N. 'Structure and Age Changes of Testes and Ovaries of Sturgeon 
(Acipenser güldenstädt Br.) Juveniles." $D A \mathcal{N}$ SSSR (Rcports of the Acad. of Scicnccs USSR), 99(4): 645-647, 1954.

1323. Kuz'min, A. IA. "Effect of the Age of a Flower on Capacity for Hybridization of Distant Plants." Ibid., ncw scries, 59(2): 333-335, 1948.

1324. Kuksova, M. I. "Sequence of Cutting Milk Teeth in Macaca rhesus." Biull. eksperimental'noi biologii $i$ meditsiny (Bulletin of Experimental Biology and Medicine), (7): 69-72, 1954.

1325. Kunuev, L. A. "Development of the Striopallidum in the Onto- and Phylogenesis." Nevropatologiia i psikhiatriia (Neuropathology and Psychiatry), (5): 38-44, 1947.

1326. - "Ontogenesis of the Cerebral Cortcx of Man and Its Evolution in Mammals." 3-ia ob'edinennaia nauchnaia konferentsiia Instituta neurologii Akademii meditsinskikh nauk SSSR $i$ Instituta mozga. Tezisy dokladov, M. (Third Joint Scientific Conference of the Institute of Neurology of the Acad. of Medical Sciences USSR and of the Brain Institute. Theses of Papers, Moscow), 1948.

1327. Kulagin, N. "Concerning Death." Mir bozhii (God's World), 1900.

1328. " "Old Age and Death According to the Study of Naturalists" (Starost' $i$ smert' po izucheniiu estestvoispytatelie, M.), Moscow, 1907.

1329. KulakovsKaia, E. S. "Observations on the Sense of Taste and Smell of the Newborn." Zhurnal po izucheniiu rannego detskogo vozrasta (J. for Study of Early Childhood), 9(1): 15-20, 1929.

1330. Kul'tepina, O. S. "Activity of Stomach in Children of Nursing Age." Fiziologicheskii zhurnal SSSR (Physiological J. of the USSR), 39(4): 432-436, 1953.

1331. KulıabKo, B. V. "Microscopic Structure of Veins of the Heart in Different Ages and in Defects of the Heart. Rcport I." Arkhiv patologii (Archives of Pathology), (1): 62-71; "Report II." Ibid., (6): 20-29, 1947.

1332. Kunakov, K. A. "Embryonic Development of Nuclei of the Sixth and Seventh Cranial Nerves (Abducens and Facial) in Man." Sbornik; Ontogenez mozga, L. (Ontogenesis of the Brain, Leningrad), 1949, pp. 166-174.
1333. and IOFFE, F. I. "Embryonic Development of the Inferior Olivary Bodies in Man." Ibid., 1949, pp. 193-203.

1334. Kunevich, V. G. "Age Characteristics of Muscular Exertion and of the Tonic Reflexes." Materialy 1-i nauchnoi konferentsii po voprosam vozrastnoi morfologii $i$ fiziologii. Tezisy. Izd-vo Akademii pedagogicheskikh nauk RSFSR, M. (Data of the First Scientific Conference on Problems of Age-Associated Morphology and Physiology. Theses. State Publishing House of the Acad. of Pedagogical Sciences RSFSR, Moscow), 1952, pp. 84-85.

1335. Kuraev, A. I. "Protein Structure of Muscles at Rest and Active (Data on Problem of Principles of Muscular Work)" ( $O$ belkovom sostoianii myshts pokoinykh i deiatel'nykh (materialy $k$ voprosu ob istochnikakh myshechnoi raboty). Diss. SPb.), a dissertation, St. Petersburg, 1896.

1336. Kurbanaliev, D. S. "Alteration of Bone Marrow at Different Ages." Trudy kafedry gistologii Azerbaidzhanskogo med. in-ta Baku (Transactions of the Chair of Histology of the Azerbaidzhan med. in-ta, Baku), (1): 47-61, 1935.

1337. - "Characteristics of the Vascularization of the Brain (Changes of Elastic Fibers in Capillaries of the Brain at Different Ages). Ibid., (1): 77-80, 1935.

1338. Kurbatov, A. D., and Miniailo, D. D. "Effect of Age of Mated Swine on Ratio of the Sexes in Descendants." Vesinik $L G U$ (J. of the Leningrad State Univ.), (1): 57-63, 1954.

1339. Kurepina, M. M. "The Ontogenesis of the Optic Thalamus of Man." Trudy Instituta mozga. M., Medgiz (Transactions of the Brain Institute. Moscow. State Publishing House of Medical Lit.), (5): 199232, 1940.

1340. -Development of Fibrous Structures of Optic Thalamus in the Early and Middle Ontogenesis of Man." $U_{c h}$. zap. Moskouskogo gor. pedagogicheskogo in-ta (Annals of the Moscow Municipal Pedagogical Institute), 24(2): 209-219, 1953.

1341. - "Development of Fibrous Structures of the Optic Thalamus in the Late Ontogenesis of Man." Ibid., 24(2): 220251, 1953.

1342. KURK1N, P. I. "Morbidity Statistics for the Population of the Moscow District" 
(Statistika boleznennosti naseleniia Moskovskoi gubernii. Izd. 1903-1913 gg.), 1903-1913 editions.

1343. - "Birth Rate and Mortality in the Capitalistic Countries of Europe" (Rozhdaemost' i smertnost' $v$ kapitalisticheskikh stranakh Evropy, M.-L.), Moscow-Leningrad, 1938.

1344. Kurokhtina, T. P. "Study of Intensity of Restoration of Plasma Proteins in the Organism with the Aid of Methionine S35." Biokhimiia (Biochemistry), 19(1): 16-18, 1954.

1345. Kursanov, A. L., and Batiushrova, $\mathrm{K}$. "Effect of Enzymes in Leaves of Different Stages in Connection with Their Individual Development and the Total Development of the Plants." Ibid., 5(2): 188-197, 1940.

1346. Kursanov, A. L., and Kriukova, N. N. "Age Changes in the Tannins of Plants." Ibid., 6(3): 326-333, 1941.

1347. Kursanov, A. L., and VyskrebentSEva, E. I. "Gas Exchange of the Cavity Fluid of the Mulberry Silkworm in the Period of Pupal Development." Ibid., 18(3): 363370, 1953.

1348. Kustelian, M. A., and Olevi'kil, M. I. "Board Session of the All-Ukrainian Institute for Maternal and Child Welfare" (Ukr.: Vseukrains'kii Institut Okhmatditu do z'izdu Rad.). Profilaktichna meditsina (Prophylactic Medicine), (12): 34, 1934.

1349. Kustria, D. K. "Results of Rejuvenation by the Steinach Operation and the Voronov Operation." Fiziologicheskii zhurnal SSSR (Physiological J. of the USSR), 8(3-4): 127, 1925.

1350. Kutchak, E. N., and Ul'ianova, A. A. "Change of the Electro-Conductivity of the Skin of Man in the Ontogenesis." Ibid., 40(1): 82-85, 1954.

1351. Kutsenko, N. A., and Nechaeva, G. A. "Effect of Different Disorders of Muscle Innervation on the Content in It of Adenosine Triphosphoric Acid, Phosphocreatine, Glycogen, and Lactic Acid." Ibid., 39(6): 719-728, 1953.

1352. Kucherova, F. N. "Control of the Embryological Development of Animals by Treatment Through the Maternal Organism." Uspekhi sovremennoi biologii (Ad- vances in Contemporary Biology), 29(1): 145-158, 1950.

1353. Kuslev, N. E. "Problem of Old Age." Vrachebnaia gazeta (Medical Gazette), (22): 1547-1552, 1928.

1354. - "The Self-Observation of a Physician on Old Age." Kazanskii meditsinskii zhurnal (The Kazan Medical J.), (8): 1021-1025, 1937.

L

1355. Lavdovskll, M. D. "New Data for Histology, the History of Development, and Physiology of the Peripheral Nerves and Terminal Networks." Voenno-meditsinskii zhurnal (J. of Military Medicine), (11-12): -, 1884 and $(1,3,5:-, 1885$.

1356. LAVRENT'Ev, B. I. "Morphology of Sensory Innervation of the Internal Organs" (Morfologiia chuvstvitel'noi innervatsii vnutrennikh organov. Izd-vo Akademii meditsinskikh nauk, M.), Publ. House of the Acad. of Med. Sciences, Moscow, 1947.

1357. LavrovskiI. "Development of Blood Vessels and Nerves in Tail of Frog Tadpole." Zhurnal dlia normal'noi i patologicheskoi gistologii, farmakologii $i$ klinicheskoi meditsiny (J. of Normal and Pathological Histology, Pharmacology, and Clinical Medicine), 1: , 1870.

1358. Lagodin, P. F. "Pulse Frequency in Children and Juveniles." Standartnye osnovy fiziologicheskikh priznakov, M. (Normal Bases of Physiological Criteria). Moscow, 1935, pp. 19-23.

1359. Lagutina, I. N. "Change of Activity of the Central Nervous System in Old Age." (Izmenenie deiatel'nosti Ts NS pri starosti. Diss., Rostov-na Donu), a dissertation. Rostov-on-Don, 1940.

1360. Lazarev, P. P. "A Method for Determining the Terminal Age of Man." $D A \mathcal{N} S S S R$ ser. A (Reports of the Academy of Sciences USSR, series A), (10): , 1928.

1361. — , Kuper, L. M., and DubinSKaiA-Voskresenskaia, A. A. "Effect of Age on Adaptation Phenomena in Peripheral Vision." Ibid., (10): 161, 1928.

1362. Lazarev, P. P. "A Method for Determining the Age of a Person, Based on Study of the Sensitivity of the Eye." Ibid., (12): 1928. 
1363 "Conncction

Betwecn Length of Lifc and Length of Pregnancy." Ibid., (1): —, 1938.

1364. "Eifect of Agc on Function of the Nervous System and on People's Performancc." Ibid., (5): 52, 1933.

1365. Lazovskaia, A. S. "Experiments of Influcnce on Diffcrentiation of the Neurons in the Postembryonic Period." Biull. eksperimental'noi biologii $i$ meditsiny (Bulletin of lixperimental Biology and Medicine), 5(1): $41-42,1938$.

1366. Lazovskaia, L. N. "Respiration Age Changes in Blood Vessels." Ibid., 14(4): $46,1942$.

\section{7.} "Respiration Age Changes in Blood Vessels." Biokhimiia (Biochemistry), 8(4): 171-176, 1943.

1368. LazovskiI, IU, M. "Functional Morphology of the Stomach" (Funktsional'naia morfologiia zheludka. Izd.-vo Akademii meditsinskikh nauk SSSR, M.) Publ. House of Acad. of Med. Sciences USSR, Moscow, 1947.

1369. LazArenko, F. "Ein Beitrag zur Morphologie des Wachstums von embryonalen Nervengewcbe in vitro" (A Contribution to the Morphology of the Growth of Embryonic Nerve Tissue in vitro). Arch. $f$. experim. Zellforsch., 2(3): 555-590, 1931.

1370. Landa-Glaz, R. I. "Calcium and Potassium Content in the Brain of Human Embryos Depending on Their Age." Sovremennaia nevropatologiia, psikhiatriia $i$ psikhogigiena (Contemporary Neuropathology, Psychiatry, and Mental Health), 2(8): 135, 1934.

1371. "Potassium, Calcium, and Magnesium in Brain of Human Embryos Depending on Their Age." Trudy Instituta im. V. M. Bekhtereva po izucheniiu mozga, II, Fiziko-khimicheskie osnovy nervnoi deiatel'nosti, Biomedgiz, L. (Transactions of the V. M. Bekhterev Institute on Study of the Brain. II. Physico-Chemical Bases of Nervous Activity. Statc Publishing House of Biomedical Lit., Leningrad), 1935, p. 213.

1372. Landau, G. M. "Reaction of Erythrocyte Precipitation as Reactivity Index of a Child's Organism" (Reaktsiia osedaniia eritrotsitov kak pokazatel' reaktivnosti organizma rebenka. $S$ predisloviem prof. G. Speranskogo, Smolensk, Zapgiz), with forcword by Prof. G. Spcr- anskii, Smolensk, State Publishing Ilouse of the Institute of Dentistry, 1937.

1373. Larionov, V. F. "Tempcrature Factor and Postcmbryonic Dcvelopment of Chicks." Uch. zap. MGU (Annals of Moscow State Univ.), 43: 一, 1940.

1374. - "Agc Symptoms in Ducks and Their Use for Evaluation of Propagation." DAN SSSR (Reports of thc Acad. of Scicnces USSR), 93(3): 555-558, 1953. Referativnyi zhurnal, Biologiia (Abstract J.: Biology), (5): abstract 11822, 1955.

1375. Lauer, N. V. "Problcm of the Effect of Low Atmospheric Prcssure on the Electrocardiogram of the Newborn" (Ukr.: Do pitannia pro vpliv znizhenogo almosfernogo tisku na elektrokardiogramu novonarodzhenikh). Medichnii zhurnal AN URSR (Medical J. of the Acad. of Sciences, UkrSSR), IO(5): 1531-I538, (date omitted).

1376. "Role of Adaptation Reactions in Resistance of Newborn to Anoxia" (Pro rol' adaptatsiinikh reaktsii $v$ rezistentnosti novonarodzhenikh do anoksii). Ibid., 15: 23$38,1946$.

1377. "Problem of the Role of Carbohydrates in Resistance to Anoxia" (Do pitannia pro rol' uglevodiv u rezistentnosti do anoksii). Ibid., 16: 198-306, 1947.

1378. - " "Investigation of Liver Glycogen and Blood Sugar in Newborn at Hypoxia" (Ukr.: Doslidzhennia glikogenu pechinki ta tsukru krovi u novonarodzhenikh pri sipoksii). Ibid., 18(1): 90-101, 1948.

1379. - "Problem of Increased Rcsistance of Newborn to Anoxia." Konferentsiia po kislorodnoi nedostatochnosti organizma (lezisy dokladov), Kiev, AN USSR (Conference on Oxygen Deficiency of Organism (Theses of Reports). Kiev, Acad. of Sciences, UkrSSR), 1948, pp. 46-49.

1380. —. "Problem of the Role of Survival of the Respiratory Center in Increased Resistance of the Newborn to Anoxia." Biull. eksperimental'noi biologii $i$ meditsiny (Bulletin of Experimental Biology and Medicine), 27(1): 27-32, 1949.

1381. "Problem of Resistance of the Newborn to Oxygen Deficicncy. Hypoxia." Trudy konferentsii po probleme kislorodnoi nedostatochnosti organizma, Kiev, $A \mathcal{N}$ USSR (Transactions of the Confcrence on the Problem of Oxygen Deficiency of the 
Organism. Kiev, Acad. of Sciences, UkrSSR), 1949, pp. 84-86.

1382. "Study of Effect on Activity of the Respiratory Centcr of the Newborn in Acute Anoxia." Kislorodnaia terapiia i kislorodnaia nedostatochnost'. Kiev, AN URSR (Oxygen Therapy and Oxygen Deficiency. Kiev, Acad. of Sciences, UkrSSR), 1952, pp. $39-46$.

1383. - "Age Characteristics of Reactions on the Part of the Blood Pressure to Asphyxia." Ibid., 1952, pp. 47-52.

1384. "Pathomorphological Changes in the Brain During Hypoxia in Rabbits in the Early Pcriod of the Postnatal Ontogenesis." Trudy konferentsii po vozrasinym izmeneniiam obmena veshchesto $i$ reaktivnosti or ganizma, Kiev, AN USSR (Transactions of the Conference on Age Changes of Metabolism and Reactivity of the Organism. Kiev, Acad. of Sciences UkrSSR, 1951, pp. 200211.

1385. "Data on Effect on the Respiratory Center of the Newborn in Conditions of Anoxia." Konferentsiia po kislorodnoi terapii $i$ kislorodnoi nedostatochnosti. Tezisy dokladov. Kiev, AN USSR (Conference on Oxygen Therapy and Anoxia. Theses of papers. Kiev, Acad. of Sciences, UkrSSR), 1950 , p. 44.

1386. - "Stability of Respiratory Center to Anoxia in the Ontogenesis" (Pro stiikist' dikhal'nogo tsentra do anoksii v ontogenezi). Medichnii zhurnal, AN URSR (Medical J. of the Acad. of Sciences, UkrSSR), 19(1): 48$59,1949$.

1387. Lakhtina, E. M., Lukomskaia, M. M., Model', M. M., Popov, N. A., and Tolkachevskaia, N. F. "Problem of the Effect of the Central Nervous System on the Development of the Child. Preliminary Report." Neronaia reguliatsiia pitaniia, M. Medgiz (Nervous Regulation of Nutrition. Moscow, State Publishing House of Medical Lit.), 1933, pp. 3-9.

1388. Lakhtina, E. M., and Lukomskaia, M. M. "Functional Hemogram of Children up to One Year of Age with Different Indices in the Physical State." Sovetskaia pediatriia (Soviet Pediatrics), (10): 10-18, 1934.

1389. Lebedev, M. I. "Age and Functional Changes in Weight of Bones and Ligaments of the Tarsal Joint of Horse." Sb. rabot Leningradskogo veterinarnogo in-ta. Sel'khozgiz, L. (Collection of Works of the Leningrad Institute of Veterinary Medicine Farm Publ. House, Leningrad), (15): 200204, 1955.

1390. Levi, A., and Galler, F. "Physiology of Acclimatization to Altitude in Newborn Lambs." Sb. pod red. $K$. $M$. Bykova: Opyt izucheniia reguliatsii fiziologiches. kikh funktsii (Experiment of Studying Regulation of the Physiological Functions. K M. Bykov, editor), 1949.

1391. Levi-Gorinevskaia, E. G. "Characteristics of the Child Organism." Fizicheskoe vospitanie detei doshkol'nogo vozrasta. Tsentral'nyi nauch.-issled. in-t fizkul'tury, Uchpedgiz, M. (Physical Training of Children of Preschool Age. Central Scientific Research Institute of Physical Culture. State Educational and Pedagogical Publishing House, Moscow), 1942, pp. 14-31.

1392. Levin, S. L. "Characteristics of Conditioned Reflex Activity in Hypnotic State of Children." Fiziologicheskii zhurnal SSSR (Physiological J. of the USSR), 17(2): 196-206, 1934.

1393. - "Method of Developing Conditioned Reflexes for Study of Age Characteristics of the Higher Nervous Activity of Children." Voprosy pediatrii $i$ okhrany materinstva $i$ detstva (Problems of Pediatrics and Maternal and Child Welfare), 14(5-6): 45$47,1946$.

1394. Levina, M. IA. "Some Data Relative to the Structure and Development of the Umbilical Vessels of the Human Fetus." $D A \mathcal{N}$ SSSR (Reports of the Acad. of Sciences USSR), 89(1): 171-174, 1953.

1395. Levintova, S. E. "Problem of Al" lergic Reactions in Child Rheumatics." Pediatriia (Pediatrics), (4): 10-16, 1941.

1396. Levitus, E. L., and Gurevich, F. D. "Age Syndromes of the Heart of Children and Juveniles." Okhrana zdorov'ia detei $i$ podrostkov (Health Care of Children and Juveniles), (5-6): 60-70, 1933.

1397. - "Age Characteristics of the Auscultative Variants of the Heart Norm in Children and Adolescents. First Report." (Ukr.: Vikovi osoblivosti auskul'tativnikh variantiv normi sertsia $u$ ditei ta pidlitkiv. Pershe pividomlennia). Pitannia kliniki $i$ ozdorovlennia ditei $i$ pidlitkiv. Vid-vo in-ta OZDiP, Kharkiv (Problem of the Clinic and Health Care 
of Children and Adolescents. Publishing House of the Institute of Health Care of Children and Adolescents, Khar'kov), 1934, pp. 5-17.

1398. Levitus, E. L. Age Characteristics of the Cardiovascular System of Children (Ukr.: Vikovi osoblivosti serdtsevosudinnoi sistemi u ditei. Ukrains'kii in-t udoskonalcnnia likariv, v-vo "Mistetstvo," Kharkiv), Ukrainian Institute for Advanced Training of Physicians. "Championship" Publishing House, Khar'kov, 1938, 25 pp.

1399. Legun, A. F., and Molghanova, S. P., with the assistance of CHEGlieL'NITSKaiA, N. N., and FrolovaiA, A. I. "Daily Expenditure of Energy in School-Age Children (Ages 8-14)." Voprosy pitaniia (Problems in Nutrition), 4(4): 44-57, 1935.

1400. Legun, A. F., with the assistance of Chechel'Nitskaia, N. N. 'Daily Expenditure of Energy in Children 2-3 Years of Age." Ibid., 5(4): 108-119, 1936.

1401. Lezinava, A. S. "Certain Patterns of Tissue Development in the Ontogenesis." Trudy 5-go Vsesoiuznogo s'ezda anatomov, gistologov, $i$ embriologov., 1942. L. Medgiz (Transactions of the 5th All-Union Congress of Anatomists, Histologists, and Embryologists, 1942. Leningrad. State Publishing House of Medical Lit.), 1951, pp. 510-513.

1402. Leibson, R. "Ontogenetic Changes in Activity of Cholinesterase in Skeletal Muscle of Rabbit." Biull. eksperimental'noi biologii $i$ meditsiny (Bulletin of Experimental Biology and Medicine), 7(6): 522-525, 1939.

1403. - "Respiration of Erythrocytes in the Embryonic Period." Fiziologicheskii zhurnal SSSR (Physiological J. of the USSR), 28(6): 630-641, 1940.

1404. "Effect of Methylene Blue on Erythrocyte Respiration of the Growing Organism." Ibid., 29(3): 200-210, 1940.

1405. Leibson, L. G., and Leibson, R. S. "Nerve and Humoral Regulation of Blood Sugar Content in the Process of Ontogenesis. Report I. Blood Sugar Content in Chick Embryos and Chicks at an Early Agc." Izvestiia AN SSSR (Bulletin of the Academy of Sciences USSR), (2): 93, 1943.

1406. "Nerve and Humoral Regulation of the Blood Sugar Content in the Process of Ontogenesis. Report II. Effect of Introduction of Insulin, Adrenalin, and
Glucose on Blood Sugar Content in Chick Embryos." Ibid., (3): 176, 1943.

1407. Leibson, L. G. "Regulation of Blood Sugar Content in the Process of Embryogenesis." VII Vsesoiuznyi s'ezd fiziologov, biokhimikov i farmakologov. M., Medgiz (Seventh All-Union Congress of Physiologists, Biochemists, and Pharmacologists. Moscow, State Publishing House of Medical Literature), 1947, pp. 495-496.

1408. - "Nerve and Humoral Reaction of Blood Sugar Content in the Process of Ontogenesis." Fiziologicheskii zhurnal SSSR (Physiological J. of the USSR), 35(1): 114 $123,1949$.

1409. - "Glycogen Content in Liver of Chick Embryos on Different Days of Incubation." Ibid., 36(2): 191-202, 1950.

1410. "Nerve and Humoral Regulation of the Blood Sugar Content in the Process of Ontogenesis. Report IV. Further Data on the Effect of Ephedrine on Blood Sugar Content in Chick Embryos." Ibid., 36(6): 696-703, 1950.

1411. - "Effect of Insulin on Glycogen Content in Liver of Chick Embryos." Ibid., 37(3): 343-348, 1951.

1412. - "Effect of Ephedrine on Glycogen Content in Liver of Chick Embryos." Ibid., 38(1): 100-104, 1952.

1413. LeKAKH, A. B. "Reactivity of the Organism and Methods of Influence on It." Sbornik: VII Vsesoiuznyi s'ezd fiziologov, biokhimikov i farmakologiv, M. Medgiz (Collection: Seventh All-Union Congress of Physiologists, Biochemists, and Pharmacologists, Moscow. State Publishing House of Med. Lit., Moscow), 1947, pp. 9-10.

1414. Leonov, V. A. "Meningeal Permeability (Penetrability of the Hemato-Encephalitic Barrier) of Children." Russkaia klinika (Russian Clinic), (43): 658-678, 1927.

1415. - "Carbonic Anhydrase of the Blood in the Newborn." Izvestiia $A \mathcal{N}$ BSSR (Bulletin of the Acad. of Sciences, Belorussian SSR), (6): 167-175, 1948.

1416. Leontovicir, A. V. "Some Data on Brain Weight of Man of Different Ages in Biometric Treatment." Sb.: Starost'. Trudy konferentsii 17-19 dekabria $1938 \mathrm{~g}$. Kiev, $A \mathcal{N}$ USSR (Collection: Old Agc. Transac- 
tions of the Dec. 17-19, 1938 Confcrence, Kiev. Acad. of Sciences, UkrSSR), 1940, pp. 55-64.

1417. Leont'Ev, N. L. "Age Effect on Quality of Wood Pulp." Priroda (Naturc), (4): $53,1948$.

1418. Leont'eva, N. N. "Age Characteristics of Functional Properties of Skeletal Muscle of Children of School Age." Sb.: Trudy pervoi nauchnoi konferentsii po vozrastnoi morfologii i fiziologii, izd-vo Akademii pedagogicheskikh nauk RSFSR, M. (Collection: Transactions of the First Scientific Conference on AgeAssociated Morphology and Physiology. State Publ. House of the Acad. of PedagogiSciences, RSFSR, Moscow), 1954, pp. 224 230.

1419. "Problem of the Characteristics of Functional Properties of Skeletal Muscle of Children of School Age." Izvestiia Akademii pedagogicheskikh nauk RSFSR (Bulletin of the Acad. of Pedagogical Sciences, RSFSR), (60): 265-282, 1954.

1420. Lepeshinskaia, O. B. "Problem of Regeneration of Cells in the Animal Organism. Report 2. The Latest Data in the Area of Studying the Formation of Cells of Blood Islets from Vitelline Spheres of Chick Embryo." Arkhiv anatomii, gistologii $i$ embriologii (Archives of Anatomy, Histology and Embryology), 14(4): 639-645, 1935.

1421. "The Phylo- and Ontogenesis of the Cell." Pod znamenem marksizma (Under the Name of Marxism), (2): 177$191,1935$.

1422. - "Living Matter and the Cell. Report 4. Process of Development of Artificial Fertilization of Sturgeon Egg (Acipenser stellatus) and Yolk Change; Accumulation of Chromatin in Cells During Development of Embryo. (From the Cytological Division of the All-Union Institute of Experimental Medicine)." Arkhiv biologicheskikh nauk (Archives of Biological Sciences), 47(1): 105-130, 1937.

1423. - "Development of Life Processes in the Precellular Period." Izvestiia $A \mathcal{N}$ SSSR (Bulletin of the Acad. of Sciences USSR), (5): 85-101, 1950.

1424. and Kriukov, V. G. "Living Matter and the Problem of the Stage Factor. (Commemorative of the 80th Birthday of Prof. O. B. Lepeshinskii)." Vestnik $A$ N SSSR (J. of the Acad. of Sciences USSR), (9): 45-58, 1951 .
$1+425$. "Old Age and Its Control." Nauka $i$ zhizn (Science and Life), (7): 11-13, 1951.

1426. - "Life, Old Age, and Lontevity" (O zhizni, starosti $i$ dolgoletii. Lektsiia o-va znanii, izd-vo AN BSSR, Minsk). Lecture of the Scientific Socicty. State Publishing House of the Acad. of Scienccs, Belorussian SSR, Minsk, 1953.

1427. - - 'Problem of Longevity.' Rabotnitsa (The Factory Woman), (10): 27$29,1953$.

1428. "Physical Training and Struggle for Longevity." Sovetskii sport (Soviet Sport), Oct. 10, 1953.

1429. - - "Problem of Longevity" (Ukr.: Problema dovgolittia). Radians'ka zhinka (The Soviet Woman), (2): 14-15, 1954.

1430. LePESHKIN, V. V. "Uber physikalisch-chemische Ursachen des Todes" (On the Physical-Chemical Causes of Death). Biol. Centralb., 46: 480, 1926.

1431. Lesgaft, P. F. "Infection of the Outlet of the Stomach of the Newborn." Trudy o-va russkikh vrachei (Transactions of the Association of Russian Physicians), 1883.

1432. "School Types" (Anthropological Study) (Shkol'nye tipy. Antropologicheskii etiud. Izd-vo zhurn. "Russkoe bogatstvo" SPb), Publishing house of the journal "Russian Fortune," St. Petersburg, 1884, 124 pp.

1433. "Period of Puberty and Guidance of It." Izvestiia S.- Peterburgskoi biologicheskoi laboratorii. (Bulletin of the St. Petersburg Biological Laboratory), 2(2): 4555, 1898; 2(3): 48-60. 1898.

1434. "First Years of a Child's Life." Izvestiia S.-Peterburgskoi biologicheskoi laboratorii, $S P b$, iz-vo Soveta laboratorii pod red. $P$. Lesgafta (Bulletin of the St. Petersburg Biological Laboratory, St. Petersburg. Publishing house of the Soviet laboratory. P. Lesgaft, editor), 3(3): 46-67, 1899; 3(4): $30-46,1899 ; \mathrm{V}(1): 61-84,1901 ; 7(1): 34-78$, $1903 ; 8(4): 42-64,1907 ; 9(1): 36-77,1907$.

1435. - "General Anatomy of Organs of Plant Life." Izvestiia S.-Peterburgshoi biologicheskoi laboratorii, $\mathrm{SPb}$, (Bulletin of the St. Petersburg Biological Lab., St. Petersburg), 3(4): 47-70, 1899; 4(3): 12-41, 1900; 
$5(3): 73-97,1901 ; 6(1): 8-29,1902 ; 6(3)$ : $68,1903$.

1436. "Study of Joints and Muscles at the Present Time." Ibid., 7(4): $30-54,1905 ; 8(1): 66-93,1906 ; 8(2)$ : 68106, 1906.

1437. "Bases of Theoretical Anat. omy. Part 1" (Osnovy teoreticheskoi anatomii. Ch. 1, izd. 2-e ispravlennoe. SPb, Tovarishchestvo "Khudozhiki pechati"), Revised $2 \mathrm{~d}$ cdition, St. Petersburg. Artists of the Press Assoc., 12: 351, 1905.

1438. - "Family Training of the Child and Its Importance. School Types" Part 1, 5th edition. (Semeinoe vospitanie rebenka $i$ ego znachenie. Ch. 1, izd. 5. Shkol'nye tipy), p. 134; Part 2, 4th edition. "Basic Manifestations of the Child: Temperament, Type and Character" (Ch. 2, izd. 4. Osnoonye proiavelniia rebenka: temperament, tip i khraakter), pp. 135-247, Ibid., 1906.

1439. "General Anatomy of the Vascular System." Izvestiia S.-Peterburgskoi biologicheskoi laboratorii. SPb (Bulletin of the St. Petersburg Biological Lab., St. Petersburg), 10(1): 26-69, 1908.

1440. "General Anatomy of the Vascular System. Arterial System." Ibid., 10(2): 23-66, 1908.

1441. - "General Anatomy of the Vascular System. Development of the Blood Vessels and the Venous System." Ibid., 10(3): 19-66, 1908.

1442. - "Bases of Theoretical Anatomy." Part 2, Posthumous edition, 19091922 (Osnovy teoreticheskoi anatomii. Ch. 2, posmertnoe izdanie, 1909-1920. GIZ, Petrograd), Government Publishing House, Petrograd, v. 8: 410, 1922.

1443. "Handbook on the Anatomy of Man" (Rykovodstoo po anatomii cheloveka. Posmertnoe izdanie). Posthumous edition, 1927.

1444. Liberman, A. E., and Strel'tsova, N. 1. "Certain Characteristics of the EyePupil Component in the Orienting Reaction of Man." Zhurnal vysshei nervnoi deiatel'nosti (J. of Higher Nervous Activity), 2(6): 886893, 1952.

1445. Limıк, V. A. "Functional Changes of Hearing in Advanced Age." Starost' $i$ trudosposobnost'. Sbornik rabot NIVTE, L.
("Old Age and Work Capacity." Collection of Works of the "NIVTE" (see item 911 above) Leningrad), 1936, pp. 277-285.

1446. Lineva, V. A. "The Physiological Age of Femalc IIouse Flies, Musca domestica L. (Diptera, Muscidae)." Entomologicheskoi obozrenie (Entomological Review), 33: 162-173, 1953.

1447. Liozener, L. D., and Vorontsova, M. A. "Specific Age Properties of the Skin in the Process of the Metamorphosis of Anura." Biull. eksperimental'noi biologii $i$ meditsiny (Bulletin of Esperimental Biology and Medicine), 11(1): 32-34, 1941.

1448. Litovchenko, G. P. "Relation Between Protoplasm and Metaplasm in the Most Important Organs of White Rats Depending on Age" (Ukr.: Spivvidnoshennia mizh protoplazmoiu i metaplazmoiu u naivazhlivishikh organakh bilikh shchuriv zalezhno vid viku.) Uch. zap. Kharkiv'k'kogo derzh. un-tetu, Kharkiv (Annals of the Khar'kov State University, Khar'kov), 6-7: 263-272, 1936.

1449. - Many Age Changes in Histological Structure of the Organs of Animals" (Ukr.: Deiaki vikovi zmini gistologichnoi strukturi organiv tvarin). Pratsi nauk.-doslid. zoobiologichnogo in-tu Kharkivs'kogo derzh. un-tu, Kharkiv, Derzhmedvidav (Works of the Scientific-Research Zoobiological Institute of the Khar'kov State Univ. Khar'kov, State Publishing House of Medical Lit., 5: 102137, 1938.

1450. - "Capillarization of the Organs of the Animal Organism at Different Ages" (Ukr.: Kapiliarizatsiia or ganiv tvarinnogo organizmu v riznii vik). Ibid., 7: 91-114, 1938.

1451. - "Many Morphological Changes of the Skin of Animals in the Course of Life" (Ukr.: Pro deiaki morfologichni zmini shkiri tvarin na protizai zhittia). Ibid., 7: 115-126, 1938.

1452. "Problem of the Morphology of Change in Cartilage of Animals of Different Ages" (Ukr.: Do pitannia pro morfologichni zmini khriashcha tvarin u riznii vik). Ibid., 7: 127-134, 1938.

1453. "Age Changes of Thyroid Gland in White Rats." Ibid., (10-11): 95108, 1941 .

1454. "Age Changes of Thyroid Gland in Whitc Rats." Noukova khronika 
Kharkivs'kogo derzh. un-tetu. "Zbirnik anotatsii" (Scientific Chronicle of Khar'kov State Univ. Collection of Annotations), (3-4): 9-10, 1946.

1455. Lifshirs, I. G. "Effect of Different Factors on the E.S.R. in the Newborn." Sovetskaia pediatriia (Soviet Pediatrics), (11): 88, 1935.

1456. Lokshina, F. A., and Aleksandrova, K. P. "Insensible Perspiration of the Nursing Child in Connection with the State of Nutrition." Zhurnal po izucheniiu rannego rozrasta (J. for Study of Early Age), $10(9$ 10): $522,1930$.

1457. Lokshina, F. A. "Mitogenetic Radiation of the Blood of Children of an Early Age." Voprosy pediatrii (Problems of Pediatrics), (2-3): 62-67, 1940.

1458. Lokshina, E. S. "Hemato-Encephalitic Barrier of the Newborn from Normal Mothers and Those Poisoned with Alcohol." Gemato-entsefaliticheskii bar'er, Sb. rabot nauch.issled. in-ta fiziologii Narkomprosa RSFSR. M.-L., Biomedgiz ("Hemato-Encephalitic Barrier," a collection of works of the Scientific Research Institute of Physiology. The People's Commissariat of Public Education. RSFSR, Moscow-Leningrad. State Publishing House of Biomedical Lit.), 1935, pp. 193-202.

1459. Lomonosov, M. V. "Proliferation and Preservation of the Russian Nation" (O razmnozhenii $i$ sokhranenii rossiiskogo naroda), 1761.

1460. London, E. S., and Kryzhanovskir, I. I. "Struggle for Longevity" (Bor'ba za dolgorechnost'), Leningrad, 1924.

1461. Loskutov, A. M. "Data on Change of Morphological and Certain PhysicoChemical Properties of the Blood of Calves in Connection with Age and with Intestinal Catarrh." Sb. referatov nauchnoi konferentsii. Omskii gos. veterinaryni in-t, Omsk (Collection of Reports from the Scientific Conference. Omsk State Veterinary Institute, Omsk), 1: 777-781, 1940 .

1462. - "Change of the Morphological and Certain Physico-Chemical Properties of the Blood of Calves in Connection with Age." Trudy Omskogo veterinarnogo in-ta (Transactions of the Omsk Institute of Veterinary Medicine), 12: 51-66, 1940.

1463. Loknin, M. A. "Signs of Early Maturity and Late Maturity of Clover in
Early Phases of Development." Selektsiia ? semenovodstvo (Selection and Seed Growing), (2): $37,1937$.

1464. - "Biological Aging-One of the Main Causes of the Thinning Out of Red Clover." Agrobiologiia (Agricultural Biology), (4): 91-108, 1948.

1465. Lukomskaia, I. S. "Ways of Producing Fructose Diphosphate in Aerobic Conditions in Chick Leg Muscle Pulp." Biull. eksperimental'noi biologii $i$ meditsiny (Bulletin of Expcrimental Biology and Medicine), 40(3): 55-58, 1955.

1466. Lukomskaia M., Lakhtina, E., and Tolkachevskaia, ,N. "Problem of Age Characteristics of Protein, Fat, and Carbohydrate Exchange in Man. Report 1 (Preliminary). Protein, Fat, and Carbohydrate Exchange in Children from 1.5 Months to 1.5 Years of Age." Arkhiv biologicheskikh nauk (Archives of Biological Sciences), 39(1): 191-206, 1935 .

1467. Luk'ianov, V. S. "Preservation of Health and Work Capacity" ( $O$ sokhranenii $z$ dorov'ia $i$ rabotosposobnosti. Izd. 2-e, s predisloviem akad. K. M. Bykova, M., Medgiz). Second edition with foreword by $\mathrm{K}$. M. Bykov. Moscow, State Publishing House of Medical Lit., 1954.

1468. Lunts, A. M. "'Immortality' of Protista Obtained by Periodic Fission." Biologicheskii zhurnal (Biological J.), 4(6): 1086-1087, 1935.

1469. Lunt?, R. O. "The Nursing Child, Its Anatomical-Physiological Characteristics" (Grudnoi rebenok, ego anatomo-fiziologicheskie osobennosti. Biomedgiz, M.-L.). State Publishing House of Biomedical Lit., Moscow-Leningrad, 1930.

1470. -The Physiology and Dietetics of the Child" ( $O$ fiziologii $i$ dietetike rebenks. 5 izd., M.-L.). 5th edition. Moscow-Leningrad. 1935.

1471. Lutai, D. P. "Determination of Fluctuations in Heart Volume by the Roentgenokymographic Method in Child Rheumatics." Trudy gos. bal'neologicheskogo in-ta im. Stalina na kurorte Sochi-Matsesta. Krasnodar (Transactions of the Stalin State Balneological Institute at the Sochi-Matsest Health Resort, Krasnodar), 3-4: 207-122, 1951.

1472. L'vov, V. N. "Old Age and Death" (Starost' i smert', M.), Moscow, 1934. 
1473. L'vov, S. V. "Problem of Nitrogen Exchange in Elderly Persons. Quantitative and Qualitative Analysis of Urine in the Elderly and Certain Conclusions Made on the Basis of It." ( $\kappa$ voprosu ob azotistom obmene u starikov. Kolichestvennyi $i$ kachestvennyi analiz mochi u starikov $i$ nekotorye vyvody, sdelannye na osnovanii ego. Diss. na stepen' doktora meditsiny. Iz laboratorii kliniki S. P. Botkina, $\mathrm{SPb})$, a dissertation for the degree of doctor of medicinc. lirom the Laboratory of the S. P. Botkin Clinic, St. Petersburg, 1910.

1474. - "Study of Old Age. Experiment of Studying the Qualitative Side of Nitrogen Exchange in Middle and Old Age." Russkii vrach (Russian Physician), 9: $382,1910$.

1475. Lysenko, T. D. "Effect of the Thermal Factor on Duration of Phases of Plant Development." Trudy Azerbaidzhanskoi tsentral'noi opytno-selektsionnoi stantsii, Baku (Transactions of the Azerbaidzhan Central Experimental Selection Station, Baku), 1928.

1476. "Essentially What is the Hypothesis of the 'Wintering Ability' of Plants?"' Sel'skokhoziaistvennaia gazeta (The Farm Gazette), Dec. 7, 1929.

1477. "Problem of Regulating the Length of the Vegetation Period of Farm Plants." Biulleten' izrovizatsii (Bulletin of Vernalization), (1):, 1932.

1478. - "Is the Requirement of Photoperiods Inherent to the Nature of Farm Plants?" Ibid., (2-3): —, 1932.

1479. - "Basic Results of Work on Vernalization of Farm Plants." Ibid., (4): $-, 1932$.

1480. - "Theoretical Bases of Vernalization" (Teoreticheskie osnovy iarovizatsii. Sel'khozgiz, M.), Farm Publishing House, Moscow, 1936.

1481. Liubarskir, V. V. "As I. I. Mechnikov Taught How to Combat Old Age" (Kak uchil borot'sia so starost'iu I. I. Mechnikov. M.-L.), Moscow-Leningrad, 1927.

1482. Liuru, S. L. "Qualitative and Quantitative Investigation of Hearing in Children of School Age." Vrach (Physician), 20(39): 40, 1899.

1483. - "Function of the Hearing Apparatus in Those of School Age" (Funktsii slukhovogo apparata v shkol'nom vozraste. Diss. $\mathrm{SPb})$, a dissertation, St. Petersburg, 1899.
1484. Magaziner. "Diseases of the Eye at Diffcrent Ages. Drug zdraviia, Narodnovrachebnaia gazeta ( $A$ Fricnd of Health. The National-Medical Gazcttc), (48): 377-379, 1838.

1485. MAzo, R. E. "Characteristics of the Elcctrocardiogram of Healthy Children of Various Age Periods." Izvestiia $A \mathcal{N}$ BSSR (Bulletin of the Academy of Sciences, Belorussian SSR), 6: 177-188, 1948.

1486. Maizel', S. N. “Age Characteristics of the Structure of Nerve Elements of the Appendix." Trudy kafedry normal'noi anatomii Tashkentskogo med. in-ta (Transactions of the Chair of Normal Anatomy of the Tashkent Medical Institute), 1953, pp. 61-71.

1487. Matorov, F. P. "Conditioned Reflexes in Pups of Various Ages." Arkhiv biologicheskikh nauk (Archives of Biological Sciences), 21(3): 341-366, 1929.

1488. - - and VYRZHIKovski1, S. N. "Conditioned Rcflexes in Pups of Various Ages." Trudy fiziologicheskikh laboratorii akad. I. P. Pavlova, izd-vo Akademii meditsinskikh nauk SSSR, M. (Transactions of the I. P. Pavlov Physiological Laboratory. State Publishing House of the Acad. of Med. Sciences USSR, Moscow), 5: —, 1933.

1489. Makarevskaia, E. A. "AnatomicalPhysiological Characteristics of Leaves of the Mulberry Tree in Connection with Its Age." Doklady Vsesoiuznogo soveshchaniia po fiziologii rastenii, izd-vo AN SSSR (Reports of the All-Union Conference on the Physiology of Plants. State Publ. House of the Acad. of Sciences USSR), 4(2): - 1946.

1490. Makarova, E. I. "Fluctuations of the Amount of Carbonic Anhydrase Depending on the Day's Regimen and Its Daily Fluctuations in Blood of Children in the First Year of Lifc." Biull. eksperimental'noi biologii $i$ meditsiny (Bulletin of Experimental Biology and Medicine), 23(4): 300, 1947.

1491. Makevnin, G. IA. "Change of Titer of the Hetero-Agglutinins in Dogs in Connection with Age." Tezisy iubileinoi nauchnoi sessii instituta. Kubanskii gos. med. in- $t$, Krasnodar (Theses of the Jubilee Scientific Session of the Institute. Kubanskii State Med. Inst., Krasnodar), 1946, p. 48.

1492. Maksimov, N. A., and Mozhaeva, L. V. "Age Changes of the Colloidal- 
Chemical Properties of the Protoplasm of Plant Cells. I. Changes of Penctrability and of Viscosity of the Plasma in the Cells of Onion Scales and Cabbage Heads." D.A.Y SSSR (Reports of the Acad. of Sciences USSR), 42(5): 236-240, 1944.

1493. "Age Changes of the Colloidal-Chemical Properties of the Protoplasm of Plant Cells. II. Change of Penetrability and Viscosity in the Cells of Horsc Bcans and Oats." Ibid., 42(6): 29l-294, 1944.

1494. Maxsimovich, N. A. "Ulccrativc Lesions of the Large Intestine of Children in the Light of Macroscopic and Histological Study." Vrachebnoe delo (Medical Affairs), (10-11): 638-644, 1939.

1495. Maksimov (sic), N. A., and TuretSKAIA, R. KH. "Rooting of Potato Slips in Connection with the State of Their Age." Soretskaia botanika (Soviet Botany), 15(1): 33-36, 1947.

1496. Maksimovich, N. O., and Vigraizer, I. Z. "Two Cases of Isolated, Allergic Injuries of Kidneys of Children" (Ukr.: Dva vipadki izol'ovanikh alergichnikh urazhen' nirok $u$ ditei). Pediatriia, akusherstvo $i$ ginekologiia (Pediatrics, Obstetrics, and Gynecology), (1): 14-17, 1949.

1497. Malakhovskaia, D. B. "Study of Interaction of Unconditioned and Conditioned Plantar Reflex in Children." Trudy pervoi nauchnoi konferentsii po vozrastnoi morfologii i fiziologii, izd-vo Akademii pedagogicheskikh nauk RSFSR, M. (Transactions of the First Scientific Conference on Age-Associated Morphology and Physiology. Publishing House of the Acad. of Pedagogical Sciences RSFSR, Moscow), 1954, pp. 72-76.

1498. Malyzheva, E. S. "Motor, Secrctory, and Absorptive Functions of the Intestines and of the Growing Organism." Voprosy pediatrii $i$ okhrany materinstva $i$ detstva (Problems of Pediatrics and Maternal and Child Welfare), 15(2): 10-19, 1945.

1499. Manasevich, E. E. "Morphology of Blood of Working Elderly People.." Starost' itrudosposobnost'. Sb. rabot NIVTE, L. (Old Age and Work Capacity. Collection of works of the "NIVTE" (see item 911 above) Leningrad), 1936, pp. 213-215.

1500. Manina, A. A. "Age Changes of Tooth Pulp of Man." DAN SSSR (Reports of the Acad. of Sciences USSR), 87(3): $485-488,1952$.
1501. Manukian, G. K. "The Nuclcic Acids and Phospholipids of Rabbit Brain in the Ontogenesis." Ibid., 101(6): 1085$1088,1955$.

1502. Manukian, K. G. "The Phosphorus Exchange of Nucleic Acids and of Phospholipids of Rabbit Brain in the Ontogcnesis. Ibid., 102(3): 567-570, 1955.

1503. Margolin, G. S. "Certain Characteristics of the Clinic of Tumors of the Brain in People of Advanced Age." Trudy Smolenskogo gosudarstvennogo meditsinskogo instituta (Transactions of the Smolensk State Medical Institute), 2: 235-243, 1948.

1504. Maretskaia, M. F., and Orlova, A. P. "Dick Test and Vaccination Against Scarlet Fever for Children of Early Age." Zhurnal po izucheniiu rannego detskogo vozrasta (J. for Study of Early Childhood), 7(5): 385390, 1928.

1505. Mariupol'skaia, KH. L. "Osmotic Resistance of Erythrocytes in Blood of the Newborn and of Children of Nursing Age." Ibid., 9(3-4): 191-198, 1929.

1506. Markov, G. S., and Rogoza, M. L. "Age Dynamics of Parasite Fauna of the Common European (Grass) Frog." $D A \mathcal{N}$ SSSR (Reports of the Acad. of Sciences USSR), 93(3): 581-584, 1953.

1507. Markovina, O. N. "Age-Associated Development of Synovial Membrane of Capsule of the Coxofemoral Joint." Izvestiia Akademii pedagogicheskikh nauk RSFSR (Bulletin of the Academy of Pedagogical Sciences RSFSR), (47): 101-111, 1953. Referativnyi zhurnal, Biologiia (Abstract J., Biology), (1): abs. 1546, 1954.

1508. Markosian, A. A. "Change of Erythrocyte Precipitation Rate in Students of Classes I-IV in the Course of the School Day." Izvestiia Ibid., (47): 207-210, 1953. Ref.- Ibid., (4): abstract 5521, 1954.

1509. - "Fluctuation of the Erythrocyte Sedimentation Rate in Students 9-12 Years Old in the Course of the School Day." Izvestiia Ibid., (47): 211-218, 1953.

1510. - and Stromskaia, E. P. "Change of Blood Coagulation Time in Students 8-10 Years Old in the Course of the School Day." Ibid., (47): 219-221, 1953.

1511. Markosian, A. A., and Zinger, M. E. "Change of Blood Viscosity in Students 8-11 
Years Old in the Coursc of the School Day." Ibid., (47): 222-224, 1953.

1512. Markosian, A. A., and Alekseeva, T. E. "Change of Blood Sugar Content in Children 9-12 Years Old under the Effect of the School Day." Izvestiia Akad. nauk RSFSR (Bull. of the Acad. of Sciences RSFSR) (47): 225-227, 1953. Referativnyi zhurnal, Biologiia (Abstract J., Biology), (4): abs. 5521, 1954.

1513. Markosian, A. A., and Lomazova, K11. D. "Change of Blood Coagulation in Children 10-12 Years Old in the Course of the School Day." Ibid., (60): 201-208, 1954.

1514. Markosian, A. A. "Some Problems of Cortical Regulation of Blood Coagulation." Ibid., (60): 209-2 I2, 1954.

1515

"Problems of the Influence of the Cerebral Cortex on Change of Blood Coagulation in Students." Trudy pervoi nauchnoi konferentsii po vozrasinoi morfologii $i$ fiziologii, izd-vo Akademii pedagogicheskikh nauk RSFSR, M. (Transactions of the First Scientific Conference on Age-Associated Morphology and Physiology. State Publ. House of the Acad. of Pedagogical Sciences RSFSR, Moscow), 1954, pp. 77-86.

1516. Markushin, A. P. "Long Utilization of Horned Cattle." Trudy Saratouskogo zoovetinstituta (Transactions of the Saratov Institute of Zootechnics and Veterinary Medicine), 5: 5-20, 1954 .

1517. Martynov, V. "Physiological Degeneration of Muscle Fibers in Maturity and Old Age." Arkhiv anatomii, gistologii $i$ embriologii (Archives of Anatomy, Histology, and Embryology), 17(2-3): 220-232, 1937.

1518. Martynova, N. I. "Age-Associated Development of the Heart of Students According to Fluororoentgenography." Izvestiia Akademii pedagogicheskikh nauk RSFSR, $M$. (Bulletin of the Acad. of Pedagogical Sciences RSFSR, Moscow), (47): 17-62, 1953. Referativnyi zhurnal, Biologiia (Abstract J., Biology), (1): abstract 1511, 1954.

1519. "Electrocardiographic Indices of the Functional State of the Cardiovascular System in Students During Physisical Stress." Ibid. (Izvestiia. . .), (60): 143$170,1954$.

1520. Martyshev, F. G. "Effcct of Age of Carp Producers on the Economic Grade of Descendants." Sb.: Nauchania konferentsiia po voprosam znacheniia vozrasia pri razvedenii sel'skiolihoziaistvennykh zhivotnykh, M., izd-vo Timiriazevskoi s.-kh. akademii (Collection: Scicntific Conference on Problems of the Importance of Age in Breeding Farm Animals. Moscow. Publ. House of the Timiriazev Acadcmy of Agriculture), 1953, pp. 131-134.

1521. Marunikevic11, L. D. "Age-Associated Changes of Blood and Connective Tissue of Fowl." DAN SSSR (Reports of the Acad. of Scienccs USSR), 99(5): 841844, 1954.

1522. Martsinkovskil, B. I., and GaL'peRINA, E. I. "Problem of the Age Dynamics of Secretion of Chlorine." Sb. pod red. I. P. Razenkova " $K$ mekhanizmu reguliatsii deiatel'nosti pishchevaritel'nykh zhelez". M., izd-vo VIEM (Collection edited by I. P. Razenkov: Mechanism of Regulation of the Activity of the Digestive Glands. Moscow. Publ. House of the All-Union Institute of Experimental Medicine), 1937, pp. 455-462.

1523. Martsinkovskil, B. I. "Problem of Changes of the Secretory-Motor Function of the Stomach in Old Age." Materialy kliniki po vozrasinoi patofiziologii pod red. I. P. Razenkova i I. G. Gel'mana. VIEM, M. (Data of the Clinic on Age-Associated Pathophysiology, edited by I. P. Razenkov and I. G. Gel'man. All-Union Institute of Experimental Medicine, Moscow), 1937, pp. 17-32.

1524. - and Zhorova, KH. S. "Problem of Temperature Change of the Stomach at Time of Digestion." Ibid., 1937, pp. $40-43$.

1525. - "Problem of Heat Diffusion and Heat Regulation in Old Age." Ibid., 1937, pp. 142-159.

1526. MarchuK, P. D. "Conference on the Problem of Longevity" (Ukr.: Konferentsiia $z$ problemi dovgolittia). Visti AN URSR (Bulletin of the Acad. of Sciences UkrSSR), (I-2): 110-117, 1939.

1527. "Conference on the Problem of the Genesis of Old Age and Prophylaxis Against Premature Aging of the Organism." Vrachebnoe delo (Medical Affairs), (4): 273276, 1939; Medichnii zhurnal AN URSR (Medical J. of the Acad. of Sciences UkrSSR), 9(1): I61-168, 1939.

1528. - "Hydrophilous Test for Rabbits of Different Agc" (Ukr.: Gidrofll'na proba u krolikiv riznogo viku). Medichnii zhurnal AN URSR (Medical J. of the Acad. of Sciences UkrSSR), 10(1): 113-1 14, 1940. 
1529. Maslov, G. A. "Data on the Problem of the Morphology and Development of Blood Corpuscles"' (Materialy $k$ voprosu o morfologii $i$ razvitii krovianykh telets. Iz gistologicheskogo kabineta pri Khar'kovskom un-tete. Diss. na stepen' doktora meditsiny, s tablitsami. Khar'kov), from the Histological Dept. of Khar'kov University. Dissertation, with tables, for the degree of doctor of medicine. Khar'kov, 1896, p. 176.

1530. Maslov, M. S. "Uber die biologische Bedeutung des $\mathrm{P}$. für den wachsenden Organismus" (The Biological Significance of Phosphorus to the Growing Organism). Biochem. Zeitsch., 55: 45, 1913 and 56: 174, 1913.

1531. "Some Data on the Structure of Capillaries of Children in Connection with Constitution." Vrachebnoe delo (Medical Affairs), (24-25): -, 1943.

1532. "Bases for Instruction on the Child and Characteristics of Diseases that Inflict Him". (Osnovy ucheniia o rebenke $i$ ob osobennostiakh ego zabolevanii, izd-vo "Prakticheskaia meditsina" L.), "Practical Medicine" Publishing House, Leningrad, vols. 1 and 2, 1926; 2d edition, 1928; 3d edition, 1930.

1533. "The Endocrine System and Child Development." Vrachebnaia gazeta (Medical Gazette), (17): 1235-1244, (18): 1326-1334, and (19): 1407-1415, 1927.

1534. and TuR, A. F. "Disorders of Nutrition and Digestion in Children of Nursing Age" (Rasstroistva pitaniia $i$ pishchevareniia $u$ detei grudnogo vozrasta. M.-L., GIZ), Moscow-Leningrad, State Publishing House, 1928.

1535. "Physiology and Pathology of Digestion and Nutrition in Children of Nursing Age. Based on Data of Russian Literature, 1918-1927." Tsentral'nyi meditsinskii zhurnal (Central Medical J.), 3(4): 635-651, 1929.

1536. - "Hematopoiesis and Blood Composition in Children of Various Ages. Principles of Instruction Concerning the Child" (Krovetvorenie $i$ sostav krovi $u$ detei razlichnogo vozrasla. Osnovy ucheniia o rebenke. Rukovodstvo dlia vracher $i$ studentov), handbook for physicians and students, v. 2, 1932.

1537. "Tenth Anniversary (19251935) of the Leningrad Klara Tsetkin Scientific Institute of Maternal and Child Welfare." Sovetskii vrach (Soviet Physician), (17): 1396, 1935.
1538. "Methods and Perspectives of Pediatrics." Sovetskaia pediatriia (Soviet Pediatrics), (9): 4, 1935.

1539. Maslov, M., Tur, A., and Danilevich, M. "Handbook of Pediatrics" (Rukovodstvo po pediatrii, t. 1, pod red. zasluzh. deiatelia nauki prof. M. S. Maslova, Medgiz, L.), vol. 1, edited by the honored science worker Prof. M. S. Maslov. State Publ. House of Medical Lit., Leningrad, 1938.

1540. Maslov, M. S. "Reactivity of the Child Organism in the Light of Derangement of the Regulatory Mechanisms." Pediatriia (Pediatrics), (3): 3-11, 1946

1541. "Role of the Macroorganism and Its Reactivity at the Emergence and Liquidation of Disease." Sb. trudov Leningradskogo gos. pediatricheskogo med. in-ta, $L$. (Collection of Works of the Leningrad State Medical Institute of Pediatrics, Leningrad), 1947, pp. 15-30.

1542. Matveev, B. S. "Derivation of Teeth of Mammals According to the Data of the Ontogenesis." Trudy 5-go Vseukrainsskogo s'ezda anatomov, gistologov $i$ embriologov, Medgiz, L. (Transactions of the 5th AllUkrainian Congress of Anatomists, Histologists, and Embryologists. State Publishing House of Medical Lit., Leningrad). 1951, pp. 202-205.

1543. Matveev, N. S. "Change of Function and of Other Types of Reorganization of the Form and Function of Organs in the Ontogenesis." Zhurnal obshchei biologii (J. of General Biology), l(3): 371-396, 1940.

1544. Matveeva, S. I. "Certain Data on Local Development of an Intramural Nervous System." Voprosy morfologii, sb, 2, izd-vo Akademii meditsinskikh nauk SSSR, M. (Problems of Morphology, collection. State Publ. House of the Acad. of Med. Sciences USSR, Moscow), 2: 166-179, 1953; Referativnyi zhurnal, Biologiia (Abstract J., Biology), (1): abs. 1473, 1954.

1545. Makhin'кo, V. I. "Magnitude of Gas Exchange at Various Ages and Effect of Environmental Temperature on It" (Ukr.: Velichina gazoobminu $u$ riznomu vitsi $i$ vpliv na n'ogo temperaturi seredovishcha). Uch. zap. Kharkivs'kogo derzh. un-tetu, Kharkiv (Annals of Khar'kov State Univ., Khar'kov), 6-7: 329-340, 1936.

1546. "Age-Associated Changes in Magnitude of Gas Exchange of White Rats 
and Dependency of Thesc Changes on Environmental Tempcraturc" (Vozrasinye izmeneniia velichiny gazoobmena belykh krys i zavisimost' etikh izmenenii of temperatury sredy. Diss. na stepen' kandidata biologicheskikh nauk), dissertation for degree of candidate of biological scicnces, 1936.

1547. "Age Changes in Magnitude of Gas Exchange in White Rats and Dependency of These Changes on Environmcntal Tempcrature" (Ukr.: Vikovi zmini velichini gazoobminu $u$ bilikh shchuriv ta zalezhnist' tsikh zmin vid temperaturi otochennia). Pralsi nauk.-doslid. zoobiologichnogo in-tu Kharkivs'kogo derzh. un-tetu. Kharkiv, Derzhmedvidav (Works of the Scientific Research Institute of Zoobiology, Khar'kov State Univ., Khar'kov, State Publ. House of Med. Lit.), 5: 138-196, 1938.

1548 "Age Changes of the Coefficient of Fatigue" (Ukr.: Vikovi zmini koefitsienta sprats'ovuvaniia). Ibid., 7: 211234, 1938.

1549. - "Age Changes in Coefficient of Deterioration and Gas Exchange." Tezisy dokladov na konferentsii po voprosam spravnitel'noi biokhimii 4 7 maia $1939 \mathrm{~g}$., Kiev, AN USSR, Institut biokhimii AN USSR (Theses of Reports at the Conference on Problems of Comparative Biochemistry May 4-7, 1939, Kiev, Acad. of Sciences UkrSSR, Institute of Biochemistry, Acad. of Sciences UkrSSR), 1939, pp. 52-56.

1550. - "Many Age Characteristics of Animal Metabolism" (Ukr.: Pro deiaki vikovi osoblivosti obminu rechovin $u$ tvarin). 3-i Ukr. z'izd fiziologiv, biokhimikiv, farmakologiv, Dnipropetrous'k (Third Ukrainian Congress of Physiologists, Biochemists, and Pharmacologists, Dnepropetrovsk), 1939, p. 59.

1551. - and Stepanchenko, V. K. "Age Changes of Basal Metabolism in Guinea Pigs." Pratsi nauk.-doslid. zoobiologichnogo in-tu Kharkovs'kogo derzh. un-tetu, Kharkiv (Works of the Scientific Research Institute of Zoobiology, Khar'kov Statc Univ., Khar'kov), (10-11): 139-142, 1941.

1552. Макиin'ко, V. I. “Relationship Between Basal Metabolism and Nitrogen Exchange in Guinea Pigs at an Early Age." Uch. zap. Khar'kouskogo gos. unteta (Annals of Khar'kov State Univ.), v. 25; Trudy instituta biologii, Khar'kov, izd-vo KhGU (Transactions of the Institute of Biology. Publ. of the Khar'kov State Univ., Knar'kov), 12: 129 139, 1947.
1553. "Agc Changes of the Cocfficient of Utilization of Encrgy." Trudy konferentsii po vozrastnym izmeneniiam veshchestv $i$ reaktionosti organizma (1919). Kiev, AN USSR, Institut klinicheskoi fiziologii im. akademika A. A. Bogomol'tsa (Transactions of the Conference on Agc Changes of Substances and of Reactivity of the Organism (1949). Kiev, Acad. of Scicnces UkrSSR, A. A. Bogomolets Institutc of Clinical Physiology), 1951 , pp. 36-49.

1554. "Method of Investigating the Gas Exchangc of Bird Eggs and Small Animals." Uch. zap. (Annals) v. 53; Trudy nauch.-issled. in-la biologii Khar'kovskogo gos. un-teta (Transactions of the Scientific Rcsearch Institute of Biology of Khar'kov State Univ.), 1954, pp. 245-260.

1555. - and Serdiuk, E. E. "Data Contributory to the Physiology of Embryonic Development of Domestic Fowl. I. Relationship Between Rate of Growth and Intensity of Respiration of Duck Embryos During Incubation." Uch. zap. Khar'kouskogo gos. un-tela, Khar'kov (Annals of Khar'kov State University, Khar'kov) 53: 153-170, 1954.

1556. Макhin'ko, V. I., and Shevchenko, R. A. "Data Contributory to the Physiology of Embryonic Development of Domestic Fowl. II. Growth of Pigeon Embryos and Changes in Their Respiration During Incubation." Ibid., 53: 171-188, 1954.

1557. Makhin'ko, V. I., and Pashkova, A. A. "Data Contributory to the Physiology of Embryonic Development of Domestic Fowl. III. Phosphorus Exchange and Content of Nucleic Acids in Liver of Developing Duck Embryo." Uch. zap. Khar'kovskogo gos. un-teta, (Annals of Khar'kov State Univ., Khar'kov), v. 68; Trudy nauch.-issled. in-ta biologii i biologicheskogo $f$-ta (Transactions of Scientific Research Institute of Biology and Biological Pharmacotherapy), 24: 221-234, 1956.

1558. - and Stavitskaia, L. I. "Data Contributory to the Physiology of Embryonic Development of Domestic Fowl. IV. Change of Intensity of Respiration and Growth Rate of Certain Organs of Duck Embryo During Incubation." Uch. zap. $K h G U$ (Annals of Khar'kov State Univ.), v. 68; Trudy nauch.-issled in-ta biologii $i$ biologicheskogo f-ta (Transactions of the Scientific Research Institute of Biology and Biological Pharmacotherapy), 24: 235-244, 1956. 
1559. Makinn'ko, V. I., Kilaskin, V. V., and Shul'man, G. E. "Some Characteristics of Nitrogen Exchange in Advanced Old Age." Uch. zap. KhGU (Annals of Khar'kov State Univ.), v. 68; Trudy nauch.-issled. in-ta biologii $i$ biologicheskogo $f$-ta (Transactions of the Sci.-Res. Inst. of Biol. and Biological Pharmacotherapy), 24: 193-214, 1956.

1560. Maknovka, V. V., and Ias'kov, K. F. "Effect of Ultra-Short Waves on Intensity of Growth of Rabbit Litters." Problemy zhivotnovodstva (Problems of Animal Breeding), (2): 94-96, 1935.

1561. Medvedev, ZH. A. "Mechanisms of Age Changes of Protein Metabolism." Referaty dokladov nauch. konferentsii Moskouskoi s.-kh. akademii im. $K$. A. Timiriazeva (Reviews of Reports of the Scientific Research Conference of the Moscow K. A. Timiriazev Agricultural Academy), 16: 249-253, 1952.

1562. - "Problem of Self-Renovation and of Aging of Intracellular Proteins." Uspekhi souremennoi biologii (Advances in Contemporary Biology), 33: 202-215, 1952.

1563. "Prof. A. V. Nagornii's Theory on Aging of the Organism." Fiziologicheskii zhurnal SSSR (otdel "Kritika i bibliografiia") (Physiological J. of the USSR, "Criticism and Bibliography" section), 38(4): 523-529, 1952.

1564. - "Biochemical Principles of Growth, Aging, and Renovation of the Cell Forms of Living Matter." Uspekhi souremennoi biologii (Advances of Contemporary Biology), 25: 338-384, 1953.

1565. - "Process of Renovation and Changes of Nucleic Acids in the Organism." Ibid., 36(2;5): 161-178, 1953.

1566. "Role of the Nervous System in the Process of Aging of the Organism." Priroda (Nature), (3): 101-104, 1953.

1567. "Factors of Life Duration and Problem of a Prolongation of Life." Sb. materialov nauchnoi konferentsii po voprosam znacheniia vozrasta pri razvedenii s.-kh. zhivotnykh, M. Collection of Data of the Scientific Conference on Problems of the Importance of Growth in the Breeding of Farm Animals, Moscow), 1953, pp. 40-49.

1568. "Characteristics of Phosphorus Exchange of Nucleic Acids Formed in Various Periods of the Life of Plants." Sb. "Mechenye atomy 0 izuchenii pitaniia rastenii i primeneniia udobrenii." Izd-vo AN SSSR (Collection: Marked Atoms in Study of Nutrition of Plants and Use of Fertilizers. State Publ. House of the Acad. of Sciences USSR), 1955, pp. 61-69.

1569. - "Problems of Reproduction of Specificity of Proteins in Their Biosynthesis." Uspekhi souremennoi biologii (Advances in Contemporary Biology), 40(2,5): 159-176, 1953.

1570. "Nature of 'Age' Changes of Proteins of Yeast Culture." Uch. zap. KhGU (Annals of Khar'kov State Univ.), v. 68; Trudy nauch.-issled. in-ta biologii i biologicheskogo $f-t a$ (Transactions of Sci.-Res. Institute of Biology and Biological Pharmacotherapy), 24: 65-78, 1956 .

1571. Medvedeva, N. B. "Problem of Age Change of Protein Storage of Tissues and Effect of It on Thyroid and Sex Glands. Report I." (Ukr.: Do pitannia pro vikovi zmini bilkovogo skladu tkanin i pro vpliv na n'ogo shchitovidnoi i statevikh zalog. Povidomlennia 1. Medichnii zhurnal AN URSR (Medical J. of the Acad. of Sciences UkrSSR), 7(1): 197$212,1937$.

1572. "Age Changes of Protein Storage and Rejuvenating Effect of Hemolytic Serum" (Ukr.: Pro vikovi zmini bilkovogo skladu tkanin $i$ pro omolodzhuiuchii vpliv gamolitichnoi sirovatki). Ibid., 7(3): 793-800, 1937.

1573. - "Endocrine Effect on Age Changes of Protein and Nitrogef Storage of Tissues" (Ukr.: Pro endokrinni vplivi na vikovi zmini bilkovogo $i$ azotnogo skladu tkanin). Ibid., $7(4)$ : 1155-1165, 1937.

1574. "Effect of Thyroid and Sex Glands on Protein Deposit of Tissues of Old Animals" (Ukr.: Pro vpliv shchitovidnoi $i$ statevikh zaloz na bilkovii sklad tkanin starikh tvarin). Ibid., 8(2): 335-349, 1938.

1575. - "Age Changes in Protein Composition of the Organs" (Paper in English. Resumé.) Acta Medica URSS (Medical Transactions of the USSR), 2(4): 541-548, 1939.

1576. - "Protective Enzyme Against Proteins of Endocrine Glands in Serum of Old Animals" (Ukr.: Pro zakhisni fermenti proti bilkiv endokrinnikh zaloz u sirovattsi starikh tvarin). Medichnii zhurnal AN URSR (Medical J. of the Acad. of Sciences UkrSSR), 9(1): 7-25, 1939. 
1577. "Scnilc Change of Nitrogen and Protein Storagc of Tissues and Effect on Them of Changc of Cytotoxic Antireticular Serum" (Ukr.: Pro starechi zmini azotnogo $i$ bilkovogo skladu tkanin i pro vpliv na tsi zmini tsitoloksichnoi antiretikuliarnoi sirovatki). Ibid., 9(2): 325-338, 1939.

1578. "Changes in Water-Protein Composition of Tissucs in Old Age." Sb.: Starost', Trudy konferentsii 17-19 dekabria 1938 g., Kiev, AN USSR (Collcction: Old Age. Transactions of the Conference of Dec. 1719, 1938, Kiev, Acad. of Sciences UkrSSR), 1940, pp. 207-211.

1579. "Effect of Permanent Stimulation of the Physiological System of the Connective Tissue on Middle-Aged and Old Animals" (Ukr.: Pro vpliv trivaloi stimuliatsii fiziologichnoi sistemi spoluchnoi thanink na tvarin seredn'ogo viku i na tvarin starikh). Medichnii zhurnal $A \mathcal{N}$ URSR (Medical J. of the Acad. of Sciences UkrSSR), 10(1): 49-67, 1940.

1580. - "Distribution of Sulphur Components in Tissues and Age Changes in Amount and Distribution of Sulphur" (Ukr.: Pro rozpodil sirkovikh komponentiv po tkaninakh $i$ pro vikovi zmini $v$ kil'kosti $i$ rozpodili sirki). Ibid., 10(3): 793-801, 1940.

1581. "Many Changes in the Storage of Tissues of Old Animals and Effect on Them of Change of Serum Stimulation of the Physiological System of thc Connective Tissue" (Ukr.: Pro deiaki zmini $v$ skladi tkanin starikh tvarin i pro upliv na tsi zmini sirovatkovoi stimuliatsii fiziologichnoi sistemi spoluchnoi (kanini). Ibid., 12: 73-81, 1944.

1582. "Effect of Antireticular Serum on Senile Change in Composition of the Tissues." Arkhiv patologii (Archives of Pathology), (3): 28-32, 1947.

1583. "Age Change in Activity of the Physiological System of the Connective Tissue and Its Autocatalytic Regulation" (Ukr.: Pro vikovi zmini aktivnosti fiziologichnoi sistemi spoluchnoi tkanini ta ii avtokatalitichnu reguliatsiiu). Medichnii zhurnal AN URSR (Medical J. of the Acad. of Sciences UkrSSR), 20(4): 9-12, 1950.

1584. Medovikov, P. "The Physiology, Pathology, and Therapy of Childhood" (Fiziologiia, patologiia, i terapiia detskogo vozrasta. Gosizdat. Petrograd). State Publ. Mouse, Petrograd, 1921.

1585. Medovikov, P. S. "The Physiology, Pathology, and Therapy of the Digestion and
Nutrition of Childrcn of Nursing Age" (Fiziologiia, patologiia i terapiia pishchevareniia i pitaniia $u$ detei grudnogo vozrasta. Petrograd, GIZ), State Publ. Housc, Petrograd, 1921, p. 240 .

1586. - and Sorokina, E. Z. "Modification of Allcrgy Under the Effect of Radiant Encrgy." Pedialriia (Pediatrics), 13(2): $111-116,1929$

1587. Medovikov, P. S. "The Vegetative Nervous System of Children in Contemporary Pediatrics." Sovetskaia meditsina (Soviet Medicine), (6): 3-7, 1938.

1588. Medianik, I. A. "The Physiology of the Liver in Different Agc Periods." Uch. zap. L'vouskogo gos. un-lela im. Iv. Franka, ser. biol., Khar'kov (Annals of the L'vov Iv. Frank State Univ. Biological series, Khar'kov), 20(6): 73-102, 1952.

1589. Meister. V. A. "Problem of the UreaForming Function of the Liver" ( $K$ voprosu 0 mochevinoobrazovatel'noi funkstii pecheni, Kicv), Kiev, 1894.

1590. Melamed, E. A. "Reactivity of the Active Mescnchyma in the Newborn." Trudy In-ta akusherstva $i$ ginekologii Akademii meditsinskikh nauk SSSR, M. (Transactions of the Institute of Obstetrics and Gynecology of the Acad. of Med. Sciences USSR, Moscow), 1: $164-170,1948$.

1591. Men'shov, V. "Problem of the Assimilation of Food Fat in Old Age". ( $K$ voprosu ob usvoenii zhira pishchi o starcheskom vozraste. Diss., Spb.), a dissertation, St. Petersburg, 1893.

1592. Mepisashvili, I. "Age Changes in Number and Thickness of Muscle Fibers of the Frog." Biull. eksperimental'noi biologii $i$ meditsiny (Bulletin of Experimental Biology and Medicine), 10(1-2): 17-20, 1940.

1593. MERzon, F. S. "Course of Infections in Dystrophics as Manifestation of Hypoergia." Pedialriia (Pediatrics), (5): 44-47, 1947.

1594. "Course of Infections in Child Dystrophics as Manifestation of $\mathrm{Hy}$ poergia." Trudy VI Vsesoiuznogo s'ezd detskikh vrachei. M., Medgiz (Transactions of the Sixth All-Union Congress of Pediatricians, Moscow. State Publ. House of Medical Sciences), 1948, p. 276.

1595. MEsık, R. E. "Dynamics of Development of Inmunobiological Properties in 
Pups." Arkhiv biologicheskoi nauki (Archives of Biol. Sciences), 10(3): 43-46, 1905.

1596. - "Dynamics of the Development of Immunobiological Properties of Scrum and of the Cerebrospinal Fluid as Rcgards Normal Antibodies in Early Childhood." Sovetskaia pediatriia (Soviet Pediatrics), (2): 11-17, 1936.

1597. Metal'nikov, S. I. "The Causc of Old Age." Priroda (Nature), (September issue): 1079-1094, 1912.

1598. - "Reflexes in Unicellular Animals." Izvestiia Petrogradskikh biol. laboratorii (Bulletin of the Petrograd Biological Lab.), 15 (3-4): 5, 1916.

1599.

"Problem of Immortality in Contemporary Biology" (Problema bessmertiia $v$ souremennoi biologii), Petrograd, 1917.

1600. - "La lutta contre la mort" (The Struggle Against Death), Paris, 1937.

1601. Mechanikov, I. I. "Quelques remarques concernant l'embroylogie des $\mathrm{My}$ riapodes" (Some remarks concerning the embryology of the Myriapoda). Bull. Acad. de sciens de St. Petersb. (Bulletin of the Acad. of Sciences, St. Petersburg), 18: 231-233, 1873.

1602. - "Medical Age." Vestnik Evropy (Journal of Europe), 1: 232-283, 1874.

1603. - "Outline of Opinions on Human Nature." Ibid., 4: 537-560, 1877.

1604. - "Current Status of the Problem of Senile Atrophy." Russkii arkhiv patologii, klinicheskoi meditsiny $i$ bakteriologii (Russian Archives of Pathology, Clinical Medicine, and Bacteriology), 7: 210-225, 1899.

1605. "Milk Microbes and the Benefit to Health That They Confer (Yogurt)" (Molochnye mikroby i pol'za, prinosimaia imi zdorob'iu. (Iagurt). Perevod s frantsuzkogo L. Iu. Gdanskogo), a translation from the French by L. Iu., Gdanskii, 1901.

3606. "Etudes Biologiques sur la vieillesse, I-er mém. Sur le blanchiment des cheveux et des poils" (Biological Studies on Old Age, Report I. The Whitening of Hair and of Coats (of Animals)). Ann. de l'Inst. Pasteur, 15: 856-879, 1901.

1607. - "On the Process of Hair Turning White." Proc. Royal Soc. London, 69: 156,1901 .
1608. - "Sur la florc du corps humain" (On Flora of the Human Body). Wilde Lecture of 4-22-1901. Memoirs and Proceed., Manchester Literary and Philosophical Soc., 45(2): 1-38, 1901.

1609. - In collaboration with MESNIL and WEINBERG. "Etudes biologiques sur la vicillesse. II. Recherches sur la vic vieillesse des perroquets" (Biological Studies on Old Age. II. Researches into the Old Age of Parrots). Ann. de l'Inst. Pasteur, 16: 912-917, 1902.

1610. - "Etudes sur la nature humaine. Essai de philosophie optimiste. Paris" (Studies on Human Nature. Analysis of an Optimistic Philosophy. Paris), 1903, 405 pp.

1611. - "Les microbes intestinaux" (Intestinal Microbes). Bull. de l'Inst. Pasteur, 217-228, 265-285, 1903.

1612. - "La vieillesse." Paris, A. Davy (Old Age. Paris, A. Davy), 36 pp.; Rev. sci., (2): 65-100; 1904.

1613. - "Studies on the Nature of Man" (Etiudy o prirode cheloveka. M., izd-vo redaktsii shurnala "Nauchnoe slovo"), Moscow, Publishing House of printers of the journal "The Scientific Word," 1904; 2d. edition, supplemented with new chapters, 246 pp., 1905; 3d edition, 1908; 6th edition, Moscow-Petrograd, State Publishing House of Lit., 28 pp. (sic), 1923; 7th edition, State Publishing House of Lit., "b.g." (map?) 237 pp.; 10th edition, "DVU" (? Publ. of Far Eastern Ethnic Studies), 203 pp., 1930.

1614.1 - "Quelques remarques sur l'aigri"' (Some Remarks on Souring). Paris, A. Malone, 30 pp., 1906; American edition, New York, 16 pp., 1907.

1615. - "Studies on Optimism" (Etiudy optimizma. M., izd. "Nauchnoe slovo"), Moscow, publishers of the journal "The Scientific Word," 253 pp., 1907; 2d edition, revised and cnlarged, Moscow, same publishers, 282 pp., 1909; 3d edition, Moscow, 1913; 4th edition, revised and enlarged by the author, Moscow, same author as 1st and $2 \mathrm{~d}$ edition, 289 pp., 1917.

1616. "Essais optimistes" (Optimistical Studies), 1st edition, Paris, 438 pp.s 1907; English editions, 1908 and 1938.

1617. - " "Scientifically Soured Milk and Its Influence in Arresting Intcstinal Putrefaction." New York, 16 pp., 1907. 
1618 "The Prolongation of Life; Optimistic Studies." The English translation, edited by Chalmers Mitchell. London, W. Heinemann, 343 pp., 1907.

1619. - "Beitrage zu einer optinistischen Weltauffassung" (Contribution to an Optimistic World Concept), München, I. F. Lehınann, 309 pp., 1908.

1620. -. "Etudes sur la flore intestinale, Putrefaction intestinale. I-er mém." (Studies on Intestinal Flora. Intestinal Putrefaction. Report I). Ann. de l'Inst. Pasteur, 22: 929-955, 1908.

1621. - "Quelques remarques sur le lait aigri" (Some remarks on soured milk), Paris, E. Remy, 30 pp., 1908.

1622. - "Sur les microbes de la putrefaction intestinale" (On microbes of intestinal putrefaction), Paris, Compt. rend. Acad. Scien., 147: 579-581, 1908.

1623. - " "The Nature of Man. Studies in Optimistic Philosophy." The English translation, edited by P. Chalmers Mitchell, New York and London, G. P. Putnam's Sons, 309 pp., 1908.

1624. - "Etudes sur la flore intestinale. 2-e mem. Poisons intestinaux et scleroses" (Studies on intestinal flora. Report II. Intestinal Poisons and Scleroses). Ann. de l'Inst. Pasteur, 24: 755-770, 1910.

1625. "Weltanchauung und Medizin" (Vortrag im "Deutschen Frauenverein f. Krankenflege in den Kolonien" 1909 Sttgt.) (World Outlook and Medicine. A Lecture at the Women's Club for Nursing the Sick in the Colonies, Stuttgart, 1909). Disch. Revue, l: $56-70,1910$.

1626. Bactériothérapie intestinale (Intestinal Bacteriological Therapy). Library of Therapeutics (Bibliothéque de thérepeutique), Paris, 43 pp., 1912.

1627. Metcunikoff, E. "The Prolongation of Life." English transaltion, edited by P. Chalmers Mitchell. London, Putnam 343 pp., 1912.

1628. MeGunikov, I. I., in collaboration with Kolmann. "Sur quelques eassais de destintoxication intestinale. (Bactériothérapie intestinale) (On Some Studies of Intestinal Distintoxication. Intestinal Bacteriological Therapy). Ann. de 'Inst. Pasteur, 26: 825-85l, 1912.
1629. MEchnikov, 1. I. "Etudes sur la flore intestinale. $3 \mathrm{mém}$. Toxicité des sulfoconjugués de la serie aromatique" (Studies on Intestinal Flora. Report III. Toxicity of Sulphur Compounds of the Aromatic Series). Ann. de l'Inst. Pasteur, 27: 893-906, 1913.

1630. "Longevity." Entsiklopedicheskii slovar' Russkogo i bibliograficheskogo in-ta "Branal" (Encyclopedic Dictionary of the Russian and Bibliographical "Granat" Institute), 7th edition, Moscow, 17: 554-559, 1914.

1631. "Essais optimistes" (Optimistic Studies), 2d edition, Paris, A. Malone, 446 pp., 1914.

1632. - "Etudes sur la flore intestinale. 4 mém. les diarrhées des nourrissons" (Studies on Intestinal Flora. Report 4. The Diarrheas of Nursing Infants). Ann de l'Inst. Pasteur, 28: 89-120, 1914.

1633. "Vorzeitiges Altern und Stoffwechsel" (The Prematurely Old and Metabolism). Neue Freie Presse, (17875): 97$100,1914$.

1634. - "Interaction between Duration of Life and the Length of the Large Intestine." Priroda (Nature), (12): 1497-1504, 1915.

1635. - "La mort du papillon du murier. Un chapitre de thanatologie" (Death of the Mulberry Moth. A chapter of thanatology). Annal. Inst. Pasteur. 29, 1915.

1636. - "Etiudy o prirode cheloveka" (Studies on the Nature of Man). Gosizdat, M. (State Publ. House of Lit., Moscow), 1924.

1637. - "Forty Years of Searching for a Rational View of the World" (Sorok let iskanii ratsional'nogo mirovozzreniia, M., izd-vo "Nauchnoe slovo"), Moscow, the "Scientific Word" journal publishers, 291 pp., 1913; 2d edition, revised and enlarged, Moscow, same publishers, 333 pp., 1914; ... Moscow, State Publishing House, 280 pp., 1925.

1638. Mechnikova, O. N. "The Life of Il'ia Il'ich Mechnikov" (Zhizn' Il'i Il'icha Mechnikova), 1926.

1639. Meshcherskaia, K. A. "Adsorptive Properties of Tissues at Time of Embryonic Development." Arkhiv anatomii, gistologii $i$ embriologii (Archives of Anatomy, Histology, and Embryology), 18(2): 200-205, 1938. 
1640. Meshcherskala-SHTEinberG, K. A. "Toxicity of Potassium Ions in Various Periods of the Life of an Animal. Report I."' Biull. eksperimental'noi biologii $i$ meditsiny (Bulletin of Experimental Biology and Medicine), 7(2-3): 219-220, 1939.

1641. - "Toxicity of Potassium Ions in Various Periods of the Life of an Animal. Report II. Experiments with the ColdBlooded." Ibid., 9(1): 82-85, 1940.

1642. "Toxicity of Potassium Ions in Various Periods of the Life of an Animal. Report III. Experiments on Mice." Ibid., 9(6): $452-454,1940$.

1643. - "Toxicity of Potassium Ions in Various Periods of the Life of an Animal. Report IV. Prevention of Toxic Effect of Potassium Ions by Introduction of Camphor." Ibid., 9(6): 455-457, 1940.

1614. - "Immunity to Potassium Ions in Various Periods of Growth. Report V. Paranecrotic Alterations in Cardiac Muscle of Frog During Effect of an Excess of Potassium Ions." Ibid., 10(6): 441-442, 1940.

1645. Migina, N. I. "Complement Titer in Blood of Rheumatics." Materially kliniki po vorrastnoi patofiziologii, izd. VIEM, M. (Data of the Clinic on Growth Pathophysiology). Publication of the All-Union Institute of Experimental Med., Moscow), 1937, pp. 252-255.

1646. Mizrukhin, I. A. "Problem of Old Age. Report VI. Data of the Neuropsychiatric Investigation of Senile Persons" (Ukr.: Do problemi starosti. Povidomlennia VI. Materiali neuropsikhiatrichnogo doslidzhennia dovgorichnikh starikiv). Medichnii zhurnal $A \mathcal{N}$ URSR (Medical J. of the Acad. of Sciences UkrSSR), 8(1): 90-102, 1938.

1647. - "Study of the Psychology and Nervous System in the Aged." Sb.: Starost'. Trudy konferentsii 17-19 dekabria $1938 \mathrm{~g}$., Kiev, AN USSR (Collection: Old Age. Transactions of the Dec. 17-19, 1938. Conference, Kiev, Acad. of Sciences UkrSSR), 1940, pp. 369-381.

1648. Miller, M. V. "Fluctuations of Blood Enzymes in Children of Nursing Age." Trudy VI Vsesoiuznogo s'ezda detskikh vrachei. M., Medgiz (Transactions of the Sixth AllUnion Congress of Pediatricians. Moscow, State Publ. House of Medical Lit.), 1927, p. 628.
1649. Miller-Shabanova, M. V. "Blood Nitrogen in the Newborn." Voprosy pediatrii i okhrany materinstva $i$ detstva (Problems of Pediatrics and Maternal and Child Welfare), $7(6): 433-438,1935$.

1650. Miller, N. F. "Anatomical and Physiological Characteristics of the Child Organism" (Anatomicheskie i fiziologicheskie osobennosti detskogo organizma, M.), Moscow, 1885.

1651. MiL'man (M. S. Mühlmann). "Uber die Ursache des Alters" (On the Cause of Old Age), Wiesbaden, 1900.

1652. - "Growth of Lungs and Intestines in Man." Russkii arkhiv patologii, klinicheskoi meditsiny i bakteriologii. SPb (Russian Archives of Pathology, Clinical Medicine, and Bacteriology. St. Petersburg), 1900.

1653. "Change of the Ganglion Cells in Man." Zapiski Novorossiskogo o-va estestvoispytatelei (Journal of the New-Russian Society of Naturalists), 1901.

1654. "Das Wachstum und das Alters" (Growth and Old Age). Biologische Centralblatt, 1901.

1655. - "Weitere Untersuchungen über die Veränderungen der Nervenzellen in verschiedenen Alter" (Further researches into nerve-cell changes at various ages). Arch f. mikrosk. Anat. u. Entwickl., 58: 231-247, 1901.

1656. "Age Change of Nerve Cell Nucleoli. Preliminary Report (with 2 text figs.)." Khar'kouskii med. zhurnal, 10: 11, 1910; typography and lithography by $\mathbf{M}$. Zil'berberg and Son, Lithographers.

1657. - "Die Veränderungen der Nervenzellen in verschiedenen Alter beim Meerschweinchen" (Nerve Cell Changes at Different Ages in Guinea Pigs). Anatom. Anzeig, 19: -, 1910.

1658. " "Studien über den Bau und das Wachstum der Nervenzellen" (Studies on Structure and Growth of Nerve Cells). Arch. f. mikrosk. Anat., 76: -, 1911.

1659. "Problems of Physiological Pathology (Bioreductive Processes)." Izvestiia Azerbaidzhanskogo gos. un-teta (Bulletin of the Azerbaidzhan State Univ.), half-vol. 1: $-1922$. 
1660. "Ueber die Altersveränderungen des vegctativen Ncrvensystems" (Age Changes of the Vegetative Nervous System). Zeitschr. f. allgerneine Pathologie, 1925.

1661. - "Theory on Growth, Old Age, and Dcath." Iziestiia Azerbaidzhanskogo gos. un-teta, Baku (Bullctin of the Azerbaidzhan State Univ., Baku), 4-5: 1-122, 123-246, 1926.

1662. "Der Tod als normale Wachstumserscheinung" (Death as a Normal Phenomenon of Growth). Zeitschr. für Krebsforsch., 1926.

1663. - "Der Tod und die Konstitution" (Death and the Constitution). Ziegl. Beitr., 1926.

1664. "Problem of the Material Substrate of Death." Iubileinyi sbornik Odesskoi gorodskoi bol'nitsy (Jubilee Collection of the Odessa State Hospital), 1927.

1665. "Current Status of the Problem of the Cause of Aging of the Organism." Trudy kafedry gistologii Azerbaidzhanskogo med. in-ta pod red. prof. M. S. Mil'mana, Baku, Azerbaidzhanskii med. in-l. (Transactions of the Division of Histology of the Azerbaidzhan Medical Institute, edited by M. S. Mil'man (M. S. Mühlmann), Baku, Azerbaidzhan Medical Institute), 1: 5-12, 1935.

1666. "The Neurogenic Theory of Karyokinesis." Ibid., 1:-, 1935.

1667. - "Current Status of the Problem of the Reason for the Aging of the Organism." Ibid., 1: -, 1936.

1668. - "The Genesis of Old Age." Sb.: Starost'. Trudy konferentsii 17-19 dekabria $1938 \mathrm{~g}$. Kiev., AN USSR (Collection: Old Age. Transactions of the Dec. 17-19, 1938 Conference, Kiev, Acad. of Sciences UkrSSR), 1940, pp. 41-52.

1669. - "Growth and Aging of the Liver, Leukocytes, and Nerve Cells." Ibid., 1940, pp. 155-156.

1670. Miloserdova, A. I. "Picture of Bone Marrow of Children with Congenital Syphilis." Pedialriia (Pediatrics), (6): 11-17 1940.

1671. Minaeva, V. M. "Postnatal Development of the Upper Parietal Area of the Human Brain." Trudy Instituta mozga, Mcdgiz, M. (Transactions of the Brain Institute,
Publishing House of Med. Lit., Moscow), 6: 77-107, 1948.

1672. Minina, E. G., Igritskala, E. B., and Matskevicii, P. P. "Development of the Spike of the Wheat in Different Conditions of Soil Moisturc and Air Tempcrature from the Point of View of the Theory of Cyclic Aging and Rejuvenation." Tezisy dokladov soveshchaniia po fiziologii restenii. Izd-vo AN SSSR ('These of reports of the Council on the Physiology of Plants. State Publ. House of the Acad. of Sciences USSR), 1940.

1673. - Grammatikati, O. G., and Eremici, D. A. " "Age Changes of Plants in Various Conditions of Moisture of the Surrounding Medium." Doklady Vsesoiuznogo soveshchaniia po fiziologii restenii (Reports of the All-Union Conference on Plant Physiology), 2: $20-28,1945$.

1674. Minina, E. G., and Grammatikati, O. G. "Diagnosis of the Sugariness of Sugar Bect Roots According to the Age Morphological Criteria of the Lcaves." Biull. Moskovskogo o-va ispytatelei prirody, otd. biologii (Bulletin of the Moscow Society of Naturalists, Division of Biology), 51 2): 1-56, 1946.

1675. Minina, E. G. "Importance of Age to Determine Sex of Plants." DAN SSSR (Reports of the Acad. of Sciences USSR), 69(1): 93-96, 1949.

1676. Minkevich, M. A. "Child Sport." Sb. In-ta okhrany zdorov'ia detei i podrostkoo: Detskii sport, $M$. (Collection of the Institute for Health Care of Children and Juveniles: Child Sport. Moscow) 1935.

1677. Minker-Bogdanaova, E. T. "Phosphorus Exchange in Children 7-8 Years Old in Connection with Nutrition." Sb.: Vozrastnaia biokhimiia detei $i$ podrostkov. Institut okhrany zdorov'ia detei i podrostkov. $L$. (Collection: Growth Biochemistry of Children and Juveniles. Institutc for Health Care of Children and Juveniles, Leningrad), !: i2-84, 1935.

1678. Minkin, S. L. "Data on Clinical and Typc Anatomy of the Child of Nursing Age." Soretskaia pediatriia (Soviet Pediatrics), (8): 1 , 193;

1679. - and Svetlova, O. I. "Morphology of the Cardiovascular Systcm in the Ontogenesis." Trudy Khar'kovskogo gos. med. in-ta (Transactions of the Khar'kov State Institute of Medicine), 1935, pp. 1-26. 
1680. "Dimensions and Certain Problems of the Inner Architecture of the Heart in the Child of Nursing Age." Sovetskaia pediatriia (Soviet Pediatrics), (12): 1217, 1935.

1681. "Bounds of Position and of Form in Heart of Child of Nursing Age." Trudy Khar'kovskogo med. in-ta. Iubileinyi sbornik, Kiev ('Transactions of the Khar'kov Institute of Medicinc. Jubilee Collection, Kiev), 1936, pp. 11-26.

1682. Minkovsk11, M. "Modifications and Localization of the Reflex in Embryo, Child, and Adult." Zhurnal usobershenstvovaniia vrachei (J. for Training Physicians), (4): 352$358,1927$.

1683. Mirzolants, N. S. "The Conditioned, Orientated Reflex and Its Differentiation in the Child." Zhurnal vysshei nervnoi deiatel'nosti (J. of Higher Nervous Activity), $6(5): 616-619,1954$.

1684. Mitropolitanskaia, R. L. "Growth Changes in the Physiological Characteristics of Gray Caracul Lambs in Connection with an Analysis of Reasons for Reduced Vitality."

VIII Vsesoiuznyi s'ezd fiziologov, biokhimikov, farmakologov. Tezisy dokladov, M., izd-vo AN SSSR (Eighth All-Union Congress of Physiologists, Biochemists, and Pharmacologists. These of Reports, Moscow, publ. by Acad. of Science USSR), 1955, p. 420.

1685. Mittel'man, R. Ia. “Osmotic Stability of Erythrocytes in the Newborn." Voprosy pediatrii $i$ okhrany materinstva $i$ detstva (Problems of Pediatrics and Maternal and Child Welfare), 7(3): 230-235, 1935.

1686. Mikhallov, A. M. "Life and Death" (Zhizn' i smert', L.), Leningrad, 1926.

1687. Mikhallov, N. N. "Conversions of Substances with Phosphorus Content in Taraxacum kok-saghyz During the Ontogenesis." D.AN SSSR, novaia ser. (Reports of the Acad. of Sciences USST, new series), 59(9): 1657-1660, 1948.

1688. Mikhaleva, O. A. "Tone of Vagus Nerve Centers in Animals During the Ontogenesis." Fiziologicheskii zhurnal SSSR im. Sechenova (Sechenov Physiological J. of the USSR), 33(5): 547-556, 1947 (refs.).

1689. - - "Effect of Vagus Nerves on Functional Properties of the Heart in Newborn Animals (Rabbits and Dogs). Ibid., 36 4): 457-462, 1950.
1690. - "Reflex Regulation of the Cardiovascular Activity in Animals in the Process of Ontogenesis and Certain Data on the Mechanism of Indirect Depression of Cardiac Activity in Adult and Young Animals (Dogs and Pups).]' VIII Vsesoiuznyi s'ezd fisiologov, biokhimikov, farmakologov. Tezisy dokladov, izd, AN SSSK (Eighth All-Union Congress of Physiologists, Biochemists, and Pharmacologists. Theses of Reports, publ. by Acad. of Scienccs USSR), 1955, p. 422.

1691. Mikheev, M. "The Rennin Enzyme in Embryos." Trudy laboratorii po izucheniiu belka $i$ belkozogo obmena, izd-vo VASKhNIL, M. (Transactions of the Laboratory for Study of Protein and Protein Exchange, publ. by the All-Union Scientific Research Institute of Electrification and Mechanization of Agriculutre, Moscow), 3: - 1932.

1692. Mikhel'son. M. IA. "Conditioned Reflex Activity in Old Dog." Biull. VIEM (Bulletin of the All-Union Inst. of Experimental Medicine), (3-4): 40-41, 1934.

1693. Mitskevich, M. S. "Kole of Hormones in Process of Growth of the Organism." Sb.: Rost zhivotnykh, pod. red. S. Ia. Kaplanskogo i dr., Biomedgiz, M.-L. (Collection: Animal Growth. S. Ia. Kaplanskii et al., editors. State Publ. House of Biomedical Lit., Moscow-Leningrad), 1935, pp. 209-280.

1694. - "Derangements in Development of Chick Embryo as Result of Suppressing Function of the Embryonic Thyroid Gland with Thiouracil." DAN SSSR (Reports of the Acad. of Sciences USSR), 58(4): 693-696, 1947.

1695. - "Study of the Thyrotropic Potential of the Hypophysis of Mammal Embryos by the Method of Chorio-Allantoic Transplants." Ibid., 59(4): 821-824, 1948.

1696. -Activity of the Hypophysial-Thyroid Complex in the Embryogenesis of Mammals." Ibid., 59(5): 1033-1036, 1948.

1697. "Changes of Thyroid Gland of Guinca Pig Embryos at Time of Methylthiouracil Therapy Administered to the Pregnant Females." Ibid., 60(2): 325-328, 1948.

1698. - "Blocking Function of Thyroid Gland with Methylthiouracil in Embryos of Certain Fowl." Ibid., 69(2): 277$280,1949$.

1699. - "Time of Detecting Thyrotropic Effect of Hypophysis in Human Em- 
bryo and Certain Farm Animals." Ibid., 70(1): 165, 1950.

1700. "Activity of HypophysialThyroid Complex in Embryogencsis of Birds and Mammals." Trudy V V'sesoiuznogo s'ezda anatomov, gistologov, i embriologov, Medgiz, L. (Transactions of the Fifth All-Union Congress of Anatomists, Histologists, and Embryologists. Statc Publishing House of Med. Lit., Leningrad), 1951, p. 678.

1701. - "Study of Endocrinc Systcm in Embryos and Lambs of Gray Caracul Sheep. Report I. Thyroid, Thymus, and Sex Glands." Trudy Instituta morfologii zhivotnykh im. Severtsova $A \mathcal{N}$ SSSR, M.-L. (Transactions of the Severtsov Institute of Animal Morphology. Acad. of Sciences USSR, Moscow-Leningrad), 7: 207, 1952.

1702. - and MamUL', IA. V. "Determining Beginning of Function of Thyroid Gland in Embryos of Fowl and Mammals by Means of Radioactive Iodine (I1s1)." D.AN SSSR (Rcports of the Acad. of Sciences USSR), 88(4): 733, 1953.

1703. Mitskevich, M. S. "Accumulation of Radioactive Iodine (I131) of Embryonic Thyroid Gland in Conditions of Varied Functional State of Central Nervous System." Zhurnal obshchei biologii (J. of General Biology), 15(2): 115-127, 1954.

1704. Mogrla, M. T. "Problem of the Restoration of the Nervous System of Adult Organism." Medichnii zhurnal AN URSR (Medical J. of the Acad. of Sciences UkrSSR), 9(4): 1119-1126, 1939.

1705. Mogila, T. "Age-Associated Changes of Fat Body of Worker Bees (Apis mellifera L. and Apis mellifera remiper G.)." Biull. eksperimental'noi biologii i meditsiny (Bulletin of Experimental Biology and Medicine), 3(5): 492-494, 1937.

1706. Mogilevskir, M. Sh., and Kogan, L. S. "Hyaluronidase Activity of Testicles Depending on Age of Animals." Voprosy meditsinskoi khimii, izd-vo Akademii meditsinskikh nauk SSSR, M. (Problems of Medical Chemistry, publ. by Acad. of Med. Sciences USSR, Moscow), 2: 130-133, 1950.

1707. Moarl'NitskiI, B. N. "Problem of Morphological Changes of Nervous System in Old Age." Sb.: Starost'. Trudy konferentsii 17-19 dekabria $1938 \mathrm{~g}$. , Kiev, AN USSR (Collection: Old Aze. Transactions of the Dec. 17-19, 1938 Conference, Kicv, Acad. of Scienccs USSR), 1910, pp. 73-80.
1708. Model', L. M., Sidel'nikova, E. F., and Tsitovskaia, Ts. I. "Data on Agc Biochemistry of Children." Zhurnal okhrany zdorov'ia detei i podrostkov ( $\mathrm{J}$. for Health Care of Children and Juveniles), (5): - 1933.

1709. Model', L. M., Shutova, A. A. Parolkova, V. A., and Kocilegina, V. V. "Data on Age Biochcmistry of Children. Report I. Charactcristics of Urine of Preschool-Age Children." Sovetskaia pediatriia (Soviet Pediatrics), (5): 17, 1934.

1710. Model', M. M. "Characteristics of Sensory System in the Newborn." Zhurnal po izucheniiu rannego detskogo vozrasta (J. for Study of Early Childhood), 11(1): 7-15, 1931.

1711 and Kasatkin, N. I. "Certain Data on Conditioned Reflex Activity in Child Hydrocephalids." Kronicheskaia gidrotsefaliia v rannem detskom vozraste. M., Biomedgiz (Chronic Hydrocephalus in Early Childhood. Moscow, State Publ. House of Biomedical Lit.), 1936, pp. 75-86.

1712. Model', M. M. "Age-Associated Charactcristics of Septic-Toxic Diseases of Nervous System in Children." Referaty nauch.-issled. rabot Akademii meditsinskikh nauk SSSR, klinicheskie nauki, M. (Reviews of the Sci.-Res. Work of the Acad. of Med. Sciences USSR. Clinical Sciences, Moscow), (5): 6-7, 1948.

1713. Molseev, E. A. "Study of Changes in Elastic Properties of Rabbit Aorta in Connection with Age and With Experimental Atherosclerosis." Arkhiv biologicheskikh nauk (Archives of Biological Sciences), 26(1-3): 149-160, 1926.

1714. Molseev, A. I. "Senile Changes in Tendons." Trudy soedinitel'nykh zasedanii Petrogradskogo $i$ Moskouskogo obhchesto patologii (Transactions of the Joint Session of the Petrograd and Moscow Pathology Societies), 1923.

1715. MoLotkovskir, G. Kh. "Lengthening the Life of Certain Annual Plants Through Transplantation." D.AN SSSR (Reports of the Acad. of Sciences, USSR), 71(6): 1950.

1716. Molocilek, A. I. "Histogenesis of the Nervous System of Man." Anatomicheskie i gistostrukturnye osobennosti detskogo vozrasta, M. (The Anatomical and Histostructural Characteristics of Childhood. Moscow) 1936, pp. 329-347. 
1717. Molchanov, V. I. "Physiological Data on Childhood" (Fiziologicheskie dannye detskoge vozrasta. M.), Moscow, 1921.

1718. - "N. F. Filatov's Hundredth Anniversary, 1847-1947" (N. F. Filatov. $K$ stoletiiu so dnia rozhdeniia-1847-1947. M.) Moscow, 1947.

1719. Dombrovskaia, Iu. F., and Lebedeva, D. D. "Preliminary Instruction Concerning Disease of Childhood" (Propedevtika detskikh boleznei. M.), Moscow, 1952.

1720. Molochanov, S. G. "Blood Picture of Healthy Turkey Hens in Connection with Sex, Age, Breed, the Seasonal Factor, and Productivity" (Kartina krovi zdorovykh indeek v sviazi s polom, vozrastom, porodoi, sezonnost'iu $i$ produktivnost'iu. Avtoref. kand. diss.), Author's own abstract of his Candidate's dissertation, 1950.

1721. Molchanova, O. P., Porolkova, V. A., KocheglNa, V. V., with participation of M. L. Shkral'. "Study of Nitrogen Exchange in Children of School Age When Administered Different Dosages of Protein." Voprosy pitaniia (Problems in Nutrition), 4(3): 1-12, 1935.

1722. Molchanova, O. P., Porolkova, V. A., Kochegina, V. V., Polteva, IU. K., Gube, A. M., and GrinberG, M. E. "Study of Nitrogen Exchange and of Protein and Fat Assimilation in Children at Age 8-10 When Given Different Dosages of Protein and Fat." Ibid., 4(4): 30-43, 1935.

1723. Molchanova, O. P., Ivenskaia, I. M., Ryskina, E. B., and Polteva, Iu. K. "Problem of Protein, Fat, and Carbohydrate Norms in Nutrition of Children One-Half to Three Years Old." Ibid., 5(4): 103-108, 1936.

1724. Molchanova, O. P. "Nutrition Norms for Different Occupation and Age Groups." Acta Medica URSS (USSR Medical Reports), 2(4): 638-643, 1939.

1725. - "Calcium and Phosphorus Balance in Children of Different Ages.' Voprosy pitaniia (Problems in Nutrition), 10(1): 13-18, 1941.

1726. - "Role of Protein and of Mineral Substances in Nutrition of Children." Trudy VI Vsesoiuznogo s'ezda detskikh vrachei, M., Medgiz (Transactions of the Sixth AllUnion Congress of Pediatricians, Moscow. State Publ. House of Med. Lit.), 1948, p. 83.
1727. Morachevskata, E. V. "Innervation Mechanisms of Intestinal Motoricity in the Ontogenesis." Fiziologicheskii zhurnal SSSR (Physiological J. of the USSR), 30(6): 681-687, 688-694, 1941.

1728. "Derangement of Nerve Mechanisms for Regulation of Hematopoietic System During Dysentery Intoxication of Pups of Early Age." Arkhio biologicheskikh nauk (Archives of Biological Sciences) 62(3): 60, 1941.

1729. "Characteristics of Motor Activity of Intestines in Different Age Periods." Fiziologicheskii zhurnal SSSR (Physiological J. of the USSR), 39(4): 437-441, 1953.

1730. Morgulis, B. O. "Pubertas praccox" (Premature Puberty). Klinicheskaia meditsina (Clinical Medicine), (24): —, 1927.

1731. MoRev, V. I. "Characteristics of Acidosis at Intestinal Poisoning of Nursing Infants." Sovetskaia pediatriia (Soviet Pediatrics), (3): 3, 1936.

1732. Moreva, E. V. "Pharmacological Analysis of Posthumous. Stiffening of Skeletal Muscle (Effect of Sodium Azide and Fluoride on the Rate of Rigor Mortis)." Biull. eksperimental'noi biologii $i$ meditsinskii (Bulletin of Experimental Biology and Medicine), 38(10): $54-55,1954$.

1733. Morozov, B. D. "Study of Regeneration in Adult Mammals by a Method of Tissue Cultures." Arkhiv biologicheskikh nauk (Archives of Biological Sciences), 39(1): 87100, 1935.

1734. Mosiagina, E. N. "Effect of Injections of So-Called Stimulant Preparations on Immunobiological State of the Organism." Sovetskaia pediatriia (Soviet Pediatrics), (8): 16-22, 1936.

1735. Motylianskala, R. E. "Importance of Medical Investigations in Determining Stress Standards for Juvenile Sport Competitions." Teoriia $i$ praktika fizicheskioi kul'tury (Theory and Practice of Physical Culture), (10): 755-763, 1951.

1736. "Importance of Data of Medical Observation in Planning Pursuits for Boys and Girls in Different Typcs of Sports." Vrachebnyi kontrol' $v$ protsesse sportiunogo soiershenstvovaniia. M. (Medical Control in Process of Improving Sports. Moscow), 1952, pp. 68-75. 
1737. Mosinov, B. S. "Ontogenesis and Photoperiodism in Plants." DAN SSSR (Reports of Acad. of Acad. of Scienccs. USSR), 22(7): 465-468, 1939.

1738. Mosnkov, E. A. "Scasonal and Agc Changes in Functions of Thyroid Gland of llorned Cattlc" (Sezonnye i vozrastnye izmeneniia funktsii shchitovidnoi zhelezy krupnogo rogatogo skots. Avtoref. diss. kand. biol. nauk, in-t zoologii AY USSK, Kicv), Author's own abstract of his dissertation for candidatc of biological sciences, Institute of Zoology, Acad. of Sciences USSR, Kicv, 1935.

1739. MUganlinskaia, D. I. "Calcium and Inorganic Phosphorus Content in Blood of Calves Made Deficient in Vitamin A." D.AN Azerbaidzhan skoi SSR (Reports of the Acad. of Sciences of the Azerbaidzhan SSR) (4): 177-179, 1949.

1740. Muromtsev, S. N. "Life Cycle of Bacteria." Zhurnal obshcheibiologii (J. of General Biology), (4): 296-312, 1953.

1741. MURskII, L. I. "Electrocardiogram of Child Heart with Thoracic Derivations." Trudy Mariiskogo gos. pedagogicheskogo in-ta.

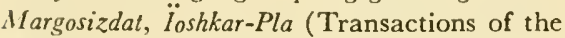
Mari State Pedagogical Institute, the Mari State Publishing House, İoshkar-Ola, 7: 1223, 115-122, 1948.

1742. - "A Child's Electrocardiogram." Trudy Mariiskogo gos. pedagogicheskogo in-ta (Transactions of the Mari State Pedagogical Institute), 7: 107-113, 1948.

1743. "Electrocardiogram of Children During Physical Stress." Ibid., 7: 123$126,1948$.

1744. and Maraeva, L. A. "Problem of Electrical Indices in the Child Heart." Ibid., 7: 129-134, 1948.

1745. Murtazi, F. F. "Topography of Assumed Area of Branchial Anlage in the Stage of Medullar Lamina of Axolotl." Biull. eksperimental'noi biologii $i$ meditsiny (Bulletin of Experimental Biology and Medicine), 6(1): 80-82, 1938.

1746. "Regeneration of External Gills and Their Rudiments in Axolotl at Time of Ontogenesis." Ibid., 6(3): 268-270, 1938،

1747. Musina, Sh. V. "Role of Medicamentous Slcep and Age of Recipient in Skin Homoplasty of Rats." DAN SSSR (Reports of the Acad. of Scienccs USSR), 84(5): 10831092, 1952.

1748. Mutalimov, B. "Modification of Ncuroglia of Central Vegetative Ncrvous System at Diffcrent Ages." Trudy kafedry gistologii Azerbaidzhanskogo med. in-la, Baku (Transactions of the Chair of Histology of the Azcrbaidzhan Mcdical Institute, Baku), (1): 42-46, 1935.

1749. Mutalimov, B. A. "Modification of Neuroglia at Different Ages of Man." Sb.: Starost'. Trudy konferentsii 17-19 dekabria 19.38 g., izd. AN USSR (Collection: Old Agc. Transactions of the Conference Dec. 17-19, 1938. Publ. by the Acad. of Scienccs UkrSSR), 1939, pp. 111-115.

1750. - "Modification of the Neuroglia at Different Ages of Man." Ibid., Kiev, 1940 (sic), pp. 111-114.

1751. Mukhin, V. G. "Indices of Temperature, Pulse, Respiration, and the Blood Picture in Horses of Varied Age." Uch. zap. Kazanskogo zoovetinstituta (Annals of the Kazan Zooveterinary Institute), 59: - 1952.

1752. Muкhis, V. I. "Biochemical Changes in the Body of Chinese Oak Silkworm Throughout Its Individual Development." Itogovaia studencheskaia nauchnaia konferentsiia Khar'kouskogo gos. un-teta. Tezisy dokladov Khar'kovskogo gos. un-leta (All-Student Scientific Conferencc of the Khar'kov State Univ. Theses of Reports of the Khar'kov State Univ.), 1952, 00. 204-206.

1753. MyL'NiKova, L. I. “Age Characteristics of Resistance of White Rats to the Analgesics 'Fenadok' (phenadesoxycorticosterone?) and Thecodine (Hydroxycodeine $\mathrm{Hy}$ drochloride)." I-ia Ural'skaia konferentsiia fiziologov, biokhimikov $i$ farmakologov 5-8 iiunia $1956 \mathrm{~g}$. Tezisv dokladov, Sverdlovsk (First Ural Conference of Physiologists, Biochemists, and Pharmacologists, June 5-8, 1956. Theses of Reports, Sverdlovsk), 1956, p. 41.

\section{$\mathrm{N}$}

1754. Navashin, M. S. "The Hereditary Factor and Variability as Stages of a Single Process of Development." Uch. zap. Moskovskogo gos. un-teta (Annals of the Moscow State Univ.), 4: 266-272, 1935.

1755. Nagornyi, A. V. "Life, Old Age, and Death" (Zhizn', starost' $i$ smert'. Gosizdat Ukrainy) State Publishing House of the Ukraine, Odessa, 1923. 
1756. - "Life, Old Age, and Death" (Zhizn', starost' $i$ smert'. Derzh. vid-tvo Ukraini), State Publ. House of the Ukraine, Khar'kov, 1923, 120 pp.

1757. "Problem of Bound Water in Live and Dead Organisms." Uch. zap. Narkompros USSR, Khar'kov (Annals of The People's Commissariat of Public Education, UkrSSR), Khar'kov, l(1): 一, 1923.

1758. —. "Altern von Gelatine" (Ages of Gelatin). Koll. Zeitsch., 41: 123, 1927.

1759. NAGORNil, O. V. (Ukr. version of the name above) "The Problem of Aging and Death and Methodical Forethought (for Intervention)" (Ukr.: Problema slurinnia $i$ smerti ia ii melodologichni peredumovi). Za marksolenins'ke prirodoznavstvo (From Marxist-Leninist Natural Sciences), (4): —, 1932.

1760. "Toward Solving the Problem of Age Physiology" (Ukr.: Do postanovki problemi pro vikovu fiziologiiu). Trudy Zoobiologicheskogo in-ta Khar'kovskogo gos. un-teta ('Transactions of the Zoobiological Institute of the Khar'kov State Univ.), 2(4): 6-9, 1934.

1761. - "Dynamics of Colloidal Systems" (Ukr.: Dinamika koloidnikh sistem) Pralsi Zoobiologichnogo in-lu Kharkivs'kogo derzh. un-tetu (Reports of the Zoobiological Institute of the Khar'kov State Univ.), 2: 66-106, 1934.

1762. - "Age Changes in the Blood" (Ukr.: Pro vikovi zmini krovi). Ibid., 2: 10-23, 1934.

1763. "The Problem of Aging and Death." (Ukr.: Problema strainnia ta smerti). Materiali do vikovoi fiziologii. Medvidav, Kharkiv (Data on Age Physiology. State Publ. House of Med. Lit., Khar'kov), 1935, p. 444.

1764. Nagornyi, A. V. "Age Physiology, Its Content and Methods." Pratsi Zoobiologichnogo in-tu Kharkivs'kogo derzh. un-tetu (Reports of the Zoobiological Inst. of the Khar'kov State Univ.), 3: 5-34, 1936.

1765. Nagornir, O. V., and Rubanovs'Ka, A. A. "Problem of the Change of ElectroConductivity of 'Tissues and Organs Dependent on Age" (Ukr.: Do pitannia pro zmini elektroprovidnosti tkanin $i$ organiv zalezhno vid viku). Ibid., 3: 35-56, 1936.

1766. NAgorniI, O. V. "Active Reaction of Organs of Animal Organism of Varied Age"
(Ukr.: Aklivna reaktsiia organiv tvarinnogo organizmu riznogo viku). Ibid., 3: 57-74, 1936.

1767. and Rubanovs'ka, A. A. "Problem of Change in Concentration of Water Ions in Blood with Age" (Ukr.: Do pitannia pro zmini kontsentratsii vodnevikh ioniv u krovi $z$ vikom). Ibid., 3: 91-118, 1936.

1768. Nagornu, O. V. "Age Physiology and Status of It in the UkrSSR on 20th Anniversary of October Revolution" (Ukr.: Vikova fiziologiia i ii stan v URSR na XX rokovini Zhovtnevoi revoliutsii). Eksperimental'na meditsina (Experimental Medicine), (8): 79-94, 1937.

1769. "Problem of Longevity and Current Status of It" (Ukr.: Problema dovgolittia $i$ ii suchasnii stan). Uch. zap. Kharkivs'kogo derzh. un-tetu (Annals of the Khar'kov State Univ.), (10: - 1937.

1770. NAGornyi, A. V. (Russian for same name). "Age Physiology in the USSR for 20 Years." Uspekhi souremennoi biologii (Advances in Contemporary Biology), 8(1): 36, 1938.

1771. NAGORNII, O. V. "Mechanisms of Age Changes and the Second Principle of Energetics" (Ukr.: Zakonomirnosti vikovikh zmin $i$ 2-i printsip energetiki). Pratsi Zoobiologichnogo in-lu Kharkivs'kogo derzh. un-telu (Reports of the Zoobiological Institute, Khar'kov State Univ.), 5: 5-21, 1938.

1772. and Sliusarenko, I. T. "Age Changes in Ability of Skin to Bind Water" (Ukr: Vikovi zmini zdibnosti shkiri zv'iazuvali vodu). Ibid., 5: 59-71, 1938.

1773. NagorniI, O. V. "Blood Catalase and Age" (Ukr.: Kalalaza krovi ta vik). Ibid., 5: 197-211, 1938.

1774. and Zelins'kil, O. P. "Age and Chemical Composition of the Urine" (Ukr.: Vik $i$ khimichnii sklad sechi). Ibid., 5: 255-269, 1938.

1775. NAGORNYI, A. V. "Length of Life and Characteristics of Internal Structure of Living Organisms." Ibid., 7: 9-34, 1938.

1776. Nagornil, O. V., OKonevs'Ka, E. K., and Kashrur, O. "Age Changes in Catalase and Anticatalase Content in Organs of the Animal Body." (Ukr.: Pro vikovi zmini vmistu kalalazi $i$ antikatalazi v organakh tvarinnogo organismu). Ibid., 7:67-80, 1938. 
1777. Nagorni1, O. V., Mirosinik, G. V., and Novikova, O. T. "Hydrophilia of Tissues in Animals of Varied Age" (Ukr.: Gidrofil]nist] [kanin u tvarin riznogo viku). Ibid., (7): 135-150, 1938.

1778. NAGORNY1, A. V. "Data on AgcAssociated Physiology and Biochcmistry. Bibliography for the USSR." Trudy Zoobiologicheskogo in-tu Khar'kouskogo gos. un-tela (Transactions of the Zoobiological Institutc, Khar'kov State Univ.), 7: 9-34, 1938.

1779. 'Certain Basic Changes of Animal Organism Throughout Its Individual Cycle" ( $O$ nekolorykh osnownykh izmenenïakh zhivolnogo organizma na protiazhenii ego individual'nogo tsikla). Tezisy dokladov na konferentsii po zoprosam sravnitel'noi biokhimii, Kiev (Theses of Reports at the Conference on Problems of Comparative Biochcmistry), Kiev, (2): 1939.

1780. Nagornit, O. V. "Many Basic Changes in the Animal Organism Throughout Its Individual Cycle" (Ukr.: Pro deiaki osnouni zmini varinnogo organizmu na proliazi iogo individual'nogo tsiklu). 3-i Ukrains]kii $z^{\prime} i z d$ fiziologiv, biokhimikiv i farmakologiv, Dnipropetrous' $k$ (Third Ukrainian Congress of Physiologists, Biochemists, and Pharmacologists, Dnepropetrovsk), 1939, p. 65.

1781. "Aging, Old Age, and Life Duration" (Ukr.: Starinnia, starist', trivalist' zhillia). Eksperimental'na medilsina (Experimental Medicine), (1): 1-8, 1939.

1782. and Golubits'ka, R. I. "Anaphylactic Shock Reaction in Animals of Varied Age and Intra-Intestinal Sensitization" (Ukr.: Reaktsiia anafilaktichnogo shoku u tvarin riznogo viku i vnutrishn'outrobna sensibilizatsiia). Ibid., (3): 6-11, 1939.

1783. NAGORNYI, A. V. "Longevity." Sovetskaia nauka (Soviet Science), $(3,4,5): 80$ 101,1940 and (5): 39-57, 1940.

1784. "Problem of Factors Stipulating Life Activity." Sb.: Starost'. Trudy konferentsii 17-19 dekabria $1938 \mathrm{~g} .$, Kiev., AN USSR (Collection: Old Age. Transactions of the Dec. 17-19, 1938 Conference, Kiev. Acad. of Sicences UkrSSR), 1940, pp. 157172.

1785. "I. I. Mechnikov and the Problem of Prolonging Life." Uch. zap. Kharkivs'kogo derzh. un-letu (Annals. Khar'kov State Univ.), 19(11): - 1940.
1786. - "Problem of Aging and Longevity" (Problema stareniia i dolgoletiia), Khar'kov, 1940, 466 pp.

1787. " "Old Age. Transactions of Conference on Problem of Genesis of Old Age and Prophylaxis for Premature Aging. Resumc." Tseniral'nyi referatiunyi zhurnal (Central Abstract J.), 26(3;3): -, 1940.

1788. Nagornil, O. V., and Golubits'Ka, R. I. "Effect of a Thyroidectomy on Fatiguability Coefficient of Animals of Varied Age" (Ukr.: Vpliv tireoideklomii na koefilsient sprats'ovuvannia u twarin riznogo viku). Eksperimental'na meditsina (Expcrimental Medicine). $(2 ; 3): 1-3,1941$.

1789. Nagornil, A. V., and Sergienko, E. F. "Fat Content in Body of Animals of Varied Age." Trudy Zoobiologicheskogo in-ta Khar'kovskogo gos. un-lela (Transactions of the Zoobiological Inst., Khar'kov State Univ.), 10-11(5): -, 1941 .

1790. Nagornyi, A. V. "Age Changes in Ratios Between Protein Metabolism and Energy Metabolism in Different Animal Species." Ibid., 10-11(5): -, 1941.

1791. "I. I. Mechnikov in Combatting Premature Aging and Death." Vrachebnoe delo (Medical Affairs), (5-6): 229$236,1945$.

1792. "Self-Rejuvenation of Organism and Problem of Combatting Aging." Uch. zap. Kzyl-Ordinskogo gos. pedagogicheskogo in-la (Annals of the Kzyl-Orda State Pedagogical Institutc), 2(21):- 1945.

1793. - "Patterns of Individual Evolution of Animal Organism. Report 1. Age Changes of Catabolic Phase of Metabolism." Uch. zap. Khar'kouskogo gos. un-lela (Annals of Khar'kov Statc Univ.), 25; Trudy Instituta biologii, Khar'kov (Transactions of the Institute of Biology, Khar'kov), 12: 19-37, 1947.

1794. - "Patterns of Individual Evolution of Animal Organism. Report II. Equilibrium Between Anabolic and Catabolic Processes in Different Stages of Individual Evolution." Uch. zap. Khar'kouskogo gos. unleta, im. Gor'kogo (Annals of the Khar'kov Gor'kii State Univ.), v. 25; Trudy nauch.-issled. in-ta biologii, 12: 38-60, 1947.

1795. — and Golubitskala, R. I. "Effect of Thyroidectomy on Nitrogen Exchange in Animals of Varicd Age." Uch. zap. Khar'kouskogo gos. un-teta (Annals of 
Khar'kov State Univ)., v. 25; Trudy Instituta biologii, Khar'kov (Transactions of the Institute of Biology, Khar'kov), 13: 149-152, 1947.

1796. Nagornyi, A. V., Dubovik, A., and Danil'chenko, K. E. "Age Changes in Content of Certain Ash Elements in the Body of White Rats." Uch. zap. Khar'kovskogo gos. un-teta, Khar'kov (Annals of Khar'kov State Univ., Khar'kov), 25: 153-158, 1947.

1797. NAGornyi, A. V., and Kasenkina, E. I. "Age Changes in Sulfur Content in Body of White Rats." Ibid., 25: 159-166, 1947.

1798. Nagornyi, A. V. "Certain Patterns of Age Changes in Catabolic Phase of Metabolism." VII Vsesoiuznyi s'ezd fiziologov, biokhimikov i farmakologov, M., Medgiz (Seventh All-Union Congress of Physiologists, Biochemists, and Pharmacologists, Moscow, State Publ. House of Med. Lit.), 1947, pp. 647-650.

1799. -. "Mechnikov and Macrolt otics" (Mechnikov i makrobiotika. Sb. posviashchennyi I. I. Mechnikovu, izd-vo KhGU, Khar'kov), Collection Dedicated to I. I. Mechnikov, publ. by the Khar'kov State Univ., Khar'kov, 1948.

1800. NagorniI, O. V., and Golubits'Ka, R. I. "Age Changes in Caloricity of Animal Body" (Ukr.: Vikovi zmini kaloriinosti tila tvarini). Ukrains'kii biokhimichnii zhurnal (Ukrainian Biochemical J.), 22(3;5): 344348, 1950.

1801. Nagornyi, A. V. "Aging and Prolongation of Life" (Straenie i prodlenie zhizn. Izd-vo "Sovetskaia nauka", M.). Soviet Science Publishing House, Moscow, 1950, $219 \mathrm{pp}$.

1802. NAGorniI, O. V. "Longevity and Nervous Activity" (Ukr.: Dovgolittia i nervova diial'nist'). Nauka i zhittia (Science and Life), $(3 ; 1):-, 1951$.

1803. NAGorNyi, A. V. "Man's Longevity and the Nervous System." Ogonek. Izd-vo "Pravda" (The Little Flame. Publ. by "Pravda"), (4): 19-20, 1951.

1304. - "The USSR, Land of Longevity." Nauka i zhizn' (Science and Life), (10;2): - 1951.

1805. - "Aging and Longevity" (Starenie $i$ dolgoletie. Izd-vo "Znanie", M.), 'Science” Publ. House, Moscow, 1953.
1306. "I Iigher Ncrvous Activity and Its Ontogenctic Devclopment." Trudy nauch.-issled. in-la biologii KhGU, Khar'kov (Transactions of the Sci-Res. Inst. of Biology, Khar'kov State Univ., Khar'kov), 21: 17-28, 1954.

1807. - "Some Patterns of Age Evolution of the Animal Organism." Nauchnaia konferentsiia po voprosam znacheniia vozrasta pri razvedenii sel'skokhoziaistvennykh zhivotnykh. Moskovskaia sel'skokhoziaistvennaia akademiia im. K. A. Timitiazeva, M. (Scientific Confcrence on Problems of Importance of Age in Brceding of Farm Animals. The Moscow K. A. Timiriazev Agricultural Academy, Moscow), 1953, pp. 28-39.

1808. Nazarishvili, G. P. "Age Characteristics of Coxofemoral Joint in X-ray l'icture." Vestnik rentgenologii i radiologii (Journal of Roentgenology and Radiology), (4): 35-43, 1952.

1809. Nazarova, N. S. "Functional Blood Formula in Comparatively Healthy Children and in Children with Simple Diseases." Zhurnal po izucheniiu rannego detshogo vozrasta (J. for Study of Early Chilhood), 8(4): 181287, 1928.

1810. Narbut, V. "Electrical Excitability of Muscles in the Newborn in Connection with Structure of Muscles and Nerve Fibers." Nevrologicheskii vestnik (Neurological J.), $10(2,3):-, 1902$.

1811. Naroditskaia, G. D. "Age Characteristics of Formation of Conditioned Reactions to Similar and Different Complcx Stimuli." Sb.: Opyt sistematicheskogo eksperimental'nogo issledovaniia ontogeneticheskogo razvitiia korkovoi dinamiki cheloveka, izd-vo VIEM, M. (Collection: Attempt at a Systematic Experimental Investigation of Ontogenetic Development of Cortical Dynamics of Man. Publ. House of the All-Union Institute of Experimental Med., Moscow), 5: 261-267, 1940.

1812. Naroditskil, E. E. "Change of Arterial Blood Pressure in Connection with the Age of Man." Terapevticheskii arkhiv (Archives of Therapeutics), 14(3): 432-443, 1936.

1813. Nasonov, D., and ALEKSANDrov, V. "Problem of Changes in Living Matter During Reversible Conversion of It in the State of Death." Arkhiv biologicheskikh nauk, ser. A (Archives of Biological Sciences, Series A), 36(1): 95-111, 1934. 
1814. NEVEZ11N, V. I. "Skin-Musclc and Tendon Reflexes in Children." Trudy o-va detskikh vrachei (Transactions of the Association of Pediatricians), 8, 1896.

1815. Nevskala, T. L. "Toxicity of Novocain and Various Age Periods in the Lifc of Animals." Farmakologiia i toksikologiia (Pharmacology and Toxicology), 18(6): 52-55, 1955.

1816. Negovskil, V. A., MaKarycilev, A. I., Telicheva, M. I., Shuster, M. I., and Gaevska1A, M. S. "Revival of Dog After Clinical Death as Result of Exsanguination." Biull. eksperimental'noi biologii $i$ meditsiny (Bulletin of Experimental Biology and Medicine), 6(3): 358-362, 1938; Arkhiv patologicheskoi anatomii $i$ patologicheskoi fiziologii (Archives of Pathological Anatomy and Pathological Physiology), 5(1): 29-49, 1939.

1817. Negovskil, V. A., Markarychev, A. I., and Vladimirov, N. N. "A Perfusion Apparatus." Voprosy neirokhirurgii, M. Medgiz (Problems of Neurosurgery, Moscow, State Publ. House of Med. Lit.), 3(6): 1939.

1818. Negovsk11, V. A. "Problem of Restoration of Life Functions of Organism." Arkhiv biologicheskikh nauk (Archives of Biological Sciences), 58(2): 135-146, 1940.

1819. - "Restoration of Life Functions to an Organism Found in an Agonal Statc and in the Period of Clinical Death" (Vosslanovlenie zhiznennykh funktsii organizma, nakhodiashchegosia $v$ sostoianii agonii $i v$ period klinicheskoi smerti. Diss., M.), a dissertation, Moscow, 1942.

1820. -. "Interrelation of Respiration and Blood Circulation in the Process of Animals' Dying from Loss of Blood and in the Subsequent Period of Restoration of Life Functions." Biull. eksperimental'noi biologii $i$ meditsiny (Bulletin of Experimental Biology and Medicine), 15(6): 37-40, 1943.

1821. - "Restoration of Life Functions to an Organism Found in the Agonal State or in the Period of Clinical Death" (Vosstanovlenie zhiznennykh funktsii organizma, nakhodiashchegosia $v$ sostoianii agonii ili $v$ period klinicheskoi smerti. Medgiz, M.), State Publ. Housc of Med. Lit., 1943.

1822. "Problem of Active Therapy for the Agonal State and Clinical Death." Gospital'noe delo (Hospital Affairs), (10): 47-52, 1943.
1823. and MARKarycheV, A. "Can Wc 'Interrupt' Death? Restoring the Vital Functions of the Organism." Sov. IVar News, 982: $3-4,1944$.

1824 . "Restoration of the Vital Functions of the Organism." Sov. Med. Chronical (sic), October 1944.

1825. Negovsk11, V. A. "Testing Therapy for Agonal State and Clinical Dcath in the War Zone" (Opyt terapii sostoianii agonii $i \mathrm{kli}$ nicheskoi smerti v voiskovom raione. Medgiz, M,). State Publ. House of Med. Lit., Moscow, 1945.

1826. "Agonal States and Clinical Death: Problem in Revival of Organism." Amer. Rev. Sov. Med., 2: 303-304, 1945.

1827. - "Treatment of the Agonal State and of Clinical Death." J.A.M.A., 129 (1226): 17, 1946.

1828. - "Treatment of Agonal (sic) and Clinical Death." Nature 157 (3980): 163, 1946.

1829. "Restoration of Vital Functions of the Organism" (Vosstanovlenie zhiznennykh funktsii organizma. Stenogramma publichnoi lektsii, izd-vo "Pravda", M.), a shorthand report of a public lecture, publ. by "Pravda", Moscow, 1947.

1830. - "Clinical Death as a State of Hypoxia." "Gipoksiia"-Trudy knoferentsii po probleme kislorodnoi nedostatochnosti organizma, izd-vo AN USSR vo L'vove, Kiev (Hypoxia. Transactions of the Conference on the Problem of Oxygen Deficiency of the Organism, L'vov. State Publ. House of the Acad. of Scicnces UkrSSR, Kiev), 1949, pp. 63-67.

1831. and ZAR, R. L. "Arterial Blood Infusion as a Therapeutic Measure for Mortal Blood Loss in Obstetrical-Gynccolog. ical Practice." Akusherstvo i ginekologiia (Obstetrics and Gynecology), (1): 20-26, 1951.

1832. Negovskil, V. A. "Clinical Death as a Reversible Stage of Dying" (Klinicheskaia smert' kak obratimyi etap umiraniia. Izd. $\Lambda \mathrm{ka}$ demii meditsinskikh nauk SSSR, M.). Publ. by Acad. of Med. Sciences USSR, Moscow, 1951.

1833. "Reflex Regulation of Function of Cardiovascular System and of Respiration in Tcrminal States." Tezisy doklada vyezdnoi sessii Akademii meditsinskikh nauk SSSR $v$ Riazani (Thescs of Reports of the Excursion 
Training Session of the Acad. of Med. Sciences USSR in Riazan), 1951, pp. 30-32.

1834. - "Experiment of Studying the Phenomena of Extinction and Restoration of Cortical and Subcortical Functions in the Dying and Revival of the Organism." Zhurnal yysshei nervnoi deiatel' nosti ( $\mathrm{J}$. of Higher Nervous Activity), 1(1): 120-127, 1951.

1835. - "Restoration of Vital Functions of the Organism." Priroda (Nature), (12): $36-44,1952$.

1836. - - and Gurvich, N. L. "Revival Feasibility for Shock Victims." Fel'dsher $i$ akusherka (The Doctor's Assistant and Midwife), (6): 6-13, 1952.

1837. Negovskit, V. A., Smirenskaia, E. M., and Bakulev, A. N. "Experimentation in Treating Terminal States." Khirurgiia (Surgery), (9): 11-17, 1952.

1838. Negovskir, V. A. "Use in the Clinic of a Complex Method of Revival in Treating Serious Stages of Shock, Death Agony, and Clinical Death." Konferentsiia, posviashchennaia probleme patofiziologii $i$ terapii terminal'nykh sostoianii v klinike i praktike neotlozhnoi pomoshchi 10-12. XII. 1952 g. Tezisy dokladov, izd-vo Akademii meditsinskikh nauk SSSR (Conference devoted to the Problem of the Pathophysiology and Therapy of Terminal States in the Clinic and Practice of Urgent Aid, Dec. 10-12, 1952. Theses of reports, publ. by Acad. of Med. Sciences USSR), 1952.

1839. —- "Role of Higher Centers of Brain in Extinction and Restoration of Vital Functions of the Organism." Ibidem, 1952.

1840. ㄴ. "Pathophysiology and Therapy of Death Agony and Clinical Death" (Patfiziologiia i terapiia agonii i klinicheskoi smerti. Medgiz, M.), State Publ. House of Med. Lit., Moscow, 1954, p. 456.

1841. Negrobov, A. I. "Cardiovascular Reaction of the Teen-Ager and Its Importance to Choice of Occupation." Materialy VI Kavkazskogo s'ezda fiziologov, biokhimikov, farmakologov. Erevan (Data of the Sixth Caucasus Congress of Physiologists, Biochemists, and Pharmacologists, Erevan (Armenia)), 1934, pp. 120-121.

1842. Negrobox, A. I. "Erythrocyte Sedimentation Test in the Healthy Teen-Ager and Its Practical Importance." (Ukr.: Reaktsiia osidannia eritrotsitiv u zdorovogo pidlitka ta ii praktichnae znachennia). Eksperimental'na meditsina (Experimcntal medicine), (3): 91, 1935.
1843. - "Stability of Erythrocytc Precipitation Tcst and Hemoglobin in Blood of Teen-Ager. Report II" (Ukr.: Pro stiikist' reaktsii osidaniia eritrotsitiv $i$ gemoglobinu v krovi pidlitka. Provid. II). Ibid.,(6): 41-50, 1937.

1844. Nemanova, Ts. P. "Reflexes Conditioned to Food Stimuli in Children in the First Months of Life." Fiziologicheskii zhurnal SSSR (Physiological J. of the USSR), 30(4): 478-483, 1941.

1845. Nemilov, A. V. "What is Death? (Death from the Point of View of the Natural Sciences)" (Chto takoe smert'? (Smert's tochki zreniia estestvennykh nauk). Gozizdat, Petrograd). State Publ. House, Petrograd, 1923.

1846. - "What Death Is" (Chto takoe smert', L.), Leningrad, 1925.

1847. —. "Hidden Coils (Elastic Qualities) in the Living Organism" (Skrytye pruzhiny zhivogo organizma. GIZ), State Publ. House, 1929.

1848. — "Rejuvenation of Domestic Animals" (Omolozhenie domashnikh zhivotnykh, M.-L.), Moscow-Leningrad, 1928.

1849. - - "Truth and Falsehood in the Problem of 'Rejuvenation'." Priroda (Nature), (8): 709-738, 1932.

1850. - "Problem of Senile Changes in Spleen of Mammals." Arkhiv anatomii, gistologii $i$ embriologii (Archives of Anatomy, Histology, and Embryology), 15(2): 40-57, 1936.

1851. - "Certain Data on Senile Changes in Lymph Nodes of Mammals." Ibid., 16(2): 187-204, 1937.

1852. Nemirovskaia, O. I. "Effect of Sulfonamides on Activity of Carbonic Anhydrase of the Blood." Voprosy pediatrii $i$ okhrany materinstva $i$ detstva (Problems of Pediatrics and Maternal and Child Welfare), I6(2): $42-45,1948$.

1853. Nechaeva, P. V. "Observations on Fluctuations of Glycolytic Activity of the Blood in Persons of Advanced Age in Abkhazia." Sb.: Starost'. Trudy konferentsii 17-19 dekabria $1938 \mathrm{~g}$., Kiev, AN USSR (Collection: Old Age. Transactions of the Dec. 17-19, 1938 Conference at Kiev. Acad. of Sciences USSR), 1940, pp. 345-346.

1854. Nechaeva, I. P. "Functional Characteristics of the Acoustic Analysor in the 
Child of Early Age." Zhurnal vysshei nerinoi deiatel'nosti (J. of Higher Nervous Activity), 4(5): 610-615, 1954.

1855. Nikitin, V. M. "Changes in Amount of Water in Blood of White Rats with Age." (Ukr.: Zmini kil'kosti zodi v krovi bilikh shchuriv z vikom). Pratsi Zoobiologichnogo in-tu Kharkivs'kogo derzh. un-tetu (Reports of the Zoobiological Institute, Khar'kov State Univ.), 2: $41-44,1934$.

1856. "Age Changes in Amount of Lipid Phosphorus, Cholesterol, and the Lipocytic Index in Blood of White Rats." (Ukr.: Vikovi zmini kil'kosti lipoidnogo fosforu, kholesterinu ta lipotsitichnogo indeksu v krovi bilikh shchuriv). Ibid., 2: 47-52, 1934.

1857. - " "Problem of Effect of IIormones on Tumcscence of Colloidal Systems" (Ukr.: Do pitanni pro vpliv gormoniv na nabriakannia koloidnikh sistem). Ibid., 2: 135-138, 1934.

1858. Nikitin, V. N. (Russian for the name above), Liubanova, V. S., and Evstaf'eva, A. V. "Age Changes in Number of Erythrocytes, Amount of Hemoglobin, and the Erythrocyte Sedimentation Rate in Blood of Horned Cattle.'] Sb. trudov Khar'kovskogo zootekhnicheskogo in-ta (Collection of Transactions of the Khar'kov Zootechnical Institute), 1: 155-172, 1934-1935.

1859. Nikitin, V. N., Babich, N., and Evstaf'Eva, A. V. "Age Changes of Surface Tension and Pigmentation in Blood Serum of Horned Cattle." Ibid., 1: 195-209, 1934-1935.

1860. Nikitin, V. M. "Age Changes of Water Content in Organs of White Rats." (Ukr.: Vikovi zmini vmistu vodi $v$ organakh bilikh shchuriv). Pratsi Zoobiologichnogo in-tu Kharkivs'kogo derzh. un-tetu (Reports of the Zoobiological Institute, Khar'kov State Univ.), 3: $136-146,1936$.

1861. - and Kuznetsova, M. P. "Age Changes of Cholesterol Content of Lipid Phosphorus and of Lipids in Organs of White Rats." (Ukr.: Vikovi zmini vmistu kholesterinu lipoidnogo fosforu $i$ lipidiv $v$ organakh bilikh shchuriv). Ibid., 2: 147-169, 1936.

1862. Nikitin, V. M. "Age Changes in Ability to Combine and to Oxygenate Phenol in the Animal Organism" (Ukr.: Vikovi zmini zdibnosti zv'iazuvannia ta zakisnennia fenolu $v$ tvarinnomu organizmi). Ibid., 5: 220-242, 1938.
1863. - "Problcm of Age Change of Creatinine Cucflicient in White Rats and Rabbits." (Ukr.: Do pitannia pro vikori zmini kreatininovogo koefitsienta $u$ bilikh shchuriv ta krolikiv). I Ibid., 5: 243-253, 1938.

1864. "Function of the Liver in Regulating the Acid-Alkaline Balance and Age Chances of 'This Function" (Ukr.: Pro funktsiiu pechiniki reguliuvati kislotno-luzhnu rivnovagu ta vikovi zmini tsiei funktsii). Ibid., 7: 35-66, 1938.

1865. - "Age Changes in Synthesis and Breakdown of Proteins in the Animal Organism." Sb.: Starost'. Trudy konferentsii 17-19 dekabria 1938 g., Kiev., AN USSR (Collection: Old Age. Transactions of the Conference of Dec. 17-19, 1938, Kiev. Acad. of Sciences UkrSSR), 1940, pp. 235-238.

1866. - "Physiology of Syzygial Digestion in Ruminants. II". Sb. Irudov Khar'kouskogo zootekhnicheskogo in-ta (Collection of Works of the Khar'kov Zootechnical Inst.), 3: 1-342, 1940.

1867. - "Age Changes in Synthesis and Breakdown of Proteins in the Animal Organism." Fiziologicheskii zhurnal SSSR (Physiological J. of the USSR), 30(5): 619628,1941 .

1868. "Review of Prof. A. V. Nagornii's book 'Problem of Aging and Longevity' (Problema staraniia $i$ dolgoletiia)." Pod znamenem marksizma (Under the Name of Marxism), 4: 200-218, 1941.

1869. - "Atlas of Hematology of Farm Animals. Part I. Leukocytes." (Atlas gematologii sel'skohoziaistvennykh zhivotnykh. Ch. 1. Belaia krov'. Sel'khozgiz USSR, s 30 tablitsami v tekste), Farm Publ. House of the UkrSSR. With 30 tables in the text, 1946, pp. 1-120.

1870. - "Age Changes of Leukocytes of Horned Cattle." Sb. trudov Khar'kovskogo zootekhnicheskogo in-ta (Collcction of Works of the Khar'kov Zootechnical Institute), 4: 74$151,1946$.

1871. - . "Age Changes in Leukocyte Formula of Blood of Horned Cattle." Zbirnik anotatsii Kharkivs'kogo derzh. un-tetu (Collcction of Notes of Khar'kov State Univ.), $3-4)$ : $11-12,1946$.

1872. - "Alexander Vasil'evich Nagornyi and Development of Age Physiology in Khar'kov State Univcrsity." Uch. zap 
Khar'kouskogo gos. un-teta (Annals of Khar'kov State Univ.), 25: 5-18, 1947.

1873. "Breakdown and Regeneration of Proteins in Organs of White Rats in Ontogenesis." Ibid., v. 25; Trudy in-ta biologii, Khar'kov (Transactions of Biology Institute, Kharkov), 12: 95-108, 1947.

1874.

"Basic Mechanisms of the Ontogenesis of Leukocytes Common to Man, Horned Cattle, and Swine." Ibid., (Annals ...) v. 25; ibidem (Transactions ...), 12: 109-128, 1947.

1875. "Synthesis and Breakdown of Protoplasm in the Ontogencsis of Animal Organisms." VII Vsesoiuznyi s'ezd fiziologo, biokhimikov i farmakologov, M., Medgiz (Seventh All-Union Congress of Physiologists, Biochemists, and Pharmacologists, Moscow, State Publishing House of Medical Lit.), 1947, pp. 10-11.

1876.

"General Patterns of Ontogenesis of Leukocytes in Horned Cattle, Swine, and Horses." Vestnik zhivotnovodstva (Journal of Animal Breeding), (3): 13-28, 1948.

1877. - "General Patterns of the Ontogenesis of Leukocytes in Horned Cattle Swine, and Horses." Sb. trudov K'har'kovskogo zootekhnicheskogo in-ta (Collection of transactions of the Khar'kov Zootechnical Institute), 5(1): 143-160, 1948.

1878. - "General Patterns of Ontogenesis of Leukocytes in Mammals." Tezisy dokladov l-i Ukarinskoi konferentsii anatomov, gistologov i embriologov, 24-30 iiunia 1948 goda, izd-vo Bol'shevik Iuzhnoi, Khar'kov (Theses of reports of the First Ukrainian Conference of Anatomists, Histologists, and Embrologists, June 24-30, 1948. Published by the "Bol'shevik of the South," Khar'kov), 1948, pp. 87-88.

1879.

"General Mechanisms of Age Changes of Leukocytes in Farm Animals and Importance of These Changes in Veterinary Science and Zootechnics." Konferentsiia fiziologov, biokhimikov, farmakologov zooveterinarnykh institutov SSSR. Tezisy dokladov (Conference of Physiologists, Biochemists, and Pharmacologists of the Zooveterinary Institutes of the USSR. Theses of papers), 1948, pp. 17-19.

1880.

"Synthesis and Breakdown of Protoplasm in the Ontogenesis of Animal Organisms." Zhurnal obshchei biologii (Journal of General Biology), 9(2): 112-130, 1948.
1881 " $\Lambda$ tlas of Blood Cclls of Farm and Laboratory Animals." (Allas kletok krovi sel'skiokhoziaistvennykh i laboratornykh zhivotnykh. Sel'khozgiz, M.) State Publ. Housc of Farm Lit., Moscow, 1949, 24 printed pagc plates.

1882. - in collaboration with L. A. Driucinina and Z. L. Semenova. "Transformation of Amino Acids in the Ontogenesis of the Animal Organism." Ukrains'kii biokhimichnii zhurnal (Ukrainian Biochemical J.), 21(3): 296-305, 1949.

1883. Nikitin, V. N. "Synthesis and Breakdown of Protoplasm in the Ontogenesis of Animal Organisms." Problemy sovetskoi fiziologii, biokhimii, farmakologii, izd-vo AN SSSR, M. (Problems of Soviet Physiology, Biochemistry, and Pharmacology, State Publishing House of the Acad. of Sciences USSR, Moscow), 1: 674-676, 1949.

1884. - in collaboration with R. I. Golubitska, L. A. Driughina, and Z. L. Semenova. "Synthetic Capabilites and Reactivity of Tissues of the Animal Organism in the Ontogenesis." Tezisy konferentsii po vozrastynm izmeneniiam obmena veshchestv $i$ reaktivnosti organizma, izd-vo AN USSR, Kiev (Theses of the Conference on Age Changes in the Metabolism and Reactivity of the Organism. State Publishing House of the Acad. of Sciences UkrSSR, Kiev), 1949, pp. 4l-44.

1885. - in collaboration with N. A. BatozsKa, P. S. Liashenko, M. I. Novikova, I. L. Poltavskil, G. F. Briazkun, and N. G. PrIKIIOD'ko. "Decisive Role of Outer Medium and of Functional State of Organism in the Ontogenesis of Leukocytes in Horses." Zhurnal obshchei biologii (J. of General Biology). II(3): 198-202, 1950.

1886. - in collaboration with A. M. Skorobogatova. "New Data on Totality of Age Change in Blood of Higher Vertebrates." Sp. trudov, Khar'kovskii zootekhnicheskii in-t (Collection of Works of Khar'kov Zootechnical Institute), 4: 59-65, 1951.

1887. - - "Age Mechanisms of $\Lambda \mathrm{gc}$ Changes in Leukocytes of Blood Picture in Higher Vertebrates. Zhurnal obshchei biologii (J. of General Biology), 12(4; July-Aug.): 287-296, 1951.

1888. Nikitin, V. N., in collaboration with R. I. Golubitska, L. A. Driuchina, and Z. L. Semenova. "Synthetic Capabilities and Reactivity of Animal Tissues in the Ontugenesis." Sb. AN USSR, Trudy konferentsii po 
vozrastnym izmeneniiam obmena veshchestv i reakiiunosti organizma. Izd-vo AN USSR, Kiev (Collection of the Acad. of Sciences UkrSSR. Transactions of Conference on Age Changes of Metabolism and of Reactivity of the Organism. Publishing House of the Acad. of Sciences UkrSSR, Kicv), 1951, pp. 17-26.

1889. Nikitin, V. N., Basina, Iu. A., Batozskaia, T. A., Brallovskaia, S. I., Volovik, M. P., and Rudaeva, A. V. "Age Changes in Electro-Colloidal Properties (IET) of Protoplasm of Rabbit Tissues at Different Type of Rearing Them." Zhurnal obshchei biologii (J. of General Biology), 13(4): 270-285, 1952.

1890. Nikitin, V. N. "Factors of Protein Synthesis in the Ontogenesis of the Animal Organism." Sb.: "Materialy 2-i nauchnoi konferentsii po voprosam vozrastnoi morfologii $i$ fiziologii. Idz. Akademii pedagogicheskikh nauk RSFSR, M. (Collection: Data of the Second Scientific Conference on Problems of Age Morphology and Physiology. State Publishing House of Pedagogical Sciences RSFSR, Moscow), 1952, pp. 102-103.

1891. "Aleksandr Vasil'evich $\mathrm{Na}$ gornyi (Obituary)." Ukrainskii biokhimicheskii zhurnal (Ukr.) (Ukrainian Biochemical J. (Ukr.)), 25(4): 472-475, 1953.

1892. - "Longevity." Nauka i zhizn' (Science and Life), (8): 27-28, 1954.

1893. "Aleksandr Vasil'evich $\mathrm{Na-}$ gornyi (Obituary)." Trudy nauch.- issled. inta biologii Khar'kouskogo gos. un-teta, Khar'kov, izd. Khar'kovskogo gos. un-teta (Transactions of the Sci.-Res. Institute of Biology of the Khar'kov State Univ., Khar'kov State Publ. House of the Khar'kov State Univ.), 21: 7-12, 1954 .

1894. "Certain Biochemical Bases of the Processes of Ontogenesis." Ibid., 21: $29-71,1954$.

1895. in collaboration with R. I. Golubitska. "Biochemical Nature of AgeAssociated Extinguishing of Processes of Protein Synthesis in Animal Organisms. 1. () $n$ togenetic Changes in Use of Macroerg Vnergy (ATP) for Synthesis of the Peptide Lond (Formation of Glutamine from Glutamic Acid and Ammonium Salts)." Ibid., 21: 113-130, 1954.

1896. "Age Changes in Aclenosine Triphosphatase Activity of Brain Tissue." Ibid., 21 : 143-152, 1954.
1897. — I. N. Bulankina, E. V. Parina, N. M. Novikova, and O. P. Silinyi. " $\Lambda$ ge Changes of Ccrtain Biochcmical Indices Connected with the Process of Protein Synthesis." Tezisy dokladov VII Vsesoiuznogo s'ezda fiziologov, biokhimikov, farmakologov. Mcdgiz, M. (Theses of Reports of the Scventh All-Union Congress of Physiologists, Biochemists, and Pharmacologists). Statc 1'ubl. House of Medical Lit., Moscow), 1955, pp. 90-91.

1898. Nikitin, V. N. "From the History of the Physiology of Man and of Animals in Khar'kov State University in the PostOctober Period." Trudy nauch.-issled. in-la biologii $i$ biologicheskogo $f$-la Khar'kovskogo gos. un-teta (Transactions of the Sci-Res. Institute of Biology and Biological Pharmacotherapy, Khar'kov State Univ.), 22: 27-40, 1955.

1899. Nikitin, V. N., and Blok, L. N. "Data on the Ontophysiology of the Oak Silkworm. 1. Changes in Content of Phosphorus Fractions (Antheraea pernyi G.-M.)." Uch. zap. Khar'kouskogo gos. un-teta (Annals of Khar'kov State Univ.), v. 68 (sic; possibly should be 63; sce below); Trudy nauch.-issled. in-ta biologii $i$ biologicheskogo f-ta (Transactions of the Sci.-Res. Institute of Biology and Biological Pharmacotherapy), 24: 117-136, 1956.

1900. - Zhukova, S. V., and SuvoRovA, G. A. "Age Changes in Content of Reticulocytes and in Osmotic Resistance of Erythrocytes." Uch. zap. Khar'kouskogo gos. un-teta (Annals of Khar'kov State Univ.), 63; Trudy nauch.-issled. in-la biologii $i$ biologicheskogo $f$-ta (Transactions of the Sci.-Res. Institute of Biology and Biological Pharmacotherapy), 24: 215-220, 1956.

1901. Nikitin, V. N., Butskaia, V. D., Vorob'eva, T. M., Ermakov, P. P., and Kovtun, N. E. "Efiect of Acidophilous Milk (Acidophilin) and Streptomycin on Growth of laboratory animals. Uch. zap. Whar'kovskogo gos. un-teta (Annals of Khar'kov State University), v. 63; Trudy nauch.-issled. in-ta biologii $i$ biologicheskogo $f$-ta (Transactions of the Sci.-Res. Inst. of Biol. and Biolog. Pharmacotherapy), 24: 275-279, 1956.

1902. Nikitin, V. N., Golubitskaia, R. I., Silin, O. P., Jikinusinina, L. G., and Blok, I. N. "Age Changes in the Biochemism of Denervated Organs. 1. Age Changes of Certain Biochemical Indices of Cross-Striated Muscles at Denervation and Tenotomy." Uch. zap. Khar'kouskogo gos. un-leta, v. 63; Trudy nauch.-issled. in-ta biologii i biologichestiogo f-ta (sec above), 24: 79-100, 1956. 
1903. Nikitin, V. N., Golubitskaia, R. I., Silin, O. P., and Stavitskaia, L. I. "Age Changes of Biochemism of Dneervated Organs. II. Age Changes of Certain Biochemical Indices of Liver at Its Denervation." Uch. zap. Khar'kovskogo gos. un-lela (see above), v. 63; Trudy nauch.-issled. in-ta biologii $i$ biologicheskogo $f$-ta (See above), 24: 101-116, 1956.

1904. Nikitin, V. N., and Morozova, V. F. "Data on the Ontophysiology of the Oak Silkworm (Antheraea pernyi G.-M.). III. Changes in Dehydrase Activity." Uch. zap. Khar'kovskogo gos. un-tela (see above), v. 63; Trudy nauch.-issled. in-la biologii i biologicheskogo f-ta (see above), 24: 153-160, 1956.

1905. Nikitin, V. N. "Hematological Atlas of Farm and Laboratory Animals" (Gematologicheskii atlas sel'skokhoziaistvennykh i laboratornykh zhivolnykh. M., Sel'khozgiz SSSR), Moscow. State Publ. House of Farm Lit. USSR, 1956.

1906. Nikitin, M. D. "Outline of Development and Current State of Knowledge of Tests in vivo." Vestnik obshchei gigieny, sudebnoi i prakticheskoi meditsiny (J. of General Hygiene, Legal and Practical Medicine), 1 (part 3): 1, 1889.

1907. - "Life of the Newborn Without Respiration." Ibid., 11 (part 3): 1, 1891.

1908. Nikitin, I. N. "Age Phase Factor and Methods of Accelerating Growth of Oak in the First Years of Its Life." Les $i$ step" (Forest and Steppe), (2): 16-26, 1949.

1909. Nikitin, P. I. "Change of the Antidiuretic Activity of the Hypophysis in the Ontogenesis." Fiziologicheskii zhurnal SSSR (Physiological J. USSR), 36(6): 728-733, 1950.

1910. - and Tverskoi, G. V. "Change of Antidiuretic and Oxytotic (sic; should be oxytocic?) Activity of the Neurohypophysis in the Ontogenesis." Ibid., 37(2): 205-209, 1951.

1911. NikitıN, G. M. "Interrelationship in Development of Orientated and Conditioned Motor Reaction in the Ontogenesis." Zhurnal vysshei nervnoi deiatel'nosti ( $\mathrm{J}$. of Higher Nervous Activity), 4(3): 406-414, 1954.

1912. Nikiforov, N. D. "Growth and Respiration of the Young of Salmon with Different Concentrations of Oxygen in the
Water." DAN SSSR (Reports of the Acad. of Sciences USSR), 36(6): 1231-1232, 1952.

1913. - "Gas and Protcin Exchange in Young Salmon." Ibid., 100 (5): 10251027, 1955.

1914. Nikiforova, N. M. "The E.S.R. and General Analysis of Blood of the Newborn." Voprosy pedialrii $i$ okhrany materinstva $i$ detstva (Problems of Pediatrics and Maternal and Child Welfare), 12(9): 391-401, 1940.

1915. NIKIS1IIN, G. V. "Irradiation and Concentration of Stimulation in the Central Nervous System in the Ontogenesis of the Axclotl." Referaly nauch.-issled. rabol Akademii meditsinskikh nauk SSSR, medikobiol. nauki (Reviews of the Sci.-Rcs. Works of the Acad. of Med. Sciences USSR, Medico-Biological Sciences), 7, 1949.

1916. Nikolaev, A. I. "Conference on Importance of Age in Animal Breeding (Introductory Speech at Conference)." Sb.: Nauchnaia konferentsiia po voprosam znacheniia vozrasta pri razvedenii sel'skokhoziaistvennykh zhivotnykh. M., izd-vo Timiriazevskoi s. kh. akademii Collection: Scientific Conference on Problems of Importance of Age in Breeding of Farm Animals. Moscow. State Publ. House of the Timiriazev Academy of Agriculture), 1953, pp. 5-8.

1917. Nixolaev, L. P. "Morphological and Weight Changes of Organs During Starvation of Children." Vrachebnoe delo (Medical Affairs), (9-10): 213-216, 1923.

1918. (11-12): 260-264, 1923.

1919. Nikolaev, N. M. "Progrcss in the Area of Problems of Hematopoiesis (Summary)." Zhurnal po izuchenïu rannego detskogo vozrasta (J. for Study of Early Childhood), 8(4): 313-329, 1928.

1920. - "Pathology of the ReticuloEndothelial System in Infants During Infections and Intoxications." Trudy I V sesoiuznogo s'ezda patologov, Kiev, izd-vo "Nauchnaia mysl" (Transactions of the First All-Union Congress of Pathologists, Kiev. The "Scientific Thought" Publ. House), 1929, pp. 194198.

1921. "Acidosis and Its Importance in Pathology of Early Age." Zhurnal po izucheniiu rannego detskogo vozrasla (J. for Study of Early Childhood), 12(4): 105-113, 1932. 
1922.

"Courscs of Dcrelopment of

Age Pathology." Suretshaia pediatriia (Sovict Pediatrics), (1): 11-16, 1934.

1923. "Some Practical Conclusions from the Scientific-Research Work for 10 lears of the Division of General and Experimental Pathology of the Central Institutc for Maternal and Child Welfarc." Sovetskaia pediatriia (Soviet Pediatrics), (11): 7, 1934.

$192 t$. "Agc Characteristics of Reticulo-Endothelial Barriers at an Early $\Lambda g e$ and Their Inmportance in the Picturc of the Infectious-Toxic Processes of Children." Retikulo-endotelial'naia sistema, hrovetvorenie i pigmentuyi obmen. M., Biomedyiz (ReticuloEndothclial System, Hcmatopoiesis, and Pigment Exchange. Moscow, State Publ. llousc of Biomcdical Lit.), 1935, pp. 37-55.

1925. - "Rcgulation of Cárbohydrate Exchange in Early Childlood." Sovetshaia pediatrian (Soviet l'ediatrics), (1): 10-18, 1935.

1926. and BARU, A. E. "Connection of Clinic and of Pathological Anatomy in Children of Early Age." Ibid., (6): 1936.

1927. Nikolaev, N. M. "Current Status and Perspectives of Devclopment of Age Pathophysiology." hlinicheskaia meditsina (Clinical Mcdicinc), 14(9): 1267, 1936

1928. - "Charactcristics of Pathology of Early Childhood" (Osobennosit patologii rannego detskogo vozrasia. Biomedgiz, М.), State P'ubl. House of Biomcd. Lit., Moscow, 1937.

1929. - "Types of Glycemic Curves and Patterns of Their Structure." Pedialriia (Pediatrics), (12): 10-18, 1938.

1930. - - " "Problcms of Age Pathology. (Activity of Division of General Pathology of Childhood)." Sb.: XXV let Instituta pediatrii Akademii meditsinskikh nauk SSSR, M. (Collcction: Twenty-Five Years of the Institute of Pcdiatrics of the Academy of Med. Scicnces USSR, Moscow), 1947, pp. 101-104.

1931. " "Rcgulation of Metabolisin and Certain of Its Characteristics in Early Childhood" (Reguliatsiia obmena veshchesto i nekolorye ee osobennosti v rannem detskom vozraste. M., Akademiia meditsinskikh nauk SSSR), Moscow. Academy of Mcd. Sciences USSR, $1948,0.281$.
1932. Nikolazva, T. G. "The Monocyte and Lymphocyte Formulas and the Phagocyte Index in So-Called Practically Healthy Children of Nursing Age." Voprosy pediatrii i okhrany malerinstva $i$ detstva (Problems of Pediatrics and Maternal and Child W'clfare), 17(5): 51-54, 1949 .

1933. Nitskevicit. "Changes in Muscle and Ncrve Ganglia of Ilcart During Pneumonia of Nursing Children" ( $O b$ izmeneniiakh $v$ myshtse i nervnykh uzlakh serdisa pri pnevmonii u grudnykh detei. Diss.), a disscrtation, 1901.

1934. Novikov, S. 'T. "Age Changes of Active Reaction and Rescrve Alkalinity of Blood in Many Anaimals (Ukr.: Vikovi zmini aktionoi reaktsii $i$ rezeronoi luzhnosti krovi $v$ deiakikh tvarin). Eksperimental'na meditsina (Expcrimental Medicine), (3): 95-102, 1937.

1935. Novikov, B. G. "Sexual Maturity and Oviparity of Swimming Fowl." Sb.: K biologii razvitiia s. kh. ptits. Trudy In-ta zoologii AN USSR, Fiev (Collection: Biology of Development of Farm Fowl. Transactions of the Institute of Zoology of the Acad. of Sciences UkrSSR, Kiev, 10: -, 1953.

1936. Novikov, B., Levitskaia, G., and Abrazie1, A. "Reaction of HypophysialThyroid Complex on Effect of Temperature in Embryonic and Postembryonic Period of Development of Certain Warm-Blooded Animals." Ibid., 10:--, 1953.

1937. Novikov, S. T. "Some PhysicoChemical Changes in the Animal Organism to Proteascs of Its Postembryonic Developmcnt" (Ukr.: Deiaki fiziko-khimichni zmini " tvarinnomu organizmi na protiazi iogo postembrional'nogo rozvilku.) Pratsi Naukdosid. Zoobiologichnogo in-lu Kharkivs'kogo derzh. untetu, Kharkiv (Works of the Sci.-Res. Zoobiological Institutc of Khar'kov State University, Khar'kov), (7): 151-180, 1938.

1938. - - "Changes of Rescrve Alkalinity and Activc Reaction of Blood in the Growing Organism Under Effect of Acid and Alkalinc Radicals" (Ukr.: Zmini rezervnoi luzhnosti $i$ aktivnoi reakts ii krovi v rostuchomu or ganizmi pid oplivom kislikh ta luzhnikh radikaliv). Eksperimental'na meditsina (Experimental Medic!ne), (3): 61-66, 1938.

1939. "Age Changes of Active Reaction and Dcgrce of Buffering of the Skin" (Ukr.: Vikovi zmini aktivnoi reaktsii $i$ stupenia zabufernosti shkiri). Eksperimental'na meditsina (Experincntal Medicinc), (3): 41-45, 1939. 
1940. Novikova, N. M. "Changes in Composition of Liver Tissue in the Conditions of Stimulated Synthesis." Uch. zap. (Annals), v. 3; Trudy nauch.-issled. Instituta biologii Khar'kovoskogo gos. un-tela (Transactions of the Sci.-Res. Institute of Biology of Khar'kov State Univ.), 1954, pp. 99-111.

1941. "Changes in Composition of Liver Tissue of Young Animals at 'Stimulated' Regeneration Synthesis." Uch. zap Khar'kovskogo gos, un-teta (Annals of Khar'kov State Univ.), v. 68; Trudy nauch.-issled. In-ta biologii $i$ biologicheskogo $f$-ta (Transactions of the Sci.-Res. Institute of Biology and Biological Pharmacotherapy), 24: 21-34, 1956.

1942. Novikova-Dantsiger, T. I. "Senile Changes of Nitrogen and Protein Stores in Tissues and Effect on Them of Cytotoxic Antireticular Serum" (Ukr.: Starechi zmini azotnogo $i$ bilkovogo skladu tkanin $i$ vpliv na nikh tsitotoksichnoi antiretikuliarnoi sirovatki). Medichnii zhurnal AN USSR (Medical J. of the Acad. of Sciences UkrSSR), 12: 150-167, 1944.

1943. Novitskil, I. S. "Age Changes of Peripheral Nervous System-the Signal Ganglia, Radiculae, and Sciatic Nerve." Trudy Omskogo med. in-ta (Transactions of Omsk Med. Inst.), 1940, pp. 90-100.

1944. Novogrudsk1I, A. M. "Ontogenetic Changes of Water Gradient in Foliated Series of Annual Cerals." DAN SSSR (Reports of the Acad. of Sciences USSR), 51(2): 159, 1946.

1945. NovoseL'ski1, S. A. "Mortality and Length of Life in Russia" (Smertnost' i prodolzhitel'nost' zhizniv Rossii). Petrograd, 1916.

1946. - and Paevskii, V.V. "Mortality Tables of the Leningrad Population for 1910-1911, 1920-1923." Materialy po statistike Leningrada $i$ Leningradskoi gubernii (Statistical Data of Leningrad and the Leningrad District), 6:-, 1925.

1947. Norkina, L. N. "Age Characteristics of External Inhibition and of Disinhibition in Children." Sb.: Opvt sistematicheskogo eksperimental'nogo issledovaniia ontogeneticheskogo razvitiia ontogeneticheskogo razvitiia korkovoi dinamiki u cheloveka, izd-vo VIEM, M. (Collection: Attempt at Systematic Experimental Study of the Ontogenetic Development of Cortical Dynamics in Man. State Publ. House of the All-Union Inst. of Experimental Med., Moscow), 5: 115-127, 1940.
1948. Nuss, M. A. "Blood Reticulocytes in Children of an Early Age." Voprosy pediatru $i$ okhrany materinstva $i$ detstva (Problems of Pediatrics and Maternal and Child Welfare), (6): 47-48, 1952.

$\mathrm{O}$

1949. Obraztsov, G. D. "The Alkaline Reserve in Children of Psychoneurotics." Russkii fiziologicheskii zhurnal (Russian Physiological J.), 13(4-5): 570-575, 1930.

1950. - "Dependency Between Ammonium Coefficient and Active Akalinity of Urine of Children of Psychoneurotics." Ibid., 13(2-5): 576-583, 1930.

1951. - "Iron Exchange in Children 7-8 Years Old in Connection with Nutrition." Vozrastnaia biokhimiza detei i podrostkoi. Sb. 1, Institut okhrany zdorov'ia detei i podrostkov, L. (Age-Associated Biochemistry of Children and Teen-Agers. Collection. Institute for the Health Care of Children and Teen-Agers. Leningrad), 1: 84-113, 1935.

1952. - Minker-Bogdanova, E. T., and Kalinnikova, M. N. "Data on Problem of Inhibiting Effect on Growth of Cats of the Claude-Bernard Puncture." Ibid., 1: 166-178, 1935.

1953. "Outline of Work of the Biochemical Laboratory of the Institute for Health Care of Children and Teen-Agers for 1926-1933. Vozrastnaia biokhimiia detei i podrostkov. Sb. 1, pod red. V. N. Ivanova, A. M. Petrun'kinoi, G. D. Obraztsova, Institut okhrany zdorov'ia detei i podrosthov, L. (Age-Associated Biochemistry of Children and Teen-Agers. Collection I, edited by V. N. Ivanov, A. M. Petrun'kina, and G. D. Obraztsov. Institute for the Health Care of Children and TeenAgers, Leningrad), 1935.

1954. Obraztsova, G. A. "Development of Vestibular Function in the Ontogenesis." Tezisy diss., izd-ro $A \mathcal{N}$ SSSR (Theses of Dissertations. State Publ. House of the Acad. of Sciences USSR), 1946; Referaty nauch.-issled. rabot Akademii meditsinskith nauk SSSR, medikobiol. nauki (Abstracts of the Sci.-Res. Works of the Acad. of Med. Sciences USSR, MedicoBiol. Sciences), 1947, p. 117.

1955. "Mobility of Nerve Processes in Ontogenesis of Rabbit." Trudy Instituta fiziologii im. I. P. Pavlova, izd-vo AN SSSR, M.-L. (Transactions of the I. P. Pavlov Institute of Physiology. State Publ. House of 
the Acad. of Sciences USSR, Moscow-leningrad), 2: 411-417, 1953.

1956. "Characteristics of Functional Disorders of the Ncrvous Systcm During liypoxia in the Ontogenesis." Fiziologicheskii zhurnal SSSR (Physiological J. of the USSR), 39(3): 339-345, 1953.

1957. "Emcrgence and Devclopment of the Conditioned Reflex of the Act of Shaking Itsclf in the Ontogenesis of Dog." Ibid., 4l(5): 593-600, 1955.

1958. Ovchinnikov, N. N. "Thcory of Cyclic Aging and Regcneration of Plants." Selektsiia i semenovodstvo (Selcction and Secd Culture), (2): 14-19, 1952.

1959. Oganisian, A. A. "Decercbration Rigidity in Guinca Pigs and Rabbits in the Ontogenesis. Fiziologicheskii zhurnal SSSR (Physiological J. of the USSR), 28(5): 476$489,1940$.

1960. and Shtamler, S. M. "Physiological Characteristics and Mechanisms of Regulation of Cardiac Activity in Different Age Periods." Tezisy dokladov 4-i nauchnoi Lonferentsii, posviashchennoi 25-letiiu deiatel'nosti instituta pediatrii Akademii meditsinskikh nauk SSSR, M\%. (Theses of Reports of the Fourth Scientific Conference Dedicated to the 25th Anniversary of the Activity of the Institute of Pediatrics, Academy of Med. Sciences USSR, Moscow), 1947, pp. 32-33.

1961. Oganisian, A. A. "Respiratory Movements of Guinea Pig Fetus in Various Stages of Intrauterinc Life." Biull. eksperimental'noi biologii i meditsiny (Bulletin of Experimental Biology and Medicine), 25(2): 109$111,1948$.

1962. 'Cardiac Instability in Various Stages of the Ontogenesis of Guinea Pig." Referaty nauch.-issled. robot Akademii meditsins'il.h nauk SSSR, klinicheskie nauki (Abstracts of tlie Sci.-Res. Works of the Acad. of Med. Sciences USSR, Clinical Sciences), (5): 39$40,1948$.

1963. "A Solitary Tetanized Contraction as Indcx of Functional State of the Nerve-Muscle System in the Ontogenesis." Fizjologicheskii zhurnal SSSR (Physiological J. of the USSK), 39(1): 87-94, 1948.

1964. Ogorodnyi, Iu. M. "Changc of pH Valuc in Chicken Egg in Course of Embryonic Development Depending on Incubation Factors." Ibid., 19: 741, 1936.
1965. Odynets, R. P. "Chcmical Composition of Pig Embryos." Trudy Kirgizskogo nauch.-issled. In-ta zhivotnovodstva (Transactions of the Kirgiz Sci.-Rcs. Institutc of Animal Husbandry), 9: 263-269, 1948.

1966. Ozeretskovskaia, N. E. "Problem of Purinc Exchange in Severc Disturbances of Nutrition and Digcstion in Children of an Early Agc. Repot I." Letnie detskie ponosy, izd-vo in-ta Okhmatdeta, M.-L. (Summer Diarrhcas of Children. State Publishing House of the Institute for Maternal and Child Welfare, Moscow-Leningrad), 1936, pp. 91103.

1967. Ozeretskovskaia, N. K. "Problcm of Purine Exchange in Severc Disturbances of Digestion in Children of an Early Age." Pediatriia (Pediatrics), 4(3): 13-19, 1937.

1968. Okanevskaia, E. K. "Effect of Thyroidectomy on Change in Intensity of Metabolism of Animals at Diffcrent Ages." Pratsi nauk.-doslid. Zoobiologichnogo in-tu, Kharkivs'kogo derzh. un-letu (Reports of the Sci.-Res. Zoobiological Institute, Khar'kov State Univ.), (10-11): 143-154, 1941.

1969. - "Effect of Thyroidectomy on Change in Intensity of Metabolism of Animals at Different Ages." Naukova khronika Kharkivs'-kogo derzh. un-tetu. Zbirnik anotatsii (Scientific Chronicle of Khar'kov State Univ. Collection of Notes), (3-4): 8-9, 1946.

1970. - "Effect of Castration on Age Changes of Metabolism." Uch. zap. Khar'kovskogo gos. un-ieta (Annals of Khar'kov State Univ.), 25: 141-148, 1947.

1971. Olevs'ki, M. I., Golomb, M. P., and LAzAREV, A. L. "Courscs of Development of Scientific Work for Health Care of Children Under 15 Years of Age in the Ukraine" (Ukr.: Shliakhi rozvitku naukovoi roboti zokhoroni zdorov'ia ditei na Ukraini za 15 rokiv). Profilaktichna meditsina (Prophylactic Medicine), (89): $33 ; 1935$.

1972. OlevskiI, M. I., and Borisova, A. P. "Effect of Fresh Air Therapy of Low Tempcrature of Childrcn's Devclopment and Nitrogen Exchange in Them." Sovetskaia pediatriia (Soviet Pediatrics), (6): 15, 1936.

1973. Olevskil, M. I. "Functional Characteristics of the Newborn." Akusherstvo $i$ ginekologiia (Obstetrics and Gynecology), (5): $20,1946$.

1974. "Effect of Varied Content of Protein in Nutrition on Dcvelopment and 
Function of the Growing Organism." Trudy VI Vsesoiuznogo s'ezda delskikh vrachei. M., Medgiz (Transactions of the Sixth AllUnion Congress of Pediatricians. Moscow, State Publ. House of Med. Lit.), 1948, p. 395.

1975. and Smirnov, G. I. "Reaction of Skin of Ncwborn to Ultraviolct Rays." Trudy Instituta akusherstva $i$ ginekologii. Idz-vo Akademii meditsinskikh nauk SSSR, M. (Transactions of the Institute of Obstetrics and Gynecology. State Publ. House of the Acad. of Med. Sciences USSR, Moscow), 1: 156-164, 1948.

1976. Olenov, Iu. M., and Pushnitsyna, A. D. "Sensitivity to X-Rays in Mammal Embryos." DAN SSSR (Reports of the Acad. of Sciences USSR), 34(2): 405-407, 1952.

1977. Olefirenko, P. D. "Age Characteristics of Nerve Regulation of the Heart in Decapitated Dogs." VII Vsesoiuznyi s'ezd fiziologov, biokhimikov, farmakologov. M., Medgiz (Seventh All-Union Congress of Physiologists, Biochemists, and Pharmacologists. Moscow, State Publ. House of Med. Lit.), 1947, pp. 530-534.

1978. Olifan, V. I. "Two Types of Periodicity in Postembryonic Development of Insects Demonstrated in a Study of Patterns of Growth." DAN SSSR (Reports of the Acad. of Sciences USSR), 35(6): 1407-1410, 1952.

1979. Ol'nianskaia, R. P. "Physiology of Altitude Acclimatization in Newborn Lambs." Opyt izucheniia reguliatsii fiziologicheskikh funktsii, M.-L., AN SSSR (Experiment in Study of Regulation of Physiological Functions. Moscow-Leningrad, Acad. of Sciences USSR), 1949, pp. 164-169.

1980. Ol'shevskaia, V. L., Brusilovskaia, R. D., Ribinchik, B. M., and Trius, R. V. "Problem of Effect of the Physical Condition of the Child on Productive Capacity and the State of Antidiphtherial Immunity." Zhur nal mikrobiologii, epidemiologii, immunologii (Journal of Mictobiology, Epidemiology, and Immunology), (7-8): 74-80, 1945.

1981. Oparin, A. I. "Enzymes and Life Cycle of Plants." Iubileinyi sbornik AN SSSR, posviashchennyi 30-letiiu Velikoi Oktiabr'skoi sotsialisticheskoi revoliutsii, M.-L. (Jubilee Symposium of the Acad. of Sciences USSR, Dedicated to the 30th Anniversary of the Great October Socialist Revolution. Moscow-Leningrad), 1948, pp. 647-659.
1982. "Problem of Origin of Life in Light of Achiciements of Contemporary Natrual Seience." Izvestiia AN SSSR, ser. biol. (Bulletin of the Aradcmy of Sciences USSK, Biological Scries), (2): 5-13, 1954.

1933. Oppel', V. V., and Fldorov, P. S. "Zur Charakteristik ol. alimentaren glykacmischen Kurve" (Characteristics of the Alimentary Glycemic Curvc). Zeitschr.f.d.ges. exper. Med., 63(3-4): - 1928.

1984. Orbant, B. "Problem of Senile Changes of the Skin" ( $K$ voprosu o slarcheskikh izmeneniiakh kozhi. Diss. SPb), a disscration. St. Petersburg, 1896.

1985. Orbeli, L. A. "Mechanism of the Emcrgence of Coordination in Pig Brain." Izvestiia nauch. in-ta im. P. F. Lesgafia (Bulletin of the P. F. Lesgaft Scientific Institute), 6: $202,1923$.

1986. - "The Principle of Evolution in Physiology." Priroda (Nature), (3-4): 77, 1933.

1987. - "Basic Problems of Physiology of Animals and Man in the Second FiveYear Plan." Russkii fiziologicheskii zhurnal (Russian Physiological J.), 16(2): 255, 1933.

1988. - "Nerve Regulation of Cardiac Activity and Circulation of the Blood." Trudy Voenno-medissinskoi akademii $R K K A, 1$ sb., $L$. (Transactions of the Academy of Military Medicine of the Workers' and Peasants' Red Army, Leningrad), 1:33-44, 1934.

1989. - "Lecture on Physiology of the Nervous System]' (Lekisii po fiziologii nervoni sisiemy. OGIZ, Biomedgiz, L.), State United Publ. Houses, Publ. House of Biomedical Lit., Leningrad, 1935.

1990. - "The Principle of Evolution in Physiology." VII Vsesoiuznyi s'ezd fiziologov, biokhimikov, farmakologov. Kn. 1, Medgiz, M. (Seventh All-Union Congress of Physiologists Biochemists, and Pharmacologists. State Publ. House of Med. Lit., Moscow), 1: 5-13, 1949.

1991. "Certain Mcthods of Studying Higher Nervous Activity of the Child." Izvestiia Akadernii pedagogicheskikh nauk RSFSR (Bulletin of the Acad. of Pedagogical Sciences RSFSR), 75(3-9): - 1955.

1992. - "Basic Landmarks in Study of the Higher Nervous Activity of the Child." VIII Vsesoiuznyi s'ezd fiziologov, biokhimikov, 
farmakologov. Tezisvdoklada, izd-r'o AS SSSR, 11. (Eighth All-Union Congress of Pliysiologits, Biochemists, and Pharmacologists. Report Theses. Statc Publ. House of the Acad. of Sciences USSR, Moscow), 1955, p. 460.

1993. Orduian, M. S. "Age and Individual Characteristics of Areolar Connective Tissue of Man as the Inner Medium of the Organism" (Vozrastnye $i$ individual'nye osobennosti rykhloi soedinitel'noi thani cheloveta, kak onuirennei sredy organizma). Avtoref. diss. na stepen' kand. med. nauk. 2-i Moskouskii med. in-t, .M. (Author's own abstract of his dissertation for the degree of candidate of medical scicnces of the Second Moscow Mcdical Institutc, Moscow), 1953. Referativnyi zhurnal. Biologiia ('The Abstract J.: Biology), (1): abstract $101,1954$.

1994. Orekhovich, V. N. "Change of Activity of Cathepsin in Tissues of Regenerated Rat Liver." Biull. eksperimental'noi biologii $i$ meditsiny (Bulletin of Experimental Biology and Medicine), 6(2): 230, 1938.

1995. and Sokolova, G. "Variability of 'Tissue Proteins in the Process of Regeneration of Organs in Amphibians." $D A \mathcal{N}$ SSSR (Reports of the Acad. of Sciences USSR), 28(8): 748, 1940.

1996. Orekhovich, V. N., Leviant, I. I., and Levchuk-Kurokhtina, T. P. "Inclusion of Tracer Amino Acids in Protein of Developing Chick Embryo." Biokhimiia (Biochemistry), 19(5): 610-615, 1954.

1997. Orlov, G. A., Anan'ina, and KalINiNA. "Age Characteristics of the Structure of Lumbar Region Truncus sympathicus." Sb. trudov Arkhagel'skogo med. in-ta (Symposium of the Works of the Arkhangel'sk Medical Institute), 5: 14-21, 1940.

1998. Orlova, G. N. "Histological Changes in Tribial Muscles and Their Innervation Systems at Cutting the Sciatic Nerve." $D A \mathcal{N}$ SSSR (Reports of the Acad. of Sciences USSR), 92(2): 421-424, 1953.

1999. Orlova, E. P. "Blood Pressurc and Age." Klinicheskaia meditsina (Clinical Mcdicine), (21): 945-948, 1931.

2000. Orlova, I. I. "Age Changes of Skeletal Muscles from Various Functional Stress in Horned Cattle" (Vozrastnye izmeneniia skeletnykh myshts s razlichnoi funktional'noi nagruzkoi u krupnogo rogatogo skota. Diss. Leningradskii veterinarnyi in- $t$ ), a dissertation. I.eningrad Vetcrinary Institute, 1951.
2001. - "Age Changes of Nuclei in Skclctal Muscles from Diffcrent Functional Strcss." Biull. eksperimental'noi biologii i meditsiny (Bullctin of Experimental Biology and Mcdicine), 38(6): 56-58, 1954.

2002. -Data on Study of Age Changes of Skeletal Muscles from Various Functional Strcss in Mammals (Agc Changes of Skeletal Muscles of Horned Cattle)." S'b. rabot Leningradskogo veterinarnogo in-la, izd-vo Narkoinzdrava SSSR (Collection of the Works of the Lcningrad Institute of Veterinary Medicine. Statc Publ. House of the People's Commissariat of Public Health USSR), (14): 195-203, 1954.

2003. Orlova, T. I. "Certain Data on State of Internal Organs and of Water Exchange in People of Advanced Age." Sb.: Vozrastnye izmeneniia obmena veshchesto $i$ reaktivnosti organizma. Izd-vo AN USSR, Kiev (Collection: Age Changes in Metabolism and Reactivity of the Organism. State Publ. House of the Acad. of Sciences UkrSSR, Kiev), 1951, pp. 227-239.

2004. Orlovskaia, G. V. "Development and Age Changes in Fibril Structures of Connective Tissue of Human Skin." Arkhiv $p a$ tologii (Archives of Pathology), (6): 51-59, 1949.

2005. Osınovski1, N. I. "Cardiovascular System in Children." Sovetskaia pediatriia (Soviet Pediatrics), (7): 40-46, 1934.

2006. "Cardiovascular System of the Child." Klinika reumatizma u detei. Biomedgiz, M.-L. (The Rheumatism Clinic of Children State Publishing House of Biomedical Lit., Moscow-Leningrad), 1935, pp. 208-213.

2007. "Data on Study of the Cardiovascular System in Children." Ibidem, 1935, pp. 237-247.

2008. - Titova, A. I., Morgolis, R. I., and Zlatopol'skaia, E. S. "Experiinents in Revival of the Child Heart." Sovetskaia pediatriia (Soviet Pediatrics), (9): 3-9, 1936.

2009. Osipova, O. P., and Timofeeva, I. V. "Study of the Protein of Chloroplasts." $D A \mathcal{N}$ SSSR (Reports of the Acad. of Scicnces USSR), 67(1): 105-108, 1949.

2010. Ostrov, S. I. "Functional Study of the Cardiovascular System of People of Advanced Age." Starost' trudosposobnost'. Sb. 
rabot .VIVITE, L. (Old Age and Work Capacity. Collection of Works of the "NIVTE" (see item 911 above), Leningrad), 1936, pp. 204-212.

2011. Ostrovs'KA, I. M. "AnatomicalPhysiological Features of Childhood. The Organization of Nursing Care and Boarding of Children." (Ukr.: Anatomo-fiziologichni osoblivosti ditiachogo viku). Organizatsiia dogliadu za dit'mi $i$ ikh kharchuvannia. Pereklad $z$ vidannia drugogo, vipravlenogo $i$ dopounenogo. Derzhmedvidav URSR, Kiiv) Translation of the $2 \mathrm{~d}$ revised and enlarged edition. State Medical Publ. House, UkrSSR, Kiev, 1954, p. 217.

2012. Ostriakova-Varshavre, V. P. "Cytology of the Impregnation of the Mulberry Silkworm in Connection with Differences in Susceptibility of Successive Phases of the Process to High Temperature." DAN SSSR (Reports of the Acad. of Sciences USSR), 33(6): 921-924, 1952.

2013. (Same Author?). "Body Movement in the Middle Years and in Old Age." Drug zdraviia (The Friend of Health); Narodnovrachebnaia gazeta (The National Medical Gazette), article 1. (7): 52-53, article II. (10): 73-74, article III. (15): 97-98, 1840.

2014. Otroshrevich, F. S. "Problem of Senile Changes in the Ovaries" ( $K$ voprosu o starcheskikh izmeneniiakh iaichnikor. Diss., SPb), a dissertation. St. Petersburg, 1896.

2015. Ochapovskil, S. V. "Apropos of 'Age' Ophthalmology." Trudy 3-i Krasnodarskoi klinicheskoi gorodskoi bol'nitsy, izd-vo Krasnodarskogo gor. zdravotdela (Transactions of the Third Krasnodar Clinical City Hospital. Publishing House of the Krasnodar City Health Dept.), 2: 5, 1936.

\section{$P$}

2016. Pavlov, V., and Isakova-Keo, M. "Studien Uber Redoxpotentiale im Hühnerei vor und während des Entwicklung" (Studies on the Redox Potential in Chicken Eggs Before and During Hatching). Bioch. Zeitsch., 216: 19, 1929.

2017. Pavlov, G. A. "Problem of Ontogenetic Development of Function of the Vegetative System." Biull. VIEM (Bulletin of the All-Union Institute of Experimental Medicine), (11-12): 26, 1935.
2018. Pavlov, G. N. "Data on the Physiology of Birds." Russki fiziologicheskii zhurnal (Russian Physiological J.), 10:301, 1927.

2019. Pavlov, I. P. "Death of Animals Following Cutting of Vagus Nerves." Trudy $O$-va russkikh vrachei v $S P b$ (Transactions of the St. Petersburg Soc. of Russian Doctors), 61 (April): , 1895; Polnoe sobranie trudov (Complete Collection of Works), 1: 326-329, 1940.

2020. - "Survival of Dogs with Vagus Nerves Cut." Trudy o-va russkikh vrachei v SPb (see above), 63 (March and June): 1896; Bol'nichnaia gazeta Botkina ('The Botkin Hospital Gazette), 1899; Polnoe sobr. trudov (see above), 1: 344-354, 1940.

2021. - "Senile Amnesia and Weakening of Inhibitory Processes." Pavlouskie sredy, izd-vo AN SSSR, M.-L. (Pavlovian Media. State Publ. House of the Acad. of Sciences USSR, Moscow-Leningrad), 1: 68, 1949.

2022. — "Weakening of the Process of Inhibition in the Cortex at Aging." Ibid., 1: 103, 1949.

2023. —_. (Same title)]' . . (Experiments of N. V. Vinogradov on 'Druzhka' (name of animal). Ibidem, 1: 116, 1949.

2024. - "Weakening of the Inhibitory Process in the Cerebral Cortex at Aging (Experiments of L. Ia. Andreev and V. K. Fedorov)." Ibid., 11: 22, 1949.

2025. — - "Weakening of the Process of Inhibition at the Aging of Dogs. Lengthening the Extinction Time (O. P. Iaroslavtseva's Experiments on 'Rex')." Ibid., 2: 39, 1948.

2026. —_. "Senile Amnesia as Magnification of Inertia of the Stimulus Process." Ibid., 2: 62, 1949.

2027. "Nature of Mobility of the Nerve Process." Ibid., 2: 64, 1949.

2028. —Weakening of the Process of Inhibition and of Mobility and Increase of Inertia at Aging of Animals (Observations of L. A. Andreeva, P. K. Anokhin, and V. K. Fedorov). Ibid., 2: 121, 1949.

2029. —Weakening of the Process of Inhibition at Aging (N. A. Podkopaev's 'Signal' (name of animal))."' Ibid., 2: 127, 1949. 
2030. "Effect of Old

Agc on Higher Ncrvous Activity of Dogs. Weakening of the Process of Inhibition in Connection with Aging is Variablc." Ibid., 2: 337, 1949.

2031. "Characteristics of Conditioncd Reflex Activity Under the Effect of Old Agc (Expcriments by A. M. Pavlova on 'Jack')."' Ibid., 3: 176, 1949.

2032. "More About Types. Unrestrained and Intense to Profound Old Age. (V. K. Fedorov's 'Rogue')." Ibid., 3: 288299, 1949.

2033. "Attempt at a Physiological Interprctation of the Symptomatology of Hysteria." Polnoe sobr. trudov, izd-vo AN SSSR, M.-L. (Complete Collection of Works. State Publishing House of the Acad. of Sciences USSR, Moscow-Leningrad), 3: 46I479, 1949. Pavlouskie sredy, stenogrammy 19351936 gg., izd-vo AN SSSR, M.-L. (Pavlovian Media, stenographic notes for 1935-1936. State Publ. House of the USSR, MoscowLeningrad), 3: 5 (for May 31, 1935), 1949. "Characteristics of Conditioned Reflex Activity under the Effect of Old Age." pp. 177-178 (sic).

2034. Pavlov, M. "Pathological-Anatomiical Changes in the Salivary Glands in Old Age" (O patologoanatomicheskikh izmenenizakh sliunnykh zhelez v starcheskom vozraste. Diss., $\mathrm{Spb})$, a dissertation, St. Petersburg, 1894.

2035. Pavlov, F. S. "Conditioned Reflex Emission of Saliva by the Submaxillary Gland in Calves." Fiziologicheskii zhurnal SSSR (Physiological Journal of the USSR), 27(1): 86-91, 1939.

2036. Pavlova, A. M. "Caffeine and Bromine Action on the Senile Central Nervous System of Dog." Trudy fiziologicheskikh laboratorii I. P. Pavlova, izd-vo AN SSSR, M.-L. (Transactions of the Physiological Lab. of I. P. Pavlov. State Publ. House of the Acad. of Sciences USSR, Moscow-Leningrad), 7: $-, 1938$.

2037. "Scnile Changes of Conditioned Reflex Activity of Dog." Tret'e soveshchanie po fiziologicheskim problemam. Tezisy doklador, M.-L. (The Third Conference on Physiological Problems. Theses of Reports, Moscow-Leningrad), 1938, p. 45.

2038. Pavlovskn1, E. N. "The Organism as the Mcdium of Residence." Priroda (Nature), (1): 80-91, 1934.
2039. Paducueva, A. L. "Agc Changes in Biochemical Composition of Blood of Shcep." Biull. eksperimental'noi biologii i meditsiny (Bull. of Exptl. Biology and Mcd.), 38(7): 33-36, 1954.

2040. Paevskil, V. V. A "Single Gencral Expression for Ability to Attain a Certain Agc in Conditions of Mortality for a Given Calendar Period." DAN SSSR (Reports of the Acad. of Scicnces USSR), 1(7): 381$387,1934$.

2041. Palladin, A. V. "Effect of Carbohydrate and Protein Starvation on Excretion of Creatine and Creatinine. Preliminary Report." Izvestiia $A \mathcal{N}$ (Bulletin of the Acad. of Sciences), series 6, part 2, v. 2(2): 11291137, 1916.

2042.

"Effect of Different Factors on Excretion of Creatine." Work done in collaboration with E. Zaianskaia and A. Ryskal'chuk. Trudy II g. o-vo estestvoispytatelei (Transactions of the Second Year of the Society of Naturalists), 47(4): 160-177, 1916.

2043. - in collaboration with A. RYSKAL'CHUK. "Effect of Carbohydrate and Protein Starvation on Endogenous Protein Exchange in Rats." Trudy Biuro po zootekhnii, Petrograd, izd-vo Uchenogo komiteta Ministerstva zemledeliia (Transactions of the Department of Zootechnics, Petrograd. Publishing House of the Scientific Committee of the Ministry of Agriculture), 12: 109-121, 1916.

2044. Palladin, A. V. "Studies on Formation and Excretion of Creatine in Animals." (Issledovaniia nad obrazovaniem $i$ vydeleniem kreatina u zhivotnykh. Khar'kov), Khar'kov, 1916.

2045. - "Excretion of Creatinine and Creatine in Sheep in Normal Conditions and During Starvation." Russkii fiziologicheskii zhurnal (Russian Physiological Journal), 5(4-6): 263-272, 1923 (19 refs.).

2046. - "Rejuvenation" (Omolozhenie. Khar'kov, "Put' prosveshcheniia"), Khar'kov, the "Road to Enlightenment" Press, 1923, 89 pp.

2047. Palladin, O. V. (Ukr. for above name) in collaboration with E. S. Savron'. "Problem of Creatinuria in Children and Its Dependency on 'Clanaula thyreoided" " (sic; apparently garbled: thyroid gland) (Ukr.: Do pitannia pro bitiachu kreatinuriiu ta zalezhnist' ii vid Clanaula thyreoided). Kharkiv, Derzh- 
vidav Ukraini (Khar'kov. State Publ. House of the Ukraine), 1926, pp. 115-127.

2048. Palladin, A. V., in collaboration with D. Ferdmann. "Uber den Einfluss des Charakters der Nahrung auf die Prozesse der Synthese und Oxydation" (Influence of Character of Food on Process of Synthesis and Oxidation) Biochem. Zs., 182(1-4): 193-203, 1927.

2049. in collaboration with $\mathrm{E}$. Ssawron (sic). "Beitrag zur Frage der kindlichen Kreatinurie und ihrer Abhangigkeit von der Schildrüse" (Contribution to the Question of Creatinuria in Children and Its Dependency on the Thyroid Gland). Ibid., 191(1-3): 1-12, 1927.

2050. Palladin, A. V. "Investigation of the Biochemistry of Creatine Phosphoric Acid and Other Phosphorous Compounds of the Muscles. Amer. 7. Physiol., 90(2): 466467, 1929. (Abstracts of Communications. XIII-th International Physiological Congress).

2051. Palladin, O. V., in collaboration with E. IA. Rashba. "Creatine in Brain During Ontogenetic Development of Vertebrates" (Ukr.: Kreatin u mozku pidchas ontogenetichnogo rozvitku khrebetnikh tvarin). Ukrains'kii biokhimichnii zhurnal (Ukrainian Biochemical Journal), 9: 5-42, 1936 (25 refs.).

2052. - "Arginine, Arginase, and Creatine in Tissues of Vertebrate Embryos" (Ukr.: Arginin, arginaza $i$ kreatin u tkaninakh embrioniv khrebetnikh tvarin). Ibid., 10(2): 193-242, 1937 (16 refs.).

2053. Palladin, A. V. "Achievements of Soviet Biochemistry for the 29 Years After the Great Proletarian Revolution." Priroda (Nature), (10): 124-141, 1937.

2054. - and Rasina, E. A. "Creatine of the Cerebrum in the Embryonic Development of Vertebrates." Fiziologicheskii zhurnal SSSR (Physiological Journal of the USSR), 24(1-2): 265-276, 1938.

2055. Palladin, O. V., and Rashba, O. Ia. "Creatine of the Cerebrum During the Ontogenetic Development of Vertebrates" (Ukr.: Kreatin u mozku pidchas ontogenetichnogo rozvitku khrebetnikh tvarin). Ukrains'kii biokhimichnii zhurnal (Ukrainian Biochemical Journal), 9(1): 34-51, 1936; Fiziologicheskii zhurnal SSSR (Physiological Journal of the USSR), 24(12): 265-276, 1938.
2056. Palladin, O. V., and Kilaikina, B. I. "Hexokinase in Cercbrum of Animals of Various Ages" (Ukr.: Geksokinaza v golounomu mozkovi tvarin riznogo viku). Ukrains'kii biokhimichnii zhurnal (sce abovc), 19(2): 169-178, 1947.

2057. Palladin, O. V. "Scientific Achievements of the Institute of Biochemistry of the Academy of Sciences UkrSSR in 1946" (Ukr.: Naukovi dosiagnennia Institutu biokhimii Akademii nauk URSR v 1946 g.). Visnik $A \mathcal{N}$ URSR (Journal of the Acad. of Sciences UkrSSR), (2): 33-38, 1947.

2058. - and Poliakova, N. M. "Aldolase of the Brain" (Ukr.: Al'dolaza mozku). Ukrains'kii biokhimichnii zhurnal (sce above), 21(4): 341-349, 1949.

2059. , Simutman, Ts. M., and Goncharova, K. O. "History of the Problem of the Sameness of Pepsin and Chymosin" (Ukr.: Do istorii pitaniia pro ednist' pepsinu $i$ khimozinu). Ibid., 25(3): 351-355, 1953.

2060. Pal'gova, L. E., and Volobuev, V. I. "Respiration in Conditions of Lowcred Atmospheric Pressure in Phylo- and Ontogenesis." Biull. eksperimental'noi biologii $i$ meditsiny (Bulletin of Experimental Biology and Medicine), 10(6): 454-456, 1940.

2061. PaL'gova, L. E. "Reflexes with Chemoreceptors of the Intestines to Blood Pressure and Respiration in the Ontogenesis." Ibid., 38(7): 7-9, 1954.

2062. - "Interoceptive Effects from the Urine-Elimination System on Blood Pressure and Respiration in the Ontogenesis." Ibid., 38(12): 3-6, 1954.

2063. Panina, L. G. "Strength of Immunity to Streptococcus scarlatinae Toxin in Different Groups of Dick-Negative Children." Trudy Leningradskogo in-ta im. Pastera, L., Medgiz (Transactions of the Leningrad Pasteur Institute, Leningrad. State Publ. House of Med. Lit.), 7: 93-99, 1940.

2064. —, Gechevskaia, V. A., and Gollerbakh, A. N. "Degree of Sensitivity to Scarlatinal Toxin of First-Grade Pupils and of Kindergarten Children as Result of an Inoculation Taking." Ibid., 7: 100-117, 1940.

2065. Panov, N. A. "Bases for X-ray Study of the Heart in Children" (Osnovy rentgenovskogo issledovaniia serdtsa $u$ detei. Medgiz, M., 1934; M., Diss. 1943), State Publ. House of 
Med. Lit., Moscow, 1934; Moscow dissertation, 19.43.

2066. - "X-ray Dimensions of the Heart in Juvenile ?" Detskie bolezni $i$ bor'ba s nimi. Medgiz, M. (Childhood Diseases and Their Control. State Publ. House of Med. Lit., Moscow), 193t, pp. 192-209.

2067. "Data on Age Characteristics of the Heart of Four-Year-Old Children in X-ray Picture." Klinika revmatizma u detei. Biomedgiz, M.-L. (Clinic of Rheumatism in Children. State Publ. House of Biomed. Lit., Moscow-Leningrad), 1935, pp. 189-204.

2068. Panteleeva, M. N. "Reactivity of the Child Organism to Specific and NonSpecific Allergies." Voprosy pediatrii i okhran materinstua $i$ detstva (Problems of Pediatrics and Protection of Motherhood and Infancy), 12(12): 614-620, 1940.

2069. Pancilenkova, E. F. "Study of Conditioned Reflexes in Guinea Pigs in the Ontogenesis." Zhurnal vysshei nervnoi deiatel'nosti (J. of Higher Nervous Activity), 5(6): 873$880,1955$.

2070. Parina, E. V. "Age Changes in Purine Exchange." Uch. zap. Khar'kovskogo gos. un-teta (Annals of Khar'kov State Univ.), v. 25; Trudy in-ta biologii, izd-vo KhGU, Khar'kov (Transactions of the Institute of Biology. State Publ. House of Khar'kov State Univ., Khar'kov), 12:83-94, 1947.

2071. - and Sopotsinskaia, E. V. "Age Changes of Oxidizing Phosphorylation in the Brain." Uch. zap. Khar'kovskogo gos. un-teta (see above), v. 68; Trudy nauch.-issled. in-ta biologii $i$ biologicheskogo $f$-ta (Transactions of the Sci.-Res. Inst. of Biology and Biological Pharmacotherapy), 24: 43-50, 1956.

2072. Parskil, K. V. "The Thyroid Gland and Its Modification with Age." (Schhitovidnaia zheleza $i$ ee izmenenie po vozrastam. Diss. iz kliniki M. P. Gundobina, Spb), a dissertation from the M. P. Gundobin Clinic, St. Petersburg, 1901.

2073. Parfenova, I. P. "Age Characteristics in Lymphatic System of Normal Lung." Pediatriia (Pediatrics), (1): 9-15, 1953.

2074. Pasechnik, A. M. "Reaction of Smooth Musculature of Intestines of Embryos and Newborn Animals to Bruccllosis and Typhoid lindotoxins." Mikrobiologichnii zhurnal (Microbiological J.), 11(2): 63-7l, 1941.
2075. - "Reaction of Sinooth Musculature of Intestincs in Embryos and Newborn Animals." Tezisy ob'edinennogo plenuma veterinarnoi sektsii BASKhNIL i Kazakhskogo filiala VASKhNIL (Theses of the Joint Plenum of the Veterinary Section of the All-Union Sci. Res. Inst. of the Electrification and Mechanization of Agriculture and the $\mathrm{Ka}$ zakh Affiliate of the same), Alma-Ata, 1944.

2076. Patrushev, V. I. "Succession of Biochemical Indications in Animals in Connection with Their Growth. I. Concentration of Glutathione in Blood and Natural Differences in the Specifications of Farm Animals." Doklady AN SSSR (Reports of the Acad. of Sciences USSR), 14(9): 573-577, 1937.

2077. - "Succession of Biochemical Indications in Animals in Connection with Their Growth. II. Catalase Content in Blood of Horned Cattle and Sheep." Ibid., 14(9): 579-584, 1937.

2078. - "Physiological Differences of Horses in Connection with Their Age, Breed, and Performance." Ibid., 23(7): 717-719, 1939.

2079. - - "Problem of Age Variability of Organisms in Zootechnical Physiology." Sb.: Nauchnaia konferentsiia po voprosam znacheniia vozrasta pri razvedenii sel'skokhoziastvennykh zhivotnykh. M., izd-vo Timiriazcvskoi s. kh. akademii (Collection: Scientific Conference on Problems of Importance of Age in Breeding of Farm Animals. Moscow. Statc Publ. House of the Timiriazev Agricultural Academy), 1953, pp. 112-123.

2080. Patusuinskaia and Tkaghenko. "The Water-Salt Economy in Hydro-Labile and Hydro-Stabile Children of an Early Agc. Report I." Sovetskaia pediatriia (Soviet Pcdiatrics), (8): 7-14, 1936.

2081. Pashoova, T. F. "Effect of Caffeinc on the Cardiovascular System of Children." (Deistvie kofeina na serdechno-sosudistuiu sistemu u detei. M.), Moscow, 1953.

2082. Pevzner, T. N. "Motor Reactions in the Newborn to Touch and Prick." Sb. naulchnykh rabot, posviashchennyi 70-letïu E. K. Seppa (Collection of Scientific Works Dedicated to the 70th Anniversary of E. K. Sepp). Moscow, Medgiz, 1948, p. 281.

2083. Penionzhievich, E. E., and Shikliar, N. M. "Data for Study of Pathological Phenomena in Embryonic Development of Chicks During Artificial Incubation" (Ukr.: 
Materiali do vivchennia patologichnykh iavishch $v$ embrional'nomu rozvitku kurchat u shtuchnii inkubatsii). Problemi inkubatsii (Problems of incubation), 1: -, 1934.

2084. Pentsik, A. S. "The Ontogenesis of Bioelectric Activity and of Cellular Structure of Cerebral Cortex of Rabbit." Biull. eksperimental'noi biologii $i$ meditsiny (Bulletin of Experimental Biology and Medicine), 4(2): 121123, 1937.

2085. - "Ontogenetic Development of Bioelectric Activity and of Cellular Structure of the Cerebral Cortex." Trudy Instituta mozga, M., Medgiz (Transactions of the Brain Institute. Moscow, State Publ. House of Med. Lit.), 1940, pp. 273-296.

2086. Pergament. "Effect of Alcoholic Poisoning of Rabbits on Bone Growth of Unborn Fetuses." ( $O$ vliianii alkogol'nogo otravleniia krolikov na rost kostei utrobnykh ikh plodov. Diss. Peterburg), a dissertation, St. Petersburg, 1900.

2087. Peremyslova, A. A. "Problem of Thermal Regulation in Early Childhood." Pediatriia (Pediatrics), (4): 710, 1940.

2088. Perikhaniants, IA. I. "Importance of Age in the Antitoxic Effect of Glucose in Tadpoles Poisoned with Strychnine." Farmakologiia $i$ toksikologiia (Pharmacology and Toxicology), (6): 70, 1939.

2089. Perov, S., and Dolinov, K. "Change of Physico-Chemical Constants of Plasma of Hen's Egg at Incubation." Trudy laboratorii po izucheniiu belka i belkovogo obmena, Izd-vo VASKhNIL, M. (Transactions of the Laboratory for Study of Protein and Protein Exchange. State Publ. House of the AllUnion Sci. Res. Inst. of the Electrification and Mechanization of Agriculture), (3): 1932.

2090. Pershin, A. V. "Change of Body Weight and Temperature in Newborn Children in the First Week of Life." Dnevnik o-va vrachei pri Kazanskom un-tete za 1891 (Journal of the Medical Society at Kazan Univ. for 1891.), (1): 27, 1891 .

2091. Petrov, A. N. "Study of the Anthropometry and Physiology of Old Age." Meditsinskie pribavleniia $k$ morskomu sborniku (Medical Supplement to the Marine Collection), April, 1899.

2092. Petrov, V. A. "Problem of Complete Starvation at Different Periods of Ani- mal Growth." Russkaia meditsina (Russian Medicine), (37, 38, 39): - 1886.

2093. Petrov, V. M. "Age Dynamics of Certain Indices of Mineral and Nitrogen Metabolism in Healthy Calves and Their Change During Dyspepsia and Bronchial Pneumonia." Author's own abstract of dissertation for degree of Candidate of Veterinary Science. Ministry of Agriculture, USSR. Alma-Ata Veterinary-Zootechnical Institute, Alma-Ata, 1953.

2094. Petrov, S. I., and Emdina, KiI. L. "Effect of Irradiation by Quartz Lamp on Physical Development of Children at an Early Age." Sovetskaia pediatriia (Soviet Pediatrics), (7): 32, 1935.

2095. Petrova, V. V. "Magnesium and Calcium Content in Mice Muscle Dependent on Age." Biull, eksperimental'noi biologii i meditsiny (Bulletin of Experimental Biology and Medicine), 9(2-3): 133-134, 1940.

2096. - and Suastin, N. R. "Problem of the Qualitative Composition of Saliva in Children." Fiziologicheskii zhurnal SSSR (Physiological J. of the USSR), 30(4): 484489,1941 .

2097. Petrova, M. K. "Narcotic Sleep, Hypnotic Sleep, as Well as Limited Protective Inhibition and Their Therapeutic Importance." Trudy ob'edinennoi sessii, posviashchennoi 20-letiiu so dnia smerti, 1. P. Pavlova, izd-vo Akademii meditsinskikh nauk SSSR (Transactions of the Joint Session in Commemoration of the 20th Anniversary of I. 1 '. Pavlov's Death. Publ. of the Academy of Medical Sciences USSR), Moscow-Leningrad, 1938.

2098. - "Origin of Old Age and Prophylaxis for Premature Aging." Nauka i zhizn' (Science and Life), (11-12): 10-22, 1944.

2099. - " Role of Functionally Weakened Cerebral Cortex in Arising of Different Pathological Processes in the Organism" ( $O$ roli funktsional'no-oslablennoi kory goloinogo mozga $v$ vozniknovenii razlichnykh patologicheskikh protsessov $v$ organizme. Medgiz. Leningradskoe otdelenie). State Publ. House of Med. Lit., Leningrad Division, 1946.

2100. - "Latest Data on Mechanism of Effect of Bromine Salts on Higher Nervous Activity and on Their Therapeutic Use for Experimental Reasons." Sobr. trudov M. K. Petrovoi, izd-vo Akademii meditsinskikh nauk 
SSSR (Collection of M. K. Petrova's Works. Publ. of the Academy of Mcdical Sciences USSR), 2: 5-154, 1953.

2101. Petrun'kina, A. M. "Problem of Nitrogen, Calcium, Magnesium, Phosphorus, and Iron Balances in Children 7-8 Years old." Vozrastnaia biokhimiia detei i podrostkov. Sb. 1, L., Instituzt OZDiP (Age Biochemistry of Children and Adolescents. Collection, Leningrad, Institute of Div. of Health Carc of Children and Adolescents), 1: 12-27, 1935.

2102. Petriaeva, A. T. "Vitamin A Content in Liver of Children and Human Fetuses of Various Age." Kazanskii meditsinskii zhurnal (Kazan Medical Journal), (9): 14-19, 1939.

2103. Peciruk, L. M. "Certain Pathophysiological Indices of Allergy During Tuberculosis in Children at an Early Age." Sovetskaia pediatriia (Soviet Pediatrics), (5): 12-18, 1936.

2104. Pigareva, Z. D. "Carbonic Anhydrase in Blood and Brain in the Embryogenesis of Rabbits and Guinea Pigs." $D A \mathcal{N}$ SSSR, nov. ser. Reports of the USSR Academy of Sciences, New series), 58(7): 1535$1538,-$

2105. - "Carbonic Anhydrase in Brain of Mature and Immature Fowl." Ibid., 60: 185, 1948.

2106. - and Cherverikov, D. A. "Cytochrome Oxidase and Succindehydrase of Brain in the Ontogenesis." Biokhimiia (Biochemistry), 15(6): 517-522, 1950.

2107. "Development of Oxidative Enzymatic Systems of Chick Brain in the Ontogenesis." DAN SSSR (see above), 28(1): 169-172, 1951.

2108. PiNes, L. IA., and KryLov, L. N. "Ontogenesis of the Subfornix (cerebri?) Organ of Man." Nevropatologiia, psikhiatriia $i$ psikhigigiena (Neuropathology, Psychiatry, and Mental Health), 4(9-10): 193-200, 1935.

2109. Pines, L. IA. "Ontogenesis of the Vegetative Centers of Man." Nevropatologiia : psikhiatriia (Neuropathology and Psycliatry), 10(3): 24-27, 1941.

2110. - "Problem of Recapitulation Phenomena in Ontogenesis of the Human Brain." Fiziologicheskii zhurnal SSSR im. Sechenova (Sechenov Physiological Journal), 33(6): 709-726, 19.47.
2111. "Phenomena of Progressive and Regressive Evolution in the Ontogenesis of the Human Brain." Sb. Ontogenez mozga, L. (Collection: Ontogenesis of the Brain. Leningrad), 1949, pp. 6-23.

2112. - "Certain Rules of Evolution in the Ontogenesis of the Brain." Trudy $V$ $V$ sesoiuznogo s'ezda anatomor, gistologov $i \mathrm{em}$ briologov, Medgiz, L. (Transactions of the 5th All-Union Congress of Anatomists, Histologists and Embryologists. State Publ. of Med. Lit., Leningrad), 1951, pp. 45-49.

2113. Pistrak, M. M. "Protein Composition of the Blood at Various Ages." Materialy kliniki po vozrastnoi patofiziologii pod redaktsiei I. P. Razenkova i I. G. Gel'mana, VIEM, M. (Data of the Clinic for Age Pathophysiology. I. P. Razenkov and I. G. Gel'man, editors. All-Union Institute of Experimental Medicine, Moscow), 1937, pp. 142-156, and 159-171.

2114. - "Elimination of Creatinine at Various Ages." Arkhiv biologicheskikh nauk (Archives of Biological Sciences), 17(2): 7686, 1937.

2115. Pletsitnyi, D. F. "Age Characteristics of Reaction of White Mice to Tetanus Toxin." DAN SSSR, Novaia ser. (Proceedings of the Acad. of Sciences USSR. New Series), 62(2): 277-280, 1948.

2116. - and ZeL'MENOVICH, R. IA. "Tetanus Antitoxin Immunity in Experimental Animals at Various Age Periods." Biull. eksperimental'noi biologii $i$ meditsiny (Bulletin of Experimental Biology and Medicine), 27(6): 444-447, 1949.

2117. Pleshrov, S. V., and Vasil'ev, N. P. "Method for Keeping Ducklings in the First Days of Life at the 'New Life' Duck-Raising Collective Farm." Ptitsevodstvo (Poultry Raising), (7): -, 1952.

2118. Plonskaia, V. P. "Diastase in Urine of the Newborn." Sovetskaia pediatriia (Soviet Pediatrics), (5): 19-22, 1936.

2119. Plotnikova, O. V. "Chronaxy of Muscles and Nerves of Lower Limbs in Healthy Children." Biull. eksperimental'noi biologii $i$ meditsiny (sce above), 6(3): 337-340, 1938.

2120. Povorinskaia, S. A. "Calcium and Magnesium Excnange in Children 7-8 Years Old in Connection with Nutrition." Vozrastnaia biokhimiia detei $i$ podrostkov. Sb. 1, L., Institut OZDiP (see abovc), 1: 46-72, 1935. 
2121. POGOREL'sKi1, V. A. "Effect of Lowered Oxygen Content on Development of Chick Embryos." Trudy In-ta evoliuisionnoi fiziologii $i$ patologii vysshei nervnoi deiatel'nosti (Transactions of the Institute of Evolution Physiology and Pathology of Highcr Nervous Activity), Leningrad, Acad. of Sciences USSR, 1: 413-416, 1947.

2122. Podkopaev, N. A. "Characteristics of Higher Nervous Activity of Dog in Old Age." Fiziologicheskii zhurnal SSSR (Physiological J. of the USSR), 24(1-2): 308-333, 1938.

2123. Podrabinnik, G. M. "Age Fluctuations of Chemical Composition of Urine of Healthy Person" (Vozrastyne kolebaniia khimicheskogo sostava mochi zdorovogo cheloveka). Dissertation, Moscow (manuscript), 1939.

2124. "Problem of Age Characteristics of the Chemical Composition of Human Urine. Report 1." Voprosy meditsinskoi khimii, izd-vo Akademii meditsinskikh nauk SSSR, M. (Problems of Medical Chemistry. Publ. of the Acad. of Med. Sciences USSR, Moscow), 5: 43-55, 1953.

2125. Pokrovskil. "Problem of Temperature Changes in the Newborn" ( $K$ voprosu ob izmeneniiakh temperatury $u$ novorozhdennykh), a dissertation, 1903.

2126. Polezhaev, L. V. "Investigations into the Mechanics of the Process of Regeneration in the USSR." Uspekhi sovetskoi biologii (Advances in Soviet Biology), 24(3;): 375$402,1947$.

2127. Polmanina, R. I., and Probatov, L. E. "Development of Perceptive Reaction to Sound Stimulus in Premature Children." Zhurnal vysshei nervnoi deiatel'nosti (J. of Higher Nervous Activity), 5(2): 227-236, 1955.

2128. (Second surname spelled Probatova in this instance.) "Stabilization and Development of an Alimentary Motor Reflex to Sound in Premature Children." Ibid., 5(2): 237-246; 1955.

2129. Polinov, A. "Metabolism in Early Periods of Life of the Animal Organism." Izvestiia Imperatorskoi Voenno-meditsinskoi akademii (Bulletin of the Imperial Acad. of Military Medicine), 7(4): 310-338, 1903.

2130. "Oxygen Requirement in the Air for Newborn Animals." Ibid., 7(4): $317,1903$.
2131. Polosukinn, A. P'. "Agc Charactcristics of Ncrve and Humoral Rcgulation of Splcen Mctabolism." Biull. eksperimental'not biologii $i$ meditsiny (Bulletin of Expcrimcntal Biology and Mcdicinc), 1(6): 600-609, 1936.

2132. $600-604,1937$.

(Samc title). Ibid., 3(6):

2133. "Effect of Emotional and Conditioned Reflex Stimuli on Spleen Mctabolism in Ontogenesis." Ibid., 6(2): 162$164,1938$.

2134. - "Mechanism of Development of Regulation of the Spleen as Blood Depot in Ontogenesis." Ibid., 6(2): 216$219,1938$.

2135. "Effect of Dermal Heat Stimuli on Spleen Metabolism in Ontogenesis." Fiziologicheskii zhurnal SSSR (see above), 27(2): 185-189, 1939.

2136. "Certain Functional Characteristics in the Onto- and Phylogenetic Aspect." VII Vsesoiuznyi s'ezd fiziologov, biokhimikov $i$ farmakologov (Seventh All-Union Congress of Physiologists, Biochemists, and Pharmacologists), Moscow, Medgiz, 1947, pp. 12-15.

2137. -Development of Certain Functions and Mechanisms and Their Regulation in the Onto- and Phylogenesis." Izvestiia $A \mathcal{N}$ Kazakhskoi SSR, No. 45 ser. fiziologicheskaia, v. 1 (Bull. of Acad. of Sciences, Kazakh SSR. Physiol. ser. $(45 ; 1)$; Sb. rabot po vozrastnoi $i$ sraunitel'noi fiziologii, Alma-Ata (Collection of Works on Age and Comparative Physiology. Alma-Ata), 1948, pp. 3-6.

2138. "Problem of Order of Development of Humoral and Reflex Regulations in the Ontogenesis." Ibid. (Izvestia ...), (45;1); ibid. (sb. ...), 1948, pp. 7-14.

2139. "Study of Role of Blood Depots. Pathogenesis and Treatment of Shock. (Section) Works in Area of Age and Comparative Physiology." Trudy Vsesoiuznogo obshchestva fiziologov, biokhimikov i farmakologov, AN SSSR, M. (Transactions of the All-Union Association of Physiologists, Boichemists, and Pharmacologists. Acad. of Scienccs USSR, Moscow), 1: 58-62, 1952.

2140. Poltev, V. I. "Phylo- and Ontogencsis of Basic Factors of Immunity." Uspekhi souremennoi biologii (Advances inContemporary Biology), 23(2): 289-296, 1947. 
2141. Pollakov, G. I. "Farly and Intermediate Ontogenesis of the Cerebral Cortex of Man" (Rannii i srednii ontogenez kory bol'shogo mozga cheloveka. Gos. institut mozga, Medgiz, M.). State Institute of the Brain. Medgiz, Moscow, 1937.

2142. - "Ontogencsis of the Isocortex in Man." Report IV. Trudy instituta mozga (Transactions of the Brain Institute), t: $9-36,1940$.

2143. (Same title). Report V. Ibid. (Gos. in-ta mozga Ministerstva zdravookhraneniia SSSR), M. Medgiz (State Institute of the Brain, Ministry of Health USSR. Moscow, State Publ. House of Med. Lit.), 1948, pp. 151-174.

2144. - "Structural Organization of the Human Cerebral Cortex According to Data of Its Development in Ontogenesis. Cyto-Architectonics of the Human Cerebral Cortex" (Strukturnaia organizatsiia kory bol'shogo mozga cheloveka po dannym razvitiia ee $v$ ontogeneze. Tsito-arkhitektonika kory bol'shogo mozga cheloveka. Medgiz, M.), State Publ. House of Med. Lit., Moscow, 1949, pp. 3391.

2145. "Some New Data on Early Embryogenesis of the Neurons of the Cerebral Cortex of Man." Zhurnal vysshei nervnoi deiatel'nosti (J. of Higher Nervous Activity), 4(1): 123-132, 1954.

2146. Poliakov, I. IA., and Pegel'man, S. G. "Certain Changes in the Physiological Characteristics of Common Field Voles in the Process of Individual Development." Zoologicheskii zhurnal (Zoological Journal), 32 (6): 1259-1266, 1953.

2147. Ponomareva, V. N. "Development of Innervation of the Carotid Body of Man." $D A \mathcal{N}$ SSSR (Reports of the Acad. of Sciences USSR), 59(4): 797-799, 1948.

2148. Pontovich, V. E. "Change of Activity of the Oxidation Enzymes (Polyphenol Oxidases) with the Age of Plants." Biokhimiia (Biochemistry), 14(5): 460-466, 1919.

2149. Ponurgaeva, A. G. "Basal Metabolism of Children at the Eupatoria Health Resort." Acta Eupathorica, (sic) 3: —, 1939.

2150. Popov, G. V. "Data for Study of Defensive Conditioned Reflexes in Young Fishes Fresh from the Spawn." Zhurnal vysshei nerunoi deiatelnosti ( $\mathrm{J}$. of Higher Nervous Activity), 3(5): $774-788,1953$.
2151. Popov, N. A. "Central Nervous Regulation of Processes of Nutrition in the Organism" ( $O$ isentral'noi nervnoi reguliatsii protsessov pitaniia v organizme. Biomedgiz, M.), State Publishing House of Biomedical Lit., Moscow, 1936.

2152. Popov, N. F. "Studies of Physiology of the Cerebral Cortex of Animals" (Issledovaniia po fiziologii kory golounogo mozga zhivot$n y k h$. Izd-vo "Sovetskaia nauka," M.). "Soviet Science" Publ. House, Moscow, 1953.

2153. Popova, Z. A. "Age Changes of Wall Structure of Ventricles of the Brain in White Mouse in the Postembryonic Life." $D A \mathcal{N}$ SSSR (see above), 105(6): 1339-1342, 1955.

2154. Popova, S. T. "Elements in Development of Motor Apparatus of the Child." Report II. Biull. eksperimental'noi biologii $i$ meditsiny, (see above) 1: 324-326, 1930.

2155. Portugalov, V. V. "Development of the Myelinic Sheath in Ontogenesis." Ibid., 20(10): 8, 1945.

2156. Porkнovnik, IA. B., and Serzhanin, P. N. "Dynamics of Changes in Cardiac Dimensions in the Newborn in X-Ray Picture." Tezisy dokladov II s'ezda akusherov i ginekologov USSR, Kiev (Theses of Papers of the Second Congress of Obstetricians and Gynecologists, Ukr.SSR, Kiev), 1938, pp. 78-80.

2157. Pospelov, S. A., and Katenin, M. F. "The Problem of Hypoglycemia in the Newborn." Pediatriia (Pediatrics), (11): 43-46, 1940.

2158. Pospelov, S. P. "Effect and Use of the Age Factor in Breeding Karakuls for Improvement of Astrakhan (Fur) production." Sb.: Nauchnaia konferentsiia po vosprosam znacheniia vozrasta pri razvedenii sel'skokhoziaistvennykh zhivotnykh, M., izd-vo Timiriazevskoi s. kh. akademii (Collection: Scientific Conference on Problems of the Importance of Age in Breeding Farm Animals. State Publ. House of the Timiriazcv Agricultural Aacademy, Moscow), 1953, pp. 98-111.

2159. Postoev, IA. IA. "Problem of Effect of Subcutaneous Injections of Brown-Sequard Infusion and Pel' Spermine on the Course of Diseases of the Central Nervous System." Meditsina, khimiia $i$ farmatsertiia (Medicine, Chemistry, and Pharmacy), (12): - 1896.

2160. Polurovska1A, E. IA. "Problem of Variation of Enzyme in Blood and Urine in 
the Postnatal Period" (Abstract). Zhurnal po izucheniiu rannego detskogo vozrasta ( $\mathrm{J}$. for Study of Early Childhood), 11(1-2): 64-65, 1923.

2161. Pratusevich, IU. M. "Retrograde Activity of Signal Systems in Children." DAVSSSR (see above), 99(4): 653-656, 1954.

2162. Pravdin, L. F. "Effect of Size and Age of Wood Grafts on Their Implanting." Referaty rabot uchrezhdenii Otdeleniia biologicheskikh nauk AVSSSR za 1941-1913 gg., izd-vo $A \mathcal{N}$ SSSR (Abstracts of Works of Institutes of the Department of Biological Sciences, Acad. of Sciences USSR, for 1941-1943. Publ. by Acad. of Sciences USSR), 1945, p. 56.

2163. Prevo, A. A., and Elanska1A, E. E. "Use of Ultraviolet Rays on the Battery Industry." Problemy zhivotnovodstva (Problems of Animal Husbandry), (2): 97-100, 1935.

2164. Predtechenski, K. D. "Comparative Rating in Laboratory Conditions of Muscle Efficiency of Elderly Persons." Starost' $i$ trudosposobnost'. Sb. rabot NIVTE, L. (Old Age and Work Capacity. Collection of Works of the "NIVTE", Leningrad), 1936, pp. 106-122.

2165. PreobrazheNskaiA, N.S. "Postnatal Development of Occipital Area of the Human Brain." Trudy In-ta mozga (Gos. In-t mozga I inisterstva zdravookhraneniia SSSR) (Transactions of the Brain Institute. State Institute of the Brain, Ministry of Health USSR), Medgiz, Moscow, 4: 44-76, 1948.

2166. Przhevoskir, Ed. "Process of Mutual Combining of Muscle Cells in Heart of Human Adult." Arkhiv biologicheskikh nauk (Archives of the Biological Sciences), 2: 286303, 1893.

2167. Privol'nez, T. I. "Swelling of Salmon Roe at Start of Development." DAJ SSSR (see above), 80(3): 641-643, 1952.

2168. Prigonirikov, I. E. "Ontogenesis of the Corpus geniculatum laterale." Sb. Ontogenez mozga (Collection: Ontogenesis of the Brain), Leningrad, 1949, pp. 99-118.

2169. PrIMAK, F. IA. "Characteristics of the Lymphatic System of the Heart in Connection with Age and with Diseases of the Heart Itself." Sb.: Starost'. Trudy konferentsii 17-19 dekabria 1938, g., Kiev, AN USSR (Collection: Old Age. Transactions of the Dec. 17-19, 1938 Conference at Kiev. Acad. of Sciences UkrSSR), 1940, pp. 97-108.
2170. Р'кокороv'а, .1. V. “-Ictive Immunization Against Flexner's (Bacillary) Dysentery of Growing Animals." Voprosy vozrastnoz immunologii, L., Gos. pediatricheskii institut (Problems of Age Immunology, Leningrad, State Pediatrics Institute), (1): 189-193, 1947.

2171. Prokof'eva, Z. N., and Bulankixa, E. M. "Physiological Characteristics of Secretory Function of Stomach at the Age of Puberty." Materialy kliniki po vozrastnoi patofiziologii, pod red. I. P. Razenkoza i I. G. Gel'mana, VIE.If (Data of the Clinic on Age Pathophysiology. I. P. Razenkov and I. G. Gel'man, editors. All-Union Institute of Explt. Med.), 1937, pp. 32-40.

2172. Prosiptov, A. N. "Certain Rules of Ontogenetic Development of Poultry Breeding in Connection with Problem of Evolution of Function of the Nervous System." Zhurnal obshchei biologii (J. of General Biology), 9(2): $145-163,1948$.

2173. Proniva, N. A. "Mechanism of Changes in Respiratory and Cardiovascular Systems Under Effect of Excess $\mathrm{CO}_{2}$ in the Air Inhaled During Various Stages of the Ontogenesis." Arkhiv biologicheskikh nauk (Archives of Biological Sciences), 64(3): $54-b 4$, 1941.

2174. - "Mechanism of Adaptation to Hypercapnia at Different Age Periods." Biull. eksperimental'noi biologii $i$ meditsiny (Bulletin of Experimental Biology and Medicine), 18(4-5): $41-43,1944$.

2175. Puzok, V. I. "Age-Associated Development of the Myocardium." Eksperimental'nye issledovaniia vysshei nervnoi deiatel'nosti rebenka. Sb. 3, Medgiz, M. (Experimental Study of the Higher Nervous Activity of Children. Collection. State Publ. House of Med. Lit., Moscow), 3: 92, 1933.

2176. - "Age-Associated Development of the Myocardium." Materialy kliniki po vozrastnoi patofiziologii, M. (Data of Clinic on Age-Associated Pathophysiology, Moscow), 1937, pp. 92-113; Tezisy dokladov nauchnoi sessii po voprosam kliniki fiziologii i professional'nogo truda podrostkovogo vozrasta, M. (Theses of Reports of Sci. Session on Problems of the Clinic of Physiology and Occupational Work of Adolescent Youth, Moscow), 1935, pp. 5-6.

2177. Idem. Ibid. (Materialy ..., izd. VIEM), (Data of Clinic on AgeAssociated Pathophysiology, Moscow, Publ. 
by the All-Union Institute of Experimental Medicinc), 1937, pp. 92-117.

2178. "Anatomical - Biological Charactcristics of Childhood." Sb.: Tuberkulez u detei (Collcction: Tuberculosis in Children), Mcdgiz, Moscow, 1947.

2179. - and KuAR'kov, A. A. “Agc Morphology of Cardiovascular System of Man" (Vozrastnaia morfologiia serdechnososudistoi sistemy cheloveka. Izd-vo Akademii pedagogicheskikh nauk SSSR, M.-L.). Publ. of the Acad. of Pedagogical Sciences USSR, Moscow-Leningrad, 1948.

2180. Puzik, V. I. "Age Morphology of Glands of Internal Secretion in Man" (Vozrastnaia morfologiia zhelez vnutrennei sekretsii u cheloveka. M., izd-vo Akademii pedagogicheskikh nauk RSFSR). Publ. of the Acad. of Pedagogical Sciences RSFSR, Moscow, 1951, p. 232.

2181. - "Importance of Age Morphology in Study of the Child." Izvestiia Akademii pedagogicheskikh nauk RSFSR (Bulletin of the Academy of Pedagogical Sciences RSFSR, Moscow, (47): 5-9, 1953.

2182. - "Age Development of Bronchi." Ibid., (47): 69-86, $1953 . \quad$ Referativnyi zhurnal. Biologiio (Abstract Journal. Biology), (4): abstract 5385, 1954.

2183. - "Age Morphology of Skeletal Musculature of Man." Izvestiia Akademii pedagogicheskikh nauk RSFSR (see above), (60): 49-87, 1954.

\section{4. - "Age-Associated Develop-} ment of Skeletal Musculature and Its Innervation System in Man." Sb.: Trudy pervoi nauchnoi konferentsii po vozrastnoi morfologii $i$ fiziologii, izd-vo Akademii pedagogicheskikh nauk RSFSR, M. (Collection Transactions of the First Scientific Conference on Age Morphology and Physiology. Publ. of the Acad. of Pedagogical Sciences RSFSR, Moscow), 1954, pp. 146-157.

2185. Puchkivs'кA, N. O. "Characteristics of Elements of the Peripheral Nervous System in View of Constant Restitution of the Nervous System of the Adult Organism" (Ukr.: Osoblivosti elementiv periferichnoi nervovoi sistemi z pogliadu postiinoi restitutsii nervovoi sistemi doroslogo organizmu). Medichnii zhurnal $A N$ URSR (Medical Journal of the Acad. of Sciences UkrSSR), (10(3): 911-936, 1940.

2186. Pusiikareva, E. Z. "Comparative Chymase and Peptic Activity of Hydrochlor- idc Extracts from Mucous Membranes of Stomachs of Cats, Dogs, and Suckling Kittens and Pups." Tezisy iubileinoi nauchnoi sessii inta Kubanskii gos. med. in-t, Frasnodar ('Theses of the Jubilce Scientific Session of the Institutc of the Kuban Statc Mcdical Institute, Krasnodar), 1946, p. 48.

2187. PEN, R. M. "I'roblcm of Typological Charasteristics of Reflex-Producing Activity of Child." Eksperimental'nye issledovaniia vysshei nerunoi deiatel'nosti rebenka. Sb., Medgiz, M. (Experimental Study of Higher Nervous Activity of Child. Collection. Medgiz, Moscow), 3: - 1933.

2188. - and Nevska1a, M. A. 'Age Characteristics of Formation of Conditioncd Reactions to Simple Stimuli in Children." Sb.: Opyt sistematicheskogo eksperimental'nogo issledovaniia ontogeneticheskogo razvitiia korkovoi dinamiki cheloveka, izd-vo VIEM, M. (Collection: Study of Systematic Experimental Investigation of the Ontogenetic Devclopment of the Cortical Dynamics of Man. Publ. of the All-Union Institutc of Experimental Medicine, Moscow, 5: 15-25, 1940.

2189. Pen, R. M. "Age Characteristics of the Formation of Conditioned Reactions to Successive Complex Stimuli." Ibid., 5: 89104, 1940.

2190. - "Diffcrentiation of Complex (Successive) Conditioning Stimuli at Different Degrees of Aging." Ibid., 5: 189-196, 1940.

\section{R}

2191. Rabinovich, V. I., and Kagan, B. IA. "The Leukocyte Formula of Children of School Age" (Ukr.: Leikotsitarna formula ditei shkil'nogo viku). Okhmatdit $i$ ozdorovlennia ditei pidlitkiv (Materualand Child Welfare and Health Carc of Prc-Adolescent and Adolcscent Children), (5-6): 35, 1931.

2192. Rabinovicil, V. I., and Muratova, L. A. "Morphological Blood Picture of Children and Adolescents" (Ukr.: Morfologichna kartina krovi ditei i pidlitkiv). Okhorona materinstva $i$ ditinstva (Protection of Motherhood and Childhood), (3): 38, 1937.

2193. Rabinovicir, E. Z. "Carbonic Anhydrase in Blood of the Newborn, the Pregnant, and the Parturient." Akusherstvo i ginekologiia (Obstetrics and Gynecology), (6): 37-42, 1947. 
2194. "Significance of Fluctuations in Level of the Enzyme Carbonic Anhydrase in the Physiology and Pathology of Fetus and Newborn." Voprosy pediatrii $i$ okhrany materinstva $i$ detstva (Problems of Pediatrics and Maternal and Child Welfare), 17(4): 24-27, 1949.

2195. Rabinovich, E. A. "Age-Associated Development and Structure of the Pleura." Izvestiia Akademii pedagogicheskikh nauk RSFSR (Bulletin of the Academy of Pedagogical Sciences RSFSR), (47): 87-100, 1953; Referativnyi zhurnal. Biologiia (Abstract J. Biology), (4): abstract 5387,1954

2196. Rabornov, T. A. "Determination of Age and Length of Life of Herbaceous Perennials." Uspekhi souremennoi biologii (Advances in Contemporary Biology), 24(1;4): 133-149, 1947.

2197. Ravikovich, O. IA. "Changes of Respiratory and Cardiovascular Systems Under Effect of High Temperature in Different Age Periods (to the Mechanism of the Arising of Thermal Dyspnea in the Ontogenesis). Biull. eksperimental'noi biologii $i$ meditsiny (Bulletin of Experimental Biology and Medicine), 24(I): 74, 1947.

2198. - "Thermal Dyspnea in Dogs at Different Age Periods." Ibid., 38(8): 2225,1954 .

2199. Ral'nikova, E. S. "Critical Periods of Development and Reactive Groups of Protein Substances." DAN SSSR (Reports of the Acad. of Sciences USSR), 95(4): 909$912,1954$.

2200. Ramenskaia, G. P. "Glutathione, Sugar, and Redox Potential in Experimental Atherosclerosis." Biologicheskii zhurnal (Biological Journal), 4: 523, 1935.

2201. Rapoport, A. I. "The Nature of Old Age." Nauka i tekhnika (Science and Technique), (12): 11-12, 1939.

2202. RASKIN, M. V. "Reaction of the Cardiovascular System in Children of School Age to Physical Stress." Sessiia, posviashchennaia itogam nauch.-issled. raboty in-ta (TsNIIFK). Tezisy dokladov za 1949, M. (Session Devoted to Results of the Sci.-Research Work of the Central Sci.-Res. Institute of Physical Culture. Theses of Reports for 1949. Moscow, 1950.

2203. RASkina-Braude, M. V. "Normative Electrocardiograms of Healthy Children of an
Early Age." Pediatriia (Pediatrics), (6): 43$49,1949$.

2204. Raspopova, N. A. "Comparative Activity of the Thyroid Gland in Human and Animal Embryos." Problemy zootekhnicheskoi $i$ eksperimental'noi endokrinologii (Problems of Zootechnical and Experimental Endocrinology), (1): 381-395, 1954.

2205. Rass, T. S. "Phases in the Ontogenesis of Bony Fishes." Zoologicheskii zhurnal (Zoological J.), 25(9): 137-148, 1946.

2206. Rafal'kes, S. B., Tsutsul'kovskaia, K. N., and Shneerson, S. B. "Problem of Importance of the Electrode Potential of Blood in the Postnatal Period." Biull. eskperimental'noi biologii i medilsiny (see below), 5(2): 197-200, 1938.

2207. RakhiLAdze, I. M. "Physiological Vitamin K Deficiency in the Newborn." Pediatriia (Pediatrics), (6): 26-27, 1945.

2208. Rachinskil, B. V., Kravtsova, B. E., and Kniaziatova, E. I. "Effect of Intensity of Light on Phosphorus Exchange of Summer Wheat in Different Periods of Its Ontogenesis." Biokhimiia (Biochemistry), 19(5): 513$520,1954$.

2209. Rashba, E. IA. "Activation of the Arginase of Tissues of Embryos by Magnesium Salts." Fiziologicheskii zhurnal SSSR (Physiological J. of the USSR), 22(3-4): 483-488, 1937.

2210. Revzina, S. I. "Homotransplantation of Embryonic Thyroid into Adult Organism in Rat." Biull. eksperimental'noi biologii $i$ mdeitsiny (Bulletin of Experimental Biology and Medicine), 8(6): 521-524, 1939.

2211. Revurskaia, P. S. "Syncytial Structure of Smooth Musculature of Amnion Tissue of Chick Embryo." Ibid., 8(3-4): 204-207, 1939.

2212. —_ "Two Ways of Development of Smooth Muscle Tissue of the Amnion of Chick Embryo." Ibid., 11(6): 507-509, 1941.

2213. Redina, L. V , and Zelenskir, A. F. "Carbonic Anhydrase of Blood of the Newborn and Its Diagnostic Importance." Akusherstvo i ginekologiia (Obstetrics and Gynecology), (1): 40-42, 1948.

2214. Reznikova, L. O. "Age Characteristics of Kidney Function in Pups, Kittens, and 
Baby Rabbits." Rcport 1. Fiziologicheskii zhurnal SSSR (Physiological J. of the USSR), 36(5): 608-615, 1950.

2215. "Effect of Water and Salt Loading on Kidney Function in Pups, Kittens, and Baby Rabbits." Ibid., 37(2): 217224,1951 .

2216. REıkıL1N, L. N. "Manifestation of Aging in the Area of Laryngeal Cartilages as Depicted by X-1Ray." Arkhiv biologicheskikh nauk (Archives of Biological Sciences), 45(3): 5-12, 1937.

2217. Reprev, A. V. "Analysis and Synthesis of Hatched Egg" (Ukr.: Analiz $i$ sintez visidzhuvanogo iaitsia). Ukrains'kii medichnii arkhiv (Ukrainian Mcdical Archives), 3: 29, 1928.

2218. RikнteR, V. "Medical Aids That Serve to Increase Populousncss in Societies" ( $O$ wrachebnykh posobiiakh, sluzhashchikh $k$ prirashcheniiu mogoliudstva $v$ obshchestvakh. Rech' v Moskouskom un-tete, M.). Speech delivered at Moscow University, Moscow, 17979.

2219. Rozanova, V. D. "The Subordination and Constitution Chronaxy of MuscleAntagonists in Ontogenesis." Arkhiv biologicheskikh nauk (see above), 66(1): 123, 1937.

2220. - "Liability of Skeletal Musculature in the Ontogenesis." Biull. eksperimental'noi biologii $i$ meditsiny (Bulletin of Experimental Biology and Medicine), 5(2): 132135, 1938. There is an English translation.

2221. "The Orbeli-Ginetsin Phenomenon in Skeletal Musculature During Ontogenesis." Ibid., 5(2): 139-141, 1938.

2222. "Sympathetic Innervation of Skeletal Musculaturc in the Ontogenesis." Fiziologicheskii zhurnal SSSR (Physiological J. of the USSR), 15(1-2): 94-101, 1938.

2223. - "Lability of Skeletal Musculature in the Ontogenesis." Reports 1 and 2. Ibid., 25(4): 391-403, 1938.

2224. ((Samc title). Report 3 . Ibid., $30(3)$ : 346,1941 .

2225. - "Chancc of Ovcrcoming Resistance to Respiration at an Early Age." Biull. eksperimental'noi biologii i meditsiny (see above), 16(3;9): 37, 1943.

2226. - "Summation Time of Signal Centers at Various Stages of the Ontogenesis." Ibid., 17(4-5): 36-39, 1944.
2227. "Mechanism of Formation of Toxic Pulmonary Emphysema at an Early Age." Farmakologiia i toksikologiia (Pharmacology and Toxicology), 8(1): 8, 1945.

2228. "Mechanism of Pulmonary Emphyscma Arising in Children at an Early Age." Novosti meditsiny, Akademiia meditsinskikh nauk SSSR, voprosy pediatrii (Medical News, Academy of Mcd. Sciences USS1R, Problems of Pediatrics), 6: 13, 1947.

2229. "Resistance of the Organism in Various Age Periods to Critical and Chronic Poisoning by Cyanides." Farmakologiia $i$ toksikologiia (see above), (3): 26, 1947.

2230. "Physiological Mechanisms of Characteristics of the Course of Poisoning and Collapse in Different Forms of Toxic Effect at Various Age Periods." VII Vsesoiuznyi s'ezd fiziologov, biokhimikov, farmakologov, M. Medgiz (Seventh All-Union Congress of Physiologists, Biochemists, and Pharmacologists. State Publ. House of Med. Lit., Moscow), 1947, pp. 699-703.

2231. Rosenfel'D, E. L. "Problem of the Existence of Various Glycogens and Their Compounds with Proteins." Biokhimiia (Biochemistry), 13(4): 306-309, 1948.

2232. Rosenfel'd, L. E. (sic) "Biochemistry of Change in the Growth Process"' (Ukr.: Biokhimichni zmini $v$ protesesi rostu). 3-i Ukrains'kii z'izd fiziologiv, biokhimikiv i farmakologiv, Dnipropetrous'k (Third Ukrainian Congress of Physiologists, Biochemists, and Pharmacologists, Dnepropetrovsk), 1939, pp. 8081.

2233. Rozovska1A, E. I. "The Heat Regulation Reflex in Childhood." Pediatriia (Pediatrics), (6): 26-36, 1947.

2234. Rokanovskala, M. K. "Problem of Surface Changes in Ovary of Aging Women." Trudy VII Vsesoiuznogo s'ezda ginekologov i akusherov, L. (Transactions of the 7 th AllUnion Congress of Gynecologists and Obstetricians, Leningrad), 1926.

2235. Romanov, K. I. "Dcath Ratc and Length of Life in Citics of Eastern Siberia for 1926-1927 (Irkutsk, Chita, Krasnoiarsk)" (Smertnost' i prodolzhetel'nost' zhizn gorodov Bostochnoi Sibiri za 1926-1927 gg. (Irkutsk, Chita, Ḱrasnoiarsk), -zd-vo Vostochno-Sibirskogo med. in-ta, Irkutsk), a publication of the Eastcrn Siberian Medical Institute, Irkutsk, 193.5. 
2236. Rossusku, D. M. "Clinic of Presenile Involution." Meditsinskii biologicheskii zhurnal (Medical Biological J.), (1): 104-107, 1927.

2237. - "Presenile Involution." Osnovy endokrinologii (Principles of Endocrinology). V. D. Shervinskii and K. P. Sakharov, editors. Leningrad, 1929, pp. 485490.

2238. Rokhlin, D. G., and Rubashova, A. E. "Dimensions of the Sella turcica in Adult Men on the Basis of X-Ray Study of Russian Craniological Material." Arkhiv biologicheskikh nauk (Archives of Biological Sciences), 39(2): 42l-426, 1935.

2239. Rokhlin, D. G., and Levental'. "Age Characteristics of the Bone System on the Basis of X-Ray Data" (Vozrastnye osobennosti kostnoi sistemy na osnovanii rentgenograficheskikh dannykh. Medgiz, L.). State Publ. House of Med. Lit., Leningrad, 1936.

2240. Rokilin, D. G. "Roentgen Diagnosis of Aging. Support Points on the Part of the Osseous System." D. G. Rokhlin's book: Skelet kisti i distal'nogo otdela predplech'ia (Skeleton of Wrist and Distal Part of the Forearm), Leningrad-Moscow, Medgiz, 1936, pp. $181-191$.

2241 . "Certain Manifestations of Aging of Bone-Joint System, Usually Considered as Diseases (Enderdon and Bouchard Nodes)." Ibid., 1936, pp. 191-202.

2242. - and Rubasheva, A. E. "Aging Manifestations of Bone-Joint System in Different Age Periods." Ibid., 1936, pp. 204-215.

2243. Rokhlin, D. G., and Reikhlin, L. N. "Age Changes in Ribs (in X-Ray Picture." Arkhiv biologicheskikh nauk (Archives of Biological Sciences), 39: 427-436, 1945.

2244. Rokhlina, M. "Protein Content in Blood of Chickens in Connection with Age, Sex, and Egg Laying." Russkii fiziologicheskii zhurnal (Russian Physiological Journal), 16(6): 937-945, 1933.

2245. Roкнцina, M. L. "Changes in Blood Calcium and Protein in Chickens During the Egg-Laying Period." Sb.: Problemy biologii $i$ meditsiny (Collection: Problems of Biology and Medicine), Moscow-Leningrad, 1935.

2246. - and Studirskil, A. N. "Effect of Adrenal Cortex Implantation on Develop- ment of Thyroid in Chick Embryo." Biull. eksperimental'noi biologii i meditsiny (Bulletin of Experimental Biology and Mcdicine), 3(2): 188-191, 1937.

2247. and Petrovskaia, O. A. "Effect of Adrenal Cortcx Substancc on Pregnancy, Childbirth, Lactation, and Development of the Endocrine Glands of Embryos." Ibid., 7(6): 552-555, 1939.

2248. Roknlina, E. IA. "Age Characteristics of Yeast Cell." Izvestiia AN SSSR, ser. biol. (Bulletin of Acad. of Sciences USSR, Biol. Series), (4): 827-833, 1936.

2249. Rubanovskaia, A. A. "Aging of Starch Bases" (Ukr.: Starinnia krokhmal'ovikh zolei). Pratsi Kharkivs'kogo tovaristua doslidzhennia prirodi (Works of the Khar'kov Society for Nature Research), Khar'kov, 53: 117-122, 1930.

2250. -Problem of the Mechanism of Precipitation of Erythrocytes" (Ukr.: Do pitannia pro zakonomirnosti osidannia eritrotsitiv). Pratsi Zoobiologichnogo in-tu Kharkivs'kogo derzh. un-tetu. Derzhmedvidav, Kharkiv (Transactions of the Zoobiological Institute of Khar'kov State Univ. State Publ. House of Med. Lit., Khar'kov), 2: 24-36, 1934.

2251. - "Changes in Precipitation Reaction and Number of Erythrocytes with Age" (Ukr.: Zmini reaktsii osidannia $i$ chisla eritrotsitiv z vikon $). \quad$ Ibid., 2: 37-40, 1934.

2252. - "Electroconductivity of Blood Serum in White Rats of Different Age" (Ukr.: Elektroprovidnist' sirovatki krovi bilikh shchuriv riznogo viku). Ibid., 3: 75-90, 1936.

2253. - "Tissue Metabolism at Various Ages" (Ukr.: Tkaninnii obmin u riznii vik). Uch. zap. Kharkivs'kogo derzh. un-tetu, Kharkiv (Annals of the Khar'kov State University, Khar'kov), 6-7: 223-228, 1936.

2254. - "Age Changes of Oxidative Processes in Tissues" (Ukr.: Vikovi zmini oksidatsiinikh protsesiv u tkaninakh). Pratsi nauk.doslid. Zoobiologichnogo in-tu. Derzhmedvidav, Kharkiv (Transactions of the Sci.-Res. Zoobiological Inst., Khar'kov. State Publ. House of Med. Lit.), 5: 212-219, 1938.

2255. —- "Age Changes in Respiration of Skin and Cartilage" (Ukr.: Vikovi zmini dikhannia shkiri ta khriashcha). Ibid., 7: 81-90, 1938.

2256. "Age Changes of Oxidation Processes in Tissues" (Ukr.: Vikovi zmini okis- 
nikh protsesiv v thaninakh). 3-i Ukrains'kii z'izd fiziologiv, biokhimikiv $i$ farmakologiv. Dnipropetrovs' $k$ (Third Ukrainian Congress of Physiologists, Biochemists, and Pharmacologists. Dnepropetrovsk), 1939, p. 83.

2257. - "Tissue Capacity for Synthesis at Various Ages." Pratsi nauk.-doslid. Zoobiologichnogo in-tu Kharkivs'kogo derzh. untetu, Kharkiv (Transactions of the Sci.-Res. Zoobiological Inst. of Khar'kov State Univ., Khar'kov), (10-11): 123-138, 1941.

2258. — and Kolomiets, E. F. "Cyano-Resistant Tissue Respiration in Animals of Various Age." Ibid., (10-11): 155-160, 1941.

2259. and Maevska1a, I. "Restorative Capacities of Tissues at Different Ages." Ibid., (10-11): 167-174, 1941; Uch. zap. (Annals), v. 53; Trudy nauch.-issled. in-ta biologii, Khar'kov (Transactions of the Sci.-Res. Institute of Biology, Khar'kov), 21: 199-205, 1954.

2260. - and Stepanchenko, B. K. "Effect of Addition of Certain Hydrogen Donors on Restorative Processes in Tissues of Various Age." Pratsi nauk. doslid. Zoobiologichnogo in-tu Kharkivs'kogo derzh. un-tetu, Kharkiv (see above), (10-11): 175-182, 1941; Uch. zap. (Annals), 53; Trudy nauch.-issled. In-ta biologii, Khar'kov (see above), 21: 207-213, 1954.

2261. Rubanovskaia, A. A. "Synthesis of Alanine in Kidneys of Animals of Different Age." Naukova khronika Kharkivs'kogo derzh. un-tetu. Zbirnik anotatsii, Kharkiv (Scientific Chronicle of Khar'kov State. Univ. Collection of Notes, Khar'kov), (3-4): 12, 1946.

2262. - "Effect of Adrenalin and Atropine on Respiration of Muscle Tissue at Various Ages." Uch. zap. Khar'kouskogo gos. un-teta, Khar'kov (Annals of Khar'kov State Univ., Khar'kov), 25: 167-176, 194 .

2263. Rubashev, S. M. "Characteristics of Surgical Diseases in the Aged." Vestnik khirurgii (Journal of Surgery), 52(138): 155158, 1937.

2264. Rubasheva, E. E. "Data on Aging of the Spine." Biull. VIEM (Bulletin of the All-Union Institute of Experimental Medicine), (8): 32-36, 1935.

2265. Rubinsirtein, B. G., and Livsiuts, A. S. "Histological Changes in the Central Nervous System at Extirpation of the Superior Cervical Sympathetic Ganglion in Young
Growing Animals. Data on the Problem of Effect of Discase of the Vegretative Nervous System on Development of the Nervous Systcm in Growing Animals." Arkhiv patologicheskoi anatomii $i$ patologicheskoi fiziologii $(\Lambda \mathrm{r}-$ chives of Pathological Anatomy and Pathological Physiology), 4(2): 101-109, 1938.

2266. Rubinsiltein, A., Birger, E., and FrEID, R. "Effect of Different Protein Rations on Growth and Development of Children 1.5-2.5 Years of Age." Sovetskaia pediatriia (Soviet Pediatrics), (7): 20-25, 1936; Biull. eksperimental'noi biologii $i$ meditsiny (Bulletin of Experimental Biology and Mcdicine), 1: 234-235, 1936.

2267. Rudnev, M. F. "Changes in Acidity and in Enzymes of Stomach Content in Children of Nursing Age Under Effect of Various Food." Zhurnal po izucheniiu rannego detskogo vozrasta (J. for Study of Early Childhood), 11(1-2): 66, 1923.

2268. - "Importancc of Quantitative and Qualitative Starvation in the Life of the Nursing Child." Pediatriia (Pediatrics), 12(2): 99, 1928.

2269. Rumiantsev, P. P. "Reaction of Myocardium of Mammals to Injury Dependent on Age of Animals." DAN SSSR (Reports of the Acad. of Science USSR), 100(3): 601$603,1955$.

2270. Rumiantseva, K. A. "Age Changes of Volume and Weight Proportions in Liver of Cross-Bred Lambs." Trudy Saratovskogo zoovetinstituta (Transactions of the Saratov Institute of Zootechnics and Veterinary Medicine), 3: 231-234, 1949.

2271. Rusanov, A. M. "Toxicity of Strychnine at Various Periods in the Development of Animals." Farmakologiia $i$ toksikologiia (Pharmacology and Toxicology), (4): 39-40, 1949 (bibl.).

2272. - "Prevention of Toxic Effect of Styrchnine with $\Lambda$ tropine at Diffcrent Pcriods of the Development of Mice." Ibid., (4): 40-42, 1949.

2273. Rukhel'man, A. A. "Biochemical Changes in the Process of Growth" (Ukr.: Biokhimichni zmini $v$ protsesi rostu). 3-i Ukrains'kii z'izd fiziologiv, biokhimikiv i farmakologiv. Dnipropetrovs'k (Third Ukrainian Congress of Physiologists, Biochemists, and Pharmacologists), 1939, p. 84.

2274. —— and Ziuravs'KA, A. A. "Biochemical Changes in Heart and Aorta in the 
Process of Growth" (Ukr.: Biokhimichni zmini sertsia $i$ aorti $v$ protsesi rostu). Biokhimichnii zhurnal (Biochemical J.), 14(3): 501-517, 1940.

2275. Rukhel'man, A., and Chernyi, P. P. "Data on Age-Associated Nitrogen Composition in Blood of Horned Cattle." Ukrains'kii biokhimichnii zhurnal (Ukrainian Biochemical J.), 25(3): 310-315, 1953.

2276. Ryvkina, D. E. "Respiratory Coefficient of Tissues During Regeneration." DAN SSSR (see above), 49(6): 469-471, 1945.

2277. Rysukina, E. S. "Age Changes in Penetrability into the Capsule of the Crystalline Lens" (Vozrasinye izmeneniia pronitsaemsti sumki khrustalika. Avtoref, diss. kand. med. nauk, Leningradskii gos. in-t usovershenstvovaniia vrachei, L.). Author's own abstract of his dissertation for the degree of candidate of medical sciences. Leningrad State Institute for Training Physicians, Leningrad, 1954.

2278. Riumin, A. V. "Importance of Temperature in the Ontogenesis and Phylogenesis of Animals." Uspekhi sovremennoi biologii (Advances in Contemporary Biology), 12(3): 504-515, 1940 .

2279. Rabinovskaia, A. M. "Data on Physiology of Animals in the Ontogenesis. Report 2. Character of Contraction of Skeletal Muscle of Mammals in Different Periods of Postembryonic Development." Fiziologicheskii zhurnal SSSR (Physiological J. of the USSR), 17(6): 1314-1317, 1934.

2280. ㄴ.. "Subsequent Data on Ontogenesis of Functions and Metabelism of Skeletal Muscle of Mammals. Transactions of the 15th International Physiological Congress." Ibid., 21(5-6): 1014-1015, 1936; Biull. eksperimental'noi biologii $i$ meditsiny (Bulletin of Experimental Biology and Medicine), l(4): 310-311, 1936.

2281. … "Certain Facts About Creatine Phosphagen in the Ontogenesis of Mammals." Sbornik, posviashchennyi 30-letiiu nauchnoi deiatel'nosti $A$. V. Palladina, izd-vo AN USSR, Kiev (Collection dedicated to the 30th anniversary of the scientific activity of $\mathrm{A}$. V. Palladin. State Publ. House of the Acad. of Sciences UkrSSR, Kiev), 1936, p. 328.

2282. - "Effect of Denervation of Skeletal Muscles of Newborn and Adult Vertebrates on the Character of Their Activity." Biull. eksperimental'noi biologii $i$ meditsiny (Bulletin of Experimental Biology and Medicine), 5(4): 425-427, 1938.
2283. "Problem of Cholinesterase in the Ontogenesis of Mammals." D.AN SSSR (see above), 26(8): 830-832, 1940.

2284. - and Gromova, E. A. "Data on the Problem of Acetyl Choline in the Ontogenesis of Mammals." Biull. eksperimental'noi biologii $i$ meditsiny (see above), 9(2-3): 119-121, 1940.

2285. Riabov, K. P. "Age and Functional Morphology of the Heart. An Age-Morphological and Experimental Study." (vozrastnaia $i$ funktsional'naia morfologiia serdtsa. (Vozrastno-morfologicheskoe i eksperimental'noe issledovanie). Avtoref. diss. na soiskanie uchenoi stepeni dokt. biologicheskikh nauk; nauch.-issled. Institut fizicheskogo vospitaniia i shkol'noi gigieny Akademii pedagogicheskikh nauk RSFSR, Uzhgorod). Author's own abstract of his dissertation for the degree of doctor of biological sciences, Sci.-Res. Institute of Physical Training and School Hygiene, Acad. of Pedagogical Sciences, RSFSR, Uzhgorod, 1953; Referativnyi zhurnal. Biologiia (Abstract J. Biology), (1): abstract 1527, 1954.

2286. - "Muscle Tissuc and Stroma of the Human Heart in the Ontogenesis." Izvestiia Akademii pedagogicheskikh nauk RSFSR (Bulletin of the Academy of Pedagogical Sciences, RSFSR), (60): 105-118, 1954.

2287. -Age Development of Specific Muscle System of the Human Heart (Purkinje's Fibers)." Ibid., (60): 119-130, 1954.

S

2288. Sadikov, V., and Shchigel'skaia. "Untersuchungen über die Zusammensetzung des lebendigen Substans. I. Uber den Gehalt an organogenen Elementen in Katze" (Researches into the Composition of Living Matter. I. On the Content of Organogenic Elements in Cat). Izvestiia $A \mathcal{N} S S S R$ (Bulletin of the Acad. of Sciences USSR), 6(15-17): 1619, 1926.

2289. Sadikov, V., and Gutner, R. "Untersuchungen über Zusammensetzung des lebendigen Substans. II. Uber den Gehalt an organogenen Elementen bei Froschen" (Researches into the Composition of Living Matter. II. On the Content of Organogenic Elements in Frogs). Ibid., 6(1-2): 95, 1927.

2290. Sadvnikova-Kol'tsova. "Genetic Analysis of the Mental Capacities of Rats. 
IV. Study of Rats on a Granman Treadmill." Biologicheshii zhurnal (Biological J.), 2(2-3): -, 1933.

2291. Sadovskil, B. V. "A Mechanism for" Reducing Quantity of Erythrocytes and Hcmoglobin in Ncwborn Animals." 1-ia Ural'skaia konferentsiia fiziologov, biokhimikov i farmakolgov 5-8 iunia 1956 goda. Tezisy dokladov, Sverdlozsk (First Ural Conferencc of Physiologists, Biochcmists, and Pharmacologists, June 5-8, 1956. Theses of the Reports. Sverdlovsk, 1956, pp. 60-61.

2292. Sazonova, E. A. "Changc of Respiration of the Organism as a Whole and of Differcnt Organs under Effect of Photodynamic Substances at Various Stages of Individual Development." Uch. zap. Khar'kouskogo gos. un-teta, Khar'kov (Annals of Khar'kov State Univ., Khar'kov), 53: 190-194, 1954.

2293. - "Age Changes of Level of Oxidative Processes in Organs." Ibid., 53: 195-198, 1954.

2294. -Data on Ontophysiology of the Oak Silkworm (Antheraea pernyi G.-M.). II. Changes in Chemical Composition and Oxidative Processes." Ibid., v. 68; Trudy nauchn.-issled. in-ta biologii $i$ biologicheskogo $f$-ta (Transactions of the Sci.-Res. Institute of Biology and of Biological Pharmacotherapy, 24: $137-152,1956$.

2295. Salganik, R. I. "Study of Age Characteristics of Renewal of Proteins of Plasma and Tissues of White Rats by Means of Methionine Traccr." Biokhimiia (Biochemistry), 19(6): 641-644, 1954.

2296. Salistovskaia, E. B. "Chronaximctric Characteristics of Skeletal Musculature in Children of an Early Age, in the Normal and in Pathology." Biull. eksperimental'noi biologii $i$ meditsiny (see above), 24(8): 152-153, 1947.

2297. "Chronaximetry of Skeletal Muscles of the Upper Extrcmities of Children at Various Age Periods in Conditions of Normal Development and in Hypotrophy." Pediatriia (Pediatrics), (1): 3-9, 1949.

2298. Samokitvalov, G. K. "Problem of Mineral Nutrition of Plants in Ontogenesis and thc Methods of Its Study." Izvestiia Kirgizskogo fliala $A \mathcal{N}$ SSSR (Bulletin of the Kirgiz Affiliate of the Acad. of Sciences USSR), 1947, pp. 119-131.

2299. Samokinavalova, G. V. "Agc Variability in Magnitude of Erythrocytcs of
Guinca Pig. Size of Body and Size of Cclls." Trudy po dinamike razvitiia, M., tipografiia "Poligrafkniga" (Transactions on Dynamics of Growth. Moscow. The Polygraph Book Prcss), 7: 120, 1933.

2300. Samokitvalova, O. F. "Amount of Milk Sucked by the Newborn in the Coursc of the First Weck." Voprosy malerinstva $i$ mladenchestva (Probicms of Motherhood and Infancy), (7): 21-23, 1939.

2301. "Certain Data on Reaction of the Newborn to Chilling." Akusherstvo $i$ ginekologiia (Obstetrics and Gynecology), (5): $44-46,1946$.

2302. Samy'Gin, G. A. "Photoperiodic Reactivity of Plants." Summary. Trudy Instituta fiziologii rastenii in $K$. A. Timiriazeva, $A$. I SSSR, M. (Transactions of the K. A. Timiriazev Institute of Plant Physiology. Acad. of Sciences USSR, Moscow), 3(2): - 1946.

2303. Sapegin, A. A. "Critical Comment on Thcory of Age Cycle." Iubileinyi sbornit. AN SSSR, Ufa, 1917-1942 Jubilee Collection of the Acad. of Sciences USSR, Ufa, 19171942), 1:359, 1944

2304. SAPER, A. L. "Study of the Motor Chronaxy in Old Age." Fiziologicheskii zhurnal SSSR (Physiological J. of the USSR), 29(3): 135-138, 1940.

2305. - "The Dynamics of Sleep in Old Age." Ibid., 29(3): 139-143, 1940.

2306. Sapozinnikova, R. G. "Some Data Concerning Dependency of Skin Temperature of the Newborn on Conditions of the Surrounding Medium." Trudy Instituta akusherstva $i$ ginekologii Akademii meditsinskikh nauk SSSR (Transactions of the Institute of Obstetrics and Gynecology of the Acad. of Med Sciences USSR), 1: 176-181, 1948.

2307. Saprygina, E. S. "Importance ol Age and of Stages of Development for Resistance to Cold (Wintcr Grains)." Trudy Dnepropetrouskogo s.-kh. in-la (Transactions of the Dnepropetrovsk Agricultural Institute), 2-3: 191-208, 1948.

2308. Saraikin, I. M. "Method of Dctermining Arterial Blood Pressure in Swine and Its Norm Depending on Age." Trudy Saratovskogo zooveterinarnogo in-ta (Transactions of the Saratov Institute of Zootechnics and Vcterinary Medicine), 4: 76-77, 1953.

2309. Sarkisov, I. M. -SERAzINI. "The Road to Hcalth, Strength, and Long Lifc" 
(Put' $k$ zdorov'iu, sile $i$ dolgoi zhizni. Izd-vo "Fizkul'tura i sport," M.). Publ. by "Physical Culture and Sport," Moscow, 1954.

2310. SARkisov, S. A. 'Postnatal Development of Independent Cyto-Architectonic Fields in Dog." Journal Psychol. and Neurol., 39: 4-6, 1929.

2311. Sarkisian, A., and Sakanian, S. K. "Blood Properties of Newborn Pups." Sbornik trudov, posviashchennyi 50-letiiu nauchno-pedagogicheskoi deiatel'nosti $V$. V. Voronina, Tbilisi, Gruzmedgiz (Collection of Works Dedicated to the 50th Anniversary of the ScientificPedagogical Activity of V. V. Voronin, Tiflis. Georgian State Publ. House of Med. Lit.), 1941 .

2312. Sarílova, K. P. "Problem of Blood Catalase in Children with Different Diseases." Pediatriia (Pediatrics), 12(3): 248, 1928; 12(4): 324, 1928.

2313. Sakharov, G. P. "Importance of Age in the Organism's Ability to Combat Infections" ( $O$ znachenii vozrasta $v$ bor'be organizma s infektsiei, M.), Moscow, 1908.

2314. "Mechnikov's Contest with Old Age." (Bor'ba so starost'iu po Mechnikovu. Studencheskoe izd-vo, M.) Student Publ. House, Moscow, 1918.

2315. - "The Problem of Old Age." Sovetskaia klinika (Soviet Clinic), (19): 614618, 1933.

2316. Sakharov, G. R. "Neuronophagia in General and Old Age in Particular." Trudy gos. med. in-ta v Moskve, M. (Transactions of the State Med. Institute in Moscow), 1:58-85, 1923.

2317. Sbornik: Trudy pervoi nauchnoi konferentsii po vozrastnoi morfologii $i$ fiziologii, 14-17 ianvaria $1953 \mathrm{~g}$. Izd-vo Akademii pedagogicheskikh nauk RSFSR, M. (Collection: Transactions of the First Scientific Conference on AgeAssociated Morphology and Physiology, Jan. 14-17, 1953). Publ. of the Acad. of Pedagogical Sciences RSFSR, Moscow, 1954.

2318. Svetlov, P. G. "Study of Local Effect of Poisons on Individual Areas of Body of Amphibian Embryos." Biull. eksperimental'noi biologii $i$ meditsiny (Bulletin of Experimental Biology and Medicine), 4(5): 461$463,1937$.

2319. Svet-Moldavskit, G. IA. "Virus Infection and Body Temperature. Influenzal
Infection in Newborn Mice at Prolong ${ }^{2}$ Chilling." Ibid., 40(6): 52-55, 1955.

2320. Svetozarov, E., and Sutraikh, G. "Change of Chemical Composition of Organism in the Process of Growth of Birds." Fiziologicheskii zhurnal SSSR, 27(5): 610-615, 1939.

2321. - "Importance of Light to General Growth and Sexual Development of Birds." Uch. zap. MGU (Annals of Moscow State University), (43): - 1940.

2322. Svechin, K. B. "Connection Between Age Changes of Growth and Productivity of Farm Animals and Stages of Their Development and the Conditions of Life." Sbornik: Nauchnaia konferentsiia po voprosam znacheniia vozrasta pri razvedenii sel'skokhoziaisstevennykh zhivotnykh, M., izd-vo Timiriazevskoi s.-kh. akademii (Collection: Scientific Conference on Problems of Importance of Age in the Breeding of Farm Animals. Moscow, Publ. House of the Timiriazev Agricultural Academy), 1953, pp. 85-97.

2323. Sevbo, N. S. "Age Characteristics in Structure of Nerve Elements of Ganglia of the Marginal Truncus sympathicus in Man" (Vozrasinye osobennosti stroeniia nervnykh elementov uzlov pogranichnogo simpaticheskogo stvola u cheloveka. Diss., L.), a dissertation, Leningrad, 1949.

2324. Severin, S. E., and Iulaev, N. A. "Change in Content of Carnosine, Anserine, and Creatine in the Ontogenesis of Animals." Biokhimiia (Biochemistry), 15(3): 286-291, 1951.

2325. Severin, S. E., and Fedorova, V. N. "Content of Carnosine, Anserine, Histidine, and Beta-Alanine in Skeletal Muscles of Chickens in the Period of Embryonic Development." DAN SSSR (Reports of the Acad. of Sciences USSR), 82(3): 443-446, 1952.

2326. Severtsev, A. N. "Studies on the History of Evolution. Individual Development and Evolution." (Etiudy po istorii evoliutsii. Individual'noe razvitie $i$ evoliutsiia). Kiev, 1912.

2327. - - "Chief Directions of the Evolution Process." (Glaunye napravleniia evoliusionnogo protsessa. Biomedgiz, M.) State Publ. House of Biomedical Lit., Moscow, 1934.

2328. - "Gencral Problems of Evolution" (Obshchie voprosy evoliutsii. Sobr., 
osch., izd-vo AN SSSR), Collcction of papcrs published by the Acad. of Scicnces USSR, 3: -, 1945 .

2329. Severtsev, D. "Comparative Content of Lecithin in Human Fetuses and in Children of Various Age" (Sravnitel'noe soderzhanie letsitina u chelovecheskikh plodov i u detei raznogo vozrasta. SPb), St. Petersburg, 1903.

2330. "Correlation Between Length of Life and Fertility of Diffcrent Kinds of Mammals." Izvestiia $A \mathcal{N}$ SSSR, otd. fiz.mat. (Bulletin of thc Acad. of Sciences USSR, Section on physiology and maternity), (9): 931, 1930.

2331. Selezneva, P. D. "Preliminary Data on Variability of Magnitude of Blood Catalase Indices in Horncd Cattle." Biologicheskii zhurnal (Biological J.), 2: 405, 1933.

2332. Semenov, N. V., and Gorbacil, I. L. "Characteristies of Certain Electro-Physiological Parametcrs in Old Age." Trudy konferentsii po vozrastnym izmeneniiam obmena veshchestv $i$ reaktivnosti organizma ('Transactions of the Conference on Age Changes of Metabolism and of Reactivity of the Organism), 58: 246-25l, 1951.

2333. Semenova, L. K. "Problem of AgeAssociated Development of the Upper Part of the Femur." Izvestiia AN RSFSR (Bulletin of the Acad. of Sciences, RSFSR), (47): 112121, 1953.

2334. - "Topographical-Anatomical Distribution of Blood Vessels of the Central Portions of the Human Cerebrum in the Age Aspect." Report 1. Ivesztiia Akademii pedagogicheskikh nauk RSFSR (Bulletin of the Academy of Pedagogical Sciences, RSFSR), (60): 25-48, 1954.

2335. - - "Agc-Associated Development of the Nerve-Muscle System of Functionally Different Muscles." Sb. Trudy pervo nauchnoi konferentsii po vozrastnoi morfologii $i$ fiziologii, izd-vo Akademii pedagogicheskikh nauk RSFSR, M. (Collection: Transactions of the First Scientific Conference of AgeAssociated Morphology and Physiology. Publ. of the Acad. of Pedagogical Sciences, RSFSR, Moscow), 1954, pp. 157-161.

2336. Semenova, O. S. "Agc-Associatcd Changes in Absorption Activity of Root Systems." DAN SSSR (Reports of Acad. of Scicnces USSR), 63(8): $373,1944$.

2337. Semenova-Tian-Silanskaia, V. V. Amyloid Corpuscles in Peripheral Nerves
(Starch Changes)." Trudy voenno-meditsinskoi akademii im. Kirova, posviashchennyi $V$. N. Tonkovu, L. ('Transactions of the Kirov Acadcmy of Military Medicinc, dedicated to V. N. Tonkov, Leningrad), 38: 300-304, 1947.

2338. - "Morphological Changes of Pcripheral Nerves of Man in Old Age" Author's own abstract of his disscrtation. Voprosy obshchei $i$ klinicheskoi neuropatologii, L. GIUV (Problems of General and Clinical Ncuropathology, Leningrad, "GIUV" (Statc Publ. House of Uber. Vet.-Med. Lit.), 2: 309-326, 1949.

2339. Semenovskaia, E. I., Verkitutina, A. I., and RozhdestVenskaia, V. M. "Rcactivity of Occipital Part of the Cerebrum in Children According to Electroencephalogram Data." Izvestiia Akademii pedagogicheskikh nauk RSFSR, M. (Bulletin of thc Acad. of Pedagogical Sciences, RSFSR, Moscow), (47): 228-240, 1953.

2340. Semenovskaia, E. N., Rozhdestvenskaia, V. I., and Verkinutina-Vasiutina, A. I. "Change of Electric Activity Reaction of Occipital Area of the Cerebral Cortex in Children in Response to Various Stimuli." Trudy pervoi nauchnoi konferentsii po vozrastnoi fiziologii $i$ morfologii, izd-vo $A$ kademii pedagogicheskikh nauk RSFSR, M. (Transactions of the First Sci. Conference on Age Physiology and Morphology. Publ. of the Acad. of Pedagogical Sciences, RSFSR, Moscow), 1954, pp. 44-49.

2341. Sent-Ileer, K. "Histology of Growth." Uspekhi souremennoi biologii (Advances in Contemporary Biology), 4: 455, 1935.

2342. Sergeev, A. I., and Sergeeva, K. A. "Physiological Variability in the Ontogenesis of Leaves of Olive and Feijoa (Feijoa selloviana)." Trudy instituta fiziologii rastenii im. Timiriazeva (Transactions of the Timiriazev Institute of Plant Physiology), 6(2): 239-248, 1949.

2343. Sergeev, L. I. "Theory of Stage Growth-Basic Rule of the Physiology of Plants." Uspekhi sovremennoi biologii (Advances in Contemporary Biology), 30(3): 356-371, 1950.

2344. Sergeeva, K. A. "Age Changes in Structure of Leaves of the Olcaceac (Olive Family)." DAN SSSR, novaia ser. (Procecdings of the Acad. of Sciences USSR, New Series.), 61(4): 745-747, 1948. 
2345. "Critical Period in the Annual Growth Cycle of the Olive." Doklady $V A S K h \mathcal{N} I L$ (Proceedings of the All-Union Sci.-Res. Inst. of the Electrification and Mechanization of Agriculture), (11): 30-33, 1949.

2346. Sergievskil, M. V., and Ostroumov, N. A. "Regulation of Respiratory Movements. Report II. Cerebrospinal Respiratory Centers in Newborn and Embryo Mammals." Trudy Kuibyshevskogo gos. med. in-ta (Transactions of the Kuibyshev State Medical Institute), 2: 89-156, 1948.

2347. SergievsKul, S. S. "Contribution to a Knowledge of the Male Climacteric." Trudy klinik Voronezheskogo gos. un-teta (Transactions of the Clinic of Voronezh State University), 3: - 1930.

2348. "The Psychopathology of the Male Climacteric." Klinicheskaia meditsina (Clinical medicine), (9): 1278, 1934.

2349. Sergievskir, F. P. "The Question of Whether Adults Fall Ill With Kaschin-Beck's Disease (Osteoarthritis deformans endemica)." Arkhiv biologicheskikh nauk (Archives of Biological Sciences), 60(2): 7-10, 1940.

2350. Sergienko, E. F. "Age and Content of Nucleoproteids in the Animal Organism. (Age Relationships Between Protoplasm and Metaplasm)." Pratsi nauk.-doslid. zoobiologichnogo in-tu Kharkivs'kogo derzh. un-tetu, Kharkiv (Works of the Sci.-Res. Zoobiological Institute of Khar'kov State Univ.), Khar'kov, (10-11): 23-32, 1941.

2351. "Age and Content of Nucleoproteids in the Animal Organism." Uch. zap. Khar'kouskogo gos. un-teta im. Gor'kogo (Annals of the Gor'kii State Univ., Khar'kov), v. 25; Trudy nauch.-issled. in-ta biologii, izd-vo KhGU (Transactions of the Sci.-Res. Institute of Biology, publ. by Khar'kov State Univ.), 12: 75-82, 1947.

2352. and Timkovitskaia, A. M. "Quantitative and Qualitative Changes in Structural Proteins Depending on Age of Animal and the Conditions of Its Nutrition." Uch. zap. Khar'kouskogo gos. un-teta, Khar'kov (Annals of Khar'kov State Univ., Khar'kov), 53: 81-86, 1954.

2353. - and ShereshevskaiA, Ts. M. "Age Changes in Protein Composition of Muscle Tissue."' Ibid., 53: 131-134, 1954.

2354. Serdiukova, G. V. "New Data on Development of Ixodes ricinus $L$. Larvae and
Nymphs in the Conditions of Nature." $D A \mathcal{N}$ SSSR (Reports of the Acad. of Sciences USSR), 83(5): 769-772, 1952.

2355. Serebriakov, I. G. "The Life of a Leaf and the Factors That Determine It." Uch. zap. Moskovskogo gorodskogo pedagogicheskogo in-ta im. V. P. Potemkina (Annals of the Moscow State V. P. Potemkin Pedagogical Institute), 19(1): 3-18, 1952.

2356. Serebriakov, P. N. "Nerve Cells of the Embryonic Type in the Adult Organism." Trudy 1 gistologicheskoi konferentsii, Biomedgiz, M.-L. (Transactions of the First Histological Conference. State Publ. House of Biomedical Lit., Moscow-Leningrad), 1935, pp. 264 265.

2357. Seredina, M. I. "Age Characteristics of Simple Generalization in Cerebral Cortex of the Child." Sb.: Opyt sistematicheskogo eksperimental'nogo issledovaniia ontogeneticheskogo razvitiia korkovoi dinamiki cheloveka. Izd-vo VIEM, M. (Collection: Study of Systematic Experimental Investigation of the Ontogenetic Development of the Cortical Dynamics of Man. Published by the All-Union Institute of Experimental Medicine, Moscow), 5: 209-224, 1940.

2358. Sesiunim, P. A. "Biological Properties of Metabolites of the Central Nervous System of Vertebrates in Individual Development (in the Ontogenesis)." Report 3. Biull. eksperimental'noi biologii $i$ meditsiny (Bulletin of Experimental Biology and Medicine), 6(3): 354-357, 1938.

2359. Sechenov, I. M. "For Whom and How to Develop Psychology?" Vestnik Evropy, aprel' 1873 g. Izbrannye proizvedeniia. Izd-vo AN SSSR, M. (Journal of Europe, April 1873. Selected Works. Publ. by Acad. of Sciences USSR, Moscow), 1: 172267, 1952.

2360. - "Elements of Thought." Vestnik Evropy, 1878, isbr. trudy. Izd-vo AN SSSR, M. (Journal of Europe, 1878. Selected Works. Publ. by Acad. of Sciences USSR, Moscow), 1: 272-426, 1943.

2361. Sidorenko, V. S. "Changes in Amount of Cholesterol and of Phosphorus Fractions in Blood Serum of Growing Rabbits" (Ukr.: Zmini kil'kosti kholesterinu i fraktsii fosforu u sirovattsi krovi rostushchikh krolikiv). Eksperimental'na meditsina (Experimental Medicine), (1): 47, 1938.

2362. Sidorenkov, I. V., and Labdau, G. M. "Polypeptides of Blood of Children of an 
Early Age Colitis and Toxic Dyspepsia." Sovelskaia pediatriia (Sovict Pcdiatrics), (6): 24-30, 1936.

2363, Silrn, O. P. "Agc Charactcristics of the Metabolisin During Starvation." Uch. zap. Khar'kouskogo gos. un-tela (Annals of Khar'kov State Univ.), v. 53; Trudy nauch.issled., in-la biologii ('Transactions of the Sci.Rcs. Institute of Biology), 1954, pp. 215-229.

2364. - "Problem of Age-Associated Disturbance of Oxidative Phosphorylation." Uch. zap. (Annals), v. 68; Trudy nauch.-issled. in-la biologii $i$ biologicheskogo f-ta K'har'kovskogo gos. un-la ('Transactions of the Sci.-Res. Institute of Biology and Biological Pharmacotherapy of Khar'kov State Univ.), 24: 51-57, 1956.

2365, Sidorov, V. P., and Pospelov. "Problem of the Morphological Composition of the Blood and Resistance of Erythrocytes to Hypotonic Solution in Young Pigs from the Age of Seven Days to Nine Months." Trudy kirouskogo zoobetinstitula (Transactions of the Kirov Institute of Zootechnics and Veterinary Medicine), 3(2-3; 10-11): -, 1938.

2366. Sidorov, N. E. "Time of Appearance of the Hormone of the Anterior Lobe of the Hypophysis in the Embryonic Life of Man." Preliminary Report. Kazanskii meditsinskii zhurnal (Kazan Medical J.), (10): 813, 1933.

2367. Silakova, A. I., and Smorodinskaia, V. G. "Data on Nitrogen Exchange in Mice at Diffcrent Stages of the Ontogenesis." Ukrains'kii biokhimichnii zhurnal (Ukrainian Biochemical J.), 27(3): 383-391, 1955.

2368. SiLiN, O. P. "Age Characteristics of Metabolism in Starvation." Uch. zap. Khar'kouskogo gos. un-teta, Khar'kov (Annals of Khar'kov Statc Univ., Khar'kov), 53: 215229, 1954.

2369. Sil'iander, A. A. "Spccial Physiological Fcaturcs of Trying to Bring $U_{p}$ the Younger Generation in Conditions of Rcduced Tcmpcraturcs." Agrobiologiza (Agricultural Biology), (5): $\quad, 1948$.

2370 Simonov, I. N. "Photosynthesis of Differcnt Varicties of Apple Trec First-Year Saplings." Doklady VASKhNIL (Proceedings of the All-Union Scientific Research Institute of the Electrification and Mechanization of Agriculture), (15-16; 24-25): 1938.
2371. Simson, '1. 1'. "Effect of Age Charactcristics on Structure and Course of Reactive Statcs (of the Child) at Time of War." Neuropalologiia $i$ psikhialriia (Neuropathology and Psychiatry), (6): 30-35, 1945.

2372. SiNEL'NiKov, R. D. 'Method of Studying Age Relationships Between Morphological Formations in the Cercbrum." Author's own abstract of his disscrtation. Trudy XIV sessii Ukrainskogo psikhonevrologicheskogo in-la, Khar'kov, Khar'kovskii med. in-t (Transactions of the 14th Scssion of the Ukrainian Psychoneurological Institutc, Khar'kov Medical Institutc, Khar'kov), 23: 180-181, 1947.

2373. Sinitsin, S. N. "Carbon/Nitrogen Coefficient in Urine at Different Ages." Arkhiv biologicheskikh nauk (Archives of Biological Sciences), 47(2): 94-105, 1937.

2374. - "Oxidative Processes at Different Ages (Carbon, Nitrogen, and the $\mathrm{C} / \mathrm{N}$ of the Urine)." Biull. eksperimental'noi biologii $i$ meditsiny (Bulletin of Experimental Biology and Medicine), 7(5): 450-452, 1939.

2375. Siniukinin, A. M. "Pattern of Ontogenetic Development of the Cells of the Growth Cone of Barley." Izvestiia AN SSSR, ser. biol. (Bulletin of the Acad. of Scienccs USSR, biol. ser.), (5): 33, 1952.

2376. Siniakin, P. G., and Komotskaia, O. D. "Functional Mobility in a Cutaneous Receptor." Fiziologicheskii zhurnal SSSR, 38(1): 60-66, 1952.

2377. Sirotinin, N. N. "Hypoergia and Its Importance in the Course of Infection." Kazanskii meditsinskii zhurnal (Kazan Medical Journal), (9): 895-904, 1934.

2378. SirotiniN, M. M. (Ukr. initials for "N. N.") "Nutrition for Anaphylaxis in the Embryonic Period" (Ukr.: Do pitannia pro anafilaksiiu $v$ embrional'nonu periodi). Medichnii zhurnal AN URSR (Medical J. of the Acad. of Scicnccs UkrSSR), 6(2): 289-295, 1936.

2379. - "Importance of Reactivity of Animals in Periods of Infection and Character of the Latter in Different Periods of Development in Conncction with Immunity and Anaphylaxis" (Ukr.: Znachennia reaktivnosti tvarin $u$ perebizi infelsii $i$ kharacter ostann'pi $v$ rizni periodi rozvilku u zv'iazku z imunitetom ta anafilaksieiu). Trudy konferentsii po medichnii biologii, Kiiv, AN URSR (Transactions of the 
Zonference on Medical Biology, Acad. of Sciences UkrSSR, Kiev), 130-142, 1937.

2380. Sirotinin, N. N. "Importance of Rcactivity of the Organism in the Pathogenesis of Shock." Vrachebnoe delo (Medical Affairs), (5): 331-336, 1938.

2381. - "Problem of the Mcchanism of Allergy." Allergiia. Kiev., AN USSR (Allergy. Acad. of Sciences UkrSSR, Kicv), 1938, pp. 80-91.

2382. Sirotinin, M. M. (sec above) "Hypoergia of the Newborn" (Ukr.: Pro gipoeregiiu novonarodzhenikh). Medichnii zhurnal A.V URSR (Medical J. of the Acad. of Scienccs UkrSSR), 8(4): 1005-1024, 1938.

2383. "Anaphylaxis of the Newborn" (Ukr.: Pro anafilaksiiu novonarodzhenikh). Ibid., 12: 13-28, 1944.

2384. Sirotinin, N. N. "Relation of Different Kinds of Reactivity and Course of Infection in Different Age Periods." Tezisy konferentsii po vozrastnym izmeneniiam obmena veshchestv $i$ reaktivnosti organizma (Theses of Conference on Age-Associated Changes in Metabolism and Reactivity of the Organism), Kiev, 1949.

2385. - "Effect of Histamine on Newborn Animals." Biull. eksperimental'noi biologii $i$ meditsiny (Bulletin of Experimental Biology and Medicine), (5): 361-364.

2386. Sirotinin, M. M. (see above) "Relation of Initial Reactivity and Immunity in Toxic Effects and Infections of the Newborn. Report II. Reaction of Newborn Rabbits to Staphylococcus Infections" (Ukr.: Pro vzaemovidnoshennia pervisnoi reaktivnosti ta imunitetu pri toksichnikh uplivakh $i$ infektsii $u$ novonarodzhenikh. Povidomlennia 2. Vidnoshennia novonarodzhenikh krolikiv do stafilokokovoi infektsii). Mikrobiologichnii zhurnal (Microbiological J.), 11(1): 58-62, 1949.

2387. Sirotinin, N. N. "Conference on Age Changes in Metabolism and Reactivity of the Organism, Kiev, December 1949." Arkhiv patologii (Archives of Pathology), (5): 95-96, 1950.

2388. Sirotinin, M. M. (see above) "Conference on Age Changes in Metabolism and Reactivity of the Organism" (Ukr.: Konferentsiia $z$ vikovikh zmin obminu rechovin i reaktivnosti organizmu). Medichnii zhurnal AN URSR (Medical J. of the Acad. of Sciences UkrSSR), 20(1): 67-70, 1950.
2389. Sirotinin, N. N. "Relation of Different Kinds of Reactivity in Different Age l'criods." Trudy konferentsii po vo:rastnym izmeneniiam obmena veshchestv $i$ reaktivnosti organizma. Kiev, AN USSR, institut klinicheskoi fiziologii imeni akademika A. A. Bogomol'tsa (Transactions of the Conference on Agc Changcs of Mctabolism and Reactivity of the Organism. Kiev, Acad. of Scicnces UkrSSR, A. A. Bogomolcts Institute of Clinical Physiology), 1951, pp. 62-73.

2390. - - "Evolution of Reactivity of the Organism." Problemy reaktivnosti $i$ shoka, M. (Problems of Reactivity and Shock. Moscow), 1952, pp. 8-19.

2391. - "Evolution of the Infcctious Proccss." Vestnik Akademii meditsinskikh nauk SSSR (Bulletin of the Acad. of Med. Sciences USSR), (2): 53-60, 1955.

2392. - and Ianovskil, V. D. "Restoration of the I Iigher Nervous Activity of Pups Revived After a 10-Minute Clinical Death Caused by Exsanguination." Sb. Fiziologïa nervnykh protessov. Kiev, AN USSl (Collection: Physiology of Nervous Processes, Kiev. Acad. of Sciences UkrSSR), 1955, pp. 123-130.

2393. Sisakian, N. M., and Filiprovicil, I. I. "Character of Changes in Activity of Enzymes of Respiration in the Process of Stage Development of Plants." DAN SSSR (Reports of the Acad. of Sciences USSR), 76(3): 443-446, 1951.

2394. Sisakian, N. M., Biriuzova, V. I., and Kobiakova, A. M. "Character of Changes in Structure and Enzymatic Activity of Plastids in the Ontogenetic Cycle of Plant Development." Biokhimiia (Biochemistry), 16(5): $449-452,1951$.

2395. Sisakian, N. M., and Kuvaeva, E. B. "Metabolism of Cavity Fluid of Mulberry Silkworm in the Process of Metamorphosis." Ibid., 18(3): 354-362, 1953.

2396. Sisakian, N. M., BeZinger, E. N., and Gumilevskaia, N. A. "Change of Amino Acid Composition of Protein Plastids in the Process of the Organism's Activity." D.A SSSR (Reports of the Acad. of Sciences USSR), 91(4): 907-910, 1953.

2397. Sisakian, N. M., and Odintsova, M. S. "Changes in the Ribonucleic Acid of Plastids in the Process of the Organism's Development." Ibid., 97(1): 119-120, 1954. 
2398. Skvirskala, E. B., and Cilepinoga, O. P. "Nucleic Acid Metabolisin in Brain and Liver Tissues in the Ontogenesis." Ibicl., 92(5): 1007-1010, 1953.

2399. Skvirskala, E. B., and Silich, T. P. "Metabolism in the Brain of Compounds Containing Phosphorus During Different Conditions of the Nervous System." Sb.: Biokhimïa nervnoi sistemy. Izd-vo AN USSR, Kiev (Collection: Biochemistry of the Nervous System. Publ. of the Acad. of Sciences UkrSSR, Kiev), 1954, pp. 36-46.

2400. Skvortsov, V. I., VAL'ter, E. M., Il'ina, Z. A., and Melent'eva, E. P. "Study to Detcrmine Blood Enzyme Indices in Children. Amylase Indices." Zhurnal po izucheniiu rannego detskogo vozrasta (J. for Study of Early Childhood), 3(2): 103-1 12, 1925.

2401. Skvortsov, V. I., Il'ina, Z. A., and Melent'eva, E. P. 'Study to Determine Blood Enzyme Indices in Children. Catalase and Protease Indices." Ibid., 3(2): 104$112,1925$.

2402. Skvortsov, V. I., et al. "Study to Determine Blood Enzyme Indiees in Children. Report II. Duration of Catalase and Protease Indices. Amylase Indices." Ibid., 3(4): 432-438, 1925.

2403. Skvortsov, V. I. "Types of Reaction to Vegetative Nervous System." Trudy IV s'ezda detskikh vrachei, M., GIZ (Transactions of the Fourth Congress of Pediatricians, Moscow. State Institute of Dentistry), 1929, pp. $757-758$.

2404. - "Basic Factors in the Growing Organism." Voprosy solsial'noi gigieny, fiziologii $i$ patologii detskogo vozrasta, pod red. Al'tgauzena-Balandera. M., Gos. med. in-t (Problems of Social Hygiene, Physiology, and Pathology of Childhood. Edited by Al'thauzen-Balander. Moscow. Statc Med. Institute), 1929, pp. 120-123.

2405. Skvortsov, M. A. "Principal Pathomorphological Patterns of Infectious Diseases of Childhood in Connection with 'Their Pathogenesis." Trudy II Vsesoiuznogo s'ezda patologov $v$ Baku (Transactions of the Second All-Union Congress of Pathologists at Baku), 1932.

2406. "Effect of Altered Reactivity of the Organism in the Course of Acute Infections." Pediatriia (Pediatries), (4): 11-20; 1949, pp. 22-28.
2407. Skvortsova, R. I. "Carbon-Phosphurus Metabolism of Muscles in the Process of Chick Ontogenesis and Importance of Carnosine and Anserine to Processes of Phosphorylation." Biokhimiia (Biochemistry), 18 (5): 594-602, 1953.

2408. Skiliarov, N. F. "Age Characteristics of the Throat." Trudy Kiubanskogo med. in-la, Krasnodar (Transactions of the Kuban' Medical Institute, Krasnodar), 1947, pp. 5-17.

2409. SkRYPNik, I. E. "Scarlet Fever in the Breast-Fed Two-Month-Old Child." Vrachebnoe delo (Medical Affairs), (8): 629-630, 1937.

2410. Skriabin, K. I. "Change of Intensity of Respiration in Young Salmon Raised in Various Conditions of the Oxygen Regimen." $D A \mathcal{N}$ SSSR (Reports of the Acad. of Sciences USSR), 88(1): 165-167, 1953.

2411. Slavocinnskaia, A. B. "Data on Arterial Blood Supply of Optic Thalamus of Man." Voprosy morfologii, sb. 2. Izd-vo Akademii meditsinskikh nauk SSSR, M. (Problems of Morphology. Publ. of Acad. of Med. Sciences USSR, Moscow), 2: 257363, 1953; Referativnyi zhurnal, Biologiia (Abstract J.-Biology), (1): abstract 1518, 1954.

2412. Slavskaia, E. M. "Experimental Grounds for Active Immunization Against Typhoid Fever by Age Plan." Voprosy vozrastnoi immunologii. Gos. pediatricheskii in-t. L. (Problems of Age Immunology. State Institute of Pediatrics, Leningrad), (1): 122$157,1947$.

2413. Sladkov. "Blood Pressure in Children" (Iirorianoe darlenie u detei. Diss. SPb), a disiertation. St. Petersburg, 1903.

2414. Stastenov, E. A. "Effect of Agc Rcactivity on Course of Searlet Fever." Sb.: Vozrastnaia reaktionost' pri infektsiiakh, pod red. E. S. Klivanskoi-Krol', 5 tip. "Poligrafkniga," Sverdlovsk (Collection: Age Reactivity in Infections. E. S. K'livanskaia-Krol', editor. Polygraph Book, Printers Sverdlovsk 1947. 5: 21-51,

2415. Slobodin, Z. G. "Age Characteristics of Structure of Nerve Ganglia of Prostate Gland of Man." Urologiia (Urology), 17(3): 28-35, 1940.

2416. "Age Characteristics of Innervation of Certain Endocrine Glands." Nauchnye trudy Tashkentskogo med. in-la im. Mo- 
lotova. Tashkent (Scientific Works of the Tashkent Molotov Institute of Medicine, Tashkent), 1947, pp. 24-28.

2417. Slovtsov, B. I. "Effect on Metabolism and Assimilation of Nitrogen and Composition of Urine of Substituting Fish for Meat as Food" ( $O$ vliianii zameny miasa pishchi ryboi na obmen $i$ usvoenie azota $i$ sostav mochi. $\mathrm{SPb})$. St. Petersburg, 1908.

2418. Slovrsov, B. "Uber die Beziehungenzwischen Körpergrösse und stoffverbrauch der Hunde bei Ruhe und Arbeit" (Ratio Between Body Size and Consumption of Material of Dogs at Work and Rest). Pflüger's Arch., 95: 158, 1903.

2419. Slonim; A. D., and Shgherbakova, O.P. "Comparative Physiology of ThermoRegulation. Report I. Chemical ThermoRegulation in Young Gamadril Anthropoids." Biull. VIEM (Bulletin of the AllUnion Institute of Experimental Medicine), (8-9): 16-17, 1934; "Report II. Study of Basil Metabolism in Monkeys." Ibid., (89): 17-18, 1934.

2420. Slonim, A. D. "Evolution of Heat Regulation in the Animal Organism." Uspekhi souremennoi biologii (Advances in Contemporary Biology), 6(1): 52, 1937.

2421 - "Animal Heat and its Regulation in the Organism of Mammals" (Zhivotnaia teplota $i$ ee reguliatsiia $v$ organizme mlekopitaiushchikh. Izd-vo AN SSSR, M.-L.), Publ. of the Acad. of Sciences USSR, Moscow-Leningrad, 1952.

2422. IAResheva, Z. S., Makarova, A. R., Ponugaeva, A. G., Dad'ko, E. K., Rashevskaia, D. A., Uzhdavini, E. R., Faiziev, S. A., and Shcheglova, A. I. "Formation of Complex Reflex Acts in the Onto- and Phylogenesis." VIII Vsesoiuznyi s'ezd fiziologov, biokhimikov, farmakologov. Tezisy dokladov, izd-vo AN SSSR, M. (Eighth AllUnion Congress of Physiologists, Biochemists, and Pharmacologists. Theses of Reports. Publ. by Acad. of Sciences USSR, Moscow), 1955, p. 560.

2423. Slonimskaia, V. M. "Some Data on Study of the Nervous System in Old Age." Trudy konferentsii po vozrastnym izmeneniiam obmena veshchestv $i$ reaktivnosti organizma, Kiev (Transactions of the Conference on Age Changes of Metabolism and Reactivity of the Organism, Kiev), 1951, pp. 240-245.

2424. Slutskir, M. IA. "Basal Metabolism in the Newborn." Voprosy pediatrii $i$ okhrany materinstva $i$ detstva (Problems of Pediatrics and Maternal and Child IVelfare), 10(2): 55-62, 1938.

2425. Smirenskaia, E. M., and Riabova, $N$. M. "Change in Answering Reaction of Vascular-Motor and Respiratory Centers to Stimulation of Sciatic Nerve at Dying and Subsequent Revival." Biull. eksperimental'roi biologii $i$ meditsiny (Bulletin of Experimental Biology and Medicine), 11:35, 1954.

2426. Smirnov, A. A., and Chetverikov, D. A. "Study of Rate of Phosphorus Exchange in Brain of Rabbits at Different Stages of the Ontogenesis with Aid of Radioactive Phosphorus." DAN SSSR (Reports of the Acad. of Sciences USSR), 90(4): 631-634, 1953.

2427. Smirnov, V. A. "Pupils, Irises, and Age." Uch. zap. 2-go Moskorskogo med. in-ta im. I. V. Stalina, M. (Annals of the Second Moscow State I. V. Stalin Institute of Medicine), 1: 61-74, 1951.

2428. Smirnova-Zamkova, A. I. "Argentophil Tissue and Its Alteration in the Process of the Aging of the Organism." Sb.: Starost'. Trudy konferentsii 17-19 dekabria $1938 \mathrm{~g}$., Kiev, AN USSR (Collection: Old Age. Transactions of the Dec. 17-19, 1938 Conference. Kiev, Acad. of Sciences UkrSSR), 1940, pp. 81-87.

2429. Smirnova-Zamkova, O. I. (Ukr. initials for the above). "Change of Fundamental Argentophil Metabolism in the Process of the Aging of the Animal Organism" (Ukr.: Zmina osnovnoi argirofl'noi rechorini $v$ protesesi starinnia organizmu tvarin). Medichnii zhurnal AN URSR (Medical J., Acad. of Sciences UkrSSR), 5: 1549-1551, 1940.

2430. Smirnova-Zamkova, A. I. (Same title in Russian). Arkhiv patologicheskoi anatomii (Archives of Pathological Anatomy), 7(1): [8-20, 194 ].

2431. SmiRnova, S. N. "Embryogenesis of Nerve Cells of the Nodose, Gasserian, and Cervical Cerebrospinal Ganglia of Man." $D A \mathcal{N}$ SSSR (Reports of the Acad. of Sciences USSR), 101(2): 355-358, 1955.

2432. Smolin, A. N. "Phosphorus Compounds in the Organism of the Oak Silkworm (Antheraea pernyi G.-M.) in Different Stages of Its Development." Biokhimiia (Biochemistry), 17(1): 61-68, 1952.

2433. Smorodintsev, I. A., and Bebelin, $K$. V. "Water and Ash Content in Brain of 
Children of Different Age." Soretshnia pediatriia (Sovict Pediatrics), (3): 3, 1937.

2434. SNEDIKov, K. (Translator's note: The " $K$ " witl which the following title should have begun in Russian was omitted. Possibly no initials were given for the author and the preposition " $K$ " was erroncously substituted.) "Problem of Absorption of Aqueous Solutions of Iron Salts by Skin of Children and Young Animals" (. . . voprosu o vsasyvanii vodnykh rastvorov solei zhcleza kozheiu detei $i$ molodykh zhivotnykh. SPb), St. Petersburg, 1881 .

2435. Snesarev, P. E. "Some New Data on Embryonic Development of Structural Parts of the Eye (of Chick)." Arkhiv biologicheskikh nauk (Archives of Biological Sciences), 38(1): 169-185, 1935.

2436. "Plastieity of the Mesenehy$\mathrm{ma}$ in the Ontogenesis. Physiology of the Connective Tissue System." Trudy konferentsii $A \mathcal{N}$ USSR, Kiev (Transactions of the Conference of the Acad. of Seiences UkrSSR, Kiev)* 1941, pp. 103-109.

2437. Sovetov, S. N. "Primary Insanity in Old Age." Arkhiv psikhiatrii, neirologii i sudebnoi psikhopatologii (Archives of Psychiatry, Neurology, and Legal Psychopathology), 3(1): 41-52, 1884.

2438. - "Senile Dementia and the Compulsion Phenomenon." Ibid., 3(2): 5966, 1884.

2439. Sokolinsk11, D. "Age Changes in Gastric Secretion." Sb.: Starost'. Trudy konferentsii 17-19 dekabria 1938, g., Kiev., AN USSR (Collection: Old Age. Transactions of the Dec. 17-19, 1938 Conference, Kiev, Acad. of Sciences UkrSSR), 1940, pp. 335340 .

2440. Sokolov, D. A. "Theory Conerening Development of an Inhibitory Nervous System in the Newborn (Vascular System)." I'rach (Physician), 10(11): 265-267, 1889.

2441. Sokolov, Di. A. "Development of Peripheral Nerves in Newborn Children." Ibid., 11(17): 384-389, 1890 and (2): 456460.

2442. Sokolov, D. M. "Vaporization from the Skin of Children in a Physiological and Pathological State." Voenno-meditsinshii zhurnal (J. of Military Medicine), 171: 41, 1891.

2443. Sokolov, L. N. "External Signs of Aging." Biull. VIEM (Bulletin of the All-
Union Institutc of Experimental Medieine), (10): 3-6, 193.4.

2444. "Senile Alterations of Morphological Critcria in Women." Arkhiv bioliogicheskikh nauk (Archives of Biological Scienees), 39: 437-450, 1935.

2445. Sokolova, K. F. "Characteristics of Natural Immunity in Hcalthy Full-Term Newborn Children and Their Mothers (Annotation)." Pediatriia (Pcdiatries), (6): 70, 1948.

2446. Sokolova-Ponamareva, O. D. "Data for Determing the Heart Boundaries of a Healthy Child by Orthodiagraph with the Body in a Vcrtical Position." (Materialy $k$ opredeleniiu granits zdorovogo detskngo serdtsa putem ortodiagrafii v vertikal'nom polozhenii tela). Tomsk, 1917, $111 \mathrm{pp}$.

2447. Sokolova, O. D. "Orthodiagraphic Dimensions of Heart of Healthy Child in Vertical Position of the Body." Vrachebnain gazeta (Medical Gazette), (3): 44-45, 1917.

2448. Sokolova, Iu. V., and Kalegaeva, A. I. "Production of Antibodies in the Growing Organism." Voprosy vozrastnoi immunologii. L., Gos. pediatricheskii in-t (Problems of Age Immunology. Leningrad. State Institute of Pediatries), (1): 97-107, 1947.

2449. - "Active Immunization Against Shigella Dysentery of Growing Animals." Ibid., (1): 172-188, 1947.

2450. Sokolova, IU. V. "Production of Antitoxin in Growing Animals at Immunization Against Shiga's Dysentery" Ibid., (1): 189-193, 1947.

2451. Soxolianskil, G. G. "Characteristies of Secondary Degeneration of Nerve Fibers in Animals Found in a Period of Development with Certain Observations Likewise on Processes of Regeneration in Them." Sb. posviashchennyi 30-leinei vrachebnoi $i$ obshchestvennoi deiatel'nosti zasl. deiatelia nauki prof. S. $\mathcal{N}$. Davidenkova, izd-vo NKZ: Okhrana materinstva $i$ mladenchestva, M.-L. (Maternal and Child Welfarc, a Collection Dedicatcd to the 30 Years of Medical and Public Works of Prof. S. N. Davidenkov, Honored Seience IVorker. Publ. by the People's Commissariat of Agriculture, Moscow-Leningrad), 1936, pp. 335-356.

2452. Salistovskaia, E. B. "Chronaximetric Characteristies of the Skeletal Musculature of Children of an Early Age in the Nor- 
mal and in Pathology." $\Lambda$ bstract of Disscrtation. Biull. eksperimental'noi biologii $i$ meditsiny (Bullctin of Experimental Biology and Medicine), 24(8; 2): 152-153, 1847.

2453. Soldatenkov, P. F., Kostromskala, V. A., and Fedorova, A. M. "Changes in Certain Blood Indices and of Carbon and Mineral Metabolism in Calves in the Postnatal Period." 1-ia Ural'skaia konferentsiia fiziologov, biokhimikov i farmakologov 5-8 iiunia $1956 \mathrm{~g}$. Tezisy dokladov, Suerdlovsk (First Ural Conference of Physiologists, Biochemists, and Pharmacologists, June 5-8, 1956. Theses of Reports. Sverdlovsk), 1956, p. 68.

2454. SOLOVEI, M. IA. "Morphological State of the Ovary and Thyroid of Certain Mammals in the Process of Their Individual Development." Biull.eksperimental'noi biologii $i$ meditsiny (Bulletin of Experimental Biology and Medicine), 8(12;6): 525-527, 1939.

2455. Soloveichik, D. I. "Effect of SoCalled Rejuvenation Operations on Higher Nervous Activity. Experimental Study on Dog by the Method of Conditioned Reflexes." Trudy fiziologicheskoi laboratorii akademika I. P. Pavlova, izd-vo Akademii meditsinskikh nauk SSSR, M.-L. (Transactions of the Physiological Laboratory of Academician I. P. Pavlov. Publ. of the Acad. of Med. Sciences USSR, Moscow-Leningrad), 4(1-2): 14, 1932.

2456. - "Disturbance of Higher Nervous Activity with Incipient Senility." Ibid., 8: 427-444, 1938.

2457. Solov'Ev, A. I. "Study of Blood in the Elderly" (Issledovanie krovi u starikov. Diss. $\mathrm{SPb})$, a dissertation. St. Petersburg, 1894.

2458. Solov'ev, V. A. "Problem of the Prolongation of Life" (Problema prodleniia zhizni. 2-e ispravlennoe izdanie. Izd. Instituta sanitarnogo prosveshcheniia, M.). $2 \mathrm{~d}$ revised edition. Publ. of the Institute of Training in Sanitation, Moscow, 1953.

2459. Solov'ev, S. K. “Problem of Assimilability of Sodium Nucleate in Old Age as Compared with Youth." Russkii vrach (Russian Physician), (25): 1065-1067, 1912.

2460. Solov'Eva, E. N. "Structure of Islands of Langerhans in Man During the Embryonic Period." DAN SSSR (Proceedings of the Academy of Sciences USSR), 91(2): $401-404,1953$.

2461. "Problem of Structure of Pancrcas in the Embryonic Pcriod." Ibid., 96(6): 1281-1284, 1954.
2462. Solomatin, M. P. "Agc Clianges of Certain Blood Indiccs in Healtlyy Colts" (Vozrastnye izmeneniia nekotorykh pokazatelei krovi $u$ zdorovykh zherebiat. Avtoref. diss. na soiskanie stepeni kandidata veterinarnykh nauk, Omskii gos. veterinarnyi in-t, Omsk), author's own abstract of his dissertation for the degree of Candidate of Vcterinary Sciences. Omsk State Institute of Veterinary Medicine, Omsk), 1954.

2463. Soltykskul, E. "Physical Dcvelopment of the Newborn. According to Data of Moscow Lying-In Hospitals for 1938." $V_{0}$ prosy materinstva $i$ mladenchestva (Problems of Motherhood and Childhood), (6): 30-38, 1940.

2464. Sopikov, P. M. "Problem of Temperature Regimen in Raising the Young of Farm Fowl." Sb. nauchnykh trudov Leningradskogo in-ta usovershenstvovaniia veturachei (Collection of Scientific Works of the Leningrad Institute for Training Veterinarians), 1948.

2465. - "Negative Effect of Overcxposure of Chicks and Ducklings in the Incubator." Ptitsevodstvo (Poultry Raising), (12): -, 1951.

2466. SorokinA, M. I. "Explanation of the Skin of an Adult as a Method for Karyological Analysis of Man." Biull. eksperimental'noi biologii $i$ meditsiny (Bulletin of Experimental Biology and Medicine), 11(5): 381-382, 1936.

2467. Spasokukotskil, Iu. A., IANKovska1A, A. S., and Shur'ian, I. M. "Functional State of the Physiological System of Connective Tissue and Blood Morphology in Old Age and Changes in Them Under the Effect of Blood Transfusion and ACS (Antireticular Cytotoxic Serum). Trudy konferentsii po vozrastnym izmeneniiam obmena veshchestv $i$ reaktivnosti organizma. Kiev (Transactions of the Conference on Age Changes of Metabolisın and of Reactivity of the Organism. Kiev), 1951, pp. 269-278.

2468. Spasokukotskil, Iu. A. "Some Results of the Use of Oxygen in the Conditions of an Oxygen Tent With Elderly Persons for the Purpose of Normalizing Body Reactivity." Tezisy dokladov nauchnoi konferentsii po fiziologii $i$ patologii dykhaniia gipo- $i$ giperoksii $i$ kislorodnoi terapii. Kiev (Theses of Reports of the Sci. Conference on Physiology and $\mathrm{Pa}$ thology of Respiration, Hypo- and Hyperoxia and of Oxygen Therapy. Kiev), 1955, pp. 178-179.

2469. - and Gitris, E. I. "Reactivity Readings for Animals of Different Age 
Groups and Changes in Them at Transfusion of Isogenous Blood" (Ukr.: Pokazniki reaktivnosti organizmu u tvarin riznikh vikovikh grup ta ihh amini pri perelivanni izogennoi krovi). Fiziologichnii zhurnal AN URSR (1'hysiological J. of the Acad. of Sciences UkrSSR), 2(1): 58-66, 1956.

2470. Spasoкuкотs'ки, IU. A. "Physiological Traits of the Organism of the Long-Lived and Conditions That Contribute to Attaining Longevity" (Ukr.: Fiziologichni osoblivosti organizmu dovgozhiteliv $i$ umovi, shcho spriiaiut' dosiagnenniu dovgolittia). Ibid., 2(3): 92-96, 1956.

2471. Spasskil, I. "Ages in Anthropological and Medieal Respects." Drug zdraviia (Health's Friend), (1): 1-5, 1838.

2472. Speranskil, G. N. "Data on a Study of Infancy" (Malerialy po izucheniiu grudnogo vozrasta), v. 1-2, 1914, Moscow.

2473. "Method of Rational Rearing of a Child" (Metodika ratsional'nogo vskarmlivaniia rebanka. Programmnyi doklad na IV Vsesoiuznom s'ezde pediatrov v Moskve 30.V-5.VI 1927. g., M., izd-vo Okhrana materinstva $i \mathrm{mla}$ denchestva, NKZ). Program paper for the 4 th All-Union Congress of Pediatrieians in Moscow May 30-June 5, 1927: Maternal and Child Welfare. Publ. by the People's Commissariat of Agriculture, Moscow), 1928.

2474 . "The Child's Organism and Allergy. Problems of Theoretical and Practical Mcdicine." Sb. VI Klinika $i$ allergiia, Gosudarstvennyi tsentral'nyi in-t usovershenstvovaniia vrachei, M. (Collection VI. Clinic and Allergy. State Central Institute for Training Physicians, Moscow), 1947, pp. 40-46.

\section{5 .}

"Reactivity of a Child's Organism and Its Upheavals in 'Time of War." Trudy vtoroi sessii Akademii meditsinskikh nauk SSSR, M. (Transactions of the Second Session of the Acad. of Med. Seiences USSR, Moseow), 1947, pp. 102-109.

2476. "Reactivity of a Child's Organism with Physical Therapy Mcasures." Trudy nauchnoi sessii, posviashchennoi 25-letiiu Gosudarstvennogo in-la fizioterapii, Institut fizioterapii, M. (Transactions of the Seicntifie Session of the Institute of Physical Therapy, Moscow, Dedieated to the 25th Anniversary of the Institute), 2: 276-284, 1948.

2 177. Spirina, V. P. "Gas Exchange in Newborn Chitdren Depending on Time of Birth." Biokhimiia (Biochemistry), 20(6): 795-800, 1955.
2478. Stavitskaia, L. I. "Age Changes in Ribonucleic Aetivity of 'Tissues." Uch. zap. KhGU (Annals of Khar'kov State Univ.), v. 68; Trudy nauch.-issled. in-la biologii $i$ biologicheskogo $f$-ta (Transactions of the Sci. Res. Institute of Biology and Biological Pharmacothcrapy), 24: 59-64, 1956.

2479. Stakalici, E. P. "Developinent of Ccrebrospinal Coordination in Mammals in the Ontogenesis." Trudy institula evoliutsionnoi fiziologii i patologii vysshei nervnoi deiatel'nosti im. I. P. Pavlova (Transactions of the I. P. Pavlov Institute of Evolutional Physiology and Pathology of Higher Nervous Activity), (1): 387, 1947.

2480. Stal'Nenko, E. S. “Electrogastrogram of Infants with Different Types of Food." Klinicheskaia meditsina (Clinical Mcdicine), 17(8): 90-93, 1939.

2481. Stanevich, P. "Problem of Functional Testing of Children's Heart." Okhrana zdorov'ia detei i podrostkov (Health Care of Children and Adolescents), (1-2): 30-33, 1932.

2482. Stankevich, E. "Age Changes in Nerve Cells of Man." Arkhiv anatomii, gistologii $i$ embriologii (Archives of Anatomy, Histology, and Embryology), 13(2): 359-367, 1943.

2483. - "Vom Lebensalter abhangige Nervenzellenveranderungen beim Menschen (Age Dependent on Nerve Cell Changes in Man). Zeitsch. f. Zellforsch., v. 22; Microsh. Anat., 1934, pp. 80-88.

2434. Stankevicir, I. A. "Development of Infra-Parietal Area in Man in the Postnatal Period." Trudy Instituta mozga (Transactions of the Brain Institute, Medgiz, Moseow), (3-4): 107-156, 1938.

2485. - "Problem of Development of Cortical Struetures in Man." Nevropatologiia ipsikhiatriia (Neuropathology and Psychiatry), 8(2-3): 99-106, 1939.

2486. - "Development of Insular Area of the Brain of Man in the Postnatal Period." Ibid., (6): 130-150, 1948.

2487. Starovoitov, A. M., and ArKinpoveTs, A. I. "Age Characteristics of Digestion in Swine." VIII Vsesoiuznyi s'e:d fiziologov, biokhimikov, farmakologov. Tezisy dokladov, izcl-vo AN SSSR, M. (Eighth All-Union Congress of Physiologists, Biochemists, and Pharmacologists. Theses of Papers. P'ubl. 
of the Acad. of Scicnces USSR, Moscow), 1955, p. 584 .

2488. "Old Age." (Starost'. Trudy konferentsii po probleme geneza slarosti i profilaktiki prezhdevremennogo stareniia organizma, 17-19 dekabria 1938, g., Kiev, AN USSR) Transactions of the Conference on the Problcm of the Origin of Aging and Prophylaxis for Prcmature Aging of the Organism, Dcc. 17-19, 1938. Kiev, Acad. of Sciences UkrSSR, 1940.

2489. "Old Age and Work Capacity." (Starost' i trudosposobnost'. Sbornik rabot po ekspertize trudosposobnosti $i$ trudoustroistvu lits starcheskogo vozrasta. Pod rcd. doktora, Z. E Grigor'eva, NIVTE, L.) Collection of Works on Appraisal of Work Capacity and Work Facility of Pcople of Advanced Age Dr. Z. E. Gribor'ev, editor. "NIVTE" (see item 911 above), Leningrad, 1937.

2490. Ibid., 1936, pp. 159-176.

2491. Stegallo, E. A. "Physiology and Pharmacology of the Excretory Work of the Kidneys in the Light of Ontogenesis. Report I. Method." Farmakologiia i loksikologiia (Pharmacology and Toxicology), 7(3): 1822, 1944.

2492. - "Effect of Age on Susceptibility of Organism to Cardiac Glycosides." Ibid., 7(5): 6-11, 1944.

2493. "Physiology and Pharmacology of Excretory Work of the Kidneys in the Light of Ontogenesis. Report II. Excretory Function." Ibid., 10(4): 25-3I, 1947.

2494. - "Pharmacodynamics of Diuretics in the Ontogenesis." Fiziologicheskii zhurnal SSSR (Physiological J. of the USSR), 37(4): 494-499, 1951.

2495. - "Characteristics of the Action of Cardiac Glycosides Dependent on Age." VIII Vsesoiuznyi s'ezd fiziologov, biokhimikov, farmakologov. Tezisy dokladov, izd-vo AN SSSR, M. (Eighth All-Union Congress of Physiologists, Biochemists, and Pharmacologists. Theses of Reports. Publ. of Acad. of Sciences USSR, Moscow), 1955, p. 588.

2496. Stepanenko, A. S. "Tyrosine, Tryptophane, and Cystine Content in Blood Proteins of Newborn Rabbits and Their Mothers." Sbornik rabot po fiziologii, 1-i Moskouskii med. in-t, M. (Collection of Works on Physiology, First Moscow Med. Inst., Moscow), 1939, pp. 155-167.
2497. Stefanovskaia, M. "Development of Nerve Cclls of Cerebral Cortex in Mice After Birth." Travaux de Lab. de l'insl. Salvey, Bruxelles (Works of the Lab. of Solvey Institute, Brusscls, Belgium), (3): - 1897.

2498. StrRazhesko, N. D. "Charactcristics of the Appcarance and Coursc of Diseases in the Aged." Sb.: Starost'. Trudy konferentsii po probleme geneza starosti $i$ profilaktiki prezhdevremennogo slareniia organizma. Kiev., izd-vo AN USSR (Collection: Old Agc. Transactions of the Conference on the Problem of th Origin of Old Age and Prophylaxis of Prematurc Aging of the Organism. Kiev. Publ. of the Acad. of Sciences UkrSSR), 1940, pp. 19-20.

2499. Stroganov, S. U. "Method to Determine Age and Analysis of Age Composition of the Ermine Population." Zoologicheskii zhurnal (Zoological J.), 16(1): 113-129, 1937.

2500. Stroganova, E. V. "Problcm of Spccies and Age Resistance of Fowl to Reduction of Barometric Pressure." Fiziologicheskii zhurnal SSSR (Physiological J. of the USSR), 36(3): 360-369, 1950.

2501. Stroganova, N. S. "Propertics of Penetrability to Colloids of Kidney BloodBearing Capillaries of Newborn Animals." $D A \mathcal{N}$ SSSR (Reports of the Acad. of Scienccs USSR), 84(4): 801-804, 1952.

2502. - "Some Problems of Age Histo-Physiology of Animals." Arkhiv analomii, gistologii $i$ embriologii (Archives of Anatomy, Histology, and Embryology), 30(2): 78-85, 1953.

2503. Strokına, T. $V$. "Interaction Between First and Second Signal Systems at Formation of Differentiation in Child Neurotics." Zhurnal vyshei nervnoi deialel'nosii (J. of Higher Nervous Activity), 3(2): 215-237, 1953.

2504. Struve, M. E. "llistochemistry of Arginine and Histidine in Both Developing and Formed Motor Cells of the Spinal Cord and Pyramid Cells of the Cerebral Cortex." DAN SSSR (see above), 91 (3): 659-662, 1953.

2505. Strukov, A. I. "Characteristics of Specific Muscle System of thc Ileart of Children and Adolescents." Sb.: Anatomo-fiziologicheskie osobennosti detskogo vozrasia. M.-L., Biomedgiz (Collection: Anatomical-Physiological Traits of Childhood. State Publ. House of Biomed. Lit., Moscow-Leningrad), 1935, pp. 146-174. 
2506. "Pathomorphology of the" Pneumonia of Measles in the Light of Data on Age." Pedialriia (Pediatrics), (12): 3-11, 1940 .

2507. al. "Pathomorphology of Local and General Changes in Dysentry of Young Children." Arkhiv patologicheskoi anatomii $i$ patologicheskoi fiziologii (Archives of Pathological Anatomy and of Pathological 'hysiology), 6(1-2): 99, 1940.

2508. Strutsovska1A, A. L. "Study of Formation of Conditioned Phagocytic Reaction in Children." Zhurnal zysshei nervnoi deiatel'nosti (J. of Higher Nervous Activity), 3(2): 138-146, 1953.

2509. Studitskil, A. N. "Thyrotropic Reaction in Chick Embryo." DAN SSSR (see above), 20(6): 495-500, 1938.

2510. "Parathyrotropic Reaction of Chick Embryo." Ibicl., 20(6): 501-504, 1938.

2511. "Experimental Analysis of Role of the Hypophysis in Development of Structure and Function of Thyroid and Parathyroid of Chick Embryo." Arkhiv anatomii, gistologii, embriologii (Archives of Anatomy, 1 Iistology, and Embryology), 26(1): 3, 1941.

2512. "Endocrine Correlation of Eimbryonic Development of Higher Vertebrates" (Endokrinnye korreliatsii zarodyshevogo razvitiia vysshikh pozionochnykh. Izd. AN SSSR, M.-L.). Publ. of the Acad. of Sciences USSR, Moscow-Leningrad, 1947.

2513. STYRIkovich, V. L. "Characteristics of a 'Natural Glycemic Reaction' in Early Infancy." Voprosy pediatrii $i$ okhrany materinstva $i$ detstva (Problems of Pediatrics and Maternal and Child Welfare), 1: 28-42, 1929.

2514. Suglitskir, A. B. "Age Changes of Spermogenic Wave in Convoluted Seminiferous Tubule of Mammals." Trudy nauchnoi sessii Voenno-Morskoi Akademii, L. (Transactions of the Scientific Session of the Academy of Marine Medicine, Leningrad), (1): 182183, 1945.

2515. Sumtsov, M. P. "Urate Infarct of the Newborn" (Mochekislyi infarkt novorozhdennykh. Diss. SPb), a dissertation. St. Petersburg, 1903.

2516. Surikov, M. P. "Study of the Pigment of Aging in Nerve Cells." Biull. eksperimental'noi biologii $i$ meditsiny (Bullctin of Ex- perimental Biology and Medicine), 2.5(.i): $397,1948$.

2517. Surovy1, P. G. "Statc of Cardiovascular System and of Kidneys in Old Age." Starost' $i$ trudosposobnost'. Sb. rabot Instituta vrachebnotrudovoi ekspertizy, izd-vo NIVTE, L. (Old Age and Work Capacity. Collection of Works of thc Institute of Medical-Labor Appraisal. Publ. of the "NIVTE" (see item 911 above), Leningrad), 1936, pp. 187-203.

2518. Sukrova, E. N. "Evolution of Heart and Emergence of "Vagus Reflex' in Pups." Fiziologicheskii zhurnal SSSR (Physiological J. of the USSR), 20(4): 657-662, 1936.

2519. Sushcheva, N. "Study of Effect of Age, Sex, and Castration on Number of Red Blood Cells and Hemoglobin Content in Horned Cattle, Swine, and Sheep." Ellengerger's Archiv f. Physiologie, 1910, pp. 97-112.

2520. SYrkin, L. "Fight for Longevity" (Bor'ba za dolgoletie. Riga, Latviiskoe gos. izd-vo). Riga, the Iatvian State Publ. House, 1948 , p. 40.

\section{T}

2521. "Mortality Tables" (Tablitsy smertnosti-Mortalite el durée de la vie population de l'URSS, Tables de mortalité. Plankhozgiz, M.) Mortality and Life Span of the USSR Population, Mortality Tables. State Publication of the Plan of the Economy, Moscow, 1930.

2522. TANk, L. I. "Nicotine Toxicity in Different Growth Periods and Analysis of the Processes of Rendering It Harmless." Biull. eksperimental'noi biologii $i$ meditsiny (Bulletin of Experimental Biology and Medicine), 25(6): $462,1948$.

2523. "Effect of Monoiodo Acetate and Ionto Acetamide on White Mice at Diffcrent Stages of Extra-Utcrine Development." Ibid., 38(5): 45-48, 1954.

2524. "Rigor Mortis Rate in Different Stages of Postnatal Development." Fiziologicheskii zhurnal SSSR (Physiological J. of the USSR), 40 (2): 221-223, 1954.

2525. Tarabrina, M. "Function Compensation in the Pertinent Half of the Cerebral Cortex at Early Age Lobotomy in Cats." Sb. nauchnykh rabot studentov. Rostorskii gos. untet (Collection of Scientific Works of Students, Rostov State Univ.), (1): 90-92, 1949. 
2526. Taranov, M. T. "Nitrogen Exchange of Blood Serum of Horses of Varied Age." Konevodstvo (Horse Brceding), (4): 28-30, 1953.

2527. "Nitrogen Profile and Amino Acid Composition of Blood Serum of Colts of Various Age." Ibid., (10): 9-14, 1953.

2528. Tarasevich, L. M. "Forms of Phosphorus and Nitrogen in Healthy Mulberry Silkworm (Bombyx mori L.) Caterpillars and in Those Ill with Yellow Jaundice." Biokhimiia (Biochemistry), 17(3): 282-287, 1952.

2529. TARnogradskala, B. S. "Functional Study of Reticulo-Endothelial System in Children by Color (Dye Solution) Methods." Voprosy pediatrii $i$ okhrany materinstva $i$ detstva (Problems of Pediatrics and Maternal and Child Welfare), 17(1): 40-44, 1949.

2530. TARKHANOV, I. R. "Longevity of Animals, Plants, and People." Vestnik Evropy (Bulletin of Europe), vs. 5-9, 1891.

2531 . "Psychomotor Centers and Their Development in Man and Animals" ( $O$ psikhomotornykh tsentrakh i razvitii ikh $u$ cheloveka $i$ zhivotnykh. SPb), St. Petersburg, 1879.

2532. Takitadzhan, A. L. "Relationship of Ontogenesis and Phylogenesis in Higher Plants." Trudy Erevanskogo gos. un-teta (Transactions of the Erevan (Armenia) State Univ.), 22: 71-176, $19+3$.

2533. Ter-Grigorova, E. N. "Respiratory Function of the Digestive Tract in the Newborn." Pediatriia (Pediatrics), (3): 48-54, 1942 (bibliog.)

2534. TerezA, G. I. "Age Variability of Semipermeability Properties of the Placenta." Biull. eksperimental'noi biologii i meditsiny (Bulletin of Experimental Biology and Medicine), 3: 492-494, 1937.

2535. Trvanov, A. A. "Physical Culture in the Middle-Aged" (Fizicheskaia kul'tura v pozhilom vozraste). Fizul'tura, M. (Physical Culture, Moscow), 1955.

2536. Timashev, P. P. "Problem of Iron and Calcium Content in the Organism of Young Animals Depending on Age and the Conditions of Nutrition" ( $K$ voprosu o soderzhanii zheleza $i$ kal'tsiia $v$ organizme molodykh zhivotnykh $v$ zavisimosti ot rosta $i$ uslozii pitaniia), Petrograd, 1916.
2537. Timirinzev, K. A. "Historic Mcthod in Biology" (Istoricheskii metod $v$ biologii. Izbr. soch., v 4 tomakh, OGIZ-Scl'klozgiz, M.). Selected papers in 4 vols., State United Publishing Houses-Statc Publ. Housc of Sovkhoz and Kolkhoz Lit., Moscow), 3: 3.55$519,1949$.

2538. Timofeev, N. V., Pokryvalova, K. P., Kogan, A. D., and Solovei, O. V. "Age Charactcristics of Hearing Acuity for Toncs and Speech." Trudy pervoi nauchnoi konferentsii po vozrastnoi morfologii $i$ fiziologii, izd-vo Akademii pedagogicheskikh nauk RSFSR, M. (Transactions of the First Scientific Confcrence on Morphology and Physiology. Publ. by Acad. of Pedagogical Sciences, RSFSR, Moscow), 1954, pp. 56-63.

2539. Timofeev, N. N. "Importance in Selection of Variability of Criteria in the Ontogenesis." Doklady Moskovskoi s.-kh. akademii im. Timiriazava (Reports of the Moscow Timiriazev Agriculatural Academy), (7): 97 $103,1948$.

2540. Timofilv'kir, O. D., and Benevolens"KA, S. V. "Age Changes in Proliferative and Functional Capacity of Cells of Mesenchymous Origin in Explantation Studies" (Ukr.: Vikovi zmini proliferativnoi i funktsional'noi zdatnosti klitini mezenkhimnogo pokhodzhennia v doslidakh eksplantatsii. Dopovidi viddilu biologichnikh nauk $A \mathcal{N}$ URSR, Kiev). Reports of Dept. of Biological Sciences, Acad. of Sciences, UkrSSR, Kiev), 3: 85-101, 1947.

2541. TIpol'T, A. N. "Method for Constructing a Mortality Table for the Age Group 0-1 Year." Voprosy pediatrii i okhrany materinstva $i$ detstva (Problems of Pediatrics and Maternal and Child Welfare), 6(5-6): 336-351, 1934.

2542. "Variation in Child Mortality According to Calendar Months in the Agc Group of Those up to One Year Old." Ibid., 11(1-2): 86-91, 1939.

2543. Titaev, A. A., and Petrov, S. I. "Age Characteristics of Gastric Secretion." Biull. eksperimental'noi biologii $i$ meditsiny (Bulletin of Experimental Biology and Medicine), 3(5): 533-536, 1937.

2544. "Effect of Temperature Stimulus on Gastric Excretion in Dogs of Various Age. Biull. eksperimental'noi biologii $i$ meditsiny (Bulletin of Experimental Biology and Medicine), 3(5): 537-542, 1937.

2545. TitakV, A. A., and Veis, R. A. “. Ige Characteristics of Penetrability of Organs. 
Report II. Penctrability of Liver." Ibid., 5(2): 148-149, 1938.

2546. Titaev, A. A. "Stomach Potential of Young Children and Its Dependence on the Sccretion of Gastric Juicc." Pediatriia (Pediatrics), (9-10): 5-8, 1939.

2547. - "Agc Characteristics for Intake of Carbohydrates and Pcptone." Biull. eksperimental'noi biologii i meditsiny (see above), 9(4): 273-275, 1940.

2548. "Enzymatic Oxidation of Vitamin B in the Organism and Its Age Characteristics." Novosti meditsiny (News of Medicine), v. VI; Voprosy pediatrii, Akademiia meditsinskikh nauk, M. (Problcms of Pediatrics. Acad. of Mcd. Sciences, Moscow), 1947, pp. 32-33.

2549. - "Enzymatic Oxidation of Vitamin B in the Organism, Its Biological Importance and Age Characteristics." Trudy VI Vsesoiuznogo s'ezd detskikh vrachei, M., Medgiz (Transactions of the Sixth All-Union Congress of Pediatricians, Moscow. State Publ. House of Med. Lit.), 1948, p. 431.

2550. Trrov, K. G. "Medullary Hematopoiesis in Healthy Children." Sovetskaia pediatriia (Soviet Pediatrics), (8-9): 21-30, 1934.

2551. Tovstik, O. V. "Histological Analysis of Age Changes of Gonads in Muskrat." Uch. zap. Leningradskogo gos. pedagogicheskogo in-ta (Annals of Leningrad State Pedagogical Institute), 88: 99-113, 1953; Referativnyi zhurnal. Biologiia (Abstract J. Biology), (I): abstract 107, 1954.

2552. TokaR', I. S. "Age Changes in Number of Leukocytes and the Leukocyte For' mula of the Blood fo Red German Cattle." Doklady VASKhNIL (Reports of the All-Union Scientific Research Institute of the Electrification and Mechanization of Agriculture), (1314; 22-23): 16-22, 1938.

2553. Tokin, B. P. "Problem of Cell Ontogeny. Report I. Regeneration in Light of the Problem of Ontogeny in the Cell." Biologicheskii zhurnal (Biological J.), 3(2): -, 1934.

2554. "Cell Ontogeny and Blastomatous Growth." Zhurnal obshchei biologii (J. of Gcneral Biology), 3(4): 262, 1942.

2555. Tolgskaia, M. S. "Changes in Coronary Vessels of the Heart in Rheumatism with Calculation of Their Age Charactcris- tics." Arkhiv patologii (Archives of Pathology), (1): 72-80, 1947.

2556. - "Age Devclopment of the Hypothalamus Rcgion." Izvestiia Akademii pedagogicheskikh nauk RSFSR, M. (Bulletin of the Acadcmy of P'cdagogical Scicnces, Russian Sovict Fcderative Socialist Republic, Moscow), (47): 27-43, 1953; Referationyz zhurnal. Biologii (Abstract J. Biology), (1): abstract $1500,1954$.

2557. - "Age Morphology of Blood Vessels of the Brain. Izvestiia Akademii pedagogicheskikh nauk RSFSR, M. (see above), (47): 53-68, 1953; Referationyi zhurnal. Biologiia (Abstract J. Biology), (1): abstract 1524, 195.

2558. Tolkachevskaia, N. F. "Metabolic Characteristics of the Infant in the First Stages of Its Development." Novosti meditsiny (News of Medicine), v. VI; Voprosy pedialrii, M. Akademiia meditsinskikh nauk SSSR (Problems of Pediatrics, Moscow, Acad. of Med. Sciences USSR), 1947, pp. 17-18.

2559. and Aluker, R. A. "Physiological Creatinuria of Children." VII Vsesoiuznyi s'ezd fiziologov, biokhimikov, farmakologov. M., Medgiz (Seventh All-Union Congress of Physiologists, Biochemists, and Pharmacologists. Moscow. State Publ. House of Med. Lit.), 1947, pp. 487-488.

2560. - "Ontogenesis of Nitrogen Exchange and Balance in Children in the First Year of Life." Trudy VI Vsesoiuznogo s'ezd detskikh vrachei, M., Medgiz (Transactions of the Sixth All-Union Congress of Pediatricians, Moscow, Medgiz), 1948, p. 428.

2561. Tolkachevskaia, N. F. "Devclopment of Metabolic Processes in Children in the First Year of Life" (Razuitie protsessoc obmena u detei pervogo goda zhizn. M., Akademii meditsinskikh nauk SSSR), Moscow, Acad. of Med. Sciences USSR, 1951.

2562. - "Characteristics of Mctabolism in Infants in the First Stages of Development." Trudy pervoi nauchnoi konferentsii po vozrasinoi morfologii i fiziologii. Izd-vo Akadcmii pedagogicheskikh nauk, RSFSR, M. (Transactions of the First Sci. Conference on Agc Morphology and Physiology. Publ. of the Acad. of Pedagogical Sciences, RSFSR, Moscow), 1954, pp. 111-116.

2563. - "Amides of Dicarboxylic Acids in Urine of Ncwborn Children at Term and in Premature Children." VIII Vsesoiu- 
znyi s'ezd fiziologov, biokhimikov, $i$ farmakologov. Tezisy doklador, izd-vo AN SSSR, M. (Eighth All-Union Congress of Physiologists, Bioehemists, and Pharmacologists. Theses of Papers. Publ. by Acad. of Seicnees USSR, Moscow), 1955, p. 604.

2564. 'Tolmacheva-Mel'nichenko, E. A. "Effect of Ultraviolet Rays on Development of Amphibians. Report II. Effeet of a Single Exposure to Embryo Axolotls in Different Stages of Development." Biull. eksperimental'noi biologii $i$ meditsiny (Bulletin of Experimental Biology and Medieine), 8(3-4): 208-210, 1939.

2565. Tomilin, S. A. "The Economic Value of Human Life to the Nation." Professional'naia meditsina (Occupational Medicine), 4(8): 41, 1925.

2566. "Basic Demographic Indexes for the Ukraine in Recent Years as Compared with Such Indexes in the Pre-War Period." Profilakticheskaia meditsina (Prophylactic Medicine), (12): 81, 1928.

2567. - "Problems of Old Age. Report VII. Attempt at a Sanitary-Demographic Study of Long-Lived Individuals in Abkhazia" (Ukr.: Do problemi starosti. Pouidomlennia VII. Sproba sanitarno-demografichnogo vivchennia dovgorichnikh osib v Abkhazii). Medichnii zhurnal AN URSR (Medical J. of the Acad. of Sciences of thc UkrSSR), 8(1): 103, 1938.

2568. - "Statisties of Longevity." Sb.: Starost'. Trudy konferentsii 17-19 dekabria 1938, g. Kiev, AN USSR (Collection: Old Age. Transactions of the Dee. 17-19, 1938 Conference, Kiev. Acad. of Seiences UkrSSR, 1940 , pp. $247-253$.

2569. "CContribution of Russian Scientists in a Study of the Problem of Longevity." Vrachebnoe delo (Medical Affairs), (2): 174-180, 1951 .

2570. Tonkıkн, A. V. "Problem of Conditioned Reflexes in Old Dog." Trudy Obshchestva russkikh vrachei v SPb za 1911-1912 gg., sentiabr'oktiabr'. (Transactions of the St. Petersburg Association of Russian Physicians for 1911-1912, September-October). Vrachebnaia gazeta (Medical Gazette), (48): 1745$1746,1912$.

2571. Toropova, M. N. "Problem of Senile Plaques." Sovetskaia psikhonevrologiia (Soviet Psychoneurology), (1): 79-87, 1933.
2572. Toropova, T. K. "Morpliology of the Blood Vessels and Capillaries of Children" (Morfologiia sosudov i kapilliarov u deter, Sb. II Instituta vospitaniza $i$ gigieny, lizev), Collection of the Institute of Education and $11 \%$ giene, Kiev, 2: -, 1928.

2573. Tregubenko, M. IA. "Keduction of Resistance to Frost of Alfalfa witl Age." Doklad Vsesoiuznoi akademii s.-kh. nauk im. Lenina (Report of the All-Union Lenin Aeademy of Agricultural Sciences), (23-24): 1719,1940 .

2574. TRET'IAKOV, D. K. "Immortality and Longevity" (Bessmertie $i$ dolgoletic). Biblioteka naturalista (Library of the Naturalist), 1911 .

2575. 1913.

(Same title), St. Petersburg,

2576. Trifonovi, A. N. "Differentiation and Growth in Development of Teleostei Roe." Biull. VIEM (Bulletin of the AllUnion Institute of Experimental Medicine), $(6-7): 16,1934$.

2577. Tret'lakov, N. P. "Directed Cultivation of Chicks in Conditions of Lowered, Variable Temperatures." Sovetskaia zootekhniia (Soviet Zootechnics), (10): - 1950.

2578. - "Problem of Reduction of Embryonic Mortality of Farm Fowl and Enhaneed Vitality of the Young." Trudy X.YXI plenuma veterinarnoi sektsii Akademii s.-kh. nauk im. V. 1. Lenina. Sel'khozgiz, M. (Transactions of the 31 st Plenum of the Veterinary Section of the V. I. Lenin Aeademy of Agricultural Seiences. State Publ. House of Farm Lit., Moscow), 1952.

2579. "Raising the Young of Farm Poultry in Conditions of Redueed Temperatures and with Introduction of Periodic Rest." Irudy nauch.-issled. Institula plitsevodsiva (Transactions of the Sei.-Res. Institute of Poultry Raising), 23: —, 1953.

2580. — "New Methods for Raising Young Poultry." Miasnaia industriia (Meat Industry), (1): - 19450.

2581. Trifonova, A. N. "Critical Periods in Embryonic Development." Uspekhi sovremennoi biologii (Advances in Contemporary Biology), 28(4;1): 154-168, 1949.

2582. TroitskaiA-Andreeva, A. M. "Collagenous Substance in Arteries of Man at Different Ages." Arkhiv biologicheskikh nauk 
(Archives of Biological Sciences), 30)(5-6): 519-527, 1930.

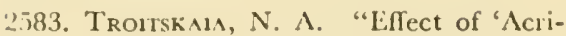
chin' (Atebrin) on Heart of Animals at an liarly Age." Fiziologicheskii zhurnal SSSR (Physiological J. of the USSR), 32(2): 273$282,1946$.

2584. TroitskaiA, S. A. "Effect of Transplantation of Anterior Lobe of Hypophysis to Thyroid Gland of Chick Embryo." Biull. rlisperimental'noi biologii $i$ meditsiny (Bulletin of Experimental Biology and Medicine), 6(5): 558-560, 1938.

2585. - "Prenatal Ontogenesis of Cortical End of the Motor Analyzer in Rabbit." Arkhiv analomii, gistologii $i$ embriologii (Archives of Anatomy, Histology, and Embryology), 30(1): 21-31, 1953.

2586. "Age Characteristics in Development of Cells of Rabbit Cerebral Cortex in Conditions of Culturing Outside the Organism." Ibid., 30(2): 19-26, 1953.

2587. Trortskn, I. V. "Digestion That is Carried on in the Stomach of Young Children" (Zheludochnoe pishchevarenie u malen'kikh detei. Meditsinskoe obozrenie), medical survey, 1890.

2588. "Soran Efesskii as the First Pediatrician of the Eternal City (Rome)" (Soran Efesskii kak pervyi pedialr vechnogo goroda. Izd-vo Kievskogo un-teta, Kiev). Kiev Univ. Publ., Kiev, 1893.

2589. Importance of Characteristics of the Growing Organism When Administering Medicaments" (Znachenie osobennostei rastyshchego organizma pri dozirovanii lekarsivennykh sredstv. Izd-vo Kievskogo un-teta, Kiev). Kiev Univ. Publ., Kiev, 1899.

2590. "Beauty and Health in Childhood." Russkii vrach (Russian Physi(ian), 1903.

2591. "Training Concerning Discases of Childhood." Zap. Khar'kovshogo unlela, Khar'kov (J. of Khar'kov Lniv., Khar'kov), (I-4): - 1907.

2592. "The Views of Chr. WV. Hufeland on Pediatrics in the Light of Contemorary Knowledge." Ibid., (2): 1910.

2593. - "Physiology of Metabolism in the Growing Organism of the Child."
I'rachebnaia gazela (Medical Gazette), (4451): - 1910.

2594. "Characteristics of the Gastro-Intestinal System in Childhood." Ibid., $(41-43):-, 1911$.

2595. - "Hygiene of Childhood" (Gigiena detskogo vozrasta. SPb), St. Petersburg, 1912.

2596. TRofimov, N. M. "Problem of Cortical Regulation of the Respiration." Fiziologicheskii zhurnal SSSR (Physiological J. of the USSR), 38(5): 58t-592, 1952.

2597. Trosninnin, V. A. "Ccrtain Sources of Study of Higher Nervous Activity in the Ontogenesis." Zhurnal vysshei nervnoi deiatel'nosti (J. of Higher Nervous Activity), 2(4): $561-571,1952$.

2598. - (Same title) Sb.: 50 let ucheniia I. P. Pavlova ob uslovnykh reffeksakh, izdvo AN SSSR, M.-L. (Collection: 1. P. Pavlov's 50 Years of Instruction on Conditioned Reflexes. Publ. of the Acad. of Sciences USSR, Moscow-Leningrad, 1952, pp. 196208

2599. - "Effect of Age and Breeding on Variability of Types of the Nervous System." Doklad v Instilute vysshei nervnoi deiatel'nosti AN SSSR 17 fevralia 1953 goda (Report at the Institute of Higher Nervous Activity of the Acad. of Sciences USSR, February 17, 1953), 1953

2600. "Development of Oriented Reaction and Stabilization of Motor Conditioned Defense Reflexes in Pups." Fiziologicheshii zhurnal SSSR (Physiological J. of the USSR), 39(3): 265-274, 1953.

2601. - and Makarenkov, A. N "Method for Study of Conditioned Reflex Activity of Pups in Early Ontogenesis." Zhurnal vysshei nerinoi deiatel'nosti (see above), 4(5): 724-727, 1954.

2602. Trosilikiln, V. A., Vavilova, N. M., Kalinina, E. 1., Kleptsova, M. P., KobaKova, E. M., Mirzakarimova, M. G., Obraztsova, G. A., Pomazanskala, L. F., and Stel'mak1, L. N. "Certain Sides of the Stabilization of Conditioned and Unconditioned Reflex Activity in the Ontogenesis." VIII Vsesoiuzny i 'ezd fiziologov, biokhimikov, farmakologov. Tezisy dokladov, izd-vo AN SSSR (Eighth All-Union Congress of Physiologists, Biochemists, and Pharmacologists. Theses of papers publ. by Acad. of Sciences USSR), 1955, p. 615. 
2603. Trosinkinna, P. M. "Change of Respiratory Rhythnı in the Ontogenesis of Animals." Fiziologicheshii zhurnal SSSR (Physiological J. of the USSR), 39(1): 66-69, 19.53.

2604. Trusov, S. I. "Study of Protein Fractions of the Protein Plasma of Chicken Eggs in the Process of Incubation." Sovetshoe ptitsevodstvo (Soviet Poultry l3reeding), ( $(B-9)$ : $56,1938$.

2605. Trutovskil, IA. IA. "Mania and Melancholia in Old Age." Arkhiv psitkhiatrii, neirologii $i$ sudebnoi psikhopatologii (Archives of Psychiatry, Neurology, and Legal Psychopathology, 23(3): - 1894.

2606. Truknina, E. P. "Morphological Blood Composition of Calves of the Tagil Breed in the Ontogenesis." 1-ia Ural'skaia konferentsiia fiziologov biokhimikov i farmakologov 5-8 iiunia $1956 \mathrm{~g}$., Sverdlovsk (First Ural Conference of Physiologists, Biochemists, and Pharmacologists June 5-8, 1956. Sverdlovsk), 1956, p. 71.

2607. TumpovsкiI, M. D. "Nitrogen Metamorphosis in the First Month of Life When Breast Feeding" (Azotistyi metamorfoz na pervom mesialse zhizni pri kormlenii grud'iu. Diss., SPb), a dissertation. St. Petersburg, 1390.

2608. TuR, A. F. "Certain Characteristics of Changes in Uric Acid Metabolism of Children Under Effect of Loading with Purines." Vrachebnaia gazela (Medical Gazctte), (17): 1244-1252, 1927.

2609. - " "Problem of Cholesteremia in Childhood." Russkaia klinika (Russian Clinic), (51): 30-47, 1928.

2610. "Blood and Gastric Juice Enzymes of Children in the First Year of Life and Importance of Studying Them For Evaluation of the Individual Characteristics of the Child." Zhurnal rannego detskogo vozrasta (J. of Early Childhood), 7(3): 209-225, 1928.

2611. - "Problem of a Rational Arrangement of the Nutrition in Establishments for Children of Early Age." Voprosy pediatrii $i$ okhrany materinstva $i$ detstva (Problems of Pediatrics and Maternal and Child Welfare), 3(3): 303-324, 1931.

2612. "Practical Hematology of Childhood" (Prakticheskaia gematologiia detskogo vozrasta. Gosmedizdat, L.-M.). State Publ. House of Med. Lit., Leningrad-Moscow, 1931.
2613. -Protein Blood l'icture in Children of Early Agc." Zhurnal sovetstioi prediatrii (J. of Sovict P'cdiatrics), (8-9): 1934.

2614. "Physiology and l'athology of Children in the Nconatal P'eriod" (Fiziologiia i patologiia detei perioda novorozhdennosti, M1., Bionncdgiz). State Publ. Housc of Biomedical Lit., Mloscow, 1936, p. 191.

2615. - "Patlological Characteristics of Children When Newborn." Rukovodstvo po pediatrii M. S. Maslova, A. F. Tura, M. G. Danilcvicha, Mcdgiz (Handbook for Pediatricians by M. S. Maslov, A. F. Tur, and M. G. Danilcvich. State Publ. House of Med. Lit., Leningrad, 1938, Chapter 9, pp. 254-281.

2616 "Physiology and Pathology of Children in the Neonatal Period" (Fiziologiia i patologiia detei perioda novorozhdennosti. Medgiz). State Publ. I louse of Med. Lit., 1947.

2617. - "Preliminary Instructions on Diseases of Childhood' (Propedeutika detskikh boleznei. L.), Leningrad, 1949.

2618. Turbina-Shruga, E. I. "Contribution to the Knowledge of the Automatic Center in Pups." Zhurnal eksperimental'noi biologii i meditsiny ( $\mathrm{J}$. of Experimental Biology and Medicine), 8(20): 405, 1927.

2619. 'Turgin, F. V., Guminskaia, M., and Plysievskaia, E. G. "Protein and Chlorophyll Renewal Rate in Higher Plants." Izvestiia AN SSSR, ser. biol. (Bulletin of the Acad. of Sciences USSR, Biological Series), (6): $66-78,1953$

2620. Turetskaia, R. Kin. "Effect of Age of the Mother Plant on Cuttings Taking Root." DAN SSSR (Rcports of the Acad. of Sciences USSR), 39(1): 78-80, 1942.

2621. Turkov, N. M. "Effect of Restorative and Oxidative Solutions on the Age State of Plant Tissues." Tezisy dokladov Vsesoiuznogo soveshchaniia po fiziologii rastenii 28.I-3.II $1910 \mathrm{~g}$., izd-vo AN SSSR (Theses of Reports of the All-Union Conference on Plant Plisyiology Jan. 28-Feb. 3, 1940. Publ. House of the Acad. of Sciences USSR), 1940.

2622. Turovets', I. M. "TheProblem of Old Age. Report IV. Gas Exchange and Biochemical Alteration in Blood of Exceptionally Long-lived Eldcrly Persons" (Ukr.: Do problemi starosti. Poridomlennia IV. Ga- 
zoobmin $i$ biokhimichni zmini krovi $u$ vinialkovo dougorichnikh starikiv). Medichnii zhurnal $A \mathcal{N}$ URSR (Medical J. of the Acad. of Scicnces UkrSSR), (1): 77-85, 1938.

2623. "Many l'acts Conccrning Gas Exchange and Biochcınical Impairment of the Blood in Old Age" (Ukr.: Deiaki dani pro gazoiii obmin i biokhimichni zrushennia krovi v litn'omu vitsi). Ibidem (sic-USSR), 8(3): 819-826, 1938.

2624. "Hemodynamics in Those of Advanced Years. Report II" (Ukr.: Gemodinamika u dovgolitnikh starihiv. Povidomlennia II). Ibid. (sic, corrcctly-UkrSSR), 9(2): 477-483, 1939.

2625. and Pravdina, L. I. "Certain Characteristics of the Metabolism of the Agcd." Sb.: Starost'. Trudy konferentsii I7-19 dekabria 1938, g., Kiev, $\Lambda N$ USSR (Collection: Old Age. Transactions of the Dec. 1719, 1938 Conference, Kicv. Acad. of Sciences UkrSSR), 1940, pp. 321-334.

2626. Tustanovskil, A. A. "Variability of Amino Acid Composition of the Brain." Biokhimiia (Biochemistry), 3: 219, 1938.

2627. Tiunina, V. N. "Study of Carnosine, Anscrine, and Creatine in Human Muscles in the Process of Ontogenesis." DAN SSSR, novaia ser. (Reports of the $\Lambda$ cad. of Sciences USSR. New Series), 72(6): 1095-1097, 1950.

\section{U}

2628. Udintsov, F., and Radionov. "Change of Functional Properties of the Coronary Vessels of the Heart Depending on the Age of Animals" (Ukr.: Pro zminu funktsional'nikh vlastivostei koronarnikh sudin sertsia zalezhno vid viku tvarin). Ukrains'ki medichni vistki (Ukr. Med. News), 3: 59-65, 1927.

2629. Uzbekov, G. $\Lambda$. "Problem of Activization of Proteins of the Organism (Activation of Body Proteins with Ascorbic Acid)." Tezisy doklada na XIV nauchnoi konferentsii Riazanshogo med. in-ta im. I. P. Pavlova. Riazan' (Theses of Rcports at the 14th Scientific Confercnce of the I. P. Pavlov Riazan Mcd. Institute. Riazan), 1954, pp. 38-41.

2630. Uklonskaia, R. $\Lambda$. "Data for Study of the Leukocytc Picturc in Premature Children in the First Months of Life." Pedialriia (Pediatrics), (5): 23-25, 1953.
2631. UL'ianov, L. D. "The Population of the Ukraine." Profilakticheskaia meditsin (Prophylactic Medicine), 4(1): 81, 1925.

2632. Usievicil, M. $\Lambda$. "Effect of Bromine Preparations on Ncrvous System of Old Dog." Trudy fiziologicheshoi laboratorii I. P. Pavlova (Transactions of the I. P'. Pavlov Physiological Laboratory), 8: 453-462, $1938 . \quad$ Sb.: Fiziologiia yysshei nervnoi deiatel'nosti. Izd-vo Akademii mcditsinskikh nauk SSSR, M. (Collection: Physiology of Higher Nervous Activity. Publ. of the Acad. of Med. Sciences USSR, Moscow), 1953, pp. 299-305.

2633. - "Age Characteristics of Higher Nervous Activity in Dogs." Tezisy dokladov iubileinoi nauchnoi sessii $A \mathcal{N}$ SSSR posviashchennoi 100-letiiu so dnia rozhdeniia akad. I. P. Pavlova, 20-26 sentiabria $1949 \mathrm{~g}$. Izd-vo AN SSSR, M. (Theses of Reports of the Jubilee Sci. Session of the Acad. of Sciences USSR Dedicated to the 100th Anniversary of I. P. Pavlov's Birth, Sept. 20-26, 1949. Publ. by Acad. of Sciences USSR, MoscowLeningrad, 1949.

2634. - “I. P. Pavlov's Instruction on the Ontogenesis of Higher Nervous Activity and the Prospect of Its Development." Fiziologicheskii zhurnal SSSR (Physiological J. of the USSR), 37(5): 539-546, 1951.

2635. Iusov, A. G. "Problem of Cortical' Regulation of Respiration in Old Age.' Ibid., 38(5): 576-583, 1952.

2636. Usov, A. G. (sic) "Experimental Data for Problem of Effect of Air Enriched with Oxygen on Higher Nervous Activity of Very Old People." Zhurnal vysshei nervnoi deiatel'nosti ( $\mathrm{J}$. of Higher Nervous Activity), 5(3): 351-357, 1955.

2637. - "Study of Induction Interrelations of the Signal Systems in Very Old Healthy Persons and in Patients with Senile Psychosis." Ibid., 5(6): 807-815, 1955.

2638. Ufliand, Iu., and Shalyt, S. "Effect of Sex, Age, Physical Developmcnt, and Constitution on Quantity of Oxygen Consumer.' Trudy Leningradskogo in-la po izucheniiu professional'nykh zabolevanii (Transactions of the Leningrad Institute for Study of Occupational Diseases), v. 5. Raboty fiziologicheskoi laboratorii (Works of the Physioloigcal Laboratory), 1931, pp. 86-113.

2639. UfLIAND, Iu. M. "Theory and Practice of Chronaximetry" (Teoriia i praktika khronaksimetrii. Lengiz, L.) Leningrad Publ., Leningrad, 1941. 
2640. - " "Rebuilding Motor Coordinations in Children." Trudy pervoi nauchnoi konferentsii po vozrasinoi morfologii i fiziologii. Izd-vo Akademii pedagogicheskikh nauk RSFSR, M. (Transaetions of the First Scicntific Conference on Age Morphology and Physiology. Publ. by Acad. of Pedagogical Sciences, Russian Soviet Federative Socialist Republic, Moscow), 1954, pp. 190-197.

\section{F}

2641. Fadeeva, V. K. "Characteristies of Interaction of First and Second Signal Systems at Formation of Conditioned Reaction to Complex Stimulus in Children." Zhurnal vysshei nervnoi deiatel'nosti ( J. of Higher Nervous Activity), 1(3): 36l-375, 1951.

2642. FAERMARK, S. E., with assistance of I. S. Zingerman. "Gonadotropic Aetivity of the Hypophysis at Different Stages of the Sexual Cycle and Pregnancy." Biull. eskperimental'noi biologii $i$ meditsiny (Bulletin of Experimental Biology and Medicine), 6(1): 90-93, 1938.

2643. Fainberg, V. B. "Appearance of Reaction from Clumping by $\mathrm{O}$ Aggultinin in Human Embryos." Souremennye problemy gematologii i perelivaniza krovi, M. Medgiz (Current Problems of Hematology and Blood Transfusion. Moscow, State Publ. House of Med. Lit.), (9-10): 65-71, 1934.

2644. - and Bondarenko, E. A. 'Dynamies of Changes of Morphological Composition of Peripheral Blood in Human Embryos in the First Half of Fetal Life." Ibid., $(9-10): 72-81,1934$.

2645. FAINBERG, V. B. "Appearance of Agglutiongens in Human Embryos, I." Kazanskii meditsinskii zhurnal (Kazan' Medical J.), (8-9): 1025-1029, 1935.

2646. Fainshmid, O. I., et al. "Faets About Age Characteristies in Content and Conversion of Energy Substances in Muscles" (Ukr.: Dani pro vikovi osoblivosti u vmisti i peret-

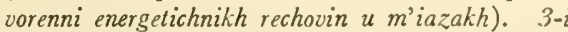
Ukrains'kii z'izd fiziologiv, biokhimikiv, farmakologiv, Dnipropetrovs'k (Third Ukrainian Congress of Physiologits, Biochemists, and Pharmacologists. Dnepropetrovsk), 1939, p. 101.

2647. Fainshimid, O. I., and Osinskaia, V. O. "Age Charaeteristies in Content and Conversion in Muscles of Substances That
Play a Role in Their Activity." Biokhimiza (Biochemistry), 5(1): 12-24, 1940.

2648. FAL'K, A. A. "I Ieart Growth in the Child Aceording to Age" (Rost serdisa u detei po vozrastam. Diss.), a dissertation, 1901.

2649. FARFEL', V. S. "Threshold Requirement of Oxygen in Man, Its Dependeney on Age and Sex, Physieal Development and Training." VII Vsesoiuznyi s'ezd fiziologov, biokimikov, farmakologov. Doklady. Medgiz, M. (Seventh All-Union Congress of Physiologists, Biochemists, and Pharmacologists. Reports. State Publ. House of Med. Lit., Moscow), 1947, p. 616.

2650. - - (Same title) Proúlemy sozetskoi fiziologii, biokhimii, farmakologii, M. (I'roblems of Soviet Physiology, Biochemistry, and Pharmacology. Moseow), 1: 667-668, 1949.

2651. - Vasiutina, A. I., Tambieva, A. P., and Korol', V. M. 'Fast Running of Boys 8-1 5 Years of Age." Trudy pervoi nauchnoi konferentsii po vozrastnoi morfologii i fiziologii. izd-vo Akademii pedagogicheskikh nauk RSFSR, MI. (Transactions of the First Sei. Conference on Age Morphology and Physiology. Publ. of the Acad. of Pedagogical Sciences, Russian Soviet Federative Socialist Republic, Moscow), 1954, pp. 217-224.

2652. Fedorov, V. V. "Age Changes in Liveliness of Nerve Processes." Fiziologicheskii zhurnal SSSR (Physiological J. of the USSR), 37(4): 446-452, 1951 .

2653. FEDorov, V. K. "Problem of the Physiological Mechanism of Reduction of Conditioned Reflexes to Old Age." Zhurnal vysshei nervnoi deiatel'nosti (J. of Higher Nervous Activity), 4(4): 568-573, 1954.

2654. Fedorov, P. S. "Problem of Phosphorus Content in Blood of Children." Vrachebnoe delo (Medical Afrairs), (7): 505 , 1930.

2655. Feidereg, I. M. "Study of Respiration and Gas Exchange at Rest and With Maximal Work in Children of School Age." Trudy pervoi nauchnoi konferentsii po vozrastnoi morfologii i fiziologii, izd-vo Akademii pedagocheskikh nauk RSFSR, M. (Transaetions of the First Sei. Conferenee on Age Morphology and Physiology. Publ. by Acad. of Pedagogical Sciences, RSI'SR, Moseow), 1954 , pp. $200-217$.

2656. FeL'DMAN, N. G. "Method of Ontogenetic Study of the Optic Tract." Arkhiv 
biologicheskikh nauk (Arehives of Biological Seienccs), 53(2-3): 154-157, 1939.

2657. "Ontogenesis and Histopathology of the Rctina" (Ontogenez i gistopatologiia setchathi. Izd-vo Akademii meditsinskikh nauk, M.). Publ. by Aead. of Med. Scienees, Moseow), 1951, 122 pp.

2658. - - "Ontogenesis of the Retina and Histopathological Alteration of Its Nerve Elements in Expcrimentation." Trudy V Vsesoiuznogo s'ezda anatomov, gistologov $i \mathrm{em}-$ briologov, Medgiz, L. (Transaetions of the Fifth All-Union Congress of Anatomists, Histologists and Embryologists. St. Publ. House of Mect. Lit., Leningrad), 1951, pp. 563-565.

2659. Perdman, D. I.., and Mestechikina, A. IA. "Effeet of $\Lambda T P$ on Chemieal Composition of Musele and on Course of the Atrophic Proeess After Breaking Motor Innervation." Ukrainskii biokhimicheskii zhurnal (Ukrainian Biochemical J.), 24(3): 337-353, 1952.

2660. Figurin, N. L., and Denisova, M. P. "Short Diagnostie Seheme of the Child up to One Year Old." Novoe v refleksologii i fiziologii nervnoi sistemy (The New in Reflexology and Physiology of the Nervous System), 2: 282, 1926.

2661. Fizhenko, N. V., and Shgherbakova, M. P. "Vitamin A Content in Blood of the Newborn." Voprosy pediatrii $i$ okhrany meterinstva $i$ detstva (Problems of Pediatries and $\mathrm{Ma}$ ternal and Child Welfare), 16(5): 29-31, 1948.

2662. Filatov, V. P., and Biber, V. A. "Problem of the Nature of Biogenie Stimulators of Surving Plant Tissues." DAN SSSR (Proeeedings of the Acad. of Seienees USSR), 62(2): 259-262, 1948.

2663. Filatovich, V. V. "Dynamics of Erythrocytes in the Ontogencsis in the Case of Directed Breeding and in the Process of Lactation of Tagil Cattle" (Dinamika krasnoi krovi $v$ ontogeneze pri napravlennom vospitanii $i v$ protsesse laktatsii u tagil'skogo skota. Avtoref. kand. diss.). Author's own abstract of the dissertation for candidate's degrec, 1953.

2664. Filimonov, I. N. "Embryonic and Postembryonie Development of the Cerebral Cortex." Zhurnal psikhologii i nevrologii (J. of Psychology and Neurology), 39(4-6): -, 1929.

2665. - "Problem of the Embryonie and Postembryonie Development of the Cere- bral Cortex of Man." Sovetskaia nevropatologiia, psikhiatriia $i$ psikhogigiena (Soviet Neuropathology, Psychiatry, and Mental Hygiene), (11-12): 198-304, 1934.

2666. "Nllocortical and Periallocortical Formations in Man and Their Ontogenesis." Trudy Instituta mozga, Medgiz, M. (Transactions of the Brain Institute), State Publ. House of Med. Lit., Moseow, (3-4): 15-106, 1938.

2667. - "The Glaustrum of Man and Its Ontogenesis." Ibid., (6): 108-129, 1948.

2668. - "Evolution of the Nervous System and I. P. Pavlov's Instruction on Higher Nervous Aetivity." Sb.: Uchenie I. P. Pavlova v teoreticheskoi i prakticheskoi meditsine, M., Medgiz (Collection: I. P. Pavlov's Instruction in Theoretical and Practical Medicine. Moscow, Medgiz), 1953, pp. 289-309.

2669. Filıppova, T. A. "Age Characteristics of Watcr Exchange in the Animal Organism." Uch. zap. Khar'kovskogo gos. un-teta (Annals of Khar'kov State Univ.), v. 53; Trudy nauch.-issled. instituta biologii (Transaetions of the Sci.-Res. Institute of Biology), 1954, pp. 231-243.

2670. 1 - "Age Charaeteristics of $\mathrm{Wa}^{-}$ ter Exehange in Conditions of High Temp rature of the Surrounding Medium." Uch. zap. Khar'kovskogo gos. un-teta (see above), v. 68. Trudy nauch.-issled. Instituta biologii $i$ biologicheskogo f-ta (Transactions of the Sci.-Res. Institute of Biology and Biologieal Pharmacotherapy), 24: 183-192, 1956.

2671. Finkel'sirtein, E. A. "The Arising and Development of Natural Death." Estestvoznanie i marksizm (Natural Science and Marxism), (4): 51-74, 1929.

2672. - - and Shapiro, E. M. "Effect of Carnosine on Development of Triton taeniatus Embryos." Biull. eksperimental'noi biologii $i$ meditsiny (Bulletin of Experimental Biology and Medieine), 6(2): 150-151, 1938.

2673. Finkel'shtein, E. A. "Effect of an Excess of Oxygen on Various Stages of Development of Amphibians." I Ibid., 8(5): 296-300, 1939.

2674. Firsova, L. A. "Motor Reflexes Conditioned to Chains of Stimuli in Young Chimpanzees." Zhurnal vysshei nervnoi deiatel'nosti (J. of Higher Nervous Activity), 5(2): 247$254,1955$. 
2675. Fligel'MAN, I. M. "Ontogenetic and Comparative Anatomy Data on Development of the Substantia nigra." Sb.: Ontogenez mozga. L. (Collection: Ontogenesis of the Brain. Leningrad), 1949, pp. 140-148.

2676. Fogel'son, L. I. "Effect on Circulation of Factors of the Constitution, Agc, and Sex." Bolezni serdisa $i$ sosudov, M. (Diseases of the Heart and Blood Vessels. Moscow), 1951, pp. 273-284.

2677. Fokina, T. V., and Probatova, L. E. "Properties of Hemoglobin Exchange in Premature Children." Pediatriia (Pediatrics), (5): 17-23, 1953.

2678. Fol'bort, G. V., and Semernina, A. V. "Change of Work Capacity of Central Elements That Provide Higher Nervous Activity in Old Age in Dogs." Sb.: Starost'. Trudy konferentsii 17-19 dekabria $1938 \mathrm{~g}$., Kiev, $A \mathcal{N}$ USSR (Collection: Old Age. Transactions of the Dec. 17-19, 1938 Conference at Kiev, Acad. of Sciences, UkrSSR), 1940, pp. 199-205.

2679. Fomin, D. A. "Problem of the Secretion of Salivary Glands in Calves." Fiziologicheskii zhurnal SSSR (Physiological J. of the USSR), 30(4): 524-526, 1941.

2680. Fortunatov, I. K. "Morphological Expression of Age of Heterophyllous Poplar (Populus) Shoots." DAN SSSR (Reports of the Academy of Sciences USSR), 64(3): 395$396,1949$.

2681. Forshtadt, R. A., and Chulkova, O. N. "Nerve-Humoral Regulation of the Sphincter of the Bladder in the Ontogenesis." Trudy Vsesoiuznogo o-va fiziologov, biokhimikov, farmakologov, izd-vo AN SSSR, M. (Transactions of the All-Union Assoc. of Physiologists, Biochemists, and Pharmacologists. Publ. by Acad. of Sciences USSR, Moscow), 1: 95-96, 1952.

2682. FrakitskaiA, E. A., and Tsvetaeva, T. A. "Age-Sex Fluctuations in Functional Criteria of the Cardiovascular System of Children and Adolescents." Teoriia praktika fizicheskoi kul'tury (Theory and Practice of Physical Culture), (5): 76-77, 1938.

2683. FreidberG, I. M. "Development of Threshold Competence of the RespiratoryCirculatory System of Adolescent Sportsmen" (Razvitie predel'noi deesposobnosti dykhatel'notsirkuliatornoi sistemy u podrostkov-sportsmenov. Sessiia, posviashchennaia itogam nauch.issled, raboty TsNIIFK. Tezisy). Session dedicated to the results of the scientific research work of the Central Scientific Research Institute of Physical Culture. Theses, 1948.

2684. Frenkel', Z. G. "Posing the Question of Prolonging Human Life." Sovetskaia vrachebnaia gazeta (Soviet Medical Gazette), (16): 1193-1203, 1934

2685. - "How Many People Livc Beyond the Age of a Iundred?" Ibid., (7): 573-580, 1935.

2686. - - "Invalidity of Viewing Death as a liactor in Selection of the LongLived." Ibid., (24): 1927-1940, 1935.

2687. - "Life Extension in a Country of Socialism in the Making." Gigiena i sanitariia, M. (Hygiene and Sanitation, Moscow), (8): 14-29, 1936.

2688. - "Posing the Problem in the USSR of Extension of Long Life and Control of Aging." Sovetskii vrachebnii zhurnal (Soviet Med. J.), (3): 205-216, 1941.

2689. -Prolongation of Life and an Active Old Age" (Udlinenie zhizni i aktivnaia starost'. L., Institut usovershenstvovaniia vrachei), Leningrad, Institute for Training Physicians, 1945, p. 372.

2690. - "Prolongation of Life and an Active Old Age" (Udlineniia zhizni i deiatel' naia starost') Akademiia meditsinskikh nauk SSSR, M. (Academy of Med. Sciences of the USSR, Moscow), 1949, p. 394.

2691. Frid, S. M., and Zibitsker, D. Kil. "Importance of Age and Sex of Horses in Case of Hyperimmunization." Zhurnal mikrobiologii, epidemiologii, immunologii ( J. of Microbiology, Epidemiology, and Immunology), (11-12): 172-176, 1939.

2692. Fridman, A. P., and Petrova, V. V. "Comparative Determination of Electrolytes (Cl, P, Ca, Mg) in the Cerebrospinal Fluid of Animals and Man." Arkhiv biologicheshikh nauk (Archives of Biological Sciences), 39: 209-218, 1935.

2693. Friduan, G. A. "Typhoid Fever in the Offspring." Vrachebnoe delo (Medical Affairs), (10-11): 850-851, 1930.

2694. FridMaN, FridRIKH (Friedrich FriedMANN). "Age Changes and Treatment of Them. Instruction on Old-Age Involution in Connection with Physiology, Pathology, and Its Therapy." (Starcheshie izmeneniia $i$ ikh 
lechenie. Uchenie o starcheskoi involiutsii v sviazi $s$ fiziologiei, patologiei $i$ terapieii ee. Izd-vo zhurnala "Prakticheskaia meditsina," SPb). A publ. of the journal Practical Medicine, St. Petersburg, 190.4.

2695. Froenchenko, I. S. "Change of Various Fractions of Phosphorus During Starvation of Animals of Differcnt Age." Ilogovaia studencheskaia nauchnaia konferentsiia Khar'kovskogo gosudarstvennogo universiteta. Tezisy dokladov KhGU (Scientific Conference of the Entire Student Body of Khar'kov State Univ. Theses of reports of Khar'kov State Univ), 1952, pp. 185-187.

2696. Frumkix, IA. P. "Clinical Studies of Mental Changes." Sb.: Starost'. Trudy kon. ferentsii 17-19 dekabria 1938 g., Kiev, AN USSR (Collection: Old Age. Transactions of the Dec. 17-19, 1938 Conference, Kiev. Acad. of Sciences of the UkrSSR), 1940, pp. 357-368.

2697. Fudel'-Osipova, S. I., and KhoKhol, E. N. "Disturbance of Conditioned Reflex Activity in Children with Chronic Dyspepsia." Zhurnal vysshei nervnoi deiatel'nosti (J. of Higher Nervous Activity), 3(2): 260-266, 1953.

2698. Furman, E. P. "Reflexes in Infants" (O refleksakh u grudnykh detei. Diss. SPb), a dissertation. St. Petersburg, 1903.

2699. Fuflygina, T. P. "Experimental Study of Irradiation of the Braking Process from Secondary Signal System to First." Zhurnal vysshei nervnoi deiatel'nosti (see above), 3(5): 718-727, 1953.

\section{$\mathrm{KH}$}

2700. Khai, L. M., Gollerbakh, A. N., Tolghinskaia, G. IA., and Konstantinova, O. M. "Data on Determination of Degree of Susceptibility of School Children in Grades II-V to Dick Toxin and Results of Inoculations in the Different Groups." Trudy Leningradskogo in-ta im. Pastera, L., Medgiz (Transactions of the Leningrad Pasteur Institute, Leningrad. State Publ. House of Med. Lit.), 7: 74-78, 1940.

2701. Khaikina, B. I., and Gongiharova, K. O. "Activity of Phosphoglucomutase of Brain at Different Stages of Development of Animals" (Ukr.: Aktivnist' fosfogliukomutazi mosku na riznikh stadiiakh rozvilku tvarin). Ukrains'kii biokhimichnii zhurnal (Ukrainian Biochemical J.), 19(1): 88-95, 1947.
2702. Kinaikina, B. I., and Goriukinina, T. O. "Inhibition, with Phlorhizin, of Glycolysis in Cerebrum of Animals at Differcnt Stages of the Ontogencsis" (Gal'muvannia glikolizu v golovnomu mozku tvarin na riznikh etapakh onlogenezu foridzinom). Ibid., 19(2): 209-217, 1947.

2703. Kinalatov, S. S. "Old Age and Xanthomatosis." Sb.: Starost' (Trudy konferentsii 17-19 dekabria 1938 g.), Kiev, izd-vo AN USSR (Collection: Old Age. Transactions of the Dec. 17-19, 1938 Conference, Kiev. Publ. by Acad. of Sciences UkrSSR, 1940, pp. 67-71.

2704.

"Physiological

Endocrine System and Endocrinopathy in the Light of the New Theory of Nature and of the Derivation of Hormal Elements" (Fiziologicheskaia endokrinnaia sistema $i$ endokrinopatiia $v$ svete novoi teorii prirody $i$ proiskhozdeniia gornonal'nykh nachal. Mediz, M.). State Publ. House of Med. Lit., Moscow, 1944.

2705. Khanin, M. N. "Importance of Age in Development of Experimental Cirrhosis of the Liver." Biull. eksperimental'noi biologii $i$ meditsiny (Bulletin of Experimental Biology and Medicine), (3): 25, 1954.

2706. KhaR'kov, A. A. "'Sexual Characteristics of Hemodynamics in the Teen-Age Period. I. Age-Sexual Changes in Blood Pressure and Anatomical-Physiological Characteristics of the Cardiovascular System According to the Data of Literature." Anatomofiziologicheskie osobennosti detskogo vozrasta. Biomedgiz., M.-L. (Anatomical-Physiological Characteristics of Childhood. State Publ. House of Biomedical Lit., MoscowLeningrad), 1935, pp. 196-228.

2707. - "The Anatomical-Physiological Age of a Child and Methods for Studying It." Izvestiia Akademii pedagogicheskikh nauk RSFSR, M., (Bulletin of the Acad. of Pedagogical Sciences RSFSR, Moscow), 47: 10-16, 1953.

2708. K11askina-Munder. "Average Standards of Blood Hemoglobin in Working TeenAgers." Vrachebnoe delo (Medical Affairs), (11): - 1928.

2709. Khlopina, I. D. "Tropilic Changes in Bones of the Hind Quarters of Rabbit After Intersection of the Sciatic Nerve." $D A \mathcal{N}$ SSSR (Reports of Acad. of Sciences, USSR), 91 (6): 1381-1383, 1953.

2710. Kulystova, Z. S. "Age Changes in Structure of Human Gall Bladder." Trudy 
Chkalouskogo med. in-ta, Chkalov (Transactions of the Chkalov Med. Institute, Chkalov), 2: (is $3-77,1950$.

2711. Khodzilasil, A. V., and Tikhomrov, V. P. "Age Indices of Blood Hemoglobin in Adolescents in Connection with Physical Development. Materialy kliniki po vozrastnoi patojiziologii pod red. I. P. Razenkova i I. G. Gel'mana, VIEM, M. (Data of the Clinic on Age Pathophysiology. I. P. Razenkov and I. G. Gel'man, editors. All-Union Institute of Experimental Medicine. Moscow), 1937, p. 133.

2712. KHozAK, L. E. "Age Characteristics of Motor Generalization and Synthesis." Sb.: Opyt sistematicheskogo eksperimental'nogo is sledovaniia ontogeneticheskogo razvitiia korkovoi dinamiki cheloveka, izd-vo VIEM, M. (Collection: Study of Systematic Experimental Investigation of Ontogenetic Development of Cortical Dynamics of Man. Publ. by AllUnion Inst. of Exptl. Med., Moscow), 5: $105-114,1940$

2713. - "Age Characteristics of Limiting Inhibition." Ibid., 5: 128-138, 1940.

2714. - "Age Characteristics of Extinguishing Inhibition (Three Standards for It)." Ibid., 5: 154-167, 1940.

2715. Kholina, A. A. "Old Age Changes in the Eyes." Sb.: Starost' Trudy konferentsii 17-19 dekabria 1938 g., Kiev, AN USSR (Collection: Old Age. Transactions of the Dec. 17-19, 1938 Conference at Kiev of the Acad. of Sciences UkrSSR), 1940, pp. 351356.

2716. KHOLODKovskiI, N. "Tod und Unsterblichkeit in der Tierwelt" (Death and Immortality in the Animal World), Zool. Anz., 5: 一, 1882.

2717. Kholodnyi, N. G. "Problem of Age and Contemporary Physiology of Plants." Uspekhi sovremennoi biologii (Advances in Contemporary Biology), 4(6): 438, 1935.

2718. - and Kocherzhenko, I. E. "Control by Processes of Development of the Lemon Tree with the Help of Growth Substances." DAN SSSR (Reports of the Acad. of Sciences USSR), 61(2): 391-394, 1948.

2719. Khotovitski, S. F. "Pediatrics" ( $P \ell-$ diatrika. SPb). St. Petersburg, 1847.

2720. Khokol, E. N., and Kudriashova, O. D. "Study of the Use of Capillaroscopy in Children at an Early Age." Zhunral po po izucheniiu rannego detskogo vozrasta ( $\mathrm{J}$. for Study of Early Childhood), 9(8): 591-597, 1929.

2721. KнокіlоL, E. N. "Changes in the Physiological Systcm of Connective 'Tissue in Children with Acutc Nutritional Disorders." Pediatriia (Pediatrics), (5): 22-26, 1947; 1 rudy VI Vsesoiuznogo s'ezda detskikh vrachei, M., Medgiz (Transactions of the Sixth All-Union Congress of Pediatricians. Moscow, Statc Publ. House of Med. Lit.), 1948, pp. 95-99.

2722. KнокоL, O., and SMOROdins'KA, A. "McClure and Aldrich's Test of Babies" (Ukr.: Proba McClure'a i Aldrich'a u nemovliat). Ukrains'kii medichnii arkhiv (Ukrainian Mcdical Archives), 6(1-2): 217, 1930.

2723. Khrenov, I. I. "Analysis of Age Characteristics of Circulation and Gas Exchange in People." DAN SSSR, novaia ser. (Reports of the Acad. of Scicnces USSR, new series), 58(6): 1239-1242, 1947.

2724. Khrustalev, S. A. "Quantitative and Morphological Composition of Regular Elements of Peripheral Blood and Results of in vivo Study of Megakaryocytes in Marrow of Healthy Bones of Various Age." Uch. zap. Kazanskogo zooveterinarnogo in-ta (Annals of the Kazan' Institute of Zootechnics and Veterinary Medicine), 51: 1, 1939.

2725. - (Same title). Trudy Kievskogo zooteckhnichesko-veterinarnogo in-ta (Transactions of the Kiev Institute of Zootechnics and Veterinary Medicine), 4(2; 14): 163-209, 1940.

2726. Khrutskil, E. T. "Nerve-Humoral Regulation of Motor Activity of the MultiChambered Stomach of Calves and Lambs."

Trudy Vsesoiuznogo o-va fiziologov, biokhimikov, farmakologov, izd-vo AN SSSR, M. (Transactions of the All-Union Assoc. of Physiologists, Biochemists, and Pharmacologists. Publ. of the Acad. of Sciences USSR, Moscow), (1): 92-93, 1952.

2727. Khruskchev, P. D. "Mortality and the Five Ages of Life." Nauchnoe slovo (Zhurn. izdavalsia v Moskve) (The Scientific Word. A j. publ. in Moscow), (2): 48-76, 1903.

2728. Khudorozheva, A. T. "Study of the Tone-Motor Phenomenon in the Ontogenesis." Tezisy dokladov 1 soveshchaniia biogruppy $A \mathcal{N}$ SSSR po fiziologicheskim problemam (Theses of Reports of the First Conference of the Biological Group of the Acad. of Sciences USSR on Physiological Problems), 52: - 937. 
2729. "Functional Properties of the Nerve-Muscle System in the Ontogenesis." Fiziologicheskii zhurnal SSSR (Physiologis al J. of the ('SSR), 33(5): 637-650, 1947.

2730. "Evolution of Functional Properties of the Nerve-Muscle System and Its Innervation Relationships in the Ontogenesis." Izrestiia $A \mathcal{N}$ SSSR, ser. biol. (Bulletin of the Acad. of Sciences USSR, Biol. Series), (5): 617-636, 1949.

2731. "Charactcristics of the Development of Conditioned Reflex Activity in the Ontogenesis of Pups." Zhurnal vysshei nervnoi deiatel'nosti ( $\mathrm{J}$. of Iligher Nervous Activity), 4(1): 93-103, 1954.

\section{TS}

2732. Tsvetaeva, T. A. "Cardiovascular System of Adolescents and Its Altcration in Employments with Physical Exerciscs" (Serdechnososudistaia sistema podrostkov $i$ ee izmeneniia pri zaniatïakh fizicheskimi uprazheniiami. Diss. Khar'kov), a dissertation. Khar'kov, 1941.

2733. TSvetkov, A. N. "Theory of Physiological Units." DAN SSSR (see above), (20): 467, 1929.

2734. TSEituin, S. M., Veisk, R. A., and DANiEL'SON, A. K. "I Mata Contributing to a Knowledge of Age Characteristics of the Hematoencephalic Barricr. Report 1. IIcmatoencephalic Barricr in Dogs One to Eight Months Old." Sovetshaia pediatriia (Soviet Pediatrics), (7): 18, 1935.

2735. TSEItlin, S. M. Effect of Hyperthermia on Function of Different Organs in Females at Different Physiological Periods. Report II. Effect of Hyperthermia on the Hematoencephalic Barrier in Dogs at Different Physiological Periods (Rut, Pregnancy, and Lactation). Biull. eksperimental'noi biologii $i$ meditsiny (Bulletin of Exptl. Biology and Med.), 1(1): 82-83, 1936.

2736. Tsimbler, I. V., and Neisiltadt, M. I. "Calcium Content in Blood of Infants." Zhurnal po izucheniiu rannego detskogo vozrasta (J. on Study of Early Childhood), 4(4): 1-12, 1926.

2737. Tsimbler, I. V., and Begam, L. L. "Content of Inorganic Phosphorus in Blood of Nursing Children." Ibid., 5(1): 3-9, 1927.
2738. T'simblek, I. V., and Neisutait, M. I. "Acidosis at Tulocrculosis in Children of an Early Agc." Ibicl., 12(4): 118, 1932.

2739. Tsimblek, I. V., Peciuuk, L. M., and GureviciI, A. E. "Tuberculin-Eosinophil Phenomenon (with Mantoux's test) as an Index of Allergy." Sovetshaia pediatriia (Soviet Pediatrics), (4): $11-18$ and (5): $3-11$, 1936.

2740. TSINBERG, I. S. "Characteristics of the Tempo and Rhythm of Work Movements in the Aged." Starost' $i$ trudosposobnost'. Sb. rabot NIVTE, L. (Old Age and Work Capacicty. Collection of Works of the "NIVTE" (see item 911 above), Leningrad), 1936, pp. 123-145.

2741. Tsinzering, V. D. "Pathogencsis of Atherosclerosis." Arkhiv biologicheskikh nauk (Archives of Biological Sciences), 26: 141, 1926.

2742. Tsitovicir, I. S. "Plyysiology and Pharmacology of Age Changes." Ob'edinennaia sessiia, posviashchennaia 10-letiiu so dnia smerti I. P. Pavlova, M., AMN SSSR (Joint Scssion Dcdicated to the 10th Anniversary of I. P. Pavlov's Death by the Acad. of Med. Sciences USSR, Moscow), 1948, pp. 239249.

2743. 'I'sobkalo, G. I. "Effect of Picrotoxin on Central Nervous System in Different Periods of the Ontogenetic Development." DAN SSSR, novaia ser. (Reports of the Acad. of Sciences USSR. Ncw serics), 52(9): 827$829,1946$.

2744. - - (Same title). Trudy Instituta evoliutsionnoi fiziologii $i$ patologii vysshei nervnoi deiatel'nosti im. akad. I. P. Pavlova, izd-vo AN SSSR, M.-L. (Transactions of the I. P. Pavlov Institute of Evolution Physiology and Pathology of Highcr Nervous Activity. Publ. by Acad. of Scicnces USSR, Moscow-Lcningrad), 1: 369, 1947.

2745. "Use of the Pharmacological Mcthod for Study of the Evotion Function of the Central Nervous System in the Ontogenesis." I'Il V'sesoiuznyi s'ezd fiziologov, biokhimikov, farmakologov, M., Mcdgiz (Seventh AllUnion Congrcss of Physiologists, Biochemists, and Pharmacologists, Moscow), State Publ. House of Med. Lit.), 1947, pp. 708-709.

2746. - "Effect of Corasole (Pentylenetetrazolc) on Nervous System in the Embryonic and Postnatal Pcriods of Development." Fiziologicheskii zhurnal SSSR (Physi- 
ological $J$. of the USSR), 37(6): 727-731, 1951.

2747. Tsuverkalov, D. A. "Biochemical Bascs of Osteogencsis." Sb.: VII Vsesoiuznyi s'ezd fiziologov, biokhimikov i farmakologov, Medgiz, M. (Seventh All-Union Congress of Physiologists, Biochcmists, and Pharmacologists. State Publ. House of Med. Lit., Moscow), 1947, p. 665.

2748. Tsuker, M. B., and Gotovtseva, L. "Tendon and Cutaneous Reflexcs in Children of Early Age." Neuropatologiia i psikhiatriia (Neuropathology and Psychiatry), (3): 5961, 1947.

\section{CII}

2749. Cinaika, E. I. "Age-Associated Morphology of the Heart." Sb.: Starost"; Trudy konferentsii 17-19 dekabria $1938 \mathrm{~g}$., AN USSR, Kiev (Collection: Old Age. Transactions of the Dec. 17-19, 1938 Conference, Acad. of Sciences UkrSSR, Kiev), pp. 89-95.

2750. Chiebotarevskaia, T. N. "Newborn Children." Bol'shaia meditsinskaia entisklopediia (The Large Medical Encyclopedia), 21: 455, 1932.

2751. Chelombit'ko, lu. P. "Revival of the Newborn in a State of Asphyxia at Birth." Akusherstvo i ginekologiia (Obstetrics and Gynecology), (6): 22-23, 1941.

2752. Chenykaeva, E. Iu. "Acctylcholine Content in Embryonic and Denervatcd Muscles of Rabbit." Izvestiia AN SSSR, ser. biol. (Bull. of the Acad. of Sciences USSR. Biological series), (1): 35, 1943.

2753. Chepinoga, O. P., Skvirs'ka, E. B., Rukina, L. P., and Smolich, T. P. "Interrelationship Between Exchange of Nucleic Acids in the Liver and in the Central Nervous System" (Ukr.: Vzaemozv'iazok mizh obminom nukleinovikh kislot $u$ pechintsi ta $v$ tsentral'nyi nervovii sistemi). Ukrains'kii biokhimichnii zhurnal (Ukrainian Biochemical J.), 24(3): 177187, 1952.

2754. Cheprakova, IU. I. "Oxygen Requirement of Carassius auratus gibelio (Bloch) at Different Stages of Development." DAN SSSR (Reports of the Acad. of Sciences USSR), 98(5): 877-880, 1954.

2755. Cherkasova, E. V. "Gas Exchange of Mulberry Silkworm." Izvestiia AN Turkmenskoi SSR (Bulletin of the Acad. of Sciences Turkmen SSR), (4): 86-89, 1953.
2756. Chernenko, E. S. "Change of Age Criteria in Varictics of $A$ pple Trees with Diffcrent Ratc of Maturity and Rate of FruitBcaring." Doklad l'sesniuznoi akademii s.-l.h. nauk im. Lenina (Report of the All-Union Lenin Academy of Agricultural Scienccs), (5): 19-27, 1948.

2757. - Ontogenetic Changes in Young Hybrid (Fruit) Seccllings." Agrobiologiia (Farm Biology), (6): 7:3-80, 1949.

2758. Chernov, A. \%. "Charactcristics of Cardiac Function in the Adolcscent-Juvenile Period." Trudy XII Vsesoiuznogo s'ezda terapevtov Medgiz, M.-L. (Transactions of the 12th All-Union Congress of Therapists. State Publ. House of Med. Lit., MoscowLeningrad), 1940, pp. 87-88.

2759. Chernaikilovskil, A. G. "Dcvelopment and Completion of $n$. depressoris and Development of Innervation of Pericardiac Paraganglia: Paraganglion aorticum and Glomus caroticum." Medichnii zhurnal AN USSR (Med. J. of the Acad. of Scienccs UkrSSR), 8(1): $179,1938$.

2760. Chertkov, L., and Bel'govskaia, E. "Cutancous Energy in Human Nurslings." Zhurnal po izucheniiu rannego detskogo vozrasta (J. for Study of Early Childhood), 10(7-8): 420-424, 1930.

2761. Chesnokova, A. P. "Dynamics of Higher Nervous Activity of Pups in the Process of Their Individual Development." Zhurnal vysshei nervnoi dieatel'nosti ( J. of Higher Nervous Activity), 1(4): 555-565, 1951.

2762. - "Restoration of Dynamic Stereotypy in Dogs of Various Age as One of the Indices of Age Characteristics of Higher Nervous Activity." Ibid., 2(3): 373-380, 1952.

2763. Chetverikov, D. A. "Carbonic Anhydrase of Tissues of the Eye in the Ontogenesis." Izvestiia AN SSSR, ser. biol. (Bulletin of the Acad. of Sciences USSR. Biological series), (4): 461-468, 1948.

2764. CiHinkA, I. I. "Devclopment of Cortical Internal Inhibition in the Ontogenesis of Pups." Trudy Instituta fiziologii im. I. P. Pavlova, AN SSSR, M.-L. (Transactions of the I. P. Pavlov Institute of Physiology, Acad. of Sciences USSR, Moscow-Leningrad), 2: 86-107, 1953.

2765. Chistiakova, A. I. "Certain Physiological Characteristics in the Neonatal Pc- 
riod." Zhurnal po izucheniiu rannego detshogo vozrasin (J. for Study of Early Childhood), (78): 322-330, 1931 and (1): 5-15, 1932.

2766. Cuichinadze, N. "Emergence and Devclopment of Ncrvous $\Lambda$ ctivity in Chick limbryos." Trudy Tbilisskogo gos. un-teta (Transactions of Tiflis Statc Univ.), 26: 61, 19.4.

2767. Chitetsova, V. M., Smolina, T. N., and P'Illuga, E. V. "Intcstinal Microflora of Ncwborn Children with Different Methods of Rearing." Voprosy akusherstva i pediatrii. Smolensk, knizhn. izd-vo (Problcms of Obstetrics and Pediatrics. Smolensk. Publ. of Sci. Books), 1956, pp. 143-148.

2768. "Dcpendency of Intestinal Microflora on Condition of the Organism of the Newborn Child in the First Days of Its Life." Ibid., 1956, pp. 149-156.

2769. Chulkov, O. N., and Forsiltadt, R. A. "Bladder Sphincter Tonus in the Ontogenesis." Trudy Vsesoiuznogo o-va fiziologov, biokhimikov $i$ farmakologov, AN SSSR, M. (Transactions of the All-Union Assoc. of Physiologists, Biochemists, and Pharmacologists. Acad. of Scicnces USSR, Moscow), 1: 95, 1952.

2770. Chumaevskaia, O. A. “Comparative Effect of Adrenalin and of Ephedrine in Early Childhood." Pediatriia (Pediatrics), (11): $34-40,1940$.

2771. Chumak, V. I. "Extinction of Oriented Reflex in Cats in the Early Postnatal Period." Zhurnal vysshei nervnoi deiatel'nosti (J. of Higher Nervous Activity), 5(6): 863-872, 1955.

Sh

2772. Sirabanova, A. N. "Old Age." Vrachebnoe delo (Medical Affairs), (10): 755764, 1927.

2773. Snabanova, M. V. "Thiamine and Its Fractions in Blood and Urine of Healthy and Sick Children." Voprosy pediatrii $i$ okhrany materinstva $i$ detstva (Problems of Pediatrics and Maternal and Child Welfare), 16(5): 37-38, 1948.

2774. Shagan, B. F. "Some Problems of the P'hysiology and Pathology of Newborn Children" (Nekotorye voprosy fiziologii i patologii novorozhdennykh detei. Izd. Akademii me- ditsinskikh nauk SSSR). Publ. of the Acad. of Mcd. Scienccs USSR, 1953.

2775. Snagov, M. "Arcus scnilis of Cornca praccox." Russhii of tal'mologicheshii zhurnal (Russian Ophthalmological J.), (7): 717-719, 1927.

2776. Shaikhet, G. Kn., and Mostova, L. O. "Inactive Humoral Immunity to Influenza in Newborn Infants" (Ukr.: Pro pasivnii gumoral'nii protivogripozni imunitet u novonarodzhenikh dilei grudnogo viku). Pediatriia, akusherstvo, ginekologiia (Pediatrics, Obstetrics, and Gynecology), (6): —, 1950.

2777. Shakleina, L. G. "Mechanism of Digestive Leukocytosis in Newborn Children." Biull. eksperimental'noi biologii $i$ meditsiny (Bull. of Exptl. Biology and Medicinc), 40(5): 27-28, 1955.

2778. Shalkov, N. A. "Alteration of Hcmodynamics in Healthy and Sick Children Under Effect of Physical Stresses." Voprosy pediatrii i okhrany materinstva $i$ detstva (Problems of Pediatrics and Maternal and Child Welfare), 14(1): 5, 1946.

2779. - "Functional Study of the Apparatus for External Respiration in Children. Report I." Ibid., 14(3): 18-30, 1946.

2780. Shamardina, I. P. "Change in Intensity of Respiration of Fish in the Course of Their Development." DAN SSSR (see above), 98(4): 689-692, 1954.

2781. Shamarina, N. M. "Cholinesterase Content in Embryonic Auricles of the Heart." Biull. eksperimental'noi biologii $i$ meditsiny (Bulletin of Experimental Biology and Medicine), 8(1): 66, 1939.

2782. - - " "Effect of Eserine on Muscles of Warm-Blooded Animals in the Ontogenesis." Trudy fiziologicheskogo in-ta im. I. P. Pavlova AN SSSR (Transactions of the I. P. Pavlov Physiological Institute of the Acad. of Sciences USSR), 1(52): —, 1945.

2783. Shamsiev, S. Sh. "Medicinal Dosing in Childhood." Pediatriia (Pediatrics), (5): 32-37, 1948.

2784. - "Analysis of Reactions of Cardiovascular and Respiratory Systems to Effect of Toxic Doses of Digitalis in Different Age Periods." Farmakologiia $i$ toksikologiia (Pharmacology and Toxicology), (3): 21-26, 1949. 
2785. "Resistance to Effect of Toxic Doses of Digitalis in Different Agc Periods.' Biull. eksperimental'noi biologii $i$ meditsiny (Bull. of Exptl. Biology and Med.), 27(1): 40-44, 1949.

2786. - - "Role of Sympathetic Innervation of the Heart in the Mechanism of Bringing About Digitalis Bradycardia at an Early Age." Ibid., 29(4): 296, 1950.

2787. Shaniavski, S. "Quantitative Analysis of a Child's Urine According to Age" (Kolichestvennyi analiz detskoi mochi po vozrastam. $\mathrm{SPb})$. St. Petersburg, 1900.

2788. Shapiro, B. I. "Ontogenetic and Comparative-Anatomy Development of the Lamina quadrigemina." Nevropatologiia, psikhiatriia, psikhogigiena (Neuropathology, Psychiatry, and Mental Hygiene), 5(11): 17831796, 1936.

2789. Shapiro, S. L., Shishliannikova, M. A., and Voskresenskala, G. S. "Reactivity of the Child's Organism to Introduction of Normal Human Serum." Pediatriia (Pediatrics), 6: 76-81, 1939.

2790. Shapot, V. S. "Interconnection of Processes of Oxidation, Combined Phosphorylation, and Biosyntheses in the Cell." Uspekhi sovremennoi biologii (Advances in Contemporary Biology), 37(3): 255-278, 1954.

2791. Sharikova, A. F., and Test, R. I. "Oxidative Enzymes in the Process of the Phylo- and Ontogenetic Development of Animals." Trudy Instituta fiziologii Narkomprosa RSFSR, Biomedgiz, M. (Transactions of the Institute of Physiology of The People's Commissariat of Public Education, Russian Soviet Federative Socialist Republic. State Publ. House of Biomed. Lit., Moscow), 2: 440, 1936.

2792. Sharikov (sic), A. F. and Miknailov, V. A. "The Catalase System in the Process of the Phylo- and Ontogenetic Development of Animals. Report I." Ibid., 2: 455, 1936.

2793. Sharina, N. A. "Acidity of Cellular Juice of Plants and the Isoelectric Point of Plasma Proteins in Connection with Age and the Effect of Temperatures." Trudy Instituta fiziologii rastenii im. $K$. A. Timiriazava, izd., M. (Transactions of the K. A. Timiriazev Institute of Plant Physiology. Published in Moscow), 2(1): 69, 1937.

2794. Sharina, A. "Problem of Creatinine Content in Urine of Newborn Children."
Ginekologiia $i$ akusherstvo (Gynecology and Obstetrics), (4): 342-350, 1924.

2795. Silarpenak, A. E. "Protein Iixchange in Developing Hen's Egg. Report I. Concentration of Frec Amino Nitrogen in Different Elements of Developing Egg." Zhurnal eksperimental'noi biologii $i$ medilsiny (see above), 13(39;A): 78, 1930.

2796. "Protein Exchange in Developing Hen's Egg. Report II. Fate of Amino Acids Introduced into Egg in the Period of Its Development." Ibid., 12(89): 83, 1930.

\section{7.} Balasheva, O. N., MarchenKov, V. F., et al. "Amino Acid Composition of Organs and Tissues of the Iruman Organism. Report I. Amino Acid Composition of Proteins of Muscles of Adolescent Boy." Fiziologicheskii zhurnal SSSR (Physiological J. of the USSR), 17(5): 1070-1077, 1934.

2798. Shastin, N. R. "Study of the Induction Mechanism in the Cerebral Cortex of Children." Russkii fiziologicheskii zhurnal (Russian Physiological J.), 12(5): 469-482, 1929 .

2799. ㄴ... "Method of Studying Conditioned Reflexes in Children." Fiziologicheskii zhurnal SSSR (see above), 24(6): 10551062, 1938.

2800. - "Physiological Immunity of Newborn and Nursing Children." Instilut pediatrii $A M N$ SSSR, 4-ia nauchenaia konferentsiia, posviashchennaia 25-letiiu deiatel'nosti instituta, M. (Institute of Pediatrics of the Acad. of Med. Sciences USSR, 4 th Sci. Conference Dedicated to the 25th Anniversary of the Institute's Activity. Moscow), 1947, pp. 3537.

2801. - "Natural Immunity of Newborn and Nursing Children. Survey of the Literature." Voprosy pediatrii i okhrany materinstva $i$ detstva (Problems of Pediatrics and Maternal and Child Welfare), 16(2): 52-61, 1948.

2802. Shatenshtein, I. L. "Blood Pressure in Old Age." Meditsinskoe obozrenie (Medical Review), (86): 121, 1917.

2803. Shaternikov, Mi. N. "Old Age." An article in the dictionary Granata, 1926.

2804. Shafershtein, S. IA. "Effect of Concentration of Food on the Glycemic Curve in 
the Nursing Child." Zhurnal po izucheniiu rannego detshogo vozrasta (J. for Studying Early Childhood), 5(3): 179-185-a, 1927.

2805. "Characteristics of Oxidative Processcs in Children of Nursing Agc." Ibid., 9(9): 687, 1929.

2806 , Popova, N. A., and OvcinaRENKo, E. P. "Pathological-Histological Changes of the Central Nervous System at Intoxications of Nursing-Age Children." Irachebnoe delo (Medical Affairs), (7): 637$6+2,1935$.

2807. Silafranovskil, A. E., and Fedorova, T. M. "Experinent of Studying the Respiratory Function in Medical Control over Child and Juvenile Sport." Teoriin i praktikn fizicheskoi kul'tury ('Theory and Practice of Physical Culture), 14(5): 332-339, 1951.

2808. Shaknabutdinov, S. Sh. "Age Characteristics of Innervation of the Prostate Gland." Trudy kafedry normal'noi anatomii Tashkentshogo meditsinskogo in-la (Transactions of the Chair of Normal Anatomy of the Tashkcnt Medical Institute), 1953, pp. 19-54.

2809. SHAKHIDZHANIAN, L. G. "Age Changes in Stomach of Horse-Anatomical Study" (Vozrasinye izmeneniia zheludka loshadi (Anatomicheskoe issledovanie). Avtoref. diss. na soiskanie uchenoi stepeni kand. biol. nauk, Institut usovershenstvovaniia vrachei, L.). Author's own abstract of his dissertation for the degree of Candidate of Biological Sciences, the Institute for Training Physicians, Leningrad, 1953.

2810. Sinknov, S. D. "Present Basis of liarly Ontogenesis of Man." Trudy gistologicheskoi konferentsii 5-9 iiuni 1947, g., Trudy A.HN SSSR, Institut eksperimental'noi meditsiny, izd-vo Akademii meditsinskikh nauk SSSR, M. (Transactions of the June 5-9, 1947 Histological Conference, Transactions of the Acad. of Mcd. Sciences USSR, Institute of Experimental Medicine. Publ. by Acad. of Med. Sciences USSR, Moscow), 1949, pp. $53-56$

2811. Shatsillo, B. A. "Hormonal Effect of Optones of Thyroid, Adrenal, and Thymus Glands on Growth of Fresh-Watcr Limneae Mussels." Problema endokrinologii (Problem of Endocrinology), 2(3): 342-350, 1937.

2812. Shvarts, A. L. "Mesenchymal Rcaction in Embryos." Biull. eksperimental'noi biologii $i$ meditsiny (Bulletin of Exptl. Biol. and Med. ), 6(3): 265-267, 1938.
2813. SHVEdKova-Roshe, T. S. "Aging of Elastic 'Tissuc and Process of Lipoidosis in Mammary Gland Tissuc" (Ukr.: Starinnia elastiki $i$ protses lipoidozu $v$ thanini grudnoi zalozi." Medichnii zhurnal AN URSR (Med. J. of the Acad. of Sciences UkrSSR), 10(2): $577-589,1940$.

2814. Sinvetsova, G. B. "Data Contributing to a Knowledge of Age Morphology of the Peripheral Part of thc Facial Nerve of Man" (Materialy k vozrastnoi morfologii perifericheskoi chasti litsevogo nerva cheloveka. Avtoref. diss. na soiskanie uchenoi stepeni kand. med. nauk, 2-i Meditsinskii in- $t, M$.), author's own abstract of the dissertation for a Candidate of Medical Sciences degree, Second Medical Inst., Moscow, 1953.

2815. Sueves, G. S. "Effect of Denervation and Tenotomy on Activity of Pyrophosphatase and Adenosinetriphosphatase." Biokhimiia (Biochcmistry), 18(1): 63-70, 1953.

2816. Shevcienko, R. A. "Respiratory Intensity and Energetics of Development of Certain Fledglings in the Period of Embryogenesis." Itogovaia studencheskaia nauchnaia konferentsiia Khar'kouskogo gosudarstvennogo universiteta. Tezisy dokladov Khar'kouskogo gos. un-teta (Scientific Conference of the Entire Student Body of Khar'kov State Univ. Theses of Papers of the Khar'kov State Univ.), 1952, pp. 187-189.

2817. Sheinberg, D. E. "Cardiosascular System of Children in the Period of Sexual Maturation." Klinika detskogo serdtsa-Sb. rabot diagnosicheskoi kliniki Leningradskogo instituta OZDiP za 1932-1933 gg., pod red. V. N. Tvanova i Prof. N. I. Osinovskogo, izd-vo Leningradskogo in-ta OZDiP, L. (The Clinic of the Child's Heart. Collection of Works of the Diagnostic Clinic of the Leningrad "OZDiP" Institute, for 1932-1933. V. N. Tvanov and Prof. N. I. Osinovskii, editors. Publ. by the Leningrad "OZDiP"' (Div. of Ilealth Care of Children and Adolescents) Institute, Leningrad, 1933, pp. 3-35.

2818. Sileinman, R. M. "Study of Acidity in the Gastric Juice of Infancy." Klinicheskaia meditsinn (Clinical Medicine), 6(2): $81-90,1928$.

2819. Shelvanov, N. M. "Development of Higher Nervous Activity and Training of Children of an Early Age." Sovetskaia meditsina (Soviet Medicinc), (4): 1-5, 1951.

2820. Sileresievska1A, Ts. Mf. "Conditions of Formation and Properties of Artificial 
Liponucleoproteid Complexes." Uch. zap. $K h G U$ (Annals of Khar'kov State Univ.), v. 68; Trudy nauch.-issled. in-ta biologii $i$ biologicheskogo $f$-ta (Transactions of the Sci.-Res. Inst. of Biology and Biological Pharmacotherapy), 24: 245-266, 1956.

2821. ShiereshevskiI, N. A. "Control of Aging and Steinach's Teaching Concerning Puberty Gland (Translator's note: Leygid interstitial cells in male; ovary lutein cells in female)." Trudy gos. med. in-ta $v$ Moskve (Transactions of the Moscow State Med. Inst.), 1(2): 101-113, 1924.

2822. - Steppun, O. A., and Rum1ANTSEV, A. V. "Bases of Endocrinology" (Osnovy endokrinologii. Biomedgiz, M.-L.). State Publ. House of Biomed. Lit., MoscowLeningrad, 1936.

2823. Shereshevskil, N. A. "Aging and the Endocrine System." Sb.: Starost"; Trudy konferentsii 17-19 dekabria $1938 \mathrm{~g}$., AN USSR, Kiev (Collection: Old Age. Transactions of the Dec. 17-19, 1938 Conference, Acad. of Sciences UkrSSR, Kiev), 1940, pp. 31-38.

2824. Shesterikova, T. P., and Poliakova, N. M. "Age Changes of Biochemical Indices of Many Glands of Internal Secretion" (Ukr.: Vikovi zmini biokhimichnikh pokaznikiv u deiakikh zalozakh unutrishn'oi sekretsii). Biokhimichnii zhurnal (Biochemical J.), 15 (2-3): 369-384, 1940.

2825. Shimkevich, V. M. "Degeneration of Aging in Lower Animals and Death of Higher Animals." Vestnik estestvoznaniia (Bulletin of Natural Science), (9): 313, 1893.

2826. Shipayev, V. G. "Problem of Controlling Aging of the Organism. Active Bacteriotherapy." Sb.: Starost'; Trudy konferentsii 17-19 dekabria $1938 \mathrm{~g}$., AN USSR, Kiev (see above), 1940, pp. 411-416.

2827. Shipachev, G. G. "Rejuvenation of the Organism and Combatting Old Age." Sovetskaia klinika (Soviet Clinic), (19): 394401, 1933.

2828. Shirkova, G. I. "Change of Higher Nervous Activity with Old Age in Monkeys (Macaca rhesus)." Zhurnal vysshei nervnoi deiatel'nosti (J. of Higher Nervous Activity), 4(2): 194-204, 1954.

2829. Shirman, A. K. "Two Rare Cases of Longevity." Nauchnaia meditsina (Scientific Medicine), (7): 804-806, 1920.
2830. SuKarip. "Protein Crmposition of Cerebral Cortex Dependent on Age." (I) belkovom sostave mozgovoi kory $v$ zavisimosti of vozrasta. Diss.), a dissertation, 1902, p. 126.

2831. Shkliar, N. M. "Problem of Catalase Content in Blood and Tissues of Chicks and Ducklings in Different Periods of the Incubations." Fiziologicheskii zhurnal SSSR (Physiological J. of the USSR), 18: 648, 1935.

2832. - "Morphological Condition of the Blood at Time of Embryonic Development of Farm Poultry (Chickens, Turkeys, Ducks, and Geese)" (Ukr.: Morfologichnii stan krovi pid chas embrional'nogo rozvitku s.-g. ptitsi (kurei, indikiv, koachok i gusei). Ptakhivnitstro. Zb. naukovikh prats', Ukrains'ka naukovo-doslidna stantsiia (Poultry Breeding. A Collection of Sci. Works of the Ukrainian Sci.-Res. Sta(ion), 1936.

2833. Shmal'gauzen, I. I. "Problem of Death and Immortality" (Problema smerti $i$ bessmertiia, GIZ, M.), State Publ. IIonse, Moscow, 1926.

2834. - "Rules of Animal Growth." Priroda (Nature), 1928, p. 815.

2835. - "Das Wachstumgesetz als Gesetz der progressiven Differenzierung" (The Law of Growth as Precept for Progressive Differentiation). Arch. f. Entzeickl. Mechan., 1930, p. 123.

2836. - "Determining Basic Concepts and Method of Study for Growth." Sb.: Rost zhivotnykh, pod red. S. IA. Kaplanskogo i dr., Biomedgiz, M.-L. (Collection: Animal Growth. S. Ia. Kaplanskii et al., editors. State Publ. House of Biomed. Lit., Moscow-Leningrad), 1935, pp. 8-60.

2837. "Growth and General Body Dimensions in Connection with Their Biological Importance." Ibid., 1935, pp. 6173.

2838. "Growth and Differentiation." Ibid., 1935, pp. 74-84.

2839. - "The Organism as a Whole in Individual and Historic Development" (Organizm kak tseloe $v$ individual'nom in istoricheskom razuitii. Izd. AN SSSR, M.-L.). Publ. by Acad. of Sciences USSR, MoscowLeningrad, 1938.

2840. Shmerling, Zh. G. "Biological Synthesis of Nucleic Acids in the Organism." Uspekhi souremennoi biologii (Advances in Contemporary Biology), 38(1;4): 18-38, 1954. 
$29 \cdot 41$. and Malinovskaia, \%. G. "Glutamine and Asparagine Exchange in Rat and Rabbit Placenta and Embryos." Biokhimiia (Biochemistry), 19(1): 30-36, 1954.

2842. Shmerl,1NG, Z11. G. "Nucleic Acid Content and Exchange in Placenta of Whitc Rats." Ibid., 19(3): 336-340, 1954.

2843. - - "Problem of Derivation of Scrum Albunin in Whitc Rat Embryos." Ibid., 19(6): 683-687, 1954.

2344. - and USPENSKA1A, V. D. "Serum Proteins of White Rat and Rabbit Embryos." Ibid., 20(1): 31-40, 1955.

2345. Sinmid, G. A., and Ragozina, M. N. "Effect of the Secondary Organizer on Primary Embryonic Material.” Biull. eksperimental'noi biologii $i$ meditsiny (Bull. of Experimental Biology and Medicine), 2(3): 218$220,1936$.

2846. SHMiDT, G. A. "Formation of Oral Sucker and Mouth Parts of Anura (Salientia) in Triton Embryo." Ibid., 2(5): 335-338, 1936.

2847. - "Ontogenetic Origins of Mesenchyme and Coelomic Mesoderm and Their Evolution." Trudy 5 Vsesoiuznogo s'ezda anatomov, gistologov $i$ embriologov, L., 1942, Medgiz (Transactions of the 5th All-Union Congress of Anatomists, Histologists, and Embryologists. Leningrad, 1942, State Publ. House of Med. Lit.), 1951, pp. 86-90.

2848. Shmidt, E. V., and Sukrovskaia, N. A. "Effect of a Word as a Conditioning Stimulus on the State of the Visual Analysor." Zhurnal vysshei nervnoi deiatel'nosti (J. of Higher Nerv., Activity), 3(6): 809-815, 1953.

2849. Sнмid, L. A. "Carbohydrate Exchange in the Newborn." Sovetskaia pediatriia (Soviet Pediatrics), (9): 6, 1935.

2850. Sнmidt, P. IU. "The Riddle of Life" (Zagadka zhizn. Petrograd), Petrograd, 1920.

2851. Sнмгd, P. "The Struggle Against Old Age" (Bor'ba so starost'iu. Gosizdat). State Publ. House, 1915.

2852. Sнмid, P. IU. "Rejuvenation-Biological Sketch" (Omolazhivanie. Biologicheskii ocherk. Izd-vo P. P. Soikina, Petrograd). P. P. Soikin, Publ. Petrograd, 1923.

2853. - "Theory and Practice of Rejuvenation" (Teoriia i praktika omolozheniia.
Perevods nemetskogo Skuirskiogo pod red. $i$ s predisloviem $B . \mathcal{N}$. Khol'tsova, Izd-vo "Prakticheskaia meditsina," Petrograd), a translation from the German of a resident of Skvira (Ukraine). Ldited by and with foreword by B. N. Khol'tsov. P'ubl. by "Practical Medicinc," Petrograd, 1923.

2854. —_. "The Struggle Against Old Age" (sce above, 1915 edition), 1924.

2855. Shiteiman, S. I. "Rearing Calves in Neontal Accommodations" (Vyrashchivanie leliat v neotaplivaemykh pomeshcheniiakh. Kostroma), Kostroma (Yaroslavl, USSR), 1947.

2856. SIIPIL' BERG, P. I. 'Strain on Knee Joint in Scnile Walking." Biull. VIEM (Bulletin of the All-Union Institute of Exptl. Med.), (5): 19-22, 1936.

2857. "Incoordination of Movements in Those of Advanced Years." Biull. eksperimental'noi biologii $i$ meditsiny (Bull. of Exptl. Biology and Medicine), 1(4): 326327, 1936.

2858. Shreder, V. N. "Chief PhysicoChemical Changes of Blood Biocolloids in Experimental Atherosclerosis of Female Rabbits." Biologicheshii zhurnal (Biological J.), 4: $507,1935$.

2859. Shtamler, S. M. "Electrocardiographic Characteristics of the Heart with Dysentery Intoxication at Different Stages of the Ontogenesis." Arkhiv biologicheskikh nauk (Archives of Biological Sciences), 62(3): 53, 1941.

2860. - - "Mechanism of Emergence of the Oral Reflex in the Ontogenesis." Fiziologicheskii zhurnal SSSR (Physiological J. of the USSR), 34(5): 627-634, 1948.

2861. Silteinbuk11, N. V. "Age Changes in the Electroencephalogram of Man" (Vozrastnye izmeneniia elektroentsefalogrammy cheloveka. Avtoref. diss. na soiskanie uchenoi stepeni kand. med. nauk Akademii med. nauk SSSR, Rostovna Donu). Author's own abstract of his dissertation for the degree of Candidate of Med. Sciences, Acad. of Med. Sciences USSR, Rostov-on-Don), 1954.

2862. Shtern, I. B. "Juvenile Nystagmus and Its Genesis." Materialy kliniki po vozrastnoi patofiziologii pod red. M. P. Razenkova i I. G. Gel'mana, VIEM, M. (Data of the Clinic on Age Pathophysiology. M. P. Razenkov and I. G. Gel'man, Editors. AllUnion Institute of Exptl. Med., Moscow), 1937, pp. 188-196. 
2863. Shtern, L., and Peiro, R. "IIcmatoEncephalic Barrier at Different Stages of Development in Different Kinds of Animals." Gematoentsefalicheskii bar'er, Sb. rabot nauch.issled. in-ta fiziologii Narkomprosa RSFSR, M.L., Biomedgiz (Hemato-Encephalic Barrier, Collection of Works of the Sci.-Res. Institutc of Physiology, the People's Commissariat of Public Education, Russian Sov. Fedcrative Socialist Republic, Moscow-Leningrad.) State Publ. of Biomedical Lit., 1935, pp. 186187.

2864. Shtern, L., and Rapoport, IA. "Conversion of Blood Colloids into Cerebrospinal Fluid at Different Stages of Devclopment in Different Animals." Ibid., 1935, pp. 188-190.

2865. Shtern, L., and Lokshina, E. S. "Hemato-Encephalic Barrier in the Newborn." Ibid., 1935, pp. 191-192.

2866. Shtern, L. S. “Principal Reasons for Aging and Death in the Light of Present Knowledge of Barriers." Pod znamenem marksizma (Under the Name of Marxism), (11): 152-174, 1940.

2867. Shtefko, V. G. "Heart Alteration According to Age at Starvation in Connection with Conditional Characteristics of It As an Organ." Klinicheskaia meditsina (Clinical Medicine), 2(9): 374-379, 1924.

2868. "Effect of Starvation on the Child's Organism" (Vliianie golodaniia na detskii organizm. Medgiz, M.). State Publ. House of Med. Lit., Moscow, 1925.

2869. "Bases of the Biological Anatomy of the Child" (Osnovy biologicheskoi anatomii rebenka. Biomedgiz, M.-L.). State Publ. Biomed. Lit., Moscow-Leningrad, 1927.

2870. - _Principles of Age Morphology" (Osnovy vozrastnoi morfologii. Sb. pod red. direktora In-ta Iu. A. Shurpe, Medgiz, M.)a collcction edited by Iu. A. Shurp, Dir. of the Institute. Medgiz (see above), Moscow, 1933.

2871. "Age Morphology of Bone Tissue." Sb.: Anatomofiziologicheskie osobennosti detskogo vozrasta. Biomedgiz, M.-L. (Collection: Anatomical-Physiological Characteristics of Childhood. State Publ. House of Biomed. Lit., Moscow-Leningrad), 1935, pp. 5-35.

2872. "Anatomical-Biological Characteristics and Problems of the Patho- genesis of 'Tubcrculosis in Those of the Agc of Puberty." Sb.: Tuberkulez u podrostkov, pod red. Z. A. Lebedevoi i prof. A. E. Rabukhina; Trudy instituta tuberkuleza Akademii meditsinskikh nauk SSSR, Mcdgiz, M. (Collcction: Tuberculosis in Adolescents. Z. A. Lebcdeva and Prof. A. E. Rabukhin, editors; Transactions of the Tuberculosis Inst., Acad. of Med. Sciences USSR. Medgiz (see above), Moscow, 2: 15-23, 1946.

2873. Shteingart, K. M. "Evolution of Kidney Function in the Ontogenesis. Report I. Age Characteristics of Kidney Function in Infants." Fiziologicheskii zhurnal SSSR (Physiological J. of the USSR), 35(3): 330$337,1949$.

2874. "Kidney Evolution in the Ontogenesis. Report II. Age Characteristics of Kidney Function According to Exposure of Chlroides in Infants." Ibid., 35(6): 709-715, 1949.

2875. - and KraGHKovskaia, M. V. "Evolution of Kidney Function in Children in the Ontogenesis." Ibid., 37(1): 86-92, 1951.

2876. Shteingart, K. M. "Development of Cortical Regulation of Cutaneo-Galvanic Reflexes in the Ontogenesis of the Healthy Child." Trudy pervoi nauchnoi konferentsii po vozrastnoi morfologii i fiziologii, izd-vo Akademii pedagogicheskikh nauk RSFSR, M. (Transactions of the First Scientific Conference on Age Morphology and Physiology. Publ. by Acad. of Pedagogical Sciences, Russian Soviet Federative Socialist Republic, Moscow, 1954, pp. 21-28.

2877. Shtraikh, G., and Svetozarov, E. "The Growth Constant and Development of Form. I. Connection of General Growth with Development of Plumage in Geese." Uspekhi zootekhnicheskikh nauk (Advances in Zootechnical Sciences), 1(2): 235, 1935.

2879. - "Study of Patterns of Animal Growth in the USSR." Uspekhi souremennoi biologii (Advances in Contemporary Biology), 8(1): 1, 1938.

2879. Sirutman, Ts. M. "Activity of Adenosinetriphosphatase in Brain of Rabbits at an Early Age and in Different Divisions of the Brain" (Ukr.: Aktivnist' adenozintrifosfatazy $v$ mozku krolikiv riznogo viku ta v riznikh viddilakh mozku). Ukrains'kii biokhimichnii zhurnal (Ukrainian Biochemical J.), 21(1): 73-75, 1949. 
28830. SHULEIKINA, K. V. "Problem of the Embryogenesis of Unconditioned Reflexes." IIII V'sesoiuzni s'ezd fiziologov, biokhimikov, farmakologov. Tezisy dokladov, izd-vo AN SSSR, 11. (Eighth All-Union Congress of Physiologists, Biochemists, and Pharmacologists. Theses of Papers. Publ. of the Acad. of Seicnces USSR, Moseow), 1955, p. 698.

2881. Suul'man, G. IA. "The Little Effeetiveness of Sulfanilamide Therapy for Dysentery in Children in the First Year of Life." Ref. nauch.-issled. rabol po akusherstou, ginekologii $i$ pediatrii, Sverdlovsk (Abstracts of Sci.-Res. Works in Obstetrics, Gynecology, and Pediatrics. Sverdlovsk), 1: 70-72, 1949.

2882. SuUl'Ts, E. A. "Rejuvenation." Sb.: Norye idei v biologii, izd-vo Obrazovanie, $\mathrm{SPb}$ (Collection: New Ideas in Biology. Publ. by "Development", St. Petersburg, 1914.

2883. Shumenko, I. D., and Kuznetsova, 1. P. "Changes in the Amount of Potassium, Sodium, and Clacium in Blood of Rats with Age" (Ukr.: Zmini kil'kosti kaliiu, natrïu ta kal'tsiiu o krovi shchuriv z vikom). Pralsi Zoobiologichnogo in-lu Kharkios'kogo derzh. unlelu, Kharkiv, Derzhmedvidav (Transactions of the Zoobiological Inst. of Khar'kov State Univ., Khar'kov. State Publ. House of Med. Lit.), 2: 45-46, 1934.

2884. Shumenko, I. D. "Changes in Amount of Many Base (Alkaline) Elements in Blood and Organs of White Rats of Different Age" (Ukr.: Zmini kil'kosli deiakikh zol'nikh elementiv $u$ krovi organakh bilikh shchuriv riznogo viku). Ibid., 3: 119-135, 1936.

2885. - - "Quantitative Relations Between Sodium, Potassium, and Clacium in Organism of White Rats in Connection with Age" (Ukr.: Kil'kisni spivvidnoshennia mizh $\mathcal{N} a$, $K, i C a$ v organizmi bilikh shchuriv u zv'iazku $z$ vikom). Uch. zap. Kharkivs'kogo derzh. un-lelu (Annals of Khar'kov State Univ., Khar'kov), 6-7: 257-262, 1936.

2886. 1937.

2887. - "Quantitative Changes in Base Elements in Blood of Rabbits During Their Development Period" (Ukr.: Pro kil'kisni zmini popil'nikh elementiv u krovi krolikiv fid chas ith roslu). Eksperimenlal'na medilsina, Kharkiv, Derzhmedvidav (Exptl. Med., Khar'kov. State Publ. House of Med. Lit.), (3): $45-54,1937$.
2888. "Changes in Mineral Composition of the Blood and Its Constancy in Growing Organisms"' (Ukr.: Zmini mineral'nogo skladu krovi $i$ iogo sliikosti u rosiuchikh organizmiv). Pratsi nauk.-doslid. Zoobiologichnogo in-lu Kharkivs'kogo derzh. un-lelu, Kharkiv (sec above), 7: 18I-186, 1938.

2889. "Changes in Mineral Composition of the Skin with Age" (Ukr.: Zmini mineral'nogo skladu shkiri z vikom). Ibid., 7: 187-190, 1939.

2890. - and Arkiнlpcienko, I. V. "Age Changes of Cystine." Ibid., (10-11): $65-68,19+1$.

2891. Shumenko, I. D. "Age Changes of Glutathione Content in Blood and Organs of Animals." Ibid., (10-11): 69-76, 1941.

2892. - "Age Changes of Redox Potential(Eh) in Muscles and Blood of White Rats." Ibid., (10-11): 77-86, 1941.

2893. …... "Age Changes of Cingo Red Indcx." Uch. zap. Khar'kouskogo gos. med. inla (Annals of Khar'kov State Med. Inst.), v. 25; Trudy nauch.-issled. in-ta biologii (Transactions of Sei.-Res. Institute of Biology), 12: $181-184,1947$.

2894. Shurygin, N. A. "Pathologieal-Anatomical Changes in Old Age" ( $O$ patologoanalomicheskikh izmeneniiakh v slarcheskom vozraste. Diss. $\mathrm{SPb}$ ), St. Petersburg dissertation, 1897.

2895. Snutova, A. A. "Colloido-Osmotic Blood Pressure in Femalc Rabbits with Experimental Atherosclerosis." Biologicheskii zhurnal (Biological J.), 4: 517, 1935.

\section{SHCH}

2896. Shchelkov, I. P. "Zur Frage über die Veranderung der Hornhautkrümmung mit zunehmenden Altcr"' (The Problem of Change of Curvature of the Cornea with Inereased Age). Centralbl.f. medic. Wissensch., 1880.

2897. Shichelovanov, N. M. "Method of Genetic Reflexology." Sb.: Novoe v refleksologii nerunoi sislemy, GIZ, L.-M. (Collection: Progress in Reflexology and Physiology of the Nervous System. State Publ. Mouse, I,eningrad-Moscow), 1:-, 1925.

2898. - and Figurin, N. L. "Comparative Study of First Stages of Behavioral 
Devclopment of Man and Animals." $S b .:$ Psikhonevrologicheskie nauki v SSSR, M.-L. (Collection: Psychoncurological Sciences in the USSR, Moscow-Leningrad), 1: - 1930.

2899. Sirchelovanov, N. M. "Need to Train Children from the First Months of Life" (Neabkhodimost' vospitaniia detei s pervykh mesiatsev zhizni. Medgiz, M.). State Publ. House of Mcd. Lit., Moscow, 1939.

2900. Shanepot'ev, A. S. "Biochemical Bases of Evolution." Novye idei v biologii. Sb., izd-vo Obrazovanic, $\mathrm{SPb}$ New Ideas in Biology. Collection. "Education" Publ. House, St. Petersburg, 1914.

2901. Shaherbakov, A. P. "Intensity of Exchange and Life Duration of Drosophila. I. Introductory Remarks and Survey of the Literature." Arkhiv biologicheskikh nauk (Archives of Biological Sciences), 38(3): 639-650, 1935.

2902. - "Intensity of Exchange and Life Duration of Drosophila. II. Duration of Life and Intensity of Exchange of Drosophila melanogaster at Different Density of Population." Ibid., 38: 651-656, 1935.

2903. Sircherbatov, I. I. "Transplantation of Auditory Vesicle of Chick Embryo in the Chorio-Allantois." Biull. eksperimental'noi biologii i meditsiny (Bull. of Exptl. Biol. and Med.), 6(5): 507-510, 1938.

\section{E (foreign e)}

2904. EgolinskiI, IA. A. "Reaction of Cardiovascular Activity of Children and Adolescents to Muscle Stress." Teoriia i praktika fiziocheskoi kul'tury (Theory and Practice of Physical Culture), (6): 55-56, 1939.

2905. - - "Data on Role of the Cerebral Hemisphere in Development of the Organism." VII s'ezd fiziologov, biokhimikov i farmakologov (Seventh Congress of Physiologists, Biochemists, and Pharmacologists), Medgiz, Moscow, 1947, pp. 244-246.

2906. Edel'man, Z. I. “Normal Electrocardiogram for Preschool and School-Age Children." Pediatriia (Pediatrics), (6): 49-57, 1949.

2907. Edel'man, N. M. 'Effect of Feeding Conditions on the Physiological State of Gypsy Moth and Poplar Hawks (Sphingid Moth Larvae)." DA.V SSSR (Reports of the Acad. of Sciences USSR), 84(4): 849-885, 1952.
2908. Eidrigevicir, E. V., and Poliakov, L. V. "Effect of Age of Parents on Character of Descendants in Horned Cattle of the Altai Breed." Zhurnal obshchei biologii (J. of General Biology), 14(6): 435-440, 1953.

2909. EKKert, AL. "Invisible Yields of Perspiration in the Physiological State of the Child's Organism." Mezhdunarodnaia klinika (International Clinic), (11): - 1882.

2910. El'bert, V. A. "Nutrition and Old Age." Sb.: Starost'. Trudy konferentsii 17-19 dekabria $1938 \mathrm{~g}$., AN USSR, Kiev (Collection: Old Age. Transactions of the Dec. 17-19, 1938 Conference, Acad. of Sciences UkrSSR, Kiev), 1940, pp. 389-394.

2911. Emdina, KH. L. "Excretory Function of the Stomach of Children of Early Age" (Ekskretornaia funktsiia zheludka u detei rannego vozrasta. Diss.), a dissertation, 1937; Pediatriia (Pediatrics), (11): 17-23, 1938.

2912. - - "Effect of Vitamin B Group on Basal Metabolism of the Child of Early Age." Ref. nauch.-islled. rabot Akademii meditsinskikh nauk SSSR, klinicheskie nauki, M. (Abstracts of the Sci.-Res. Works of the Acad. of Med. Sciences USSR, Clinical Sciences, Moscow), (5): 32-33, 1948.

2913. Eminet, P. P. "Sphygmography and Tonometry of Children in the 6-15 Age Group." Meditsinskoe obozrenie (Medical Survey), 67: - 1907.

2914. - - "Data Contributing to a Knowledge of the Pulse and Blood Pressure in Children." Zap. Khar'kouskogo un-teta (J. of Khar'kov Univ.), (2-4): —, 1908.

2915. —_. "Experiments in Artificial Production of Athrcpsia in Young Animals." Vrachebnaia gazeta (Medical Gazette), (35): 985-988, and (36): 1015-1017, 1908.

2916. - - "Contribution to a Knowledge of the Third Blood Element in Growing Organisms" ( $K$ ucheniiu o tret'em elementa krovi $u$ rastushchikh organizmov. Diss., Khar'kov), a dissertation. Khar'kov, 1911.

2917. - "Height, Weight, Pulse, and Blood Pressure Correlations Between Their Own and Certain Physiological and Pathological Conditions of the Child's Organism According to Population Groups and Age." Vrachebnaia gazeta (Medical Gazette), 1911.

2918. Emme, A. M. "Detailed Study of Age Variability of Thermo-Reactivity in Predia- 
pausc Silkworm Eggs." DAN SSSR (sce above), 82(5): 825-828, 1952.

2919. - " $\triangle \mathrm{gcc}$ Variability of Sensitivity of Mulberry Silkworm Eggs During the Diapausc to Different Combined Doses of Activation. Ibid., 93(1): 209-212, 1958.

2920. Engel'HArdt, V. A., and Vener, R. A. "Enzyme Formation in the Developing Egg." Zhurnal eksperimental'noi biologii i meditsiny (J. of ExptI. Biology and Med.), 5(15): 335-343, 1927.

2921. Epel'baum, S. E., Khaikina, B. I., and Skvirskaia, E. B. "Effect of Age on Cercbral Phosphorus Compounds." Biull. eksperimental'noi biologii $i$ meditsiny (Bulletin of Exptl. Biology and Medicine), 3(5): 548-550, 1937.

2922. EPel'baum, S. E., and Skvirs'Ka, E. B. "Glycolysis in Brain of Animals of Different Age" (Ukr.: Glikoliz v mozku tvarin riznogo viku). Biokhimichnii zhurnal (Biochemical J.), 15(2-3): 233--248, 1940.

2923. Epel'baum, S. E., and Kantor, L. F. "Effect of Denervation on the Glycolytic Processes in Muscles." Biokhimiia (Biochemistry), 19(6): 660-665, 1954.

2924. Etingof, R. N. "Asparagine and Glutamine in the Process of the Ontogenesis of Fowl." Ibid., 20(5): 591-596, 1955.

\section{IU}

2925. Iudaev, N. A., Smirnov, M. I., Razina, P. G., and Dobbert, N. N. "Biochemical Changes in Muscle After Its Denervation and Tenotomy and at Penctration of Nerve Fibcrs into It." Ibid., 18(6): 732-738, 1953.

2926. Iudaev, N. A., and Razina, L. G. "Synthesis of Carnosine in the Organism." VIII Vsesoiuznyi s'ezd fiziologov, biokhimikov, farmakologov. Tesizy dokladov, izd-vo AN SSSR, M. (Eighth All-Union Congress of Physiologists, Biochemists, and Pharmacologists. Thescs of Reports publ. by Acad. of Sciences USSR, Moscow), 1955, p. 705.

2927. Iuden, G. G. "Certain Anatomical Characteristics of the Senile Heart." Iubileinyi sbornik Smolenskogo gosudarstvennogo meditsinskogo instituta (Jubilee Collection of the Smolensk State Medical Institute), 1935, pp. $39-43$.

2928. IUdinA, N. D. "Reaction of the Hcmatopoictic Systcm to Diffcrent Stimuli in
Connection with Agc" (Ukr.: Reaktsiia gemopoetichnoi sistemi v zv'iazku z vikom na rizni podrazniki). Medichnii zhurnal AN URSR (Mcdical J. of the Acad. of Scicnces UkrSSR), 7(4): 1183-1191, 1937.

2929. - "Reactivity of 1 Hematopoietic Systcm of Rats in Conncction With Age at Atherosis and Castration" (Ukr.: Reaktivnist' gemopoetichnoi sistemi shchuriv u zv'iazku z vikom pri atireozi $i$ kastratsii). Ibid., 8(1): 109-115, 1938.

2930. - "Characteristics of Morphological Composition of Blood at Physiological Aging." Sb.: Starost'. Trudy konferentsii 1719 dckabria 1938 g., AN USSR, Kiev (Collection: Old Age. Transactions of the Dcc. 17-19, 1938 Confercnce, Acad. of Sciences UkrSSR, Kiev), 1940, pp. 173-185.

2931. - "Reaction of Hcmatopoietic System of Rats in Connection with Age to Different Stimuli." Ibid., 1940, pp. 187190.

2932. - "The Hematopoietic Function in Connection with Age." Tezisy konferentsii po vosrastnym izmeneniiam obmena veshchestv i reaktivnosti organizma, Kiev (Conference Papers on Age Changes in Metabolism and Reactivity of the Organism. Kiev), 1949, 1951.

2933. Iunusov, A. IU. "Topography of Sweat Glands in Children." VII Vsesoiuznyi s'ezd fiziologov, biokhimikov, farmakologov. Doklady. Medgiz, M. (Reports of the Seventh All-Union Congress of Physiologists, Biochemists, and Pharmacologists. State Publ. House of Med. Lit., Moscow), 1947, p. 659.

2934. Iun'ev, G. S., Selianinova, A. M., and Zilotina, P. V. "Latent Period of Motor Reaction at Electric Stimulation of the Cortex and Conduction Rate of Impulse to Spinal Cord of Newborn Animals." Biull. eskperimental'noi biologii $i$ meditsiny (Bulletin of Exptl. Biol. and Mcd.), 9(5): 341$344,1940$.

2935. IUREVich, V. A. "IJereditary and Intra-Utcrine Transfer of Agglutination Capacity and of Participation of Embryo in Producing Agglutinins at Infection of the Mother" ( $O$ nasledstvennoi $i$ vnutritrobnoi peredache aggliutinatsionnoi sposobnosti $i$ ob uchastii ploda v vjrabolke aggliutininov pri infektsii materi. Diss., $\mathrm{SPb})$ a dissertation. St. Petcrsburg, 1902; Referat $v$ lzvestiiakh Voenno-meditsinshoi akademii (an abstract in Bulletins of the Acad. of Military Med.), 7(3): 277-278, 1903. 
2936. Iushahenko, A. A. "Continuous Observations with the Secretory-Motor Method." Russkii fiziologicheskii zhurnal SSSR (Russian Physiological J. of the USSR), ll(l-2): 209-232, 1928.

\section{IA}

2937. I ablonovskil, I. M., and Subbotina, K. P. "Development of Rapidity of Running in Children of School Age" (Razvitie skorosti bega u detei shkol'nogo vozrasta. Sessiia, posviashchennaia itogam nauch.-issled. raboty in-la (IsNIIFK) za $1949 \mathrm{~g}$. Tezisy dokladov, M.). Session devoted to Results of the Sci.-Res. Work of the Central Sci.-Res. Inst. of Physical Culture for 1949. Theses of Reports, Moscow, 1950.

2938. Iablonovskir, I. M. "Physical Culture in Old Age" (Fizicheskaia kul'tura v pozhilom vozraste. M.), Moscow, 1953.

2939. Iakovenko, V. A. "Effect of Climate on Basal Metabolism of Children." Kurortnoe delo (Health Resort Affairs), 6: 14-20, 1929.

2940. Iakovlev, V. I. "Problem of Comparative Non-Susceptibility of Newborn Children and Those in the First Months of Life to Certain Contagious Diseases." Gigiena $i$ sanitariia putei soobshcheniia (Hygiene and Sanitation Through Communication), (5-6): 72-80, and (7-8): 91-99, 1923.

2941. Iaxovlev, N. N. "Some Expcrimental Data Relative to Training the Muscles of a Growing Organism." Fiziologicheskii zhurnal SSSR (Physiological J. of the USSR), 30(2): 222-228, 1941.

2942. I AKovleva, A. I. "Age Development of the Medulla oblongata in Connection with the Problem of the Respiration Center." Izvestiia Akademii pedagogicheskikh nauk RSFSR, M. (Bulletin of the Academy of Pedagogical Sciences, Russian Sov. Fed. Soc. Republic, Moscow), 47: 44-52, 1953.

2943. Iakubinskaia, N. V. "Carotene Changes in Blood of Calves Depending on Age." Trudy Institnta eksperimental'noi biologii $A \mathcal{N}$ Kazakhskoi SSR (Transactions of the Inst. of Exptl. Biol. of the Acad. of Sciences Kazakh SSR), (1): 50-55, 1953.

2944. IaKubovich, V. "Contribution to a Knowledge of the Quantitative Composition of Embryonic Muscles." Meditsinskoe obozrenie (Medical Survey), 35: 779, 1891.

2945. - "Uber die chemische Zusammensetzung der embryonalen Muskeln" (The Chemical Composition of Embryonic Muscles), Arch.f. Kinderh., 14: 344, 1893.
2946. - "Problem of Absorptive Capacity of Different Surfaces of the Child's Organism." Meditsinstioe obozrenie (Med. Survcy), (1): - 1899.

2947. Iaxushev, V. I. "Barrier Function in Enccphalitis of Animals of Young Age." Biull, eksperimental'noi biologii $i$ meditsiny (Bull. of Exptl. Biol. and Mcd.), (5): 29-31, 1946.

2948. IAnkovskaia, A. S. "Age Characteristics of Reaction of the Organism to Compatible Blood Transfusion" (Vozrastnye osobennosti reaktsii organizma na perelivanie soumestimoi krovi. Avtoref. diss. na soiskanie uchenoi stepeni kand. med. nauk. Nauch.-issled. in-t ortopedii $i$ traumatologii, inst. eksperimental'noi biologii i patologii, Kiev). Author's own abstract of his dissertation for Candidate of Med. Scienccs degree. Sci.-Res. Inst. of Orthopedics and Traumatology, Inst. of Exptl. Biol. and Pathology, Kiev, 1953.

2949. Iankovskaia, Ts. A. "Development of Pressor-Depressor Reflexes in Newborn Animals." Trudy XV Mezhdunarodnogo fiziologicheskogo kongressa (Transactions of the 15th International Physiological Congress. Fiziologicheskii zhurnal SSSR (Physiological J. of the USSR), 21(5-6): 1015, 1936.

2950. I ankovskaia, 'Ts. L. "Problem of Devclopment of Regulation of Cardiac Activity in Chicks During the Ontogenesis." Ibid., 35(2): 223-235, 1949.

2951. Iankovskil, V. D. "Problem of Restoring Functions of the Central Nervous System in Pups Which Have Survived Prolonged Clinical Death." VIII Vsesuiuznyi s'ezd fiziologov, biokhimikov, farmakologov. Tezisy dokladov, izd-vo AN SSSR, M. (Eighth All-Union Congress of Physiologists, Biochemists, and Pharmacologists. Theses of Reports. Publ. by Acad. of Sciences USSR, M., 1955, p. 715.

2952. IAtel', T. P. "Charactcristics of Certain Reactions of Immunity at Early Stages of the Ontogenesis." Trudy pervoi nauchnoi konferentsii po vozrastnoi morfologii $i$ fiziologii, izd-vo Akademii pedagogicheskikh nauk RSFSR, M. (Transactions of the First Sci. Conference on Age Morphology and Physiology. Publ. by Academy of Pedagogical Sciences RSFSR, Moscow), 1954, pp. 116-124.

2953. Iatsuta, K. Z. "Problem of Effect of Age on Absorption of Certain Medicinals Through the Stomach" ( $K$ voprosu o vliianii vozrasta na vsasyvanie nekotorykh lekarstvennykh veshchestv iz zheludka. Diss. SPb), a dissertation. St. Petersburg, 1891. 


Public Health Service Publication No. 857 